\title{
LA PALEOFLORA TRIÁSICA DE LA FORMACIÓN CORTADERITA EN LA QUEBRADA HOMÓNIMA, CUENCA DE BARREAL - CALINGASTA, PROVINCIA DE SAN JUAN, ARGENTINA
}

\section{Josefina Bodnar}

Tesis para optar al título de Doctor en Ciencias Naturales

Directora: Dra. Analía E. Artabe

Co-Director: Dr. Eduardo M. Morel

Facultad de Ciencias Naturales y Museo

Universidad Nacional de La Plata 
Conoces lo que tu vocación pesa en tí. Y si la traicionas, es a ti a quien desfiguras; pero sabes que tu verdad se hará lentamente, porque es nacimiento de árbol y no hallazgo de una fórmula.

Cuando el misterio es demasiado impresionante, es imposible desobedecer.

-Antoine de Saint-Exupéry 


\section{AGRADECIMIENTOS}

Les expreso un profundo agradecimiento a mis padres y mi hermana, quienes día a día me apoyaron para que siempre siguiera mis sueños.

Este trabajo nunca habría sido posible sin la valentía de mis maestros, Analía Artabe y Eduardo Morel, quienes se animaron a abrirme las puertas de la Paleobotánica.

Gracias a mis amigos por su compañía incondicional, especialmente a Georgina Erra, compañera infatigable del camino hacia mi tesis. A Federico Ferri, Eliana Coturel, Néstor Toledo, Leandro Martínez, Eduardo Ledo, Jorge González, Santiago Barrera por su ayuda emocional y logística. A Rocío Rocco, Juliana Ghergolet, Cecilia Villalobos, Julio Varela, Matías Taglioretti, Juliana Sterli, Natalia Mego, Ana Carignano, Lydia Calvo Marcilese, Bárbara Cariglino, por su compañía durante los cinco años del doctorado.

Gracias a mis compañeros de facultad Alejandro Otero, Pablo Gallina, Martín Pérez, quienes de alguna manera u otra me dieron energías. A Ignacio Escapa, por la paciencia al explicarme temas sobre cladística.

Les agradezco a mi compañeros de División, Ari Iglesias, Daniel Ganuza, Adolfo Zúñiga, Alba Zamuner, por estar siempre predispuestos a darme una mano.

Mis agradecimientos a Sergio Archangelsky, Luis Lezama, Georgina del Fueyo, Ricardo Martínez, Alicia Lutz, por abrirme las puertas de otros museos y colecciones.

Les expreso mis agradecimientos a las autoridades de la Facultad y Museo, y CONICET, quienes me brindaron la posibilidad de realizar el doctorado. 


\section{ÍNDICE}

I. Resumen.................................................................................1

I. Abstract................................................................................3

II. Introducción..................................................................5

II.1. Relevancia del problema......................................................5

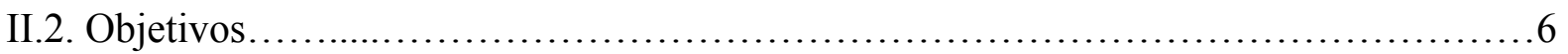

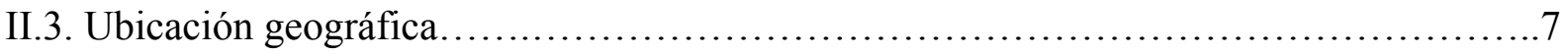

III. Antecedentes geológicos.......................................................11

III.1. El hemigraben de la Precordillera Occidental sanjuanina.............................11

III.2. Las unidades triásicas de la cuenca de Barreal-Calingasta...........................13

III.3. El Triásico en la quebrada de la Cortaderita......................................17

IV. Antecedentes paleobotánicos...................................................21

IV.1. Reseña del estudio de las megafloras triásicas en la Argentina.........................21

IV.2.Contribuciones al conocimiento de la paleoflora de la cuenca de Barreal-

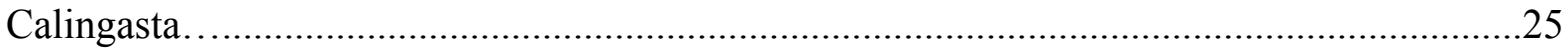

V. Materiales y métodos..........................................................31

V.1. Área estudiada............................................................... 31

V.2. Tareas efectuadas en el campo............................................ 31

V.3. Tareas efectuadas en el laboratorio y gabinete......................................

V.3.1. Preparación e ilustración del material.......................................34

V.3.2. Análisis y determinación del material.......................................35

V.3.3. Estudios filogenéticos y evolutivos................................... 36

V.3.4. Estudios tafonómicos y paleoecológicos..................................36

VI. Sedimentología y estratigrafía de la Formación Cortaderita.........................38

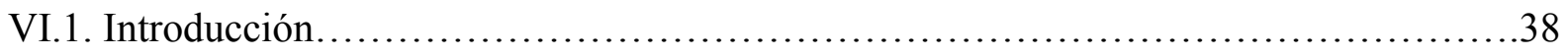

VI.2. Descripción de los perfiles sedimentológicos...................................39

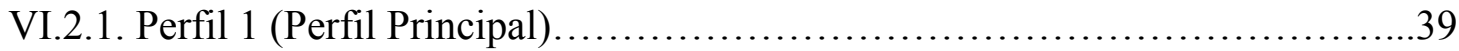

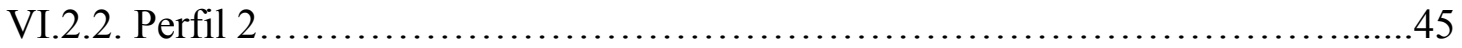

VI.2.3. Perfil 3 ............................................................... 46

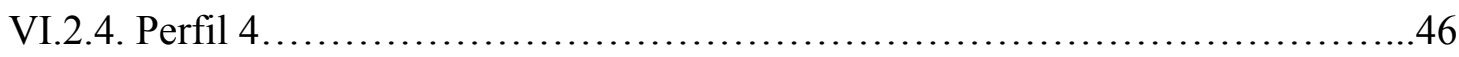

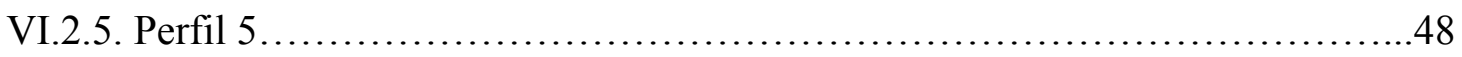

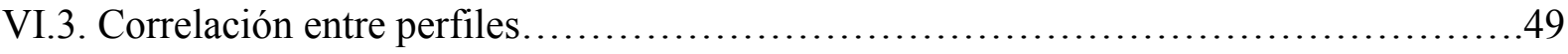


VI.4. Definición, caracterización e interpretación de las facies sedimentarias................50

VI.5. Asociación de facies e interpretación paleoambiental............................52

VI.6. Interpretación de los paleosuelos.......................................... 57

VI.7. Discusión sedimentológica...............................................58

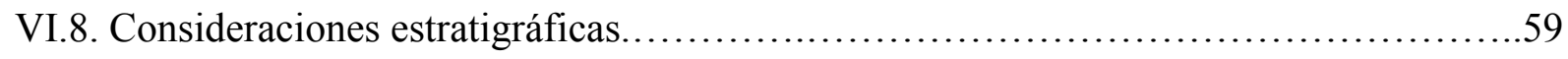

VII. Sistemática Paleobotánica......................................................61

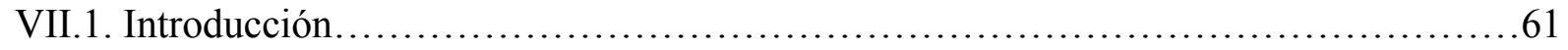

VII.2. Estratos fosilíferos de la Sección Inferior de la Formación Cortaderita.................62

Marchantiophyta incertae sedis

Género Thallites.

Bryophyta incertae sedis

Género Muscites.....................................................64

Orden Pleuromeiales

Género Lepidanthium.

Orden Equisetales

Género Neocalamites................................................65

Género Equisetites...............................................6 65

Género Phyllotheca...............................................66

Orden Marattiales

Género Rienitsia...................................................66

Orden Osmundales

Género Cladophlebis.

Orden Gleicheniales

Género Coniopteris.... .68

Género Dictyophyllum..........................................6 68

Orden Corystospermales

Familia Corystospermaceae

Estatus nomenclatural de la familia Corystospermaceae.....................71

Criterios para la clasificación de las hojas de Corystospermaceae............71

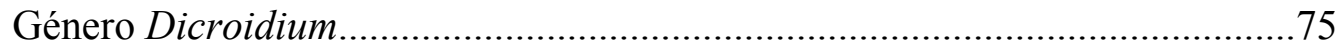

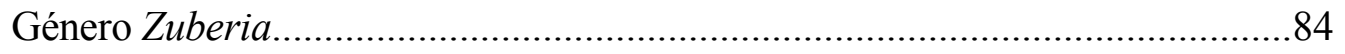

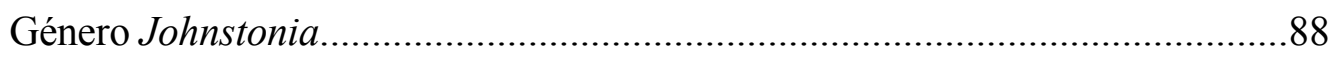

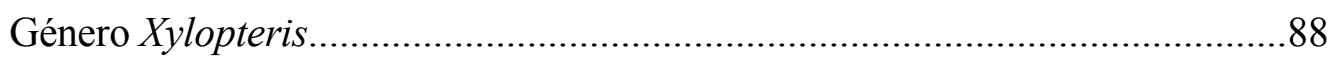

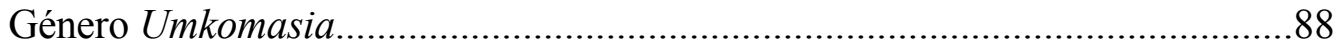


Género Rhexoxylon

Orden Peltaspermales

Género Scytophyllum. .92

Género Peltaspermum.. . .93

Género Pachydermophyllum................................................93

Género Lepidopteris.....................................................95

Género Delnortea ...............................................96

Orden Petriellales

Género Rochipteris. .98

Orden Cycadales

Género Kurtziana. 100

Género Pseudoctenis

Cycadophytas incertae sedis

Género Taniopteris. 105

Orden Ginkgoales

Género Ginkgoites. 106

Género Sphenobaiera. 107

Género Baiera.

Orden Voltziales

Género Heidiphyllum.

Orden Coniferales

Género Elatocladus

Género Pagiophyllum.

Género Rissikia

Orden Gnetales

Género Yabeiella.

Género Fraxinopsis

Espermatofitas incertae sedis

Género Cordaicarpus

Género Linguifolium.

VII.3. Estrato fosilífero de la base de la Sección Superior de la Formación Cortaderita.

Orden Osmundales

Género Cladophlebis.

Orden Corystospermales 


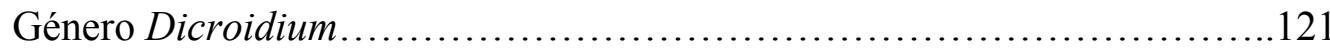

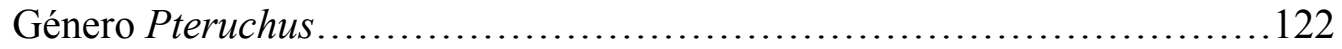

Orden Peltaspermales

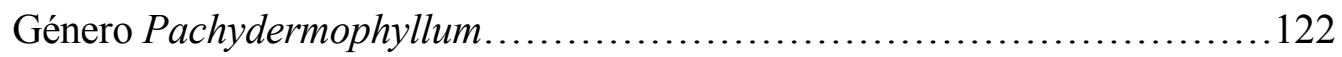

Género Scytophyllum......................................... 123

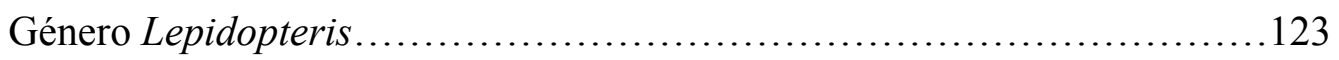

Orden Ginkgoales

Género Ginkgodium ............................................... 126

Género Sphenobaiera................................................127

Orden Cycadales

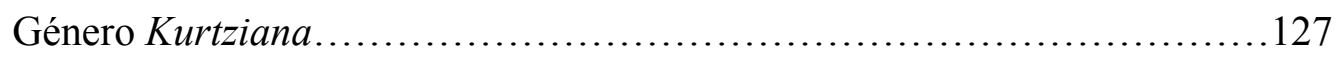

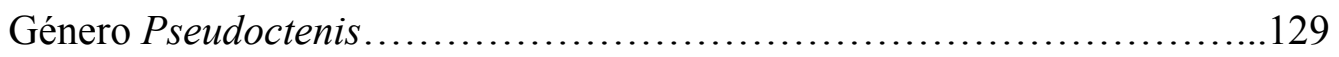

Orden Gnetales

Género Yabeiella ................................................... 130

Espermatofitas incertae sedis

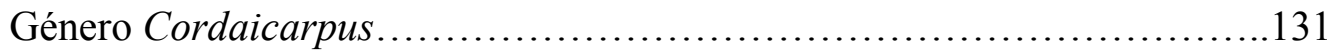

VII.4. Estratos fosilíferos de la Sección Superior de la Formación Cortaderita (excluyendo el EF5).................................................................... 133

Orden Corystospermales

Género Zuberia................................................134

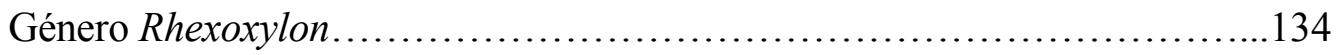

VII.5. Conclusiones sistemáticas................................................. 140

VIII. Análisis filogenético de las Corystospermaceae, utilizando caracteres caulinares...143

VIII.1. Introducción............................................................ 143

VIII.2. Elección del out-group ............................................. 145

VIII.3. Definición del in-group................................................ 147

VIII.4. Posición filogenética de las corystospermas.................................148

VIII.5. Caracteres utilizados....................................................... 150

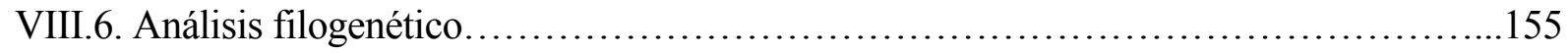

VIII.7. Resultados e interpretación de las relaciones filogenéticas..........................156

VIII.8. Conclusiones filogenéticas............................................ 157

IX. Patrones evolutivos-del desarrollo en troncos de Corystospermaceae...................159

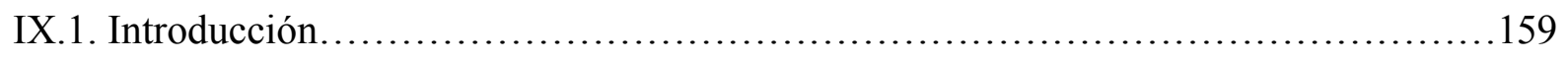

IX.2. Conceptos, teorías y clasificaciones de la Biología Evo-Devo....................160 
IX.3. Estudios evolutivos-del desarrollo en plantas.................................... 166

IX.4. Dificultades y ventajas de los estudios evo-devo en plantas fósiles...................169

IX.5. Particularidades de los estudios del desarrollo en ejes con crecimiento secundario....172

IX.6. Aplicabilidad de los principios de la Biología Evo-Devo a los tallos fósiles...........179

IX.7. Patrones evo-devo en tallos de Corystospermaceae...............................181

IX.8. Conclusiones evolutivas-del desarrollo.....................................188

X. Tafonomía y paleoclimatología.................................................190

X.1. Introducción................................................................... 190

X.2. Tipos de fosilización.......................................................... 188

X.3. Marco sedimentológico................................................... 192

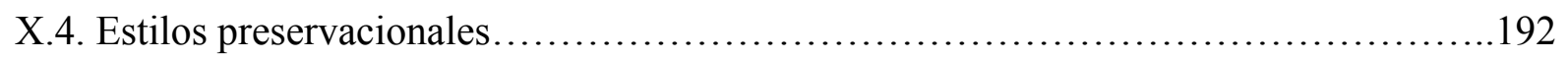

X.5. Definición e interpretación de las tafofacies.................................. 197

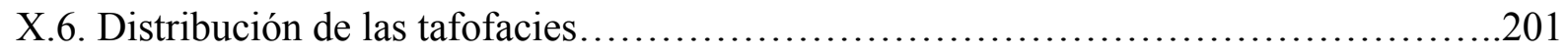

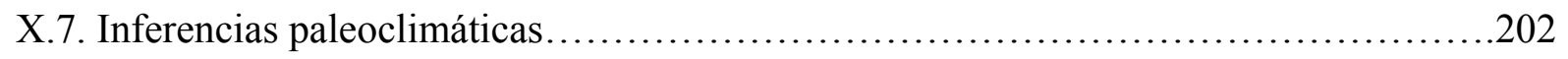

X.8. Conclusiones tafonómicas y paleoclimáticas.................................206

XI. Reconstrucción ecológica de las paleocomunidades..............................208

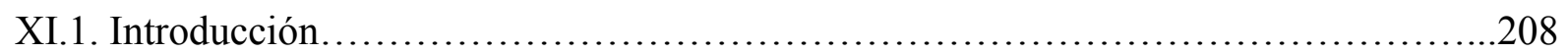

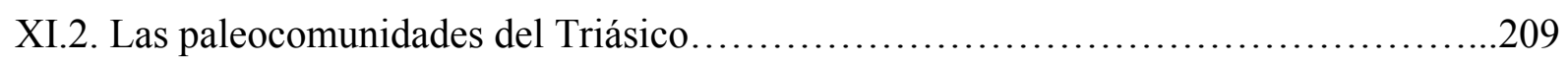

XI.3. Tafocenosis estudiadas en la Formación Cortaderita.............................212

XI.4. Análisis estructural de las paleocomunidades.................................212

XI.5. Interpretación, comparaciones y discusión...................................220

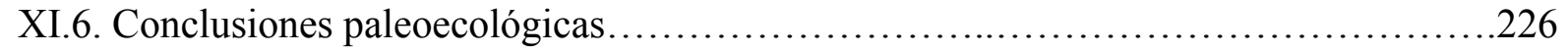

XII. Bioestratigrafía y edad de la Formación Cortaderita...............................228

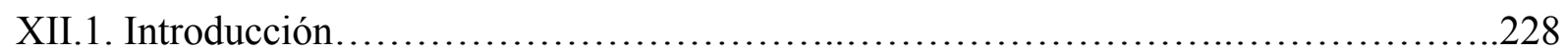

XII.2. Biozonación paleoflorística para Gondwana.................................230

XII.3. Biozonación paleoflorística de la Argentina...................................231

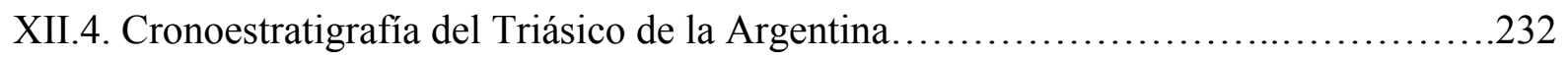

XII.5. Biostratigrafía y edad de la Formación Cortaderita..................................233

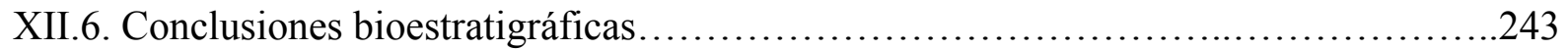

XIII. Conclusiones generales......................................................244

XIV. Bibliografía....................................................................247 


\section{RESUMEN}

El presente trabajo corresponde al estudio de "La paleoflora triásica de la Formación Cortaderita en la quebrada homónima, cuenca de Barreal-Calingasta, provincia de San Juan, Argentina", con el propósito principal de profundizar en la comprensión de la evolución de la flora triásica de la Argentina.

Durante los dos viajes de campo a la zona de Barreal-Calingasta, se reconocieron los sitios donde aflora la Formación Cortaderita, se levantaron perfiles sedimentológicos en once localidades en las quebradas de la Cortaderita y la Tinta, y se reconocieron los estratos portadores de impresiones-compresiones y permineralizaciones vegetales mencionados en trabajos previos, además de la identificación de nuevos estratos plantíferos; todos los que fueron muestreados en cuanto a la diversidad fosilífera y condiciones tafonómicas. En total, se obtuvieron alrededor de 300 ejemplares de plantas fosilizadas como impresionescompresiones y 100 muestras de troncos permineralizados.

Los estudios sedimentológicos realizados permiten decir que la Formación Cortaderita está conformada por dos secciones (que pueden ser consideradas como miembros) bien distinguibles por su litología. La Sección Inferior gris está dominada por facies Fr y Fm (limolitas y areniscas limosas grises bentoníticas), mientras que en la Sección Superior rosada predominan las facies Sm y Sh (areniscas finas a gruesas y sabulíticas rosadas y rojizas). Se interpreta que la Sección Inferior gris corresponde a sistemas fluviales meandrosos, con un importante desarrollo de paleosuelos de tipo vertisoles y eventos episódicos de lluvias de ceniza. La Sección Superior rosada se interpreta como parte de sistemas fluviales entrelazados, con la presencia de suelos de tipo aridisoles. Se constató que el contacto entre las dos secciones de la formación, es discordante, en algunos casos debido a la presencia de una discordancia erosiva y en otros, por una paraconformidad. Se cita por primera vez la presencia de paleosuelos para la unidad formacional.

En la Formación Cortaderita se reconocieron ocho estratos fosilíferos (EF): cuatro en la Sección Inferior y cuatro en la Superior. Los niveles fosilíferos hallados por otros autores fueron correlacionados con los estratos estudiados en este trabajo. Los estratos EF2, EF3 y EF4, representan horizontes con bosques in situ, constituidos por troncos y tocones permineralizados, e impresiones-compresiones de hojas y ramas. El estudio sistemático de la paleoflora permitió identificar 64 taxones. Se cita por primera vez a las divisiones Marchantiophyta y Bryophyta y las familias Asterothecaceae y Podocarpaceae. Algunos grupos que ya habían sido mencionados para la formación, como las Peltaspermales y las 
Ginkgoales, mostraron una mayor diversidad que la conocida previamente para la unidad. A nivel génerico se determinaron taxones que no habían sido antes mencionados para la formación como Thallites, Muscites, Rienitsia, Lepidopteris, Delnortea, Ginkgoites, Ginkgodium, Baiera, Rissikia. Por último, de las especies nombradas en la presente contribución, es la primera cita de Rienitsia arrondiana, Dicroidium dubium, Pachydermophyllum papillosum, Lepidopteris stormbergensis, L. africana, Delnortea abbottiae, Ginkgoites walckedensis, Sphenobaiera schenckii, S. sectina, Baiera cuyana, Ginkgodium nathorsti, Elatocladus plana, Rissikia media y Pseudoctenis longipinnata para la unidad. El hallazgo de materiales posiblemente asignables a Delnortea abbottiae constituye el primer registro de esta especie para el Triásico.

Para los análisis filogenéticos y evolutivos, se revisó la anatomía de las Corystospermaceae, de otras pteridospermas relacionadas y de las cycadales. Se realizó una aproximación filogenética de los taxones caulinares de las Corystospermaceae. Asimismo la evolución de los troncos de este grupo fue estudiada en el marco de la Biología Evolutiva-del Desarrollo (Evo-devo). Las cuatro desviaciones de la actividad cambial típica que presentan las corystospermas (diferencial, remanente, inversa y supernumeraria), guardan una relación con eventos evo-devo. Todos los tipos de patrones evo-devo pueden ser invocados en el origen y diversificación de estos tallos: heterocronía (pedomorfosis y peramorfosis) y heterotopía (homeosis y neoheterotopía).

En los estudios tafonómicos se definieron ocho tafofacies. Se constataron diferencias tafonómicas entre la Sección Inferior gris y la Superior rosada, relacionadas con cambios climáticos locales en la Formación Cortaderita, pasando de un clima subtropical subhúmedosemiárido a subtropical semiárido.

Se estudiaron tres bosques petrificados in situ, sucesivos a lo largo de las dos secciones de la Formación Cortaderita. La información cuantitativa de los bosques (densidad, separación promedio entre los árboles, altura inferida, biomasa) sumado al estudio sistemático y sedimentológico, permitió realizar la reconstrucción de tres paleocomunidades de bosques siempreverdes subtropicales estacionales a esclerófilos, con un estrato arbóreo dominado por corystospermas y desarrolladas en ambientes fluviales.

Para el análisis bioestratigráfico se comparó el contenido paleoflorístico de la Sección Inferior y Sección Superior entre sí. A partir de este análisis, se interpreta que no existe una hiatus temporal significativo intraformacional. La comparación de la paleoflora de la Formación Cortaderita con las de otras formaciones de la Argentina, permitió correlacionarla con la Formación Potrerillos, y considerarla de una edad mesotriásica media. 


\section{ABSTRACT}

This contribution belongs to the study of "The Triassic paleoflora of Cortaderita Formation, at the homonymous creek, Barreal-Calingasta basin, province of San Juan, Argentina", with the main objective to improve the comprehension of the evolution of Argentinean Triassic flora.

During field trips to Barreal zone, outcrop sites of Cortaderita Formation were recognized, sedimentological profiles were logged at eleven localities from la Cortaderita and la Tinta creeks, and previously studied fossiliferous levels were recognized, besides the identification of new fossiliferous strata; all that were sampled as far as their diversity and taphonomic conditions were pondered. Altogether, almost 300 specimens of impressioncompressions and 100 samples of permineralized trunks were obtained.

Sedimentological studies allow to claim that Cortaderita Formation is conformed by two sections (that can be considered as members) with clearly distinctive lithology. The Lower Section is dominated by facies Fr and Fm (grey bentonitic and sandy limestones), whereas Upper Section is characterized by facies Sm and Sh (pink fine sandstones to reddish sabulites). Lower Seccion is interpreted as meandering fluvial systems, with well developed paleosoils of vertisol-type, and episodic ash fall events. Upper Section is inferred as braided fluvial systems, with paleosoils of aridisol-type. There is an unconformity between two sections of the Formation, which is a disconformity in some cases, or paraconformity in other ones. It is the first mention of the presence of paleosoils for Cortaderita Formation.

Eigth fossiliferous strata (EF) were defined in Cortaderita Formation: four from Lower Section and four from the Upper Section. The fossiliferous levels found by other authors were correlated with strata studied in this work. The fossiliferous strata EF2, EF3 and EF4, represent horizons with forests in situ, constituted by permineralized trunks and stumps, and impression-compressions of leaves and branches. The systematic study of Cortaderita paleoflora allowed to identify 64 taxa. Divisions Marchantiophyta and Bryophyta and Families Asterothecaceae and Podocarpaceae are mentioned for first time. Previously cited groups for the Formation, i.e. Peltaspermales and Ginkgoales, showed a greater diversity than previosuly known for the lithostratigraphic unit. At generic level, genera Thallites, Muscites, Rienitsia, Lepidopteris, Delnortea, Ginkgoites, Ginkgodium, Baiera, Rissikia were determined for first time in Cortaderita Formation. Al last, it is the first appointment of species Rienitsia arrondiana, Dicroidium dubium, Pachydermophyllum papillosum, Lepidopteris stormbergensis, L. africana, Delnortea abbottiae, Ginkgoites walckedensis, Sphenobaiera 
schenckii, S. sectina, Baiera cuyana, Ginkgodium nathorsti, Elatocladus planus, Rissikia media and Pseudoctenis longipinnata for Cortaderita. The finding of possibly assignable materials to Delnortea abbottiae, constitutes the first record of this species for Triassic.

In phylogenetic and evolutionary analysis, the anatomy of the Corystospermaceae, others related pteridosperms and the cycadales was studied in detail. A phylogenetic approach of Corystospermaceae stems taxa was realised. Furthermore, the evolution of corystosperm trunks was studied within the framework of Evo-Devo Biology. The four deviations from typical cambial activity displayed by corystosperms (differential, remanent, inverse and succesive) are linked to evo-devo events. All the types of evo-devo pathways can be invoked in the origin and divesification of these stems: heterochrony (paedomorphosis and peramorphosis) and heterotopy (homeosis and neoheterotopy).

The taphonomic study defined eight tafofacies. Clear taphonomic differences between two sections, are liked to local climatic changes in Cortaderita Formation, passing from subtropical subhumid-semiarid to subtropical semiarid.

Three autocthonous, successive petrified forests were studied throughout the two sections of Cortaderita Formation. Quantitative information of the forest (density, average distance between trees, height inferred from the diameter, biomass) together with the systematic and sedimentological studies, leads to reconstruct three paleocomunidades of evergreen subtropical seasonal to sclerophyll forests, with arboreal strata dominated by corystosperms, and developed in a fluvial environments.

The biostratigraphic analysis consisted of the comparation between paleofloristic content of Lower Section and Upper Section each other. A significant hiatus between Lower Section and Upper Section is not interpreted. The total paleoflora of Cortaderita Formation was compared with the paleofloras recognized for other formations from Argentina. Cortaderita Formation is correlationable with Potrerillos Formation, and it is referred to Middle Triassic. 


\section{INTRODUCCIÓN}

\section{II.1. Relevancia del problema}

La era Mesozoica se inicia hace $251 \pm 0,4$ millones de años (International Comission on Stratigraphy, 2008). El Triásico es su primer período, y se distingue por importantes cambios climáticos, geológicos y biológicos. La coalescencia de Pangea, las condiciones de casa cálida y el clima megamonzónico global provocaron eventos de extinción, especiación y migración de los organismos, y por consiguiente el establecimiento de una biota diferente a la del Paleozoico (Parrish, 1993; Spalletti et al., 2003). Debido a su singularidad, el estudio del período es de suma relevancia para comprender la evolución geológica y biológica de la Tierra.

En la Argentina, el Sistema Triásico posee una de las mejores exposiciones sedimentarias y representaciones de la biota en el mundo (Morel et al., 2003; Zamuner et al., 2001). Durante las últimas dos décadas el tratamiento interdisciplinario (geológico/paleontológico) permitió el progreso en el conocimiento de las floras triásicas y la inserción de la evolución de la flora dentro de una perspectiva temporal (Artabe et al., 2007a).

En ese sentido, los registros plantíferos de la Argentina presentan una gran ventaja respecto de las tafocenosis encontradas en el resto del Gondwana, puesto que se han descubierto y estudiado tres bosques permineralizados in situ -preservados en posición de vida- en la región Centro-Oeste del país (Artabe et al., 1995a, b, 2007b; Brea, 1995; Brea et al., 2006, 2008, 2009). La investigación efectuada sobre este tipo de asociaciones fosilíferas ha permitido determinar los hábitos de vida de las corystospermas y algunas coniferofitas primitivas, los dos grupos que constituyeron los estratos arbóreos de los bosques triásicos de la Argentina.

No obstante, se cuenta todavía con poca información actualizada en algunos depocentros, como por ejemplo la cuenca de Barreal-Calingasta. Asimismo, aún existen controversias acerca de la edad de las floras contenidas en las unidades litoestratigráficas presentes en ese área (cf. Spalletti et al., 1999; Stipanicic y Marsicano, 2002). De éstas, la Formación Cortaderita registra uno de los cuatro bosques fosilizados in situ del Triásico de la Argentina, del que sólo se tiene información preliminar (Artabe et al., 1995b; 2001a).

Por todo esto, fue seleccionada para realizar el presente trabajo de Tesis, con el fin de optar al título de Doctor en Ciencias Naturales, la paleoflora de la Formación Cortaderita, en la quebrada homónima y su bifurcación (quebrada de la Tinta), en la provincia de San Juan. 


\section{II.2. Objetivos}

Este trabajo tiene como objetivo principal profundizar en la comprensión de la evolución de la flora triásica de la Argentina, mediante el estudio de las tafofloras y sedimentitas de la Formación Cortaderita.

En particular, la investigación paleobotánica analizará los megafósiles, preservados como permineralizaciones de troncos e impresiones-compresiones de hojas, ramas y estructuras reproductivas. El estudio de las sedimentitas abarcará la observación de las relaciones estratigráficas y el examen de perfiles de detalle, para realizar una interpretación paleoambiental de las secuencias.

De esta manera, la presente contribución tiende a resolver cuestiones taxonómicosistemáticas, evolutivas y paleoecológicas, respecto de las especies, géneros y familias representadas. En cuanto a los aspectos sistemáticos, son descriptos y determinados nuevos ejemplares que se recolectaron en viajes de campañas, en los que participó quien escribe. También se revisarán los materiales fósiles estudiados en décadas pasadas (Frenguelli, 1944a; Stipanicic y Menéndez, 1949; Stipanicic y Bonetti en Groeber y Stipanicic, 1953; Stipanicic, 1955, 1957, 1972, 1979; Bonetti, 1963, 1968, 1972; Artabe et al., 1995a; Zamuner et al., 1999), bajo criterios sistemáticos actualizados. Con respecto al análisis paleoecológico, es necesario redefinir a las paleocomunidad presentes a la luz de los nuevos aportes.

Otro aspecto que se abordará es la evolución de las plantas diagnósticas para el Triásico de Argentina: las corystospermas. Los troncos de esta familia preservados en la Formación Cortaderita, son considerados los más primitivos de su linaje. Por ello, el estudio morfológico y anatómico de nuevos ejemplares recuperados y la incorporación de datos complemenarios es primordial para encuadrar las corystospermas en un contexto filogenético y evolutivo.

Asimismo, el análisis de los taxones tendrá el fin específico de asignar valor cronológico a los estratos plantíferos, mediante la correlación con otras sucesiones sedimentarias.

El análisis sedimentológico proveerá información fundamental sobre las condiciones paleoambientales y paleoclimáticas, que permitirá, junto a los datos paleoflorísticos, una interpretación integral de los ecosistemas que prosperaron en el Triásico de la Formación Cortaderita.

En consecuencia, el tema elegido abarca diversos aspectos fundamentales, tales como: la localización de los estratos fosilíferos en perfiles estratigráficos y sedimentológicos en escala de detalle; revisión y estudios sistemáticos de los leños permineralizados y de las 
impresiones e impresiones-compresiones, y su ordenamiento en un esquema clasificatorio actualizado; establecimiento de series de transformación y nuevas interpretaciones evolutivas, estudio tafonómico (análisis de las tafocenosis, su relación con las facies sedimentarias e interpretación de las posibles biocenosis originales) y paleoautoecológico (formas de vida y adaptaciones morfo-estructurales), análisis crono y bioestratigráfico (mediante la comparación con otras tafocenosis de la misma índole en secuencias triásicas argentinas).

\section{II.3. Ubicación geográfica}

El área estudiada se sitúa alrededor de los $69^{\circ} 23^{\prime} \mathrm{W}$ y de los $31^{\circ} 39^{\prime} \mathrm{S}$, en la Precordillera occidental sanjuanina, $4 \mathrm{~km}$ al Este-Sudeste del centro de la ciudad de Barreal, en el departamento de Calingasta, provincia de San Juan (Figuras II.1 y 2). Dicha zona se encuentra en la carta topográfica de 3169-III, en escala 1:250.000.

Todo el ámbito al Este del Río de Los Patos, entre las localidades de Barreal e Hilario, se caracteriza por una serie de quebradas en las que afloran sedimentitas triásicos. De Sur a Norte, éstas reciben las siguientes denominaciones de: quebrada de Un Salto o de los Cerros Colorados (=“del Salto"), quebrada de la Cortaderita -incluida la quebrada de la Tinta- (="de la Cortadera", "de Araya", “del Jarillal", “de la Cantera” y "de la Bentonita”), quebrada de Cepeda (=“de Un Salto"), quebrada Algarrobito, quebrada del Carrizal (=“ÁAroyo del Salto"), quebrada Agua de los Pajaritos (=“del Jarillal”) y quebrada El Alcázar. A la quebrada de la Cortaderita se accede desde el centro de la ciudad de Barreal, hacia el Este-Sudeste, por el camino que dirige hacia el

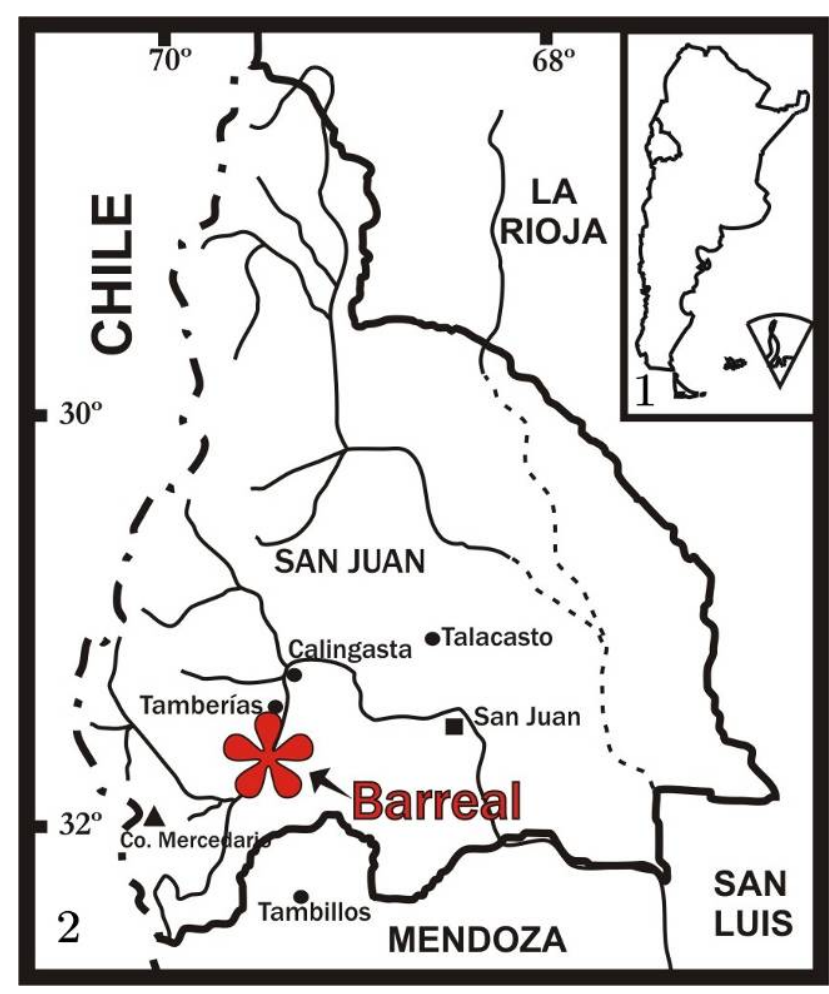

Cerro Colorado del Cementerio.

Figura II.1. Mapa de ubicación del área de Barreal, San Juan, Argentina. 1. Posición de la provincia de San Juan en un mapa de Argentina. 2. Mapa geográfico de la provincia de San Juan indicando la ciudad de Barreal. 

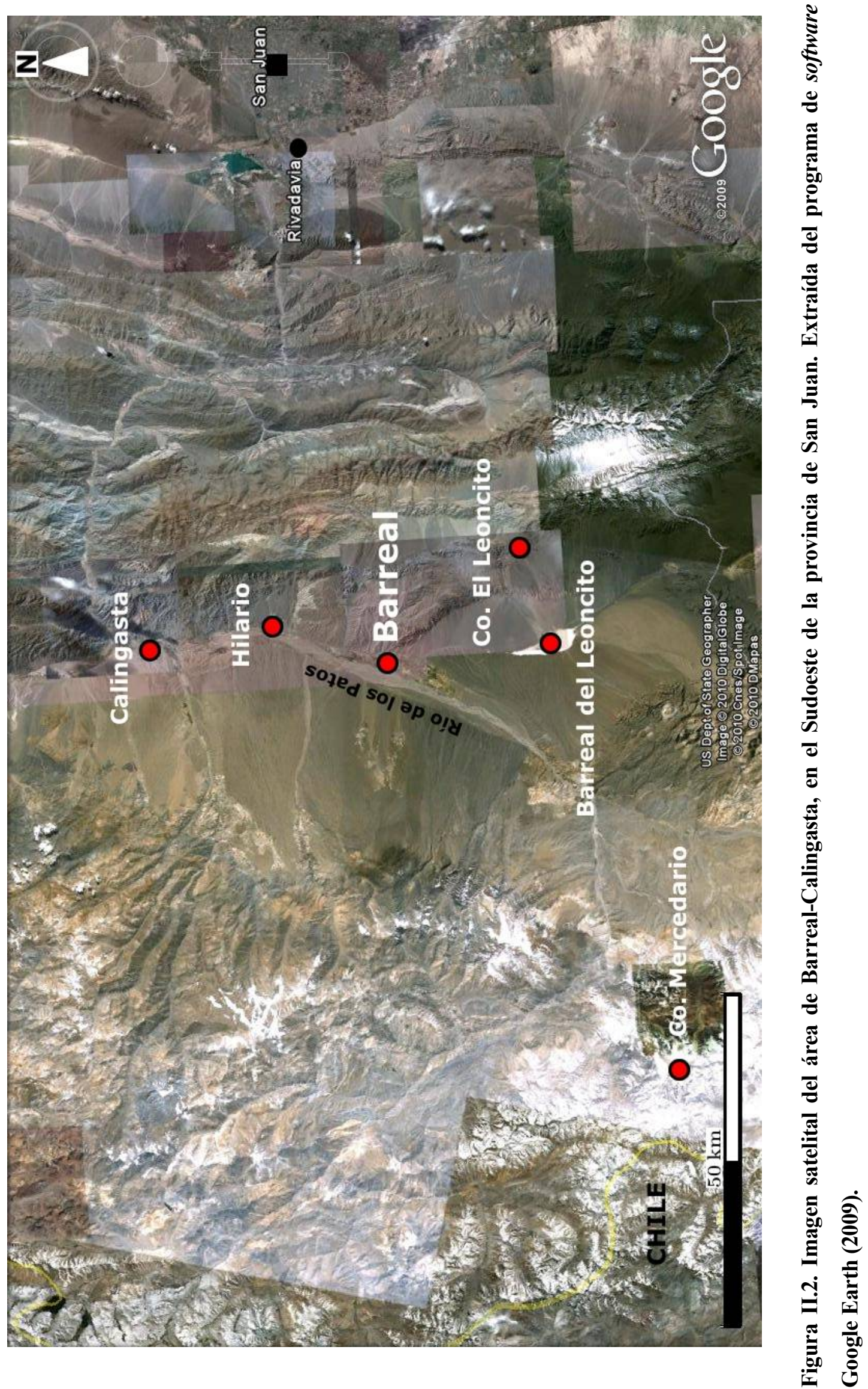


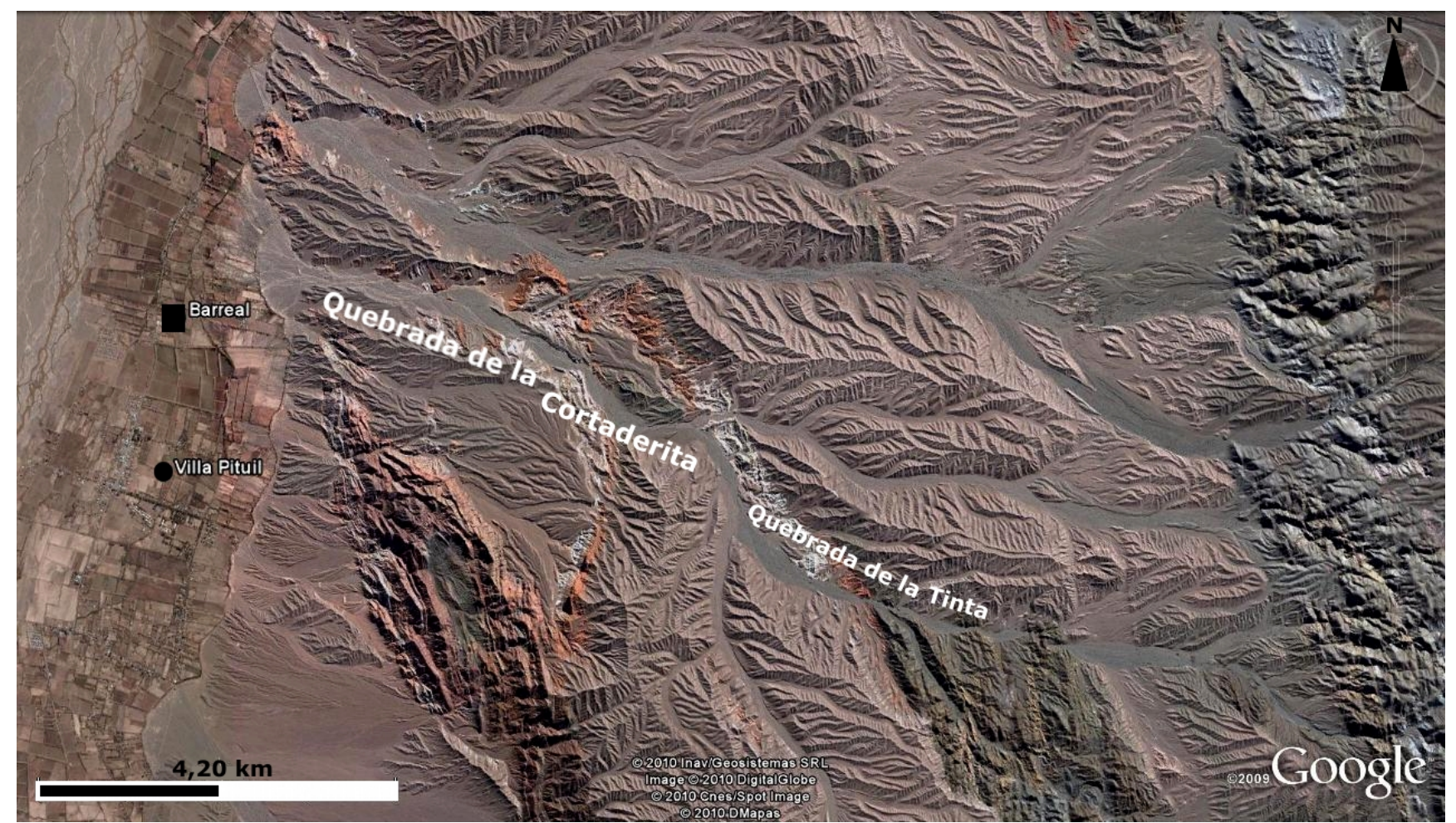

Figura II.3. Imagen satelital de las quebradas estudiadas en el área de Barreal. Extraída del programa de software Google Earth (2009).

Este estudio abarca las quebradas de la Cortaderita y de la Tinta (Figura II.3). Afloran en este sector sedimentitas y vulcanitas triásicas, las cuales albergan los estratos plantíferos y bosques in situ, que son objeto principal de este aporte. Los antecedentes más conspicuos al respecto, corresponden a Frenguelli (1944a), Stipanicic (1947, 1957, 1972, 1979, 1983), Bonetti (1963) y Artabe et al. (1995a, b, 2001a).

Este conjunto de rocas se encuentra fuertemente plegado (Figura II.4) y es conocido como Grupo Sorocayense. Está dividido, de base a techo, en tres unidades formacionales: Formación Barreal, Formación Cortaderita y Formación Cepeda (Mésigos, 1953; Groeber y Stipanicic, 1953), de las que fue estudiada la segunda.

Spalletti et al. (1999) y Spalletti (2001a) han reconocido una discontinuidad intraformacional en la Formación Cortaderita, representando un hiatus temporal, por lo que fue subdividida en: una Sección Inferior gris y una Sección Superior rosada. Estas dos secciones son altamente conspicuas en el campo (Figura II.5). 


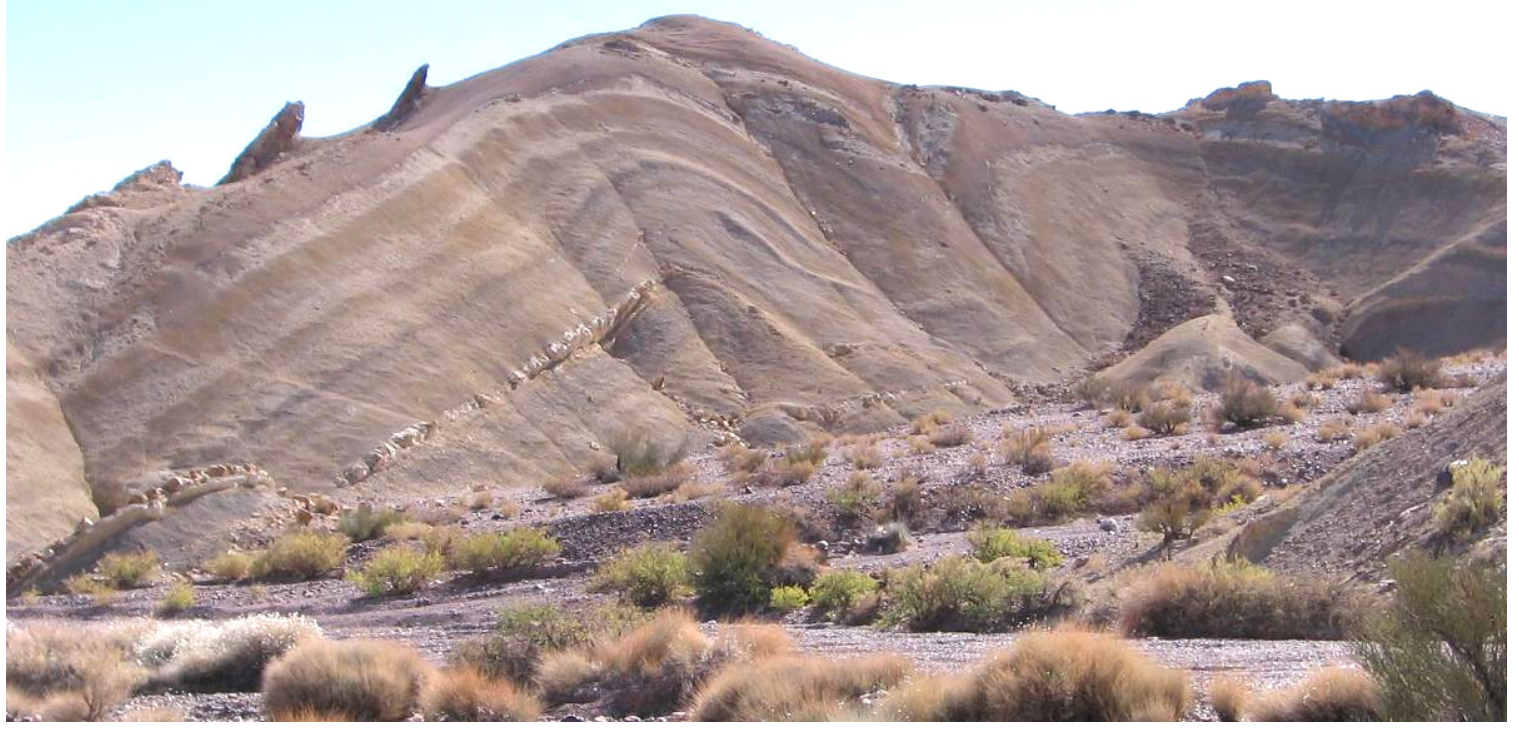

Figura II.4. Foto del paquete sedimentario triásico del Grupo Sorocayense, fuertemente plegado, en la quebrada de la Cortaderita.

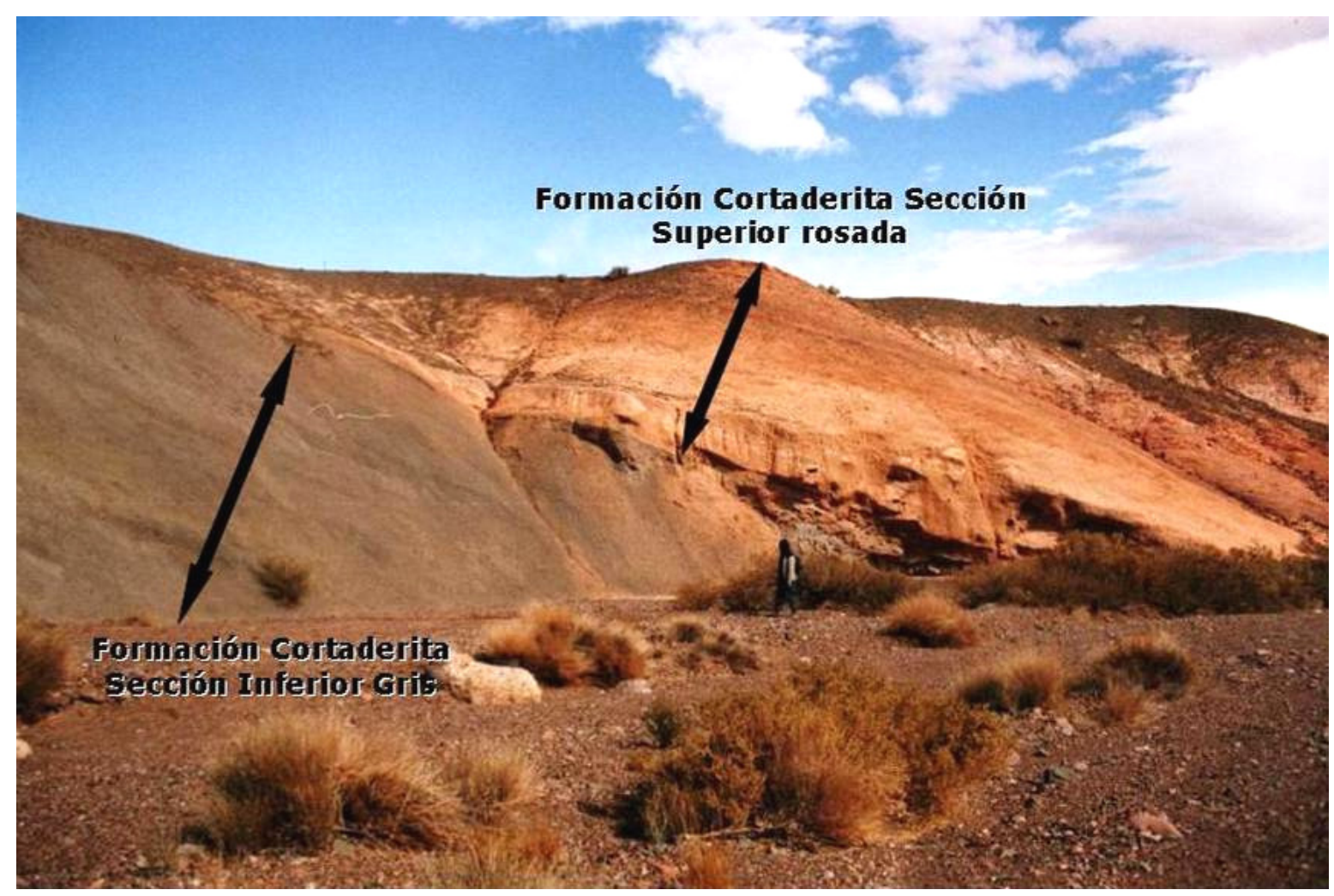

Figura II.5. Foto de la Formación Cortaderita en la quebrada homónima, mostrando su Sección inferior gris y su Sección Superior rosada. 


\section{ANTECEDENTES GEOLÓGICOS}

\section{III.1. EI hemigraben de la Precordillera Occidental sanjuanina}

El conjunto sedimentario triásico que aflora en la Precordillera occidental sanjuanina está localizado en dos sectores: Rincón Blanco (en la Sierra de Tontal) y Barreal-Calingasta (en el valle del Río de Los Patos) (Figura III.2). Las sedimentitas de Barreal-Calingasta asoman principalmente en dos áreas: en las cercanías de la ciudad de Barreal y en los alrededores de Hilario. La primera interpretación de estas rocas fue que habían sido depositadas en dos cuencas independientes (cuenca de Barreal y cuenca de Hilario) (Stipanicic, 1947; Zöllner, 1950). Posteriormente, Stipanicic (1957, 1972) planteó que estos dos depocentros estaban vinculados genéticamente y pertenecían a la misma cuenca de depositación, denominada cuenca de Barreal-Hilario (Stipanicic, 1957) o simplemente cuenca de Barreal (Stipanicic, 1972). Otros autores, por su parte, consideraron a las sedimentitas triásicas de la Precordillera sanjuanina como parte del relleno de una cuenca más abarcativa (Rolleri y Criado Roqué, 1968; Yrigoyen y Stover, 1970; Stipanicic, 1979, 1983; Strelkov y Álvarez, 1984; Kokogián y Mancilla, 1989; Kokogián et al., 1999, 2001; López Gamundí, 1994). Para Strelkov y Álvarez (1984), y Kokogián y Mancilla (1989), todos los registros triásicos argentinos comprendidos entre Barreal, en la provincia de San Juan, y el subsuelo del depocentro de General Alvear, en la provincia de Mendoza, se los puede reunir en una única cuenca llamada cuenca Triásica Mendocina-Sanjuanina (Strelkov y Álvarez, 1984) o cuenca Cuyana (Kokogián y Mancilla, 1989), constituida por las subcuencas de Alvear (Criado Roqué, 1979), Cacheuta (Rolleri y Fernández Garrasino, 1979), área de Rincón Blanco (Stipanicic, 1972) y la cuenca triásica de Barreal (Stipanicic, 1972).

Más recientemente, se ha interpretado que los depósitos del área de Barreal-Calingasta junto a los de Rincón Blanco representan el registro de un hemigraben con fuerte asimetría (López Gamundí, 1994; Barredo y Ramos, 1997), cuya rampa está ubicada hacia el Oeste y su margen fallado, con marcada subsidencia, hacia el Sudeste. De acuerdo a los autores, las sedimentitas del sector de Barreal-Calingasta fueron acumuladas en la rampa del hemigraben, esto es, el margen estable poco disturbado tectónicamente, y las del área de Rincón Blanco, en el margen tectónicamente activo. Esto explica las diferencias faciales existentes entre ambos conjuntos sedimentarios, las cuales ya habían sido señaladas por Stipanicic (1972, 1979, 2001, 2002). 


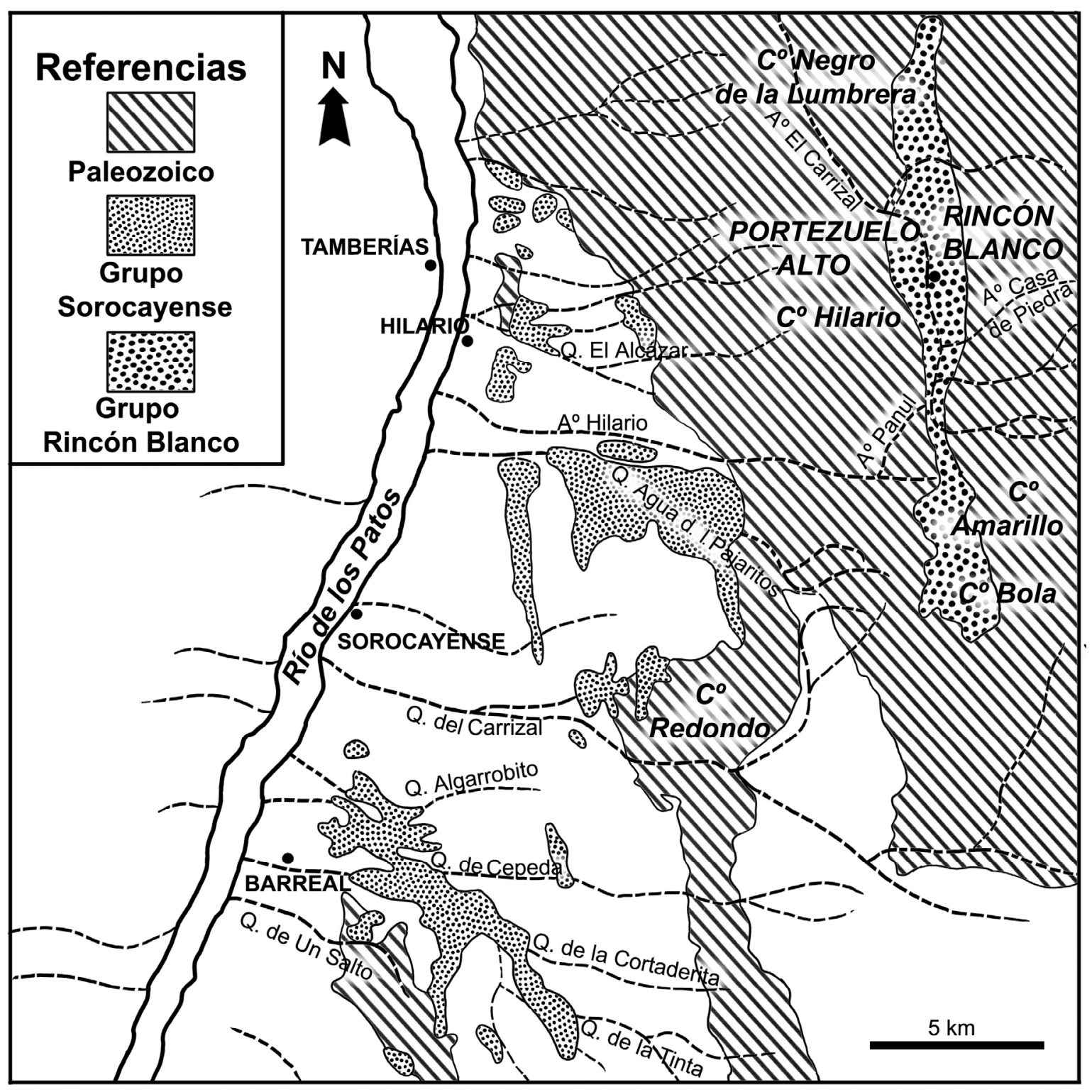

Figura III.1. Mapa geológico de la cuenca de Barreal-Calingasta. Redibujado de Kokogián et al. (2001). Dibujante: Jorge González.

Los depósitos de Rincón Blanco se diferencian de los de Barreal-Calingasta porque afloran en una franja más angosta, poseen un relieve mayor y la secuencia es considerablemente más potente y completa (López Gamundí, 1994; Stipanicic, 2002). Típicamente, las sedimentitas gruesas basales (fanglomerados) alcanzan un espesor más de diez veces mayor que en el margen pasivo del hemigraben (López Gamundí, 1994).

Las sucesiones triásicas de Barreal-Calingasta afloran en una ancha banda al Este de las localidades de Hilario, Sorocayense y Barreal, y poseen un escaso relieve relativo con baja tasa de subsidencia (Stipanicic, 1972; López Gamundí, 1994). Se componen de diversas facies sedimentarias silicoclásticas, con fuerte afinidad volcánica, interpretadas como sistemas 
depositacionales de: abanico y cono aluvial, fluvial entrelazado (gravoso y arenoso), fluvial efímero, fluvial meandroso de carga mixta o de alta sinuosidad, planicies con sedimentación piroclástica, lacustres hidrológicamente abiertos (holomícticos y meromócticos) y deltaicos de influencia fluvial (Spalletti, 2001a). Los siguientes párrafos se centrarán en este conjunto sedimentario, cuya área de depositación (el margen pasivo del hemigraben de la Precordillera occidental de San Juan) será mencionada como “cuenca de Barreal-Calingasta”.

\section{III.2. Las unidades triásicas de la cuenca de Barreal-Calingasta}

En la región de Barreal-Calingasta, la existencia de secuencias triásicas fue citada por primera vez por Stappenbeck (1910). Este autor describió en la "quebrada del Jarillal" (=quebrada del Agua de los Pajaritos) una sucesión alternada de margas y areniscas, de colores gris, verde y colorado, con vetas delgadas de andesita en su parte media e intercalaciones de capas de margas bituminosas, y de margas y areniscas con madera y plantas fósiles. Estableció que esta serie descansaba en discordancia sobre sedimentitas conglomerádicas paleozoicas, debajo de las areniscas rojas del Cretácico y recubierta parcialmente por detritos recientes. En cuanto al ambiente de sedimentación, Stappenbeck (1910) interpretó que las rocas pertenecían a depósitos terrestres o lacustres y les asignó una edad "rética" por su contenido paleoflorístico

Du Toit (1927a) observó la misma sucesión en Hilario y en las quebradas “del Jarillal” (=quebrada del Agua de los Pajaritos) y "del Salto" (=quebrada de Un Salto), la que asimiló a su "piso" IV (Trias-Rético o "Capas réticas") por la presencia de la "flora de Thinnfeldia". Además, mencionó una interlaminación de arcillas rosas y grisáceas, y areniscas y conglomerados rojos sobre esta secuencia, que pertenecían a su "piso" V correspondiente todavía al "Rético" (Frenguelli, 1948) o al Cretácico (Stappenbeck, 1910).

Heim (1945), en sus observaciones en los alrededores de Barreal, abandonó el término "Rético" y utilizó la denominación "Serie Triásica" para la sección formada por tobas, bentonitas y conglomerados con rodados de pórfido cuarcífero. Señaló que no se observaba la base de la serie, ya que desaparecía debajo de la terraza de la margen izquierda del río de los Patos. No obstante, citó cerca de la boca de la quebrada de Un Salto, las areniscas y los conglomerados rojos de la base de la serie en fuerte discordancia sobre rocas del techo del Carbonífero. De acuerdo, a Heim (1945) hacia el Oeste una gran falla cortó y hundió gran parte del relleno de la cuenca en su desarrollo.

Cuerda (1945) levantó un perfil del conjunto sedimentario de la quebrada de la Cortaderita, plegado en amplios anticlinales y sinclinales, y distinguió doce niveles: (1) 
pórfidos cuarcíferos, (2) bentonitas y tobas arcillosas, (3) arenas y gravas porfiríticas, (4) arcillo-esquistos y areniscas grises verdosas con troncos silificados, (5) tobas grises o blanquecinas con restos de plantas, (6) arcillo-esquistos tobíferos grises, (7) areniscas y tobas arcillosas pardas con plantas en la base, (8) areniscas y tobas arcillosas con intercalaciones lenticulares de conglomerados y bancos de areniscas entrecruzadas, (9) tobas arcillosas y cineríticas muy claras con intercalaciones arenosas, (10) conglomerados gruesos rojos, (11) areniscas rojas con capas arcillosas amarillas rojizas y (12) areniscas conglomerádicas rojas.

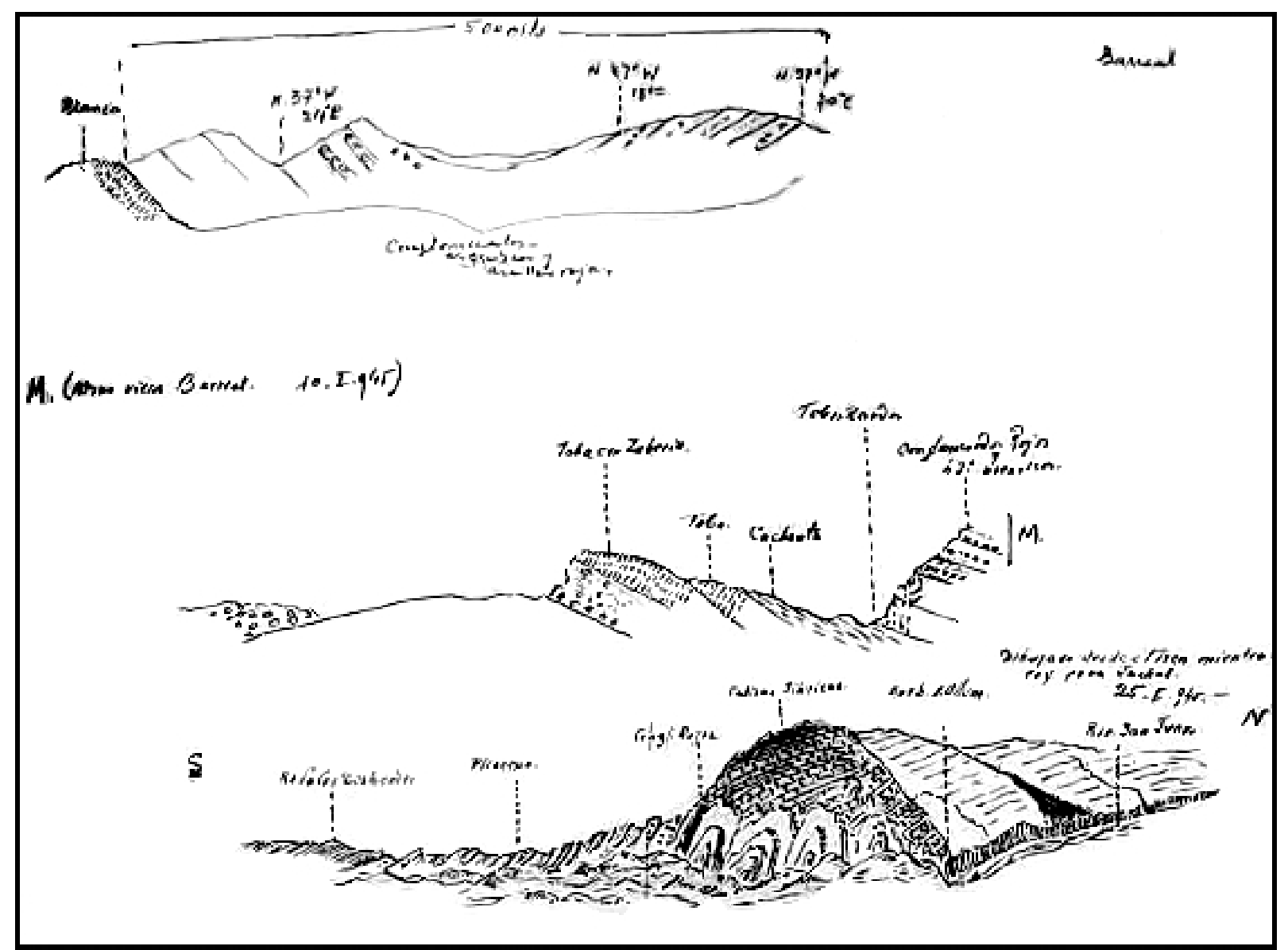

Figura III.2. Perfiles del paquete sedimentario aflorante en la localidad de Barreal. Modificado de Cuerda (1945).

Frenguelli (1948), en su compendio del "Rético" de la Argentina, comparó la columna de la cuenca de Barreal-Calingasta con la de Ischigualasto-Ischichuca. Según el autor, ambas constituían un conjunto de sedimentitas lacustres, que descansaban sobre un complejo eruptivo y que podían dividirse en cuatro "horizontes". En la quebrada de la Cortaderita, determinó un horizonte basal, correlacionado con los niveles 1, 2, 3, 4 y 5 del perfil de Cuerda (1945), y dividido en dos secciones, una inferior con predominio de psefitas y psamitas, con rodados lávicos y restos de Zuberia feistmanteli y una superior de arcillo-esquistos y tobas, 
con un nivel plantífero con abundantes restos de Z. zuberi (al igual que los "Estratos de Ischichuca"). Sobre el anterior, distinguió un horizonte conformado en su base por arcilloesquistos tobíferos y tobas arcillosas con un nivel plantífero de "Thinnfeldia" praecordillerae y Phyllotheca australis, y en su techo por areniscas conglomerádicas; y equivalente a los niveles 6, 7 y 8 de Cuerda (1945). Por encima de éste, describió el tercer horizonte, que se correspondía con el nivel 9 del perfil de Cuerda (1945) y estaba constituido por tobas cineríticas grises con una flórula de Dicroidium odontopteroides. Por último, reconoció un cuarto horizonte con areniscas y arcillas rojas sin fósiles, correlacionable a los niveles 10, 11 y 12 del perfil de Cuerda (1945).

Stipanicic (1947) dividió a la secuencia triásica de Barreal en cuatro "secciones" no equivalentes a los cuatro horizontes de Frenguelli (1948). Éstas eran, de base a techo: Sección Basal Conglomerádica o Triásico I, Sección Multicolor o Triásico II, Sección Arenosoconglomerádica superior o Triásico III y Triásico IV.

Groeber y Stipanicic (1953) se refirieron a estas sedimentitas con los nombres de Serie de Barreal y Serie de Hilario. En la Serie de Barreal reconocieron cuatro conjuntos de estratos, coincidentes con las cuatro secciones de Stipanicic (1947). De base a techo individualizaron a: los Estratos de Barreal, los Estratos de Cortaderita, los Estratos de Cepeda y los Estratos del Río de los Patos, que podían integrar con los anteriores una sola sección (Groeber y Stipanicic, 1953). Estas unidades fueron correlacionadas por estos autores con las de Cacheuta, de tal manera que los Estratos de Barreal eran considerados sincrónicos a los Estratos de las Cabras, los Estratos de Cortaderita eran coetáneos con los Estratos de Cacheuta y los Estratos de Potrerillos, y los Estratos de Cepeda (incluidos los Estratos del Río de los Patos) con los Estratos de Río Blanco. Tanto en Barreal como en Cacheuta podían diferenciarse tres grandes complejos litológicos bien distintivos por su composición: uno inferior, con conglomerados porfiríticos predominantes en su parte baja y términos más finos en su techo; el medio, con abundancia de elementos finos, arcillitas, areniscas y tobas; y el superior, integrado en casi su totalidad por areniscas gruesas y conglomerados de color rojo intenso y, constituyendo los complejos conocidos con los nombres de "Cretáceo" de Stappenbeck (1910) y de "estratos conglomerádicos del piso V" de Du Toit (1927) (Cuadro III.1).

Mésigos (1953) introdujo el nombre de Grupo Sorocayense para las rocas triásicas que afloran al Este de Barreal. Las unidades estratigráficas de esta cuenca fueron redefinidas como Formación Barreal, Formación Cortaderita y Formación Cepeda (Groeber y Stipanicic, 1953), para el sector de Barreal, y Formación Agua de los Pajaritos, Formación El Alcázar y 
Formación Hilario (Groeber y Stipanicic, 1953), para el sector de Hilario. Más tarde, el mismo autor correlacionó a las formaciones del sector de Barreal con las de Hilario, e incluyó a todas ellas en el Grupo Sorocayense (Stipanicic, 1979; Stipanicic, 1983). Este esquema estratigráfico es el que continúa vigente hasta hoy (Cuadro III.1). En cuanto a sus relaciones estratigráficas, el Grupo Sorocayense se apoya en discordancia de fuerte ángulo sobre sedimentitas paleozoicas (eopérmicas, carboníferas, devónicas, silúricas y ordovícicas) y diabasas devónicas, en el área de Barreal, y sobre "esquistos", grauvacas y diabasas del Paleozoico Inferior, en Hilario (Stipanicic, 1972).

Stipanicic $(1972,1979$, 1983) propone las siguientes correlaciones entre estas Formaciones: Barreal con Agua de los Pajaritos y parte inferior de El Alcázar; Cortaderita con la parte media y superior de El Alcázar; y Cepeda con Hilario. A su vez, éstas fueron nuevamente correlacionadas con la sucesión de Cacheuta (Grupo Uspallata), pero con modificaciones. La Formación Barreal era equivalente a la Formación Río Mendoza, antes considerada como parte de la formación suprayacente (Groeber y Stipanicic, 1953; Stipanicic, 1957) y Formación Las Cabras; la Formación Cortaderita con la Formación Potrerillos; y Cepeda con Río Blanco. Con respecto a la edad del Grupo Sorocayense, fue designado por Stipanicic (1972) y Stipanicic et al. (1996) al lapso Mesotriásico Tardío a Neotriásico Tardío, sobre la base del material fósil (micro y megaflora) y de las correlaciones estratigráficas (Cuadro III.1).

Por otro lado, Baraldo y Guerstein (1984) presentaron otra propuesta estratigráfica diferente para el área de Hilario, identificado cuatro unidades formacionales, de base a techo: Agua de los Pajaritos, Monina, El Alcázar e Hilario (Cuadro III.1). Proponen que las correlaciones con las formaciones del sector de Barreal son las que siguen: Agua de los Pajaritos con la parte inferior y media de Barreal, Monina con la parte superior de Barreal, Hilario con la parte inferior de Cortaderita, y El Alcázar con la parte superior de Cortaderita y Cepeda.

Más recientemente, Spalletti (1995, 2001a), y Spalletti et al. (1999) han reconocido una importante discontinuidad intraformacional en la Formación Cortaderita, evidenciada por cambios abruptos de facies y una significativa reorganización paleogeográfica en la cuenca, reflejada por los cambios en las paleocorrientes; por lo que subdividieron a la formación en dos secciones: una Inferior gris y otra Superior rosada (Cuadro III.1).

Spalletti et al. (1999) argumentaron, sobre la base de los datos plantíferos, que el Grupo Sorocayense no era correlacionable estrictamente con el Grupo Uspallata. Por el contrario, la paleoflora presente en la Formación Barreal vinculaba a ésta con la Formación 
Ischichuca de la cuenca de Ischigualasto-Villa Unión. No obstante, las asociaciones fosilíferas de la Sección Inferior de la Formación Cortaderita sí eran comparables con las de Potrerillos, mientras que la Sección Superior era correlacionada con la Formación Cacheuta. Los mismos autores le otorgaron la edad mesotriásica temprana-neotriásica tardía al Grupo Sorocayense. Esta unidad descansaba en discordancia angular sobre sedimentitas carboníferas y eopérmicas del Grupo Pituil, y era cubierta, en forma también discordante, por sedimentitas cuaternarias (Kokogián et al. ,1999; Spalletti, 2001).

Spalletti (1995, 2001a) propuso un modelo de sedimentación para el Grupo Sorocayense, estableciendo tres secuencias depositacionales (=SD), cuyos límites no siempre coincidían con los de las unidades litoestratigráficas. La SD 1 está representada en la Formación Barreal, la Sección Inferior de la Formación Cortaderita, en parte de la Formación Agua de los Pajaritos, y en la Formación El Alcázar. Comienza con un sistema fluvial entrelazado gravo-arenoso y un corto episodio lacustre, con una importante actividad volcánica explosiva, manifestada por depósitos piroclásticos de flujo y caída en la región de Hilario. Esta secuencia culmina con el desarrollo regional de sistemas lacustres holomícticos y meromícticos en los que se registran episodios de progradación deltaica. La SD 2, presente en la Sección Superior de Cortaderita y en la Formación Hilario, se asienta sobre una marcada discontinuidad estratigráfica (intra-Formación Cortaderita y en el límite entre El Alcázar e Hilario), y está formada por depósitos de un sistema fluvial entrelazado arenoso, asociado a planicies con dominio de acumulaciones de caída piroclástica. La SD 3, constituida por las capas rojas de la Formación Cepeda, se caracteriza por depósitos fluviales proximales, producto de procesos de reactivación tectónica y de un posible cambio climático con tendencia a la desecación.

Por su parte, Stipanicic (2002) cuestionó la postura de Spalletti (2001a) y Spalletti et al. (1999) en cuanto a la edad y correlación de las formaciones del Grupo Sorocayense, y refutó la presencia de una discontinuidad tan importante intra-Formación Cortaderita.

\section{III.3. EI Triásico en la quebrada de la Cortaderita}

En la quebrada de la Cortaderita se encuentra la sección más representativa y completa del Grupo Sorocayense, la que fue objeto de gran cantidad de estudios acerca de la estratigrafía, sedimentología y paleoflora (Stappenbeck, 1910; Du Toit, 1927a; Stipanicic, 1947, 1972, 1979; Stipanicic y Menéndez, 1949; Groeber y Stipanicic, 1953; Menéndez, 1956; Bonetti, 1963, 1968, 1972; Stipanicic y Bonetti, 1965, 1969; Lutz y Herbst, 1992; Artabe et al, 1995a, b; Spalletti, 1995, 2001a; Zamuner et al., 1999). 


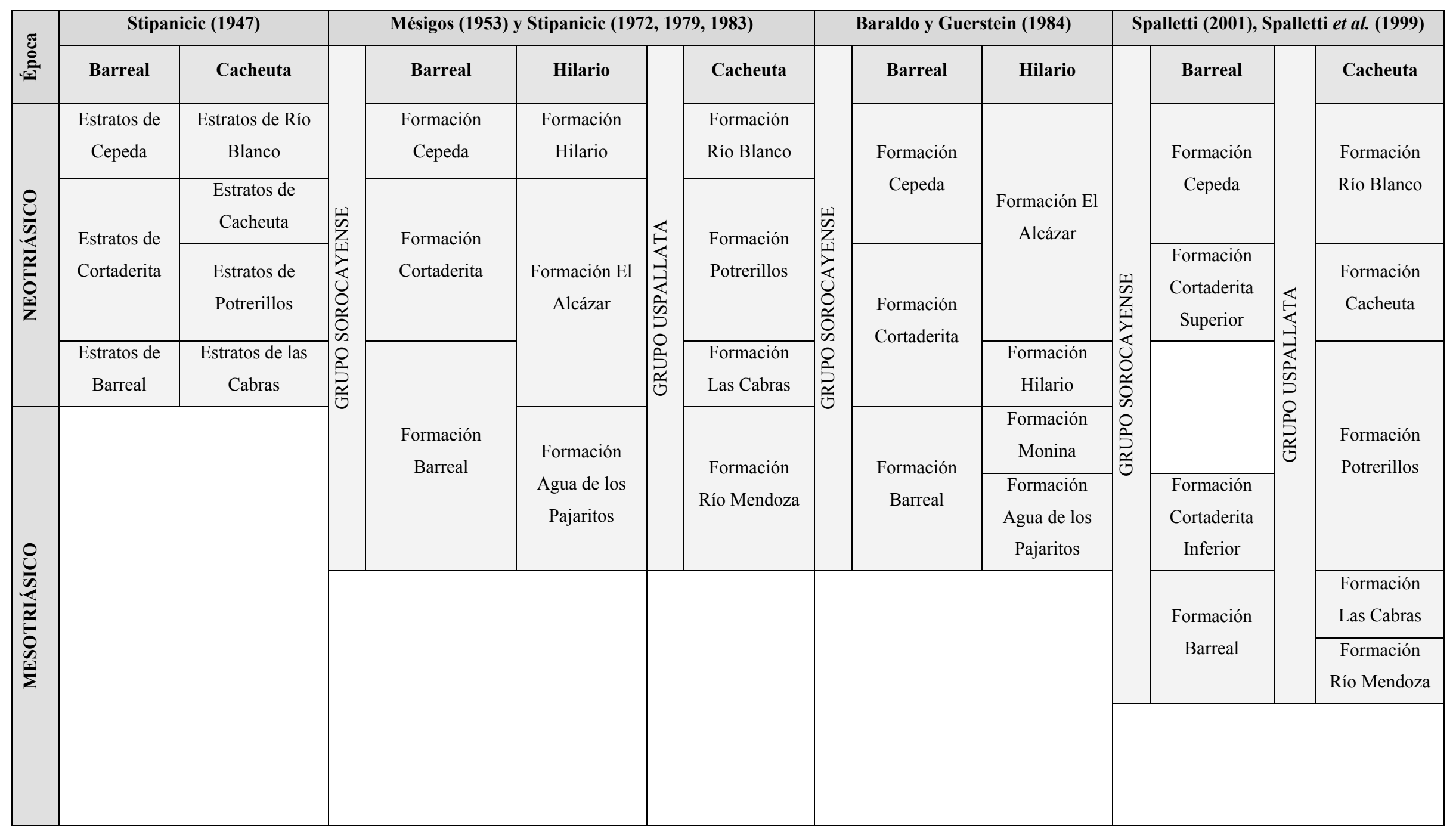

Cuadro III.1. Diferentes propuestas litoestratigráficas para la columna sedimentaria de Barreal-Calingasta y sus correlaciones con unidades de otras cuencas triásicas argentinas. 
La sucesión triásica de la quebrada de la Cortaderita alcanza un espesor total de más de 672 metros. Descansa en discordancia angular sobre areniscas y lutitas eopérmicas y carboníferas, y es cubierta parcialmente por rodados cuaternarios. Las capas triásicas tienen rumbo $\mathrm{N} 15^{\circ} \mathrm{E}$, están muy bien recortadas por la erosión, se exponen repetidas veces a causa de las suaves ondulaciones sinclinales y anticlinales que los afectan, y presentan varios estratos con plantas fósiles (ver Figura II.4) (Stappenbeck, 1910; Groeber y Stipanicic, 1953; Stipanicic, 1972).

La Formación Barreal, unidad basal del Grupo, posee un espesor de 180 a 216 metros en la quebrada. Se compone de 33 "bancos" (Stipanicic, 1972, 1979; Bonetti, 1963) de 0,10 a 100 metros de espesor, cuya litología es silicoclástica, volcaniclástica y piroclástica. Comienza con un conjunto basal muy potente de coloración rojiza constituido por conglomerados, areniscas con estratificación entrecruzada y tobas, en menor proporción. Una falla corta el perfil que continúa con areniscas, fangolitas rojizas y grises, en muchos casos tobáceas, con importantes niveles plantíferos de impresiones. Luego se intercalan bancos conglomerádicos y hacia arriba continúan las fangolitas con niveles plantíferos. Esta secuencia ha sido interpretada como un sistema fluvial gravoso-arenoso con intercalaciones lacustres (Spalletti, 1995, 2001a).

La Sección Inferior de la Formación Cortaderita contacta con la Formación Barreal mediante una superficie interpretada como el límite entre dos sistemas lacustres diferentes (Spalletti, 2001a). Esta sección alcanza un espesor de 41 metros (Spalleti, 2001a) o 56 metros (Stipanicic, 1972). Está integrada fundamentalmente por fangolitas grises y verdosas, de alto contenido de bentonita, con areniscas intercaladas. Las fangolitas contienen varios niveles con plantas fósiles (impresiones, impresiones-compresiones y permineralizaciones) y un nivel de troncos in situ (Artabe et al., 1995a, b). El ambiente de sedimentación inferido es el de un lago meromíctico (Spalletti, 1995, 2001a).

La Sección Superior de la Formación Cortaderita está separada de la Inferior por una discordancia regional, propuesta por Spalletti et al. (1999) y Spalletti (2001a), evidenciada en un cambio abrupto en las facies y en el rumbo de las paleocorrientes. Por otro lado, Stipanicic (2002) no reconoce esa discontinuidad. Esta sección presenta un espesor de 120 metros (Spalletti, 2001a) a 160 metros (Stipanicic, 1972). Se compone de areniscas y conglomerados con estratificación entrecruzada, tobas y algunos bancos de fangolitas. Contiene un nivel plantífero con impresiones, y es interpretada como un sistema fluvial entrelazado arenosogravoso (Spalletti, 1995, 2001a). 
En discordancia erosiva se apoya la Formación Cepeda, que alcanza un espesor de más de 240 metros en algunos sectores (Stipanicic, 1972, 1979). Está constituida por conglomerados y areniscas masivas, inferidas como parte de un abanico aluvial, que continúan con fangolitas y areniscas, de un sistema fluvial efímero. Hacia el techo, prosiguen los conglomerados y areniscas, en este caso, mayormente con estratificación entrecruzada, interpretados como un sistema fluvial gravoso-arenoso (Spalleti, 2001a). En esta formación se ha citado la presencia de troncos permineralizados (Herbst, 1995). 


\section{ANTECEDENTES PALEOBOTÁNICOS}

\section{IV.1. Reseña del estudio de las megafloras triásicas en la Argentina}

A Darwin (1846) se le debe la primera cita de la presencia de plantas fósiles triásicas en el territorio argentino. Este autor atribuyó al Terciario los troncos de "Araucarites" de Agua de la Zorra en el Paramillo de Uspallata, provincia de Mendoza. Actualmente estos ejemplares son referidos a la especie Agathoxylon (=Araucarioxylon) protoaraucana (Brea) Gnaedinger et Herbst 2009 (Brea, 1995, 1997).

Varias décadas más tarde, Geinitz (1876) estudió las plantas fósiles, escamas de peces (Semionotus) e invertebrados (Estheria) que recolectara Stelzner en Marayes, provincia de San Juan. Los restos de plantas fueron asignados por Geinitz (1876) al Retiano (Triásico Superior) debido a que estaban relacionados con la "Flora de Thinnfeldia" del hemisferio Norte. Por su parte, Stelzner (1885) recorrió la zona de El Challao-San Isidro, en el Noroeste de Mendoza, y comprobó la presencia de tallos de helechos y cycadales, junto a impresiones de frondes. Zuber (1889) encontró niveles con restos vegetales en el cerro Cacheuta, provincia de Mendoza, en la localidad de "Minas de Petróleo" (hoy puesto Míguez), siendo el primero en presentar una lista florística de esa región. Szajnocha (1889) efectuó las determinaciones de los restos enumerados por Zuber (1889) y consideró que esta flora pertenecía al Triásico Superior. Entre los taxones de la lista de Zuber (1889) cabe nombrar a Cardiopteris zuberi Szajnocha 1889, especie emblemática del Triásico gondwánico, que posteriormente fuera combinada por Frenguelli (1944a) como Zuberia zuberi.

Durante los años siguientes, el avance de los conocimientos se fue acentuando debido a nuevos hallazgos de plantas fósiles, especialmente en la Precordillera Mendocina y Sanjuanina, por parte de geólogos y mineros, profesionales o aficionados, como AvéLallemant, Bodenbender, Kurtz y Stappenbeck. Avé-Lallemant (1890) halló restos de "Pecopteris" (=Dicroidium) odontopteroides en las lutitas de la región de Paramillo de Uspallata. Bodenbender (1902) contribuyó con la recolección de fósiles en Salagasta, 20 km al Norte de la ciudad de Mendoza. Stappenbeck (1910) encontró los horizontes plantíferos del área de Barreal-Calingasta, provincia de San Juan. Kurtz (1893, 1902, 1921) se encargó no sólo del hallazgo de ejemplares fósiles sino de la descripción y la determinación de casi la totalidad de los taxones triásicos encontrados por los autores anteriormente citados. En 1902 Kurtz brindó una lista de ellas, a la vez que en su Atlas de plantas fósiles editado en 1921 ilustró abundante material correspondiente casi a cuarenta taxones, entre los que se destacan 
las especies de Cladophlebis y corystospermas asignables a los géneros Dicroidium, Xylopteris y Zuberia.

Du Toit $(1927 \mathrm{a}, \mathrm{b})$ realizó comparaciones geológicas, estratigráficas y paleontológicas entre las secuencias triásicas de Sudamérica, Sudáfrica y Australia. Demostró grandes similitudes entre las floras del Oeste argentino, del Cabo, del Este de Australia y Tasmania, y consideró que su "piso" o Stage IV, al cual eran asignadas las rocas portadoras de plantas fósiles, podía ser referido al Triásico Superior (Keuper) en vez de al Rético. En su síntesis acerca de los afloramientos del Stage IV, Du Toit (1927a) señaló la presencia de floras fósiles en varias localidades de la Argentina. En la región de Marayes-El Carrizal, Sudeste de la provincia de San Juan, citó la presencia de "Thinnfeldia" junto a tallos calcificados de coníferas. En la Sierra de Cerro Blanco, en la región de Ischigualasto- Villa Unión, San Juan, mencionó el registro de troncos del tipo “Araucariano”. En el área de Barreal-Calingasta hizo referencia a niveles plantíferos que incluían restos de frondes ("Thinnfeldia", Taeniopteris, etc.) y madera silicificada. En la región del Alto Paramillo de Uspallata señaló la abundante cantidad de troncos de coníferas (probablemente "Dadoxylon") en posición de vida y el registro de otros restos de plantas asignados a "Thinnfeldia", Taeniopteris, Baiera, entre otros. Además, destacó la abundancia de impresiones en las regiones de El Challao-San Isidro, Cerro Cacheuta y Potrerillos (Mendoza), entre ellas "Thinnfeldia”, Baiera, Cladophlebis, "Stenopteris" (=Xylopteris), Glossopteris (?), Marattiopsis y equisetales.

En las siguientes décadas, sobresalió la obra de Frenguelli, que significó un aporte fundamental en el desarrollo de la estratigrafía y la paleobotánica del Triásico local. Frenguelli (1937) estudió la abundante flora fósil de Paso Flores, provincia de Río Negro. En los años subsiguientes se destacaron su publicación sobre los géneros atribuidos a la "Serie de Thinnfeldia" (1943) en la que instauró el género Zuberia, la revisión de las especies de Zuberia (1944a) y la revisión del género Cladophlebis (1947). En 1948 Frenguelli realizó una contribución pionera de detalle que contemplaba la estratigrafía, geología y paleontología de la cuenca Ischigualasto-Villa Unión y su comparación con otras cuencas triásicas argentinas. En 1944a y 1948 discriminó las listas florísticas de cada nivel plantífero de BarrealCalingasta. En sus trabajos realizados entre 1937 y 1947 dio a conocer un gran número de integrantes de las floras triásicas de la cuenca Cuyana, cuyos datos fueron resumidos en su síntesis de 1948, estableciendo la distribución de las especies en niveles, para las localidades de Potrerillos y Cacheuta.

Luego de la obra de Frenguelli, sobrevinieron otros trabajos de síntesis acerca el Sistema Triásico de la Argentina, como los de Groeber y Stipanicic (1953) y Stipanicic 
(1957), en los que se ofrecían listas florísticas para cada una de las cuencas. Estudios más detallados sobre estas floras fueron realizados por Stipanicic (1947, 1955), Stipanicic y Menéndez (1949), Menéndez (1951), Archangelsky (1958, 1965, 1968), Bonetti (1963, 1966a, b, 1968, 1972), Herbst (1963), Bonetti y Herbst (1964), Stipanicic y Bonetti (1965, 1969), entre otros. Asimismo, se efectuaron los primeros análisis xilológicos en permineralizaciones de coníferas, cycadales y corystospermas, por parte de Menéndez (1951, 1956), Archangelsky y Brett (1961, 1963), Bonetti (1966b), Brett (1968). Entre estos aportes, cabe destacar que en su tesis inédita Bonetti y en sus trabajos posteriores (Bonetti, 1966a; Stipanicic y Bonetti, 1969) propuso nuclear los taxones foliares de las corystospermas. De esta manera fusionó a los géneros Zuberia, Johnstonia y Dicroidium, considerando como válido al último, y asimiló a "Dicroidium feistmanteli" a las especies Z. zuberi, Z. feistmanteli y Z. barrealensis. Esta postura fue seguida por otros investigadores argentinos como Archangelsky (1968). Le corresponde a este último, el mérito de haber demostrado que algunos troncos del Triásico argentino (Rhexoxylon) podrían vincularse con el género Dicroidium. El desarrollo de esta línea de investigación permitió ratificar el rol dominante de las corystospermas y coniferofitas en los estratos arbóreos de las paleocomunidades (Stipanicic, 2001).

Posteriormente, se realizaron nuevas compilaciones de las floras triásicas argentinas, entre las que cabe citar a las de Stipanicic $(1972,1979,1983)$ y Stipanicic y Bonaparte (1972, 1979). Otros autores llevaron a cabo revisiones críticas sobre taxones triásicos. Baldoni (1972, 1980a) evaluó los géneros Lepidopteris y Xylopteris; Herbst (1971, 1979a) se encargó de Cladophlebis y Asterotheca; Petriella (1979, 1980, 1983) hizo lo propio sobre las corystospermas; Arrondo y Petriella (1982) revisaron el género Goeppertella; y Artabe (1990) revalidó el género Zuberia.

En las últimas dos décadas se le dio otro enfoque a los estudios paleobotánicos, ya que además de la sistemática adquirieron un interés fundamental la tafonomía y la paleoecología sensu stricto. Toda la información paleoflorística comenzó a ser analizada en conjunto con los estudios faciales y tectofaciales, en los análisis sobre evolución paleoambiental de las distintas cuencas triásicas. En tal sentido, son destacables las contribuciones de Artabe (1984, 1985, 1986) y Labudía et al. (1995) sobre la tafoflora del área Los Menucos, provincia de Río Negro; Artabe et al. (1994a), Ganuza et al. (1995) y Morel et al. (1992, 2000) acerca de las floras del área de Paso Flores, provincias de Río Negro y Neuquén; Jalfin y Herbst (1995) y Gnaedinger y Herbst (1998a, b, 1999) de la flora del Grupo El Tranquilo, Santa Cruz; Artabe et al. (1999a) sobre el depocentro de Malargüe, Mendoza; Morel (1991, 1994) y Morel et al. 
(2010) acerca de la tafoflora del cerro Cacheuta; Brea (1995, 1997, 2000), Brea y Artabe (1999) y Brea et al. (2008, 2009) sobre el bosque petrificado de Agua de la Zorra; Artabe et al. (2007b), de la tafoflora de Potrerillos, Mendoza; Ganuza et al. (1998) acerca de la flora de Hilario-Agua de los Pajaritos, San Juan; Zamuner (1991), Bodnar y Artabe (2005, 2007), Crisafulli y Lutz (2008) y Arce y Lutz (2010), de la flora de la cuenca de Ischigualasto-Villa Unión; Arce y Lutz (2006), en la región de Marayes; Ottone (2006), del Grupo Rincón Blanco, en San Juan; y Stipanicic (2007) sobre hallazgos de hojas de Dicroidium en el subsuelo del depocentro de Beazley en San Luis.

Deben ser destacados los registros de nuevos taxones de troncos permineralizados de corystospermas: Rhexoxylon sp. (Lutz y Herbst, 1992); Tranquiloxylon Herbst et Lutz 1995; R. brunoi Artabe, Brea et Zamuner 1999b; Cuneumxylon Artabe et Brea 2003; Elchaxylon Artabe et Zamuner 2007; coníferas: Protocircoporoxylon marianaensis Zamuner et Artabe 1994, Agathoxylon (=Araucarioxylon) protoaraucana (Brea) Gnaedinger et Herbst 2009 (Brea, 1995, 1997), gimnospermas incertae sedis: Scalaroxylon menendezii Artabe, Spalletti, Bodnar et Morel 2009, y filicofitas: Millerocaulis stipabonettii Herbst 1995. También se han encontrado nuevos taxones sobre la base de impresiones e impresiones-compresiones, entre las que cabe nombrar a Nododendron suberosum Artabe et Zamuner $1991 \mathrm{y}$ Neocalamostachys arrondoi Brea et Artabe 1999 (equisetales), Scytophyllum bonettiae Zamuner, Artabe et Ganuza 1999 (peltaspermácea), Santaecruzia hunickenii Gnaedinger et Herbst 1998b (cycadofita). Estos nuevos hallazgos han proporcionado información para el entendimiento de la biodiversidad florística triásica.

A su vez, los avances en los estudios cuticulares (Artabe et al., 1994b; Artabe y Stevenson, 1999) y anatómicos (Zamuner, 1991; Artabe et al., 1999b; Artabe y Brea, 2003) han contribuido a reinterpretar y resolver las relaciones sistemáticas y las interpretaciones paleoautoecológicas.

En los últimos años, y a la luz de los recientes descubrimientos, se han realizado trabajos en los que se ha propuesto un ordenamiento de las floras triásicas en tiempo y espacio: la biozonación paleoflorística de Spalletti et al. (1999), los eventos florísticos de Morel et al. (2003), las provincias fitogeográficas de Artabe et al. (2003), entre otros. Además, se han publicado nuevas síntesis del Sistema Triásico, en las que se contempló a la flora desde una perspectiva más moderna (Kokogián et al., 1999; Artabe et al., 2001b, 2007a; Zamuner et al., 2001; Stipanicic y Archangelsky, 2002). 


\section{IV.2. Contribuciones al conocimiento de la paleoflora de la cuenca de Barreal- Calingasta}

Stappenbeck (1910) fue el primero en presentar una lista de plantas fósiles de esta región, las que habían sido recolectadas por él en "margas de piedra" de la "quebrada del Jarillal" (actualmente conocida como quebrada del Agua de los Pajaritos) y determinadas por Kurtz. En dicha lista enumeró, entre otras especies, a: Cladophlebis mesozoica, "Sphenopteris" (=Xylopteris) elongata, "Thinnfeldia" odontopteroides. var. lancifolia (=Dicroidium lancifolium), T. odontopteroides var. zuberi (=Zuberia zuberi), "Oleandrium mareyesiacum" (=Yabeiella mareyesiaca), “O. brackebuschianum” (=Yabeiella brackebuschiana), "Baiera argentinae var. major” (=Sphenobaiera argentinae).

Du Toit (1927a, b) indicó la presencia de la Flora de "Thinnfeldia" en las quebradas del Agua de los Pajaritos y de Un Salto, citando a los géneros "Thinnfeldia”, Taeniopteris, Baiera, Cladophlebis, "Phaenicopsis" y "Dadoxylon”. Encontró similitudes entre esta flora y floras de Australia y África. Advirtió que Taeniopteris carruthersi y T. mc'clellandi, especies conocidas para Queensland y Rhodesia del Sur (hoy República de Zimbabue), habían sido descubiertas también en Barreal-Calingasta. Otras afinidades fueron la presencia de Cladophlebis goeppertiana tanto en Barreal-Calingasta como en Natal (Sudáfrica), las formas referidas a "Sphenopteris" (=Xylopteris) elongata y "Podozamites elongatus" (=Heidiphyllum elongatum), conocidas para Barreal-Calingasta, otras regiones de Argentina, Sudáfrica y Australia.

Frenguelli (1944a) estudió las formas atribuidas a Zuberia recolectadas en la región de Barreal, además de las provenientes de otras localidades de la Argentina. Pertenecían a la cuenca de Barreal-Calingasta ejemplares de Zuberia feistmanteli, Z. zuberi y Z. barrealensis.

Posteriormente, Frenguelli (1948) estableció y describió los niveles plantíferos en las quebradas de la Cortaderita y de Un Salto, basándose en los perfiles levantados por Heim (1945) y Cuerda (1945). El nivel más antiguo de la serie triásica de Barreal se encontraba en areniscas tobáceas y tobas granulosas rosadas que se apoyaban sobre los conglomerados rojos basales. De éste procedían los restos de Zuberia feistmanteli estudiados por él en 1944a. El siguiente nivel plantífero fue hallado en tobas grises o blanquecinas, y yacía por debajo de arcillo-esquistos y areniscas grises verdosas con troncos silicificados. Frenguelli (1948) lo subdividió en una zona inferior, de tobas arcillosas gris clara estratificadas portando gran cantidad de impresiones de Zuberia zuberi y más raras de Baiera cuyana, y una superior, de tobas cineríticas arcillosas grises estratificadas con abundantes impresiones de Johnstonia stelzneriana y menos frecuentes Z. zuberi, Z. barrealensis, "Barrealia” (=Saportaea) 
dichotoma, "Barrealia" (=Saportaea) flabellata, Chiropteris barrealensis y restos indeterminables. El nivel plantífero suprayacente se encontraba a 200 metros verticales del anterior y correspondía al nombrado por Du Toit (1927a). Se componía de arcillo-esquistos, areniscas y tobas arcillosas pardos con numerosos restos vegetales, entre los que Frenguelli pudo reconocer las especies que ya habían sido mencionadas por Heim (1945): Phyllotheca australis, Equisetites fertilis, Yabeiella mareyesiaca, Cardiopteridium cyclopteroides, "Thinnfeldia” (=Pachydermophyllum) praecordillerae, Desmiophyllum sp., Xylopteris elongata, Lepidanthium sporiferum. Además, mencionó la probable existencia de un cuarto nivel más alto, quizá dentro de un conjunto de tobas (nivel 9 de Cuerda, 1945), basándose en el hecho de que entre los vegetales que Stappenbeck incluía como procedentes de la "quebrada del Jarillal" figuraban elementos como Kurtziana cacheutensis, Dicroidium odontopteroides, D. lancifolium, "Podozamites elongatus" (=Heidiphyllum elongatum), que pertenecían a un horizonte estratigráfico más alto que los anteriores. Cabe mencionar que existiría una confusión en esta interpretación, puesto que Stappenbeck llamaba con el nombre de "quebrada del Jarillal" a la quebrada del Agua de los Pajaritos, mientras que Frenguelli utilizaba esa denominación para referirse a la quebrada de la Cortaderita.

Pozzo (1948) levantó varios perfiles y recolectó numerosos restos vegetales en la zona de Hilario. Citó para la Formación Agua de los Pajaritos a "Barrealia" (=Saportaea) dichotoma, Jonhstonia stelzneriana, Neocalamites carrerei y Equisetites fertilis; y para la Formación El Alcázar, N. carrerei, Cladophlebis kurtzi, C. mendozaensis, "Thinnfeldia" (= Pachydermophyllum) praecordillerae, Dicroidium "remotum" (=odontopteroides), D. lancifolium, Johnstonia coriacea, Sphenobaiera stormbergensis y Yabeiella brackebuschiana, entre otras especies.

Stipanicic y Menéndez (1949) estudiaron las Dipteridaceae, provenientes de un nivel fosilífero que denominaron I, de la Formación Barreal, en la quebrada de la Cortaderita. Reconocieron ocho formas de dipteridacéas, entre ellas una especie nueva de Hausmannia, dos de Dictyophyllum y una de Thaumatopteris. Identificaron similitudes entre esta flórula y otras floras nórdicas atribuidas al "Rético".

Stipanicic y Bonetti (en Groeber y Stipanicic, 1953) establecieron tres niveles fosilíferos (=NF) para la "Serie de Barreal": NFI (Formación Barreal); NFII y NFIII (Formación Cortaderita). El NFI se encontraba en la parte superior de la Formación Barreal, en un conjunto de arcillas, limos y areniscas amarillentas y grises, en algunos casos tobáceas. Estaba constituido por abundantes Equisetites sp., las dipteridáceas estudiadas por Stipanicic y Menéndez (1949), Chiropteris barrealensis, Jonhstonia stelzneriana, J. coriacea, Xylopteris 
argentina, Zuberia zuberi, Z. barrealensis, "Pterophyllum barrealense" (=Pseudoctenis barrealensis), cuatro especies de Pseudoctenis, cuatro especies de Saportaea y Baiera cuyana. El NFII se hallaba en la Sección Inferior de la Formación Cortaderita, en el medio de arcillas y limos grises verdosos con niveles de areniscas. Se componía de una flora típica de Dicroidium (D. odontopteroides, D. lancifolium, D. “intermedium”, Xylopteris elongata) y Yabeiella (Y. spathulata, Y. wielandi), junto a "Cycadocarpidium” (=Fraxinopsis) andium y pocos ejemplares de Cardiopteridium cyclopteroides, Lepidanthium sporiferum, entre otras formas. El NFIII estaba emplazado en limos y areniscas rosado-claras y blanquecinas de la Sección Superior de la Formación Cortaderita. En él eran muy abundantes los ejemplares de D. lancifolium, Zuberia zuberi, Sphenobaiera stormbergensis, S. argentinae y Pseudoctenis ctenophylloides. Para la "Serie de Hilario" Stipanicic y Bonetti (en Groeber y Stipanicic, 1953) presentaron una lista florística, no discriminada en niveles fosilíferos, en la cual agregaron, a los taxones nombrados anteriormente por Pozzo (1948), a Zuberia zuberi para la Formación Agua de los Pajaritos, Dicroidium odontopteroides para la Formación El Alcázar y Neocalamites carrerei para la Formación Hilario. Además, Stipanicic y Bonetti plantearon que los fósiles de plantas recolectados por Stappenbeck (1910) pertenecían a la Formación El Alcázar.

Menéndez (1956) describió la primera especie de tronco permineralizado de la cuenca de Barreal-Calingasta, presente en la Formación Cortaderita, en la quebrada de la Tinta. El leño pertenecía a una conífera que fue denominada "Protophyllocladoxylon cortaderitaensis" (=Rhexoxylon cortaderitaense).

Bonetti $(1963,1968,1972)$ estudió en detalle la composición, la posición estratigráfica y los puntos de afloramiento de los niveles fosilíferos de los alrededores de Barreal (Figura IV.1) en su trabajo de tesis y en publicaciones ulteriores, ampliando la información dada por Stipanicic y Bonetti (en Groeber y Stipanicic, 1953). Bonetti (1963) identificó y describió tres niveles plantíferos: NFI, NFII y NFIII, equivalentes a los establecidos por Stipanicic y Bonetti (en Groeber y Stipanicic, 1953). El NFI afloraba en dos puntos (Figura IV.1): en la entrada de la quebrada de la Cortaderita (punto 11), de donde provenían la gran mayoría de las dipteridáceas estudiadas por Stipanicic y Menéndez (1949), ejemplares de Zuberia zuberi, Johnstonia coriacea, J. stelzneriana, Saportaea dichotoma, S. flabellata; y en el Este de la quebrada de la Tinta (punto 12), donde fueron encontrados ejemplares de "Dicroidium feistmanteli" (=Zubera papillata), Pteruchus “dubius” (=barrealensis), Xylopteris argentina y Pseudoctenis anomozamoides (Bonetti, 1963). El NFII afloraba en la quebrada de Un Salto (puntos 20 y 21) (Figura IV.1), conteniendo a "Cycadocarpidium" (=Fraxinopsis) andium, 
Dicroidium odontopteroides, D. lancifolium, Xylopteris elongata, Yabeiella wielandi, Umkomasia macleani, Cardiopteridium cyclopteroides, Lepidanthium sporiferum; y en la quebrada de la Tinta (punto 22) (Figura IV.1), con ejemplares de Sphenobaiera stormbergensis (Bonetti, 1963). El NFIII asomaba en seis puntos: en la quebrada de la Cortaderita (punto 30) y en la quebrada de la Tinta (puntos 31, 32, 34, 35 y 36) (Figura IV.1). De estos, los más ricos en cantidad de fósiles eran los puntos 32 y 36 . Del primero provenían los troncos silicificados de "Protophyllocladoxylon cortaderitaensis" (=Rhexoxylon cortaderitaense), estudiados por Menéndez (1956) e impresiones de Dicroidium lancifolium, "Dicroidium feistmanteli" (=Zuberia feistmanteli) y Pseudoctenis ctenophylloides. Del punto 36 procedían otros ejemplares de "Dicroidium feistmanteli" (=Zuberia feistmanteli) y Pseudoctenis ctenophylloides (Bonetti, 1963). La misma autora, además, concluyó que el nivel plantífero más antiguo de Frenguelli (1948), situado en tobas arenosas rosadas, con abundantes frondes de Zuberia feistmanteli, no sería el más basal de la serie sino el más alto (NFIII, punto 32 de Bonetti, 1963); el siguiente nivel de Frenguelli (1948), con Chiropteris barrealensis, Z. zuberi, Z. barrealensis, etc. correspondía al NFI de Bonetti (1963); y por último el tercer nivel de Frenguelli (1948), con Equisetites fertilis y Phyllotheca australis, equivalía al NF II, punto 20 de Bonetti (1963). Bonetti amplió la información sobre la flora de Barreal en su contribuciones posteriores sobre las especies del género Pseudoctenis, en donde citó a seis especies, de las que cuatro eran nuevas (P. ctenophylloides, $P$. anomozamoides, $P$. groeberiana y P. harringtoniana) (Bonetti, 1968), las Bennettitales (Bonetti, 1972) y las especies de Saportaea (Stipanicic y Bonetti, 1965).

Stipanicic (1972, 1979, 1983) mantuvo el esquema de Bonetti (1963) acerca de los niveles plantíferos de Barreal, y los correlacionó con los niveles encontrados en Hilario. El NF II de la Formación Cortaderita tenía su equivalente en un banco tobífero entre lutitas de la parte media de la Formación El Alcázar, mientras que el NF III de la primera formación era correlacionable con otro banco tobífero de la parte superior de la Formación El Alcázar.

Lutz y Herbst (1992) mencionaron la presencia de una nueva especie de Rhexoxylon (tronco permineralizado de corystosperma) para las Formaciones Barreal y Cortaderita, y realizaron una descripción preliminar del taxón. Fueron hallados numerosos ejemplares bien preservados, incluyendo sus porciones basales y raíces.

Herbst (1995) describió la primera planta fósil para la Formación Cepeda, en la quebrada homónima. Se trataba de Millerocaulis stipabonetti, tallo permineralizado de osmundáceas, del cual fueron hallados escasos ejemplares en asociación con, al menos un, tronco de Rhexoxylon. 
Artabe et al. (1995a, b) presentaron una nueva propuesta acerca de los niveles plantíferos de Barreal-Calingasta, estableciendo las correspondencias con los niveles de Bonetti (1963), agregaron nuevos niveles y nuevos taxones hallados. Definieron cuatro estratos fosilíferos en la Formación Barreal y dos en la Formación Cortaderita. El primer estrato fosilífero de la Formación Barreal, se caracterizaba por la presencia de: Dicroidium odontopteroides y Yabeiella brackebuschiana.

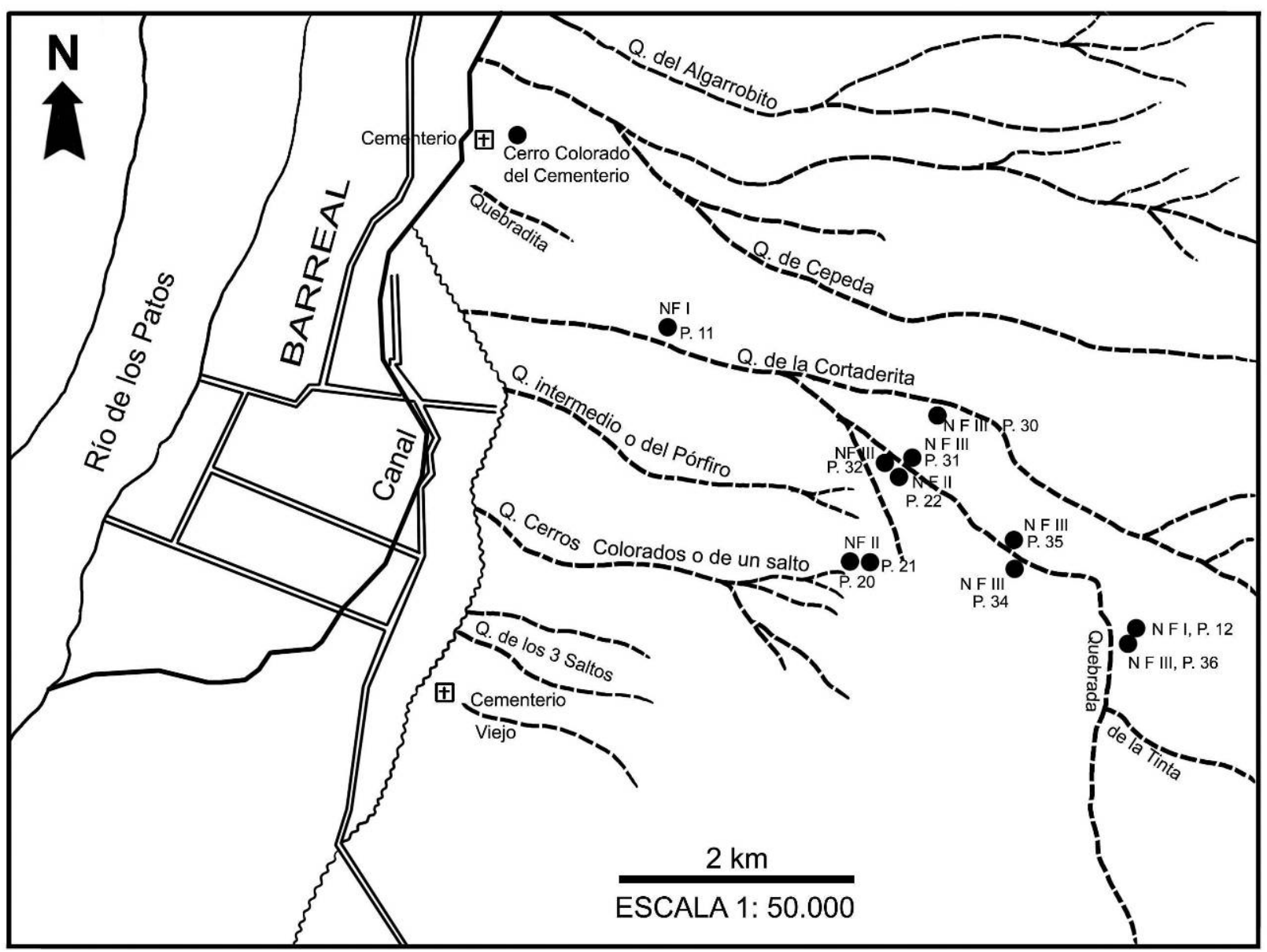

Figura IV.1. Mapa de ubicación de los puntos y niveles fosilíferos de Bonetti (1963). Redibujado de Bonetti (1963). Dibujante: Jorge González.

El segundo contenía las especies Cladophlebis antarctica y Pachydermophyllum praecordillerae. El tercero se correspondía con el NFI punto 11 de Bonetti (1963), y fue subdividido en cinco niveles, los cuales estaban constituidos por las formas citadas por Bonetti (1963) y por otras formas agregadas por Artabe et al. (1995a): Dicroidium lancifolium (Nivel 1), Lobifolia deyerseyi (Nivel 2), Zuberia papillata (Nivel 3), Sphenobaiera stormbergensis (Nivel 4), Glossopteris longicaulis (Nivel 5). El cuarto estrato fosilífero estaba conformado por Sphenobaiera argentinae. La Formación Cortaderita en su Sección Inferior contenía un estrato fosilífero, correlacionable al NFII de Bonetti (1963), caracterizado 
por troncos in situ y raigones de "Protophyllocladoxylon cortaderitaensis" (=Rhexoxylon cortaderitaense) y Rhexoxylon sp. A, los que atravesaban tres niveles fosilíferos, con impresiones de: Neocalamites sp. (Nivel 1), nuevas especies de Pseudoctenis y de Scytophyllum (posteriormente descripta por Zamuner et al. (1999) Scytophyllum bonnettiae) y estructuras fértiles del género Peltaspermun (Nivel 2), Zuberia papillata y Cladophlebis sp. (Nivel 3). En la Sección Superior de la formación citaron sólo un estrato fosilífero con Dicroidium odontopteroides y D. lancifolium, equivalente al NFIII de Bonetti (1963).

Ganuza et al. (1998) revisaron los afloramientos de Hilario, en la quebrada del Agua de los Pajaritos, reconociendo un estrato fosilífero en la Formación El Alcázar correspondiente a los dos bancos tobíferos citados por Stipanicic $(1972,1979,1983)$ y por consiguiente equivalente a los NFII y NFIII de Bonetti (1963). En ese estrato discriminaron tres niveles: N.F 1, con troncos in situ de Tranquiloxylon sp. A; N.F 2, con impresiones de hojas de Cladophlebis mesozoica, C. mendozaensis, Pachydermophyllum precordillerae, Yabeiella mareyesiaca, Heidiphyllum elongatum, entre otras; y N.F 3, con impresiones de tallos de Neocalamites carrerei.

Posteriormente, Zamuner et al. (2001) aportaron una lista del contenido megaflorístico de las formaciones del Grupo Sorocayense, planteando que aquellas formas pertenecientes al NFI del punto 12 de Bonetti (1963), de la Formación Barreal, podrían corresponder a la Sección Inferior de la Formación Cortaderita.

Artabe et al. (2001a) definieron las paleocomunidades presentes en los niveles fosilíferos de Barreal-Calingasta. En el NF I, punto 11 de Bonetti (1963), de la Formación Barreal reconocieron un bosque subtropical siempreverde estacional dominado por corystospermas tanto en el estrato arbóreo (Zuberia feistmanteli y Z. zuberi) como en el sotobosque (Johnstonia stelzneriana). En la Sección Inferior de la Formación Cortaderita distinguieron tres paleocomunidades: un bosque subtropical siempreverde estacional, cuyo estrato arbóreo estaba constituido por corystospermas (Rhexoxylon) y coníferas protopináceas ("Protophyllocladoxylon cortaderitaensis") (nivel fosilífero basal); matorrales de esfenofitas monotípicos (Neocalamites carrerei) (nivel fosilífero 1 de Artabe et al., 1995a); y bosque subtropical esclerófilo con un estrato arbóreo dominado por corystospermas. En la Sección Superior de la Formación Cortaderita identificaron una paleocomunidad herbáceo-arbustiva compuesta por Dicroidium odontopteroides y D. lancifolium. 


\section{MATERIALES Y MÉTODOS}

\section{V.1. Área estudiada}

Los análisis se desarrollaron en la cuenca Barreal-Calingasta, región situada alrededor de los $69^{\circ} 23^{\prime} \mathrm{W}$ y de $\operatorname{los} 31^{\circ} 39^{\prime} \mathrm{S}$, en la Precordillera occidental sanjuanina, a $4 \mathrm{~km}$ al EsteSudeste del centro de la ciudad de Barreal en el departamento de Calingasta, provincia de San Juan (ver Figura II.1).

Esta zona, encuadrada en la carta topográfica de 3169-III en escala 1:250.000, se conoce como el ámbito al Este del Río de Los Patos. Está caracterizada, entre las localidades de Barreal e Hilario, por una serie de quebradas en las que afloran rocas triásicas. Las sedimentitas estudiadas pertenecen al Grupo Sorocayense, constituido, de base a techo, por las Formaciones Barreal, Cortaderita y Cepeda. Las quebradas elegidas para los relevamientos de las unidades litoestratigráficas fueron las de la Cortaderita y de la Tinta (considerada una bifurcación de la anterior). Se analizaron las rocas que conforman la Formación Cortaderita y las plantas fósiles contenidas en ellas.

\section{V.2. Tareas efectuadas en el campo}

Se realizaron dos viajes de campo al área de estudio (21 al 27 de mayo de 2005 y 6 al 15 de mayo de 2006), integrados por la Dra. Analía Artabe, el Dr. Eduardo Morel, el Lic. Daniel Ganuza, el Dr. Ari Iglesias y quién escribe. En primer lugar, se reconocieron los sitios donde está expuesta la Formación Cortaderita (Cerro Colorado del Cementerio, quebrada de la Cortaderita y quebrada de la Tinta), se precisó su ubicación mediante instrumental de Sistema de Posicionamiento Global (GPS) y se sacaron fotos de las vistas generales con cámara fotográfica réflex Canon y digital Canon PowerShot 504A. Para completar el análisis regional de la formación, se relevó y esquematizó la columna estratigráfica general, reconociendo contactos entre las unidades infra y suprayacentes, y la presencia de límites de secuencia dentro de la unidad.

Dentro de la quebrada de la Cortaderita, se muestrearon las sedimentitas y los fósiles de once localidades (Figura V.1):

- Localidad 1 (S 31 39' 17,2" W 69 24' 33,2): corresponde a la localidad Arroyo Cortaderita de Spalletti (2001a).

- Localidad 2 (S $31^{\circ} 39^{\prime} 31,2^{\prime \prime}$ W 69०24' 34,9"2): distinguible por una Tapera de la Mina de bentonita. 
- Localidad 3 (S 31 39'00,1" W 69 23' 52,1"). se encuentra 300 m al Noreste del punto 12 de Bonetti (1963).

- Localidad 4 (S 31 $39^{\circ}$ 08,4" W 69 24' 28"): equivalente al punto 12 de Bonetti (1963).

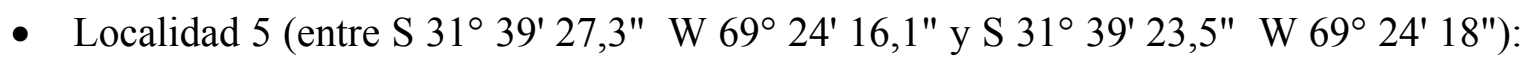
corresponde a la Mina Don Francisco (Artabe et al., 1995a, b, 2001a).

- Localidad 6 (S 31 38' 19,8" W 69 25' 19,8"): equivale al punto 32 de Bonetti (1963). Se ubica en la margen izquierda del Anticlinal al Este de Barreal (Spalletti, 2001a)

- Localidad 7 (S 31 $38^{\circ} 21,2^{\prime \prime}$ W 69 25' 03,3"): ubicada en la margen derecha del Anticlinal al Este de Barreal (Spalletti, 2001a).

- Localidad 8 (S $31^{\circ} 38^{\prime} 54,4^{\prime \prime}$ W 69² 23' 59,9"): al Noroeste de la Tapera de la Mina de bentonita.

- Localidad 9 (S 31 39' 12,6" W 69 23' 50,5"): se encuentra hacia la la entrada de la quebrada de la Tinta.

- Localidad 10 (S 31 39' 09,1" W 69² 23' 53,1"): en el comienzo de la quebrada de la Tinta

- Localidad 11 (S 31 39' 09,8" W 69 23' 51,7"): hacia el fondo de la quebrada de la Tinta.

Se realizó un examen detallado de la Formación Cortaderita, para el cual se levantaron perfiles sedimentológicos en las localidades definidas en las quebradas de la Cortaderita y la Tinta (Figura V.1), teniendo en cuenta granulometría, color, composición, estructuras sedimentarias primarias de las sedimentitas, y geometría de los cuerpos, así como también los contactos y pasajes verticales entre los cuerpos de roca sucesivos. Se realizaron mediciones y posicionamientos con cinta métrica, brújula Brunton y GPS, y se fotografiaron las principales estructuras y geometrías. Los paleosuelos fueron identificados siguiendo el criterio de Terruggi (1971), Andreis (1981) y Retallack (1988). Se recolectaron muestras de roca para su estudio en gabinete.

En estos perfiles se reconocieron los estratos portadores de impresiones-compresiones y permineralizaciones vegetales mencionados en trabajos previos, además de la identificación de nuevos estratos plantíferos; todos los cuales fueron muestreados en cuanto a la diversidad fosilífera y condiciones tafonómicas (estado de preservación, abundancia y densidad de los fósiles). En total, se obtuvieron alrededor de 300 ejemplares de plantas fosilizadas como 
impresiones-compresiones y 100 muestras de troncos permineralizados. Las impresionescompresiones fueron extraídas de las rocas por medio de cinceles y piqueta, y luego envueltas con papel, cinta adhesiva y bolsas de nylon. De las permineralizaciones se obtuvieron rodajas o porciones, mediante cortafierros, barretas y martillos. De los especimenes se precisó: tipo de fosilización, tipo de tejido/órgano o parte de la planta preservada y grado de fragmentación selección, orientación, densidad y relaciones de posición de los ejemplares.

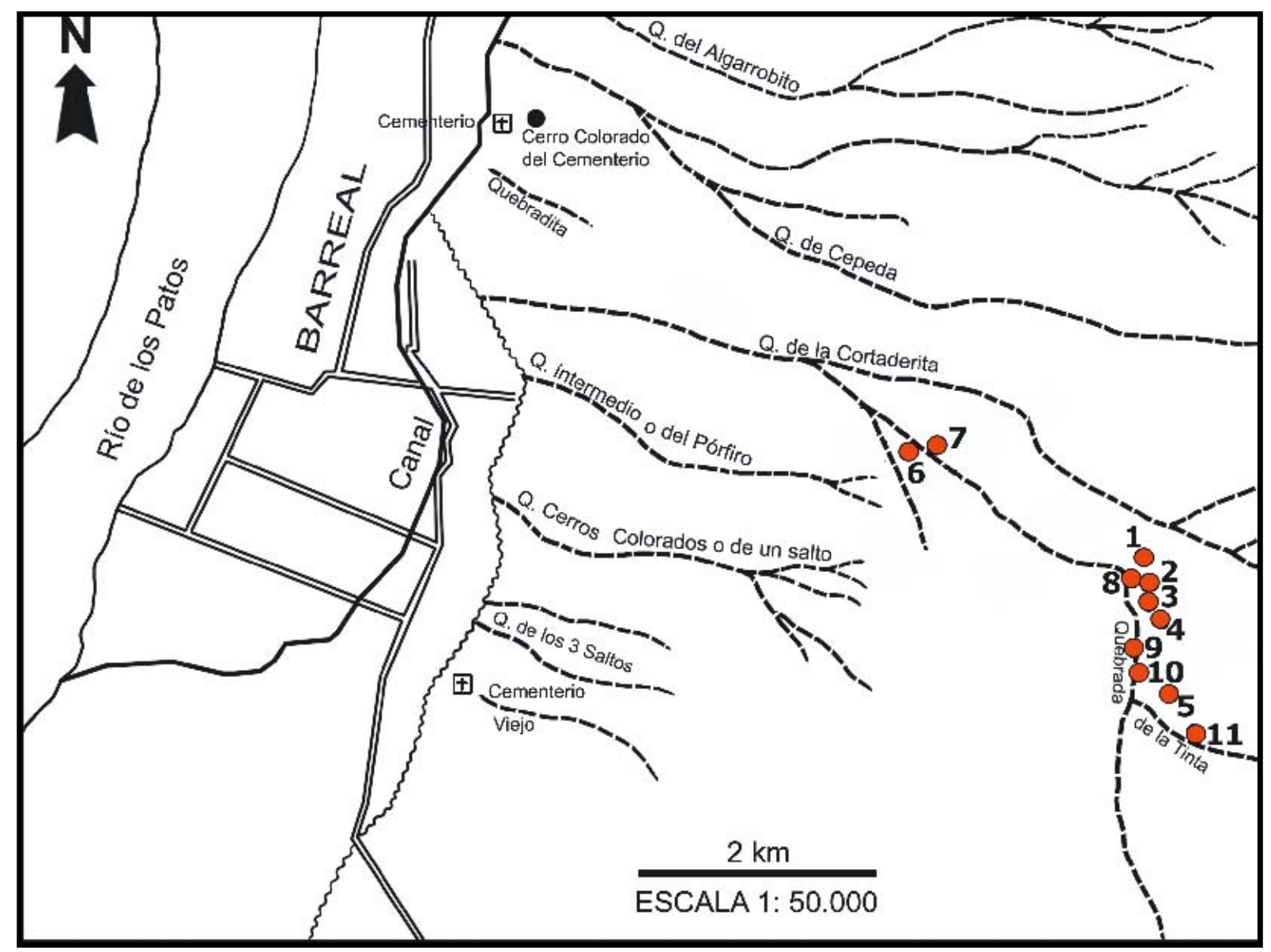

Figura V.1. Mapa de ubicación de las localidades estudiadas en las quebradas de la Cortaderita y de la Tinta. 1. Localidad 1 (Arroyo Cortaderita de Spalletti, 2001a). 2. Localidad 2 (Tapera de la Mina de bentonita). 3. Localidad 3 (300 $\mathrm{m}$ al Noreste del punto 12 de Bonetti, 1963). 4. Localidad 4 (punto 12 de Bonetti, 1963). 5. Localidad 5 (Mina Don Francisco. Artabe et al., 1995a, b, 2001a). 6. Localidad 6 (punto 32 de Bonetti, 1963 o margen izquierda del Anticlinal al E de Barreal, Spalletti, 2001a). 7. Localidad 7 (margen derecha del Anticlinal al Este de Barreal, Spalletti, 2001a). 8. Localidad 8 (Noroeste de la Tapera de la Mina de bentonita). 9. Localidad 9 (hacia la la entrada de la quebrada de la Tinta). 10. Localidad 10 (comienzo de la quebrada de la Tinta). 11. Localidad 11 (hacia el fondo de la quebrada de la Tinta). Dibujante Jorge González. 
Se identificaron cuatro niveles de bosques en los estratos fosilíferos, que fueron relevados y mapeados a cinta y brújula. Se midió el área ocupada por cada bosque, el diámetro, la orientación y la distancia al vecino más próximo de los árboles.

\section{V.3. Tareas efectuadas en el laboratorio y gabinete}

\section{V.3.1 Preparación e ilustración del material}

\section{Sedimentitas}

Los datos de GPS -recavados en los viajes de campo- más la información tomada de mapas geológicos previos, imágenes satelitales Landsat ETM 232/82 e imágenes de Google Earth, permitieron ubicar con precisión los sitios muestreados (Figura V.1).

Los perfiles sedimentológicos relevados fueron ilustrados mediante el programa CorelDraw 9.0 y CorelDraw12, a una escala de 1:100. Las muestras de roca se observaron bajo lupa binocular Nikon.

\section{Fósiles}

El material fósil recolectado fue preparado según el tipo de fosilización. Las impresiones-compresiones fueron limpiadas mecánicamente con cinceles, agujas y lápiz neumático. Para mejorar el contraste entre la roca y el fósil, sólo en pocos casos se adicionó alcohol, ya que la gran proporción de contenido bentonítico en la mayoría de las muestras no lo permitió. Para ilustrar los ejemplares, se los fotografió con cámara digital Canon Powershot S40 y luz rasante, y se realizaron dibujos bajo cámara clara y sobre las propias fotografías.

Los ejemplares permineralizados tienen una composición silícea y una calidad de preservación regular. Se obtuvieron superficies pulidas de los tres planos de corte básicos usados en histología (Transversal, Longitudinal Radial y Longitudinal Tangencial), utilizando una sierra con cuchilla metálica de borde diamantado y pulidora con polvos abrasivos (carborundum: carburo de silicio) de tamaño de grano decreciente. Como los troncos tienen un grado de permineralización diferente en el leño que en la corteza, los radios parenquimatosos y la médula, los fósiles fueron incluidos en resinas para realizar los pulidos. Las superficies así terminadas se examinaron con luz incidente por medio de la utilización de lupa binocular Nikon e ilustrados mediante fotografías con sistema Leica DC 150 y cámara digital Canon Powershot S40, y dibujos a cámara clara o sobre la fotografía misma. Para mejorar la observación se aplicó sobre las superficies pulidas aceite mineral. La histología en detalle se estudió mediante la realización de cortes delgados petrográficos, para lo cual se montaron rodajas de varios milímetros de espesor sobre portaobjetos, con un adhesivo firme, de tipo epoxirresina. Cada sección se pulió y rebajó, hasta que un espesor tan delgada que por 
transparencia pudiera observarse bajo el microscopio (entre 35 y $40 \mu \mathrm{m}$ ). Luego se la cubrió con epoxirresina y se colocó un cubreobjeto. Los cortes fueron estudiados con microscopio óptico Leitz Wetzlar Ortholux y fotografíados con sistema Leica DC 150 y cámara digital Canon Powershot S40. Con las fotografías y dibujos se confeccionaron láminas utilizando programas de software Adobe Photoshop CS, CorelPhotoPaint 12 y CorelDraw 12. Los cortes y pulidos fueron realizados por el Técnico Ricardo Ponti.

Los materiales megascópicos y microscópicos fueron depositados en las colecciones de Paleobotánica del Museo de Ciencias Naturales de San Juan y del Museo de La Plata, bajo las siglas PBSJ/ PBSJPm y LPPB/ pmLPPB, respectivamente. Además de estos materiales, se revisaron fósiles recolectados en las mismas localidades y estudiados previamente por Frenguelli (1943, 1944a), Menéndez (1956), Bonetti (1963), Lutz y Herbst (1992) y Artabe et al. (1995a,b), los que se encuentran en las colecciones de Paleobotánica del Museo Argentino de Ciencias Naturales "Bernardino Rivadavia", de la Universidad Nacional del Nordeste y del Museo de La Plata, bajo las siglas de BAPb/ BAPbPm, CTES-PB/PMP-CTES y LPPB/ pmLPPB, respectivamente. De los materiales de Menéndez (1956) -troncos permineralizados-se obtuvieron nuevos cortes petrográficos.

\section{V.3.2. Análisis y determinación del material}

\section{Sedimentitas}

Para la definición de facies sedimentarias y sus asociaciones, se utilizó el criterio de Miall $(1978,1996)$. Los paleosuelos fueron clasificados de acuerdo al esquema de Retallack (1988) y Mack et al. (1993).

\section{Fósiles}

Para la descripción de las hojas (impresiones-compresiones) se aplicaron los términos brindados por el diccionario de botánica de Font Quer (1963, 1982). Para el estudio de los troncos (permineralizaciones) se empleó la terminología de los glosarios de anatomía de maderas (Boureau, 1956; Fahn, 1990; IAWA, 2004), y el atlas de anatomía de maderas de Greguss $(1955,1968)$. La medida de los distintos elementos morfológicos y anatómicos se obtuvo en base a un registro de 30 mediciones. Para los materiales megascópicos, se utilizaron reglas y cintas métricas para medir sobre el fósil, o mediante reglillas de la lupa binocular. Para los cortes petrográficos, se utilizaron las reglillas del microscopio.

Para el tratamiento nomenclatural se utilizó el International Code of Botanical Nomenclature (Vienna Code, McNeill et al., 2006), el Phylogenetic Code of Biological Nomenclature (Cantino y de Queiroz, 2006; Cantino et al., 2007) y el Indices Nominum 
Supragenericorum Plantarum Vascularium (Reveal, 2007). Los criterios sistemáticos supragenéricos fueron tomados de Archangelsky (1970), Stewart y Rothwell (1993), Kenrick y Crane (1997), Smith et al. (2006), Taylor et al. (2009). La sistemática genérica e infragenérica fue tratada de acuerdo a posturas particulares para cada caso, que son detalladas en el Capítulo VII.

\section{V.3.3. Estudios filogenéticos y evolutivos}

Para los análisis filogenéticos y evolutivos de las Corystospermaceae, componente principal de la xiloflora de la Formación Cortaderita, se revisó la anatomía de dicho grupo, de otras pteridospermas relacionadas (Amosioxylon, Lyginopteridaceae, Medullosaceae, Callistophytaceae) y de las cycadales.

Las relaciones filogenéticas de las Corystospermaceae con otros grupos de gimnospermas estuvieron basadas en análisis previos (Doyle y Donogue, 1992; Nixon et al., 1994; Rothwell y Serbet, 1994; Crane, 1996; Doyle, 1996; Axsmith et al., 2000, entre otros). Las relaciones filogenéticas entre los integrantes de las Corystospermaceae fueron inferidas a partir de una matriz, en la que fueron incluidos todos los taxones de tallos descriptos para las corystospermas. La matriz resultante fue analizada con TNT 1.1 (Goloboff et al., 2008), bajo enumeración implícita.

La evolución de los troncos de este grupo fue estudiada en el marco de la biología evolutiva y del desarrollo (Evo-Devo), aplicando los conceptos de heterocronía, heterotopía y homeosis. Para la heterocronía, se utilizará el modelo de Alberch et al. (1979), mientras que para la homeosis y la heterotopía se empleará el esquema propuesto por Baum y Donoghue (2002). Se testearon, en el contexto de la biología Evo-Devo, modelos evolutivos previos (Archangelsky y Brett, 1961; Petriella, 1981; Artabe y Brea, 2003).

\section{V.3.4. Estudios tafonómicos y paleoecológicos}

Para la designación de las tafofacies, se aplicó una combinación de códigos de letras para los estilos preservacionales y las litofacies -siguiendo la clasificación de Miall (1996) y Colombi y Parrish (2008). Se consideraron los siguientes atributos: facies sedimentarias, tipo de fosilización, densidad, grado de fragmentación y orientación de los fósiles.

La definición de las paleocomunidades se realizó teniendo en cuenta las tafocenosis preservadas. Se siguió la metodología aplicada por Artabe et al. (2001a): a) asignación sistemática del material, b) determinación de hábitos de vida, c) abundancia, y d) grado de 
preservación. La clasificación de la vegetación se realizó utilizando un criterio fisonómicoestructural.

Para el análisis estructural de los bosques se utilizaron los programas de software Crimestat III (Levine, 2009), PAST (Hammer et al., 2007) y STATISTICA 7.0 (StatSoft, 2004). Para los cálculos de altura y biomasa, se aplicaron las ecuaciones de Niklas (1994a, b, c) y Brown (1997), respectivamente. 


\section{SEDIMENTOLOGÍA Y ESTRATIGRAFÍA DE LA FORMACIÓN CORTADERITA}

\section{VI.1. Introducción}

Las secuencias triásicas de la región de Barreal-Calingasta han sido interpretadas como parte de la cuenca Cuyana (Rolleri y Criado Roqué, 1968; Yrigoyen y Stover, 1970; Stipanicic, 1979) o como el relleno del margen pasivo de un hemigraben con marcada asimetría (López Gamundí, 1994; Barredo y Ramos, 1997; Spalletti, 2001a).

En las quebradas de la Cortaderita y de la Tinta, el Grupo Sorocayense se apoya en discordancia sobre las sedimentitas neopaleozoicas del Grupo Pituil, y es cubierto, en forma también discordante, por depósitos clásticos cuaternarios. El conjunto sedimentario triásico se encuentra plegado en amplios sinclinales y anticlinales (ver Figura II.4), por lo que los estratos se exponen repetidas veces. La participación piroclástica fue intensa, como se observa en los repetidos niveles de tobas y bentonitas (lluvias de ceniza) y la alta proporción de contenido piroclástico en las rocas epiclásticas.

La Formación Cortaderita presenta un contacto concordante y transicional con la unidad subyacente (Formación Barreal) y discordante con la que la cubre (Formación Cepeda). Se compone de una Sección Inferior gris y una Superior rosada, bien diferenciables una de la otra (Spalletti, 1995, 2001a) (ver Figura II.5). El límite entre las dos secciones estaría marcado por una discontinuidad intraformacional y un hiatus temporal importantes, de acuerdo a Spalletti (1995, 2001a) y Spalletti et al. (1999), que quedaría evidenciada por cambios abruptos de facies y una significativa reorganización paleogeográfica en la cuenca, reflejada por los cambios en las paleocorrientes. A su vez, para la Formación Cortaderita se establecieron modelos de sedimentación, en el que se interpreta a la Sección Inferior gris como el registro de un sistema lacustre meromíctico, y a la Sección Superior rosada como parte de un sistema fluvial entrelazado arenoso (Spalletti, 2001a).

Para precisar la localización de los niveles fosilíferos y encuadrar las tafofloras estudiadas en un contexto paleambiental, se levantaron cinco perfiles de detalle a lo largo de las dos secciones de la Formación Cortaderita. Asimismo, sobre la base de la descripción de las rocas y el contenido fosilífero, se elaboró una interpretación sedimentológica y estratigráfica de los perfiles relevados. 


\section{VI.2. Descripción de los perfiles sedimentológicos}

Se eligieron localidades representativas para levantar los perfiles (ver Figura V.1): Localidad 1 (Arroyo Cortaderita de Spalletti, 2001a), Localidad 3 (300 m al Noreste del punto 12 de Bonetti, 1963), Localidad 4 (punto 12 de Bonetti, 1963), Localidad 5 (Mina Don Francisco, Artabe et al. 1995a, b, 2001a), Localidad 6 (punto 32 de Bonetti, 1963 o margen izquierda del Anticlinal al E de Barreal, de Spalletti, 2001a), y Localidad 10 (comienzo de la quebrada de la Tinta).

\section{VI.2.1. Perfil 1 (Perfil principal)}

Comienza en la Localidad 4 (S 31 $39^{\prime} 05,9^{\prime \prime}$ W 69 23' 52,3") y culmina en la Localidad 10 (S 31 39' 09,1" W 69²3' 53,1"), en la entrada de la quebrada de la Tinta. La sucesión sedimentaria relevada alcanza un espesor total de 43,33 m, abarca las dos secciones de la Formación Cortaderita y se compone de base a techo de la siguiente manera (Figura VI.6):

\section{-Sección Inferior gris:}

0 (Base)- $30 \mathrm{~m}$ por encima del contacto con la Formación Barreal, cuerpos lenticulares amalgamados de areniscas gruesas amarillentas, con estratificación entrecruzada en artesa.

1- 0,25 m. Paraconglomerados polimícticos gruesos, con clastos subangulosos de hasta $0,05 \mathrm{~m}$ de diámetro, en discordancia erosiva sobre los cuerpos lenticulares de la base del perfil.

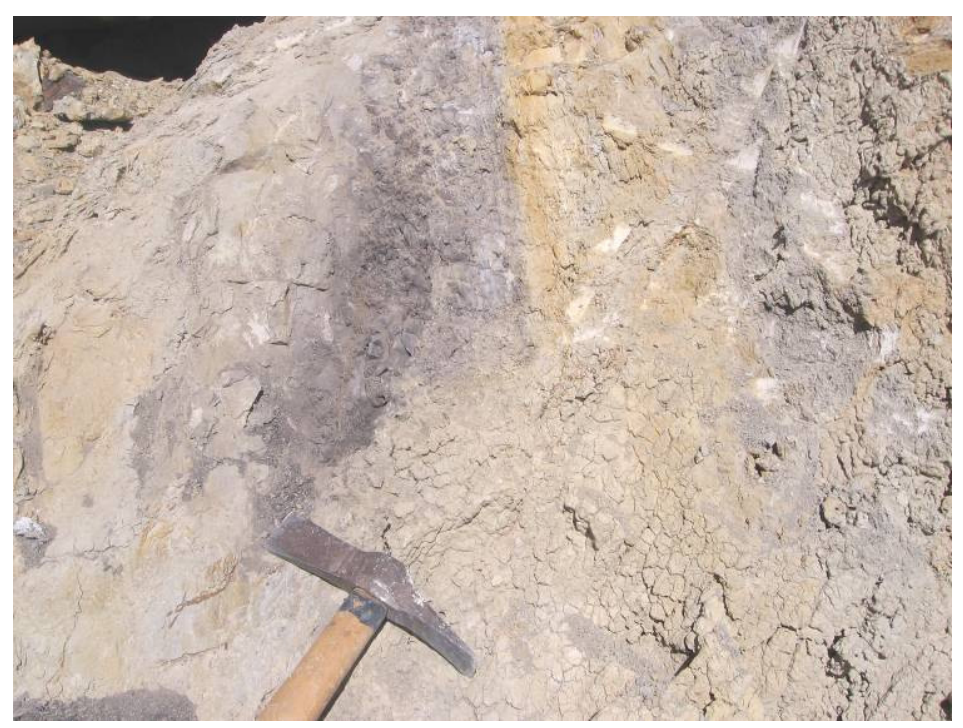

Figura VI.1. Limolitas bentoníticas grisáceas masivas con niveles carbonosos (oscuros) y de óxidos (ocres). 2- 0,35 m. Lente de morfología cóncavo-convexa de areniscas gruesas de tonalidades rojizas, con moldes de troncos.

3- $1 \mathrm{~m}$. Lentes amalgamados con bases erosivas, de conglomerados finos y sabulitas de tonalidades rojizas con estratificación entrecruzada planar.

4- 2,5 m. Estratos tabulares de 0,50 m de espesor, de areniscas medianas a finas grisáceas claras, polimícticas y bien seleccionadas, con laminación entrecruzada de bajo ángulo. 
5- $1 \mathrm{~m}$. Limolitas bentoníticas grisáceas masivas con niveles carbonosos oscuros y niveles ocres de óxidos (Figura VI.1). Contienen rizolitos de hasta 0,07 $\mathrm{m}$ de longitud.

6- 0,28 m. Lente de areniscas medianas grisáceas-amarillentas polimícticas bien seleccionadas masivas.

7- 0,18 m. Limolitas bentoníticas grisáceas masivas, con rizolitos.

8- 0,80 m. Lentes amalgamados de 0,33 $\mathrm{m}$ de espesor individual y $4 \mathrm{~m}$ de longitud, de areniscas medianas, finas y muy finas y limolitas grisáceas masivas.

9- 1,74 m. Limolitas grises-amarillentas con materia orgánica oxidada, intercalados con lentes de limolitas y sabulitas de $0,20 \mathrm{~m}$ de espesor. Portan rizolitos mal preservados y clastos pumíceos.

10- 0,15 m. Areniscas finas limosas muy alteradas, con niveles ocres de óxidos.

11- 0,30 m. Estrato de base erosiva, conglomerados finos polimícticos, que contienen grandes intraclastos angulosos a subangulosos arenosos (de hasta $0,45 \mathrm{~m}$ de diámetro) e intraclastos tobáceos (Figura VI.2).

Figura VI.2. Intraclasto tobáceo, anguloso y de gran tamaño, que corresponde a una carpeta traccional, en el conglomerado del nivel 11.

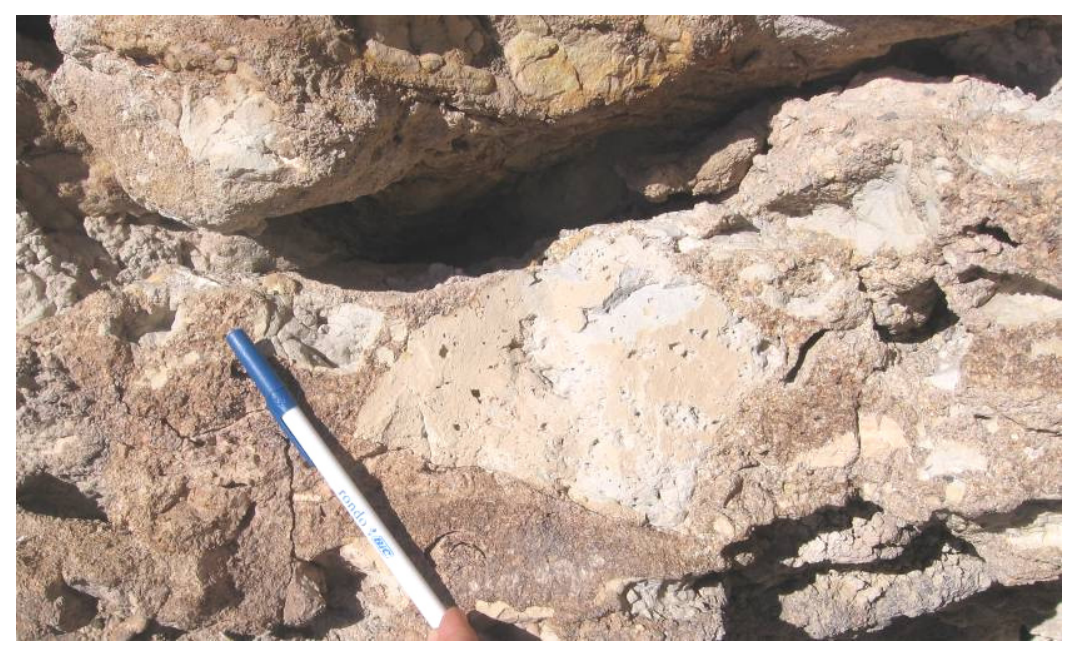

12- 0,45 m. Lentes de base fuertemente erosiva de areniscas sabulíticas masivas, que llevan moldes de troncos de gran porte (Figura VI.3).

13- 2,4 m. Areniscas sabulíticas y conglomerados finos con intraclastos, en sets de estratos entrecruzados de alto ángulo con base tangencial. Contienen moldes de troncos de gran porte, en la base de los estratos entrecruzados.

14- 5,5 m. Limolitas bentoníticas grises masivas, muestran niveles carbonosos y niveles de óxidos, rizolitos de coloración clara, superficies espejadas del tipo slickensides, y hacia el techo, venas de yeso. 
15- 0,60 m. Limolitas grises oscuras masivas, con venas de yeso e impresiones-compresiones oxidadas de raíces en la base, y hacia el techo, láminas de yeso, nódulos de hierro, impresiones-compresiones de raíces y gran cantidad de troncos y tocones silicificados caídos y en posición de vida.

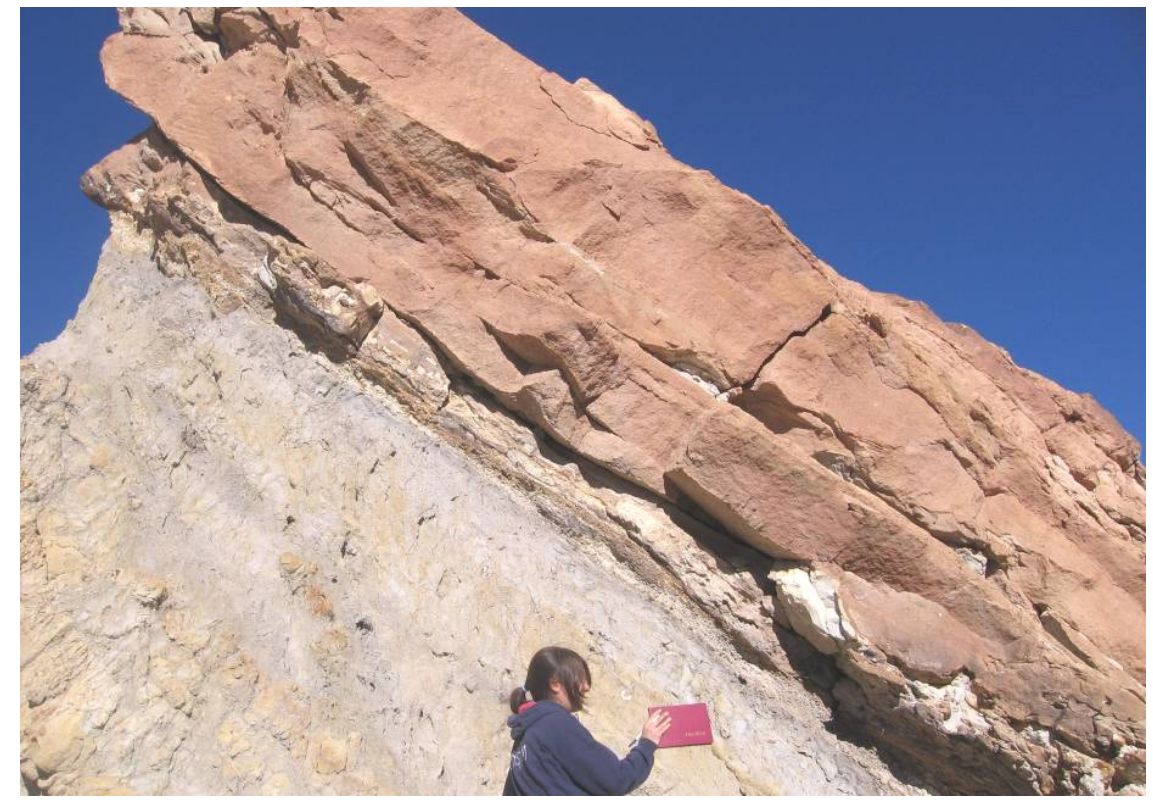

Figura VI.3. Lentes amalgamados de areniscas. Por debajo, conglomerados con intraclastos del nivel 11, y subyace a este último, un paquete de limolitas masivas del nivel 10.

16- 3,7 m. Bentonitas grises a verdosas y rosadas claras, falladas y diaclasadas, que contienen clastos volcánicos aislados subangulosos, madera y raíces carbonizadas, nódulos de hierro aislados y láminas de yeso (Figura VI.4).

\section{-Sección Superior rosada:}

17- 0,88 m. En discordancia erosiva sobre las bentonitas subyacentes, estratos de 0,06 a 0,17 $\mathrm{m}$ de espesor, de areniscas finas rosadas bien seleccionadas laminadas. Hacia el techo, láminas intercaladas de 0,005 a $0,015 \mathrm{~m}$ de espesor de areniscas muy finas grises ondulíticas y niveles de briznas vegetales carbonizadas y nódulos de hierro (Figura VI.5).

18- 1,2 m. Estratos potentes, 0,61 $\mathrm{m}$ de espesor, de areniscas finas rosadas y muy finas grises, de laminación entrecruzada de bajo ángulo,

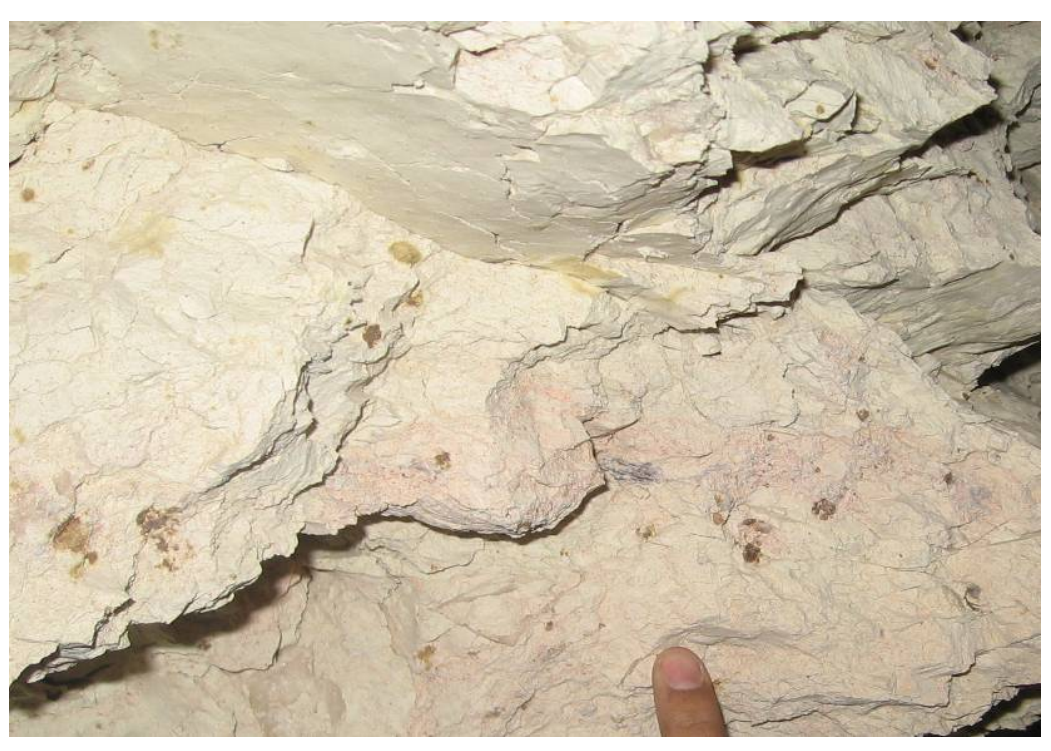

Figura VI.4. Detalle de las bentonitas del nivel 16, mostrando los clastos volcánicos aislados. 
con gran cantidad de clastos volcaniclásticos y niveles de yeso.

19- 1,1 m. Areniscas medianas violáceas de moteado rosado, con laminación mal preservada, y clastos pumíceos y nódulos de hierro.

20- 1,30 m. Lente de areniscas finas a medianas amarillentas con moteado violáceo, laminación muy fina y clastos pumíceos.

21- 3,90 m. Bancos lentiformes de areniscas medianas a gruesas rojizas y rosadas con clastos piroclásticos, bien seleccionadas y muy alteradas. 22- 0,50 m. Lentes amalgamados de

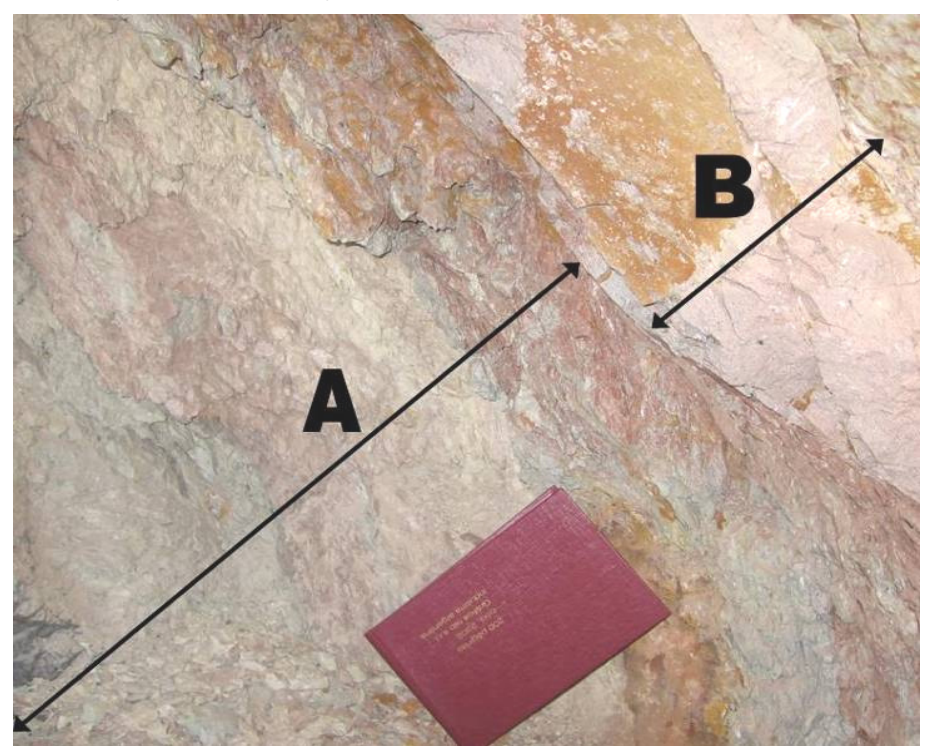

Figura VI.5. Contacto erosivo entre las bentonitas (A) y las areniscas fluviales sobreyacentes (B).

base erosiva de conglomerados finos sabulíticos a sabulitas conglomerádicas, polimícticos, violáceos, rojizos y blanquecinos, con muchos clastos piroclásticos y estratificación entrecruzada en artesa.

23- 1,80 m. Areniscas muy finas rojizas con moteado de color blanquecino verdoso, sin estructura evidente.

24- 4,30 m. Estrato tabular de areniscas finas a medianas violáceas con moteado de color rosado, alto contenido piroclástico, estratificación entrecruzada de bajo ángulo y laminación interna.

25- 4,60 m. Areniscas medianas violáceas con moteado de color rosado, intercaladas con láminas de areniscas finas grisáceas con óndulas.

26- $0,85 \mathrm{~m}$. Sabulitas y areniscas medianas sabulíticas anaranjadas a rojo ladrillo y grises moteadas, con clastos pumíceos y abundante contenido lítico, y laminación difusa. Contienen niveles de 0,01 m de sílice, evaporitas y calcita, formando un silcrete. Presentan troncos silicificados y moldes de raíces.

27- 1,10 m. Areniscas medianas con mucho contenido piroclástico, clastos de pómez, con laminación muy fina (láminas de menos $0,01 \mathrm{~m}$ de espesor).

28- 0,60 m. Lentes amalgamados de areniscas medianas a finas violáceas y blanquecinas con clastos líticos y piroclásticos.

Techo: hacia arriba, continúan los estratos de areniscas rosadas característicos de la Sección Superior de la Formación Cortaderita, pero ya no se registran niveles fosilíferos. 


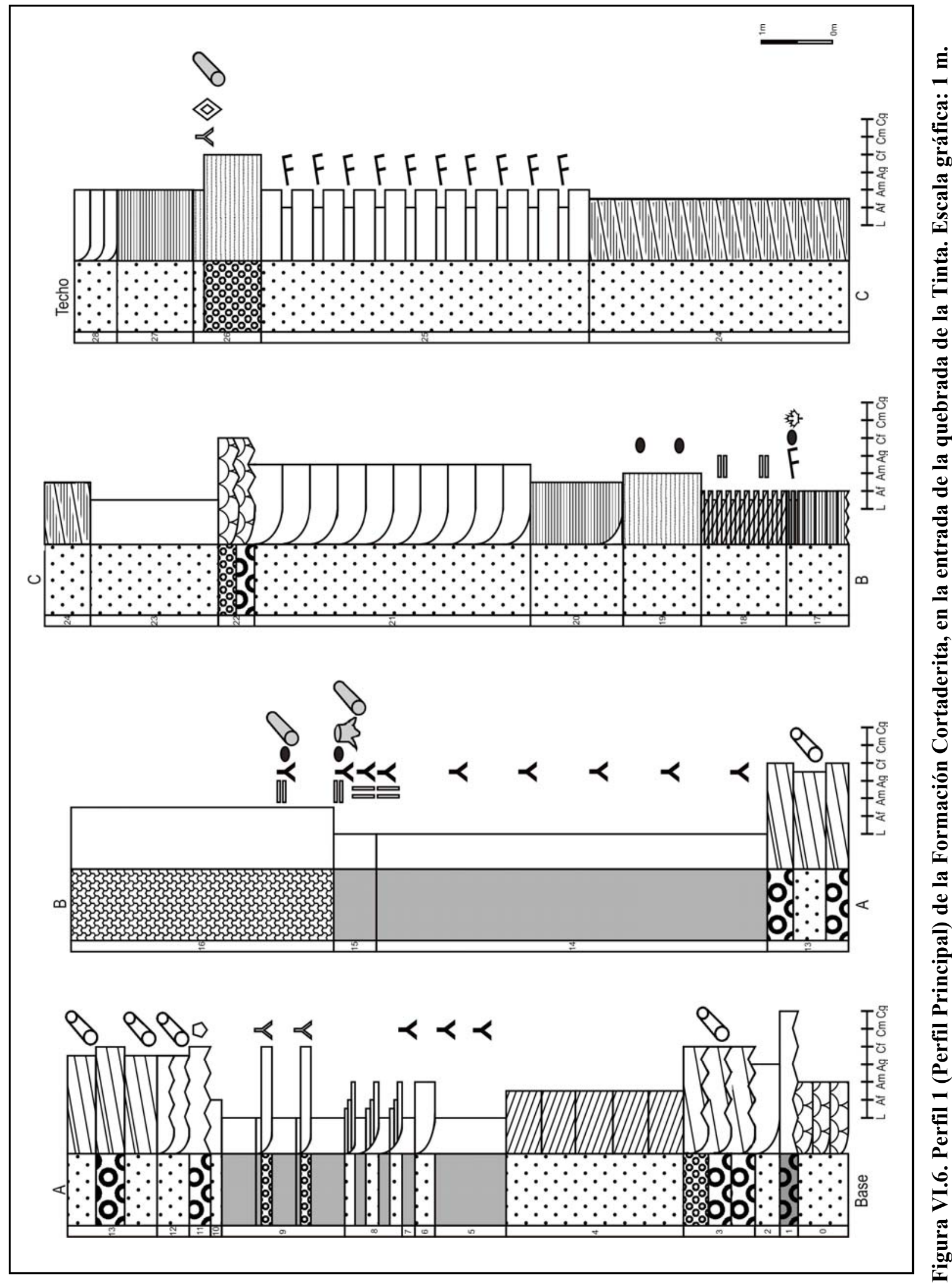




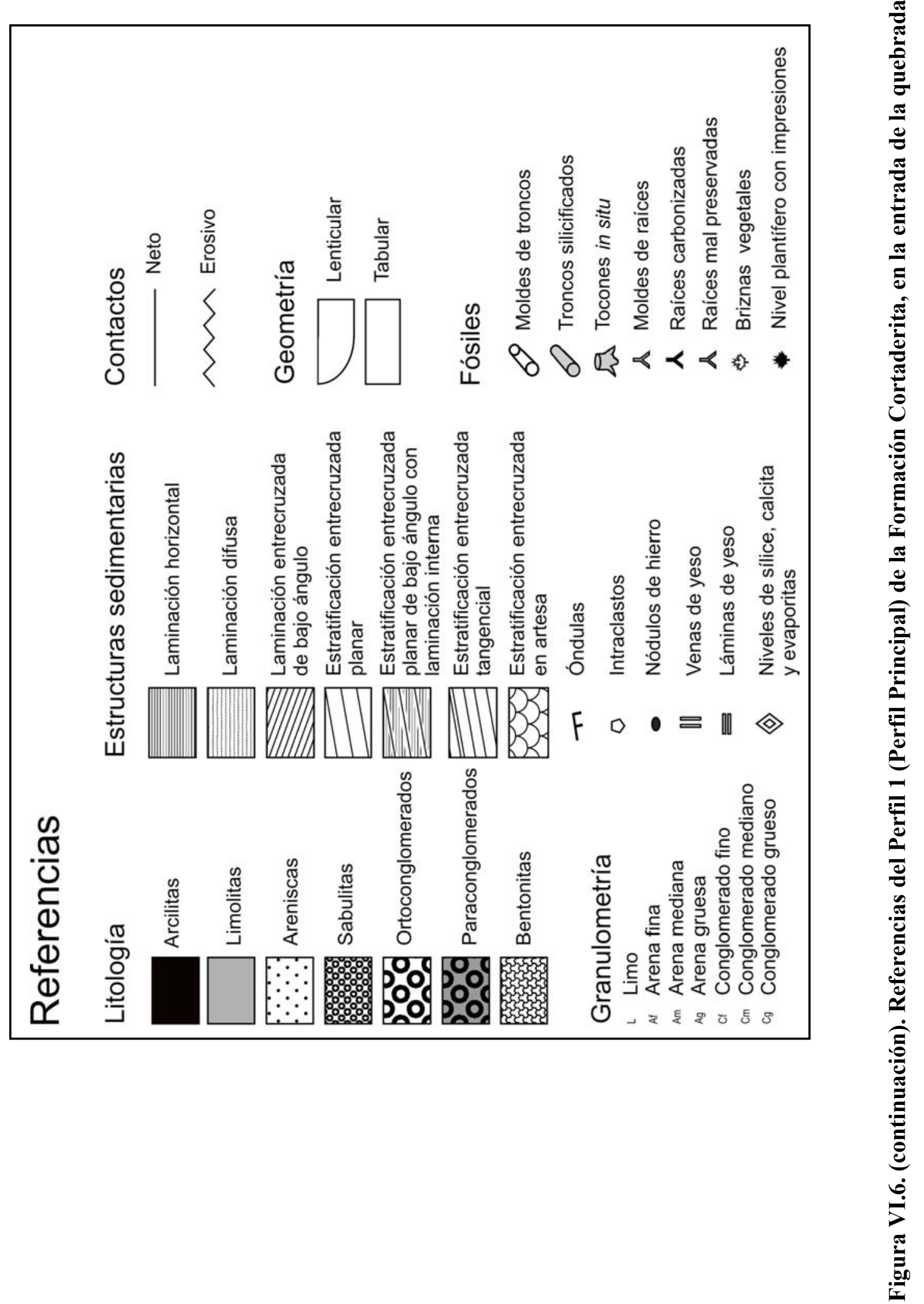




\section{VI.2.2. Perfil 2}

Fue levantando en la Localidad 3, en la quebrada de la Cortaderita, $300 \mathrm{~m}$ al Noreste del punto 12 de Bonetti (1963) (S 31 39' 00,1" W 69² 23' 52,1"). En esta localidad, no se encuentran las facies arenosas y conglomerádicas de los niveles $1,2,3,4,11,12$ y 13 , ni el nivel 16 de bentonitas del perfil 1. Abarca parte de la Sección Inferior gris de la Formación Cortaderita. De base a techo se puede reconocer (Figura VI.7): Base- cubierta.

a- más de $4 \mathrm{~m}$. Limolitas bentoníticas grisáceas masivas con niveles oscuros carbonosos y niveles ocres de óxidos, rizolitos, tocones de troncos silicificados en posición de vida (in situ), con rizomas laterales. En el techo, limolitas bentoníticas grises con intercalaciones de areniscas finas amarillentas, niveles de óxidos, briznas vegetales y numerosas impresiones e impresiones-compresiones de hojas. Sobre la base de las similitudes litológicas y las relaciones estratigráficas, este nivel es correlacionable con el nivel 9 del perfil 1.

b- 3,1 m. Bentonitas grises claras falladas $y$ diaclasadas.

c- 9,52 m. Limolitas bentoníticas grises masivas, con niveles oscuros carbonosos y niveles ocres de óxidos, rizolitos, troncos silicificados de gran porte. Las relaciones estratigráficas y las semejanzas litológicas permiten correlacionar

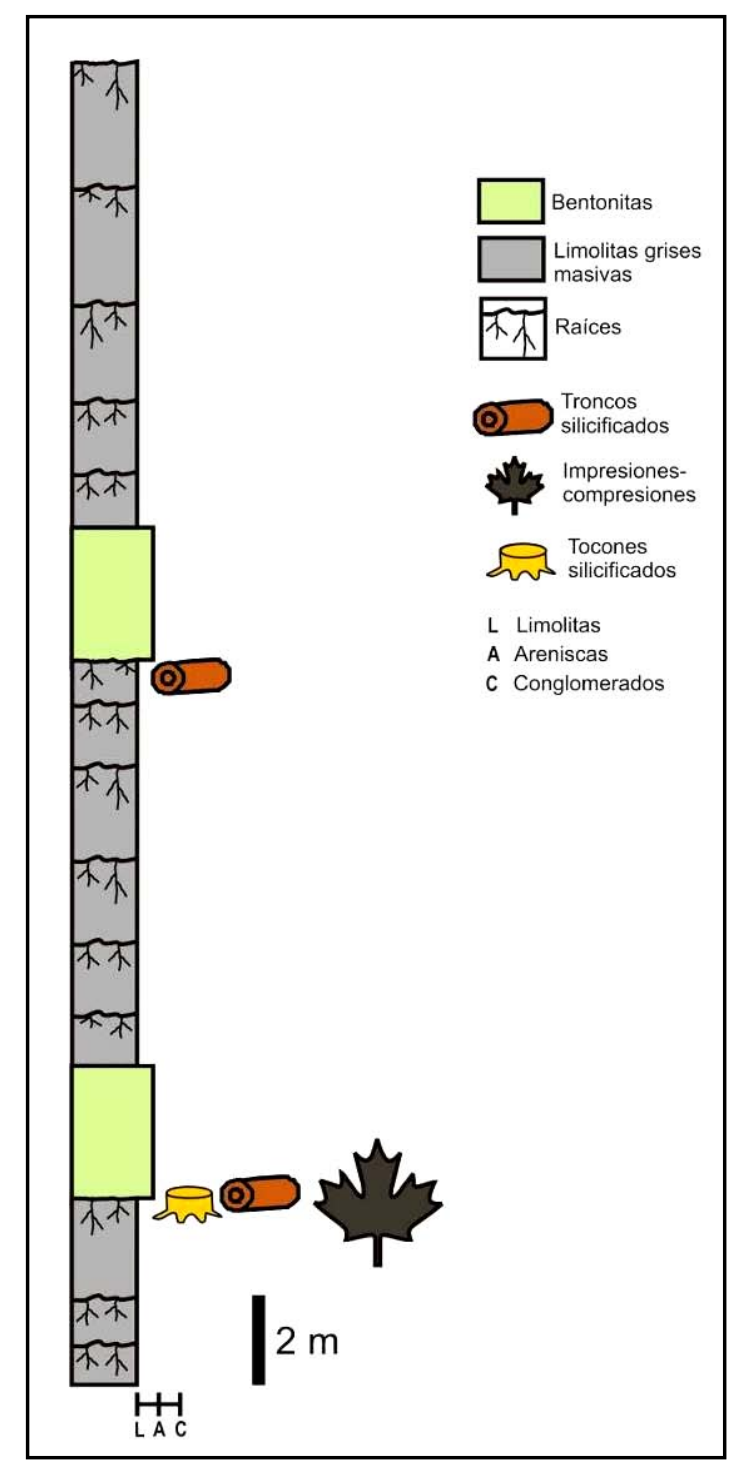

Figura VI.7. Perfil 2, $300 \mathrm{~m}$ NE del punto 12 de Bonetti (1963), en la quebrada de la Cortaderita. Escala gráfica: $\mathbf{2} \mathbf{m}$. este nivel con el nivel 14 del perfil 1.

d- 2,9 m. Bentonitas grises claras falladas y diaclasadas

e- 11,13 m. Limolitas bentoníticas grises masivas con niveles carbonosos y niveles de óxidos ocres, rizolitos. Este nivel es correlacionable con nivel 15 del perfil 1.

Techo: hacia arriba, en discordancia erosiva areniscas rosadas de la Sección Superior rosada. 


\section{VI.2.3. Perfil 3}

Relevado en la Localidad 5, en la Mina Don Francisco, en la quebrada de la Tinta (S $31^{\circ} 39^{\prime} 16,4^{\prime \prime}$ W $\left.69^{\circ} 23^{\prime} 16,4^{\prime \prime}\right)$. En esta localidad, no se encuentran las facies arenosas $y$ conglomerádicas de los niveles 1, 2, 3 y 4 del perfil 1. Incluye una parte de la Sección Inferior gris. De base a techo, se observa (Figura VI.8):

Base- cubierta.

A- Aproximadamente $2 \mathrm{~m}$ expuestos de limolitas bentoníticas grisáceas masivas con niveles oscuros carbonosos y nivel ocres de oxidación, rizolitos, tocones de troncos de diferentes portes silicificados $\mathrm{y}$ carbonizados in situ, con rizomas laterales $\mathrm{y}$ raíces articuladas. Este nivel es correlacionable con el nivel 9 del perfil 1.

B- Aproximadamente $3 \mathrm{~m}$ de bentonitas grises claras falladas y diaclasadas. En la base, abundantes impresiones de hojas y troncos carbonizados in situ con corteza y raíces articuladas preservadas.

C- 30,72 m cubiertos por derrubio.

D- 0,6 m de limolitas bentoníticas grises masivas con niveles oscuros carbonosos y niveles ocres de óxidos, y rizolitos. Este nivel es correlacionable

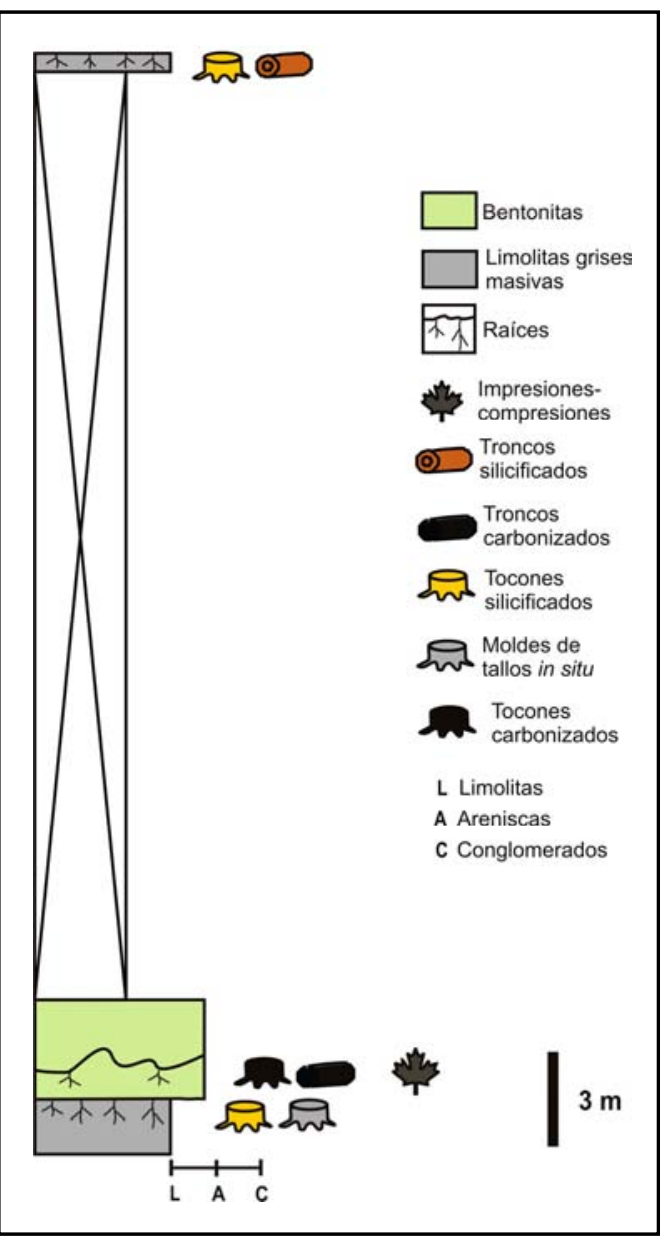

Figura VI.8. Perfil 3, Mina Don Franciso, en la quebrada de la Tinta.

Escala gráfica: 3 m. con nivel 15 del perfil 1.

Techo: cubierto.

\section{VI.2.4. Perfil 4}

Este perfil incluye el límite entre la Sección Inferior y la Sección Superior de la Formación Cortaderita. Fue levantado en la Localidad 6 (S 31 38 $38^{\prime} 19,8^{\prime \prime}$ W 69² 25' 19,8") conocida como punto 32 (Bonetti, 1963) o margen izquierda del Anticlinal al Este de Barreal (Spalletti, 2001a), en la entrada de la quebrada de la Cortaderita. Se ha reconocido, de base a techo (Figura VI.9):

I- 0,05 m expuestos. Areniscas finas grises oscuras masivas con rizolitos. Este nivel es correlacionable con nivel 15 del perfil 1. 
II- $0,10 \mathrm{~m}$. Este nivel se apoya en paraconformidad sobre las areniscas grises masivas subyacentes (Figura VI.10). Comienza con areniscas finas rojas a moradas con impresiones de hojas en su base, siguen areniscas finas rosadas $y$ limolitas grises laminadas con impresiones de hojas en su techo y termina con arcilitas y limolitas grises y rosadas laminadas con impresiones de hojas. Este nivel representaría el nivel más inferior de la Sección Superior.

III- 0,11 m. Areniscas

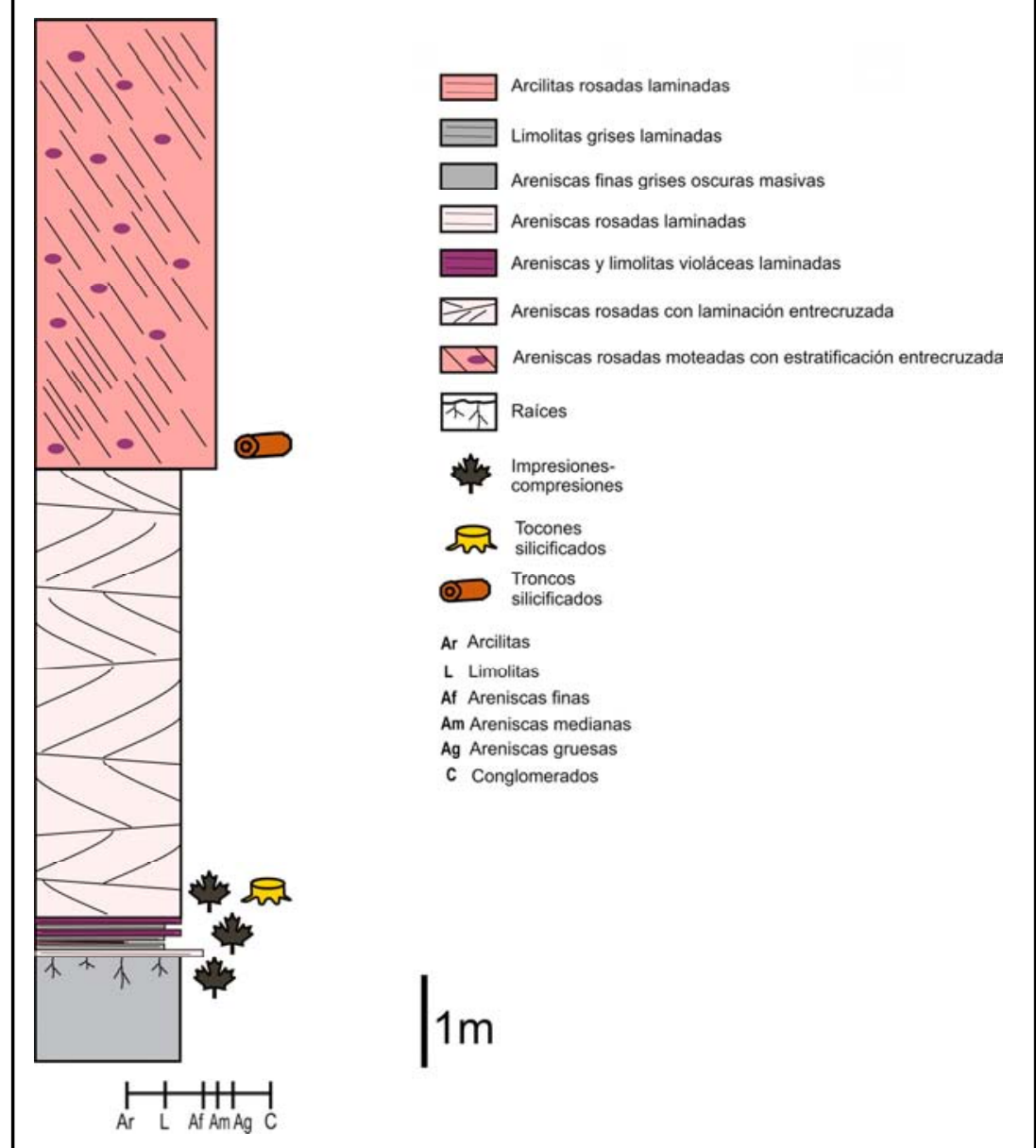

Figura VI.9. Perfil 4, en la entrada de la quebrada de la Cortaderita. Escala gráfica: $1 \mathrm{~m}$.

finas y limolitas violáceas y grises claras laminadas.

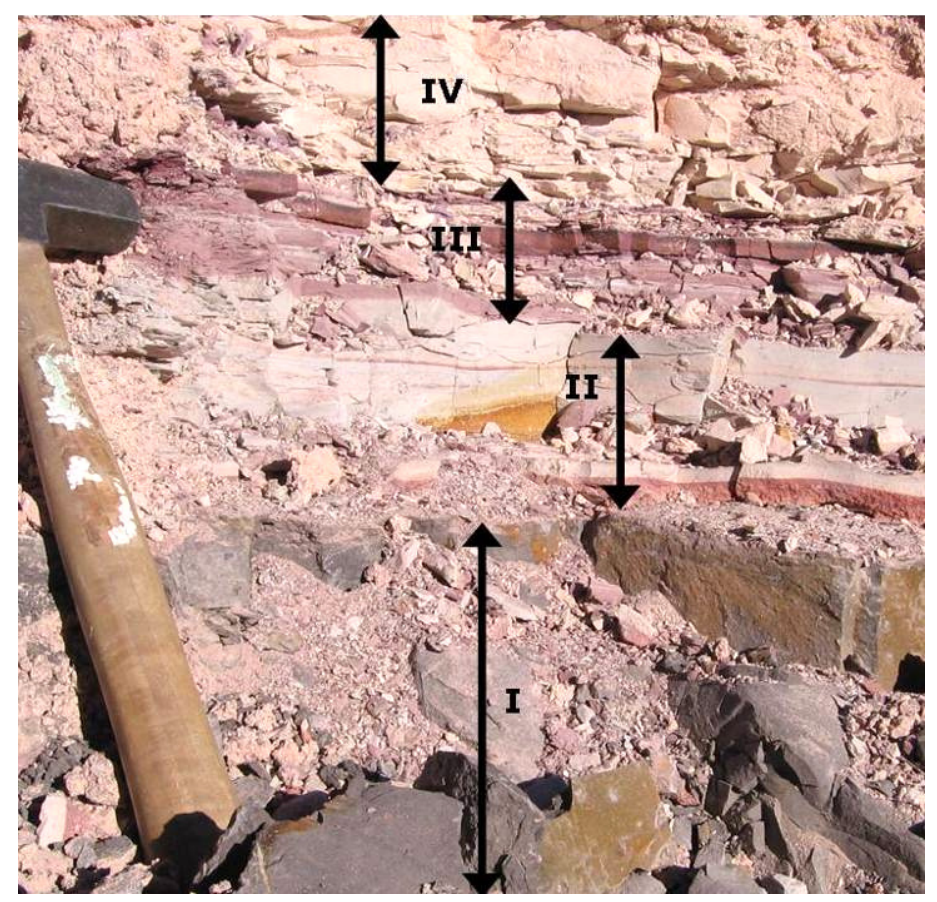

Figura VI.10. Límite entre la Sección Inferior y la Sección Superior de la Formación Cortaderita, fotografiado en la entrada de la quebrada homónima. I. Areniscas finas grises masivas (techo de la Sección Inferior). Entre I y II, límite discordante entre las secciones.

II.

Estrato basal de la Sección Superior, conteniendo un nivel plantífero. III. Areniscas y limolitas violáceas, laminadas. IV. Areniscas rosadas típicas de la Sección Superior. 
IV- 0,20 $\mathrm{m}$ expuestos (aproximadamente $5 \mathrm{~m}$ totales meteorizados, en parte cubiertos). Areniscas muy finas blanquecinas a rosadas oligomícticas con laminación entrecruzada de bajo ángulo, con impresiones de hojas.

V- $5 \mathrm{~m}$. Areniscas medianas rosadas con moteado violeta, oligomícticas con muchos clastos pumíceos, con estratificación entrecruzada. Se observa un tronco paralelo a la estratificación. Este nivel sería correlacionable al nivel 18 del perfil 1, de mucho más espesor.

Techo: hacia arriba, continúan las facies de areniscas rosadas de la Sección Superior.

\section{VI.2.5. Perfil 5}

Este perfil fue relevado en la Localidad 1 (Arroyo Cortaderita, de Spalletti, 2001a) (S $31^{\circ} 38^{\prime} 46,3^{\prime \prime}$ W 69 23' 55,9"). Abarca la base de la Sección Inferior de la Formación Cortaderita. De base a techo, se ha observado (Figura VI.11):

Base: niveles superiores de la Formación Barreal, bentonitas varicolores bandeadas. El contacto de estos estratos con los de la Formación Cortaderita es transicional.

i- $2 \mathrm{~m}$. Limolitas grises masivas con rizolitos y tocones silicificados. Representa el nivel basal de la Sección Inferior de Cortaderita.

ii- $3 \mathrm{~m}$. Bentonitas grises con numerosas impresiones-compresiones de hojas en su base. iii- 9,5 m. Limolitas grises masivas con rizolitos.

Techo: Cubierto con detritos recientes. Por encima, continúan las secuencias típicas de la Sección Inferior de limolitas grises masivas alternadas con bentonitas.

Figura VI.11. Perfil 5, en la quebrada de la Cortaderita. La flecha roja indica el contacto con la Fm Barreal. Escala gráfica: 2 m.

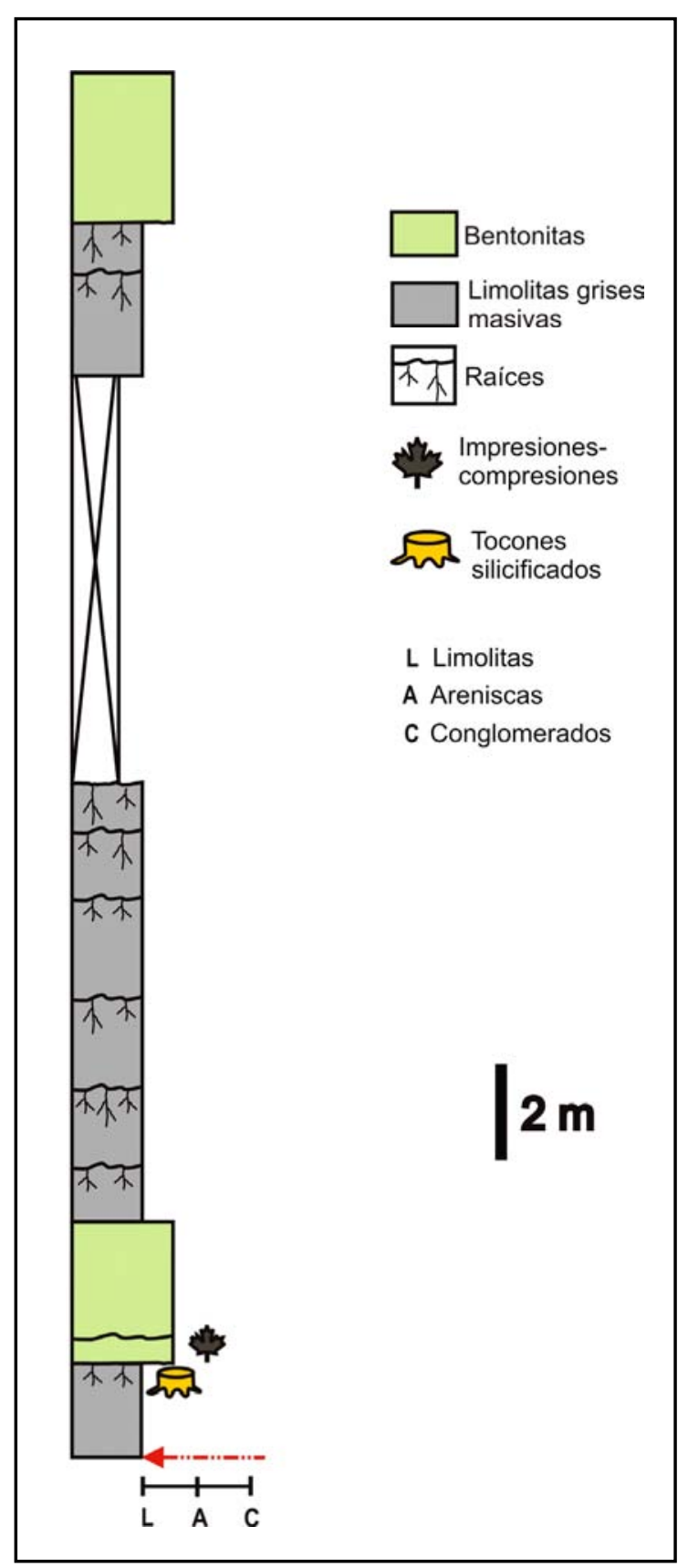




\section{3. Correlación entre perfiles}

La correlación entre los cinco perfiles se ilustra en la Figura VI.12.

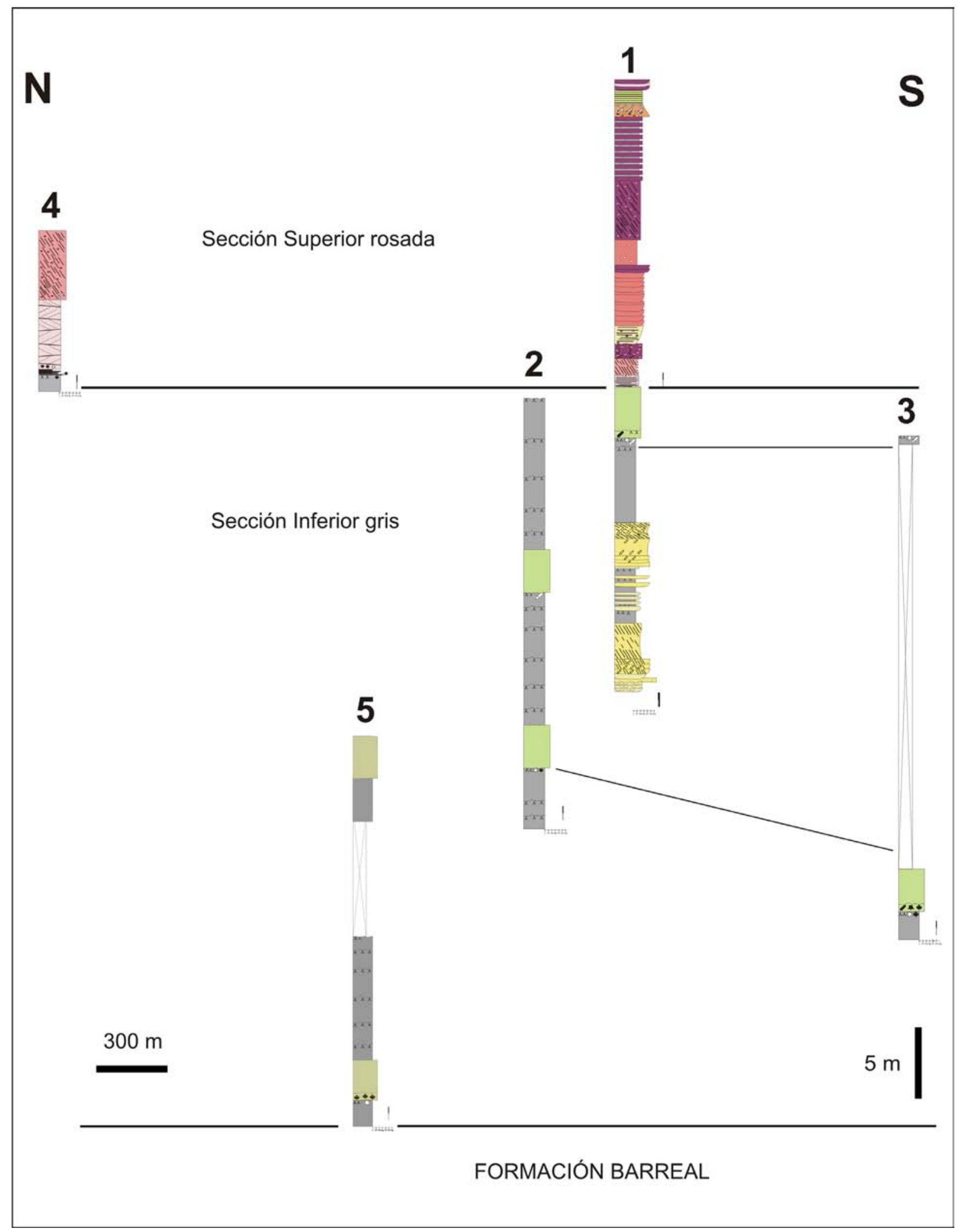

Figura VI.12. Correlación entre los cinco perfiles de la Formación Cortaderita. Escala gráfica: vertical, $1 \mathrm{~m}$; horizontal, $300 \mathrm{~m}$. 


\section{VI.4. Definición, caracterización e interpretación de las facies sedimentarias}

Las litofacies se han sido definidas de acuerdo al criterio de Miall (1978). Para su interpretación, se han aplicado las posturas de Spalletti (1980), Reading (1986) y Miall (1996). En la Sección Inferior gris, se reconocieron:

1. Facies Gmm (Paraconglomerados gruesos masivos) (nivel 2): Paraconglomerados polimícticos gruesos con clastos subangulosos de hasta $0,05 \mathrm{~m}$ de diámetro, con fuerte base erosiva. Son interpretados como depósitos de alto régimen de flujo, constituyendo el piso o lecho de un canal arenoso-gravoso.

2. Facies Gcm (Conglomerados finos con intraclastos) (nivel 11): Conglomerados finos polimícticos con grandes intraclastos angulosos a subangulosos arenosos (de hasta 0,45 $\mathrm{m}$ de diámetro) e intraclastos tobáceos, con fuerte base erosiva. Son interpretados también como depósitos de alto régimen de flujo que conforman el lecho de un canal arenoso-gravoso. Las diferencias entre esta facies y la anterior, se deberían a las características de los depósitos que fueron transportados por estos flujos, mayormente traccionales.

\section{Facies Gp (Conglomerados finos y sabulitas con estratificación entrecruzada planar)} (nivel 3): Conglomerados finos y sabulitas de tonalidades rojizas con estratificación entrecruzada planar. Se presentan en lentes amalgamados con bases erosivas. Son interpretados como formas de lecho transversales, constituyendo el relleno de un canal, en ocasiones con marcada migración lateral.

4. Facies Gtg (Conglomerados finos y areniscas sabulíticas con estratificación entrecruzada tangencial) (nivel 13): Areniscas sabulíticas y conglomerados finos con intraclastos que poseen estratificación entrecruzada de alto ángulo con base tangencial. Conforman sets de estratos entrecruzados. Son interpretados también como formas de lecho transversales que forman el relleno de un canal aislado, sin migración lateral marcada.

5. Facies Sm (Areniscas gruesas y sabulíticas masivas) (niveles 2, 12): Areniscas gruesas y sabulíticas, de geometría lenticular. Interpretadas como parte del relleno de canales arenosogravosos.

\section{Facies Sg (Areniscas finas a medianas y sabulitas masivas) (niveles 6, 8, 9, II):} Areniscas desde finas hasta gruesas y sabulitas, masivas, de geometría lenticular. Generalmente presentan una disminución de la granulometría hacia el techo. Interpretadas como flujos canalizados de la planicie de inundación (canales de crevasse).

7. Facies Se (Areniscas con laminación entrecruzada de bajo ángulo) (nivel 4): Areniscas medianas a finas grisáceas claras, polimícticas y bien seleccionadas, con laminación 
entrecruzada de bajo ángulo, en estratos tabulares. Interpretadas como depósitos de capa plana de alto régimen (flujo crítico), forman parte de una barra en espolón.

8. Facies St (Areniscas con estratificación entrecruzada en artesa) (nivel de base 0): Areniscas con estratificación entrecruzada en artesa, en lentes amalgamados. Se interpretan como formas de lecho de crestas sinuosas a linguoides (dunas 3D), conformando un canal arenosos con marcada migración lateral.

9. Facies Fm (Areniscas y limolitas grisáceas masivas) (niveles 8, 9, 10): Areniscas muy finas, areniscas limosas y limolitas con signos de bioturbación. Interpretados como depósitos de decantación, que fueron posteriormente expuestos a condiciones subaéreas. Forman el techo de canales de crevasse o canales abandonados en la planicie de inundación.

10. Facies Fr (Limolitas grisáceas masivas con rizolitos) (niveles 5, 7, 10, 14, 15, a, c, e, A, D, I, i, iii): Limolitas bentoníticas grisáceas masivas, con niveles oscuros carbonosos y niveles ocres de óxidos, con rasgos pedogenéticos (bioturbación, rizolitos, tocones de árboles con raíces in situ, evaporitas, slickensides, nódulos y estructuras moteadas). Constituyen depósitos finos de desbordamiento que sufrieron procesos pedogenéticos.

11. Facies Bt (Bentonitas) (niveles 16, b, d, B, ii): Bentonitas grises a verdosas o rosadas, claras, falladas y diaclasadas, con clastos volcánicos aislados subangulosos, madera y raíces carbonizadas, nódulos de hierro aislados y láminas de yeso. Interpretados como depósitos piroclásticos de caída (tobas) acumulados en la planicie de inundación, posteriormente alterados por bioturbación, meteorización y diagénesis.

En la Sección Superior rosada, se identificaron:

12. Facies Gt (Conglomerados finos y sabulitas con estratificación entrecruzada en artesa) (nivel 22): Conglomerados finos sabulíticos a sabulitas conglomerádicas, polimícticos violáceos, con muchos clastos piroclásticos. Conforman lentes amalgamados de base erosiva. Interpretados como depósitos de relleno de canales o barras gravosas.

13. Facies GI (Sabulitas y areniscas sabulíticas con laminación difusa) (nivel 26): Sabulitas y areniscas medianas sabulíticas, tobáceas y bentoníticas, moteadas, de tonalidades anaranjadas a rojo ladrillo y grises; intercaladas con niveles de sílice, evaporitas y calcita. Contienen clastos pumíceos y abundante contenido lítico. Presentan una laminación difusa. Portan troncos silicificados. Interpretadas como depósitos de barras arenoso-gravosas, posteriormente abandonadas, con el consecuente desarrollo de un paleosuelo, con una duricostra silícea. 


\begin{tabular}{|c|c|c|c|c|}
\hline Código & Litología & $\begin{array}{c}\text { Estructuras } \\
\text { sedimentarias }\end{array}$ & Geometría & Interpretación \\
\hline $\mathrm{Fr}$ & $\begin{array}{c}\text { Limolitas y areniscas limosas } \\
\text { grisáceas }\end{array}$ & Masiva, rizolitos & Tabular & Pedogénesis \\
\hline $\mathrm{Fm}$ & Limolitas grisáceas & Masiva, bioturbación & Lenticular & Decantación y pedogénesis \\
\hline $\mathrm{Fl}$ & $\begin{array}{l}\text { Areniscas, limolitas y arcilitas, } \\
\text { grisáceas, rosadas y moradas }\end{array}$ & Laminación horizontal & Tabular & $\begin{array}{l}\text { Capa plana de alto régimen } \\
\text { (flujo en manto) }\end{array}$ \\
\hline $\mathrm{Sm}$ & $\begin{array}{c}\text { Areniscas finas a gruesas y sabulitas, } \\
\text { rojizas, rosadas y violáceas }\end{array}$ & Masiva & Lenticular & $\begin{array}{l}\text { Depósitos de flujo } \\
\text { gravitacional }\end{array}$ \\
\hline $\mathrm{Se}$ & $\begin{array}{c}\text { Areniscas medianas a finas grisáceas } \\
\text { claras, polimícticas y bien } \\
\text { seleccionadas }\end{array}$ & $\begin{array}{l}\text { Laminación entrecruzada } \\
\text { de bajo ángulo }\end{array}$ & Tabular & $\begin{array}{l}\text { Depósitos de capa plana de } \\
\text { alto régimen (flujo crítico) }\end{array}$ \\
\hline $\mathrm{Sg}$ & $\begin{array}{c}\text { Areniscas finas a medianas y } \\
\text { sabulitas }\end{array}$ & Masiva & Lenticular & Flujo canalizado aislado \\
\hline Sl & $\begin{array}{l}\text { Areniscas muy finas a medianas y } \\
\text { sabulitas de tonalidades rojizas, } \\
\text { rosadas y violáceas }\end{array}$ & $\begin{array}{l}\text { Laminación horizontal a } \\
\text { entrecruzada de bajo } \\
\text { ángulo, bioturbación }\end{array}$ & Tabular & $\begin{array}{l}\text { Depósitos de capa plana de } \\
\text { alto régimen (flujo crítico) }\end{array}$ \\
\hline $\mathrm{Sh}$ & $\begin{array}{c}\text { Areniscas finas a medianas a } \\
\text { sabulíticas y sabulitas rosadas, rojas } \\
\text { violáceas y amarillentas }\end{array}$ & Laminación horizontal & $\begin{array}{l}\text { Tabular o } \\
\text { lenticular }\end{array}$ & $\begin{array}{c}\text { Formas de bajo régimen de } \\
\text { flujo (flujo canalizado aislado) }\end{array}$ \\
\hline $\mathrm{Sr}$ & Areniscas finas a medianas grisáceas & $\begin{array}{c}\text { Laminación entrecruzada, } \\
\text { óndulas }\end{array}$ & Tabular & $\begin{array}{l}\text { Óndulas (bajo régimen de } \\
\text { flujo) }\end{array}$ \\
\hline $\mathrm{Sp}$ & Areniscas finas a medianas violáceas & $\begin{array}{l}\text { Estratificación entrecruzada } \\
\text { de bajo ángulo, laminación } \\
\text { interna }\end{array}$ & Tabular & $\begin{array}{l}\text { Formas de lecho transversales } \\
\text { a linguoides (dunas 2D) }\end{array}$ \\
\hline St & Areniscas medianas & $\begin{array}{c}\text { Estratificación entrecruzada } \\
\text { en artesa }\end{array}$ & Lenticular & $\begin{array}{c}\text { Formas de lecho de crestas } \\
\text { sinuosas a linguoides (dunas } \\
\text { 3D) }\end{array}$ \\
\hline $\mathrm{Gmm}$ & Paraconglomerados gruesos & Masiva & $\begin{array}{c}\text { Tabular, base } \\
\text { erosiva }\end{array}$ & Carpeta traccional \\
\hline $\mathrm{Gcm}$ & Conglomerados finos & Masiva, intraclastos & $\begin{array}{c}\text { Tabular, base } \\
\text { erosiva }\end{array}$ & Carpeta traccional \\
\hline Gp & Conglomerados finos y sabulitas & $\begin{array}{c}\text { Estratificación entrecruzada } \\
\text { planar }\end{array}$ & $\begin{array}{l}\text { Lenticular, } \\
\text { base erosiva }\end{array}$ & Formas de lecho transversales \\
\hline Gtg & Conglomerados finos & $\begin{array}{c}\text { Estratificación entrecruzada } \\
\text { de alto ángulo con base } \\
\text { tangencial }\end{array}$ & $\begin{array}{l}\text { Set de estratos } \\
\text { entrecruzados }\end{array}$ & Formas de lecho transversales \\
\hline Gt & Conglomerados finos y sabulitas & $\begin{array}{c}\text { Estratificación entrecruzada } \\
\text { en artesa }\end{array}$ & $\begin{array}{l}\text { Lenticular, } \\
\text { base erosiva }\end{array}$ & Rellenos de canal \\
\hline Gl & Niveles de sílice, evaporitas y calcita & Moldes de raíces & Tabular & $\begin{array}{l}\text { Precipitación química, } \\
\text { pedogénesis }\end{array}$ \\
\hline $\mathrm{Bt}$ & Bentonitas grises claras & $\begin{array}{c}\text { Madera y raíces } \\
\text { carbonizadas, bioturbación }\end{array}$ & Tabular & $\begin{array}{l}\text { Depósitos piroclásticos de } \\
\text { caída (tobas), devitrificados }\end{array}$ \\
\hline
\end{tabular}

Cuadro VI.1. Litofacies reconocidas en la Formación Cortaderita. 


\section{Facies SI (Areniscas con laminación horizontal a entrecruzada de bajo ángulo)} (niveles 17, 18, 19, 27, IV): Areniscas muy finas a medianas y sabulitas de tonalidades rojizas, rosadas y violáceas, laminadas, con rasgos de exposición subaérea (evaporitas) y pedogénesis (moteado, bioturbación, raíces). Corresponden a depósitos de capa plana de alto régimen (flujo crítico), y constituyen mantos arenosos laminados efímeros.

16. Facies Sh (Areniscas con laminación horizontal) (nivel 20): Areniscas finas a medianas amarillentas con moteado violáceo, laminación muy fina y geometría lenticular. Interpretadas como formas de bajo régimen de flujo, que integran un flujo canalizado aislado.

17. Facies Sr (Areniscas finas a medianas con óndulas) (niveles 17, 25): Areniscas finas a medianas grisáceas con óndulas. Inferidas como formas de bajo régimen de flujo, resultado de ciclos de disminución de la energía del flujo. Son parte de mantos arenosos laminados.

\section{Facies Sp (Areniscas con estratificación entrecruzada planar y laminación interna)} (nivel 24):.Areniscas finas a medianas violáceas con moteado rosado, alto contenido piroclástico, con estratificación entrecruzada de bajo ángulo y laminación interna. Interpretadas como formas de lecho transversales a linguoides (dunas 2D), conforman depósitos de barra longitudinal arenosa.

19. Facies FI (Areniscas, limolitas y arcilitas con laminación horizontal) (niveles II, III): Areniscas finas, limolitas y arcilitas grisáceas, rosadas y moradas laminadas. Inferidas como depósitos de capa plana de alto régimen (flujo crítico), representando un flujo en manto de la planicie de inundación (cuenca de inundación propiamente dicha).

Las características de las litofacies descriptas son sintetizadas en el cuadro VI.1.

\section{VI.5. Asociación de facies e interpretación paleoambiental}

En la Sección Inferior gris las litofacies preponderantes son las facies limolíticas y bentoníticas, que se alternan con las facies arenosas menos frecuentes. En esta sucesión sedimentaria se definieron dos asociaciones de facies: AF1 y AF 2, en cada una se observa un ordenamiento grano-decreciente de las litofacies (Figura VI.13).

Se infiere que la AF 1 (Gm, Gp, Sm, Se, Fr, Fm, Sg, Bt) correspondería a un primer ciclo de sistema fluvial meandroso. Puede ser caracterizado como gravoso-arenoso de mediana sinuosidad. Las facies Gm, Gp y Sm representarían los depósitos de un canal gravoso-arenoso con marcada migración lateral, mientras que la facies Se correspondería a la barra en espolón. Las facies Fr, Fm y Sg constituirían los depósitos de la planicie de inundación, de gran desarrollo areal y en espesor (persistentes en el tiempo). Algunos episodios de desbordes del canal principal resultaron en la formación de canales de crevasse 
$(\mathrm{Sg})$. En la planicie de inundación se desarrollaron sucesiones de paleosuelos en los que se asentaron comunidades arbóreas y arbustivas. En algunas áreas se acontecieron episódicamente lluvias de cenizas (depósitos de tobas Bt), que sepultaron las comunidades vegetales, favoreciendo su preservación como impresiones-compresiones. En la mayoría de las ocasiones una parte de las comunidades continuaron creciendo sobre los depósitos piroclásticos, con lo que éstos tienen rasgos de bioturbación.

La AF 2 (Gcm, Gtg, Sm, Fr, Sg, Bt) es interpretada como un segundo ciclo de sistema fluvial meandroso. Puede ser descrito como gravoso de alta sinuosidad. Las facies Gcm, Gtg y Sm representan los depósitos de un canal gravoso-arenoso aislado sin migración lateral. Las facies Fr, Fl y Sg constituyen los depósitos de la planicie de inundación, también de gran desarrollo areal y espesor. Algunos episodios de desbordes del canal principal resultaron en la formación de canales de crevasse $(\mathrm{Sg})$ sobre la planicie de inundación. En esta última se desarrollaron paleosuelos, en los que se asentaron comunidades arbóreas y arbustivas, que fueron sepultadas en ciertas áreas por lluvias de cenizas (depósitos de tobas $\mathrm{Bt}$ ). Algunas plantas continuaron creciendo sobre los depósitos piroclásticos, evidenciado en los rasgos de bioturbación.

En la Sección Superior rosada, son reconocidas también dos asociaciones de facies. En esta sección no es tan claro el ordenamiento de las facies, no obstante parece existir un stacking grano-creciente en cada asociación (Figura VI.14). Se infiere que la AF 3 (Fl, Sl, Sh, Sr, Sm) constituye un primer ciclo de sistema fluvial entrelazado, comparable al modelo de sistema entrelazado arenoso distal dominado por flujos en manto, característico de las regiones áridas o semiáridas (Distal Sheetflood Sand-Bed Braided River de Williams, 1971). Está caracterizado por flujos efímeros que forman una red de canales poco definidos y de poca profundidad. Estas descargas episódicas condujeron a una depositación preferencial de capas de régimen de flujo transicional a alto, predominantemente areniscas con laminación horizontal (Sh) y areniscas con laminación entrecruzada de bajo ángulo ( $\mathrm{Sl}$ ). En el techo de los estratos son frecuentes los rasgos de exposición subaérea (niveles de yeso, moteado, bioturbación, nódulos de hierro) que evidencian las interrupciones episódicas del flujo ácueo.

La AF 4 (Gt, Gl, Sm, Sl, Sr, Sp, P) representaría un sistema entrelazado arenoso, de alta energía. Las facies Gt representan depósitos de la faja de canales inicial. Las facies Sm, $\mathrm{Sh}, \mathrm{Sr}$ y Sp conforman depósitos de barras arenosas. La facies Gl se intercala con la facies $\mathrm{P}$, pudiendo ser interpretada como una barra longitudinal gravosa, con un episodio de abandono del canal y formación de paleosuelos en el tope (moteado, bioturbación, moldes de raíces, 
formación de duricostra). Una reactivación de la faja de canales está marcada por depósitos de rellenos de canales y/o barras arenosas (facies $\mathrm{Sl} \mathrm{y} \mathrm{Sm}$ ).

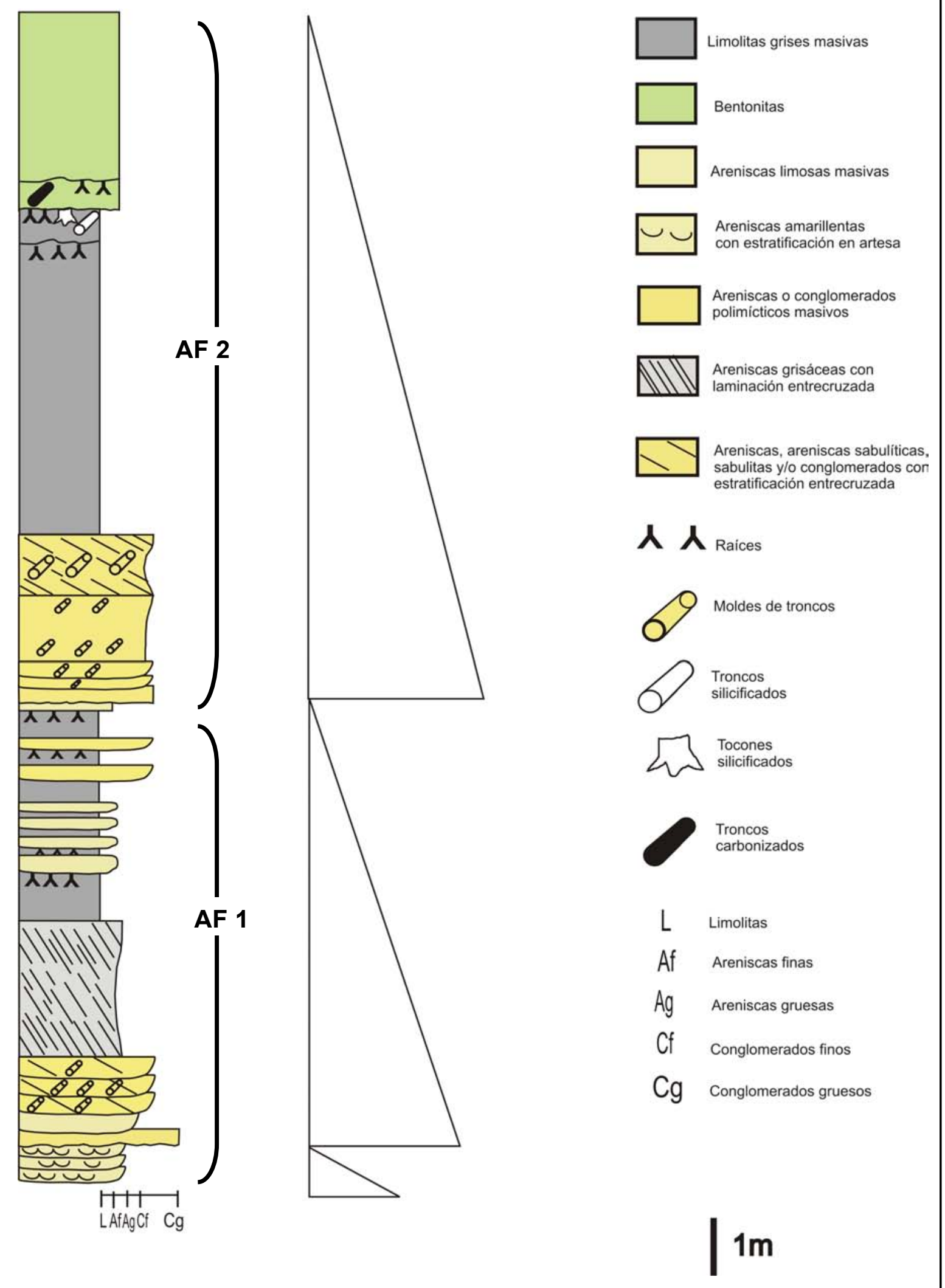


(Página anterior) Figura VI.13. Perfil 1, mostrando el ordenamiento de las asociaciones de facies en la Sección Inferior de la Formación Cortaderita Escala gráfica: 1 m.

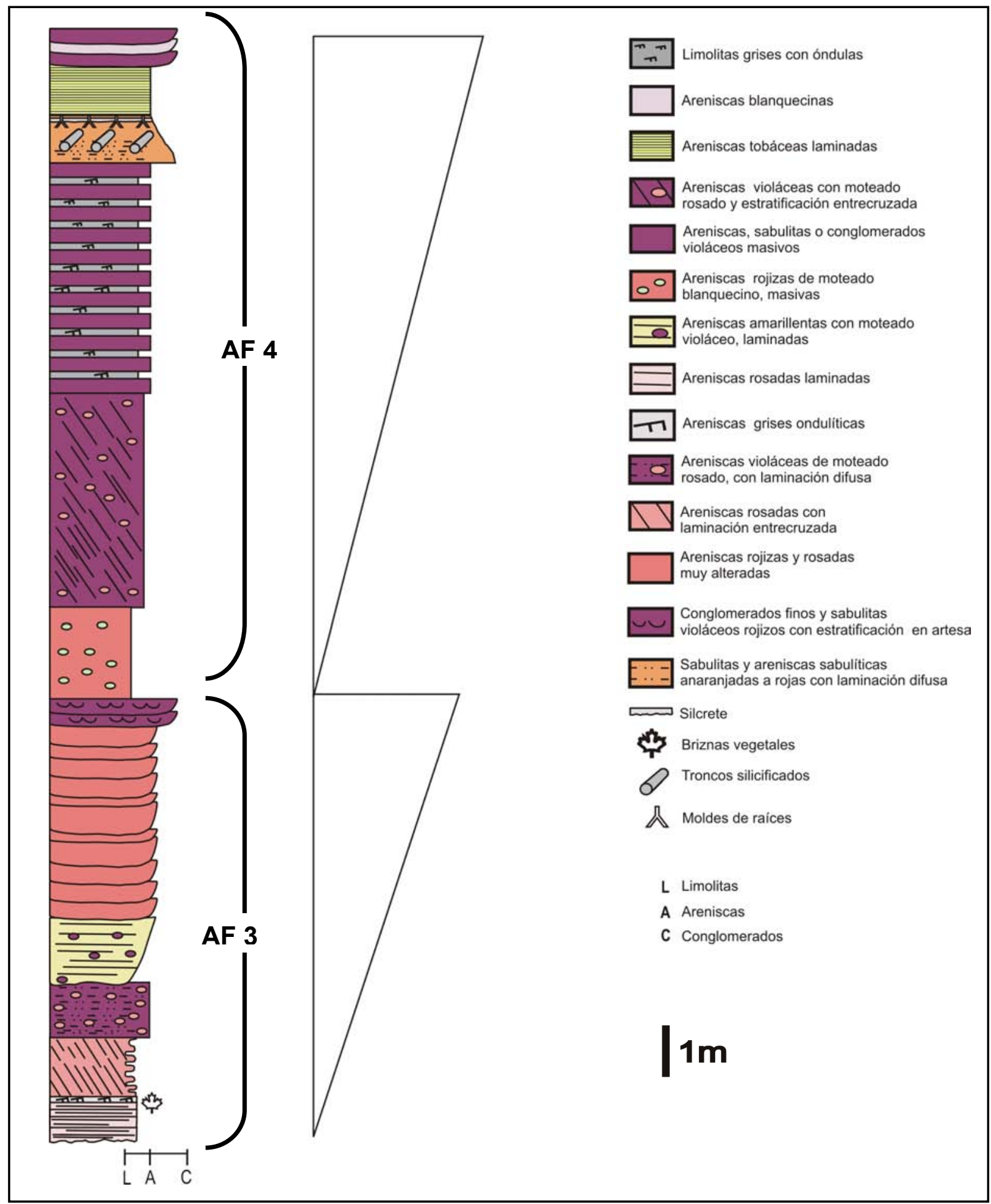

(Esta página) Figura VI.14. Perfil 1, mostrando el ordenamiento de las asociaciones de facies en la Sección Superior de Cortaderita. Escala gráfica: 1 m. 


\section{VI.6. Interpretación de los paleosuelos}

Se considera que un suelo es un cuerpo natural que difiere del material parental en cuanto a sus propiedades morfológicas, físicas, químicas y mineralógicas, y sus características biológicas (e.g. Joffe, 1949; Buol, 1973, 1989; Birkeland, 1984). La formación del suelo es una función de la topografía, el material parental, los organismos que viven en el ambiente, del intervalo de tiempo implicado, y mayormente, del clima regional (Jenny, 1941).

Paleosuelos es un término que designa los suelos formados bajo condiciones distintas de las que predominan en la región donde se los halla. Su presencia implica que ha habido cambios climáticos, de vegetación y/o de topografía. El nombre de suelos soterrados (buried soils) es en parte sinónimo de paleosuelos; sin embargo existen paleosuelos que no están enterrados o sepultados bajo otros depósitos (Teruggi, 1971).

Al igual que las estructuras sedimentarias físicas y las trazas fósiles, los caracteres paleopedológicos reflejan muchos de los parámetros ambientales que prevalecen durante la fase de depositación lenta; pero como los paleosuelos se forman in situ, también proveen un excelente registro durante períodos de no depositación (McCarthy y Plint, 1999).

En los perfiles levantados de la Formación Cortaderita se han reconocido dos tipos de paleosuelos:

1. En la Sección Inferior gris: paleosuelos desarrollados en limolitas y areniscas finas bentoníticas, que conformar los depósitos finos de desbordamiento sobre la planicie de inundación. Como rasgos paleopedogenéticos se han reconocido: rizolitos, rizoconcreciones, impresiones-compresiones de raíces, pérdida de la estructura sedimentaria original, moteado, marcas de lluvia, niveles de yeso, nódulos de hierro, estructura espejada tipo slickensides, evaporitas, diferentes niveles de oxidación y contenido de materia orgánica. De acuerdo al criterio de Retallack (1988) y la clasificación de los suelos del Soil Survey Staff (1999), estos paleosuelos podrían corresponder al tipo vertisoles. Este tipo de suelos son característicos de los climas estaciones. Presentan un alto contenido de arcilla expansiva (=montmorillonita) que forma profundas grietas en las estaciones secas, debido a los cambios abruptos de humedad del ambiente. Sufren una fuerte expansión al humedecerse y una marcada contracción, y precipitación de evaporizas, al secarse (Soil Survey Staff, 1999).

2. En la Sección Superior: paleosuelos desarrollados en areniscas y sabulitas tobáceas y bentoníticas, de tonalidades anaranjadas, rosadas y rojas, correspondientes a una barra abandonada. Como rasgos pedogenéticos se han reconocido: moldes de raíces, pérdida de la estructura sedimentaria original, una duricostra de sílice (silcrete), evaporitas y calcita. De acuerdo al criterio de Retallack (1988) y la clasificación de los suelos del Soil Survey Staff 
(1999), estos paleosuelos podrían corresponder al tipo aridisoles. Estos suelos se presentan en zonas de clima árido y semiárido. Es característico que estos suelos posean un horizonte superficial claro y pobre en materia orgánica. Los procesos involucrados en su génesis incluyen la migración y acumulación de sales solubles, carbonatos y arcillas silicatadas o concentraciones de calcáreo o sílice (Soil Survey Staff, 1999). La presencia de este tipo de paleosuelos en la Sección Superior indicaría una desecación del clima.

\section{VI.7. Discusión sedimentológica}

La Formación Cortaderita estaría conformada por dos secciones (que podrían ser consideradas como miembros) bien distinguibles por su litología. De acuerdo al análisis realizado, la Sección Inferior gris está dominada por facies Fr y Fm (limolitas y areniscas limosas grises bentoníticas), mientras que en la Sección Superior rosada predominan las facies Sm y Sh (areniscas finas a gruesas y sabulíticas rosadas y rojizas). Se puede reconocer un cambio paleoambiental importante entre ambas secciones, como fuera propuesto anteriormente por Spalletti (1995, 2001a).

Sobre la base de la interpretación sedimentológica, tafonómica y paleobotánica realizada en este trabajo, la Sección inferior gris se considera como perteneciente a depósitos de sistemas fluviales meandrosos, a diferencia de las interpretaciones previas ( $c f$. Spalletti, 1995, 2001a; Artabe et al., 1995b), con un importante desarrollo de paleosuelos de tipo vertisoles y eventos episódicos de lluvias de ceniza. Las facies pelíticas alcanzan grandes espesores, lo que caracteriza a los paleoambientes lacustres (Spalletti, 1980) y, entre otras evidencias, apoyaría un modelo de sedimentación lacustre para la Sección Inferior gris, como fuera inferido en los trabajos anteriores (cf. Spalletti, 1995, 2001a; Artabe et al., 1995b). La significativa proporción de material de granulometría fina, en el modelo fluvial meandroso aquí propuesto, podría ser explicada por las intensas y frecuentes lluvias de cenizas que se ocurrían en la cuenca de Barreal-Calingasta y el apilamiento de paleosuelos. Justamente la mayoría de las sedimentitas de la Formación Cortaderita tienen un alto contenido tobáceo/bentonítico. Las características paleoambientales habrían permitido el gran desarrollo en espesor de los paleosuelos de tipo limosos y bentoníticos. Estudios en suelos recientes han mostrado que a partir de cenizas volcánicas se pueden desarrollar apilamientos de suelos, de espesores importantes (30 m cf. Lizcano et al., 2006). En cuanto al contenido fosilífero, las limolitas grises masivas de esta sección han sido intensamente procesadas para la búsqueda de palinomorfos y microfósiles calcáreos, resultando en todas las muestras estériles tanto de 
palinomorfos (Zavattieri, com. pers.), como de microfósiles (Carignano, com. pers.) lo que es bastante común en sedimentitas correspondientes a paleosuelos.

De acuerdo al análisis de las asociaciones de facies, la Sección Superior rosada representaría depósitos de sistemas fluviales entrelazados, lo que concuerda con las interpretaciones previas (cf. Spalletti, 1995, 2001a).

\section{VI.8. Consideraciones estratigráficas}

El límite entre la Sección Inferior y la Sección Superior está marcado por una discontinuidad, reconocida por Spalletti (1995, 2001a) y Spalletti et al. (1999) sobre la base de los cambios abruptos de facies y la reorganización paleogeográfica en la cuenca, reflejada por los cambios en las paleocorrientes.

Conforme al modelo de sedimentación aquí propuesto, la discontinuidad entre la Sección Inferior y la Sección Superior, correspondería a un límite entre dos secuencias deposicionales, representadas por dos tipos diferentes de ambientes en cada sección, por lo que constituiría una superficie limitante de séptimo orden (Miall, 1996).conformaría.

Spalletti (1995, 2001a), y Spalletti et al. (1999) han propuesto que dicha discontinuidad constituiría una discordancia regional, es decir una superficie limitante del octavo orden (Miall, 1996), con lo que el hiatus temporal variaría entre uno y diez millones de años. Si se siguiera esta interpretación, las dos secciones de la Formación Cortaderita deberían ser dos formaciones independientes, puesto que no deben agruparse en una misma unidad formacional sucesiones separadas por discordiancias regionales y hiatus temporales importantes (Comité Argentino de Estratigráfica, 1992). Por otro lado, Stipanicic (2002) no reconoce un hiatus estratigráfico dentro de la Formación Cortaderita.

A partir del presente análisis de facies, no se puede sostener, pero tampoco descartar, la presencia de la discordancia regional. Sin embargo, el cambio facial y paleoambiental en la presente interpretación (de fluvial meandroso gravoso a entrelazado arenoso) no sería tan abrupto como en los modelos previos (de lacustre meromíctico a fluvial entrelazado) lo que tal vez esté indicando que no hubo una reorganización estructural tan significativa como para conformar una discordancia regional.

Sobre la base de la interpretación sedimentológica y sumando las evidencias bioestratigráficas (tratadas en el Capítulo XII), la discontinuidad entre las secciones de la Formación Cortaderita correspondería a un límite secuencia, contemplando un hiatus del orden de menos de 1 millón de años. 
Por lo tanto, y tomando una postura conservadora, las dos secciones seguirían perteneciendo a la misma unidad formacional, y cada una podría constituir un miembro de la misma formación. 


\section{SISTEMÁTICA PALEOBOTÁNICA}

\section{VII.1. Introducción}

En el Capítulo IV se ha realizado una breve reseña de los estudios acerca de los fósiles vegetales de la Formación Cortaderita. Groeber y Stipanicic (1953), Stipanicic (1972, 1979) y Bonetti (1963) realizaron el primer ordenamiento preciso y estudio en detalle de su contenido paleobotánico. Artabe et al. (1995a, b) y Zamuner et al. (2001) modificaron ese esquema, complementando con nuevos datos paleoflorísticos, paleoambientales y paleoecológicos. En el siguiente cuadro (Cuadro VII.1) se ilustran las dos posturas mencionadas.

\begin{tabular}{|c|c|c|}
\hline & $\begin{array}{c}\text { Groeber y Stipanicic (1953), Stipanicic } \\
\qquad(1972,1979), \text { Bonetti (1963) }\end{array}$ & Artabe et al. (1995a), Zamuner et al. (2001) \\
\hline $\begin{array}{l}\text { Sección Inferior } \\
\text { de la Formación } \\
\text { Cortaderita }\end{array}$ & $\begin{array}{l}\text { NF II: Pleuromeiales (Lepidanthium } \\
\text { sporiferum), Corystospermales (Dicroidium } \\
\text { odontopteroides, D. lancifolium, Xylopteris } \\
\text { elongata, Umkomasia macleani), } \\
\text { Ginkgoales (Sphenobaiera stormbergensis), } \\
\text { Gnetales (Yabeiella wielandi, Fraxinopsis } \\
\text { andium) y gimnospermas incertae sedis } \\
\text { (Cordaicarpus mackayi) }\end{array}$ & $\begin{array}{l}\text { EF de Cortaderita Inferior: troncos in situ y } \\
\text { raigones de Coniferales (“Protocircoporoxylon } \\
\text { cortaderitaense”) y Corystospermales (Rhexoxylon } \\
\text { sp.), que atraviesan } 3 \mathrm{NF} \text { : } \\
\text { - Nivel 1: Equisetales (Neocalamites sp.) } \\
\text { - Nivel 2: Peltaspermales (Scytophyllum } \\
\quad \text { bonettiae) y Cycadales (Pseudoctenis sp. A) } \\
\text { - Nivel 3: Osmundales (Cladophlebis sp.) y } \\
\text { Corystospermales (Zuberia papillata) }\end{array}$ \\
\hline $\begin{array}{l}\text { Sección } \\
\text { Superior de la } \\
\text { Formación } \\
\text { Cortaderita }\end{array}$ & $\begin{array}{l}\text { NF III: Corystospermales (Dicroidium } \\
\text { lancifolium, Zuberia feistmanteli), } \\
\text { Cycadales (Pseudoctenis ctenophylloides), } \\
\text { Coniferales ("Protocircoporoxylon } \\
\text { cortaderitaensis") }\end{array}$ & $\begin{array}{l}\text { EF de Cortaderita Superior: Corystospermales } \\
\text { (Dicroidium odontopteroides y D. lancifolium) }\end{array}$ \\
\hline
\end{tabular}

Cuadro VII.1. Niveles fosilíferos reconocidos para la Formación Cortaderita $(\mathrm{NF}=$ nivel fosilífero; $\mathbf{E F}=$ estrato fosilífero).

Los presentes estudios pudieron discriminar cuatro estratos fosilíferos ( $=\mathrm{EF} 1,2,3$ y 4$)$ en la Sección Inferior de la Formación Cortaderita, y cuatro estratos fosilíferos en la Sección Superior (=EF5, 6, 7 y 8).

De la Sección Inferior, el EF más basal (=EF1) contiene gran número de impresionescompresiones de hojas, ramas y estructuras reproductivas. Cada uno de los EF2, 3 y 4, representa un nivel de bosque in situ, constituido por troncos y tocones permineralizados, e impresiones-compresiones de hojas, ramas y estructuras reproductivas. Conjuntamente, los 
cuatro EF son equivalentes al NF II de Bonetti (1963) y el EF de Cortaderita Inferior de Artabe et al. (1995a).

El EF5, emplazado en la base de la Sección Superior, está formado por varios niveles superpuestos, cada uno con gran cantidad de impresiones de hojas. Es correlacionable al EF de Cortaderita Superior de Artabe et al. (1995a). Se distingue de los otros tres EF de la Sección Superior por las condiciones tafonómicas, y por eso será tratado aparte.

Los restantes EF de la Sección Superior corresponden en conjunto al NF III de Bonetti (1963). El EF 6 contiene escasas permineralizaciones y moldes de troncos y tocones in situ, y algunas impresiones-compresiones de hojas. En el EF7 se han encontrado troncos permineralizados dispersos. Por último, El EF8 representa un nivel de bosque constituido por numerosos troncos permineralizados.

\section{VII.2. Estratos fosilíferos de la Sección Inferior de la Formación Cortaderita}

\section{$\underline{\text { Localización }}$}

En la localidad 1 -sitio Arroyo Cortaderita (Spalletti, 2001a) S $31^{\circ} 39^{\prime} 17,2^{\prime \prime}$ W $69^{\circ}$ 24' 33,2"- se ha reconocido el EF1. El EF2 se ha identificado en las localidades 2 (Tapera, S

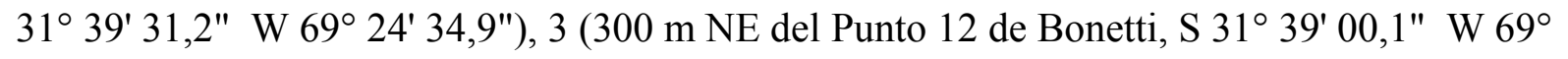
23' 52,1") y 5 (Mina Don Francisco, entre S $31^{\circ} 39^{\prime} 27,3^{\prime \prime}$ W 69² 24' 16, '" y S $31^{\circ} 39^{\prime} 23,5^{\prime \prime}$ W 69 24' 18"). El EF 3 se ha descripto para la localidad 3, mientras que el EF4 se ha definido en la localidad4 (Punto 12 de Bonetti, S $31^{\circ} 39^{\prime}$ 08,4" W 69² 24' 28").

\section{$\underline{\text { Tafonomía }}$}

Los fósiles vegetales de la Sección Inferior han quedados preservados en sedimentitas de tipo limolitas y areniscas bentoníticas masivas, y bentonitas grises verdosas. Cada estrato es interpretado como parte de un paleosuelo, de tipo vertisol desarrollado en la planicie de inundación de un sistema fluvial meandroso y cubierto por depósitos piroclásticos de caída (tobas) posteriormente alterados por bioturbación, meteorización y diagénesis. En este ambiente se pueden reconocer tres tipos de preservación, producto de tres tipos diferentes de procesos sedimentarios y geoquímicos:

1-Evento de inundación por desborde del canal: que sepultó los niveles de hojarasca de los bosques, preservando hojas, ramas y estructuras reproductivas como impresionescompresiones en varios niveles de pocos milímetros de espesor.

2-Lluvia de cenizas volcánicas: cubrió al bosque in situ, preservando troncos, ramas y hojas carbonizados. 
3-Devitrificación de las tobas: en su proceso de alteración a bentonitas, ha suministrado la sílice para la permineralización de los troncos y tocones.

\section{$\underline{\text { Sistemática Paleobotánica }}$}

\section{División Marchantiophyta (sensu Kenrick et Crane, 1997)}

\section{$\underline{\text { Criterio para el tratamiento sistemático de las hepáticas }}$}

Se ha seguido la postura de Oostendorp (1987), que utiliza el nombre genérico Thallites para aquellos fósiles que no pueden ser inequívocamente asignados a las marchantiofitas pero presentan cierta afinidad con las mismas. Los ejemplares de Cortaderita muestran una forma de crecimiento similar al de las hepáticas, así como una evidente costa media. Sin embargo, por el estado de preservación de estos materiales, caracteres como los rizoides, el detalle celular y las estructuras reproductivas no son observables; con lo que no pueden ser asignados con total seguridad a algún grupo de hepáticas. Este género ha sido mencionado para la Formación Cacheuta en la Argentina (Jain y Delevoryas, 1967).

\section{Incertae sedis}

\section{Género Thallites Walton 1925}

Especie tipo. Thallites erectus (Leckenby) Walton 1925.

\section{Thallites sp. 1}

Figura VII.1.1

Descripción: Fragmentos de talos postrados, de 1,45 a 3,1 cm de largo y 1,05 a 2,2 cm de ancho, de morfología en abanico o triangular y divididos de manera dicotómica abierta. Los talos se dividen por lo menos 3 veces formando segmentos de 0,3 a 0,6 cm de ancho, que parten con un ángulo de 20 a $45^{\circ}$, poco espaciados entre sí. Los márgenes de los segmentos son lisos a algo ondulados, mientras que los ápices son redondeados, lobulados. La costa central es conspicua y de 0,04 a $0,11 \mathrm{~cm}$ de espesor.

Material estudiado: PBSJ 408.

Estrato fosilífero y localidad: EF2, Localidad 2. 


\section{Thallites sp. 2}

Figura VII.1.2

Descripción: Fragmentos de talos postrados, de $4 \mathrm{~cm}$ de diámetro, de morfología en abanico o en roseta y dividido de manera dicotómica abierta. El talo se divide hasta 5 veces, formando segmentos de $0,2 \mathrm{~cm}$ de ancho en la región proximal y 0,5 a $076 \mathrm{~cm}$ de ancho en la región distal. Los segmentos parten con un ángulo de 25 a 55 . Los márgenes de los segmentos son lisos a algo ondulados, mientras que los ápices son redondeados, incisos. La costa central es conspicua y de $0,065 \mathrm{~cm}$ de espesor.

Material estudiado: PBSJ 409.

Estrato fosilífero y localidad: EF2, Localidad 2.

\section{División Bryophyta (sensu Kenrick et Crane, 1997)}

\section{Incertae sedis}

\section{Género Muscites Brongniart 1828a}

Especie tipo. Muscites tournalii Brongniart 1828a.

\section{Muscites sp.}

Figura VII.1.3

Descripción: Gametofitos simples, no ramificados, que consisten en ejes foliosos de 0,3 a 1 cm de longitud, 0,1 a 0,4 cm de ancho. Los ejes (caulidios) son muy delicados, de 0,013 cm de diámetro, cubiertos densamente por hojuelas de disposición helicoidal. Las hojuelas (filidios) son lineares, con costa media, de $0,1 \mathrm{a} 0,4 \mathrm{~cm}$ de longitud y 0,006 a $0,03 \mathrm{~cm}$ de ancho, con base ensanchada, márgenes lisos y ápice agudo, insertas con un ángulo de 25 a $50^{\circ}$. No se observan rizoides ni esporofitos.

Materiales estudiados: PBSJ 410.

Estrato fosilífero y localidad: EF2, Localidad 2.

Comentarios: este material es referido al género Muscites, siguiendo el criterio de Ottone y Archangelsky (2001) y tomando en consideración el estado de preservación regular de los ejemplares. La ausencia de esporofitos, sumado a que no son observables los detalles de las células foliares, impiden la asignación específica del material. 


\section{División Tracheophyta Sinnott ex Cavalier-Smith 1998}

Subdivisión Lycopodiophytina Tippo ex Reveal 1996

Clase Isoetopsida Rolle 1885

Orden Pleuromeiales sensu Retallack 1997

Género Lepidanthium Schimper 1872

Especie tipo. Lepidanthium microrhombeum (Braun) Schimper 1872.

Lepidanthium sporiferum (Feistmantel) Frenguelli 1944b

Estrato fosilífero y localidad: EF2, Localidad 2.

Material revisado: LPPB 20402.

Comentarios: Esta especie fue descripta por Frenguelli (1944b) con materiales provenientes de la Formación Cortaderita. Posteriormente, Bonetti (1963) pasó estos ejemplares a la especie tipo del género (Lepidanthium microrhombeum) y los ubicó en su NF II, punto 20. Aquí se acepta la designación original de Frenguelli (1944b).

Subdivisión Euphyllophytina Kenrick et Crane 1997

Clase Equisetopsida Agardh 1825

Orden Equisetales Dumortier 1829

Familia Apocalamitaceae Radczenko 1957.

Género Neocalamites Halle 1908

Especie tipo. Neocalamites hoerensis (Schimper) Halle 1908.

\section{Neocalamites sp.}

Estrato fosilífero y localidad: EF2, Localidad 5.

Comentarios: Citada por Artabe et al. (1995a) para el nivel fosilífero 1 del EF de Cortaderita Inferior.

Familia Equisetaceae Michaux ex de Candolle 1804

Género Equisetites Sternberg 1833

Especie tipo. Equisetites muensteri Sternberg 1833. 


\section{Equisetites fertilis Frenguelli 1944c}

Estrato fosilífero y localidad: EF2, Localidad 2.

Comentarios: Esta especie fue definida por Frenguelli (1944c) para la Formación Potrerillos. Asimismo, Frenguelli. (1944b) mencionó la presencia de Equisetites fertilis en una colección de plantas fósiles de Faltis, provenientes de la la quebrada de un Salto y entre los que están los materiales estudiados de Lepidanthium sporiferum. Bonetti (1963) cita la especie para el NF II, punto 20, y el NFI, punto 12.

\section{Familia Phyllothecaceae sensu Boureau 1964}

Género Phyllotheca Brogniart emend. Townrow 1955

Especie tipo. Phyllotheca australis Brongniart 1828a.

\section{Phyllotheca australis Brongniart 1828a}

Estrato fosilífero y localidad: EF2, Localidad 2.

Comentarios: Esta especie fue reconocida, descripta e ilustrada por Frenguelli (1944d) para la Formación Ischigualasto. En otra publicación, este autor (1944b) cita a Phyllotheca australis en una colección de plantas fósiles de Faltis, provenientes de la la quebrada de un Salto y entre los que están los materiales estudiados de Lepidanthium sporiferum. Bonetti (1963) cita la especie para el NF II, punto 20, y el NFI, punto 12.

\section{Clase Marattiopsida Doweld 2001}

Orden Marattiales Link 1833

Familia Asterothecaceae sensu Boureau et Doubinger 1975

Género Rienitsia Walkom 1932

Especie tipo. Rienitsia spathulata Walkom 1932.

\section{Cf. Rienitsia arrondiana Herbst 1979b}

Figuras VII.1.4 y 5

Descripción: Dos fragmentos de una fronde bipinnatífida a bipinnatisecta, de forma y tamaño desconocido. Raquis principal no preservado. Un fragmento abarca tres pinnas, tiene un ancho de $1,71 \mathrm{~cm}$ y una longitud de $2,28 \mathrm{~cm}$. El otro fragmento incluye una sola pinna, de 
$1,17 \mathrm{~cm}$ de ancho y $2,76 \mathrm{~cm}$ de longitud. Ninguna de las pinnas está preservada en toda su longitud. Sus fragmentos tienen una longitud de $1,13 \mathrm{~cm}, 1,41 \mathrm{~cm}$ y $1,71 \mathrm{~cm}$ y un ancho de $0,71 \mathrm{~cm}, 0,75 \mathrm{~cm}$ y $0,89 \mathrm{~cm}$. Son alargadas, pinnatisectas en su región media, y pinnatífidas en su región apical, culminando en un lóbulo impar de ápice agudo. Los ráquises de las pinnas tienen 0,5 a 0,85 $\mathrm{mm}$ de espesor. Los lóbulos tienen una morfología asimétrica, se inclinan a partir del raquis de la pinna con un ángulo de 58 a $72^{\circ}$, tienen un ápice redondeado a ligeramente redondeado-agudo. En los sectores más pinnatisectos, los lóbulos pueden considerarse como verdaderos segmentos contiguos, unidos por la base. En los lóbulos y segmentos medios a proximales, existe una vena media que se origina en la base cerca del margen basicópico, con un ángulo de $60^{\circ}$ aproximadamente; luego se curva siendo su concavidad hacia la base de la pinna, y culmina cerca del ápice del lóbulo o segmento. De las venas laterales, la más basal parte con un ángulo agudo directamente del raquis de la pinna. Las siguientes venas laterales parten con un ángulo agudo de la vena media son alternas y arqueadas con la concavidad hacia el raquis. Se dicotomizan hasta dos veces. En los lóbulos medios a distales, la venación es semejante, excepto porque la vena media tiene un recorrido levemente sinuoso hasta llegar al ápice. En los lóbulos más distales hay una tendencia a perderse la vena media.

Material estudiado: PBSJ 411.

Estrato fosilífero y localidad: EF2, Localidad 2.

Comentarios: Este ejemplar se asemeja a Rienitsia porque es una fronde pinnada a bipinnatífida, con pinnas alargadas, lóbulos o segmentos de último orden con un ángulo de inclinación agudo y con vena media no siempre definida; rasgos que fueron utilizados en la diagnosis de Walkom (1932) para formas fértiles. Por tratarse de un ejemplar fragmentario de pinnas estériles, fue asignado con dudas a Rienitsia Walkom 1932, ya que todas las especies del género fueron descriptas sobre la base de material fértil. La revisión de Herbst (1979b) amplia el concepto del género a formas estériles, y crea más especies para el Triásico Superior de la Cuenca El Tranquilo (Santa Cruz, Argentina). El material PBSJ 411 se asemeja a la especie Rienitsia arrondiana Herbst $1979 \mathrm{~b}$ en que las pínnulas son pinnatífidas a pinnatisectas y los lóbulos ligeramente asimétricos, pero no se lo puede asignar con seguridad a la especie porque es una forma estéril.

\section{Clase Polypodiopsida Cronquist, Takhtajan et Zimmerman 1966 \\ Orden Osmundales Link 1833}

Familia Osmundaceae Martinov 1820 
Género Cladophlebis Brongniart emend. Frenguelli 1947

Especie tipo. Cladophlebis albertsii (Dunker) Brongniart 1849.

\section{Cladophlebis mendozaensis (Geinitz) Frenguelli 1947}

Material revisado: $\mathrm{BAPb} 4311,4312,4314$.

Estrato fosilífero y localidad: EF2, Localidad 2.

Comentarios: Ejemplares asignados a esta especie fueron estudiados por Bonetti (1963), para el NF I, punto 12.

Cladophlebis sp.

Material revisado: $L P P B 13840$.

Estrato fosilífero y localidad: EF2, Localidad 5.

Comentarios: Citada por Artabe et al. (1995a) para el nivel fosilífero 3 del EF de Cortaderita Inferior.

Orden Cyatheales Frank in Leunis 1877

Familia Dicksoniaceae Schomburgk 1848, nomina conservanda

Género Coniopteris Brongniart emend. Harris 1961

Especie tipo. Coniopteris murrayana (Brongniart) Brongniart emend. Harris 1961

\section{Coniopteris sp.?}

Material revisado: $\mathrm{BAPb} 4296,4297,4299$.

Estrato fosilífero y localidad: EF2, Localidad 2.

Comentarios: Mencionada por Groeber y Stipanicic (1953), para el NF II.

Orden Gleicheniales sensu Smith, Pryer, Schuettpelz, Korall, Schneider et Wolf 2006

Familia Dipteridaceae Seward et Dale 1901

Género Dictyophyllum (Lindley et Hutton) Webb 1982

Especie tipo. Dictyophyllum rugosum Lindley et Hutton 1834. 


\section{Dictyophyllum tenuifolium Stipanicic et Menéndez emend. Bonetti et Herbst 1964}

Figuras VII.1.6, 7,8 y 9

Descripción: Fragmentos de 3,03 a 4,23 cm de largo y 1,25 a 2,56 cm de ancho, de una fronde peciolada, monopinnada, de aspecto palmado. Pecíolo no preservado. Raquis corto y bifurcado. Lámina dividida en dos hemiláminas equivalentes. Cada hemilámina dividida varias veces en su margen catadrómico de manera dicótomica, generando pinnas dispuestas acroscópicamente. Pinnas de forma linear-oblanceolada, fusionadas en la base, de aproximadamente 4,23 cm de longitud y 0,97 a $1,5 \mathrm{~cm}$ de ancho. Márgenes lobuladoaserrados con senos leves a profundos, y lóbulos irregulares, asimétricos, de contorno triangular y ápice agudo-acuminado. Venas principales conspicuas, de 0,037 a 0,05 cm de espesor. Venas secundarias muy marcadas, alternas a subalternas, que salen con un ángulo de 45 a $60^{\circ}$ de las venas principales y continúan con un recorrido curvado hasta perderse cerca del margen de la lámina. En la región basal de la pinna, las venas secundarias están débilmente marcadas y tienen un recorrido sinuoso. Venas de tercer orden que se anastomosan originando un reticulado poligonal irregular con aréolas de 0,09-0,41 cm x 0,080,2 cm de diámetro, disminuyendo su tamaño hacia el margen de la pinna. Dentro de cada áreola se generan venas de cuarto orden, las cuales a menudo se anastomosan generando otro orden de aréolas, de 0,06-0,09 $\mathrm{cm}$ x 0,06 cm de diámetro.

Materiales estudiados: PBSJ 412.

Estrato fosilífero y localidad: EF 3, Localidad 3.

Comentarios: Los materiales estudiados reúnen todos los atributos de los ejemplares descriptos como Dictyophyllum tenuifolium por Stipanicic y Menéndez (1949) para la Formación Barreal, y por Bonetti y Herbst (1964) para la Formación Paso Flores. 

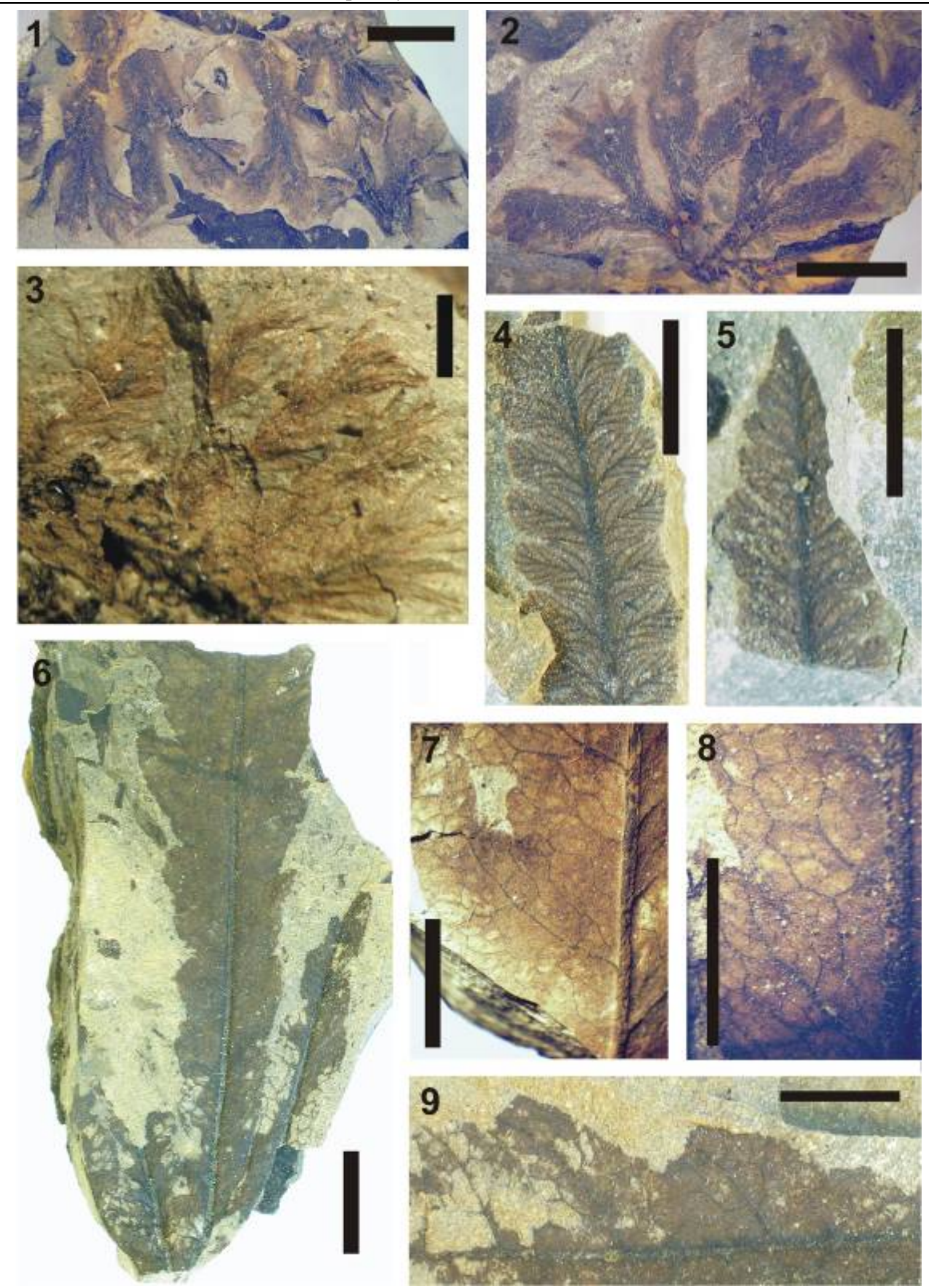

Figura VII.1. 1. Thallites sp. 1. PBSI 408. 2. Thallites sp. 2. PBSJ 409. 3. Muscites sp. PBSJ 410. 4,

5. Cf. Rienitsia arrondiana Herbst 1979b. PBSJ 411. 4. Parte media de la pinna. 5. Parte apical de la pinna. 6-9. Dictyophyllum tenuifolium Stipanicic et Menéndez emend. Bonetti et Herbst 1964. PBSJ 412. 6. Vista general. 7. Detalle de la venación. 8. Detalle de venación, mostrando las areolas de mayor orden. 9. Detalle del margen de la pinna, mostrando los lóbulos. 1, 2, 4, 5, 6: escala $1 \mathrm{~cm}$; 3 : escala $0,1 \mathrm{~cm} ; 7,8,9$ : escala $0,5 \mathrm{~cm}$. 


\section{Clase Spermatopsida Serbet et Rothwell 1995 \\ Orden Corystospermales Petriella 1981 \\ Familia Corystospermaceae Thomas 1933}

\section{Estatus nomenclatural de la Familia Corystospermaceae}

Cuando Thomas (1933) erige la familia Corystospermaceae, deriva el nombre de la morfología de las cúpulas de los órganos ovulados (corysto= portador de casco) y no del nombre de un género, sosteniendo que el hecho de que la familia estaba integrada por morfogéneros de varios tipos, impedía elegir uno como el más característico. De acuerdo al ICBN (McNeill et al., 2006) "el nombre de una familia se forma a partir del genitivo singular de un nombre legítimo de un género incluido" (Artículo 18.1.). De los nombres de familias no derivados de nombre genérico, únicamente se tratan como válidamente publicados los nombres de familias mencionados en el Artículo 18.5. y en la lista de nombres conservados (Apéndice IIA). Dado que entre ellos no se encuentra el nombre Corystospermaceae, aún se mantiene como un nombre inválidamente publicado.

Posteriormente, Meyen (1984) genera el nombre de Umkomasiaceae para las corystospermas, sobre la base del género Umkomasia Thomas 1933. Aunque está publicado válidamente, la tradición histórica ha provocado que el nombre Umkomasiaceae haya sido escasamente utilizado y superado significativamente en el uso por el nombre Corystospermaceae. Por esto, en este trabajo, se sigue sosteniendo el nombre Corystospermaceae, a la espera de una inminente propuesta de nomina conservanda.

\section{Criterios para la clasificación de las hojas de Corystospermaceae}

Las hojas de Corystospermaceae son fácilmente reconocibles por su característico raquis bifurcado, que puede llevar una lámina foliar entera, partida, mono o bipinnada. Aunque se han preservado como petrificaciones (Pigg, 1990), en la Argentina han fosilizado como impresiones y/o compresiones. No existe total acuerdo en la delimitación de los géneros foliares de esta familia, existiendo varias posturas al respecto (Zamuner et al., 2001).

El género Dicroidium fue instituido por Gothan (1912) para separar del género Thinnfeldia Ettingshausen 1852 a aquellas formas del hemisferio Sur caracterizadas por poseer su raquis principal bifurcado, lámina monopinnada a veces bipinnada, venación odontopteroide a veces aletopteroide, células epidérmicas con bordes delgados y sinuosos, y estomas dispuestos irregularmente con células subsidiarias poco especializadas. Posteriormente, Frenguelli (1943) revisó las posturas de Antevs (1913) y Halle (1927) con respecto a Dicroidium; y acepta el género de Gothan (1912), agregando a la diagnosis original 
los caracteres de disposición y morfología de las pinnas (alternas a subopuestas, desde ovadas a alargadas y de base ancha). A su vez, cambia la circunscripción del mismo, excluyendo ciertas formas en tres géneros nuevos: Dicroidiopsis, Diplasiophyllum y Zuberia, sobre la base de la morfología externa de las frondes. Dicroidiopsis fue definido para hojas bipinnatífidas, con pinnas de base contraída algo decurrente, con una vena media que se extiende hasta cerca del ápice de las pinnas y venas laterales que en su recorrido muy oblicuo se dicotomizan sólo una vez. Por otro lado, Diplasiophyllum fue creado para aquellas hojas de gran tamaño, con pinnas subcoriáceas de base decurrente, con venación taeniopteroide. Por último, el género Zuberia fue definido como: Fronde de gran tamaño, coriácea, bipinnada, con raquis bifurcado. Pinnas alargadas lineares, alternas a subopuestas. Pínnulas opuestas a subopuestas, rectangulares, romboidales u orbiculares, ápice obtuso a redondeado, base ancha, venación odontopteroide, sin vena media. En la misma contribución, Frenguelli (1943) instituye el género Xylopteris para reunir ciertas hojas frondiformes triásicas del Gondwana que habían sido atribuidas a Stenopteris Saporta 1872, pero que no muestran los caracteres propios de dicho género jurásico y nórdico. Posteriormente, Frenguelli (1950) propone un nuevo género, Tetraptilon, para formas muy semejantes a Dicroidium pero con el raquis bifurcado dos veces.

Townrow (1957) enmienda la diagnosis del género Dicroidium Gothan, de la siguiente manera: Hoja pinnada a bipinnada, raquis bifurcado. Pinnas usualmente subopuestas y algo decurrentes; más cortas en el lado interno cerca del punto de bifurcación. Pínnulas usualmente con ápice obtuso, base ligeramente contraída y decurrente. Material de la lámina bastante delgado. Venación a menudo esfenopteroide, menos a menudo odontopteroide o aletopteroide; venas que parten de un punto común de origen cerca del margen basiscópico. Cutícula bastante delgada (1-3 $\mu \mathrm{m})$, estomas en ambas caras de la lámina, pero más frecuentes en la cara abaxial, dispersos y orientados heterogéneamente. Células epidérmicas elongadas a lo largo de las venas, poligonales entre las venas; márgenes sinuosos, o con extensiones laterales. Superficie de las células normalmente con una papila. Estomas típicamente dicíclicos, expuestos, o con polos expuestos y apertura hundida; pared entre las células oclusivas y las subsidiarias fuertemente cutinizada cuando la apertura está hundida. Células subsidiarias poco especializadas, que comúnmente consisten en dos células polares y dos laterales. Células vecinas no especializadas. Cutícula del raquis dorsiventral, superficie adaxial como la cutícula de la lámina, superficie abaxial con células elongadas a lo largo del raquis las venas, y estomas dispuestos en ángulos rectos, o al menos oblicuamente, al eje mayor de las células. Ambas superficies muestran células alargadas en el margen del raquis. 
De acuerdo a este autor, este género se diferencia de Thinnfeldia por las características detalladas en el Cuadro VII.2.

\begin{tabular}{ll}
\hline $\begin{array}{c}\text { Dicroidium Gothan emend. Townrow 1957 } \\
\text { (especie tipo: D. odontopteroides (Morris) Gothan 1912) }\end{array}$ & \multicolumn{1}{c}{$\begin{array}{c}\text { Thinnfeldia } \text { Ettingshausen } 1852 \\
\text { (especie tipo: T. rhomboidalis Ettingshausen 1852) }\end{array}$} \\
\hline $\begin{array}{l}\text { 1. Casi siempre bifurcada. } \\
\text { 2. Hoja anfistomática, estomas dispersos, células subsidiarias }\end{array}$ & $\begin{array}{l}\text { 1. Nunca bifurcada. } \\
\text { no forman anfistomática, estomas mayormente en bandas }\end{array}$ \\
paredes de las células oclusivas y de las células subsidiarias & y rodeado por un anillo regular de células subsidiarias \\
fuertemente cutinizadas, al menos en aquellas especies que & especializadas, paredes entre las células oclusivas y las \\
tienen estomas hundidos. & células subsidiarias laterales sólo débilmente \\
& cutinizadas. \\
3. Márgenes de las células sinuosos o con procesos; & 3. Márgenes de las células rectos; superficie de la \\
normalmente presente una papila sobre cada célula & cutícula lisa. \\
epidérmica. &
\end{tabular}

Cuadro VII.2. Cuadro comparativo de los géneros Dicroidium y Thinnfeldia (Townrow, 1957).

En el mismo trabajo, Townrow (1957) incluye al género Johnstonia Walkom 1925 dentro de Dicroidium, y señala una gran similitud entre las cutículas de Dicroidium y Xylopteris. Además considera innecesario mantener los géneros Dicroidiopsis, Diplasiophyllum y Zuberia; los dos primeros por falta de conocimiento acerca de las cutículas de los ejemplares y el último por poseer cutículas semejantes a Dicroidium, ya que considera insuficiente el carácter de división de la lámina para mantener separadas las hojas asignadas a Zuberia. No obstante, Townrow (1957) crea un nuevo género Hoegia para ciertas formas de Thinnfeldia que se diferencian en su venación y cutícula, y que probablemente tienen un raquis indiviso. Con respecto a Tetraptilon, este autor no hace referencia.

A la postura de Townrow (1957) de unir todos los tipos foliares mesozoicos gondwánicos de raquis bifurcado en el género Dicroidium, sobre la base de las similitudes cuticulares, se sumaron otros autores como Bonetti (1966a), Archangelsky (1968), Anderson y Anderson (1970, 1983), Holmes y Ash (1979), Holmes (1982), Holmes y Anderson (2005).

Bonetti (1966a) considera que tanto morfológica como anatómicamente, Hoegia puede perfectamente asimilarse a Dicrodium. Archangelsky (1968) adhiere al criterio de Bonetti, y realiza la sinonimia formal de Hoegia, Xylopteris y Dicroidium. Anderson y Anderson (1983) agregan a la sinonimia a Tetraptilon, como consecuencia de que el carácter que los define se suele encontrar en formas aberrantes de frondes del género Dicroidium.

En contraposición al criterio unificador, otros autores adoptaron una postura más atomizadora (Cuadro VII.3), siguiendo en parte la propuesta de Frenguelli (1943, 1944a, 1950). Por un lado, Retallack (1977), Petriella (1979) y Artabe (1985), entre otros, consideran 
a los géneros Dicroidiopsis, Diplasiophyllum, Zuberia y Hoegia sinónimos junior del género Dicroidium, mientras que sí reconocen la independencia de los géneros Xylopteris y Johnstonia, especialmente por las diferencias en la venación. Por otro lado, Artabe (1990) revalida a Zuberia como un género separado, sobre la base de la existencia de pínnulas intercalares, carácter ausente en Dicroidium, Johnstonia y Xylopteris. Este criterio fue seguido por Gnaedinger y Herbst (1998a, 2001), Zamuner et al. (2001), Morel et al. (2003), Ottone (2006) y Artabe et al. (2007b, c). A su vez, Gnaedinger y Herbst (1998a) reconocen al género Diplasiophyllum a causa de que sus caracteres morfológicos no coinciden con los de Dicroidium, aunque aún no se conozca mucho acerca de sus atributos cuticulares. Esta postura es mantenida por Zamuner et al. (2001) y Artabe et al. (2007a).

Zamuner et al. (2001) opinan que la existencia de cuatro géneros de troncos asignados a las Corystospermaceae apoya la idea de la presencia de más de un género de hojas en la familia ya que, desde un punto de vista evolutivo, los tallos son órganos más conservativos. Esta aseveración estaría certificada por el hallazgo en asociación de diferentes tallos con distintos tipos foliares (Archangelsky, 1968; Meyer-Berthaud et al., 1993; Yao et al., 1995).

En la presente contribución, se reconocen los géneros Dicroidium, Xylopteris, Johnstonia, Zuberia y Diplasiophyllum. Esta postura es adoptada debido a su utilidad en el estudio de impresiones-compresiones que carecen de cutículas bien preservadas asociadas, así como también apoyándose en el hecho de la importante diversidad de troncos asignados a la familia Corystospermaceae. Si bien el reconocimiento de la variabilidad intraespecífica es innegable, en el caso de los fósiles es muy difícil determinar hasta que punto esa variabilidad no tiene valor taxonómico. Además, si aceptamos que en Paleobotánica estamos trabajando con partes, cuya nomenclatura se aleja bastante de la realidad biológica, y son tratadas como morfotaxones, parecería algo excesivo el énfasis puesto en la variabilidad que puede existir dentro de una misma especie, a la hora de realizar determinaciones y clasificaciones.

De esta manera, y en rasgos generales:

1. Dicroidium agrupa a aquellas hojas de lámina monopinnada, a veces bipinnada, con pinnas de forma variada, de base ancha, a veces contraída en uno o ambos márgenes, ápice desde obtuso a agudo y venación odontopteroide o aletopteroide;

2. Johnstonia se distingue por su lámina entera o pinnatífida y su venación taeniopteroide;

3. Xylopteris incluye a frondes mono hasta tripinnadas, con pinnas muy angostas, simples e inervadas por una sola vena (venación cenopteroide); 
4. Zuberia se caracteriza por su lámina bipinnada a tripinnatífida, la presencia de pínnulas intercalares y pínnulas normales de venación odontopteroide;

5. Diplasiophyllum reúne a hojas monopinnadas de gran tamaño, con largas pinnas del raquis principal constrictas, de venación aletopteroide.

\begin{tabular}{|c|c|c|c|}
\hline \multirow{2}{*}{ Criterio } & \multirow{2}{*}{ Unificador } & \multicolumn{2}{|c|}{ Atomizador } \\
\hline & & Moderado & Extremo \\
\hline Autores & $\begin{array}{l}\text { Townrow (1957), Bonetti } \\
\text { (1966b), Archangelsky (1968), } \\
\text { Anderson y Anderson (1970, } \\
\text { 1983), Holmes y Ash (1979), } \\
\text { Holmes (1982), Holmes y } \\
\text { Anderson (2005) }\end{array}$ & $\begin{array}{l}\text { Retallack (1977), Petriella } \\
\text { (1979) y Artabe (1985) }\end{array}$ & $\begin{array}{l}\text { Frenguelli (1943, 1944a, 1950). } \\
\text { Gnaedinger y Herbst (1998a, } \\
\text { 2001), Zamuner et al. (2001), } \\
\text { Morel et al. (2003), Ottone } \\
\text { (2006), Artabe et al. (2007a, c) }\end{array}$ \\
\hline $\begin{array}{l}\text { Géneros } \\
\text { reconocidos }\end{array}$ & Dicroidium & $\begin{array}{l}\text { Dicroidium } \\
\text { Xylopteris } \\
\text { Johnstonia }\end{array}$ & $\begin{array}{l}\text { Dicroidium } \\
\text { Xylopteris } \\
\text { Johnstonia } \\
\text { Zuberia } \\
\text { Diplasiophyllum (por algunos) } \\
\text { Dicroidiopsis (por algunos) } \\
\text { Tetraptilon (por algunos) }\end{array}$ \\
\hline $\begin{array}{l}\text { Tipo de } \\
\text { caracteres } \\
\text { utilizados }\end{array}$ & $\begin{array}{l}\text { Morfológicos (reconocimiento } \\
\text { de la variabilidad morfológica } \\
\text { intraespecífica) } \\
\text { Cuticulares }\end{array}$ & $\begin{array}{l}\text { Morfológicos (diferencias en } \\
\text { la venación) }\end{array}$ & $\begin{array}{l}\text { Morfológicos (diferencias en la } \\
\text { forma de las pinnas, presencia de } \\
\text { pínnulas intercalares, bifurcación } \\
\text { del raquis) } \\
\text { Relación con los géneros de } \\
\text { troncos }\end{array}$ \\
\hline
\end{tabular}

Cuadro VII.3. Diferentes criterios para la clasificación de las formas foliares de corystospermas.

\section{Género Dicroidium Gothan emend. Townrow 1957}

\section{Especie tipo. Dicroidium odontopteroides (Morris) Gothan 1912.}

\section{Criterio de clasificacion infragenérica de Dicroidium}

Dentro de los géneros foliares reconocidos en la familia Corystospermaceae, Dicroidium es el más diverso y por lo tanto existen varios criterios taxonómicos (Retallack, 1977; Petriella, 1979; Anderson y Anderson, 1983; Gnaedinger y Herbst, 1998a, 2001; entre otros). Siguiendo el enfoque de Gnaedinger y Herbst (1998a), la clasificación adoptada es una postura intermedia entre los diversos criterios. Así, se reconocen 16 especies de Dicroidium, cuyos caracteres y distribución estratigráfica y geográfica se sintetizan en el Cuadro VII.4.

Algunas formas de Dicroidium se ajustan al gradiente de morfologías, denominado por Holmes y Anderson (2005) como el complejo "Dicroidium odontopteroides". Estos tipos 
foliares se caracterizan por ser monopinnados, con pinnas de base ancha, variando en morfología desde semi-orbiculares a ampliamente triangulares, a rectangulares alargadas o ligeramente ahusadas, con ápice redondeado o ampliamente obtuso; las pinnas alargadas tienen una vena media y venación aletopteroide; las pinnas cortas y semicirculares tienen venación odontopteroide. Gothan (1912) distinguió dos especies entre estas morfologías: $D$. lancifolium y D. odontopteroides.

Anderson y Anderson (1983) consideran que es más acertado que las hojas asignadas a D. lancifolium sean consideradas como formas de pinnas alargadas dentro de la especie $D$. odontopteroides. Retallack (1977), seguido por Petriella (1979) entre otros, postulan que existirían diferencias en la morfología de las pinnas que hacen reconocibles a las dos especies. Se puede decir que las pinnas de D. lancifolium son lanceoladas, angostas, más de tres veces más largas que anchas, con base ancha, ápice redondeado a subagudo, venación siempre aletopteroide; mientras que las pinnas de D. odontopteroides son desde orbiculares a semicirculares o triangulares alargadas, anchas, menos de tres veces más largas que anchas, con base ancha, ápice redondeado a obtuso, venación odontopteroide en las pinnas cortas o aletopteroide en las pinnas alargadas.

Dentro de la especie D. odontopteroides Retallack (1977) reconoce seis variedades: argenteum, crassum, moltenense, obtusifolium, odontopteroides y remotum. De éstas, Petriella (1979) segrega a las variedades crassum y argenteum en una la especie D. crassum, y continúa reconociendo las otras cuatro variedades. Por su parte, Anderson y Anderson (1983) separan a las variedades crassum, moltenense, obtusifolium y remotum en una especie (D. crassinervis); mientras que a argenteum y odontopteroides las asimilan en una sola variedad de la especie D. odontopteroides (var. odontopteroides). Stipanicic et al. (1996) vuelven a la postura de Townrow (1957) de elevar la variedad obtusifolium a la categoría específica. Posteriormente, Gnaedinger y Herbst (2001) distribuyen a las variedades de $D$. odontopteroides propuestas por Retallack (1977) en cuatro especies: D. argenteum $(=D$. odontopteroides var. argenteum), D. crassum ( $=D$. odontopteroides var. crassum), D. odontopteroides $(=D$. odontopteroides var. moltenense $+D$. odontopteroides var. odontopteroides + D. odontopteroides var. remotum), y D. obtusifolium (=D. odontopteroides var. obtusifolium).

Por otro lado, Retallack (1977) distingue dos variedades dentro de la especie $D$. lancifolium: lineatum y lancifolium. Esta postura es seguida por Petriella (1979) entre otros. Anderson y Anderson (1983) encuadran esta especie en D. odontopteroides, incluyendo a la variedad lineatum en D. odontopteroides var. lineatum, y a la variedad lancifolium en D. 
odontopteroides var. odontopteroides. Posteriormente, Gnaedinger y Herbst (1998a, 2001) reconocen a $D$. lancifolium como especie; sin embargo, como también en el caso de $D$. odontopteroides, no utilizan los rangos infraespecíficos, argumentando que no reflejan una realidad biológica.

En la presente contribución se consideran a las especies D. lancifolium y $D$. odontopteroides como entidades taxonómicas independientes. A su vez, se aceptan los criterios de Townrow (1957), Petriella (1979), Stipanicic et al. (1996) Gnaedinger y Herbst (2001), reconociendo también las especies D. argenteum, D. crassum y D. obtusifolium.

La mayoría de los ejemplares estudiados para la Formación Cortaderita y asignados a D. odontopteroides corresponde a formas intermedias dentro del gradiente de variabilidad del complejo “D. odontopteroides" de Holmes y Anderson (2005), con pinnas 2 a 3 veces más largas que anchas, alargadas y con venación aletopteroide bastante definida.

\section{Cf. Dicroidium argenteum (Retallack) Gnaedinger in Gnaedinger et Herbst 2001}

Figura VII.2 y 8.12

Descripción: Hoja monopinnada. Los fragmentos miden entre 2,43 y 4,27 cm de longitud y 1,41 y $2,53 \mathrm{~cm}$ de ancho. Pecíolo no preservado. Raquis de 0,2 a 0,28 cm de espesor. Pinnas desde subopuestas, subalternas a alternas. El ángulo de inserción de las pinnas es de 64 a $82^{\circ}$. La morfología de las pinnas varía desde orbiculares a ovadas orbiculares o triangulares a subromboidales, con una base constricta, márgenes lisos y un ápice redondeado. Varían en longitud de 0,71 a 1,27 cm y en ancho de 0,48 a $0,93 \mathrm{~cm}$. La venación es odontopteroide a aletopteroide.

Materiales estudiados: PBSJ 422, 608, 609.

Estrato fosilífero y localidad: EF2, Localidad 2.

Figura VII.2. Cf. Dicroidium argenteum (Retallack) Gnaedinger in Gnaedinger y Herbst 2001. PBSJ 608. Morfología de las pinnas. Escala: 0,1 cm.

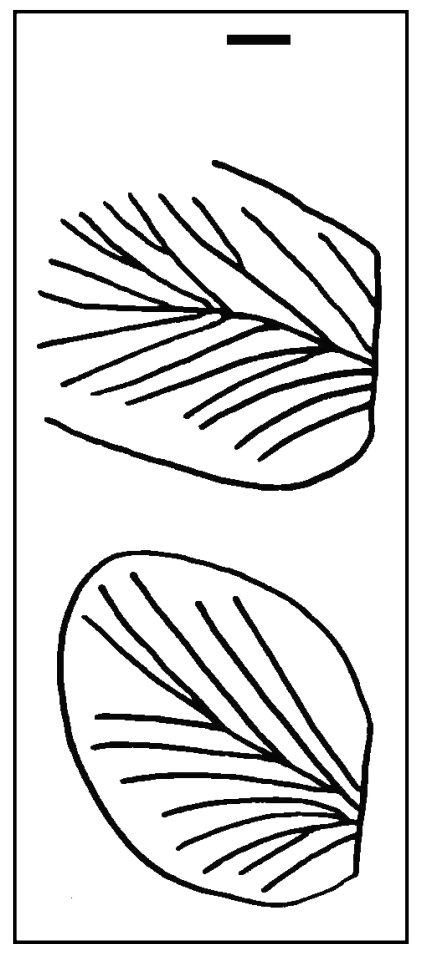




\section{Dicroidium crassum (Menéndez) Petriella 1979}

Estrato fosilífero y localidad: EF2, Localidad 2.

Comentarios: Esta especie fue citada por Stipanicic (1979), para el NF II.

\section{Dicroidium dubium (Feistmantel) Gothan 1912}

D. dubium subsp. switzifolium Anderson et Anderson 1983

Figura VII.3 y $8.1,2$ y 3

Descripción: Hojas bipinnatífidas a bipinnadas de 3,4 a 7,2 cm de longitud, con pecíolo robusto de 0,2 a 0,35 cm de espesor. Raquis bifurcado con un ángulo de 45 a $55^{\circ}$ y de 0,1 a $0,2 \mathrm{~cm}$ de espesor. Pinnas generalmente menos divididas del lado interno del raquis, lineares a lineares-lanceoladas, con ápice redondeado, opuestas a subalternas, muy próximas entre sí hasta imbricadas, insertas con un ángulo de $55^{\circ}$ a $90^{\circ}$. Miden de 0,4 a 1,38 cm de longitud, siendo más cortas en el lado interno del raquis que en el externo; y desde 0,15 hasta 0,5 cm de ancho. Ráquises secundarios también robustos, de 0,06 a 0,07 cm de espesor. Pínnulas anchas y cortas, equidimensionales, desde circulares, subrómbicas a rectangulares, de márgenes rectos, opuestas a subalternas, muy próximas entre sí y a menudo imbricadas, insertas por su ancho máximo con un ángulo de 45 a $90^{\circ}$. Miden 0,13 a $0,27 \mathrm{~cm}$ de longitud y 0,13 a $0,26 \mathrm{~cm}$ de ancho. Las pínnulas apicales coalescen y generan un ápice redondeado de la pinna. Venación muy poco visible, probablemente aletopteroide a odontopteroide

Materiales estudiados: PBSJ 408, 410, 413, 610, 611, 612, 613, 614, 615, 616.

Estrato fosilífero y localidad: EF2, Localidad 2.

Comentarios: Se siguió la postura de Anderson y Anderson (1983) de dividir a la especie Dicroidium dubium en subespecies. Para determinar estos ejemplares en particular, se aceptó el concepto de D. dubium subsp. switzifolium de Anderson y Anderson (1983). 
Josefina Bodnar - La paleoflora triásica de la Formación Cortaderita ...

\begin{tabular}{|c|c|c|c|c|c|c|c|}
\hline Especie & $\begin{array}{l}\text { Distribución } \\
\text { Estratigráfica }\end{array}$ & $\begin{array}{l}\text { Distribución } \\
\text { Geográfica }\end{array}$ & $\begin{array}{l}\text { Bifurcación } \\
\text { del raquis }\end{array}$ & $\begin{array}{c}\text { División de la } \\
\text { lámina }\end{array}$ & $\begin{array}{c}\text { Ángulo de } \\
\text { inserción de las } \\
\text { pinnas }\end{array}$ & Morfología de las pinnas & Venación \\
\hline $\begin{array}{l}\text { 1. D. argenteum (Retallack) } \\
\text { Gnaedinger in Gnaedinger } \\
\text { et } \text { Herbst } 2001\end{array}$ & $\begin{array}{l}\text { Triásico Medio- } \\
\text { Superior }\end{array}$ & $\begin{array}{l}\text { Argentina, Chile } \\
\text { Nueva Zelanda }\end{array}$ & Sí & Monopinnada & Recto & $\begin{array}{l}\text { Subcirculares, con ápice obtuso- } \\
\text { redondeado y base constricta }\end{array}$ & Odontopteroide \\
\hline $\begin{array}{l}\text { 2. D. crassum (Menéndez) } \\
\text { Petriella } 1979\end{array}$ & $\begin{array}{l}\text { Triásico Medio- } \\
\text { Superior }\end{array}$ & $\begin{array}{c}\text { Argentina, Chile } \\
\text { Australia } \\
\text { Sudáfrica }\end{array}$ & Sí & Monopinnada & Muy agudo & $\begin{array}{c}\text { Equidimensionales a alargadas } \\
\text { subrómbicas, con ápice subagudo y } \\
\text { base constricta (a veces subpeciolada) }\end{array}$ & Odontopteroide \\
\hline $\begin{array}{l}\text { 3. D. dubium (Feistmantel) } \\
\text { Gothan } 1912\end{array}$ & $\begin{array}{l}\text { Triásico Inferior- } \\
\text { Superior }\end{array}$ & $\begin{array}{l}\text { Argentina, Chile } \\
\text { Australia } \\
\text { Sudáfrica }\end{array}$ & Sí & $\begin{array}{r}\text { Mono a } \\
\text { bipinnada }\end{array}$ & $\begin{array}{l}\text { Generalmente } \\
\text { agudo }\end{array}$ & $\begin{array}{l}\text { Alargadas rectas, con ápice obtuso- } \\
\text { redondeado, a veces subagudo y base } \\
\text { no constricta }\end{array}$ & Aletopteroide \\
\hline $\begin{array}{l}\text { 4. D. eskense (Walkom) } \\
\text { Jacob et Jacob } 1950\end{array}$ & $\begin{array}{l}\text { Triásico Medio- } \\
\text { Superior }\end{array}$ & Australia & $?$ & Monopinnada & Agudo & $\begin{array}{c}\text { ¿Lanceoladas?, ápice agudo y base } \\
\text { constricta }\end{array}$ & Aletopteroide \\
\hline $\begin{array}{l}\text { 5. D. fremouwense Pigg } \\
1990\end{array}$ & $\begin{array}{c}\text { Triásico Inferior- } \\
\text { Medio }\end{array}$ & Antártida & Sí & Bipinnatífida & Más o menos recto & $\begin{array}{l}\text { Alargadas, con ápice obtuso- } \\
\text { redondeado, a veces subagudo y base } \\
\text { no constricta }\end{array}$ & Odontopteroide \\
\hline 6. D. gouldii Retallack 1977 & $\begin{array}{c}\text { Triásico Inferior- } \\
\text { Medio }\end{array}$ & Australia & Sí & Monopinnada & $\begin{array}{l}\text { Agudo tendiendo a } \\
\text { recto }\end{array}$ & $\begin{array}{l}\text { Oblanceoladas, con ápice redondeado, } \\
\text { ¿base no ancha? }\end{array}$ & ¿Odontopteroide? \\
\hline $\begin{array}{c}\text { 7. D. hernandezii } \\
\text { Gnaedinger et Herbst } 2001\end{array}$ & Triásico Superior & Chile & No & Pinnatilobadas & Agudo & $\begin{array}{l}\text { Basales y apicales equidimensionales, } \\
\text { medias redondeadas a alargadas, con } \\
\text { ápice redondeado a obtusamente } \\
\text { agudo y base coalescente }\end{array}$ & Aletopteroide \\
\hline $\begin{array}{l}\text { 8. D. incisum (Frenguelli) } \\
\text { Anderson et Anderson } 1970\end{array}$ & $\begin{array}{l}\text { Triásico Inferior- } \\
\text { Superior }\end{array}$ & $\begin{array}{l}\text { Argentina } \\
\text { Australia } \\
\text { Sudáfrica }\end{array}$ & Sí & Bipinnatífida & $\begin{array}{l}\text { Agudo tendiendo a } \\
\text { recto? }\end{array}$ & $\begin{array}{l}\text { Lanceoladas, lobuladas, con ápice } \\
\text { agudo y base constricta }\end{array}$ & ¿Odontopteroide? \\
\hline $\begin{array}{l}\text { 9. D. lancifolium (Morris) } \\
\text { Gothan } 1912\end{array}$ & $\begin{array}{c}\text { Triásico Inferior- } \\
\text { Medio }\end{array}$ & $\begin{array}{l}\text { Argentina, Chile, } \\
\text { India, Nueva } \\
\text { Zelanda, Australia, } \\
\text { Sudáfrica }\end{array}$ & Sí & Monopinnada & Agudo a recto & $\begin{array}{l}\text { Basales equidimensionales y medias } \\
\text { lanceoladas, con ápice redondeado a } \\
\text { subagudo y base ancha }\end{array}$ & Aletopteroide \\
\hline
\end{tabular}


Josefina Bodnar - La paleoflora triásica de la Formación Cortaderita ...

\begin{tabular}{|c|c|c|c|c|c|c|c|}
\hline $\begin{array}{c}\text { 10. D. nondichotoma } \\
\text { Anderson et Anderson } 1989\end{array}$ & Triásico Superior & Sudáfrica & No & Monopinnada & Más o menos recto & $\begin{array}{c}\text { Subromboidales, con ápice } \\
\text { redondeado, base algo constricta o } \\
\text { algo ensanchada }\end{array}$ & ¿Odontopteroide? \\
\hline $\begin{array}{l}\text { 11. D. obtusifolium } \\
\text { (Johnston) Townrow 1966a }\end{array}$ & $\begin{array}{l}\text { Triásico Inferior- } \\
\text { Medio }\end{array}$ & $\begin{array}{c}\text { Chile } \\
\text { Australia }\end{array}$ & Sí & Monopinnada & Obtuso & $\begin{array}{l}\text { Semicirculares o romboidales, con } \\
\text { ápice redondeado y base ancha, } \\
\text { coalescente }\end{array}$ & Odontopteroide \\
\hline $\begin{array}{l}\text { 12. D. odontopteroides } \\
\text { (Morris) Gothan } 1912\end{array}$ & $\begin{array}{l}\text { Triásico Medio- } \\
\text { Superior }\end{array}$ & $\begin{array}{c}\text { Argentina, Chile } \\
\text { Brasil, Australia } \\
\text { Nueva Zelanda } \\
\text { Sudáfrica, India } \\
\text { Antártida }\end{array}$ & Sí & Monopinnada & Más o menos recto & $\begin{array}{l}\text { Equidimensionales a alargadas, com } \\
\text { ápice redondeado a obtuso y base } \\
\text { ancha }\end{array}$ & Odontopteroide \\
\hline $\begin{array}{l}\text { 13. D. pinnis-distantibus } \\
\text { (Kurz) Frenguelli } 1943\end{array}$ & $\begin{array}{l}\text { Triásico Inferior- } \\
\text { Superior }\end{array}$ & Argentina Australia & Sí & Monopinnada & Agudo & $\begin{array}{l}\text { Angostas, com ápice agudo a } \\
\text { subagudo y base no constricta }\end{array}$ & Aletopteroide \\
\hline $\begin{array}{l}\text { 14. D. robustum Kerp et } \\
\text { Vörding in Abu Hamad, } \\
\text { Kerp, Vörding et Bandel } \\
2008\end{array}$ & Pérmico Superior & Jordania & ¿? & Bipinnada & ¿? & Alargadas & Odontopteroide \\
\hline $\begin{array}{c}\text { 15. D. superbum (Shirley) } \\
\text { Townrow } 1957\end{array}$ & $\begin{array}{l}\text { Triásico Medio- } \\
\text { Superior }\end{array}$ & $\begin{array}{l}\text { Australia } \\
\text { Sudáfrica }\end{array}$ & Sí & Tripinnatífida & $\begin{array}{c}\text { Agudo tendiendo a } \\
\text { recto? }\end{array}$ & $\begin{array}{c}\text { Ahusadas, con ápice redondeado- } \\
\text { agudo y base angosta }\end{array}$ & ¿Odontopteroide? \\
\hline $\begin{array}{l}\text { 16. D. townrovii Retallack } \\
1977\end{array}$ & $\begin{array}{l}\text { Triásico Inferior- } \\
\text { Medio }\end{array}$ & $\begin{array}{l}\text { Australia } \\
\text { Argentina }\end{array}$ & Sí & Bipinnada & Agudo & $\begin{array}{c}\text { Alargadas ahusadas, con ápice agudo } \\
\text { ybase angosta }\end{array}$ & ¿Odontopteroide? \\
\hline
\end{tabular}

\section{Cuadro VII.4. Especies de Dicroidium reconocidas en la presente tesis.}




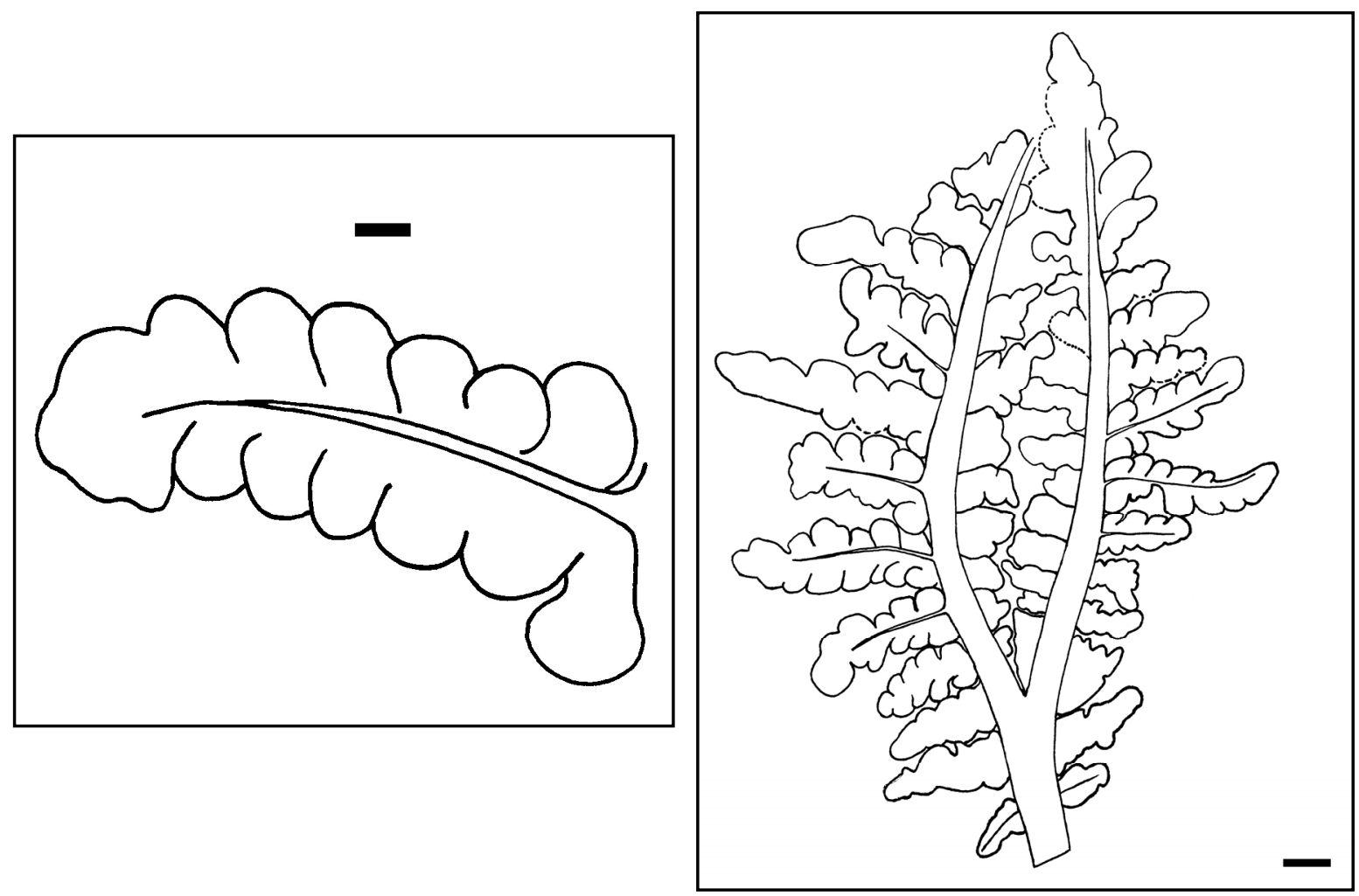

Figura VII.3. Dicroidium dubium subsp. switzifolium Anderson et Anderson 1983. PBSJ 408. Izquierda, morfología de una pinna; derecha, morfología general de la fronde. Escala: 0,1 cm.

\section{D. dubium subsp. tasmaniense (Anderson et Anderson) Retallack 1977}

Figura VII.4 y 8.4 y 6

Descripción: Hoja desde monopinnada, bipinnatífida a bipinnada. Fragmentos de 1,95 a 7 cm de longitud y 1 a 3,5 cm de ancho. Pecíolo robusto, de 0,22 a 0,44 cm de espesor. Raquis bifurcado con un ángulo de 39 a $51^{\circ}$, y con un espesor de 0,1 a $0,32 \mathrm{~cm}$. Pinnas opuestas, subopuestas a subalternas, insertas con un ángulo de 40 a $92^{\circ}$. Pinnas desde enteras triangulares-romboidales, ovadas o lanceoladas de márgenes lobados a divididas linearlanceoladas, con base ancha o levemente constricta en la margen acroscópico y ensanchada en el basiscópico, y ápice redondeado agudo a redondeado romo. Longitud de las pinnas desde 0,24 a 3,28, siempre menor del lado interno de la bifurcación del raquis. Ancho de las pinnas de 0,18 a $0,82 \mathrm{~cm}$. Cuando las pinnas están divididas, el raquis secundario mide de 0,07 a $0,11 \mathrm{~cm}$ de espesor, y las pínnulas son circulares a romboidales o rectangulares redondeadas, de 0,17 a 0,46 cm de largo y 0,16 a 0,44 cm de amplitud, insertas con un ángulo de 47 a $73^{\circ}$. La venación en las pinnas es del tipo aletopteroide y en cada pínnula es odontopteroide. 
Materiales estudiados: PBSJ 415, 417, 613, 617, 618, 619, 620, 621, 622, 623, 624, 625, $626,627$.

Estrato fosilífero y localidad: EF2, Localidad 2 y EF3, Localidad 3.

Comentarios: Si bien en este caso se mantuvo la postura de Anderson y Anderson (1983) de dividir a la especie Dicroidium dubium en subespecies, se aplicó el concepto de D. dubium subsp. tasmaniense de Retallack (1977).
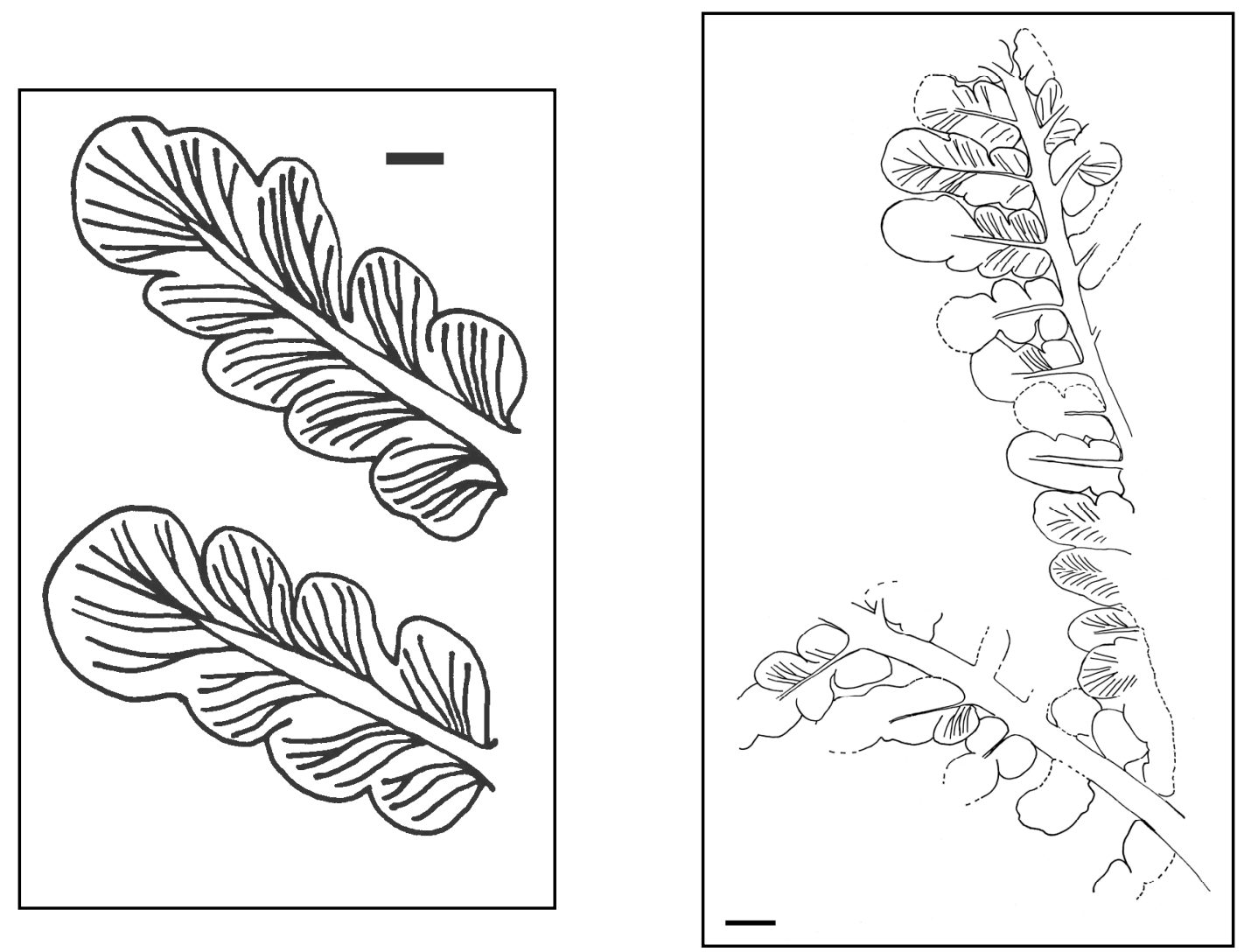

Figura VII.4. Dicroidium dubium subsp. tasmaniense (Anderson et Anderson) Retallack 1977. PBSJ 415. Izquierda: morfología de las pinna y detalle de la venación. Escala: 0,1 cm; derecha: morfología general de la fronde. Escala: $0,3 \mathrm{~cm}$.

\section{Dicroidium odontopteroides (Morris) Gothan 1912}

Figura VII.5 y 8

Descripción: Hoja monopinnada. Los fragmentos miden entre 1,6 y $8 \mathrm{~cm}$ de longitud y entre 0,9 y $5 \mathrm{~cm}$ de ancho. Pecíolo de 0,14 a $0,4 \mathrm{~cm}$ de espesor. Raquis de 0,08 a 0,35 cm de espesor, raquis bifurcado con un ángulo 25 a $50^{\circ}$. Pinnas desde opuestas a subopuestas, subalternas a alternas. El ángulo de inserción de las pinnas es de 45 a $90^{\circ}$, tendiendo a ser más 
agudo en el raquis y recto en el pecíolo. La morfología de las pinnas varía desde triangulares a semiovoidales o lanceoladas cortas en el lado interno del raquis a ovadas alargadas, lanceoladas a algo falcadas en el lado externo y en el pecíolo. Tienen una base generalmente ancha (en algunos casos ligeramente ensanchada), márgenes lisos y rectos (a veces algo curvados) y un ápice redondeado agudo a redondeado romo. Varían en longitud de 0,25 a 1,75 $\mathrm{cm}$ y en ancho de 0,25 a 0,81 cm. La venación es del tipo aletopteroide.

Materiales estudiados: PBSJ 414, 416, 418, 420, 628, 629, 630, 631, 632, 634, 635.

Estrato fosilífero y localidad: EF2, Localidad 2 y EF 3, Localidad 3.

Comentarios: Ejemplares correspondientes a esta especie habían sido descriptos e ilustrados por Bonetti (1963) para el NFI, punto 12 y el NFII, puntos 20 y 21.

Figura VII.5 Dicroidium odontopteroides (Morris) Gothan 1912. PBSJ 628. Morfología de las pinnas internas (arriba) y externas (abajo) al raquis. Escala:

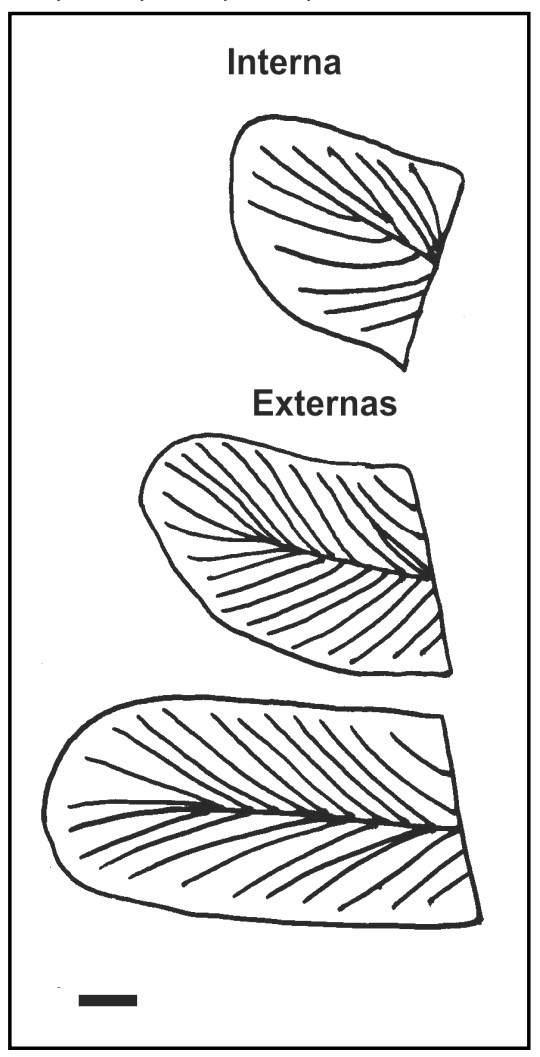

\section{Dicroidium lancifolium (Morris) Gothan 1912}

Figura VII.6 y 8.10

Descripción: Hoja monopinnada. Fragmentos de 2,04 a 3,89 cm de largo y 2,36 a 2,82 cm de ancho. Pecíolo no preservado. Raquis bifurcado, de 0,1 a $0,17 \mathrm{~cm}$ de espesor. Pinnas opuestas, subopuestas a alternas, lanceoladas, angostas, insertas por toda la base (a veces algo ensanchada), con un ángulo de 47 a $82^{\circ}$. Tienen márgenes lisos y ápice agudo, y varían en longitud de 1,07 a 2,02 cm y en ancho de 0,44 a 0,79 cm. La venación es de tipo aletopteroide.

Materiales estudiados: PBSJ 421, 636, 637, 638

Estrato fosilífero y localidad: EF2, Localidad 2 y EF 3, Localidad 3. 
Comentarios: Materiales asignados a esta especie habían sido descriptos e ilustrados por Bonetti (1963) para el NFI, punto 12 y el NFII, puntos 20 y 21.

Figura VII.6. Dicroidium lancifolium (Morris) Gothan 1912. PBSJ 636. Morfología de las pinnas y detalle de la venación. Escala: $0,2 \mathrm{~cm}$.

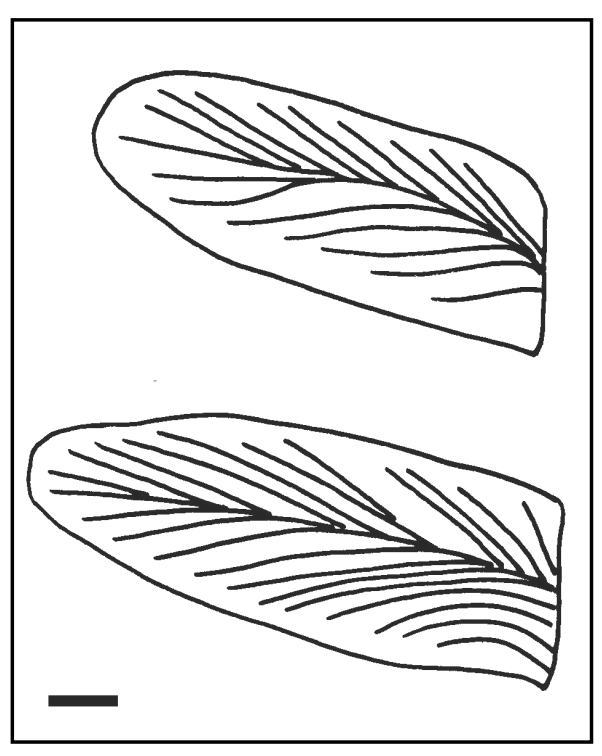

Género Zuberia Frenguelli emend. Artabe 1990

Especie tipo. Zuberia zuberi (Szajnocha) Frenguelli 1943.

\section{Criterio de clasificacion infragenérica de Zuberia}

Se reconocen cinco especies para el género Zuberia, más dos especies formalmente asignadas al género Dicroidium (D. irnense Abu Hamad et Kerp in Abu Hamad, Kerp, Vörding et Bandel 2008 y D. jordanense Abu Hamad et Kerp in Abu Hamad, Kerp, Vörding et Bandel 2008) pero por poseer pínnulas intercalares también aquí son inlcuidas en el género Zuberia (Cuadro VI.5).

\section{Zuberia papillata (Townrow) Artabe 1990}

Figura VII.8.11

Materiales estudiados: Sólo fotografiado en el campo.

Materiales revisados: LPPB 13841.

Estrato fosilífero y localidad: EF2, Localidad 5.

Comentarios: Esta especie fue incluida por Artabe et al. (1995a), en su nivel fosilífero 3, del EF de Cortaderita Inferior.

\section{Zuberia zuberi (Szajnocha) Frenguelli 1943}

Figura VII.7 y 8.8 
Descripción: Fragmentos de hoja bipinnada, de 1,75 a 2,33 cm de longitud y 0,62 a 0,85 cm de ancho. Raquis de 0,094 a 0,1 cm de espesor. Pínnulas rectangulares a subromboidales o algo circulares, opuestas, de 0,29 a $0,46 \mathrm{~cm}$ de largo y 0,33 a $0,58 \mathrm{~cm}$ de ancho, márgenes rectos y paralelos, ápice obtuso paralelo al raquis de la pinna. Pínnulas apicales confluentes. La venación es odontopteroide.

Materiales estudiados: PBSJ 419, 639.

Materiales revisados: LPPB 9528, 9529, 9530, 9531; BAPb 4376.

Estrato fosilífero y localidad: EF2, Localidad 2.

Comentarios: Bonetti (1963) había reconocido esta especie para el NFI, punto 12.

Figura VII.7. Zuberia zuberi

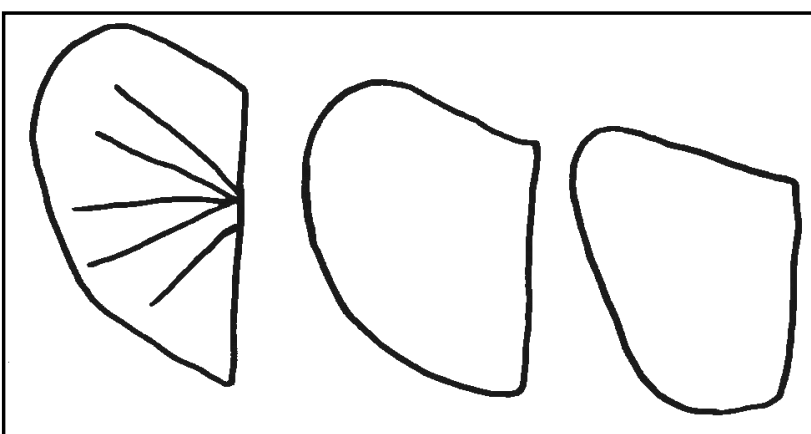
(Szajnocha) Frenguelli 1943. PBSJ 639. Diferentes morfologías de las pínnulas. Escala: $0,1 \mathrm{~cm}$.

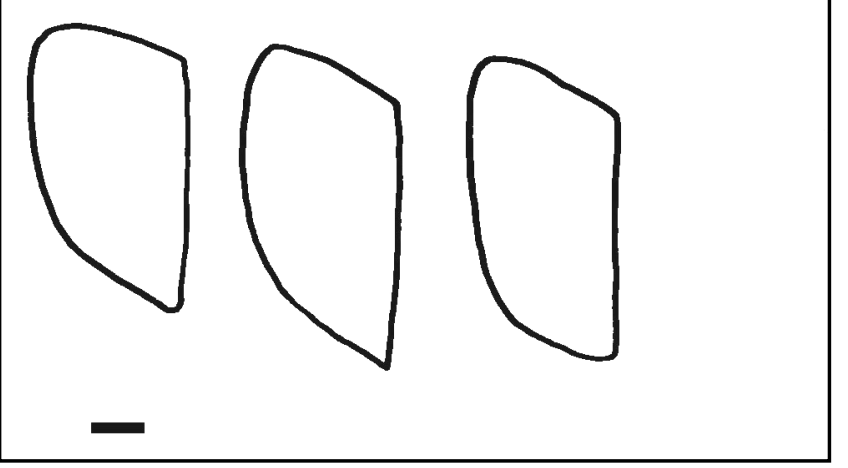

Zuberia barrealensis Frenguelli 1943

Materiales revisados: LPPB 9527.

Estrato fosilífero y localidad: EF2, Localidad 2.

Comentarios: Bonetti (1963) consideró que materiales estudiados por Frenguelli (1943, 1944a) y asignados a Z. barrealensis provenían del NFI, punto 12 . 


\begin{tabular}{|c|c|c|c|c|c|c|}
\hline Especie & $\begin{array}{c}\text { Distribución } \\
\text { Estratigráfica }\end{array}$ & $\begin{array}{l}\text { Distribución } \\
\text { Geográfica }\end{array}$ & $\begin{array}{c}\text { División de la } \\
\text { lámina }\end{array}$ & Morfología de las pínnulas & Morfología de interpínnulas & Venación \\
\hline $\begin{array}{l}\text { 1. Z. barrealensis } \\
\text { Frenguelli } 1943 *\end{array}$ & $\begin{array}{l}\text { Triásico } \\
\text { Inferior-Medio }\end{array}$ & $\begin{array}{l}\text { Australia, Argentina } \\
\text { India }\end{array}$ & $\begin{array}{l}\text { Bipinnada- } \\
\text { Tripinnatífida }\end{array}$ & $\begin{array}{l}\text { Dos veces más largas que anchas, con } \\
\text { margen lobado }\end{array}$ & $\begin{array}{l}\text { Semejantes a las normales, } \\
\text { lobadas }\end{array}$ & Odontopteroide \\
\hline $\begin{array}{l}\text { 2. Z. sahnii (Seward) } \\
\text { Frenguelli } 1943\end{array}$ & $\begin{array}{l}\text { Triásico } \\
\text { Inferior- } \\
\text { Superior }\end{array}$ & $\begin{array}{l}\text { Argentina, India, } \\
\text { Sudáfrica }\end{array}$ & Bipinnatífida & $\begin{array}{l}\text { Equidimensionales, redondeadas, erectas } \\
\text { sobre el raquis }\end{array}$ & $\begin{array}{l}\text { Semejantes a las pínnulas } \\
\text { normales }\end{array}$ & Odontopteroide \\
\hline $\begin{array}{l}\text { 3. Z. feistmantelii } \\
\text { (Johnson) Frenguelli } \\
\text { emend. Artabe } 1990\end{array}$ & $\begin{array}{l}\text { Triásico } \\
\text { Inferior-Medio }\end{array}$ & $\begin{array}{l}\text { Australia, Argentina, } \\
\text { Sudáfrica, Tasmania, } \\
\text { Brasil }\end{array}$ & Bipinnada & $\begin{array}{l}\text { De gran tamaño, cuadrangulares, } \\
\text { subromboidales o subtriangulares, de } \\
\text { margen entero }\end{array}$ & Cuadrangulares & Odontopteroide \\
\hline $\begin{array}{l}\text { 4. Z. papillata } \\
\text { (Townrow) Artabe } \\
1990\end{array}$ & $\begin{array}{l}\text { Triásico } \\
\text { Inferior-Medio }\end{array}$ & $\begin{array}{l}\text { Australia, Argentina, } \\
\text { Sudáfrica, Brasil }\end{array}$ & Bipinnada & $\begin{array}{l}\text { Más largas que anchas, de gran tamaño, } \\
\text { inclinadas sobre el raquis, subrómbicas o } \\
\text { rómbicas, con margen lobado }\end{array}$ & $\begin{array}{l}\text { Redondeadas lobadas, a veces } \\
\text { de mayor tamaño que las } \\
\text { pínnulas normales }\end{array}$ & Odontopteroide \\
\hline $\begin{array}{l}\text { 5. Z. zuberi (Szajnocha) } \\
\text { Frenguelli } 1943\end{array}$ & $\begin{array}{l}\text { Triásico } \\
\text { Inferior- } \\
\text { Superior }\end{array}$ & $\begin{array}{l}\text { Australia, Argentina, } \\
\text { Sudáfrica, Brasil, } \\
\text { Chile }\end{array}$ & Bipinnada & $\begin{array}{l}\text { Cuadrangulares, subcuadrangulares, } \\
\text { inclinadas sobre el raquis, de márgenes } \\
\text { paralelos y margen apical redondeado o } \\
\text { recto }\end{array}$ & $\begin{array}{l}\text { Semejantes a las pínnulas } \\
\text { normales o redondeadas }\end{array}$ & Odontopteroide \\
\hline $\begin{array}{l}\text { 6. D. irnense Abu } \\
\text { Hamad et Kerp in Abu } \\
\text { Hamad, Kerp, Vörding } \\
\text { et Bandel } 2008\end{array}$ & $\begin{array}{l}\text { Pérmico } \\
\text { Superior }\end{array}$ & Jordania & Bipinnada & $\begin{array}{l}\text { Anchas, trapezoidales con ápice } \\
\text { redondeado; base ancha no decurrente }\end{array}$ & $\begin{array}{l}\text { Triangulares a romboidales, } \\
\text { asimétricas }\end{array}$ & Odontopteroide \\
\hline $\begin{array}{l}\text { 7. D. jordanense Abu } \\
\text { Hamad et Kerp in Abu } \\
\text { Hamad, Kerp, Vörding } \\
\text { et Bandel } 2008\end{array}$ & $\begin{array}{l}\text { Pérmico } \\
\text { Superior }\end{array}$ & Jordania & Bipinnada & $\begin{array}{l}\text { Lingüiformes a triangulares asimétricas, a } \\
\text { menudo ligeramente constrictas cerca de } \\
\text { la base, ápice obtuso a agudo }\end{array}$ & $\begin{array}{l}\text { Ocasionales, triangulares, } \\
\text { asimétricas, más pequeñas que } \\
\text { las pínnulas normales. }\end{array}$ & Odontopteroide \\
\hline
\end{tabular}

Cuadro VII.5. Especies de Zuberia reconocidas en la presente tesis. * En Zuberia barrealensis se incluyen los ejemplares australianos, argentinos e indios que Rettallack (1977) incluyó en Dicroidium brownii. 

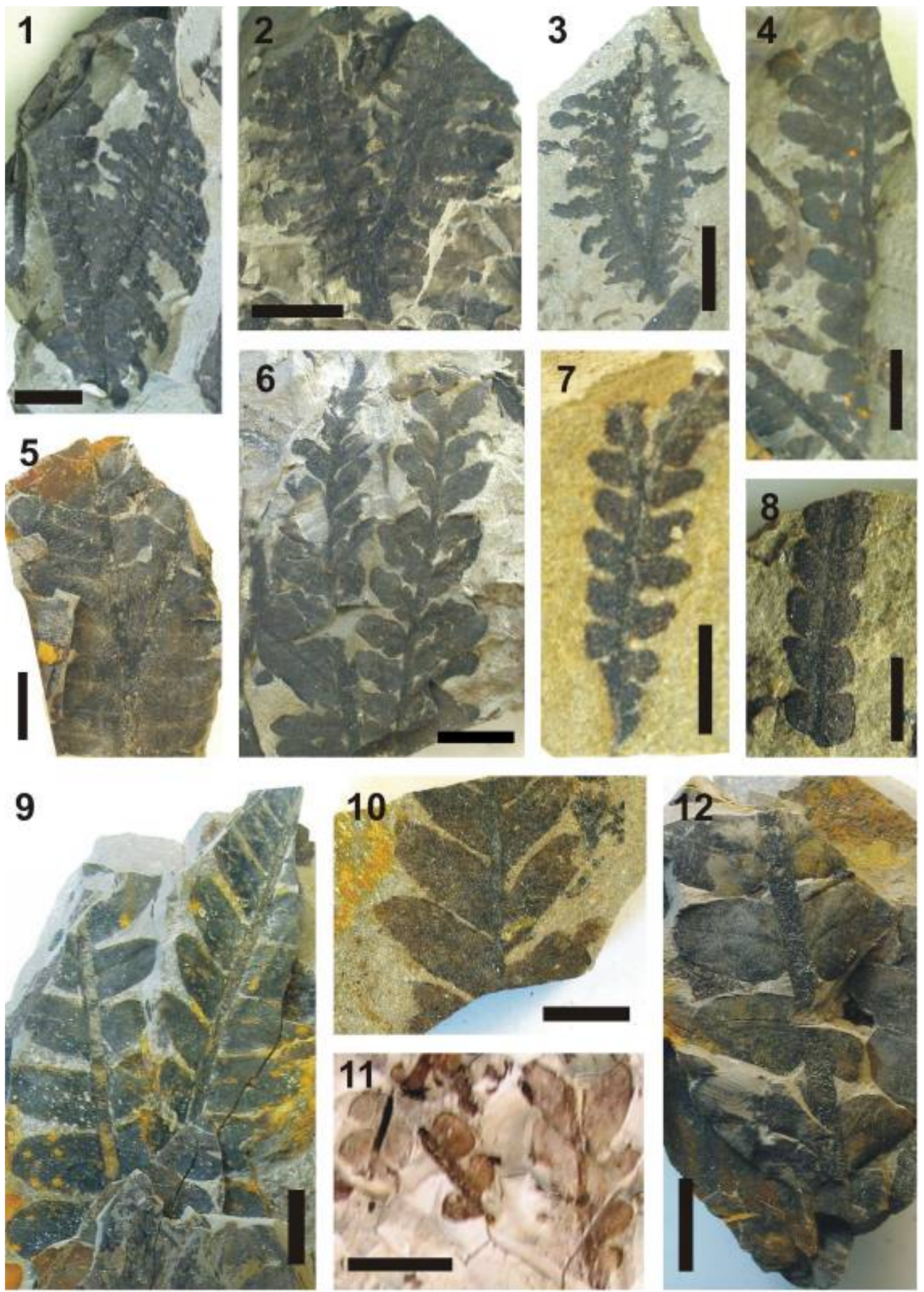

FiguraVII.8. 1-3. Dicroidium dubium subsp. switzifolium Anderson et Anderson 1983. 1. PBSJ 410. 2. PBSJ 413. 3. PBSJ 414. 4, 6. Dicroidium dubium subsp. tasmaniense (Anderson et Anderson) Retallack 1977. 4, PBSJ 415. 6. PBSJ 417. 5, 7, 9. Dicroidium odontopteroides (Morris) Gothan 1912. 5. PBSJ 416. 7. PBSJ 418. 9. PBSJ 410. 8. Zuberia zuberi (Szajnocha) Frenguelli 1943. PBSJ 419. 10. Dicroidium lancifolium (Morris) Gothan 1912. PBSJ 421. 11. Zuberia papillata (Townrow) Artabe 1990 (fotografiado en el campo). 12. Cf. Dicroidium argenteum (Retallack) Gnaedinger in Gnaedinger et Herbst 2001. PBSJ 422. Escala: 1 cm. 
Género Johnstonia Walkom 1925

Especie tipo. Johnstonia coriacea (Johnston) Walkom 1925.

Johnstonia stelzneriana (Geinitz) Frenguelli 1943

Estrato fosilífero y localidad: EF2, Localidad 2.

Comentarios: Especie citada por Zamuner et al. (2001).

Género Xylopteris Frenguelli 1943

Especie tipo. Xylopteris elongata (Carruthers) Frenguelli 1943.

Xylopteris argentina (Kurtz) Frenguelli 1943

Estrato fosilífero y localidad: EF2, Localidad 2.

Comentarios: Especie citada por Bonetti (1963), para el NF I, punto 12, y para el NF II, punto 21 .

Xylopteris elongata (Carruthers) Frenguelli 1943

Estrato fosilífero y localidad: EF2, Localidad 2.

Comentarios: Bonetti (1963) considera que esta especie está presente en el NF II, puntos 20 y 21.

Género Umkomasia Thomas 1933

Especie tipo. Umkomasia macleani Thomas 1933.

Umkomasia macleani Thomas 1933

Estrato fosilífero y localidad: EF2, Localidad 2.

Comentarios: Citada por de Bonetti (1963), para el NF II, punto 20. 


\title{
Género Rhexoxylon Bancroft 1913 emend. Archangelsky et Brett 1961
} Especie tipo. Rhexoxylon africanum Bancroft 1913 emend. Walton 1923

\section{Rhexoxylon cortaderitaense (Menéndez) Bodnar 2008}

FiguraVII.9

\begin{abstract}
Descripción: Troncos excéntricos y ovalados en sección transversal, con un diámetro de 8 a
\end{abstract} $80 \mathrm{~cm}$. Los ejemplares presentan médula, xilema secundario y floema secundario preservados. Son ejes polixílicos, debido a la presencia de dos anillos cambiales que desarrollan xilema y floema secundarios centrípetos hacia la médula, y xilema y floema secundarios centrífugos hacia la corteza. En los ejemplares con médula preservada, ésta mide 3,22 cm x 1,3 cm de diámetro, es ovalada y heterogénea, con idioblastos poliédricos con contenidos oscuros, nidos escleróticos y cavidades secretoras. El floema secundario centrípeto tiene un espesor de 0,35 a $0,6 \mathrm{~cm}$. Debido a su pobre preservación, los caracteres anatómicos del floema no pueden ser estudiados en detalle, pero se han podido observar fibras floemáticas agrupadas. El xilema secundario centrípeto tiene un espesor de 0,75 a 3,6 cm. Cada segmento de xilema centrípeto es de 0,9 a $2 \mathrm{~cm}$ de ancho. Está separado del xilema secundario centrífugo por tejidos parenquimatosos con células comparables a las de la médula (=parénquima tangencial o de dilatación) que se origina del cámbium remanente. El xilema primario, que debería estar localizado entre el xilema secundario centrípeto y centrífugo, no es discernible; sin embargo puede inferirse como mesarco. El xilema secundario centrífugo tiene un espesor de 4 a $14 \mathrm{~cm}$. La disposición del tejido vascular en cuñas es resultado de la actividad diferencial del cámbium alrededor de la circunferencia de los ejes. Hay cordones de cámbium que sólo producen parénquima radial, entonces el leño está dividido por radios parenquimatosos. Este tipo de radios pueden desarrollarse localmente dentro de las cuñas xilemáticas. Cada cuña xilemática mide 4,5 a 7,5 cm de espesor. Los radios parenquimatosos son de 0,1 a $0,5 \mathrm{~cm}$ de ancho y consisten en tejidos similares a aquellos de la médula. Además, la fragmentación tangencial dentro de las cuñas xilemáticas se observa en algunos especímenes, como consecuencia de la actividad de cámbiumes sucesivos. Internamente en el xilema secundario centrípeto y centrífugo, se desarrollan anillos de crecimiento, con una abrupta disminución del diámetro radial de las traqueidas hacia el final del anillo. Éstos son anillos discontinuos y discordantes, porque los límites son interrumpidos por los radios parenquimatosos. Las traqueidas del xilema secundario son cuadrangulares a rectangulares redondeadas en corte transversal. El diámetro radial de las traqueidas es de 6,66- $(38,89)-73,47 \mu \mathrm{m}$ y el diámetro 
tangencial es de 20,41-(37,85)-56,39 $\mu \mathrm{m}$. El espesor de la doble pared entre dos traqueidas es de 6,5-(10,96)-15,89 $\mu \mathrm{m}$ en sección radial y de 6,14-(11,25)-17,74 $\mu \mathrm{m}$ en sección tangencial. Las traqueidas tienen punteaduras areoladas principalmente biseriadas, menos comúnmente triseriadas y uniseriadas, tanto en las paredes radiales y tangenciales. Las punteaduras son circulares, comprimidas verticalmente, dispuestas densamente en hileras alternas, con poros circulares. Las punteaduras miden 6,69-(13.67)-11,77 $\mu \mathrm{m}$ de diámetro. Los campos de cruzamiento tienen una punteadura simple, de contorno circular a elíptico, de $11,44 \times 21,59-(18,71 \times 30,38)-26,18 \times 39,3 \mu \mathrm{m}$ de diámetro, organizados en hileras verticales. Los radios xilemáticos secundarios son homocelulares; uniseriados, raramente biseriados. Los radios son cortos y rectilíneos, y varían entre 62,59-(197,73)-860,83 $\mu \mathrm{m}$ y 1(5)-23 células de altura. Están compuestos por células parenquimáticas rectangulares, de $18,21-(33,44)-49,03 \mu \mathrm{m}$ de altura, 16,87-(27,10)-37,95 $\mu \mathrm{m}$ de ancho y 27,65-(58,21)-169,96 $\mu \mathrm{m}$ de largo. Parénquima axial y traqueidas radiales, ausentes. La corteza no está preservada.

Materiales estudiados: PBSJ 423, 424, 425, 426, 427, 428.

\section{Materiales revisados: PB-CTES 10178.}

Estrato fosilífero y localidad: EF2, localidades 2, 3 y 5; EF 3, localidad 3; EF4, localidad 4.

Comentarios. Se han descripto siete géneros de troncos de Corystospermaceae: Rhexoxylon Bancroft 1913 emend. Archangelsky et Brett 1961 (Argentina, Brasil, Sudáfrica y Antártida), Tranquiloxylon Herbst et Lutz 1995 (Argentina y Chile), Cuneumxylon Artabe et Brea 2003 (Argentina) y Elchaxylon Artabe et Zamuner 2007 (Argentina) con crecimiento secundario atípico; y Kykloxylon Meyer-Berthaud, Taylor et Taylor 1993 (Antártida), Jeffersonioxylon del Fueyo, Taylor, Taylor et Cúneo 1995 (Antártida) y Antarcticoxylon Seward 1914 (Brasil y Sudáfrica), con un cilindro vascular secundario típico. Los tallos de Rhexoxylon muestran un leño picnoxílico asociado a un modo único de producción de tejidos vasculares secundarios. Todas las especies asignadas a este género tienen un patrón caracterizado por una médula rodeada por un cilindro vascular secundario; este último compuesto por dos zonas: 1- una interna (i.e. zona vascular perimedular o sistema vascular medular) formada por uno o más ciclos de haces de xilema+floema secundarios, que son centrípetos o centrípetos y centrífugos; y 2- una externa (i.e. zona vascular periférica o sistema vascular cilíndrico) constituida por cuñas de xilema+floema secundarios centrífugos separados por radios parenquimatosos (Archangelsky y Brett, 1961; Artabe et al. 1999b; Artabe y Brea, 2003). 

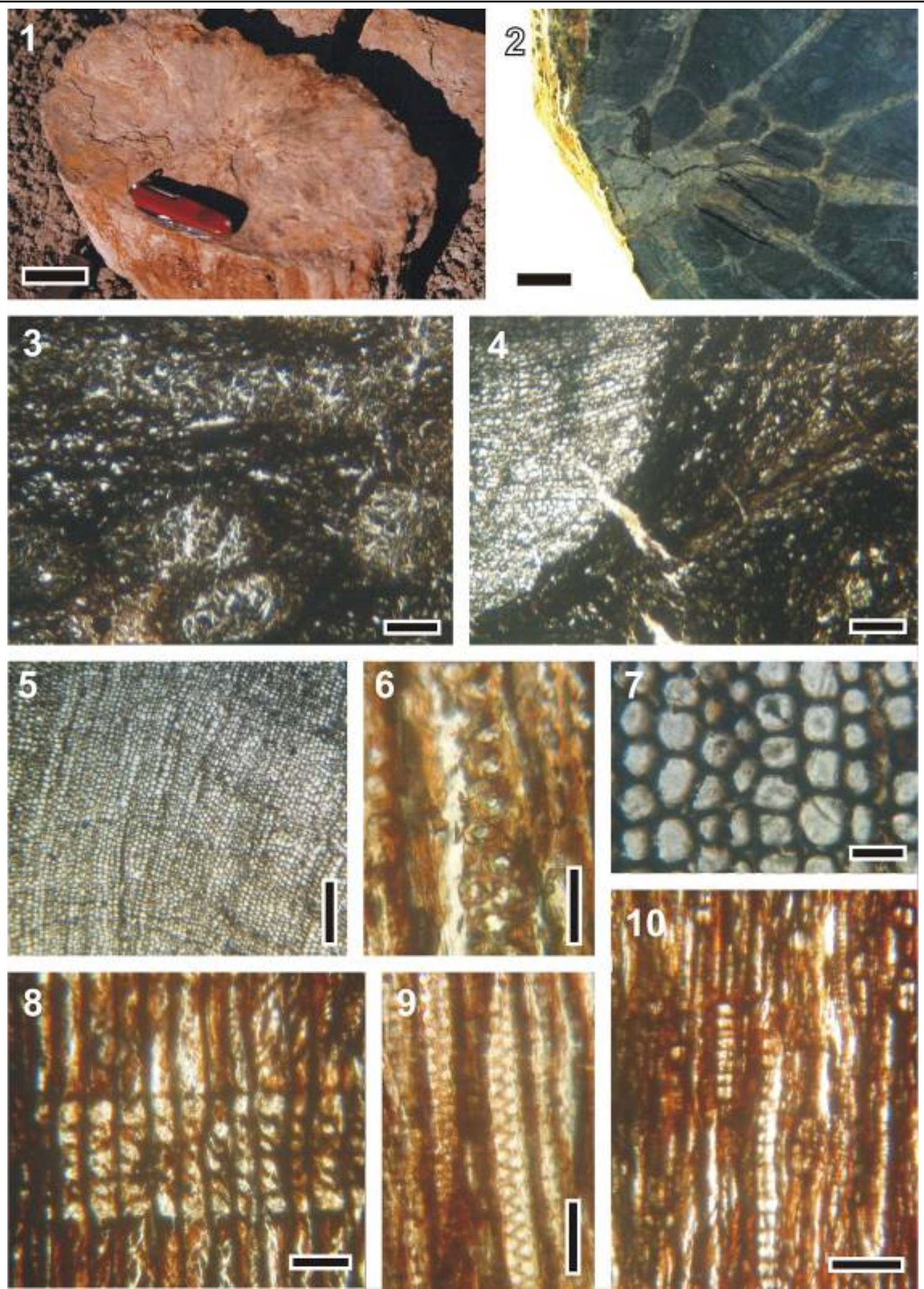

Figura VII.9. Rhexoxylon cortaderitaense (Menéndez) Bodnar 2008. 1. Ejemplar fotografiado en el campo. Escala: $5 \mathrm{~cm}$. 2. PBSJ 423. Superficie pulida. Del centro a la periferia se observa: la médula, el floema secundario centrípeto, el xilema secundario centrípeto y el xilema secundario centrífugo +los radios parenquimatosos. Escala: $1 \mathrm{~cm}$. 3. PBSJ 424. Corte transversal de la médula con idioblastos, nidos escleróticos y cavidades secretoras. Escala: $600 \mu \mathrm{m}$. 
Figura VII.9. (continuación) 4. PBSJ 424. Detalle del floema secundario centrípeto (derecha) y del xilema secundario centrípeto (izquierda). Escala: $300 \mu \mathrm{m}$. 5. PBSJ 425. Corte transversal del xilema secundario centrífugo, mostrando el desarrollo de anillos de crecimiento. Escala: $400 \mu \mathrm{m}$. 6. PBSJ 424. Detalle de las punteaduras radiales de las traqueidas. Escala: $40 \mu \mathrm{m}$. 7. PBSJ 426. Detalle de las traqueidas, en corte transversal. Escala: $40 \mu \mathrm{m}$. 8. PBSJ 427. Vista general del corte radial, mostrando con campos de cruzamiento fenestriformes. Escala: $80 \mu \mathrm{m}$. 9. PBSJ 424. Detalle de las punteaduras radiales de las traqueidas, mostrando su disposición alterna y biseriada. Escala: $60 \mu \mathrm{m}$. 10. PBSJ 428. Corte tangencial, con radios homocelulares uniseriados. Escala: $200 \mu \mathrm{m}$.

Los materiales provenientes de las mismas sedimentitas descriptos por Lutz y Herbst (1992) como Rhexoxylon sp. (PB-CTES 10178), pertenecen a la especie Rhexoxylon cortaderitaense, la que ha sido recientemente asignada a las corystospermas por Bodnar (2006, 2008) (ver más abajo en este mismo capítulo), puesto que originalmente había sido descripta como una conífera por Menéndez (1956).

Dentro del género, es la única especie que no produce haces perimedulares de xilema+floema secundarios centrípeto-centrífugos, sino que desarrolla haces sólo centrípetos. Los ejemplares provenientes de la Sección Inferior de la Formación Cortaderita muestran un importante desarrollo del xilema y floema centrípetos, mucho mayor al material tipo de la especie.

Orden Peltaspermales Meyen 1987

Familia Peltaspermaceae Thomas 1933

Género Scytophyllum Bornemann 1856

Especie tipo. Scytophyllum bergeri Bornemann 1856.

Figura VII.11.1

\section{Scytophyllum bonettiae Zamuner, Artabe et Ganuza 1999}

Descripción: Hojas monopinnadas, imparipinnadas, lanceoladas, de 5 a $12 \mathrm{~cm}$ de longitud y 2 a $4 \mathrm{~cm}$ de ancho máximo aproximado en la zona media, angostándose hacia la base y ápice en forma gradual. Raquis robusto de 0,15 a $0,22 \mathrm{~cm}$ de espesor, con protuberancias en su superficie. Pinnas lanceoladas, de márgenes paralelos, enteros a levemente lobulados o dentados, decurrentes en la base. El ángulo de inserción de las pinnas varía desde 45 a $50^{\circ}$ en 
la zona distal y de 70 a $85^{\circ}$ en la media y basal. Las pinnas varían en longitud desde $0,5 \mathrm{~cm}$ en la base, a 2,5 cm en la zona media; y en ancho de 0,3 a $0,8 \mathrm{~cm}$. La zona más ancha de la pinna es la más cercana a la base, luego se angosta y se vuelve a ensanchar haciéndose decurrente al raquis. El margen acroscópico es contraído y confluente con el basiscópico que conforma un ala inervada desde el raquis de 0,1 a $0,15 \mathrm{~cm}$ de ancho. Venación compleja. Vena media conspicua que llega hasta el ápice de cada pinna. Las venas secundarias salen en forma pinnada de la vena media. De las venas secundarias parten de manera pinnada venas de tercer orden.

Materiales estudiados: LPPB 13842, 13843, 13844, 13845, 13846, 13847.

Materiales revisados: LPPB 13091, 13092, 13093, 13094, 13095, 13096, 13099, 13100, 13101, 13102, 13103, 13104, 13105, 13106, 13107, 13108, 13109.

Estrato fosilífero y localidad: EF1, Localidad 1 y EF 2, Localidad 5.

Comentarios: En los mismos niveles de los que provienen estos materiales, se han encontrado los ejemplares tipo de esta especie, la que es muy abundante (Zamuner et al., 1999).

Género Peltaspermum Harris emend. Townrow 1960

Especie tipo. Peltaspermum rotula Harris 1937.

\section{Peltaspermun sp.}

Materiales revisados: LPPB 13097.

Estrato fosilífero y localidad: EF1, Localidad 1.

Comentarios: Ejemplares designados al género Peltaspermum han sido descriptos e ilustrados por Zamuner et al. (1999), para el nivel 2 del EF de Cortaderita Inferior.

Género Pachydermophyllum Thomas et Bose 1955

Especie tipo. Pachydermophyllum papillosum Thomas et Bose 1955.

\section{Pachydermophyllum papillosum Thomas et Bose 1955}

Figura VII.10, 11.2 y 3 
Descripción: Hojas monopinnadas, de más de $8 \mathrm{~cm}$ de largo y de 2,56 a 5,5 cm de ancho. Pecíolo no preservado, raquis de $0,13 \mathrm{~cm}$ de espesor. Pinnas lanceoladas, opuestas en la base a subalternas en el ápice de la hoja, insertas con un ángulo de 45 a $60^{\circ}$. Margen basal inferior de las pinnas decurrente; margen basal superior contraído. Ápice agudo a subagudo. Longitud de las pinnas de 0,76 a 3,5 cm; ancho máximo de las pinnas de 0,37 a $0,65 \mathrm{~cm}$, el que se encuentra cerca de su base. Vena media marcada, nace paralela al raquis y luego se curva haciéndose paralela a los márgenes de la pinna. Venas secundarias parten alternas con un ángulo agudo de la vena media o algunas directamente del raquis, y se dicotomizan cerca su salida.

Materiales estudiados: PBSJ 429.

Estrato fosilífero y localidad: EF 2, Localidad 2 y EF3, Localidad 3.

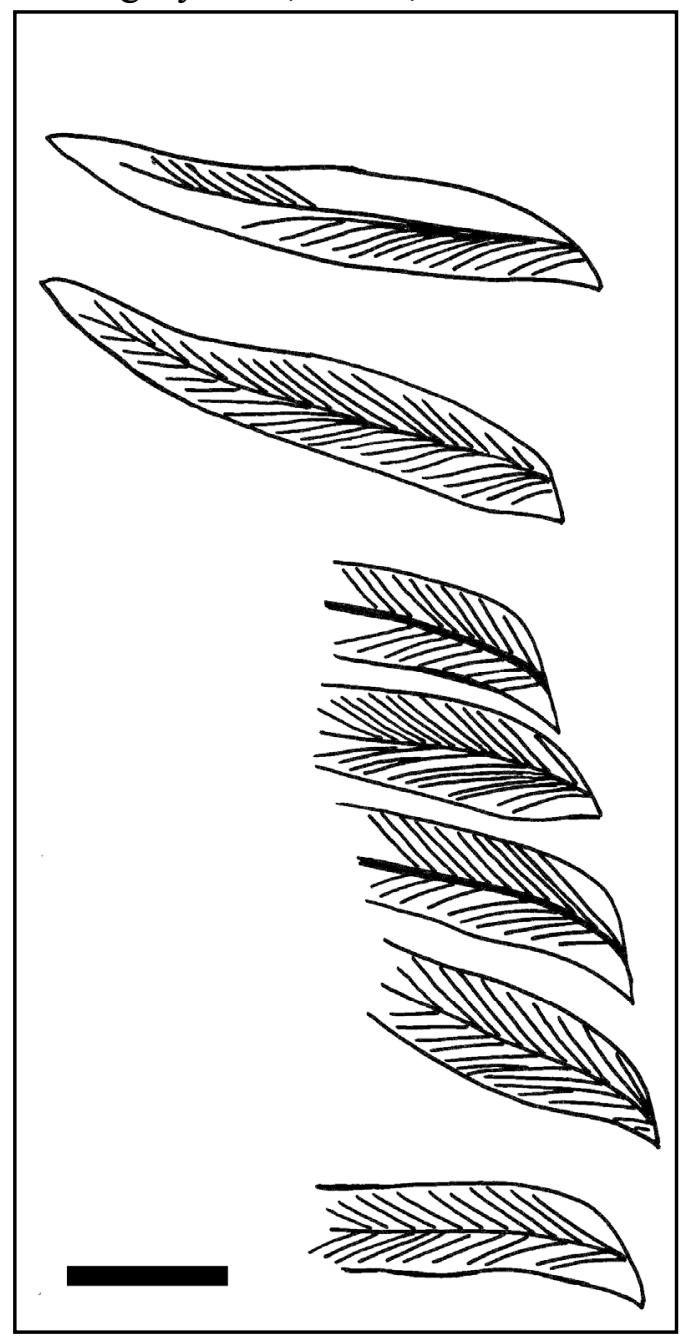

Figura VII.10. Pachydermophyllum papillosum Thomas et Bose 1955 PBSJ 429. Detalle de la morfología y venación de las pinnas. Escala: $1 \mathrm{~cm}$.

Comentarios: Pachydermophyllum papillosum fue definida por Thomas y Bose (1955) con los siguientes caracteres morfológicos: hojas pecioladas, monopinnadas, raquis estríado y a veces con arrugas, pinnas ovadas a lanceoladas, margen inferior decurrente al raquis, margen superior contraído, ápice redondeado, vena media visible pero no prominente, venas laterales simples o divididas dicotómicamente. De acuerdo a Retallack (1981) Pachydermophyllum papillosum se caracteriza por poseer pinnas gruesas, coriáceas, lanceoladas a ovadas, contraídas en la base, alcanzando su ancho máximo a una corta distancia de la base y disminuyendo hacia un ápice subagudo. Los ejemplares descriptos coinciden con esta caracterización y con la diagnosis original de la especie. 


\section{Pachydermophyllum praecordillerae (Frenguelli) Retallack 1981}

Figura VII.11.4

Descripción: Hojas monopinnadas, de más de 4,5 cm de largo y de 2,26 a 2,7 cm de ancho. Pecíolo no preservado, raquis de 0,16 a $0,17 \mathrm{~cm}$ de espesor. Pinnas lanceoladas, alternas, insertas con un ángulo de 56 a $62^{\circ}$, con base levemente ensanchada, márgenes rectos y ápice redondeado. Varían en longitud de 1,26 a $1,51 \mathrm{~cm}$ y en ancho de 0,57 a 0,86 cm. Venación mal preservada, hay una media marcada, de la que parten con un ángulo agudo venas secundarias, que parecen dicotomizarse.

Materiales estudiados: PBSJ 431.

Estrato fosilífero y localidad: EF3, Localidad 3.

Comentarios: De acuerdo a Retallack (1981) Pachydermophyllum praecordillerae se caracteriza por poseer pinnas alargadas, de márgenes paralelos, con ápices redondeados.

Los ejemplares descriptos reúnen estos atributos, si bien sus pinnas no son marcadamente alargadas. Esta especie había sido citada por Bonetti (1963), para el NF II, punto 20.

\section{Género Lepidopteris (Schimper) Townrow 1956}

Especie tipo. Lepidopteris stuttgardiensis (Jaeger) Schimper 1869.

\section{Lepidopteris stormbergensis (Seward) Townrow 1956}

Figura VII.11.5

Descripción: Fragmentos de 3,37 a 3,63 cm de longitud y 1,23 a 3,6 cm de ancho de hojas bipinnadas. Raquis robusto. Pinnas alargadas, opuestas a subopuestas, de 0,41 a 0,76 de ancho y 0,95 a 2,32 cm de largo, no preservadas en toda su longitud, insertas con un ángulo de 48 a $64^{\circ}$. Pínnulas opuestas a subopuestas y subalternas, insertas con un ángulo de 47 a $61^{\circ}$, de morfología lanceolada-falcada, base ancha, márgenes ligeramente lobados y curvados, ápice subagudo. Su longitud varía de 0,32 a $0,48 \mathrm{~cm}$ y su ancho de 0,16 a $0,32 \mathrm{~cm}$. Interpínnulas con base ancha asimétrica, ensanchada en el márgen basiscópico, márgenes curvados, ápice redondeado, de 0,19-0,23 cm x 0,26-0,32 cm, insertas con un ángulo de 44 a $77^{\circ}$. Puede haber más de una interpínnula entre dos pinnas. La venación está bastante oscurecida. En cada pínnula, hay una vena media que llega hasta el ápice, de la que parten venas secundarias en ángulo agudo y de manera subalterna, alcanzando una densidad de 10 venas por pínnula. La venación de las interpínnulas es semejante a la de las pínnulas.

Materiales estudiados: PBSJ 432, 640, 641. 
Estrato fosilífero y localidad: EF3, Localidad 3.

Comentarios: La morfología del género Lepidopteris Townrow 1956 está definida como hojas bipinnadas, lanceoladas, con raquis grueso, usualmente cubierto por protuberancias, generalmente con interpínnulas, pínnulas lanceoladas, raramente contraídas en la base (Gnaedinger y Herbst, 1998a). Hasta el momento se reconocen seis especies dentro del género para el Triásico del Gondwana: L. madasgascariensis (Carpentier) Townrow 1966b, L. stormbergensis (Seward) Townrow 1956, L. africana (Du Toit) Holmes 1982, L. brownii (Seward) Anderson et Anderson 1989, L. langlohensis Anderson et Anderson 1989 у L. callipteroides (Carpentier) Retallack 2002. Estos taxones se pueden diferenciar morfológicamente por los atributos sintetizados en el cuadro VII.6.

\begin{tabular}{|c|c|c|c|c|c|}
\hline Especie & $\begin{array}{c}\text { División de la } \\
\text { lámina }\end{array}$ & $\begin{array}{c}\text { Relación entre las } \\
\text { pinnas }\end{array}$ & $\begin{array}{c}\text { Morfología de las } \\
\text { pínnulas }\end{array}$ & $\begin{array}{c}\text { Número de } \\
\text { interpínnulas } \\
\text { entre pinnas }\end{array}$ & Venación \\
\hline $\begin{array}{c}\text { L. madasgascariensis } \\
\text { (Carpentier) Townrow } \\
1966 \mathrm{~b}\end{array}$ & Bipinnada & Espaciadas & $\begin{array}{l}\text { Lineares con ápices } \\
\text { redondeados }\end{array}$ & Una a tres & $\begin{array}{c}\text { Venas laterales } \\
\text { simples }\end{array}$ \\
\hline $\begin{array}{c}\text { L. stormbergensis } \\
\text { (Seward) Townrow } 1956\end{array}$ & $\begin{array}{c}\text { Bipinnada } \\
\text { (ocasionalmente } \\
\text { tripinnatífida) }\end{array}$ & Contiguas & $\begin{array}{c}\text { Lanceoladas con ápices } \\
\text { agudos a obtusos }\end{array}$ & Una a tres & $\begin{array}{c}\text { Venas laterales } \\
\text { simples o } \\
\text { dicotomizadas }\end{array}$ \\
\hline $\begin{array}{c}\text { L. africana (Du Toit) } \\
\text { Holmes } 1982\end{array}$ & $\begin{array}{c}\text { Bipinnada } \\
\text { (ocasionalmente } \\
\text { bipinnatífida) }\end{array}$ & Espaciadas & Incipientes & $\begin{array}{c}\text { Una a tres } \\
\text { interpínnulas } \\
\text { incipientes }\end{array}$ & $\begin{array}{c}\text { Venas laterales } \\
\text { simples }\end{array}$ \\
\hline $\begin{array}{c}\text { L. brownii (Seward) } \\
\text { Anderson et Anderson } \\
1989\end{array}$ & $\begin{array}{l}\text { Bipinnatífida a } \\
\text { bipinnada }\end{array}$ & Espaciadas & $\begin{array}{l}\text { Lineares con ápices } \\
\text { redondeados y bases } \\
\text { expandidas }\end{array}$ & Una a tres & $\begin{array}{c}\text { Venas laterales } \\
\text { simples }\end{array}$ \\
\hline $\begin{array}{l}\text { L. langlohensis Anderson } \\
\text { et Anderson } 1989\end{array}$ & Bipinnada & $\begin{array}{l}\text { Separadas a } \\
\text { contiguas }\end{array}$ & $\begin{array}{l}\text { Lanceoladas con ápices } \\
\text { redondeados y bases } \\
\text { algo expandidas a muy } \\
\text { contraídas }\end{array}$ & Una & $\begin{array}{c}\text { Venas laterales } \\
\text { simples (?) }\end{array}$ \\
\hline $\begin{array}{c}\text { L. callipteroides } \\
\text { (Carpentier) Retallack } \\
2002\end{array}$ & $\begin{array}{c}\text { Mono a bipinnada y } \\
\text { con raquis } \\
\text { dicotómico }\end{array}$ & Separadas & $\begin{array}{l}\text { Ovadas con ápices } \\
\text { redondeados }\end{array}$ & --- & $\begin{array}{c}\text { Venas laterales } \\
\text { simples o } \\
\text { dicotomizadas }\end{array}$ \\
\hline
\end{tabular}

Cuadro VI.6. Comparación morfológica entre las especies de Lepidopteris reconocidas para el Triásico del Gondwana (Anderson y Anderson, 1989; Gnaedinger y Herbst, 1998a).

Género Delnortea Mamay, Miller, Rohr et Stein 1986

Especie tipo. Delnortea abbottiae Mamay, Miller, Rohr et Stein 1986. 


\section{Cf. Delnortea abbottiae Mamay, Miller, Rohr et Stein 1986}

Figura VII.11.6, 7, 8 y 9

Descripción: Hojas simples, de 5,97 cm de longitud y 0,77 a 1,6 cm de ancho, linearoblongas, pecioladas (¿?), con ápice agudo y márgenes crenulados. Lóbulos del margen ligeramente irregulares, de 0,17 a $0,73 \mathrm{~cm}$ de ancho y 0,21 a $0,75 \mathrm{~cm}$ de largo, con ápice redondeado o agudo. Hay una disminución del largo y/o ancho de los lóbulos hacia la base y el ápice de la hoja. Márgenes de la lámina enrollados, con un reborde engrosado. Venación pinnada compleja. Vena principal robusta, de 0,14 a $0,19 \mathrm{~cm}$ de espesor, con estrías y carenas longitudinales bien marcadas. Venas secundarias desde opuestas o subopuestas a subalternas o alternas, salen con un ángulo de 58 a $90^{\circ}$ de la vena principal y llegan hasta el ápice de los lóbulos donde se fusionan con el reborde engrosado del margen de la lámina. Las venas de tercer orden parten de las venas secundarias con un ángulo agudo, subopuestas a opuestas, llegan a una densidad de aproximadamente 12 venas por lóbulo y se dicotomizan de manera anisótoma, una a tres veces cerca del margen del lóbulo, generando un cuarto orden de venación.

Material estudiado: PBSJ 433, 434, 435, 436.

Estrato fosilífero y localidad: EF3, Localidad 3.

Comentarios: Estos ejemplares no son comparables con taxones presentes en el Triásico del Gondwana. No obstante, se asemejan al género Delnortea Mamay, Miller, Rohr et Stein 1986; el que había sido originalemente asignado a las Gigantopteridales, pero luego se le sugerió una mayor afinidad a las pteridospermas (Mamay et al., 1988) y más concretamente a las Peltaspermales (DiMichele et al., 2005). Delnortea es un género monotípico del Pérmico Inferior de Norteamérica y Venezuela (Mamay et al., 1986; Ricardi et al., 1999), cuya única especie (D. abbottiae) incluye hojas parcialmente permineralizadas, simples, pecioladas, oblongo-elípticas, con márgenes desde enteros a crenulados, enrollados con tejidos esclerenquimáticos y venación pinnada con cuatro órdenes de venas, en la que la vena media consiste en 8-10 haces colaterales (Mamay et al., 1988). Este taxón tiene ciertas características que la diferencia de las restantes gigantopterídeas: margen de la lámina con un reborde engrosado, venas secundarias que terminan en los senos del margen crenulado y que se extienden hasta el margen de la lámina donde se fusionan con el reborde marginal engrosado (DiMichele et al., 2000). Los ejemplares de la Formación Cortaderita se aproximan a Delnortea abbottiae porque son hojas simples, oblongas, con márgenes lobulados, venación pinnada compleja con cuatro órdenes de venas, margen de la lámina enrollado y con un 
reborde engrosado, y venas secundarias que terminan en el ápice de los lóbulos del margen crenulado fusionándose con el reborde. Por otra parte, se diferencia del taxón pérmico por el tamaño (D. abbottiae llega a tener una longitud de más de $30 \mathrm{~cm}$ ) y en que las venas secundarias terminan en los lóbulos del margen crenulado y no en los senos (aunque en escasas ocasiones en los ejemplares aquí descriptos algunas venas secundarias parecieran culminar en los senos).

\section{Orden Petriellales Taylor, del Fueyo et Taylor 1994}

\section{Incertae sedis}

\section{Género Rochipteris Herbst, Troncoso et Gnaedinger 2001}

Especie tipo. Rochipteris lacerata (Arber) Herbst, Troncoso et Gnaedinger 2001.

\section{Rochipteris cyclopteroides (Frenguelli) comb. nov.}

Basónimo. Cardiopteridium cyclopteroides Frenguelli 1944e.

Materiales revisados: LPPB 20403.

Estrato fosilífero y localidad: EF2, Localidad 2.

Comentarios: Se revisaron los materiales originales sobre los que Frenguelli (1944e) basó su especie Cardiopteridium cyclopteroides. Las características de esta hoja (ver la descripción original de Frenguelli, 1944e) se ajustan a la diagnosis genérica de Rochipteris Herbst, Troncoso et Gnaedinger 2001, y por eso se considera más conveniente asimilarlo a ese género. Asimismo, se siguió el criterio de Artabe et al. (2007c) de asignar el género Rochipteris a las Petriellales. 

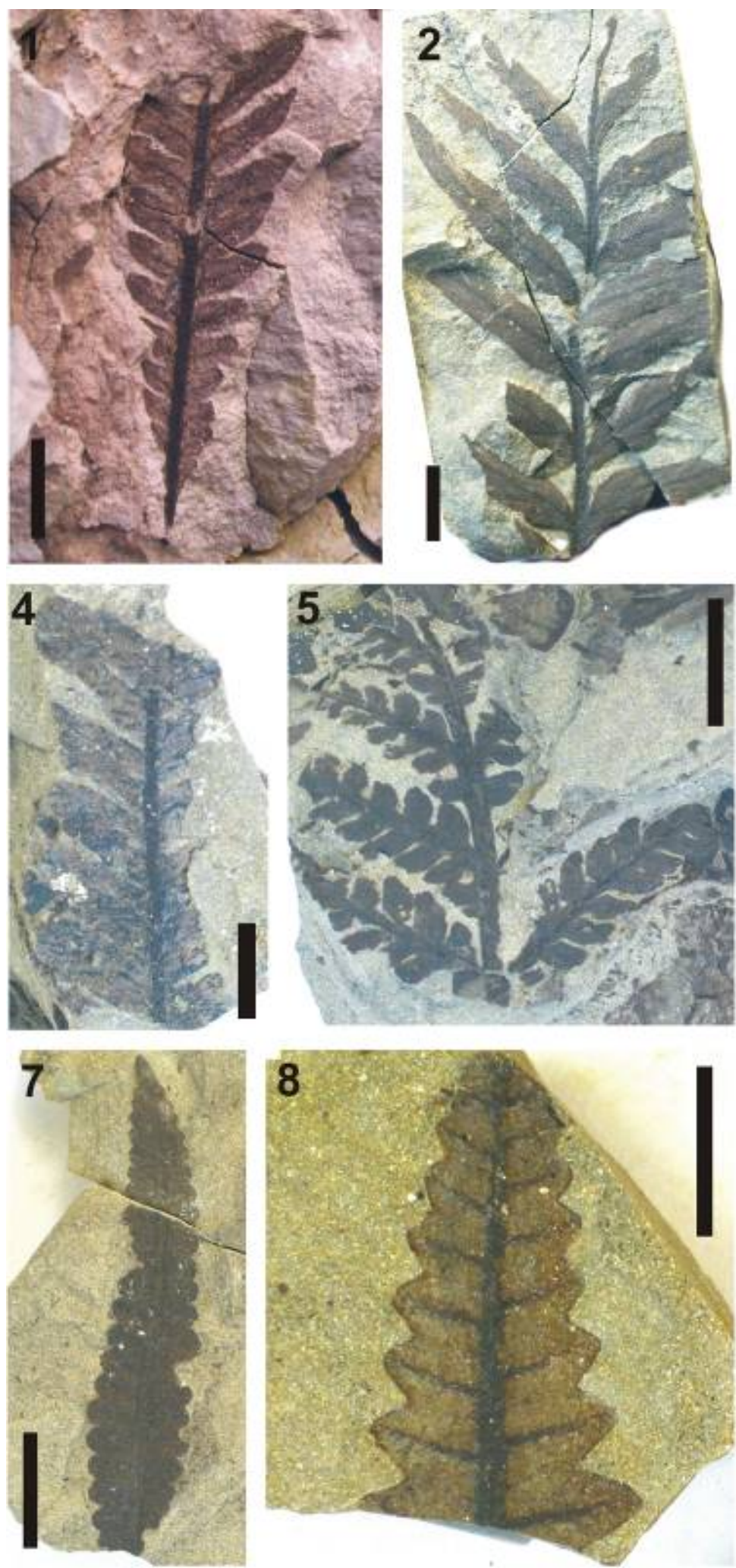
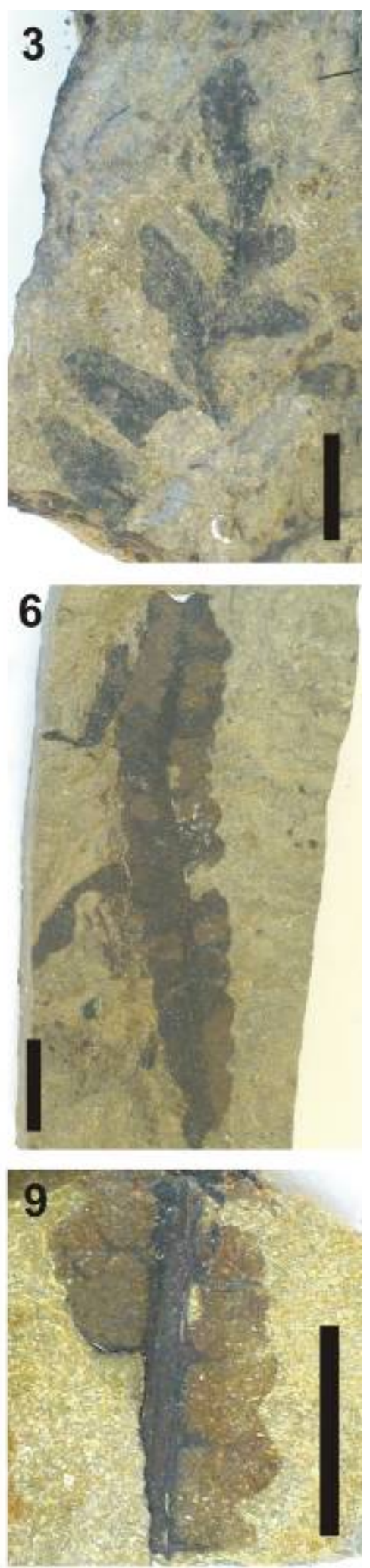

Figura VII.11. 1. Scytophyllum bonettiae Zamuner, Artabe et Ganuza 1999. Material fotografiado en el campo. 2,3. Pachydermophyllum papillosum Thomas et Bose 1955. 2. PBSJ 429. 3. PBSJ 430. 4. Pachydermophyllum praecordillerae (Frenguelli) Retallack 1981. PBSJ 431. 5. Lepidopteris stormbergensis (Seward) Townrow 1956. PBSJ 432. 6-9. Cf. Delnortea abbottiae Mamay, Miller, Rohr et Stein 1986. 6. PBSJ 433. 7. PBSJ 434. 8. PBSJ 435. Detalle de la vena media y las venas secundarias. 9. PBSJ 436. Detalle de la vena media estríada, las venas secundarias y las de tercer orden. Escala: $1 \mathrm{~cm}$ 
Orden Cycadales Dumortier 1829

Incertae sedis

Género Kurtziana Frenguelli emend. Petriella et Arrondo 1982

Especie tipo. Kurtziana cacheutensis (Kurtz) Frenguelli emend. Petriella et Arrondo 1982.

\section{Kurtziana cacheutensis (Kurtz) Frenguelli emend. Petriella et Arrondo 1982}

Estrato fosilífero y localidad: EF 2, Localidad 2.

Comentarios: Especímentes designados a la especie Kurtziana cacheutensis han sido estudiados por Bonetti, para el NF II, punto 20.

\section{Familia Stangeriaceae Johnson 1959}

Género Pseudoctenis Seward emend. Harris 1964

Especie tipo. Pseudoctenis eathiensis (Richards) Seward 1911.

Pseudoctenis sp. nov.

Figura VII.12.1, 2 y 3

Pseudoctenis A. Artabe, Zamuner, Ganuza y Spalletti 1995a.

Descripción: Los materiales de los que se dispone son 17 ejemplares correspondientes a hojas monopinnadas preservadas como impresiones. Seis corresponden a la parte basal. Los once restantes representan la región media de la hoja, lo que se infiere porque el tamaño de los segmentos es mayor que en la base. La forma de la hoja entera no puede ser determinada con seguridad, probablemente sea lanceolada. Se puede estimar una longitud hipotética de la hoja de más de $60 \mathrm{~cm}$. Los ejemplares más completos miden $22 \mathrm{~cm}$ de largo y $18 \mathrm{~cm}$ de ancho. El raquis es robusto, conservando el grosor $(0,6 \mathrm{~cm}$ en promedio) en toda su extensión. Está fuertemente estriado longitudinalmente. En algunos ejemplares hay una carena central de $0,3 \mathrm{~cm}$ de ancho. La disposición de los segmentos es subopuesta a opuesta. Los segmentos se insertan lateralmente al raquis por toda su base, con un ángulo de entre 70 y $90^{\circ}$. La longitud de los segmentos basales es de 2 a $2,7 \mathrm{~cm}$, mientras que la de los segmentos medios está entre 4,5 y más de $8 \mathrm{~cm}$. Su ancho es irregular, principalmente en la región central de la hoja, 
variando entre 1 y 1,5 cm en los segmentos de la base, y entre 1,3 y 2,5 cm en los centrales. Tienen una morfología espatulada, el ápice es muy redondeado a romo y asimétrico, ya que el margen basiscópico es más corto que el acroscópico. La base está ensanchada en su inserción. Los márgenes acroscópico y basiscópico son pro y decurrentes respectivamente en los segmentos medios, mientras que en los basales son paralelos a levemente pro y decurrentes. La separación entre segmentos es irregular; de 0,3 a 0,6 cm entre los segmentos basales. Los segmentos centrales son confluentes en su región basal formando un ala sobre el raquis de entre 0,2 y $0,6 \mathrm{~cm}$. No hay una constricción peribasal. La venación es conspicua y sigue en la zona basal la procurrencia y decurrencia de los márgenes. Entran de 12 a 16 venas por segmento. Algunas son simples pero la mayoría se bifurcan una vez, ocasionalmente dos veces. Generalmente el punto de bifurcación es próximo al raquis. En determinados ejemplares algunas se dicotomizan distalmente. No se observan anastomosis. La densidad de venas es de 16 a 24 venas $/ \mathrm{cm}$.

Materiales estudiados: LPPB 13848, 13848, 13850, 13851, 13852, 13853, 13854, 13855, 13856, 13857, 13858, 13859, 13860, 13861, 13862, 13863, 13864, 13865, 13865, 13866, 13867.

Estrato fosilífero y localidad: EF1, Localidad 1 y EF2 Localidad 5.

Comentarios: El género Pseudoctenis fue establecido para ciertas hojas pinnadas que concuerdan con el hábito de Ctenis Lindley et Hutton 1834, pero se distinguen por la ausencia casi completa de alguna anastomosis entre las venas. En este carácter se asemeja al género Pterophyllum Brongniart 1828b, del que se aleja por la venación más marcada de Pseudoctenis (Seward, 1911). Algunas de las formas con pinnas angostas se asemejan bastante a especies de Zamites, siendo su carácter distintivo el margen inferior decurrente de los segmentos (Seward, 1917).

Harris (1964) enmienda la diagnosis de Pseudoctenis de Seward, incorporando aspectos de la epidermis. De tal manera dicha diagnosis quedaría establecida como sigue: "Hoja grande, elongada, monopinnada. Pinnas anchas o angostas y elongadas, lanceoladas, o de márgenes paralelos, insertándose lateralmente al raquis. Márgenes de las pinnas enteros, ápice truncado o contraído, base expandida o contraída. Venas numerosas, paralelas, simples o bifurcadas, no anastomosadas. Lámina gruesa, hipostomática. Estomas esparcidos, orientación variable o longitudinal, haplocélicos, células guarda hundidas en una depresión cutinizada formada por un anillo de células haplocélicas subsidiarias. Paredes de las células rectas o casi rectas”. 
Du toit (1927b) adopta un criterio que distingue a este género en presencia de impresiones, el que radica en que Pseudoctenis posee segmentos más o menos confluentes entre sí, con márgenes basiscópicos decurrentes y venas curvadas sobre el raquis.

De las especies triásicas del Gondwana (Cuadro VII.7), la más semejante a esta nueva especie es $P$. spectabilis Harris 1932a, b. Se diferencia en las dimensiones máximas de los segmentos, en el ala basal de los mismos -la que está más desarrollada en Pseudoctenis sp. nov.- y la densidad de venas. En comparación con los materiales de P. spectabilis de Argentina, descriptos por Artabe (1985) en la Formación Vera (Los Menucos, provincia de Río Negro), y por Morel y Povilauskas (2002) en la Formación Potrerillos (Cacheuta, provincia de Mendoza), se acercarían en mayor medida a los ejemplares mendocinos que a los patagónicos debido a la densidad de venas de los primeros: 18-20 venas $/ \mathrm{cm}$.

De las especies descriptas para el género, nuestros ejemplares no se ajustan a ninguna. Estos materiales habían sido citados como Pseudoctenis sp. A, tentativamente como una nueva especie (Artabe et al., 1995a); lo que aquí se confirma.

\section{Pseudoctenis anomozamoides Bonetti 1968}

Materiales revisados: $\mathrm{BAPb} 4228,4383$.

Estrato fosilífero y localidad: EF2, Localidad 2.

Comentarios: Bonetti (1968) erigió esta especie sobre la base de ejemplares hallados en el NF I, punto 12

\section{Pseudoctenis falconeriana Bonetti 1968}

Materiales revisados: $\mathrm{BAPb} 4212,4229$.

Estrato fosilífero y localidad: EF2, Localidad 2.

Comentarios: Bonetti (1968) erigió esta especie sobre la base de ejemplares hallados en el NF I, punto 12. 
Josefina Bodnar - La paleoflora triásica de la Formación Cortaderita ...

\begin{tabular}{|c|c|c|c|c|c|c|c|c|c|c|c|c|}
\hline Especie & $\begin{array}{c}\text { Tamaño de la } \\
\text { hoja } \\
\text { (largo-ancho) }\end{array}$ & $\begin{array}{l}\text { Grosor del } \\
\text { raquis }\end{array}$ & $\begin{array}{c}\text { Inserción } \\
\text { de los } \\
\text { segmentos }\end{array}$ & $\begin{array}{c}\text { Longitud } \\
\text { del } \\
\text { segmento }\end{array}$ & $\begin{array}{l}\text { Ancho del } \\
\text { segmento }\end{array}$ & $\begin{array}{c}\text { Disposición } \\
\text { de los } \\
\text { segmentos }\end{array}$ & $\begin{array}{l}\text { Separación } \\
\text { de los } \\
\text { segmentos }\end{array}$ & Expansión de la base & $\begin{array}{c}\text { Constricción } \\
\text { peribasal }\end{array}$ & Ápice & Venación & $\begin{array}{l}\text { Densidad } \\
\text { de venas }\end{array}$ \\
\hline $\begin{array}{l}\text { Pseudoctenis sp. } \\
\text { nov. }\end{array}$ & $22 \mathrm{~cm}-18 \mathrm{~cm}$ & $0,6 \mathrm{~cm}$ & $70 / 90^{\circ}$ & $2 / 8 \mathrm{~cm}$ & $\begin{array}{l}\text { irregular } \\
1 / 2,7 \mathrm{~cm}\end{array}$ & $\begin{array}{c}\text { subopuesta a } \\
\text { opuesta }\end{array}$ & $\begin{array}{c}\text { irregular } \\
0,3 / 0,6 \mathrm{~cm}\end{array}$ & $\begin{array}{l}\text { con ala, segmentos } \\
\text { confluentes }\end{array}$ & ausente & $\begin{array}{l}\text { asimétrico, } \\
\text { romo, muy } \\
\text { redondeado }\end{array}$ & \begin{tabular}{|c|} 
en gral. \\
bifurcada 1 \\
vez en la base \\
\end{tabular} & $16 / 24 \mathrm{v} / \mathrm{cm}$ \\
\hline $\begin{array}{l}P . \\
\text { anomozamoides } \\
\text { Bonetti } 1968\end{array}$ & $(?)-1,5 / 1,6 \mathrm{~cm}$ & $\begin{array}{l}0,25 \mathrm{~cm} \\
\text { menor } \\
\text { hacia el } \\
\text { ápice }\end{array}$ & ca. $90^{\circ}$ & $0,6 / 0,7 \mathrm{~cm}$ & $\begin{array}{c}\text { desigual } \\
0,2 / 0,5 \mathrm{~cm}\end{array}$ & $\begin{array}{c}\text { subopuesta a } \\
\text { alterna }\end{array}$ & $0,05 / 0,2 \mathrm{~cm}$ & $\begin{array}{l}\text { apenas en el borde } \\
\text { inferior }\end{array}$ & presente & truncado & \begin{tabular}{|c|} 
bifurcada 1 \\
vez en la base
\end{tabular} & $26 \mathrm{v} / \mathrm{cm}$ \\
\hline $\begin{array}{l}\text { P. balli } \\
\text { (Feistmantel) } \\
\text { Seward } 1917\end{array}$ & $21 \mathrm{~cm}-c a .3 \mathrm{~cm}$ & $\begin{array}{l}0,15 \mathrm{~cm} \\
\text { base } \\
0,1 \mathrm{~cm} \\
\text { ápice } \\
\end{array}$ & ca. $90^{\circ}$ & $\begin{array}{c}\text { menor o } \\
\text { igual a 1,5 } \\
\mathrm{cm}\end{array}$ & $\begin{array}{l}\text { irregular, } \\
\text { angosto }\end{array}$ & $\begin{array}{c}\text { subopuesta a } \\
\text { alterna }\end{array}$ & importante & $\begin{array}{l}\text { con ala, segmentos } \\
\text { confluentes }\end{array}$ & ausente & $\begin{array}{l}\text { asimétrico, } \\
\text { romo, } \\
\text { truncado, algo } \\
\text { redondeado, }\end{array}$ & \begin{tabular}{|c|} 
bifurcada 2 \\
veces: $1^{\circ}$ en la \\
base, $2^{\circ}$ en el \\
$1 / 3$ inferior \\
\end{tabular} & $8 / 10 \mathrm{v} / \mathrm{seg}$. \\
\hline $\begin{array}{l}\text { P. barrealensis } \\
\text { (Frenguelli } \\
\text { emend. } \text { Bonetti ) } \\
\text { Artabe } 1985 \\
\end{array}$ & (?)-ca.4 cm & $\begin{array}{l}\text { constante } \\
c a .0,3 \mathrm{~cm}\end{array}$ & $\begin{array}{c}c a .90^{\circ} \\
\text { base- } \\
40 / 45^{\circ} \\
\text { ápice } \\
\end{array}$ & $1,75 / 1,95 \mathrm{~cm}$ & $\begin{array}{c}\text { variable } \\
0,17 / 0,8 \\
\mathrm{~cm}\end{array}$ & $\begin{array}{l}\text { alterna a } \\
\text { subalterna }\end{array}$ & $\begin{array}{l}\text { segmentos } \\
\text { distantes }\end{array}$ & $\begin{array}{c}\text { leve, con ala de } 0,075 \\
\mathrm{~cm}\end{array}$ & ausente & acuminado & $\begin{array}{c}\text { simple, } \\
\text { algunas } \\
\text { dicotomías }\end{array}$ & $c a .30 \mathrm{v} / \mathrm{cm}$ \\
\hline $\begin{array}{l}\text { P. brownii (Du } \\
\text { Toit) Anderson } \\
\text { et Anderson } 1985\end{array}$ & $\begin{array}{l}\text { porte grande- } \\
+28 \mathrm{~cm}\end{array}$ & $\begin{array}{l}\text { raquis } \\
\text { delgado }\end{array}$ & $90^{\circ}$ & $+13 \mathrm{~cm}$ & \begin{tabular}{|c|} 
variable \\
$0,6 / 1,5 \mathrm{~cm}$
\end{tabular} & $\begin{array}{l}\text { opuesta a } \\
\text { alterna }\end{array}$ & $\begin{array}{l}\text { segmentos } \\
\text { espaciados }\end{array}$ & $\begin{array}{c}\text { margen basiscópico } \\
\text { decurrente, segmentos } \\
\text { confluentes }\end{array}$ & moderada & desconocido & simple (?) & $20 \mathrm{v} / \mathrm{cm}$ \\
\hline $\begin{array}{l}\text { P. capensis Du } \\
\text { Toit } 1927 \mathrm{~b}\end{array}$ & $\begin{array}{l}\text { porte grande- } \\
15 / 16 \mathrm{~cm}\end{array}$ & $0,6 \mathrm{~cm}$ & $75 / 80^{\circ}$ & $7 / 7,5 \mathrm{~cm}$ & $1,5 \mathrm{~cm}$ & $\begin{array}{c}\text { opuesta a } \\
\text { levemente } \\
\text { subopuesta }\end{array}$ & $\begin{array}{c}\text { importante } \\
1,1 \mathrm{~cm}\end{array}$ & leve & presente & redondeado & \begin{tabular}{|c|} 
gruesa y \\
conspicua, \\
dicotomías a \\
distintas \\
alturas \\
\end{tabular} & $12 \mathrm{v} / \mathrm{cm}$ \\
\hline $\begin{array}{l}\text { P. carteriana } \\
\text { (Oldham et } \\
\text { Morris) Du Toit } \\
\text { 1927b }\end{array}$ & $15 \mathrm{~cm}-4 \mathrm{~cm}$ & $0,15 / 0,2 \mathrm{~cm}$ & $50 / 65^{\circ}$ & $1,5 / 2 \mathrm{~cm}$ & $\begin{array}{c}\text { desigual } \\
0,5 / 1,5 \mathrm{~cm}\end{array}$ & $\begin{array}{l}\text { opuesta o } \\
\text { subopuesta }\end{array}$ & irregular & $\begin{array}{c}\text { borde inferior } \\
\text { decurrente, segmentos } \\
\text { a veces confluentes }\end{array}$ & ausente & $\begin{array}{l}\text { agudo, } \\
\text { redondeado o } \\
\text { truncado }\end{array}$ & $\begin{array}{c}\text { no muy } \\
\text { conspicua, } \\
\text { simple o } \\
\text { bifurcada en } \\
\text { la base } \\
\end{array}$ & $14 / 18 \mathrm{v} / \mathrm{cm}$ \\
\hline $\begin{array}{l}P . \\
\text { ctenophylloides } \\
\text { Bonetti } 1968\end{array}$ & $80 \mathrm{~cm}-13 \mathrm{~cm}$ & $\begin{array}{l}\text { constante } \\
0,6 \mathrm{~cm}\end{array}$ & $90 / 60^{\circ}$ & $6 \mathrm{~cm}$ & $0,3 / 1,5 \mathrm{~cm}$ & $\begin{array}{l}\text { opuesta, } \\
\text { alterna }\end{array}$ & $0,1 / 0,2 \mathrm{~cm}$ & $\begin{array}{l}\text { leve en el borde } \\
\text { inferior }\end{array}$ & ausente & agudo & $\begin{array}{l}\text { mayormente } \\
\text { simple }\end{array}$ & $30 / 40 \mathrm{v} / \mathrm{cm}$ \\
\hline $\begin{array}{l}\text { P. falconeriana } \\
\text { (Oldham } \text { et } \\
\text { Morris) Bonetti } \\
1968 \\
\end{array}$ & (?)-ca. $8 \mathrm{~cm}$ & $0,2 \mathrm{~cm}$ & $60 / 65^{\circ}$ & $2,7 / 3,7 \mathrm{~cm}$ & $0,5 / 0,7 \mathrm{~cm}$ & $\begin{array}{c}\text { alterna, } \\
\text { subopuesta }\end{array}$ & (?) & $\begin{array}{l}\text { presente, segmentos a } \\
\text { veces confluentes }\end{array}$ & ausente & $\begin{array}{c}\text { subredondeado } \\
\text { algo } \\
\text { acuminado }\end{array}$ & $\begin{array}{c}\text { gruesa, } \\
\text { bifurcada 1 } \\
\text { vez cerca de } \\
\text { la base } \\
\end{array}$ & $14 / 15 \mathrm{v} / \mathrm{seg}$ \\
\hline $\begin{array}{l}\text { P. fissa Du Toit } \\
\text { 1927b }\end{array}$ & $\begin{array}{l}\text { porte pequeño- } \\
\quad+2 \mathrm{~cm}\end{array}$ & $\begin{array}{c}0,2 \mathrm{~cm} \text { base } \\
0,3 \mathrm{~cm} \\
\text { ápice }\end{array}$ & $c a .90^{\circ}$ & $0,8 \mathrm{~cm}$ & $0,5 / 0,8 \mathrm{~cm}$ & $\begin{array}{c}\text { opuesta a } \\
\text { subopuesta }\end{array}$ & $\begin{array}{c}\text { desigual, } \\
\text { amplia } 0,3 / 0,5 \\
\mathrm{~cm}\end{array}$ & $\begin{array}{c}\text { ala de } 0,1 \mathrm{~cm} \\
\text { segmentos confluentes, } \\
\text { algunos incisos a } \\
\text { diferentes alturas }\end{array}$ & ausente & redondeado & $\begin{array}{l}\text { fuerte, } \\
\text { bifurcada } 1 \\
\text { (2) veces, } \\
\text { cerca de la } \\
\text { base }\end{array}$ & $24 \mathrm{v} / \mathrm{cm}$ \\
\hline $\begin{array}{l}\text { P. gracipinnata } \\
\text { Anderson } \text { et } \\
\text { Anderson } 1989 \\
\end{array}$ & $\begin{array}{l}\text { porte pequeño- } \\
6 \mathrm{~cm}\end{array}$ & (?) & (?) & pequeños & angosto & opuesta & (?) & leve & fuerte & desconocido & \begin{tabular}{|c|} 
bifurcada $1 \mathrm{o}$ \\
2 veces en la \\
base o en el $1 / 2$ \\
\end{tabular} & $20 \mathrm{v} / \mathrm{cm}$ \\
\hline $\begin{array}{l}\text { P.grandifolia } \\
\text { (Fontaine) } \\
\text { Artabe } 1985 \\
\end{array}$ & $\begin{array}{c}+100 \mathrm{~cm}-+50 \\
\mathrm{~cm}\end{array}$ & $0,8 \mathrm{~cm}$ & $45 / 90^{\circ}$ & $30 \mathrm{~cm}$ & $1 / 1.5 \mathrm{~cm}$ & opuesta & $0,2 / 1 \mathrm{~cm}$ & muy leve & ausente & desconocido & \begin{tabular}{|c|} 
muy fuerte, \\
bifurcada 1 \\
vez en la base \\
\end{tabular} & $26 \mathrm{v} / \mathrm{cm}$ \\
\hline P. groeberiana & $(?)-2 \mathrm{~cm}$ & $0,3 \mathrm{~cm}$ base & $90^{\circ}$ & máx. $2 \mathrm{~cm}$ & $0,07 / 0,1 \mathrm{~cm}$ & opuesta o & $c a \cdot 0,2 \mathrm{~cm}$ & con ala, algunos & ausente & agudo & bifurcada 1 & $40 \mathrm{v} / \mathrm{cm}$ \\
\hline
\end{tabular}


Josefina Bodnar - La paleoflora triásica de la Formación Cortaderita ...

\begin{tabular}{|c|c|c|c|c|c|c|c|c|c|c|c|c|}
\hline Bonetti 1968 & & $\begin{array}{l}0,25 \mathrm{~cm} \\
\text { ápice }\end{array}$ & & & & subopuesta & & $\begin{array}{l}\text { segmentos coalescen } \\
\text { algunos incisos }\end{array}$ & & & vez en la base & \\
\hline $\begin{array}{l}\text { P. harringtoniana } \\
\text { Bonetti } 1968\end{array}$ & $\begin{array}{c}30 \mathrm{~cm}-7,5 / 10 \\
\mathrm{~cm}\end{array}$ & $\begin{array}{l}0,1 \mathrm{~mm} \\
\text { carena } \\
\text { central }\end{array}$ & $60 / 85^{\circ}$ & $3,5 / 4 \mathrm{~cm}$ & $\begin{array}{c}\text { variable } \\
1,7 / 0,7 \mathrm{~cm}\end{array}$ & $\begin{array}{c}\text { subopuesta a } \\
\text { alterna }\end{array}$ & $\begin{array}{l}\text { variable } \\
0,1 / 0,4 \mathrm{~cm}\end{array}$ & $\begin{array}{l}\text { presente, más en borde } \\
\text { inferior, algunos } \\
\text { segmentos incisos }\end{array}$ & ausente & $\begin{array}{l}\text { algo agudo } \\
\text { redondeado }\end{array}$ & $\begin{array}{l}\text { raramente } \\
\text { bifurcada }\end{array}$ & $\begin{array}{l}24 / 26 \text { may- } \\
18 / 20 \text { men. } \\
\text { v/cm }\end{array}$ \\
\hline $\begin{array}{l}\text { P. lanciformis Du } \\
\text { Toit 1927b }\end{array}$ & $\begin{array}{l}\text { porte mediano- } \\
9 \mathrm{~cm}\end{array}$ & $0,3 \mathrm{~cm}$ & ca. $90^{\circ}$ & muy variable & $+0,5 \mathrm{~cm}$ & alterna & regular & $\begin{array}{c}\text { con ala angosta, } \\
\text { segmentos confluentes }\end{array}$ & $\begin{array}{c}\text { muy } \\
\text { importante }\end{array}$ & agudo (?) & $\begin{array}{c}\text { bifurcada } 1^{\circ} \\
\text { en la base y } 2^{\circ} \\
\text { en el } 1 / 3 \\
\text { inferior } \\
\end{array}$ & $9 \mathrm{v} / \mathrm{cm}$ \\
\hline $\begin{array}{l}\text { P. longipinnata } \\
\text { Anderson } \text { et } \\
\text { Anderson } 1989\end{array}$ & $\begin{array}{l}\text { porte grande- } \\
22 \mathrm{~cm}\end{array}$ & (?) & ca. $90^{\circ}$ & (?) & (?) & alterna & algo irregular & presente & ausente & $\begin{array}{l}\text { agudo } \\
\text { redondeado }\end{array}$ & $\begin{array}{c}\text { raras las } \\
\text { dicotomías }\end{array}$ & $22 \mathrm{v} / \mathrm{cm}$ \\
\hline $\begin{array}{l}\text { P. megaspatulata } \\
\text { Herbst } \text { et } \\
\text { Troncoso } 2000\end{array}$ & $60 \mathrm{~cm}-40 \mathrm{~cm}$ & $\begin{array}{l}\text { muy fuerte } \\
\text { hasta } 1,3 \\
\mathrm{~cm}\end{array}$ & $80 / 90^{\circ}$ & hasta $20 \mathrm{~cm}$ & hasta $3 \mathrm{~cm}$ & $\begin{array}{c}\text { subopuesta a } \\
\text { alterna }\end{array}$ & $1 / 2 \mathrm{~cm}$ & $\begin{array}{l}\text { asimétrica, bien } \\
\text { marcada, más en el } \\
\text { margen basiscópico, } \\
\text { ala de } 0,3 \mathrm{~cm}\end{array}$ & notoria & algo aguzado & $\begin{array}{c}\text { gruesa, } \\
\text { dicotomías } \\
\text { ocasionales }\end{array}$ & $16 / 20 \mathrm{v} / \mathrm{cm}$ \\
\hline $\begin{array}{l}\text { P. multilineata } \\
\text { (Shirley) Herbst } \\
\text { et Troncoso } 2000\end{array}$ & (?)-(?) & $0,2 / 0,3 \mathrm{~cm}$ & $90^{\circ}$ & $\begin{array}{c}\text { variable } \\
3,8 / 6,5 \mathrm{~cm}\end{array}$ & $\begin{array}{c}\text { variable } \\
1,2 / 1,9 \mathrm{~cm}\end{array}$ & $\begin{array}{c}\text { alterna a } \\
\text { subopuesta }\end{array}$ & regular & leve & ausente & $\begin{array}{l}\text { redondeado o } \\
\text { truncado }\end{array}$ & \begin{tabular}{|c|} 
muy fina, es- \\
casas \\
dicotomías \\
cerca de la \\
base \\
\end{tabular} & $\begin{array}{c}\text { variable, } \\
37 / 39 \mathrm{v} / \mathrm{cm} \\
\text { largos } \\
58 \mathrm{v} / \mathrm{cm} \\
\text { cortos } \\
\end{array}$ \\
\hline $\begin{array}{l}\text { P. sanipassiensis } \\
\text { Anderson } \text { et } \\
\text { Anderson } 1989\end{array}$ & $\begin{array}{l}\text { porte grande- } \\
\quad 24 \mathrm{~cm}\end{array}$ & (?) & ca. $90^{\circ}$ & (?) & angostos & alterna & algo irregular & leve & leve & $\begin{array}{l}\text { agudo } \\
\text { redondeado }\end{array}$ & $\begin{array}{c}\text { bifurcada } 1 \\
\text { vez cerca de } \\
\text { la base }\end{array}$ & $15 \mathrm{v} / \mathrm{cm}$ \\
\hline $\begin{array}{l}\text { P. spatulata Du } \\
\text { Toit 1927b }\end{array}$ & $\begin{array}{c}c a .72,5 \mathrm{~cm}^{-} \\
10 / 18 \mathrm{~cm}\end{array}$ & $\begin{array}{c}0,5 \mathrm{~cm} \text { base } \\
1,5 \mathrm{~cm} \\
\text { ápice }\end{array}$ & $80 / c a .90^{\circ}$ & $\begin{array}{c}1,5 \mathrm{~cm} \\
\text { (base) } \\
4 / 8 \mathrm{~cm}(1 / 2)\end{array}$ & $\begin{array}{c}\text { desigual } \\
1,2 / 2,4 \mathrm{~cm}\end{array}$ & $\begin{array}{c}\text { opuesta a } \\
\text { subopuesta }\end{array}$ & $\begin{array}{c}\text { desigual, } 0,3 / 2 \\
\mathrm{~cm}\end{array}$ & $\begin{array}{l}\text { a veces ala de } 0,1 \mathrm{~cm} \text {, } \\
\text { segmentos confluentes }\end{array}$ & marcada & $\begin{array}{l}\text { redondeado } \\
\text { obtuso }\end{array}$ & $\begin{array}{c}\text { fuerte, en gral. } \\
\text { bifurcada } 1 \\
\text { vez en la base }\end{array}$ & $16 / 20 \mathrm{v} / \mathrm{cm}$ \\
\hline $\begin{array}{l}\text { P. spectabilis } \\
\text { Harris 1932a }\end{array}$ & $\begin{array}{l}\text { porte grande- } \\
c a .35 \mathrm{~cm}\end{array}$ & $0,5 / 0,7 \mathrm{~cm}$ & $70 / 90^{\circ}$ & máx. $17 \mathrm{~cm}$ & $2,5 / 4 \mathrm{~cm}$ & $\begin{array}{c}\text { opuesta o } \\
\text { subopuesta }\end{array}$ & $\begin{array}{l}\text { distantes (?) } \\
\text { más o menos } \\
\text { irregular }\end{array}$ & $\begin{array}{l}\text { presente, segmentos } \\
\text { confluentes }\end{array}$ & ausente & $\begin{array}{l}\text { recto, } \\
\text { redondeado, } \\
\text { algo agudo }\end{array}$ & $\begin{array}{c}\text { conspicua, en } \\
\text { gral. bifurcada } \\
1 \text { vez cerca de } \\
\text { la base } \\
\end{array}$ & $10 / 20 \mathrm{v} / \mathrm{cm}$ \\
\hline $\begin{array}{l}\text { P. strahani } \\
\text { (Johnston) } \\
\text { Anderson } \text { et } \\
\text { Anderson } 1989\end{array}$ & porte mediano & grácil & $c a .90^{\circ}$ & (?) & irregular & alterna & algo irregular & $\begin{array}{l}\text { presente, segmentos } \\
\text { varias veces incisos }\end{array}$ & ausente & desconocido & $\begin{array}{c}\text { bifurcada } 1 \\
\text { vez en la base } \\
\text { o en el } 1 / 2\end{array}$ & $12 \mathrm{v} / \mathrm{cm}$ \\
\hline $\begin{array}{l}\text { P. truncata } \\
\text { Leppe } \text { et Moisan } \\
2003\end{array}$ & $(?)+6,5 \mathrm{~cm}$ & $0,2 \mathrm{~cm}$ & $60 / 70^{\circ}$ & $5 \mathrm{~cm}$ & $2 / 2,5 \mathrm{~cm}$ & $\begin{array}{l}\text { opuesta o } \\
\text { alterna }\end{array}$ & $\begin{array}{c}2,5 / 3 \mathrm{~cm} \text { base } \\
3,5 \mathrm{~cm} \text { ápice }\end{array}$ & ausente & $1,5 / 3 \mathrm{~cm}$ & desconocido & simples & $4 \mathrm{v} / \mathrm{cm}$ \\
\hline $\begin{array}{l}\text { P. wardii } \\
\text { (Fontaine in } \\
\text { Ward) Artabe } \\
1985\end{array}$ & $\begin{array}{c}+11 \mathrm{~cm}-10,5 \\
\mathrm{~cm}\end{array}$ & $0,5 \mathrm{~cm}$ & $60^{\circ}$ & $6,5 \mathrm{~cm}$ & $1,7 \mathrm{~cm}$ & $\begin{array}{c}\text { alterna o } \\
\text { subopuesta }\end{array}$ & $0,3 \mathrm{~cm}(?)$ & $\begin{array}{l}\text { borde inferior } \\
\text { confluente }\end{array}$ & ausente & $\begin{array}{l}\text { redondeado, } \\
\text { obtuso o } \\
\text { truncado }\end{array}$ & \begin{tabular}{|c|} 
bifurcada 1 \\
vez a distintas \\
alturas
\end{tabular} & $18 \mathrm{v} / \mathrm{cm}$ \\
\hline
\end{tabular}

Cuadro VI.7. Especies de Pseudoctenis citadas para Gondwana (según Bonetti, 1968; Artabe, 1985; Anderson y Anderson, 1989; Gnaedinger, 1999; Herbst y Troncoso, 2000; Zamuner et al., 2001) 


\section{Cycadofitas incertae sedis}

Dentro de este agrupación de incluyen aquellas formas foliares que podrían pertenecer tanto a Cycadales como a Cycadeoideales.

\section{Género Taeniopteris Brongniart 1832}

Especie tipo. Taeniopteris vittata Brongniart 1832

\section{Taeniopteris carruthersi Tenison-Woods 1883}

Materiales revisados: $\mathrm{BAPb} 4370$.

Estrato fosilífero y localidad: EF2, Localidad 2.

Comentarios: Esta especie fue citada por Bonetti (1963), para el NF II, punto 20.

\section{Taeniopteris macclellandi Oldham et Morris 1862}

Estrato fosilífero y localidad: EF2, Localidad 2.

Comentarios: Los materiales asignados a esta especie fueron citados por $\mathrm{Du}$ Toit (1927b) para la quebrada de Un Salto. Posteriormente Bonetti (1963) ubica estos hallazgos en su NF II, punto 20.

\section{Taeniopteris plicatella (Solms) Menéndez 1951}

Materiales revisados: $\mathrm{BAPb} 4248$

Estrato fosilífero y localidad: EF2, Localidad 2.

Comentarios. Esta especie fue citada por Bonetti (1963), para el NF II, punto 21.

\section{Orden Ginkgoales Gorožankin 1904}

\section{Criterio para la clasificación de hojas de Ginkgoales}

Para la descripción de las formas foliares de ginkgoales se utilizó la terminología morfológica propuesta por Gnaedinger y Herbst (1999), adaptada de Font Quer (1963). De acuerdo a estos autores, segmento es un sector de una hoja palmatisecta, cuyo ancho es mayor a $0,5 \mathrm{~cm}$, mientras que lacinia es un segmento por lo general profundo y angosto (menor de 0,5 cm de ancho) con aspecto filamentoso. En cuanto a las incisiones de la lámina, éstas se definen teniendo en cuenta la relación profundidad/radio de la 
hoja: en una incisión leve es menor a 1/3; en una incisión mediana, entre $1 / 3$ y $2 / 3$; y en una incisión profunda, mayor a 2/3 (Gnaedinger y Herbst, 1999).

Para la delimitación de los géneros foliares de ginkgoales, también se aplicó la postura de Gnaedinger y Herbst (1999), que los define de la siguiente manera:

-Ginkgoites abarca a hojas pecioladas con lámina amplia, de contorno semicircular a triangular ancha, flabeladas con pecíolos generalmente muy largos; lámina entera a ligeramente o fuertemente dividida en segmentos; ángulo basal generalmente mayor a $90^{\circ}$; pecíolos largos con dos venas principales que se bifurcan en número variable de veces; generalmente más de 4 venas por segmento.

-Sphenobaiera incluye a formas largamente triangulares, angostas, más o menos divididas en segmentos o lacinias, sin clara distinción entre lámina y pecíolo, ángulo basal generalmente menor que $90^{\circ}$.

-Baiera engloba a las hojas pecioladas, de lámina de contorno semicircular a triangular, ángulo basal generalmente menor de $90^{\circ}$, lámina profundamente dividida en lacinias, generalmente con no más de 4 venas por lacinia.

-Ginkgodium representa a tipos foliares enteros o bilobulados, obovados angostos con una relación largo/ancho 3:1 o más, con una o dos incisiones leves en el ápice, pecíolo corto con una única vena que se dicotomiza repetidas veces hasta la mitad de la lámina, ángulo basal menor que $90^{\circ}$.

\section{Incertae sedis}

\section{Género Ginkgoites Seward emend. Maheshwari et Bajpai 1992}

Especie tipo. Ginkgoites obovata (Nathorst) Seward 1919.

\section{Ginkgoites waldeckensis (Anderson et Anderson) Troncoso et Herbst 1999}

Figura VII.12.4

Descripción: Hoja peciolada, pequeña. Lámina de 2,3 $\mathrm{cm}$ de largo y 2,7 cm de ancho de contorno semicircular a subreniforme. Pecíolo de 1,3 cm de largo y 0,2 cm de ancho. La base es subcordada, comienza triangular conformando un ángulo de $90^{\circ} \mathrm{y}$ rápidamente se abre ampliándose el ángulo basal hasta $200^{\circ}$. Lámina dividida cuatro veces en 8 segmentos. La primera incisión es profunda, a 0,2 cm de la base laminar, dividiéndola en 2 mitades de $0,4 \mathrm{~cm}$ de ancho basal. La segunda incisión también es profunda, a 0,4 o 0,5 cm de la base laminar, formando segmentos de 0,15 a 0,3 cm de ancho basal y 0,95 a $1,1 \mathrm{~cm}$ de ancho terminal. La tercera, es mediana, varía en su 
distancia a la base laminar de 0,6 a 1,3 cm y forma segmentos de 0,15 a 0,4 cm de ancho medio. La cuarta incisión no ocurre en toda la lámina; es leve, a 0,8 a $2 \mathrm{~cm}$ de la base laminar y resulta en 8 lóbulos terminales muy angostos de 0,1 a $0,25 \mathrm{~cm}$ de ancho medio y de ápices truncados. La quinta incisión es ocasional y muy leve, generando, cuando existe un margen terminal ondulado. La venación se ve muy oscurecida debido a la concentración de cutícula. Las venas se dicotomizan hasta 6 veces a partir de 2 venas que nacen de los cordones del pecíolo. La densidad de venas en la base es 6 venas por $0,5 \mathrm{~cm}$ y llega a 8 venas por $0,5 \mathrm{~cm}$ en la región apical.

Materiales estudiados: PBSJ 437.

Estrato fosilífero y localidad: EF2, Localidad 2.

Comentarios: En cuanto a la designación específica, se siguieron los criterios de Anderson y Anderson (1989), Troncoso y Herbst (1999), y Gnaedinger y Herbst (1999). El ejemplar de la Formación Cortaderita determinado como Ginkgoites waldeckensis coincide con los caracteres diagnósticos de la especie, excepto porque es de menores dimensiones que el material tipo.

\section{Género Sphenobaiera Florin 1936}

Especie tipo. Sphenobaiera spectabilis (Nathorst) Florin 1936.

\section{Sphenobaiera sectina Anderson et Anderson 1989}

Figura VII.12.7

Descripción: Fragmentos de hojas largamente triangulares, angostas, sin pecíolo definido. La longitud de los fragmentos es de 2,8 a 5,6 cm. Su ancho máximo es de 2,2 y $2,5 \mathrm{~cm}$, disminuyendo progresivamente hasta 0,4 y $0,25 \mathrm{~cm}$ en la base. El ángulo basal es de 30 a $45^{\circ}$. La lámina está dividida 2 veces. La primera incisión es profunda, aproximadamente a 2,2 $\mathrm{cm}$ de la base de la hoja. La segunda incisión es mediana o profunda y se produce a distancias diferentes de la base, formando 4 segmentos de 0,3 a 0,5 cm de ancho, cuyos ápices no se observan. La venación no es claramente visible por la probable presencia de estrías intervenas. Las venas se dicotomizan varias veces a diferentes alturas, a partir de 4 venas en la base. La densidad de venas es de 6 por 0,5 $\mathrm{cm}$ en la base de la primera incisión y de 8 venas por $0,5 \mathrm{~cm}$ en la base de la segunda incisión.

Materiales estudiados: PBSJ 440, 642, 643, 644 
Estrato fosilífero y localidad: EF2, Localidad 2.

Comentarios: Para la designación específica, se siguieron los criterios de Anderson y Anderson (1989), Troncoso y Herbst (1999), y Gnaedinger y Herbst (1999). Estos especímenes coinciden con los caracteres diagnósticos de la especie Sphenobaiera sectina Anderson et Anderson 1989, excepto que son de menores dimensiones que el material tipo de la especie.

\section{Sphenobaiera schenkii (Feistmantel) Florin 1936}

Figura VII.12.6

Descripción: Hoja triangular, sin pecíolo definido. La base no está preservada. Lámina de 5,5 cm de largo y $4 \mathrm{~cm}$ de ancho máximo. El ángulo basal es de 55 a $60^{\circ}$. La lámina está dividida 3 veces. La primera incisión es profunda y divide la lámina en 2 segmentos de 0,5 a $0,7 \mathrm{~cm}$ de ancho basal. La segunda incisión es mediana, forma 4 segmentos de 0,4 a 0,5 cm de ancho. La tercera incisión es leve, generando, cuando existe, un ápice lobulado y obtuso. Las venas se dicotomizan varias veces a diferentes alturas, a partir de 4 (?) venas en la base. La densidad de venas es de 4 venas por 0,5 cm en la región basal de la hoja y de 8 venas por $0,5 \mathrm{~cm}$ en la región terminal.

Materiales estudiados: PBSJ 439.

Estrato fosilífero y localidad: EF2, Localidad 2.

Comentarios: Este ejemplar se asimila a la especie Sphenobaiera schenkii (Feistmantel) Florin 1936 de acuerdo a los criterios de Anderson y Anderson (1989), Troncoso y Herbst (1999), y Gnaedinger y Herbst (1999).

\section{Sphenobaiera argentinae (Kurtz) Florin 1940}

Figura VII.12.8, 9 y 10

Descripción: Fragmentos de hojas largamente triangulares, angostas, sin pecíolo definido. La longitud de los fragmentos es de 1,7 a 4,62 cm. Su ancho máximo es de 0,7 a 2,48 cm, disminuyendo progresivamente hasta 0,02 o $0,56 \mathrm{~cm}$ en la base. El ángulo basal es de 20 a $40^{\circ}$. Lámina generalmente dividida una única vez, por una incisión profunda o leve, que genera 2 segmentos espatulados de 0,3 a $1,04 \mathrm{~cm}$ de ancho o 2 lóbulos redondedados a obtusos de 0,2 a $0,25 \mathrm{~cm}$ de ancho. En tres ejemplares se observa una segunda incisión, que es leve y genera un ápice lobulado en cada segmento. 
Las venas se dicotomizan a diferentes alturas, a partir de 4 venas en la base. La densidad de venas es de 5 a 8 por $0,5 \mathrm{~cm}$ en la parte media de la hoja, y de 9 a 10 venas por 0,5 $\mathrm{cm}$ en la parte terminal.

Materiales estudiados: PBSJ 441, 442, 443, 645.

Estrato fosilífero y localidad: EF2, Localidad 5 y Localidad 2.

Comentarios: Frenguelli (1946), Artabe (1985), Anderson y Anderson (1989), y Gnaedinger y Herbst (1999) han planteado ciertos atributos para caracterizar la especie Sphenobaiera argentinae (Kurtz) Florin 1940, los que pueden ser sintetizados como sigue: hoja pequeña, de forma triangular, lámina dividida una vez (raramente dos veces) cerca de la base o cerca del ápice, segmentos aproximadamente iguales, ápices atenuados o redondeados.

Bonetti (1963) describió e ilustró ejemplares asignables a esta especie para el NF II, punto 20. Los ejemplares aquí estudiados abarcan una gran variedad de formas, con bifurcaciones profundas o leves, y una amplitud de rango en cuanto al ángulo basal y el ancho máximo de la lámina. No obstante, todos pueden ser asimilados a S. argentinae.

\section{Sphenobaiera stormbergensis (Seward) Frenguelli 1948}

Estrato fosilífero y localidad: EF2, Localidad 2.

Comentarios: Bonetti (1963) citó esta especie para el NF II, puntos 20 y 22.

\section{Género Baiera Braun 1843}

Especie tipo. Baiera dichotoma Braun 1843.

\section{Baiera cuyana Frenguelli 1942a}

Figura VII.12.5

Descripción: Fragmento de la región apical de una hoja triangular. La base y el pecíolo no están preservados. Lámina de $2,43 \mathrm{~cm}$ de largo y $1,53 \mathrm{~cm}$ de ancho máximo. El ángulo basal es de 20 a $24^{\circ}$. La lámina está dividida 3 veces por incisiones profundas; las dos primeras incisiones a la misma altura, la tercera a una distancia de aproximadamente de $0,5 \mathrm{~cm}$ de las anteriores. Las lacinias resultantes son 7 , más o menos lineares, con el ápice no preservado. El ancho de las lacinias es de 0,1 a 0,2 cm. 
Las venas se dicotomizan varias veces, llegando a una densidad de 2 a 4 venas por lacinia.

Materiales estudiados: PBSJ 438.

Estrato fosilífero y localidad: EF3, Localidad 3.

Comentarios: De las especies del género Baiera, citadas para el Triásico de Argentina (Cuadro VII.8), el material estudiado se asigna sin dudas a la especie Baiera cuyana.

\begin{tabular}{|c|c|c|c|c|c|c|}
\hline Especie & $\begin{array}{c}\text { Contorno de } \\
\text { la hoja }\end{array}$ & Lacinias & División de la lámina & Pecíolo & Venación & Ápice \\
\hline $\begin{array}{l}\text { Baiera africana } \\
\text { Baldoni } 1980 \mathrm{~b}\end{array}$ & $\begin{array}{l}\text { Hoja de } \\
\text { contorno } \\
\text { triangular }\end{array}$ & $\begin{array}{l}\text { Lacinias filiformes, } \\
\text { de más de } 5 \mathrm{~cm} \text { de } \\
\text { largo y } 0,2-0,3 \mathrm{~cm} \\
\text { de ancho }\end{array}$ & $\begin{array}{l}\text { Profunda incisión } \\
\text { basal que forma dos } \\
\text { mitades, cada mitad } \\
\text { dividida 4-6 veces }\end{array}$ & Pecíolo largo & $\begin{array}{l}\text { 6-8 venas } \\
\text { por lacinia }\end{array}$ & $\begin{array}{l}\text { Ápice subanguloso } \\
\text { a subredondeado }\end{array}$ \\
\hline $\begin{array}{l}\text { Baiera bidens } \\
\text { (Tenison- } \\
\text { Woods) } \\
\text { Feistmantel } \\
1890\end{array}$ & $\begin{array}{l}\text { Hoja de } \\
\text { contorno } \\
\text { flabeliforme }\end{array}$ & $\begin{array}{l}\text { Lacinias angostos de } \\
\text { más de } 12 \mathrm{~cm} \text { de } \\
\text { largo y } 0,4 \mathrm{~cm} \text { de } \\
\text { ancho }\end{array}$ & $\begin{array}{l}\text { Profunda incisión } \\
\text { basal que forma dos } \\
\text { mitades, cada mitad } \\
\text { dividida 2-3 veces a } \\
\text { diferentes alturas }\end{array}$ & $\begin{array}{l}\text { Pecíolo largo, } \\
\text { angosto de } 10 \\
\mathrm{~cm} \text { de largo y } \\
0,2 \mathrm{~cm} \text { de } \\
\text { ancho, y con } \\
\text { estrías finas, }\end{array}$ & $\begin{array}{l}\text { 3-8 venas } \\
\text { por lacinia }\end{array}$ & Ápice agudo \\
\hline $\begin{array}{l}\text { Baiera cuyana } \\
\text { Frenguelli } \\
1942 a\end{array}$ & $\begin{array}{l}\text { Hoja de } \\
\text { contorno } \\
\text { flabeliforme }\end{array}$ & $\begin{array}{l}\text { Lacinias filiformes, } \\
\text { de } 4-6 \mathrm{~cm} \text { de largo y } \\
0,15-0,3 \mathrm{~cm} \text { de } \\
\text { ancho }\end{array}$ & $\begin{array}{l}\text { Profunda incisión } \\
\text { basal que forma dos } \\
\text { mitades, cada mitad } \\
\text { dividida } 2-3 \text { veces a } \\
\text { diferentes alturas }\end{array}$ & $\begin{array}{l}\text { Pecíolo corto, } \\
\text { de } 0,15 \mathrm{~cm} \mathrm{de} \\
\text { ancho }\end{array}$ & $\begin{array}{l}4 \text { venas por } \\
\text { lacinia }\end{array}$ & $\begin{array}{l}\text { Ápice } \\
\text { subtruncado, } \\
\text { redondeado }\end{array}$ \\
\hline $\begin{array}{l}\text { Baiera furcata } \\
\text { (Lindley et } \\
\text { Huton) Braun } \\
1843\end{array}$ & $\begin{array}{l}\text { Hoja grande } \\
\text { de contorno } \\
\text { triangular }\end{array}$ & $\begin{array}{l}\text { Lacinias filiformes, } \\
\text { de } 0,2-0,25 \mathrm{~cm} \text { de } \\
\text { ancho }\end{array}$ & $\begin{array}{l}\text { Profunda incisión } \\
\text { basal que forma dos } \\
\text { mitades, cada mitad } \\
\text { dividida hasta } 3 \text { veces }\end{array}$ & $\begin{array}{l}\text { Pecíolo de } 2 \mathrm{~cm} \\
\text { de largo y } 0,2 \\
\mathrm{~cm} \text { de ancho }\end{array}$ & $\begin{array}{l}1 \text { vena por } \\
\text { lacinia }\end{array}$ & Ápice redondeado \\
\hline $\begin{array}{l}\text { Baiera } \\
\text { ginkgoides } \\
\text { Shirley } 1898\end{array}$ & $\begin{array}{l}\text { Hoja de } \\
\text { contorno } \\
\text { flabeliforme }\end{array}$ & $\begin{array}{l}\text { Lacinias de } 6-5 \mathrm{~cm} \\
\text { de largo, 0,2-0,8 cm } \\
\text { de ancho } \\
\text { (ensanchándose } \\
\text { hacia el ápice }\end{array}$ & $\begin{array}{l}\text { Profunda incisión } \\
\text { basal que forma dos } \\
\text { mitades, cada mitad } \\
\text { dividida } 1-2 \text { veces }\end{array}$ & $\begin{array}{l}\text { Pecíolo de } 0,1- \\
0,5 \mathrm{~cm} \text { de } \\
\text { ancho, con } \\
\text { estrías } \\
\text { longitudinales }\end{array}$ & $\begin{array}{l}8 \text { venas por } \\
\text { lacinia }\end{array}$ & $\begin{array}{l}\text { Ápice subtruncado } \\
\text { (?) }\end{array}$ \\
\hline $\begin{array}{l}\text { Baiera rollerii } \\
\text { Frenguelli } 1946\end{array}$ & $\begin{array}{l}\text { Hoja pequeña } \\
\text { de contorno } \\
\text { triangular } \\
\text { alargado }\end{array}$ & $\begin{array}{l}\text { Lacinias lineares, de } \\
0,1 \mathrm{~cm} \text { de ancho }\end{array}$ & $\begin{array}{l}\text { Tres incisiones } \\
\text { principales casi al } \\
\text { mismo nivel }\end{array}$ & $\begin{array}{l}\text { Sin verdadero } \\
\text { pecíolo }\end{array}$ & $\begin{array}{l}3 \text { venas por } \\
\text { lacinia }\end{array}$ & Ápice truncado \\
\hline
\end{tabular}

Cuadro VII.8. Especies de Baiera citadas para el Triásico de Argentina (Walkom, 1915; Seward, 1919; Frenguelli, 1942a, 1946; Baldoni, 1980b; Artabe et al., 1999a, 2007b; Gnaedinger y Herbst, 1999; Herbst y Troncoso, 2000; Zamuner et al., 2001) 

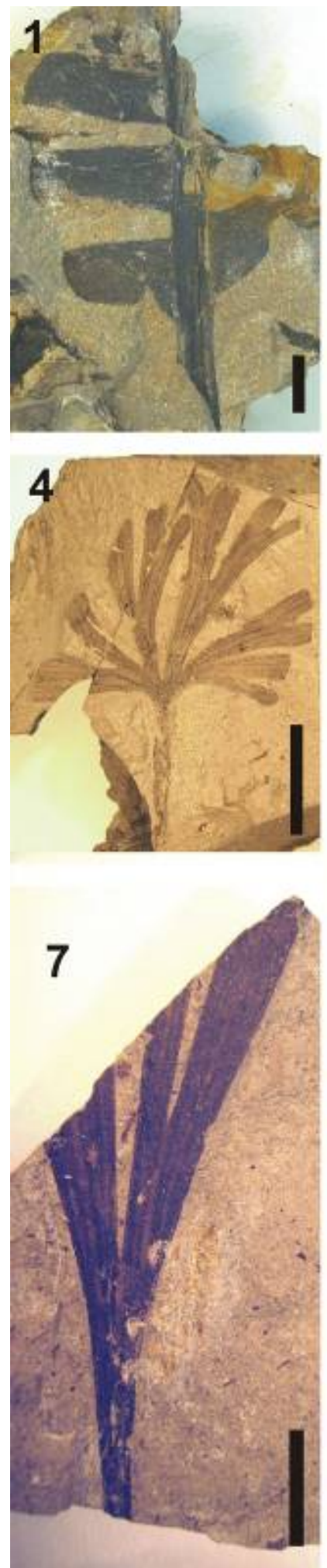
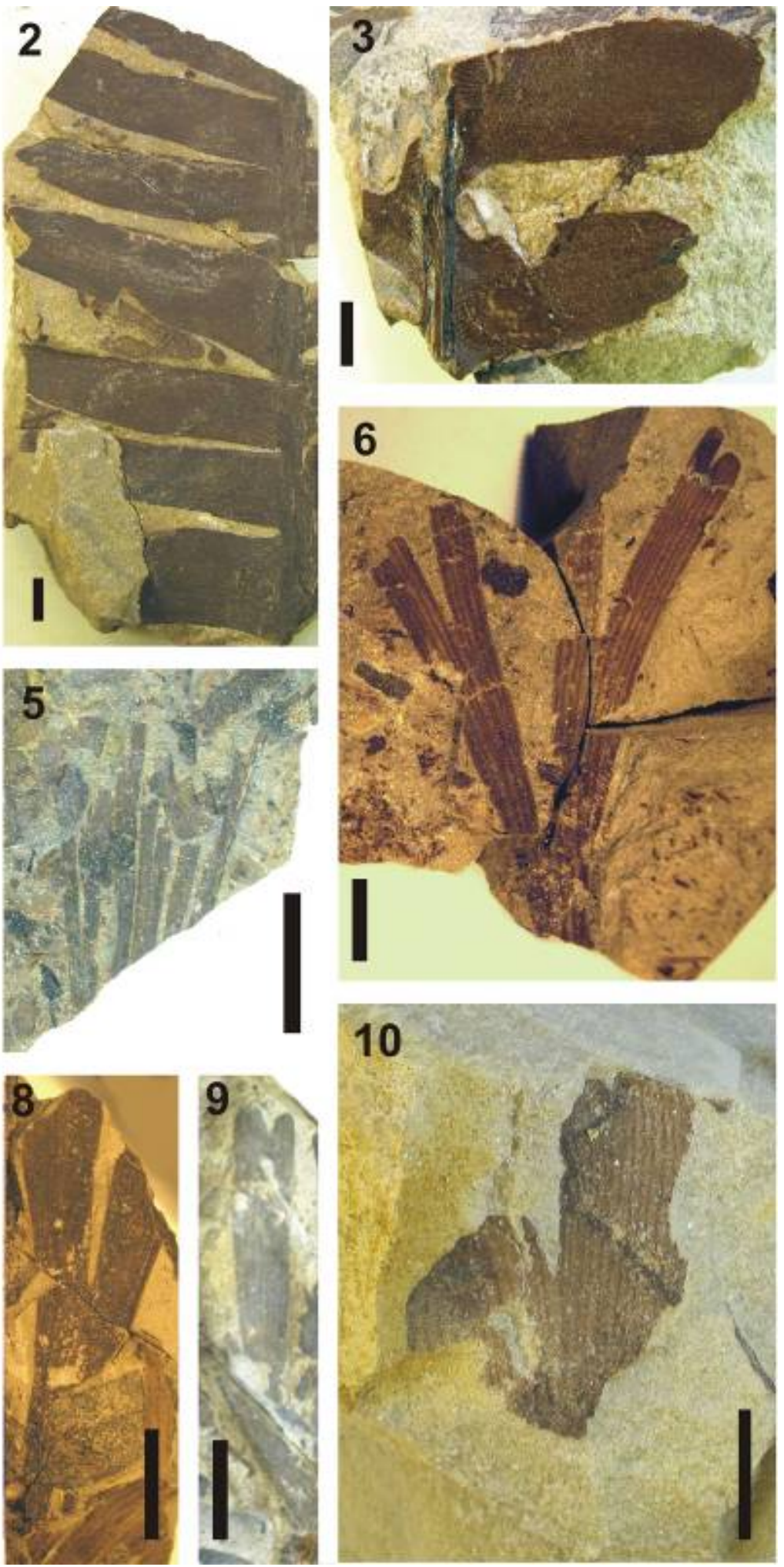

Figura VII.12. 1-3. Pseudoctenis sp. nov. 1. LPPB 13848. 2. LPPB 13858 3. LPPB 13849. 4. Ginkgoites waldeckensis (Anderson et Anderson) Troncoso et Herbst 1999. PBSJ 437. 5. Baiera cuyana Frenguelli 1942a. PBSJ 438. 6. Sphenobaiera schenkii (Feistmantel) Florin 1936. PBSJ 439. 7. Sphenobaiera sectina Anderson et Anderson 1989. PBSJ 440. 8-10. Sphenobaiera argentinae (Kurtz) Florin 1940. 8. PBSJ 441. 9. PBSJ 442. 10. PBSJ 443. Escala: $1 \mathrm{~cm}$ 


\section{Orden Voltziales sensu Stewart et Rothwell 1993}

Familia Voltziaceae Arnold 1947

Género Heidiphyllum Retallack 1981

Especie tipo. Heidiphyllum elongatum (Morris) Retallack 1981.

\section{Heidiphyllum elongatum (Morris) Retallack 1981}

Figura VII.13.1

Descripción: Fragmento de 2,9 cm de largo y 0,4 de ancho de un hoja linear incompleta, con base y ápice no preservados. Márgenes y venación, paralelos. Densidad venas, 15 en la lámina.

Materiales estudiados: PBSJ 444.

Estrato fosilífero y localidad: EF2, Localidad 2.

Comentarios: Retallack (1981) creó el género Heidiphyllum para aquellas formas antiguamente incluidas dentro del género Podozamites Braun 1843, pero que se diferenciaban de este último por su distribución exclusivamente gondwánica y la ausencia de un verdadero pecíolo. De esta manera, y en ausencia de cutícula, Heidiphyllum incluye hojas alargadas, lineares-elípticas a lineares-oblanceoladas, de base foliar apeciolada, que se angosta gradualmente; ápice foliar subagudo a redondeado obtuso; venas paralelas, bien espaciadas, a menudo con conspicuas estrías intervenas; que convergen cerca del ápice; cada una de las 2-4 venas basales se dicotomizan una o dos veces solamente cerca del ápice (Retallack, 1981). Los ejemplares aquí descriptos se pueden asimilar a la especie H. elongatum (Morris) Retallack 1981.

\section{Heidiphyllum clarifolium Anderson et Anderson 1989}

Figura VII.13.2 y 3

Descripción: Hoja linear-oblanceolada, con una base muy angosta (pseupeciolada). La lámina mide 2,5 a 4,2 cm de largo y 0,35 a 0,5 de ancho en la parte media de la lámina. El ápice obtuso-redondeado. La venación se dicotomiza una vez en la base de la lámina, a partir de dos venas. Las cuatro venas que se originan son paralelas en la parte media de la lámina y parecen converger cerca del ápice.

Materiales estudiados: PBSJ 445, 446. 
Estrato fosilífero y localidad: EF2, Localidad 2.

Comentarios: La especie Heidiphyllum clarifolium fue erigida por Anderson y Anderson (1989) para hojas pequeñas (de 7,5 cm de largo y 0,35 cm de ancho), linearelípticas, con el ápice obtuso redondeado, base angosta sésil, venas bien espaciadas (10 por $\mathrm{cm}$ ), normalmente 4 venas por hoja que nacen de la bifurcación de dos venas en la base. Posteriormente, este taxón fue elevado a la categoría de género -Clariphyllum Anderson et Anderson 2003- como consecuencia de una reconsideración del género Heidiphyllum (Anderson y Anderson, 2003). De acuerdo a estos autores, ambos géneros se distinguen porque Clariphyllum incluye hojas pequeñas, de dispuestas en ramas, con un arreglo helicoidal laxo, sin brácteas y con 4 venas paralelas por hoja; mientras que Heidiphyllum abarca hojas grandes, dispuestas en braquiblastos, con un arreglo en apretados pseudoverticilos con brácteas triangulares cortas y 10 venas paralelas por hoja. No obstante, estas diferencias no están contempladas en la diagnosis original de Heidiphyllum (Retallack, 1981), y H. clarifolium puede ser perfectamente asimilado al género. Los ejemplares aquí descriptos encajan con todos los atributos de la especie, siendo de menores dimensiones que el holotipo de la misma.

\section{Heidiphyllum minutifolium Anderson et Anderson 1989}

Figura VII.13.4

Descripción: Hoja oblanceolada, de 2,1 cm y 0,67 cm de ancho máximo, con base angosta y ápice obtuso redondeado. Las venas se dicotomizan varias veces a diferentes alturas, a partir de 2 venas en la base, llegando a una densidad de 15 por centímetro cerca del ápice.

\section{Materiales estudiados: PBSJ 447.}

Estrato fosilífero y localidad: EF3, Localidad 3.

Comentarios: La especie Heidiphyllum minutifolium fue erigida por Anderson y Anderson (1989) para hojas muy pequeñas (de $4 \mathrm{~cm}$ de largo y $0,5 \mathrm{~cm}$ de ancho), oblanceoladas, con el ápice redondeado, base angosta sésil, venas moderadamente espaciadas $(15$ por $\mathrm{cm})$, que se dicotomizan repetidamente a mitad de camino. A esta especie también puede asimilarse los ejemplares descriptos por Menéndez (1951) como Podozamites lanceolatus var. minor (Schenk) Heer 1877 para la Formación Llantenes. Los especímenes de la Formación Llantenes se diferencian de P. lanceolatus porque ésta última incluye hojas linear-lanceoladas, con el ancho máximo más cerca de la base, 
de ápice agudo acuminado, y base contraída en un corto pecíolo; mientras que los ejemplares de Menéndez son formas oblanceoladas, con el ancho máximo más cerca del ápice, el que es reondeado, y con base angosta pero no contraída en un pecíolo. Estos atributos, más el tamaño de las hojas y las características de la venación, permiten asignar tanto al material de Menéndez, como al espécimen de la Formación Cortaderita aquí estudiado, a la especie $H$. minutifolium.

\section{Orden Coniferales Engler 1897}

Incertae sedis

Género Elatocladus Halle 1913 emend. Harris 1979

Especie tipo. Elatocladus heterophylla Halle 1913.

\section{Elatocladus plana (Feistmantel) Seward 1919}

Figura VII.13.6, 8 y 10

Descripción: Fragmentos de ramas de 0,03 a $0,32 \mathrm{~cm}$ de grosor y 1,12 a 2,28 $\mathrm{cm}$ de largo, que llevan hojas sésiles distribuidas helicoidalemente. Hojas uninervias, de lámina linear a acicular, de ápice agudo; miden 0,51 a 1,28. cm de largo y 0,03 a 0,09 cm de ancho. La vena media es conspicua.

Materiales estudiados: PBSJ 449, 451, 452.

Estrato fosilífero y localidad: EF2, Localidad 2.

Comentarios: El género Elatocladus fue creado por Halle (1913) para las ramas estériles de coníferas, tanto de simetría radial o dorsiventral, que no podían ser asignadas a géneros mejor definidos. Harris $(1969,1979)$ realizó sucesivas enmiendas de la diagnosis original, redefiniendo el género como: ramas que portan hojas helicoidalmente, hojas aplanadas dorsiventralmente, con una única vena, hojas divergentes del eje. Los ejemplares aquí descriptos son determinados como Elatocladus plana (Feistmantel) Seward 1919 porque comparte con esta especie las siguientes características: hojas uninervias alargadas, angostas, lineares, achatadas dispuestas helicoidalmente, base no contraída, y ápice simétrico.

A esta especie pertenecen los materiales descriptos como Elatocladus sp. por Bonetti (1963), para el NF II, punto 20. 
Género Pagiophyllum Heer emend. Harris 1979

Especie tipo. Pagiophyllum circinium (Saporta) Heer 1881.

\section{Pagiophyllum sp.}

Figura VII.13.7 y 9

Descripción: Fragmentos de 5 y 6,5 cm de longitud de dos ramas, de 1 y $0,35 \mathrm{~cm}$ de grosor, respectivamente, recorrida por finas estrías longitudinales. Portan ramas de mayor orden de disposición alterna, de 0,4 a $0,5 \mathrm{~cm}$ de espesor. Hojas uninervias, escuamiformes; miden 0,33 a 0,4 cm de largo y 0,17 a $0,2 \mathrm{~cm}$ de ancho. La vena media es conspicua.

Materiales estudiados: PBSJ 450.

Estrato fosilífero y localidad: EF2, Localidad 5.

Comentarios: El material estudiado se ajusta a la definición del género Pagiophyllum Heer emend. Harris 1979, cuyas características se sintetizan en el Cuadro VII.9.

\section{Familia Podocarpace Endlicher 1847}

Género Rissikia Townrow 1967

Especie tipo. Rissikia media (Tenison-Woods) Townrow 1967.

\section{Rissikia media (Tenison-Woods) Townrow 1967}

Figura VII.13.5

Descripción: Fragmento de una rama de 0,09 $\mathrm{cm}$ de grosor y 4,35 $\mathrm{cm}$ de largo, recorrida por finas estrías longitudinales, que lleva hojas sésiles distribuidas helicoidalemente. Hojas uninervias, de lámina linear a acicular, de ápice agudo; miden 0,97 a $1,16 \mathrm{~cm}$ de largo y 0,06 a $0,84 \mathrm{~cm}$ de ancho. La vena media es conspicua.

Material estudiado: PBSJ 448.

Estrato fosilífero y localidad: EF3, Localidad 3.

Comentarios: Las hojas de Rissikia Townrow 1967, se caracterizan por ser lineares, aplanada, univervias, tener un arreglo helicoidal y flexionarse en su base, de manera que parecen disponerse de manera opuesta (Anderson y Anderson, 2003). Son muy semejantes a las del género Elatocladus Halle 1913, pero se diferencian por los caracteres brindados en el cuadro VII.9. y VII.10. 


\begin{tabular}{|l|l|l|l|l|}
\hline $\begin{array}{l}\text { Elatocladus Halle } \\
\mathbf{1 9 1 3}\end{array}$ & Simetría radial & Hojas adpresas & $\begin{array}{l}\text { Hojas cortas y } \\
\text { falcadas }\end{array}$ & $\begin{array}{l}\text { Disposición } \\
\text { espiralada }\end{array}$ \\
\cline { 2 - 5 } & Simetría bilateral & Hojas no adpresas & $\begin{array}{l}\text { Hojas chatas, } \\
\text { largas y menos } \\
\text { falcadas }\end{array}$ & $\begin{array}{l}\text { Disposición en un } \\
\text { plano }\end{array}$ \\
\hline $\begin{array}{l}\text { Rissikia Townrow } \\
\mathbf{1 9 6 7}\end{array}$ & Simetría bilateral & Hojas no adpresas & $\begin{array}{l}\text { Hojas desde } \\
\text { escuamiformes a } \\
\text { lineares alargadas }\end{array}$ & $\begin{array}{l}\text { Disposición } \\
\text { helicoidal pero } \\
\text { aparentemente en } \\
\text { un plano }\end{array}$ \\
\hline $\begin{array}{l}\text { Pagiophyllum } \\
\text { Heer emend. } \\
\text { Harris 1979 }\end{array}$ & Simetría radial & Hojas adpresas & $\begin{array}{l}\text { Hojas } \\
\text { escuamiformes } \\
\text { oblanceoladas }\end{array}$ & $\begin{array}{l}\text { Disposición } \\
\text { helicoidal }\end{array}$ \\
\hline
\end{tabular}

Cuadro VII.9. Comparación de los tres géneros de ramas foliosas de Coniferales encontrados en la Formación Cortaderita (Townrow, 1967; Archangelsky, 1970; Anderson y Anderson, 2003).

\begin{tabular}{|l|l|l|l|l|}
\hline \multicolumn{1}{|c|}{ Taxón } & \multicolumn{1}{|c|}{ Ramas } & \multicolumn{1}{|c|}{$\begin{array}{c}\text { Disposición de las } \\
\text { hojas }\end{array}$} & Forma de las hojas & \multicolumn{1}{c|}{$\begin{array}{c}\text { Base, margen y } \\
\text { ápice }\end{array}$} \\
\hline $\begin{array}{l}\text { Elatocladus } \\
\text { australis Halle 1913 }\end{array}$ & $\begin{array}{l}\text { De 3-5 cm de } \\
\text { largo }\end{array}$ & $\begin{array}{l}\text { Helicoidal, dística, 0,3 } \\
\text { cm de separación entre } \\
\text { hojas }\end{array}$ & $\begin{array}{l}\text { Alargadas, angostas } \\
\text { y lineares, } \\
\text { fuertemente } \\
\text { achatadas }\end{array}$ & $\begin{array}{l}\text { Base decurrente y } \\
\text { contraída, márgenes } \\
\text { no muy paralelos } \\
\text { ápice obtuso y } \\
\text { asimétrico }\end{array}$ \\
\hline $\begin{array}{l}\text { Elatocladus plana } \\
\text { Halle 1913 }\end{array}$ & $\begin{array}{l}\text { De 5-18 cm de } \\
\text { largo }\end{array}$ & $\begin{array}{l}\text { Helicoidal, 0,2 cm de } \\
\text { separación entre hojas }\end{array}$ & $\begin{array}{l}\text { Alargadas, angostas } \\
\text { y lineares, } \\
\text { fuertemente } \\
\text { achatadas }\end{array}$ & $\begin{array}{l}\text { Base no contraída, } \\
\text { márgenes paralelos, } \\
\text { ápice simétrico }\end{array}$ \\
\hline $\begin{array}{l}\text { Rissikia media } \\
\text { Townrow 1967 }\end{array}$ & $\begin{array}{l}\text { De 3-12 cm de } \\
\text { largo }\end{array}$ & $\begin{array}{l}\text { Helicoidal pero } \\
\text { aparentemente en un } \\
\text { plano, 0,3 cm de } \\
\text { separación entre hojas }\end{array}$ & $\begin{array}{l}\text { ylargadas, angostas } \\
\text { achatadas }\end{array}$ & $\begin{array}{l}\text { Base no contraída, } \\
\text { márgenes paralelos, } \\
\text { ápice simétrico }\end{array}$ \\
\hline $\begin{array}{l}\text { Rissikia apiculata } \\
\text { Townrow 1967 }\end{array}$ & $\begin{array}{l}\text { De 3-16 cm de } \\
\text { largo }\end{array}$ & $\begin{array}{l}\text { Helicoidal pero } \\
\text { aparentemente en un } \\
\text { plano, 0,3-0,5 cm de } \\
\text { separación entre hojas }\end{array}$ & $\begin{array}{l}\text { Alargadas, angostas } \\
\text { y lineares, de } \\
\text { sección romboidal }\end{array}$ & $\begin{array}{l}\text { Base no contraída, } \\
\text { márgenes paralelos, } \\
\text { ápice simétrico }\end{array}$ \\
\hline
\end{tabular}

Cuadro VI.10. Comparación de las especies más representativas de Elatocladus y Rissikia (Townrow, 1967; Archangelsky, 1970; Anderson y Anderson, 2003).

\section{Orden Gnetales Luerssen 1879}

Género Yabeiella Ôishi emend. Pal 1984

Especie tipo. Yabeiella mareyesiaca (Genitz) Ôishi 1931.

\section{Yabeiella brackebuschiana (Kurtz) Ôishi 1931}

Materiales revisados: $\mathrm{BAPb} 4350$.

Estrato fosilífero y localidad: EF2, Localidad 2.

Comentarios: El género Yabeiella fue recientemente asignado a las Gnetales por Anderson y Anderson (2003). Esta especie fue citada por Bonetti (1963), para el NF II, punto 20 . 


\section{Yabeiella mareyesiaca (Geinitz) Ôishi 1931}

Materiales revisados: $\mathrm{BAPb} 4364,4365$.

Estrato fosilífero y localidad: EF2, Localidad 2.

Comentarios: Ejemplares asignables a esta especie fueron estudiados por Bonetti (1963), en el NF II, punto 20.

\section{Yabeiella spathulata Ôishi 1931}

Materiales revisados: $\mathrm{BAPb} 4332,4342,4349,4368$

Estrato fosilífero y localidad: EF2, Localidad 2.

Comentarios: Bonetti (1963) estudió varios especímenes que asignó a este taxón, provenientes del NFII, puntos 20 y 21 .

\section{Yabeiella wielandi Ôishi 1931}

Materiales revisados: $\mathrm{BAPb} 4333,4337,4341,4345,4346,4352,4353,4354,4359$, 4347, 4348,

Estrato fosilífero y localidad: EF2, Localidad 2.

Comentarios: Esta especie fue citada por Bonetti (1963), para el NF II, puntos 20 y 21, sobre la base de abundante material.

\section{Género Fraxinopsis Wieland 1929}

Especie tipo. Fraxinopsis minor Wieland 1929.

Fraxinopsis andium (Frenguelli) Anderson et Anderson 2003

Estrato fosilífero y localidad: EF2, Localidad 2.

Comentarios: El género Fraxinopsis fue creado por Wieland (1929) para semillas halladas en sedimentitas triásicas de Argentina, de afinidad dicotiledónea. Posteriormente, Ôishi (1931), descarta la relación de los materiales triásicos argentinos con las dicotiledóneas, y argumenta que probablemente corresponden a una gimnosperma semejante a Cycadocarpidum Nathorst 1886. Frenguelli (1941) erige una nueva especie, Cycadocarpidum andium, e indica que las formas de Wieland son típicos ejemplares de Cycadocarpidium y que Fraxinopsis minor Wieland 1929, corresponden 
a C. andium. Posteriormente, Anderson y Anderson (2003) combinan esta especie con Fraxinopsis, relacionando este género a la Gnetales.

Originalmente, Frenguelli (1941, 1944f) había citado la especie Cycadocarpidium andium para la quebrada de la Cortaderita. Esto materiales fueron adscriptos por Bonetti (1963) al NFII puntos 20 y 21. Aquí se acepta la combinación de Anderson y Anderson (2003), por lo que se la considera como Fraxinopsis andium.

\section{Espermatofitas incertae sedis}

Género Cordaicarpus Geinitz 1862

Especie tipo. Cordaicarpus cordai (Geintiz) Seward 1917.

\section{Cordaicarpus mackayi (Arber) comb. nov.}

Basónimo. Carpolithus mackayi Arber 1917.

\section{Materiales revisados: $\mathrm{BAPb} 4214$}

Estrato fosilífero y localidad: EF2, Localidad 2.

Comentarios. Citada por Bonetti (1963), para el NF I, punto 12. La semejanza de estos materiales con el género de semillas gimnospérmicas Cordaicarpus fue mencionada por Artabe et al. (1999a), postura que se sostiene en el presente trabajo. Dado que el género Carpolithus Linnaeus emend. Seward 1917, es utilizado para otra entidad biológica (semillas de angiospermas cretácico-terciarias), se recomienda abandonar su utilización para semillas gimnospérmicas (Millan, 1974) y se propone aquí reubicar a Carpolithus mackayi Arber 1917 en el género Cordaicarpus.

\section{Género Linguifolium Arber emend. Retallack 1980}

\section{Especie tipo. Linguifolium lilleanum Arber 1913.}

\section{Linguifolium sp.}

Materiales revisados: LPPB 11140 y $\mathrm{BAPb} 4208$.

Estrato fosilífero y localidad: EF2, Localidad 2.

Comentarios: Retallack (1980) enmienda la diagnosis del género de hojas de Linguifolium Arber 1913 y relaciona este género con semillas asignables a "Carpolithus mackayi”, por lo que podrían representan la misma entidad biológica.

Este género fue citado por por Bonetti (1963), para el NF II, punto 20. 

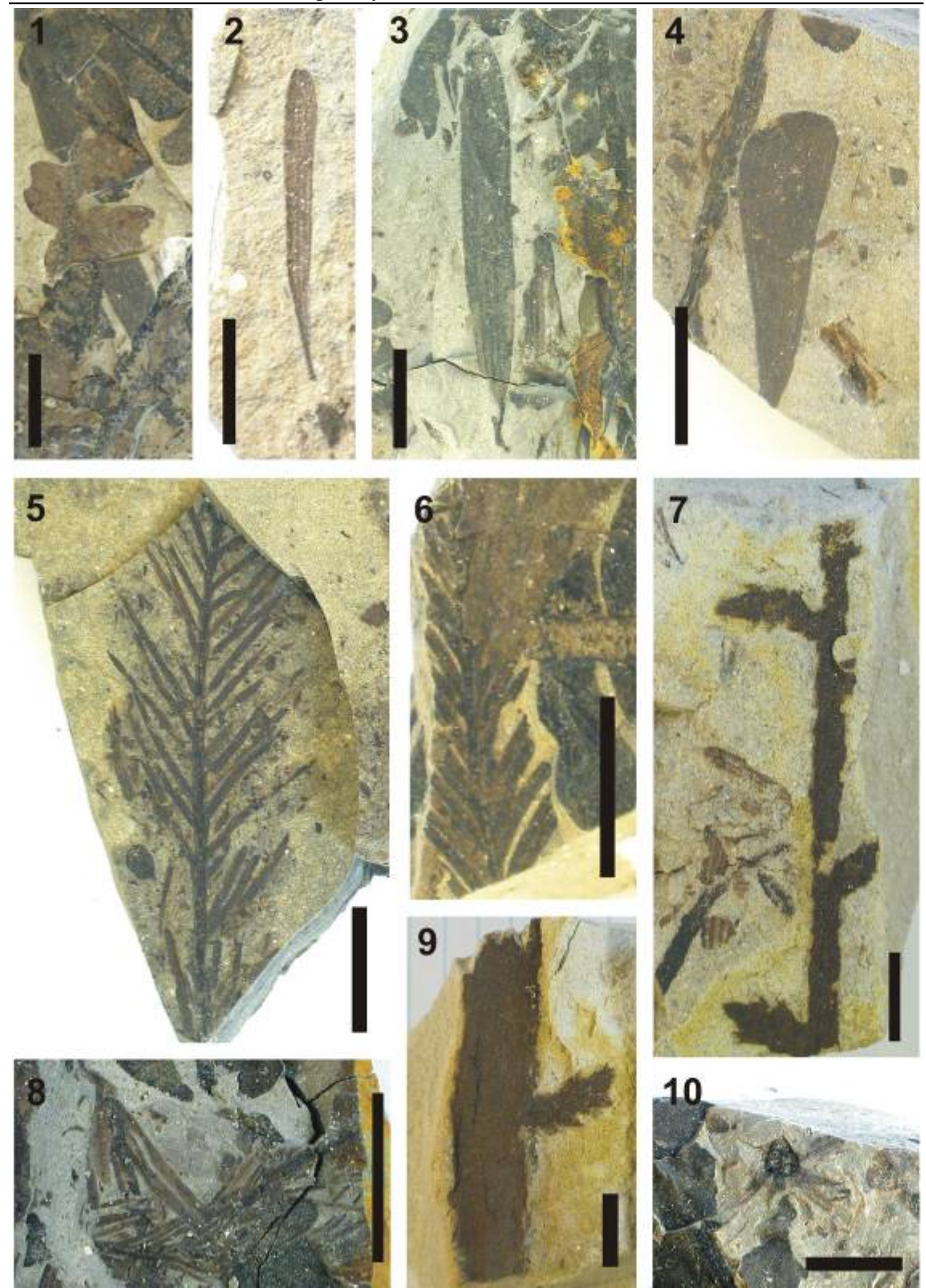

Figura VII.13. 1. Heidiphyllum elongatum (Morris) Retallack 1981. PBSJ 444. 2,3 . Heidiphyllum clarifolium Anderson et Anderson 1989. 2. PBSJ 445. 3. PBSJ 446. 4. Heidiphyllum minutifolium Anderson et Anderson 1989. PBSJ 447. 5. Rissikia media (Tenison-Woods) Townrow 1967. PBSJ 448. 6, 8, 10. Elatocladus plana (Feistmantel) Seward 1919. 6. PBSJ 449. 8. PBSJ 451. 10. PBSJ 452. 7, 9. Pagiophyllum sp. PBSJ 450. Escala: $1 \mathrm{~cm}$ 
VII.3. Estrato fosilífero de la base de la Sección Superior de la Formación Cortaderita

\title{
$\underline{\text { Localización }}$
}

El EF5 comprende varios niveles de sedimentitas fosilíferas que se encuentra hacia la base de la Sección Superior de la Formación Cortaderita. Este estrato plantífero ha sido encontrado en la localidad 6, equivalente al NF III Punto 32 (Bonetti, 1963), y a la Margen izquierda del Anticlinal al E de Barreal (Spalletti, 2001a) (S 31 $38^{\circ} 19,8^{\prime \prime} \mathrm{W}$ $\left.69^{\circ} 25^{\prime} 19,8^{\prime \prime}\right)$, y en la localidad 7, correspondiente a la Margen derecha del Anticlinal al E de Barreal (Spalletti, 2001a).

\section{$\underline{\text { Tafonomía }}$}

Los fósiles vegetales del EF5 han quedados preservados en sedimentitas de tipo areniscas finas rosadas laminadas, y limolitas y arcilitas grises y rosadas laminadas. Este estrato es interpretado como parte de la planicie de inundación de un sistema fluvial meandroso, el cual hacia el techo sufre una transición a un sistema fluvial entrelazado. En este ambiente los fósiles se han preservado en diferentes niveles superpuestos al ser sepultados sucesivamente por varios eventos de inundación por desborde del canal.

\section{Sistemática Paleobotánica}

\section{División Tracheophyta Sinnott ex Cavalier-Smith 1998}

Subdivisión Euphyllophytina Kenrick et Crane 1997

\author{
Clase Polypodiopsida Cronquist, Takhtajan et Zimmerman 1966 \\ Orden Osmundales Link 1833 \\ Familia Osmundaceae Martinov 1820 \\ Género Cladophlebis Brongniart emend. Frenguelli 1947 \\ Especie tipo. Cladophlebis albertsii (Dunker) Brongniart 1849.
}

\section{Cladophlebis mendozaensis (Geinitz) Frenguelli 1947}

Materiales revisados: $\mathrm{BAPb} 4317$.

Estrato fosilífero y localidad: EF5, Localidad 6 y Localidad 7. 
Comentarios: Especímenes asignados a esta especie fueron estudiados por Bonetti (1963), para el NF III, puntos 31 y 32.

Clase Spermatopsida Serbet et Rothwell 1995

Orden Corystospermales Petriella 1981

Familia Corystospermaceae Thomas 1933

Género Dicroidium Gothan emend. Townrow 1957

Especie tipo. Dicroidium odontopteroides (Morris) Gothan 1912.

\section{Dicroidium odontopteroides (Morris) Gothan 1912}

Figura VII.14.1 y 3

Descripción: Fragmentos de 3,76 a 8,13 cm de largo y 1,09 a 5,39 cm de ancho de hojas monopinnadas pecioladas, con raquis bifurcado. Pecíolo de 0,23 a 0,28 $\mathrm{cm}$ de espesor. Raquis de 0,12 a 0,27 cm de espesor, con un ángulo de bifurcación de 22 a $31^{\circ}$. Pinnas opuestas a subopuestas, de morfología rectangular, ovada a lanceolada corta o lanceolada, con base ancha, márgenes lisos, ápice redondeado a redondeado-agudo, insertas con un ángulo de 57 a $84^{\circ}$, y variando en longitud de 0,57 a 1,78 cm y en ancho de 0,32 a $0,88 \mathrm{~cm}$. La venación es de tipo aletopteroide.

Material es estudiados: PBSJ 453, 455, 646, 647.

Materiales revisados: LPPB 13868, 13869.

Estrato fosilífero y localidad: EF5, Localidad 6 y Localidad 7.

Comentarios: Para el tratamiento sistemático de esta especie, ver sección VII.2. También corresponden a esta especie y al EF5 materiales estudiados por Artabe et al. (1995a) para el EF de Cortaderita Superior.

\section{Dicroidium lancifolium (Morris) Gothan 1912}

Figura VII.14.2

Descripción: Fragmentos de 2,97 a 7,96 cm de largo y 2,82 a 4,15 cm de ancho, de hojas monopinnadas. Pecíolo no preservado. Raquis de 0,085 a 0,23 cm de espesor. Pinnas desde opuestas y subopuestas a subalternas y alternas, lanceoladas, angostas, con base ancha, márgenes lisos algo curvados, ápice redondeado-agudo a agudo, insertas 
con un ángulo de 49 a $78^{\circ}$, y de 1,02 a 2,88 cm de longitud y de 0,46 a $1,02 \mathrm{~cm}$ de ancho. La venación es de tipo aletopteroide.

Material es estudiados: PBSJ 453, 454, 648.

Estrato fosilífero y localidad: EF5, Localidad 6.

Comentarios: Para el tratamiento sistemático de esta especie, ver sección VII.2. También corresponden a esta especie, y al EF5, materiales estudiados por Bonetti (1963) para el NF III, puntos 31 y 32, y por Artabe et al. (1995a) para el EF de Cortaderita Superior.

Género Pteruchus Thomas 1933

Especie tipo. Pteruchus africanus Thomas 1933.

\section{Pteruchus barrealensis (Frenguelli) Holmes et Ash 1979}

Materiales revisados: LPPB 9525, 9526, BAPb 4389.

Estrato fosilífero y localidad: EF5, Localidad 6 y Localidad 7.

Comentarios: Corresponden a esta especie materiales provenientes del NFIII, punto 32, estudiados por Bonetti (1963).

\section{Orden Peltaspermales Meyen 1987}

Familia Peltaspermaceae Thomas 1933

Género Pachydermophyllum Thomas et Bose 1955

Especie tipo. Pachydermophyllum papillosum Thomas et Bose 1955.

\section{Pachydermophyllum papillosum Thomas et Bose 1955}

Figura VII.14.5

Descripción: Fragmentos, algunos deformados, de 1,99 a 6,11 cm de largo y 1,56 a 3,69 $\mathrm{cm}$ de ancho, de hojas monopinnadas pecioladas. Pecíolo de 0,18 $\mathrm{cm}$ de espesor Raquis de 0,09 a 0,18 cm de espesor. Pinnas desde subopuestas en la base, subalternas en la parte media de la hoja y subopuestas cerca del ápice; ovadas a oblanceoladas, angostas, con margen basal inferior levemente decurrente, margen basal superior contraído y ápice agudo o redondeado-agudo, insertas con un ángulo de 48 a $84^{\circ}$, varíando en longitud de 0,59 a 2,06 $\mathrm{cm}$ y en ancho de 0,34 a 0,62 cm. Venación 
aletopteroide, vena media marcada, venas secundarias que parten subopuestas con un ángulo agudo de la vena media, y se dicotomizan cerca de su salida o a mitad de su recorrido.

Material es estudiados: PBSJ 457, 649.

Estrato fosilífero y localidad: EF5, Localidad 7.

Comentarios: Estos materiales coinciden con la diagnosis de la especie otorgada por Thomas y Bose (1955) y la caracterización de la misma postulada por Retallack (1981).

\section{Género Scytophyllum Bornemann 1856}

Especie tipo. Scytophyllum bergeri Bornemann 1856.

\section{Scytophyllum bonettiae Zamuner, Artabe et Ganuza 1999}

Figura VII.14.7 y 8

Descripción: Cinco fragmentos, de 5,46 a 5,52 cm de largo y 1,78 a 2,33 $\mathrm{cm}$ de ancho, de hojas monopinnadas, imparipinnadas, lanceoladas. Raquis robusto, estríado, de 0,13 a $0,16 \mathrm{~cm}$ de espesor, con protuberancias en su superficie. Pinnas opuestas a subalternas lanceoladas algo falcadas, margen basal inferior levemente decurrente, margen basal superior contraído, ápice agudo, insertas con un ángulo de 50 a $65^{\circ}$, variando en longitud de 0,84 a 1,47 cm y en ancho de 0,34 a 0,64 cm. Venación compleja. Vena media conspicua que llega hasta el ápice de cada pinna. Venas secundarias salen en forma pinnada y con un ángulo muy agudo de la vena media. De las venas secundarias parten de manera pinnada venas de tercer orden.

Materiales estudiados: PBSJ 650.

Estrato fosilífero y localidad EF5, Localidad 7.

Comentarios: En este estrato esta especie es mucho menos abundante que en los estratos fosilíferos de la Sección Inferior.

\section{Género Lepidopteris (Schimper) Townrow 1956}

Especie tipo. Lepidopteris stuttgardiensis (Jaeger) Schimper 1869.

\section{Lepidopteris africana (Du Toit) Holmes 1982}

Figura VII.14.9 
Descripción: Fragmentos de 3,03 a 6,15 cm de longitud y 1,63 a 3,67 cm de ancho de una hoja bipinnatífida. Raquis de 0,14 a 0,15 cm de espesor, con estrías longitudinales y protuberancias superficiales. Pinnas alargadas, oblanceoladas, opuestas o alternas, con márgenes fuertemente lobulados y ápice agudo, insertas con un ángulo de 51 a $63^{\circ}$. Longitud de las pinnas de 1,47 a 2,39 cm, ancho de las pinnas de 0,45 a 0,65 cm. Margen basal de las mismas decurrente en su sector inferior, formando una incipiente interpínnula triangular redondeada, de 0,04-0,32cm x 0,17 cm. Venación oscurecida por la gruesa cutícula con abundantes papilas. Vena media conspicua, venas laterales decurrentes, luego se curvan hasta hacerse perpendiculares a la vena media. Se dicotomizan cerca del final de su recorrido.

Materiales estudiados: PBSJ 651.

Estrato fosilífero y localidad: EF5, Localidad 7.

Comentarios: Los ejemplares estudiados coinciden con la caracterización de la especie, sintetizada en el cuadro VII.6.

\section{Lepidopteris stormbergensis (Seward) Townrow 1956}

Figura VII.14.4 y 6

Descripción: Fragmentos de 2,27 a 7,07 cm de longitud y 1,78 a 7,7 cm de ancho de hojas bipinnadas. Raquis de 0,1 a 0,36 cm de espesor. Pinnas alargadas, opuestas a subopuestas o alternas a subalternas, no preservadas en toda su longitud, insertas con un ángulo de 31 a 59 . Su longitud varía de 1,32 a 4,79 $\mathrm{cm}$ y su ancho de 0,48 a 1,2 cm. Ráquises secundarios de 0,04 a 0,15 cm de espesor. Pínnulas opuestas a subopuestas y alternas, pecopterídeas (rectangulares cortas, de base ancha algo decurrente $o$ coalescente y ápice redondeado a agudo), insertas con un ángulo de 48 a $71^{\circ}$. Su longitud varía de 0,24 a $0,81 \mathrm{~cm}$ y su ancho de 0,16 a $0,45 \mathrm{~cm}$. Interpínnulas redondeadas triangulares a triangulares o romboidales, de 0,14-0,43 x 0,15-0,51 cm. Venación de las pínnulas, pecopteroide

Materiales estudiados: PBSJ 456, 652.

Estrato fosilífero y localidad: EF5, Localidad 7.

Comentarios: Los ejemplares estudiados coinciden con la caracterización de la especie, sintetizada en el cuadro VII.6. Esta especie, también registrada en la Sección Inferior de la Formación Cortaderita, es muy abundante en el EF5. 


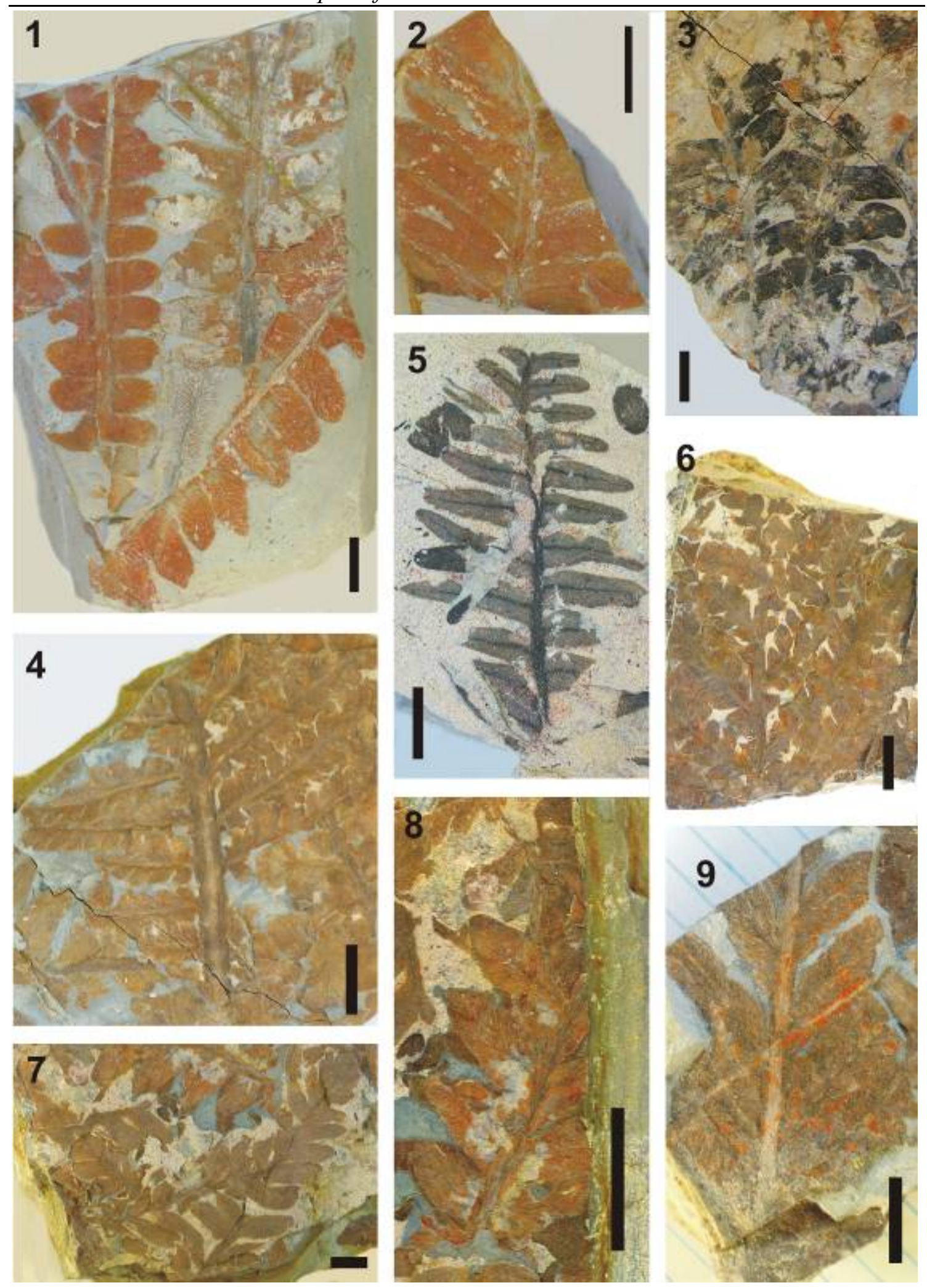

Figura VII.14. 1, 3. Dicroidium odontopteroides (Morris) Gothan 1912. 1. PBSJ 453. 3. PBSJ 455. 2. Dicroidium lancifolium (Morris) Gothan 1912. PBSJ 454. 4, 6. Lepidopteris stormbergensis (Seward) Townrow 1956. 4. PBSJ 456. 6. PBSJ 652. 5. Pachydermophyllum papillosum Thomas et Bose 1955. PBSJ 457. 7, 8. Scytophyllum bonettiae Zamuner, Artabe et Ganuza 1999. PBSJ 650. 9. Lepidopteris africana (Du Toit) Holmes 1982. PBSJ 651. Escala: $1 \mathrm{~cm}$. 
Orden Ginkgoales Engler 1897

Incertae sedis

Género Ginkgodium Yokoyama 1889

Especie tipo. Ginkgodium nathorsti Yokoyama 1889.

\section{Ginkgodium nathorsti Yokoyama 1889}

Figura VII.15.1

Descripción: Fragmento de hoja triangular peciolada. Pecíolo corto, de 0,07 cm de espesor. Longitud de la lámina 4,19 cm, ancho máximo de 2,64 cm, disminuyendo progresivamente hasta $0,2 \mathrm{~cm}$ en la base. El ángulo basal es de $40^{\circ}$. La lámina está dividida 2 veces. La primera incisión es mediana, aproximadamente a 2,52 cm de la base de la hoja. La segunda incisión es leve. Se distinguen 2 segmentos de 1,25 cm de ancho, de ápices bilobulados. La venación no es claramente visible por la presencia de finas estrías intervenas. En la base de la lámina hay 3 venas que se dicotomizan a diferentes alturas, llegando a una densidad de venas es de aproximadamente 8 venas por $0,5 \mathrm{~cm}$ en la base de la primera incisión y de 10 venas por $0,5 \mathrm{~cm}$ en la base de la segunda incisión.

\section{Material estudiado: PBSJ 653.}

\section{Estrato fosilífero y localidad EF5, Localidad 7.}

Comentarios: Este espécimen coincide, en rasgos generales, con el criterio de Gnaedinger y Herbst (1999) que define al género Ginkgodium como: hojas enteras o bilobuladas, obovadas angostas con una relación largo/ancho 3:1 o más, con una o dos incisiones leves en el ápice, pecíolo corto con una única vena que se dicotomiza repetidas veces hasta la mitad de la lámina, ángulo basal menor que $90^{\circ}$. De estas características, el material estudiado no posee una relación largo/ancho 3:1 o mayor. Esta relación puede ser mayor a la observada en el ejemplar ya que éste no se ha preservado en toda su longitud. Además, Gnaedinger y Herbst (1999) atribuyen al género formas con una relación largo/ancho menor a 3:1. En cuanto a la designación específica, este ejemplar coincide con la descripción de Ginkgodium nathorsti proporcionada por Seward (1919): hojas enteras o divididas por una incisión mediana en dos segmentos divergentes; lámina de contorno obovado o cuneado, culminando (en las formas enternas) de manera truncada o lobada amplia; trece venas por hoja, estrías intervenas presentes. 


\section{Género Sphenobaiera Florin 1936}

Especie tipo. Sphenobaiera spectabilis (Nathorst) Florin 1936.

\section{Sphenobaiera argentinae (Kurtz) Florin 1940}

Figura VII.15.2 y 3

Descripción: Fragmentos de hojas largamente triangulares, angostas, sin pecíolo definido. Longitud de la lámina de 2,11 a 8,24 cm. Ancho máximo de 1,5 a 4,2 cm, disminuyendo progresivamente hasta la base. Ángulo basal de 27 a 40 . Lámina dividida 2 veces. Primera incisión mediana a profunda o leve, segunda incisión siempre leve. Se distinguen 2 segmentos de 1,15 a 1,2 cm de ancho. La venación es dicotómica abierta, las venas se dicotomizan a diferentes alturas, llegando, en los ejemplares mayores, a una densidad de 6-7 venas por $0,5 \mathrm{~cm}$ en la base de la primera incisión y 8 a10 venas por $0,5 \mathrm{~cm}$ en la base de la segunda incisión; $y$, en los ejemplares menores, de 12 venas por $0,5 \mathrm{~cm}$ en la base de la primera incisión y 14 venas por $0,5 \mathrm{~cm}$ en la base de la segunda incisión.

Materiales estudiados: PBSJ 455, 646, 654.

Estrato fosilífero y localidad: EF5, Localidad 6 y Localidad 7.

Comentarios: Los ejemplares aquí descriptos abarcan una gran variedad de formas, con bifurcaciones profundas o leves, y una amplitud de rango en cuanto al ángulo basal y el ancho máximo de la lámina. No obstante, todos pueden ser asimilados a $S$. argentinae. Esta especie había sido citada por Bonetti para el NFIII, punto 32.

\section{Sphenobaiera stormbergensis (Seward) Frenguelli 1948}

Estrato fosilífero y localidad: EF5, Localidad 6 y Localidad 7.

Comentarios: Bonetti (1963) citó esta especie para el NFIII, puntos 31 y 32.

Orden Cycadales Dumortier 1829

Incertae sedis

Género Kurtziana Frenguelli emend. Petriella et Arrondo 1982

Especie tipo. Kurtziana cacheutensis (Kurtz) Frenguelli emend. Petriella et Arrondo 1982. 


\section{Kurtziana cacheutensis (Kurtz) Frenguelli emend. Petriella et Arrondo 1982}

Figura VII.15.4

Descripción: Fragmentos 3,67 a 3,82 cm de largo y 2,08 a 3,18 cm cm de ancho de una hoja monopinnada, peciolada. Pecíolo de 0,2 cm de espesor. Raquis estriado, de 0,19 $\mathrm{cm}$ de espesor. Pinnas subopuestas a subalternas, oblanceoladas, con base contraída, a veces decurrente en su márgen basicópico, ápice redondeado agudo, insertas con un ángulo de 55 a $69^{\circ}$. Varían en longitud de 0,86 a 1,26 cm y en ancho de 0,43 a 0,45 cm. Vena media marcada, alcanza el tercio distal de la pinna y se resuelve en varias dicotomías. Venación lateral poco visible, de tipo aletopteroide.

Materiales estudiados: PBSJ 655, 656.

Estrato fosilífero y localidad: EF5, Localidad 7.

Comentarios: Frenguelli (1942g) creó el género Kurtziana sobre la base de formas anteriormente atribuidas a Danaeopsis por Kurtz (1921) de la Formación Cacheuta (Triásico Superior, Mendoza), y lo definió como frondes simples, lineares, paripinnadas; con raquis robusto, longitudinalmente surcado-estríado; pinnas subcoriáceas; subequiláteras, ápice truncado o acuminado-redondeado, insertas al raquis con la base contraída, a veces apenas decurrente, y con un pecíolo corto; venas medias de las pinnas, gruesas y canaliculadas, disminuyendo hacia el ápice en venillas; venas laterales repetidamente dicotómicas, que parten con ángulos agudos, suavemente curvadas.

Posteriormente, Petriella y Arrondo (1982) enmiendan la diagnosis del género sobre la base de material encontrado en la Formación Nestares (Jurásico Inferior de Neuquén). Estos autores modifican un carácter morfológico de la diagnosis original (la condición paripinnada por la de imparipinnada de la fronde) y adicionan caracteres epidérmicos: células epidérmicas isodiamétricas a subrectangulares de paredes regularmente engrosadas, aparatos estomáticos aperígenos con células oclusivas hundidas, células vecinas con o sin engrosamientos cutinizados o papilas). Petriella y Arrondo (1982) además enmiendan las diagnosis de las dos especies del género, incorporando datos epidérmicos. Más tarde, Artabe et al. (1991) adicionan otras características cuticulares al taxón sobre la base de lo materiales de Petriella y Arrondo (1982), y asocian a Kurtziana con las cycadópsidas.

Herbst y Gnaedinger (2002) perciben a las enmiendas de Petriella y Arrondo (1982) como inválidas y redefinen a Kurtziana como un género de frondes estériles y 
sin cutículas, asignándolo con dudas a las pteridospermas. A su vez, excluyen los ejemplares estudiados por Petriella y Arrondo (1982) y Artabe et al. (1991), erigiendo con ellos un nuevo género: Alicurana. De esta manera, para Herbst y Gnaedinger (2002) Kurtziana es un taxón exclusivamente triásico. No obstante, las diferencias morfológicas entre Alicurana y Kurtziana (frondes imparipinnadas en la primera y paripinnadas en la segunda) no justifican la creación de un nuevo género. De hecho, en ciertas formas actuales conviven las dos condiciones en una misma planta [por ejemplo, en algunas especies de marattiáceas (Rolleri, 2004)]. Al mismo tiempo, la diagnosis original de Frenguelli (1942f) no excluye a las hojas con cutícula preservada.

Por otro lado, Anderson y Anderson (2003) opinan que Pachydermophyllum Thomas et Bose 1955 es un sinónimo junior de Kurtziana, fundamentando su postura con el hecho de que la afiliación a las cycadales está basada únicamente en los caracteres epidérmicos y de acuerdo a estos autores las cutículas estudiadas no presentan estomas y células subsidiarias claramente preservadas. Esta postura es discutible, ya que ambos géneros presentan diferencias morfológicas conspicuas, como la base subpeciolada o cordada de las pinnas en Kurtziana y la base ancha o decurrente de las pinnas en Pachydermophyllum.

En síntesis, aquí se considera a Kurtziana como un género de hojas monopinnadas, pari o imparipinnadas, con raquis longitudinalmente surcado-estríado; pinnas insertas al raquis con la base contraída o cordada y venación aletopteroide. Este taxón incluye dos especies: K. cacheutensis (Kurtz) Frenguelli 1942b y K. brandmayri Frenguelli 1944g; las cuales se diferencian porque la primera tiene pinnas contiguas a espaciadas, insertas lateralmente al raquis y con bases constrictas o constrictadecurrentes, mientras que la segunda porta pinnas imbricadas a contiguas, insertas sobre el raquis y con bases cordadas (Petriella y Arrondo, 1982; Herbst y Gnaedinger, 2002). La tercera especie $-K$. paipotensis- creada para el género por Herbst y Gnaedinger (2002), no presenta diferencias significativas con $K$. cacheutensis, por lo que se la considera un sinónimo subjetivo de esta última.

Familia Stangeriaceae Johnson 1959

Género Pseudoctenis Seward 1911

Especie tipo. Pseudoctenis eathiensis (Richards) Seward 1911. 


\section{Pseudoctenis longipinnata Anderson et Anderson 1989}

Figura VII.15.7 y 8

Descripción: Fragmentos de 2,34 a 6,44 cm de largo y 2,89 a 8,68 cm de ancho de una hoja monopinnada. Raquis robusto, fuertemente estriado longitudinalmente, de 0,4 a $0,55 \mathrm{~cm}$ de espesor. Segmentos foliares subopuestos, insertos lateralmente al raquis por toda su base, con un ángulo de aproximadamente $90^{\circ}$. Ancho de los segmentos irregular, de 0,54 a 1,09 cm, longitud preservada de los segmentos 2,37 a 4,55 cm. Morfología de los segmentos desconocida (¿espatulada?), con base ancha o levemente ensanchada, márgenes paralelos. Venación poco conspicua, entran 11 a 12 venas por segmento que se dicotomizan en la base o cerca de ella, manteniéndose paralelas en todo el recorrido, en la zona media llegan a una densidad de 23-24 venas $/ \mathrm{cm}$.

Material estudiado: PBSJ 657.

Estrato fosilífero y localidad EF5, Localidad 7.

Comentarios: Los ejemplares estudiados coinciden con la caracterización de la especie, sintetizada en el cuadro VII.7.

\section{Pseudoctenis ctenophylloides Bonetti 1968}

Materiales revisados: $\mathrm{BAPb} 4223,4379,4381$.

Estrato fosilífero y localidad: EF5, Localidad 6.

Comentarios: Bonetti (1968) erigió la especie Pseudoctenis ctenophylloides sobre la base de ejemplares hallados en el NFIII, punto 36

\section{Orden Gnetales Luerssen 1879}

Género Yabeiella Ôishi emend. Pal 1984

Especie tipo. Yabeiella mareyesiaca (Genitz) Ôishi 1931

\section{Yabeiella mareyesiaca (Geinitz) Ôishi 1931}

Materiales revisados: LPPB 20400, 20401, BAPb 4368, 4369.

Estrato fosilífero y localidad: EF5, Localidad 7.

Comentarios: Esta especie había sido citada por Bonetti (1963), para el NF III, punto 31. 


\section{Yabeiella brackebuschiana (Kurtz) Ôishi 1931}

Figura VII.15.5

Descripción: Fragmentos de 1,16 a 2,88 cm de largo y 0,84 a 1,05 cm de ancho, de hojas enteras de tipo taeniopterídea, con una vena media robusta, estriada, de 0,14 a $0,26 \mathrm{~cm}$ de espesor. Las venas laterales salen bajo ángulos de $41 \mathrm{a} 73^{\circ}$, en la base de la lámina se dicotomizan en su origen y en la región media de la lámina se dicotomizan hacia la mitad de su recorrido. Llegan a una densidad de 18 venas/cm. Vena colectora marginal muy próxima al borde foliar.

Materiales estudiados: PBSJ 453.

Estrato fosilífero y localidad: EF5, Localidad 7.

Comentarios: Los ejemplares aquí descriptos coinciden con los atributos brindados por Oishi (1931) para caracterizar la especie Yabeiella brackebuschiana.

\section{Espermatofitas incertae sedis}

Género Cordaicarpus Geinitz 1862

Especie tipo. Cordaicarpus cordai (Geintiz) Seward 1917.

Cordaicarpus mackayi (Arber) comb. nov.

Estrato fosilífero y localidad: EF5, Localidad 6.

Comentarios. Citada por Bonetti (1963), para el NFIII, punto 32. 

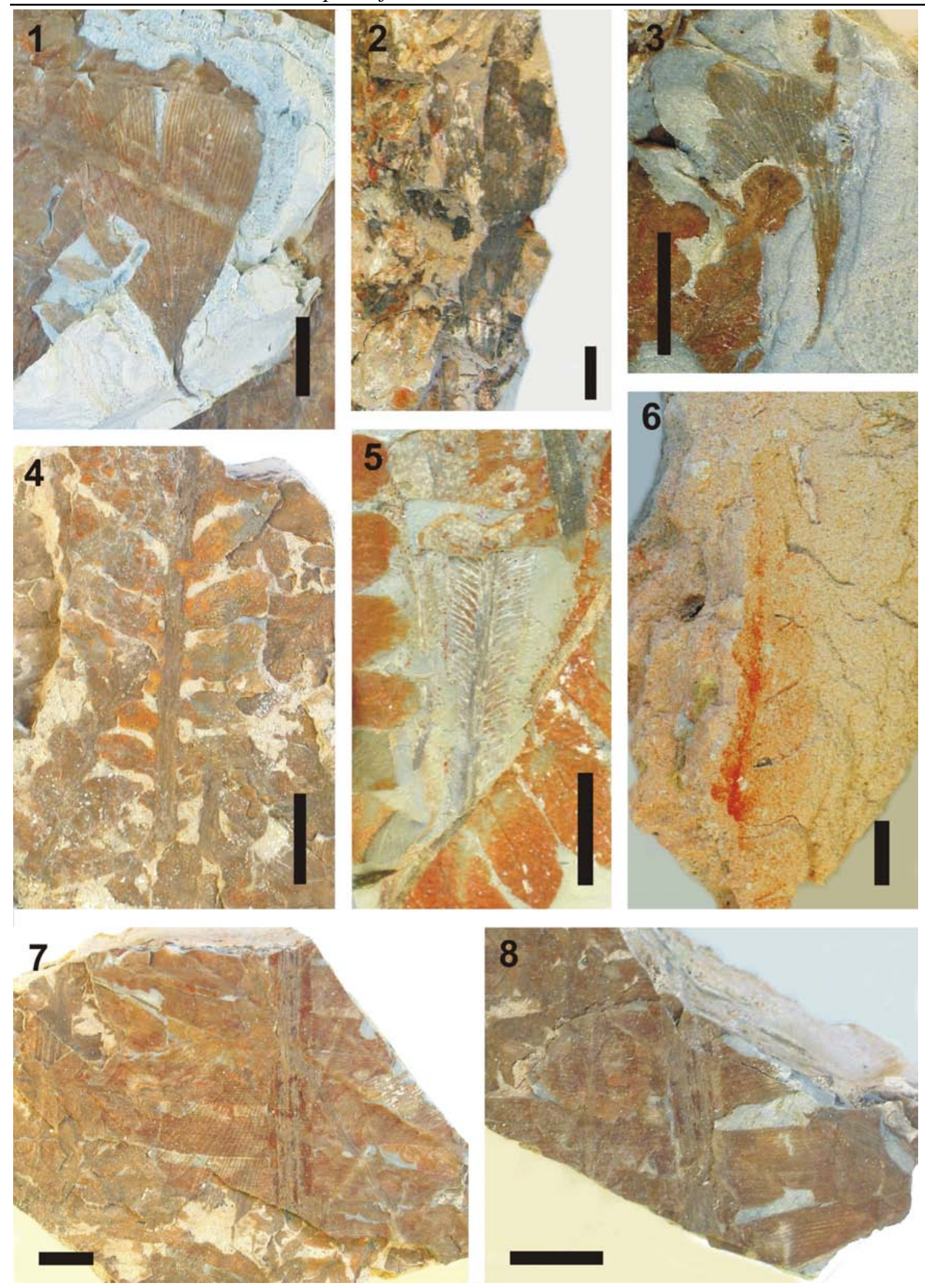

Figura VII.15. 1. Ginkgodium nathorsti Yokoyama 1889. PSBJ 653. 2, 3. Sphenobaiera argentinae (Kurtz) Florin 1940. 2. PSBJ 646. 3. PSBJ 654. 4. Kurtziana cacheutensis (Kurtz) Frenguelli emend. Petriella et Arrondo 1982. PSBJ 655. 5. Yabeiella brackebuschiana (Kurtz) Ôishi 1931. PSBJ 453. 6. Zuberia feistmanteli (Johnston) Frenguelli emend. Artabe 1990. LPPB 13870. 7, 8. Pseudoctenis longipinnata Anderson et Anderson 1989. 8. PSBJ 656. 9. PSBJ 657. Escala: $1 \mathrm{~cm}$ 


\section{VII.4. Estratos fosilíferos de la Sección Superior de la Formación Cortaderita (excluyendo el EF5)}

\section{$\underline{\text { Localización }}$}

En la Localidad 6 (S $31^{\circ} 38^{\prime}$ 19,8" W 69² 25' 19,8"), equivalente al NF III Punto 32 de Bonetti (1963) y a la Margen izquierda del Anticlinal al E de Barreal de Spalletti (2001a), se reconoce el EF 6. En la localidad 8 (S 31 $38^{\prime}$ 54,4" W 69² 23' 59,9") -NW de la Tapera en la quebrada de la Cortaderita- se ha encontrado al EF 7. Por último, el EF 8 es un estrato fosilífero de gran extensión areal, comenzando en la Localidad 9 (S $\left.31^{\circ} 39^{\prime} 12,6^{\prime \prime} \mathrm{W} 69^{\circ} 23^{\prime} 50,5^{\prime \prime}\right)$-hacia la entrada de la quebrada de la Cortaderita-

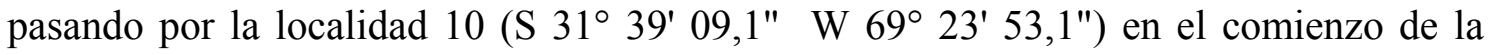
quebrada de la Tinta y terminando en la localidad 11 (S 31 39'09,8" W 69²3' 51,7") hacia el fondo de la quebrada de la Tinta.

\section{$\underline{\text { Tafonomía }}$}

Los fósiles vegetales de la Sección Superior han quedados preservados en sedimentitas de tipo areniscas, areniscas sabulíticas y sabulitas de tonalidades anaranjadas, rojas y rosadas. El EF6, contenido en areniscas muy finas blanquecinas a rosadas con laminación entrecruzada de bajo ángulo, es interpretado como depósitos de mantos arenosos laminados efímeros en la planicie de inundación de un sistema fluvial entrelazado, los que habrían sepultado frondes de gran tamaño. Posteriormente estos sedimentos fueron alterados por procesos de pedogenésis y se desarrolló un suelo donde se asentaron los árboles que quedaron silicificados in situ. El EF7, constituido por troncos alóctonos silicificados en areniscas rosadas con estratificación entrecruzada, representaría depósitos de barra dentro del canal del sistema fluvial entrelazado arenoso. Por otra parte, el EF8 es interpretado como un bosque monoespecifíco, del que quedó preservada gran cantidad de árboles silicificados y moldes de raíces, en sabulitas y areniscas sabulíticas anaranjadas a rojo ladrillo, de estructura laminada alterada, intercaladas con niveles de sílice, evaporitas y calcita (silcrete). Estas sedimentitas son interpretadas como depósitos de una barra abandonada, con el consecuente desarrollo de un paleosuelo de clima semiárido. La silicificación de los troncos es consecuencia de la percolación de fluidos ricos en sílice a través de los poros de sedimentos gruesos. La saturación de las soluciones por este mineral proviene de la abundancia del mismo en un ambiente que sufrió la influencia de importante actividad volcánica. 


\section{División Tracheophyta Sinnott ex Cavalier-Smith 1998}

Subdivisión Euphyllophytina Kenrick et Crane 1997

Clase Spermatopsida Serbet et Rothwell 1995

Orden Corystospermales Petriella 1981

Familia Corystospermaceae Thomas 1933

Género Zuberia Frenguelli emend. Artabe 1990

Especie tipo. Zuberia zuberi (Szajnocha) Frenguelli 1943.

\section{Zuberia feistmanteli (Johnston) Frenguelli emend. Artabe 1990 \\ Figura VII.15.6}

Descripción: Fragmento de una hoja bipinnada, de 5,62 cm de longitud y de 1,58 cm de ancho. Pínnulas rectangulares, subopuestas, insertas con un ángulo de 65 a 58 , de 0,84 a $0,91 \mathrm{~cm}$ de largo y 1,05 a $1,28 \mathrm{~cm}$ de ancho, márgenes rectos y paralelos, ápice obtuso paralelo al raquis de la pinna. Pínnulas apicales confluentes. La venación parece odontopteroide.

Material estudiado: LPPB 13870.

Materiales revisados: LPPB 8021, 8022, 8023, 8024, 8025, 8026, 8027, 8028, 8030, 8031, 8032, 8033, 8034, 8035, 8036, 8037,8039, 8040.

Estrato fosilífero y localidad: EF6, Localidad 6.

Comentarios: De este estrato y localidad provienen los materiales estudiados por Frenguelli (1944a) para definir a la especie Zuberia feistmanteli.

\section{Género Rhexoxylon Bancroft 1913 emend. Archangelsky et Brett 1961}

Especie tipo. Rhexoxylon africanum Bancroft 1913 emend. Walton 1923.

\section{Rhexoxylon cortaderitaense (Menéndez) Bodnar 2008}

Figura VII. 16 y 17

Descripción: Troncos excéntricos y ovalados en sección transversal, con un diámetro de 10 a $30 \mathrm{~cm}$. Los ejemplares presentan médula, xilema secundario, floema secundario y corteza preservados. Son ejes polixílicos, debido a la presencia de dos anillos cambiales que desarrollan xilema y floema secundarios centrípetos hacia la médula, xilema y floema secundarios centrífugos hacia la corteza. En los ejemplares con médula 
preservada, ésta mide de 3-4 cm x 1,4-3,2 cm de diámetro, es ovalada y heterogénea, con células parenquimáticas esféricas, idioblastos poliédricos de contenidos oscuros, nidos escleróticos, cavidades secretoras y probablemente haces vasculares. El floema secundario centrípeto tiene un espesor de 0,1 a $1,1 \mathrm{~cm}$. Debido a su pobre preservación, los caracteres anatómicos del floema no pueden ser estudiados en detalle, pero se han podido observar fibras floemáticas agrupadas en bandas separadas por bandas de células rotas y deformadas. El xilema secundario centrípeto tiene un espesor 0,24 a 1,4 cm. Cada segmento de xilema centrípeto es de 0,37 a 1,3 cm de ancho. Está separado del xilema secundario centrífugo por tejidos parenquimatosos con células comparables a las de la médula. El xilema primario no es discernible pero puede inferirse como mesarco. El xilema secundario centrífugo tiene un espesor de 3,3 a $11.5 \mathrm{~cm}$. Cada cuña xilemática mide 1,1 a $6,5 \mathrm{~cm}$ de ancho. Radios parenquimatosos son de 0,07 a 0,45 de ancho y consisten en tejidos similares a aquellos de la médula. Se observa en algunos especímenes la fragmentación tangencial dentro de las cuñas xilemáticas. Internamente en el xilema secundario centrípeto y centrífugo, se desarrollan anillos de crecimiento discontinuos y discordantes, con una abrupta disminución del diámetro radial de las traqueidas hacia el final del anillo. Traqueidas del xilema secundario, rectangulares a pentagonales, en corte transversal. El diámetro radial de las traqueidas es de 16,33$(37,11)-65,31 \mu \mathrm{m}$ y el diámetro tangencial de las traqueidas es de 28,57-(40,77)-58,77 $\mu \mathrm{m}$. El espesor de la doble pared entre dos traqueidas 4,16-(7,99)-24,49 $\mu \mathrm{m}$ en sección radial y 4,16-(7,70)-20,41 en sección tangencial. Las traqueidas tienen punteaduras areoladas principalmente biseriadas, menos comúnmente triseriadas y uniseriadas tanto en las paredes radiales y tangenciales. Las punteaduras son circulares o ligeramente hexagonales, contiguas o comprimidas, dispuestas densamente en hileras alternas, con poros circulares o elípticos Las punteaduras miden 10,40-(13,67)-18,72 $\mu \mathrm{m}$ de altura y 11,44-(14,10)-22,88 $\mu \mathrm{m}$ de ancho. Los campos de cruzamiento tienen una, ocasionalmente dos, punteaduras simples, de contorno circular a elíptico, de 10,4 x $14,56 \mu \mathrm{m}-(16,89 \times 23,44 \mu \mathrm{m})-29,7 \times 33 \mu \mathrm{m}$ de diámetro, organizadas en hileras verticales. Los radios xilemáticos secundarios son homocelulares, uniseriados, raramente biseriados. Los radios son cortos y rectilíneos, y varían entre 48,98-(198,65)$448,98 \mu \mathrm{m}$ y $1-(3)-15$ células de altura. Están compuestos por células parenquimáticas rectangulares de paredes delgadas, de 20,41-(31,31)-42,9 $\mu \mathrm{m}$ de altura y 12,24(24,96)-36,73 $\mu \mathrm{m}$ de ancho. La longitud de estas células no pudo medirse debido a la mala preservación. Parénquima axial y traqueidas radiales, ausentes. La corteza es de 1 
a $3 \mathrm{~cm}$ de ancho y consiste en dos zonas. La zona interna muestra continuidad con los tejidos secundarios centrífugos y los parenquimatosos, y está constituida por numerosos haces vasculares rodeados por células parenquimáticas, idioblastos y nidos escleróticos. La zona externa está pobremente preservada y está compuesta de floema secundario centrífugo y tejidos suberosos. El floema primario no está preservado.

Material estudiado (tipo): Lectotipo BAPb 5410; BAPbPm 5410, 505, 506, 507 y 520. Paralectotipos BAPb 5372, 5378, 5382 y 5417; BAPbPm 5433; LPPB 13083, 13084, 13085, 13086, pmLPPB 1358, 1359, 1360, 1361, 1362, 1363, 1364.

Material estudiado (adicional): BAPb 5411, LPPB 13087, 13088, 13089, 13090.

Estrato fosilífero y localidad EF6, Localidad 6; EF7, Localidad 8; y EF8, Localidades 9,10 y 11.

Comentarios: Estos materiales corresponden a los materiales tipo de la especie Rhexoxylon cortaderitaense, la que también es abundante en la Sección Inferior de la Formación Cortaderita. Los ejemplares de la Sección Superior muestran diferencias con los de la Inferior; siendo de menor tamaño y con menor desarrollo de los tejidos vasculares secundarios centrípetos.

Los primeros ejemplares pertenecientes a esta especie que se encontraron en la Sección Superior de la Formación Cortaderita (BAPb 5410) fueron originalmente descriptos por Menéndez (1956) y denominados como Protophyllocladoxylon cortaderitaensis. Este autor los asignó a ese morfogénero de conífera sobre la base de los caracteres del xilema secundario (leño picnoxílico, radios uniseriados, campos de cruzamiento con una única punteadura simple y ovalada, traqueidas con punteaduras areoladas ligeramente hexagonales con un arreglo alterno). No obstante, en la época en que Menéndez (1956) realizó su contribución, no era bien conocida la anatomía de los ejes de corystospermas. La comprensión de dicha anatomía avanzó significativamente en los años subsiguientes con las contribuciones de Archangelsky y Brett $(1961,1963)$, Brett (1968), Petriella (1981, 1983), Herbst y Lutz (1988, 1995), Zamuner (1991), Meyer-Berthaud et al. (1993), Brea (1995), Artabe et al. (1999b), Artabe y Brea (2003), Artabe y Zamuner (2007).

Por otra parte, los troncos de corystospermas tienen un leño picnoxílico comparable al de las coníferas primitivas. Puntualmente, Kräusel (1949) reconoció una fuerte similitud entre el xilema secundario de Rhexoxylon y el leño tipo Protophyllocladoxylon. Como consecuencia, es muy difícil distinguir uno del otro si sólo se encuentra xilema secundario aislado. Menéndez (1956), aunque tenía un tronco 
completo, solamente estudió, describió e ilustró el leño de los especímenes; lo que resultó en que los autores posteriores no notaran la naturaleza corystospérmica de esos fósiles. Protophyllocladoxylon cortaderitaensis Menéndez 1956 ha sido también mencionada como una conífera primitiva por Schultze-Motel (1961), Vogellehner (1965) y Serra (1966). Lepekhina (1972) consideró a P. cortaderitaense, y el género entero, como un morfotaxón gimnospérmico, no necesariamente restringido a las coníferas.

La especie fue más tarde revisada e incluida en la familia "Protopinaceae" por Vogellehner (1967), quien la recombinó como Protocircoporoxylon cortaderitaense. Además, varias revisiones de la paleoflora de Barreal, realizadas por Bonetti (1963), Stipanicic (1972, 1979), Artabe et al. (1995a, b), Zamuner et al. (1999, 2001) y Artabe et al. (2001a, 2003), señalaron la presencia de troncos de coníferas sobre la base de las descripciones e ilustraciones de Menéndez (1956).

Archangelsky (1990, anotación inédita en la etiqueta de la colección Paleobotánica de Museo Argentino de Ciencias Naturales) revisó el material tipo de Protocircoporoxylon cortaderitaense y notó que probablemente pertenecía a Rhexoxylon. Esta suposición fue confirmada por Bodnar $(2006,2008)$ : el material tipo de Protocircoporoxylon cortaderitaense corresponde a la especie de Rhexoxylon previamente descripta como Rhexoxylon sp. por Lutz y Herbst (1992), también citada como "Rhexoxylon kraeuselii" (Spalletti et al., 1999; Morel et al., 2001; Artabe y Brea, 2003), y “Rhexoxylon sp. A (R. kraeuselii?)" (Zamuner et al., 2001; Morel et al., 2001; Artabe y Brea, 2003). 
Josefina Bodnar - La paleoflora triásica de la Formación Cortaderita ...
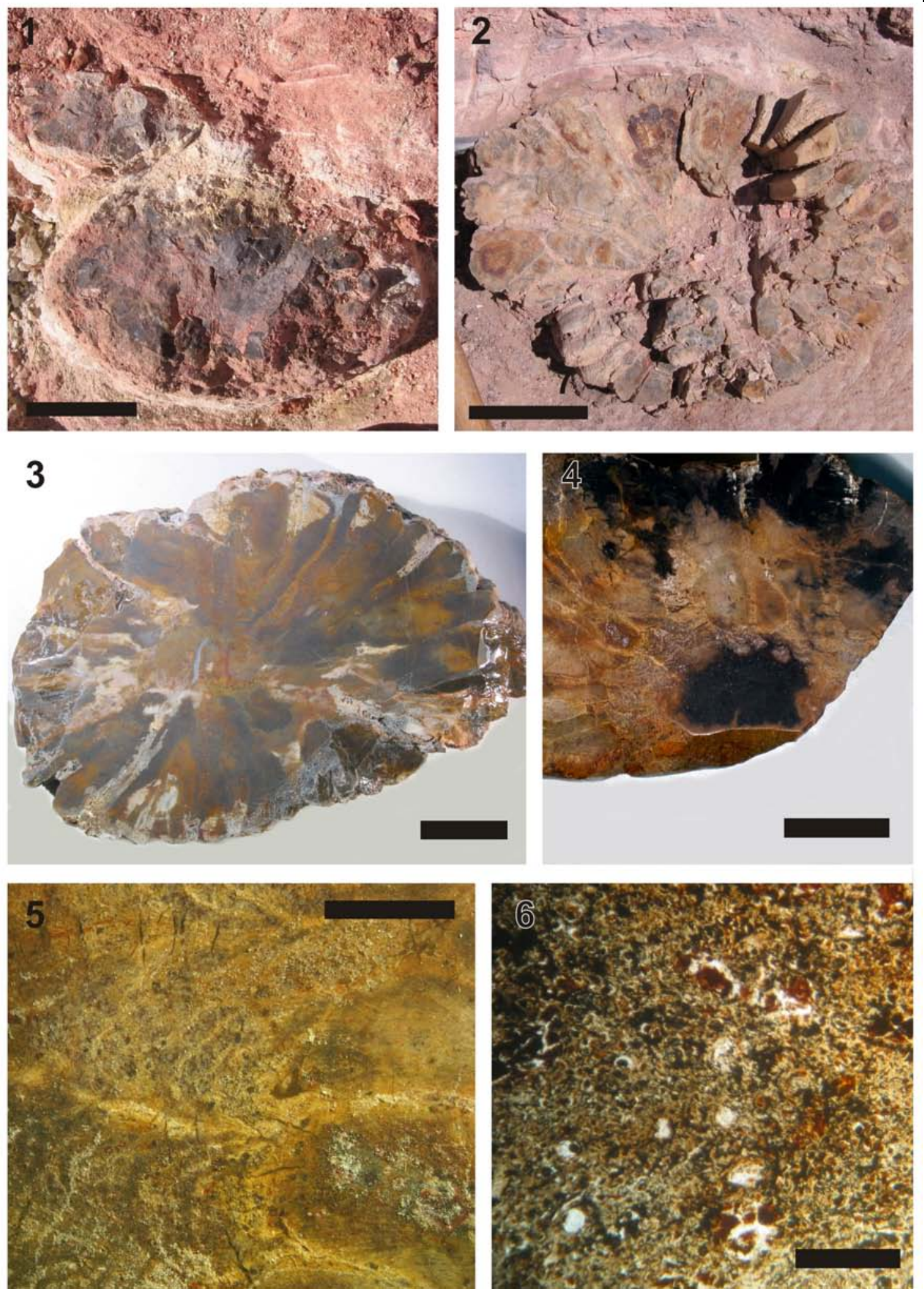

Figura VII.16. Rhexoxylon cortaderitaense (Menéndez) Bodnar 2008. 1. Fotografiado en el campo. Escala: $10 \mathrm{~cm}$. 2. Fotografiado en el campo. Escala. $10 \mathrm{~cm}$. 3. Superficie pulida del aspecto general del cilindro vascular. LPPB 13084 . Escala: $3 \mathrm{~cm}$. 4 . Superficie pulida con la zona perimedular del cilindro vascular. Del centro a la periferia se observa: la médula, el floema centrípeto, el xilema centrípeto y el xilema centrífugo+los radios parenquimatosos. LPPB 13083. Escala: $2 \mathrm{~cm}$. 5. Detalle del floema centrípeto (izquierda) y del xilema centrípeto (derecha). LPPB 13083. Escala: $0,5 \mathrm{~cm}$. 6. Corte transversal de la médula con idioblastos, nidos escleróticos y cavidades secretoras. pmLPPB 1358. Escala: $700 \mu \mathrm{m}$. 

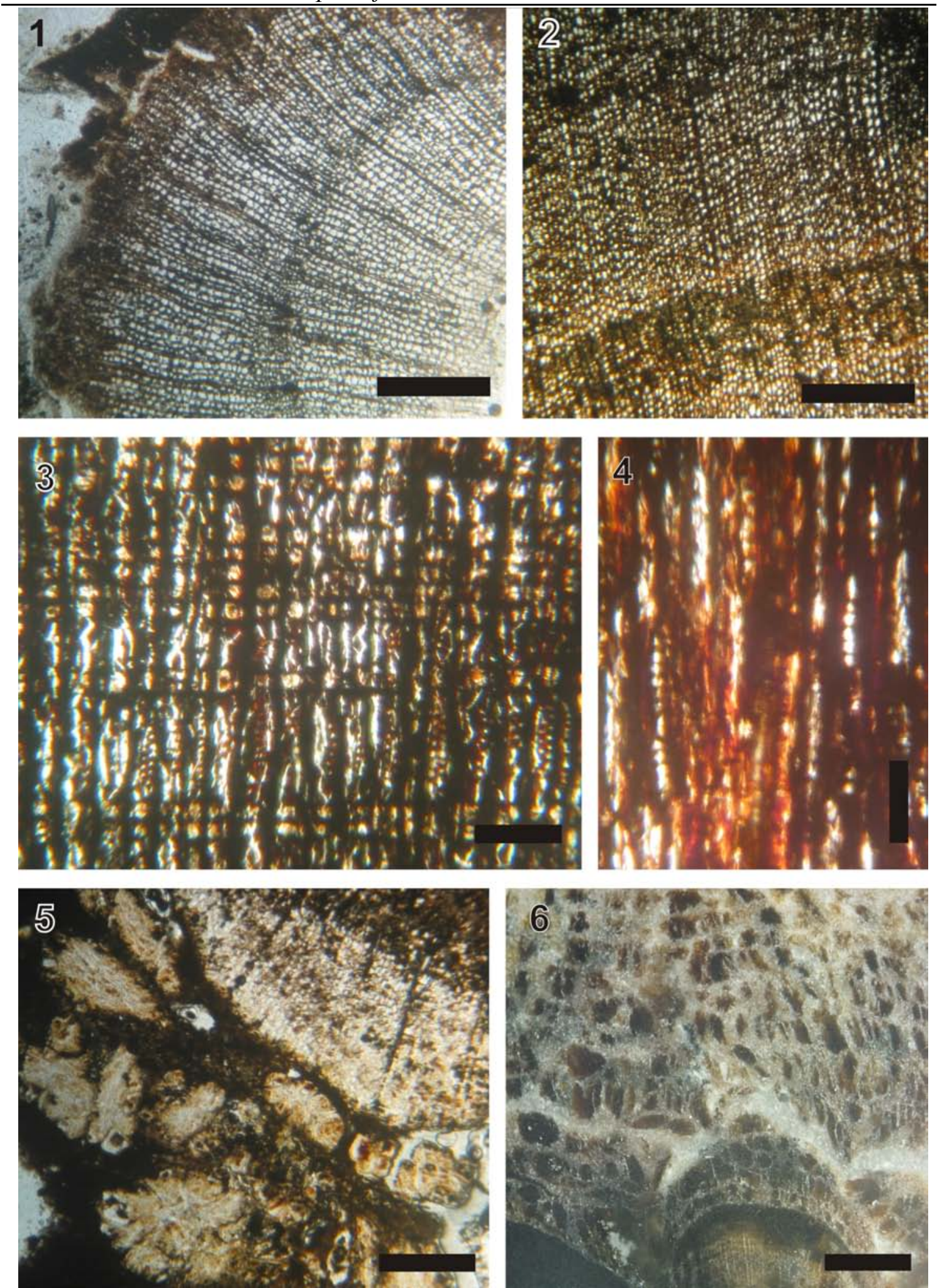

Figura VII.17. Rhexoxylon cortaderitaense (Menéndez) Bodnar 2008. 1. Corte transversal del xilema secundario centrípeto, con anillos de crecimiento. pmLPPB 1358 . Escala: $0,1 \mathrm{~cm}$. 2 . Corte transversal

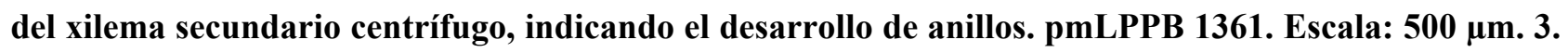
Vista general del corte radial, mostrando campos de cruzamiento fenestriformes y punteaduras biseriadas de las traqueidas. pmLPPB 1359. Escala: $100 \mu \mathrm{m}$. 4. Corte tangencial, con radios homocelulares uniseriados. pmLPPB 1362. Escala: $100 \mu \mathrm{m}$. 5. Corte transversal del borde externo de las cuñas xilemáticas centrífugas y de los haces vasculares de la corteza. pmLPPB 1364. Escala: 600 $\mu \mathrm{m}$. 6. Detalle de una traza rameal y de la zona interna de la corteza con haces vasculares. LPPB 13086. Escala: 0,5cm. - 139 - 


\section{VII.5. Conclusiones sistemáticas}

En el presente estudio de los estratos fosilíferos de la Formación Cortaderita, y en comparación con trabajos previos, se redefinió el esquema estratigráfico de los mismos. Los dos niveles fosilíferos de Bonetti (1963) y los dos estratos definidos por Artabe et al. (1995a), se han reajustado en 8 estratos fosilíferos (EF): cuatro en la Sección Inferior, y cuatro en la Superior.

Los materiales previamente estudiados por Frenguelli (1944a, b, c, d, e, f, g), Menéndez (1956), Bonetti (1963), Stipanicic (1972, 1979), Artabe et al. (1995a), Lutz y Herbst (1992) y Zamuner et al. (1999) fueron revisados, actualizados en su sistemática y reubicados en el nuevo esquema de estratos fosilíferos.

Los materiales vegetales preservados en los EF han sufrido diferentes procesos de fosilización, relacionados siempre con ambientes fluviales influenciados por importante actividad volcánica.

En el cuadro VII.10. se sintetizan los resultados sistemáticos. De estos, cabe destacar que:

1- Los estratos fosilíferos mostraron ser más numerosos que lo propuesto en trabajos anteriores. Los fósiles vegetales de la Formación Cortaderita muestran una distribución muy amplia tanto lateralmente como verticalmente.

2- Todos los ejemplares de troncos permineralizados encontrados hasta ahora pertenecen a la especie Rhexoxylon cortaderitaense, la cual persiste a lo largo de toda la columna estratigráfica de la formación.

3- Es la primera vez que se cita para la formación las Divisiones Marchantiophyta y Bryophyta y las familias Asterothecaceae y Podocarpaceae.

4- De los grupos que ya habían sido mencionados para la formación, las Peltaspermales y las Ginkgoales mostraron una mayor diversidad de la que era conocida en dicha unidad.

5- Se determinaron géneros que no habían sido antes mencionados para la formación: Thallites, Muscites, Rienitsia, Lepidopteris, Delnortea, Ginkgoites, Ginkgodium, Baiera, Rissikia.

6- De las especies nombradas en la presente contribución, es la primera cita de Rienitsia arrondiana, Dicroidium dubium, Pachydermophyllum papillosum, Lepidopteris stormbergensis, L. africana, Delnortea abbottiae, Ginkgoites walckedensis, Sphenobaiera schenckii, S. sectina, Baiera cuyana, Ginkgodium 
nathorsti, Elatocladus plana, Rissikia media y Pseudoctenis longipinnata para la unidad.

7- El hallazgo de materiales posiblemente asignables a Delnortea abbottiae constituye el primer registro de esta especie para el Triásico, ya que únicamente había sido encontrada en el Pérmico Inferior.

8- Se realizó la descripción de una nueva especie de Pseudoctenis, que será publicada válidamente en un trabajo inmediato.

9- Se efectuaron dos nuevas combinaciones: Cordaicarpus mackayi (Arber) comb. nov. y Rochipteris cyclopteroides (Frenguelli) comb. nov.

\begin{tabular}{|c|c|c|c|c|c|c|c|c|}
\hline \multirow{2}{*}{ Taxones } & \multicolumn{8}{|c|}{ Estratos fosilíferos } \\
\hline & 1 & 2 & 3 & 4 & 5 & 6 & 7 & 8 \\
\hline Thallites sp. 1 & & $\mathrm{x}$ & & & & & & \\
\hline Thallites $\mathrm{sp} .2$ & & $\mathrm{x}$ & & & & & & \\
\hline Muscites sp. & & $\mathrm{x}$ & & & & & & \\
\hline Lepidanthium sporiferum (Feistmantel) Frenguelli 1944b & & $\mathrm{x}$ & & & & & & \\
\hline Neocalamites sp. & & $\mathrm{x}$ & & & & & & \\
\hline Equisetites fertilis Frenguelli $1944 \mathrm{c}$ & & $\mathrm{x}$ & & & & & & \\
\hline Phylloteca australis Brongniart $1828 \mathrm{a}$ & & $\mathrm{x}$ & & & & & & \\
\hline Cf. Rienitsia arrondiana Herbst $1979 \mathrm{~b}$ & & $\mathrm{x}$ & & & & & & \\
\hline Cladophlebis mendozaensis (Geinitz) Frenguelli 1947 & & $\mathrm{x}$ & & & $\mathrm{x}$ & & & \\
\hline Cladophlebis sp. & & $\mathrm{x}$ & & & & & & \\
\hline $\begin{array}{l}\text { Dictyophyllum tenuifolium Stipanicic et Menéndez emend. Bonetti et Herbst } \\
1964\end{array}$ & & $\mathrm{x}$ & $\mathrm{x}$ & & & & & \\
\hline Coniopteris? sp. & & $\mathrm{x}$ & & & & & & \\
\hline Dicroidium dubium (Feistmantel) Gothan 1912 & & $\mathrm{x}$ & $\mathrm{x}$ & & & & & \\
\hline D. odontopteroides (Morris) Gothan 1912 & & $\mathrm{x}$ & $\mathrm{x}$ & & $\mathrm{x}$ & & & \\
\hline D. lancifolium (Morris) Gothan 1912 & & $\mathrm{x}$ & $\mathrm{x}$ & & $\mathrm{x}$ & & & \\
\hline D. crassum (Menéndez) Petriella 1979 & & $\mathrm{x}$ & & & & & & \\
\hline $\begin{array}{l}\text { Cf. Dicroidium argenteum (Retallack) Gnaedinger in Gnaedinger et Herbst } \\
2001\end{array}$ & & $\mathrm{x}$ & & & & & & \\
\hline Zuberia. feistmanteli (Johnston) Frenguelli emend. Artabe 1990 & & & & & & $\mathrm{x}$ & & \\
\hline Z. papillata (Townrow.) Artabe 1990 & & $\mathrm{x}$ & & & & & & \\
\hline Z. zuberi (Szajnocha) Frenguelli 1943 & & $\mathrm{x}$ & & & & & & \\
\hline Z. barrealensis Frenguelli 1943 & & $\mathrm{x}$ & & & & & & \\
\hline Johnstonia stelzneriana (Geinitz) Frenguelli 1943 & & $\mathrm{x}$ & & & & & & \\
\hline Xylopteris argentina (Kurtz) Frenguelli1943 & & $\mathrm{x}$ & & & & & & \\
\hline X. elongata (Carruthers) Frenguelli 1943 & & $\mathrm{x}$ & & & & & & \\
\hline Pteruchus barrealensis (Frenguelli) Holmes et Ash 1979 & & & & & $\mathrm{x}$ & & & \\
\hline \multicolumn{9}{|l|}{ Umkomasia macleani Thomas 1933} \\
\hline Rhexoxylon cortaderitaense (Menéndez) Bodnar 2008 & & $\mathrm{x}$ & $\mathrm{x}$ & $\mathrm{x}$ & & $\mathrm{x}$ & $\mathrm{x}$ & $\mathrm{x}$ \\
\hline Scytophyllum bonettiae Zamuner, Artabe et Ganuza 1999 & $\mathrm{x}$ & $\mathrm{x}$ & & & $\mathrm{x}$ & & & \\
\hline Peltaspermun sp. & $\mathrm{x}$ & & & & & & & \\
\hline Pachydermophyllum praecordillerae (Frenguelli) Retallack 1981 & & & $\mathrm{x}$ & & & & & \\
\hline P. papillosum Thomas et Bose 1955 & & $\mathrm{x}$ & $\mathrm{x}$ & & $\mathrm{x}$ & & & \\
\hline Lepidopteris stormbergensis (Seward) Townrow 1956 & & & $\mathrm{x}$ & & $\mathrm{x}$ & & & \\
\hline L. africana (Du Toit) Holmes 1982 & & & & & $\mathrm{x}$ & & & \\
\hline Cf. Delnortea abbottiae Mamay, Miller, Rohr et Stein 1986 & & & $\mathrm{x}$ & & & & & \\
\hline Cordaicarpus mackayi (Arber) comb. nov. & & $\mathrm{x}$ & & & $\mathrm{x}$ & & & \\
\hline
\end{tabular}


Josefina Bodnar - La paleoflora triásica de la Formación Cortaderita...

\begin{tabular}{|c|c|c|c|c|c|c|}
\hline Pseudoctenis ctenophylloides Bonetti 1968 & & & & $\mathrm{x}$ & & \\
\hline P. longipinnata Anderson et Anderson 1989 & & & & $\mathrm{x}$ & & \\
\hline P. falconeriana Bonetti 1968 & & $\mathrm{x}$ & & & & \\
\hline P. anomozamoides Bonetti 1968 & & $\mathrm{x}$ & & & & \\
\hline Pseudoctenis sp. nov. & $\mathrm{x}$ & $\mathrm{x}$ & & & & \\
\hline Ginkgoites waldeckensis (Anderson et Anderson) Troncoso et Herbst 1999 & & $\mathrm{x}$ & & & & \\
\hline Sphenobaiera sectina Anderson et Anderson 1989 & & $\mathrm{x}$ & & & & \\
\hline S. schenkii (Feistmantel) Florin 1936 & & $\mathrm{x}$ & & & & \\
\hline S. argentinae (Kurtz) Florin 1940 & & $\mathrm{x}$ & & $\mathrm{x}$ & & \\
\hline S. stormbergensis (Seward) Frenguelli 1948 & & $\mathrm{x}$ & & $\mathrm{x}$ & & \\
\hline Baiera cuyana Frenguelli 1942a & & & $\mathrm{x}$ & & & \\
\hline Ginkgodium nathorsti Yokoyama 1889 & & & & $\mathrm{x}$ & & \\
\hline Yabeiella brackebuschiana (Kurtz) Ôishi 1931 & & $\mathrm{x}$ & & $\mathrm{x}$ & & \\
\hline Y. spathulata Ôishi 1931 & & $\mathrm{x}$ & & & & \\
\hline Y. wielandi Ôishi 1931 & & $\mathrm{x}$ & & & & \\
\hline Y. mareyesiaca (Geinitz) Ôishi 1931 & & $\mathrm{x}$ & & $\mathrm{x}$ & & \\
\hline Taeniopteris carruthersi Tenison-Woods 1883 & & $\mathrm{x}$ & & & & \\
\hline T. macclellandi Oldham et Morris 1862 & & $\mathrm{x}$ & & & & \\
\hline T. plicatella (Solms) Menéndez 1950 & & $\mathrm{x}$ & & & & \\
\hline Rochipteris cyclopteroides (Frenguelli) comb. nov. & & $\mathrm{x}$ & & & & \\
\hline Kurtziana cacheutensis (Kurtz) Frenguelli emend. Petriella et Arrondo 1982 & & $\mathrm{x}$ & & $\mathrm{x}$ & & \\
\hline Heidiphyllum elongatum (Morris) Retallack 1981 & & $\mathrm{x}$ & & & & \\
\hline H. clarifolium Anderson et Anderson 1989 & & $\mathrm{x}$ & & & & \\
\hline H. minutifolium Anderson et Anderson 1989 & & & $\mathrm{x}$ & & & \\
\hline Fraxinopsis andium (Frenguelli) Anderson et Anderson 2003 & & $\mathrm{x}$ & & & & \\
\hline Rissikia media (Tenison-Woods) Townrow 1967 & & & $\mathrm{x}$ & & & \\
\hline Elatocladus plana (Feistmantel) Seward 1919 & & $\mathrm{x}$ & & & & \\
\hline Pagiophyllum sp. & & $\mathrm{x}$ & & & & \\
\hline Linguifolium sp. & & $\mathrm{x}$ & & & & \\
\hline
\end{tabular}

\section{Cuadro VII.10. Taxones reconocidos en cada EF de la Formación Cortaderita.}




\section{ANÁLISIS FILOGENÉTICO DE LAS CORYSTOSPERMACEAE, UTILIZANDO CARACTERES CAULINARES}

\section{VIII.1. Introducción}

El método cladístico es ampliamente empleado para reconstruir la historia filogenética de los organismos. El primer paso fundamental hacia una mejor comprensión de la evolución de las plantas es el desarrollo de una estimación detallada de su filogenia. Es imposible alcanzar un adecuado conocimiento de las relaciones filogenéticas de las plantas sin tener en cuenta la diversidad adicional brindada por las plantas fósiles (Crane et al., 2004).

Sin embargo, subsisten algunas reticencias a incorporar taxones fósiles en los análisis cladísticos del Reino Chlorobiota. Los potenciales problemas de los taxones fósiles son: la gran cantidad de datos faltantes y ciertas incertidumbres acerca de la homología de partes vegetales (Nixon, 1996). Una dificultad importante, al menos para las plantas fósiles de mayor porte y mayor complejidad (e.g., arbustos y árboles), es que los diferentes órganos derivados de la misma planta viva raramente son hallados en conexión en las tafocenosis. De este modo, aunque las hojas, semillas, granos de polen, tallos y otras partes de las plantas fósiles pueden estar muy bien preservadas, es difícil determinar cuáles de estas partes dispersas pertenecen a la misma especie fósil (Crane et al., 2004).

No obstante, la construcción modular de las plantas permite realizar análisis evolutivos en las partes individuales por separado (Mosbrugger, 1995; Raff y Raff, 2000; Olson y Rosell, 2006).

Si bien los vegetales fósiles son más pobremente conocidos que sus contrapartes vivientes, en algunas ocasiones son descubiertos con un grado de preservación excelente. Esos casos, entre los que se encuentran los tallos permineralizados, ofrecen un nivel de detalle estructural que no puede ser recuperado de plantas vivientes sin una inversión significativa de tiempo y esfuerzo (Crane et al., 2004).

Por muchos años, hemos tenido ideas generales acerca del origen de las novedades evolutivas centrales de las plantas, pero sin la información complementaria otorgada por las plantas fósiles es imposible desarrollar una interpretación más profunda y específica, puesto que nuestro conocimiento de los procesos implicados es 
incompleto. Estamos atrapados en una paradoja: los taxones actuales pueden ser estudiados en un detalle enorme, pero en algunas ramas del árbol de la vida vegetal son muy escasos los ejemplares vivientes de toda la diversidad que la que ha existido en el pasado (Crane et al., 2004). Las gimnospermas, hoy representadas por los grupos relictuales de las coníferas, ginkgoales, cycadales y gnetales, eran extremadamente más diversas en el pasado. Entre las gimnospermas extintas se puede trazar la aparición de las novedades evolutivas cruciales de las espermatofitas, de ahí la importancia de estudiar en detalle su morfología, anatomía y relaciones filogenéticas.

El muestreo extensivo de taxones, incluidos los taxones fósiles, mejora los resultados e incrementa el contenido empírico de los análisis filogenéticos. Además, varios análisis han demostrado que los fósiles se encuentran entre los taxones con mayor influencia para la resolución de los cladogramas. Avances metodológicos recientes han indicado posibles maneras de evadir las dificultades asociadas a la inclusión de plantas fósiles en los análisis cladísticos (e.g. el concepto de "homología dinámica" y el método PCR=Reduced Positional Congruence) (Escapa el al. 2009).

Entre los grupos vegetales extintos, se considera que las "pteridospermas" tienen una influencia fuerte en la topología de los árboles filogenéticos de las plantas con semilla. A pesar de que no conforman un clado monofilético, representan un plexo de gimnospermas del que derivan grupos monofiléticos más definidos. Además, la incorporación de las "pteridospermas" a los cladogramas permite dilucidar los patrones de adquisición de caracteres morfológicos, siendo cruciales para entender las relaciones de las espermatofitas (Hilton y Bateman, 2006).

El estudio de las relaciones filogenéticas de las Corystospermaceae es particularmente relevante por su calidad de grupo totalmente extinto, perteneciente a las “pteridospermas" mesozoicas, y su papel fundamental en las paleocomunidades triásicas gondwánicas. Las particularidades anatómicas de los tallos de Corystospermaceae incluyen innovaciones morfoanatómicas de importancia evolutiva para todas las espermatofitas. El excelente grado de preservación de sus tallos fósiles permite codificar una cantidad adecuada de caracteres, para efectuar un análisis filogenético sobre la base de rasgos caulinares.

Los caracteres anatómicos de los tallos han sido una fuente importante de caracteres informativos en cuanto a la sistemática (Herendeen y Miller, 2000). Los atributos xilológicos han sido incluidos en varios análisis cladísticos; algunos de los que sólo utilizan este tipo de caracteres (Baas y Zweypfenning, 1978; Baas et al., 1988; 
Zhang, 1992; Gasson, 1994, 1996; Terrazas, 1994; Noshiro y Baas, 1998; Klaassen, 1999), mientras que otros combinan la anatomía del leño con otros rasgos morfológicos y anatómicos (Anderberg, 1992; Hufford, 1992; Hufford y Dickison, 1992; Graham et al., 1993; Keller et al., 1996).

No obstante, las características del crecimiento secundario caulinar no son empleadas tan habitualmente como lo esperado. La anatomía comparativa del leño tiene mucho que aportar, desde la utilidad práctica de la identificación de la madera hasta revelar caracteres únicos que diagnostican clados (Olson, 2005).

Por otra parte, un análisis detallado de los trabajos sobre la filogenia de las espermatofitas demuestra que no se ha realizado una evaluación clara de algunos de los caracteres que presentan los tallos de las corystospermas (Artabe y Brea, 2007).

A la luz se los nuevos estudios anatómicos de las corystospermas y otras gimnospermas cuya anatomía caulinar es comparable (Artabe y Brea, 2003; Artabe et al., 2005; Artabe y Zamuner, 2007; Bodnar, 2008), se realizó una aproximación filogenética de los taxones de tallos de las Corystospermaceae, familia que representa el principal componente arbóreo de la paleoflora de la Formación Cortaderita.

\section{VIII.2. Elección del out-group}

La presencia de un crecimiento secundario caulinar atípico relaciona a las corystospermas con las medullosales y cycadales, $y$ se ha propuesto que las corystospermas y las cycadales podrían haberse originado de un precursor tipo Medullosa o similar (Petriella, 1981; Artabe y Brea, 2003; Artabe et al., 2005).

Sin bien la vinculación de las Medullosales con las Cycadales ha sido postulada por muchos investigadores (Worsdell, 1906; Delevoryas, 1955; Stewart y Rothwell, 1993) sólo en algunos análisis cladísticos estos grupos aparecen directamente relacionados, y se agrupan en el mismo clado (Crane, 1985). Generalmente, las Medullosales aparecen como basales del resto de las espermatofitas con verdadero óvulo (Nixon et al., 1994; Rothwell y Serbet, 1994). Debido a esta posición, se ha utilizado a un taxón de las Medullosales como grupo externo. Se eligió a Medullosa noei Steidtmann 1937, puesto que tiene un patrón caulinar polixílico bastante generalizado.

Petriella (1981), Meyen (1987) y Artabe y Brea (2003) postularon que las corystospermas estarían más estrechamente relacionadas con las peltaspermas. En los análisis filogenéticos no aparecen estos dos grupos formando un clado (Doyle y 
Donoghue, 1986; Nixon et al., 1994; Axsmith et al., 2000; Rothwell et al., 2009). Además, las peltaspermas presentan la dificultad de que no se conocen los tallos preservados, por lo que no pudieron ser incluidas en el grupo externo de este análisis.

Crane (1985) y Doyle y Donoghue (1992) resuelven a las corystospermas como el sister group del clado "antofítico" (Bennettitales, Pentoxylales, Gnetales y angiospermas). No se toma en cuenta esta postura, ya que con los recientes estudios filogenéticos ha quedado en desuso el concepto del clado antofítico (Chaw et al., 2000; Bowe, 2000; Rothwell et al., 2009).

En otros análisis cladísticos de plantas con semilla (Doyle y Donoghue, 1986; Nixon et al., 1994; Axsmith et al., 2000; Hilton y Bateman, 2006) las corystospermas se ubican junto con las Cycadales y las Peltaspermales, por fuera del crown group de las espermatofitas (coniferofitas y angiospermas). En el esquema filogenético de Axmisth et al. (2000) -modificación de la matriz de Nixon et al. (1994)- aparecen las Callistophytales como ancestro común más cercano al grupo corystospermas + cycadales + peltaspermas + coniferofitas + angiospermas. Siguiendo esta hipótesis, se agregó como grupo externo a Callistophyton poroxyloides Delevoryas et Morgan 1954.

En oposición a las propuestas del origen extragondwánico de las corystospermas (Petriella, 1981; Retallack, 1977; Meyen, 1987), Archangelsky (1996) postuló que Botrychiopsis Kurtz emend. Archangelsky y Arrondo 1971 probablemente perteneciera al grupo de pteridospermas ancestrales de las que podrían haber evolucionado las corystospermas mesozoicas. Aunque algunos caracteres morfológicos de las frondes y las pocas fructificaciones conocidas son comparables, no se han encontrado todavía los tallos de Botrychiopsis (Artabe y Brea, 2003). Hallazgos recientes de troncos carboníferos de Argentina, que presentan una anatomía atípica del cilindro vascular secundario (Césari et al., 2005), podrían ayudar a dilucidar el origen de la anatomía caulinar de corystospermas. Estos tallos fueron asignados al género monotípico Amosioxylon Césari, Vega et Archangelsky 2005, e interpretados como una pteridosperma paleozoica primitiva del Gondwana perteneciente probablemente a la familia Austrocalyxaceae (Vega y Archangelsky, 2001; Césari et al., 2005). Por todo esto, se agregó a Amosioxylon australis Césari, Vega et Archangelsky 2005 al grupo externo de las corystospermas. 


\section{VIII.3. Definición del in-group}

Las corystospermas fueron descriptas originalmente por Thomas (1933), y desde su descripción original, quizás se hayan convertido en el grupo más conocido de “pteridospermas" mesozoicas (Taylor et al., 2006).

Thomas (1933) describió a las frondes bifurcadas (Dicroidium), los órganos ovulados (Umkomasia, Pilophorosperma, Spermatocodon) y los órganos microsporangiados (Pteruchus), que fueron vinculados sobre la base de la asociación íntima en las mismas capas sedimentarias de la Formación Molteno (Triásico Superior de Sudáfrica), las semejanzas cuticulares, y la presencia de granos del polen bisacados en las cúpulas y semillas. Sin embargo, Thomas (1933) no había encontrado ningún eje caulinar con anatomía preservada en asociación con las plantas de Molteno. Fue Archangelsky (1968) el primero que relacionó troncos permineralizados a las corystospemas, sustentándose en la coexistencia de Rhexoxylon pianitzkyi (tallos) con hojas de "Dicroidium zuberi" (=Zuberia zuberi) en la Formación Ischigualasto (Triásico Superior de Argentina). Esta vinculación ha sido apoyada por diversos autores en los años subsiguientes (Petriella, 1978; Retallack y Dilcher, 1988; Zamuner, 1991; Artabe y Brea, 2003, 2007). Meyer-Berthaud et al. (1992, 1993) describieron una reconstrucción adicional de las corystospermas, proveniente de la Formación Fremouw (Triásico Medio de Antártida). Estos autores relacionaron tallos de Kykloxylon fremouwense con hojas de Dicroidium fremouwense, utilizando la presencia de cavidades secretoras distintivas en los dos tipos de órganos (Taylor, 1996; Klavins et al., 2002).

Aquí se considera que el concepto de "corystosperma" abarca plantas con un hábito arbustivo, o arbóreo escasamente ramificado (Figura VIII.1.1) o profusamente ramificado de manera monopodial (Figura VIII.1.2), hojas pinnadas con el raquis comúnmente bifurcado (Figura VIII.1.3), troncos con leño picnoxílico y un crecimiento secundario generalmente atípico (Figura VIII.1.4), órganos ovulíferos cupulados (Figura VIII.1.5), sacos polínicos dispuestos en un sistema ramificado (Figura VIII.1.6 y 7) y granos de polen bisacados (Figura VIII.1.8).

Hasta el momento, se conocen quince especies de troncos de Corystospermaceae: Antarcticoxylon preistleyi Seward 1914 (Formación Irati, Grupo Estrada Nova, Pérmico, Estado de Saô Pablo, Brasil, y Formación Molteno, Grupo Stormberg, Triásico Medio a Tardío, Natal, Sudáfrica) (Walton, 1923; Mussa, 1980), Cuneumxylon spallettii Artabe et Brea 2003 (Formación Paramillo, Grupo Uspallata, Triásico Medio, provincia de 
Mendoza, Argentina), Elchaxylon zavattieriae Artabe et Zamuner 2007 (Formación Río Blanco, Grupo Uspallata, Triásico Tardío, provincia de Mendoza, Argentina), Jeffersonioxylon gordonense del Fueyo, Taylor, Taylor et Cúneo 1995 (Formación Fremouw, Supergrupo Beacon, Triásico Medio, Antártida), Kykloxylon fremouwense Meyer-Berthaud, Taylor et Taylor 1993 (Formación Fremouw, Supergrupo Beacon, Triásico Medio, Antártida), Rhexoxylon africanum Bancroft 1913 emend. Walton 1923 (Formación Elliot Inferior? o "red beds", Grupo Stormberg, Triásico Tardío o Jurásico Temprano?, provincia del Cabo, Sudáfrica), R. brasilense Herbst et Lutz 1988 (Formación Caturrita, Grupo Rosário do Sul, Triásico Tardío, Rio Grande do Sul, Brasil), R. brunoi Artabe, Brea et Zamuner 1999b (Formacion Los Colorados, Grupo Uspallata, Triásico Tardío, provincia de Mendoza, Argentina), R. cortaderitaense (Menéndez) Bodnar 2008 (Formación Cortaderita, Grupo Sorocayense, Triásico Medio a Tardío, provincia de San Juan, Argentina), R. piatnitzkyi Archangelsky et Brett 1961 emend. Brett 1968 (Formación Ischigualasto, Grupo Agua de La Peña, Triásico Tardío, provincia de San Juan, Argentina), R. tetrapteridoides Walton 1923 emend. Archangelsky et Brett 1961 (Formación Molteno, Grupo Stormberg, Triásico Medio a Tardío, Natal, Sudáfrica), Rhexoxylon sp. (Formación Fremouw, Supergrupo Beacon, Triásico Medio, Antártida) (Taylor, 1992), Tranquiloxylon petriellai Herbst et Lutz 1995 (Formación Laguna Colorada, Grupo El Tranquilo, Triásico Tardío, provincia de Santa Cruz, Argentina), Tranquiloxylon sp. A (Formación El Alcázar, Grupo Sorocayense, Triásico Medio a Tardío, provincia de San Juan, Argentina) (Ganuza et al., 1998), y Tranquiloxylon sp. (Formación Pular, Triásico Medio a Tardío, Región de Antofagasta, Chile) (Chong Díaz et al., 1997; Niemeyer et al, 2008).

Fueron excluidas de este análisis: Antarcticoxylon, debido a las controversias acerca de la circunscripción de este género; Rhexoxylon sp., ya que no se conoce la organización del sistema medular; y Tranquiloxylon sp. A y Tranquiloxylon sp., puesto que su anatomía no ha sido estudiada en detalle. Jeffersonioxylon y Kykloxylon son tratados como un único taxón terminal porque representarían la misma planta.

\section{VIII.4. Posición filogenética de las corystospermas}

Las corystospermas generalmente son incluidas en los análisis filogenéticos como un único taxón terminal compuesto por varios morfogéneros. Así, Crane (1985), Doyle y Donoghue (1986, 1987, 1992), codifican a las corystospermas como plantas que abarcan a los taxones Dicroidium, Rhexoxylon, Pteruchus y Umkomasia, interpretando a las 
estructuras reproductivas como homólogas de las hojas (megasporofilos/microsporofilos) (sensu Townrow, 1962). Rothwell y Serbet (1994) consideran a la reconstrucción de Dicroidium realizada para la Antártida, teniendo en cuenta la asociación Dadoxylon/Dicroidium sumado a las estructuras reproductivas: Pteruchus y Umkomasia; incluyen además, atributos de las Petriellales en las estructuras reproductivas femeninas (cf. Doyle, 1996; Taylor et al., 2006). Hilton y Bateman (2006) siguen el criterio de Crane (1985) y Doyle (1996), y agregan detalles de la anatomía del leño de Meyer Berthaud et al. (1993), del hábito señalado por Axsmith et al. (2000) para las corystospermas y los datos de las estructuras reproductivas de Klavins et al. (2002).

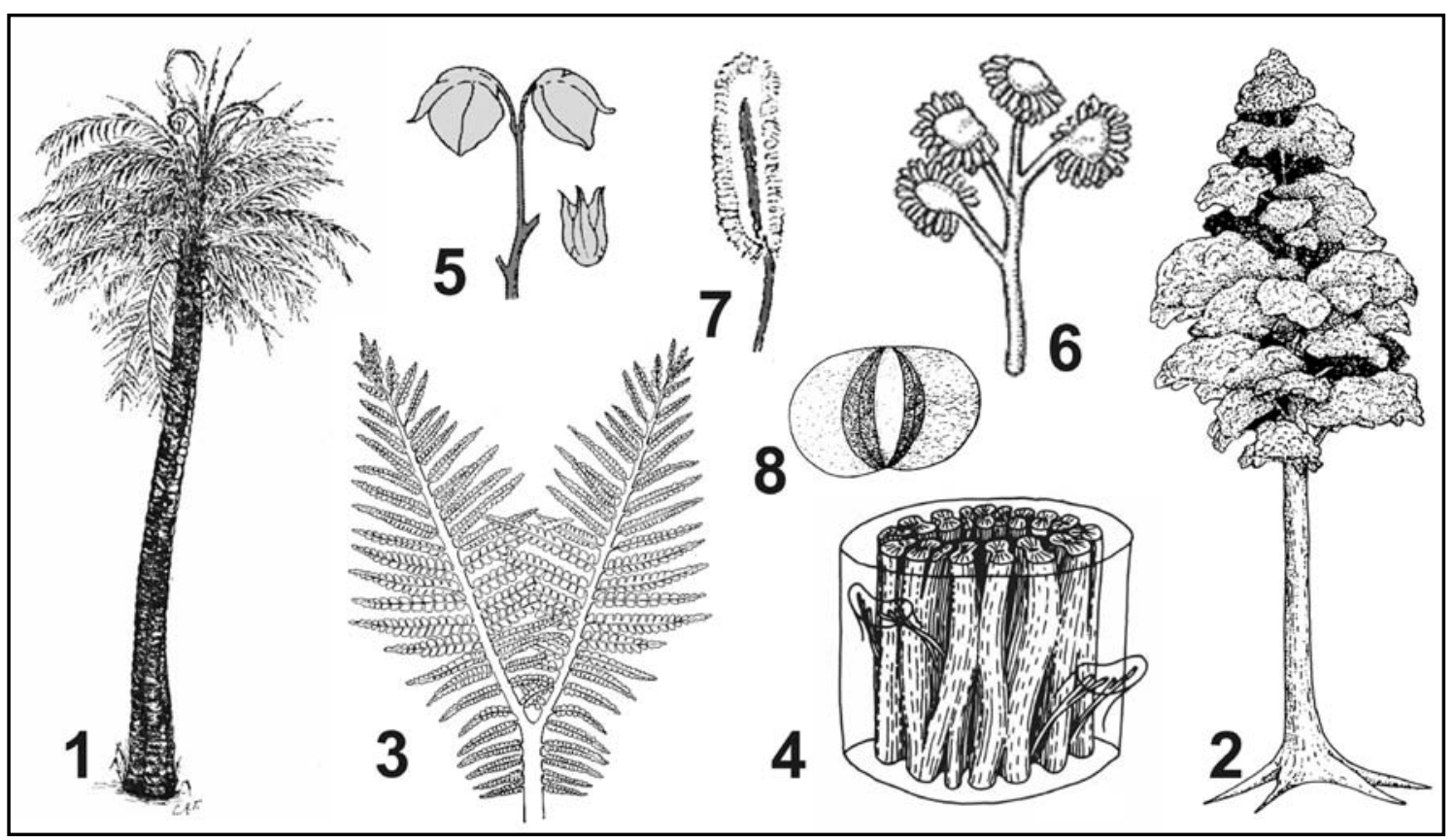

Figura VIII.1. Hábito y órganos de las corystospermas. 1. Reconstrucción efectuada por Petriella (1978). 2. Reconstrucción efectuada por Meyer-Berthaud et al. (1992, 1993). 3. Hoja típica de Zuberia. 4. Sección de un tronco de Rhexoxylon. 5. Esquema del órgano ovulífero correspondiente a Umkomasia. 6. Dibujo del órgano polínico perteneciente a Pteruchus. 7. Detalle de un microsporofilo. 8. Grano de polen asignable a Alisporites (Modificado de Petriella, 1978; Retallack y Dilcher, 1988; Stewart y Rothwell, 1993; Zamuner et al., 2001; Taylor et al. 2006).

Artabe y Brea (2007) realizaron una revisión de los diferentes criterios para tratar a las características de los tallos de corystospermas en los trabajos cladísticos. La mayoría de los estudios filogenéticos utilizan al tipo de estela como un carácter informativo. Crane (1985) considera solamente el tipo estelar, y codifica a la Medullosales como protostélicas mientras que a las Cycadales y a las Corystospermales como eustélicas. Para designar las 
particularidades que presentan Medullosales, Cycadales y Corystospermales -i.e. el desarrollo de xilema secundario inverso y polixilia- Doyle y Donoghue $(1986,1992)$ consideran al carácter del tipo estelar con tres estados: protostela (0), eustela con xilema secundario solamente externo (1), y eustela con xilema secundario interno (2). Estos autores codifican a las Medullosales como protostélicas, a las Cycadales como eustélicas con xilema secundario externo solamente y a las Corystospermales como eustélicas con xilema secundario interno. Rothwell y Serbet (1994) desglosan este carácter en dos, y consideran al tipo de estela: carácter 16 (protostela 0 , eustela 1) y a la distribución del xilema secundario: carácter 19 (xilema secundario sólo externo 0, xilema secundario externo e interno 1). En cuanto al desarrollo del xilema secundario "interno" lo señalan en Medullosa, pero no en Cycadales y Corystospermales. Nixon et al. (1994) codifican el tipo estelar como: protostela 0 , eustela 1, polistela 2, y consideran a las Medullosaceae y Cycadaceae como polistélicas y a las Zamiaceae, Stangeriaceae y Corystospermales como eustélicas. En un nuevo estudio filogenético, Doyle (1996) elimina el carácter presencia de xilema inverso (ausente/presente) de Rothwell y Serbet (1994) debido a que lo considera polimórfico en Medullosales (presente en Medullosa, pero no en Quaestora), en Cycadales y Corystospermales. Por último Hilton y Bateman (2006) utilizan el tipo estelar y el desarrollo de "polistelia" como caracteres diferentes y consideran que la polistelia está presente en Medullosa y Cycadaceae, y ausente en Zamiaceae y Corystospermales. Como resultado de este análisis, Artabe y Brea (2007) concluyen que los autores no utilizan conceptos equivalentes del grupo y de las características anatómicas de las corystospermas. Otro problema más general que señalan las autoras es el sesgo en la utilización de los caracteres caulinares de las Medullosales, Corystospermales y Cycadales: sólo algunas propuestas tienen en cuenta el desarrollo de xilema secundario inverso (Rothwell y Serbet, 1994; Hilton y Bateman, 2006), y ningún análisis considera el desarrollo de polixilia centrífuga, sistema medular y polixilia centrípeta (Artabe y Brea, 2007).

\section{VIII.5. Caracteres utilizados}

Como hay controversias acerca de la terminología de la anatomía caulinar resultante de la actividad cambial atípica, en primer lugar se aclarará de manera detallada el criterio con el que se utiliza aquí cada término y concepto.

El crecimiento secundario atípico de Rhexoxylon, Tranquiloxylon, Cuneumxylon y Elchaxylon genera un cilindro vascular secundario disecto y tejidos vasculares de desarrollo y posición inusuales. Esto es causado por cuatro clases de desviación de la 
actividad cambial típica: 1. actividad diferencial a lo largo de la circunferencia de los ejes -lo que resulta en un cilindro vascular radialmente fragmentado por radios parenquimatosos; 2. actividad remanente, que conduce a la formación de abundante parénquima de dilatación -originando un cilindro vascular tangencialmente fragmentado-; 3. cámbium inverso o centrípeto -que desarrolla tejidos vasculares hacia la médula-; y 4. cámbium es supernumerarios inversos y/o normales (polixilia)-que conduce a la presencia de varios ciclos de xilema y floema secundarios (Archangelsky y Brett, 1961; Zamuner, 1991; Artabe et al., 1999b; Artabe y Brea, 2003). El patrón anatómico más complejo del tronco de una corystosperma consiste en (Figura VII.2): un sistema vascular cilíndrico constituido por cuñas de tejidos secundarios centrífugos separados por radios parenquimatosos, con varios ciclos de floema y xilema secundarios, y un sistema vascular medular, separado del cilíndrico por parénquima de dilatación, que comprende uno o más ciclos de haces perimedulares dobles (i.e. tejidos centrípetos + tejidos centrífugos).

Los radios parenquimatosos son radios secundarios constituidos por células parenquimáticas isodiamétricas, idioblastos y nidos escleróticos (=grupo de esclereidas) y originados a partir de las células cambiales interfasciculares. Dividen al cilindro vascular secundario en cuñas.

Se habla de dos sistemas vasculares debido a la presencia de más de un cámbium (=polixilia) que genera varios ciclos de xilema y floema secundarios. Estos cámbium es supernumerarios o sucesivos, pueden formar anillos o estar interrumpidos y conformar arcos aislados discordantes o concordantes. La polixilia puede ser centrífuga o centrípeta. La polixila centrífuga genera varios ciclos de floema y xilema secundarios que crecen hacia la corteza. La polixilia centrípeta origina floema y xilema secundarios hacia la médula.

Cuando los tejidos centrífugos van creciendo, se separan de los centrípetos por la aparición de parénquima de dilatación, que es un tejido secundario con células semejantes a las de los radios parenquimatosos y es el resultado de la actividad cambial remanente, provocada por células parenquimáticas que reanudan sus divisiones mitóticas.

Una vez separados los tejidos centrípetos de los centrífugos, en el borde externo de los centrípetos aparece un nuevo ciclo de tejidos centrífugos, constituyendo haces perimedulares dobles. Sólo cuando hay haces perimedulares dobles, con una porción 
centrípeta y una porción centrífuga, se habla de un sistema vascular medular independiente del cilíndrico.

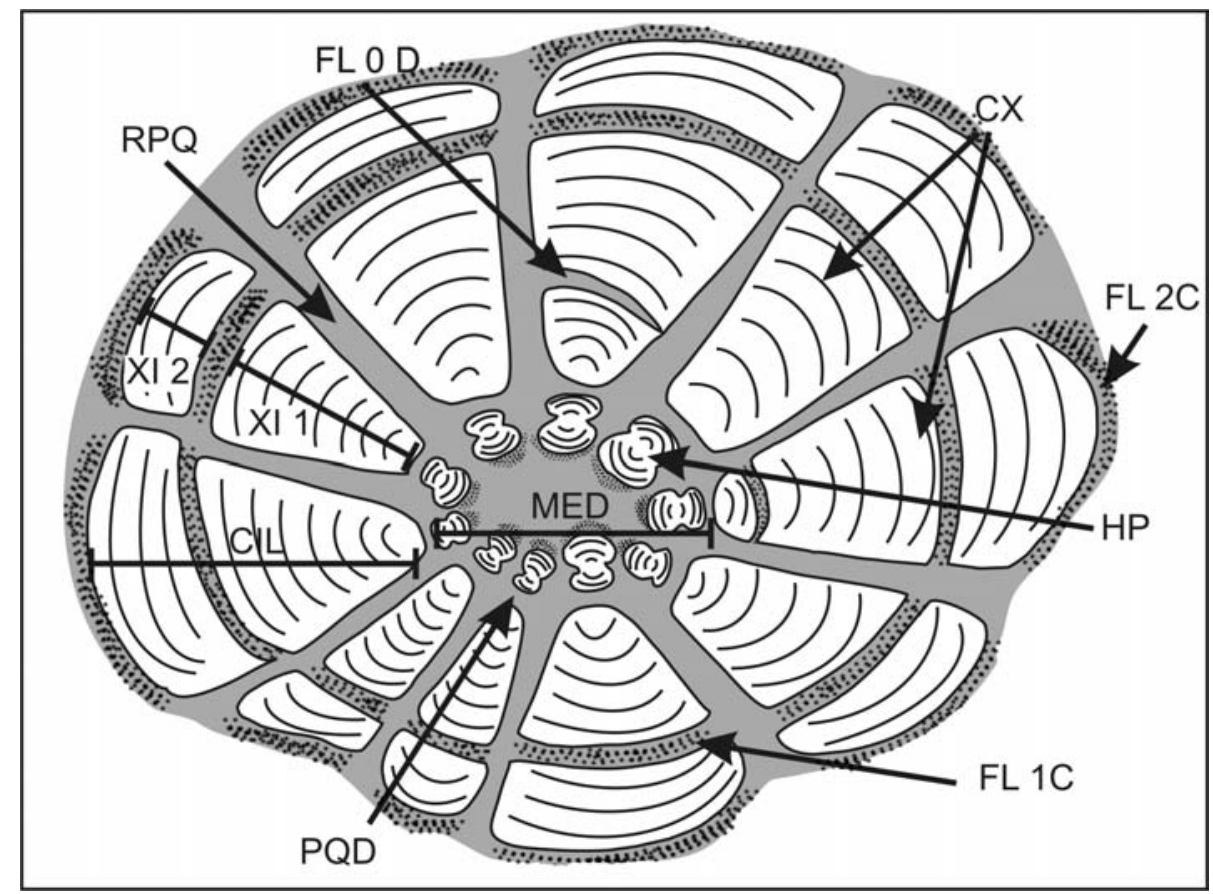

Figura VIII.2. Patrón anatómico de un tronco de corystosperma. CIL, sistema vascular cilíndrico. MED, sistema vascular medular. RPQ, radios parenquimatosos, producto de la actividad cambial diferencial y que separan las cuñas centrífugas (CX). PQD, parénquima de dilatación, resultado de la actividad cambial remanente, que separa el sistema medular del cilíndrico. HP, haces perimedulares dobles, originado por cámbiumes supernumerarios inversos y normales. FL 0D, primer ciclo de floema secundario, que se presenta en algunas cuñas, y que sólo está formado por células parenquimáticas. FL 1C, primer ciclo de floema secundario continuo en todas las cuñas. FL 2C, segundo ciclo de floema secundario continuo. En gris: parénquima, rayado: xilema secundario, punteado: floema secundario.

A partir de estas características, y otros atributos anatómicos de los tallos, fueron codificados 27 caracteres:

1. Relación diámetro de la médula/ diámetro del cilindro vascular (mayor que 0,1 0/ menor que 0,1 1). Esta relación ha sido considerada de importancia en la sistemática de las Cycadales por Artabe et al. (2005). De manera análoga, se utilizó el rasgo en el presente análisis.

2. Cavidades secretoras en la médula (presentes 0/ ausentes 1). El valor sistemático y evolutivo de las cavidades secretoras ha sido citado para las Corystospermales y las Cycadales (Artabe y Brea, 2003; Artabe et al., 2005). Otros análisis de las Lygnophyta 
también han tenido en cuenta a las estructuras secretoras (e.g. Nixon et al., 1994; Rothwell y Serbet, 1994; Hilton y Bateman, 2006).

3. Nidos escleróticos en la médula (ausentes $0 /$ presentes 1). Este carácter es reconocido de valor sistemático para las Cycadales y "pteridospermas" por Artabe et al. (2005)

4. Elementos vasculares en la médula (presentes 0/ ausentes 1).

5. Radios parenquimatosos (anchos $0 /$ angostos 1 ). Se considera que los radios son anchos cuando tienen un espesor mayor a la tercera parte de la amplitud tangencial de las cuñas xilemáticas. La presencia de radios parenquimatosos provoca la interrupción del cilindro vascular secundario. Esto es producto de la actividad diferencial del cámbium (el cámbium interfascicular forma células de relleno en vez de células conductoras). Herendeen y Miller (2000) sostienen que ésta y otras variantes de la actividad típica del cámbium son caracteres potencialmente útiles para la cladística.

6. Separación entre xilema centrífugo y centrípeto (por la aparición de parénquima tangencial o de dilatación) (contiguos 0/ separados 1). Es el resultado de la actividad remanente del cámbium, otra variante de su actividad típica.

7. Xilema primario (mesarco 0/ endarco 1). La maduración del xilema primario fue tomada en cuenta en los análisis cladísticos de Nixon et al. (1994), Rothwell y Serbet (1994), Artabe y Brea (2003), Artabe et al. (2005) y Hilton y Bateman (2006).

8. Engrosamientos de las traqueidas del xilema primario (espiralados 0/ escalariformes 1/ reticulados 2) (Ordenado).Carácter aplicado por Nixon et al. (1994), Rothwell y Serbet (1994) y Hilton y Bateman (2006).

9. Leño (manoxílico 0/ picnoxílico 1). Utilizado por Nixon et al. (1994).

10. Anillos de crecimiento en el leño (ausentes $0 /$ continuos $1 /$ discontinuos y desplazados 2/ discontinuos y concordantes 3) (No ordenado). Reconocido por Herendeen y Miller (2000).

11. Morfología en corte transversal de las traqueidas del xilema secundario: (cuadrangulares $0 /$ poligonales $1 /$ redondeadas 2) (No ordenado).

12. Parénquima axial (ausente 0/presente 1). El parénquima axial es considerado por Herendeen y Miller (2000) de potencial valor cladístico.

13. Número de series de punteaduras de las traqueidas (mayormente tri $o$ multiseriadas 0 / mayormente biseriadas $1 /$ uni a biseriadas $2 /$ mayormente uniseriadas 3) (Ordenado). 
14. Arreglo de las punteaduras de las traqueidas (densas $0 /$ contiguas $1 /$ espaciadas 2) (Ordenado).

15. Morfología de las punteaduras de las traqueidas (hexagonales 0, achatadas 1, circulares 2) (Ordenado).

16. Disposición de las hileras de punteaduras de las traqueidas (alternas 0, opuestas $1)$.

El tipo de punteado intervascular (13 a 16) es un carácter que ha sido utilizado por la mayoría de los autores en sus análisis filogenéticos (Nixon et al., 1994; Rothwell y Serbet, 1994; Hilton y Bateman; 2006). Herendeen y Miller (2000) también reconocen el valor filogenético de estos rasgos.

17. Morfología del poro de la punteadura de las traqueidas (elíptico 0/ circular 1).

18. Engrosamientos terciarios en las traqueidas (ausente 0/presente 1). Aplicado por Hilton y Bateman (2006).

19. Punteaduras de los campos de cruzamiento (areoladas 0/ simples 1).

20. Número por campo de punteaduras de los campos de cruzamiento (más de 3 como máximo $0 / 3$ cómo máximo 1).

21. Morfología de las punteaduras de los campos de cruzamiento (circular 0/ ovalada o elíptica 1).

22. Radios leñosos (heterocelulares 0/ homocelulares 1).

23. Número de series de radios leñosos (multiseriados $0 /$ uni y biseriados $1 /$ sólo uniseriados 2) (Ordenado).

24. Número de células de altura (cortos, hasta 10 células de altura $0 /$ medianos a largos, 13 a más células de altura 1$)$.

Herendeen y Miller (2000) enfatizaron el plausible valor filogenético de las características de los radios leñosos.

25. Polixilia centrípeta (presente $0 /$ ausente 1). Este carácter ha sido considerado de valor sistemático para las Cycadales por Artabe et al. (2005). De manera análoga, se utilizó el rasgo en el presente análisis.

26. Sistema vascular medular (ausente 0 , un ciclo completo 1 , un ciclo completo y un ciclo incompleto 2, dos ciclos completos 3) (Ordenado).

27. Polixilia centrífuga (ausente 0 , en $\operatorname{arcos}$ poco frecuentes 1 , en arcos muy frecuentes 2, en anillos 3) (Ordenado).

Los caracteres 25, 26 y 27 han sido incluidos en conjunto en el carácter poliestela de Hilton y Bateman (2006), y como el estado poliestela del carácter estela de 
Nixon et al. (1994). Por su parte, Rothwell y Serbet (1994) consideran el carácter xilema secundario sólo externo, o externo e interno; que en parte es equivalente al carácter 25 de este estudio.

\section{VIII.6. Análisis filogenético}

Se incluyeron en el análisis 10 especies de tallos de corystospermas y los tres outgroup elegidos (Medullosa noei, Callistophyton poroxyloides y Amosioxylon australis) han sido utilizados de manera simultánea. La matriz resultante (Cuadro VIII.1) fue analizada con el programa de software TNT 1.1 (Goloboff et al., 2008) bajo enumeración implícita.

\begin{tabular}{|c|c|c|c|c|c|c|c|c|c|c|c|c|c|c|}
\hline Taxones $\backslash$ caracteres & 1 & 2 & 3 & 4 & 5 & 6 & 7 & 8 & 9 & 10 & 11 & 12 & 13 & 14 \\
\hline Callistophyton poroxyloides & 0 & 0 & 0 & 1 & $?$ & $?$ & 0 & [0-1] & 1 & 0 & 0 & 0 & 0 & 0 \\
\hline Medullosa noei & 0 & 0 & 1 & 0 & 0 & 0 & 0 & ? & 0 & 0 & 0 & 0 & 0 & 0 \\
\hline Amosioxylon australis & ? & 1 & 0 & 0 & 0 & 0 & 0 & ? & 1 & 0 & 0 & 0 & 0 & 0 \\
\hline Tranquiloxylon petriellai & 0 & 1 & 1 & 0 & 1 & $?$ & 1 & 0 & 1 & 2 & 1 & 0 & 2 & 2 \\
\hline Cuneumxylon spallettii & 1 & 1 & 0 & 0 & 1 & $?$ & 1 & ? & 1 & 3 & 0 & 0 & 2 & {$[1-2]$} \\
\hline $\begin{array}{l}\text { Kykloxylon fremowensel } \\
\text { Jeffersionoxylon } \\
\text { gordonense }\end{array}$ & 1 & 0 & 1 & 1 & ? & $?$ & 1 & {$[1-2]$} & 1 & 1 & 1 & 0 & 2 & {$[1-2]$} \\
\hline Elchaxylon zavattieriae & 0 & 1 & 0 & 1 & ? & 0 & 0 & ? & 1 & 1 & 0 & 1 & 2 & {$[0-1]$} \\
\hline Rhexoylon cortaderitaense & 0 & 0 & 1 & 1 & 0 & 1 & 0 & ? & 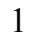 & 2 & 1 & 0 & 1 & {$[0-1]$} \\
\hline Rhexoxylon tetrapteridoides & 0 & 0 & 1 & 0 & 0 & 1 & 0 & ? & 1 & 2 & $?$ & 0 & 1 & 0 \\
\hline Rhexoxylon pianitzkyi & 0 & 0 & 1 & 0 & 0 & 1 & 0 & 0 & 1 & 2 & 2 & 0 & 2 & 0 \\
\hline Rhexoxylon brasilense & 0 & 0 & 1 & 1 & 0 & 1 & 0 & ? & 1 & 2 & 1 & 0 & 1 & $?$ \\
\hline Rhexoxylon brunoi & 1 & 0 & 0 & 1 & 0 & 1 & 0 & ? & 1 & 3 & ? & 0 & 3 & 1 \\
\hline Rhexoxylon africanum & 0 & 0 & 1 & 0 & 0 & 1 & 0 & ? & 1 & 2 & ? & 0 & 2 & {$[1-2]$} \\
\hline
\end{tabular}

Cuadro VIII.1. Matriz analizada.

\begin{tabular}{lccccccccccccc}
\hline Taxones\ caracteres & $\mathbf{1 5}$ & $\mathbf{1 6}$ & $\mathbf{1 7}$ & $\mathbf{1 8}$ & $\mathbf{1 9}$ & $\mathbf{2 0}$ & $\mathbf{2 1}$ & $\mathbf{2 2}$ & $\mathbf{2 3}$ & $\mathbf{2 4}$ & $\mathbf{2 5}$ & $\mathbf{2 6}$ & $\mathbf{2 7}$ \\
\hline Callistophyton poroxyloides & 0 & 0 & 0 & 0 & 0 & 0 & 0 & 1 & 1 & 1 & 1 & $?$ & 0 \\
Medullosa noei & 0 & 0 & 0 & 0 & 0 & 0 & 0 & 1 & 0 & 1 & 0 & 0 & 0 \\
Amosioxylon australis & 0 & 0 & 0 & 0 & 0 & 0 & 0 & 0 & 1 & 0 & 0 & 0 & 0 \\
Tranquiloxylon petriellai & 1 & 0 & 1 & 0 & 1 & 1 & $?$ & 1 & 1 & 1 & 1 & 0 & 2 \\
Cuneumxylon spallettii & {$[0-1]$} & 0 & 1 & 0 & 1 & 0 & 0 & 1 & 2 & 1 & 1 & 0 & 3 \\
Kykloxylon fremowense/ & 2 & {$[0-1]$} & 1 & 0 & 1 & 0 & {$[0-1]$} & 1 & 2 & 0 & 1 & 0 & 0 \\
Jeffersionoxylon & & & & & & & & & & & & & \\
gordonense & & & & & & & & & & & & & \\
Elchaxylon zavattieriae & {$[1-2]$} & {$[0-1]$} & 1 & 0 & 1 & 1 & {$[0-1]$} & 1 & 2 & 1 & 0 & 0 & 0 \\
Rhexoylon cortaderitaense & {$[0-1]$} & 0 & 1 & 0 & 1 & 1 & {$[0-1]$} & 1 & 1 & 1 & 0 & 0 & 1 \\
Rhexoxylon tetrapteridoides & {$[0-1]$} & 0 & $?$ & 0 & $?$ & 1 & 0 & 1 & 2 & 0 & 0 & 1 & 1 \\
Rhexoxylon pianitzkyi & 1 & 0 & 1 & 1 & 1 & 1 & {$[0-1]$} & 1 & 2 & 1 & 0 & 2 & 1 \\
Rhexoxylon brasilense & 0 & 0 & 1 & 0 & 1 & $?$ & $?$ & 1 & $?$ & $?$ & 0 & 2 & 2 \\
Rhexoxylon brunoi & {$[1-2]$} & 1 & 1 & 1 & 1 & 1 & 1 & 1 & $?$ & $?$ & 0 & 2 & 2 \\
Rhexoxylon africanum & {$[1-2]$} & $?$ & $?$ & 0 & 1 & 1 & {$[0-1]$} & 1 & 2 & 1 & 0 & 3 & 2 \\
\hline Cuadro VIII. Matric
\end{tabular}

Cuadro VIII.1. Matriz analizada (Continuación). 


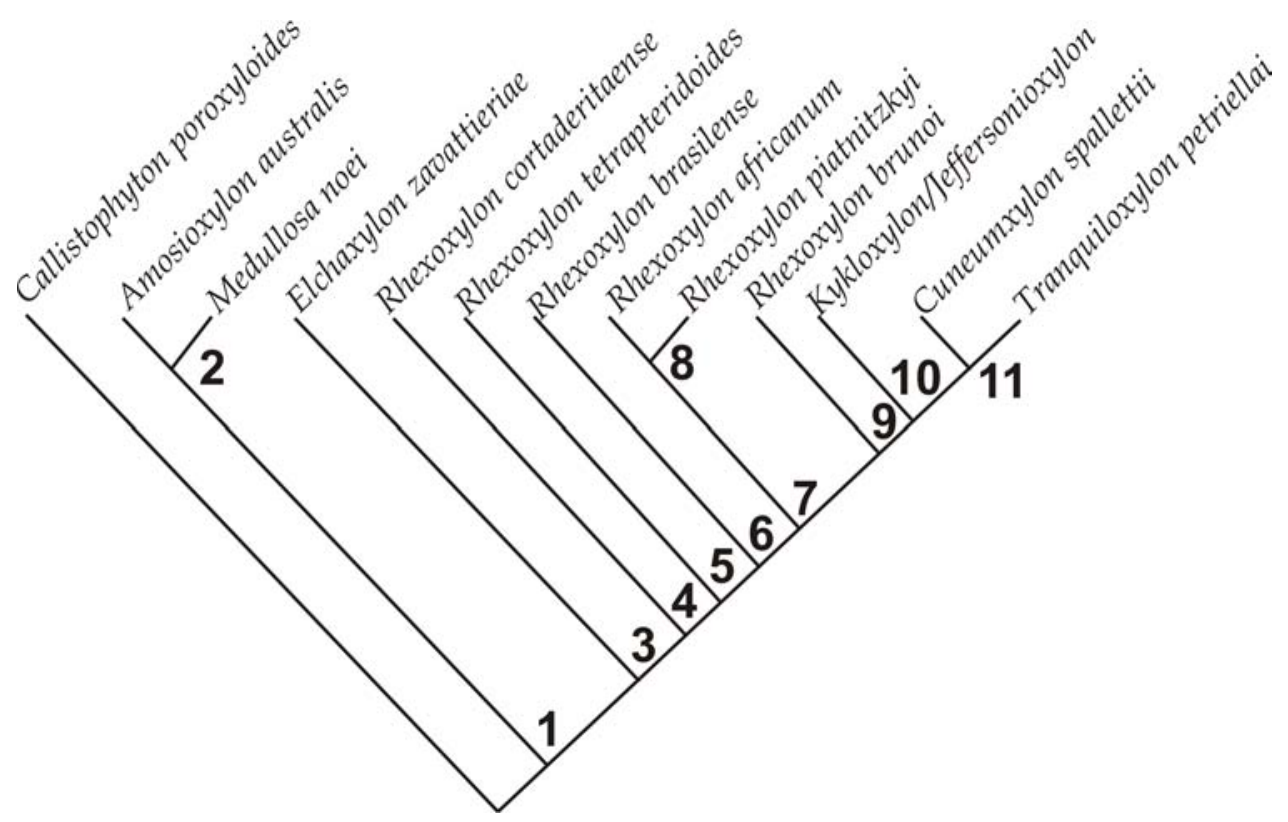

Figura VIII.3. Árbol más parsimonioso obtenido, los números indican los nodos.

\section{VIII.7. Resultados e interpretación de las relaciones filogenéticas}

Se obtuvo un árbol más parsimonioso (Figura VIII.3). Las sinapomorfías y autapomorfías de los nodos y taxones terminales se sintetizan en el cuadro VIII.2.

Las corystospermas (nodo 3), en cuanto a los rasgos de sus troncos, son reunidas en un clado sostenido por cuatro sinapomorfías: punteaduras de las traqueidas mayormente biseriadas, poro de las punteaduras circular, campos de cruzamiento con punteaduras simples y con un máximo de 3 por campo.

Elchaxylon zavattieriae se separa en la base de las restantes especies, como consecuencia de que carece de cavidades secretoras en la médula y posee parénquima axial.

El género Rhexoxylon queda resuelto como un plesion. $R$. africanum y $R$. pianitzkyi se agrupan en un clado por la presencia de elementos vasculares mezclados en el tejido parenquimatoso de la médula. $R$. brunoi aparece como grupo hermano de las corystospermas sin tejidos vasculares centrípetos porque comparte con estos taxones una relación médula/cilindro vascular baja.

Las corystospermas sin tejidos vasculares centrípetos (Kykloxylon fremowense) Jeffersionoxylon gordonense + Cuneumxylon spallettii + Tranquiloxylon petriellai) conformar un clado definido por el xilema primario endarco y la ausencia del polixilia centrípeta. Cuneumxylon y Tranquiloxylon constituyen un grupo natural por la ausencia de cavidades secretoras y la presencia de elementos vasculares en la médula. 


\begin{tabular}{|c|c|}
\hline Nodos y taxones terminales & Autapomofías o sinapomorfías \\
\hline Callistophyton poroxyloides & Sin autapomofías \\
\hline Nodo 1 & Sin sinapomorfías \\
\hline Nodo 2 & Sinapomorfía: carácter $4,1 \rightarrow 0$ \\
\hline Medullosa noei & Autapomorfías: carácter $3,0 \rightarrow 1$; carácter $9,1 \rightarrow 0$; carácter $23,1 \rightarrow 0$ \\
\hline Amosioxylon australis & Autapomorfías: carácter $2,0 \rightarrow 1$; carácter $22,1 \rightarrow 0$; carácter $24,1 \rightarrow 0$ \\
\hline Nodo 3 & $\begin{array}{l}\text { Sinapomorfías: carácter } 13,0 \rightarrow 1 \text {; carácter } 17,0 \rightarrow 1 \text {, carácter } 19,0 \rightarrow 1 \text {, } \\
\text { carácter } 20,0 \rightarrow 1\end{array}$ \\
\hline Elchaxylon zavattieriae & Autapomorfías: carácter $2,0 \rightarrow 1$; carácter $12,0 \rightarrow 1$; carácter $13,1 \rightarrow 2$ \\
\hline Nodo 4 & $\begin{array}{l}\text { Sinapomorfías: carácter } 3,0 \rightarrow 1 \text {; carácter } 6,0 \rightarrow 1 \text {, carácter } 11,0 \rightarrow 1 \text {, } \\
\text { carácter } 27,0 \rightarrow 1\end{array}$ \\
\hline Rhexoylon cortaderitaense & Sin autapomofías \\
\hline Nodo 5 & Sinapomorfía: carácter $26,0 \rightarrow 1$ \\
\hline Rhexoxylon tetrapteridoides & Autapomorfías: carácter $4,1 \rightarrow 0$; carácter $24,1 \rightarrow 0$ \\
\hline Nodo 6 & Sinapomorfías: carácter $26,1 \rightarrow 2$; carácter $27,1 \rightarrow 2$ \\
\hline Rhexoxylon brasilense & Sin autapomofías \\
\hline Nodo 7 & Sinapomorfías: carácter $13,1 \rightarrow 2$; carácter $15,0 \rightarrow 1$ \\
\hline Nodo 8 & Sinapomorfía: carácter $4,1 \rightarrow 0$ \\
\hline Rhexoxylon africanum & Autapomorfía: carácter $26,2 \rightarrow 3$ \\
\hline Rhexoxylon pianitzkyi & Autapomorfías: carácter $18,0 \rightarrow 1$; carácter $27,2 \rightarrow 1$ \\
\hline Nodo 9 & Sinapomorfías: carácter $1,0 \rightarrow 1$; carácter $14,0 \rightarrow 1$ \\
\hline Rhexoxylon brunoi & $\begin{array}{l}\text { Autapomorfías: carácter } 3,1 \rightarrow 0 \text {; carácter } 13,2 \rightarrow 3 \text {; carácter } 16,0 \rightarrow 1 \text {; } \\
\text { carácter } 18,0 \rightarrow 1 \text {; carácter } 21,0 \rightarrow 1\end{array}$ \\
\hline Nodo 10 & Sinapomorfías: carácter $7,0 \rightarrow 1$; carácter $25,0 \rightarrow 1$, carácter $26,2 \rightarrow 0$ \\
\hline $\begin{array}{l}\text { Kykloxylon fremowensel } \\
\text { Jeffersionoxylon gordonense }\end{array}$ & $\begin{array}{l}\text { Autapomorfías: carácter } 10,2-3 \rightarrow 1 \text {; carácter } 15,1 \rightarrow 2 ; \text { carácter } 24 \text {, } \\
1 \rightarrow 0 ; \text { carácter } 27,2 \rightarrow 0\end{array}$ \\
\hline Nodo 11 & Sinapomorfías: carácter $2,0 \rightarrow 1$; carácter $4,1 \rightarrow 0$ \\
\hline Cuneumxylon spallettii & Autapomorfías: carácter $3,1 \rightarrow 0$; carácter $11,1 \rightarrow 0$; carácter $27,2 \rightarrow 3$ \\
\hline Tranquiloxylon petriellai & Autapomorfías: carácter $1,1 \rightarrow 0$; carácter $23,2 \rightarrow 1$ \\
\hline
\end{tabular}

Cuadro VIII.2. Sinapomorfías de los nodos y autapomorfías de los taxones terminales.

\section{VIII.8. Conclusiones filogenéticas}

Esta es la primera aproximación de las relaciones filogenéticas no sólo del grupo de las corystospermas, sino dentro de una familia de "pteridospermas". Resultará de un valor innegable para la comprensión de la evolución de las espermatofitas ampliar este tipo de análisis a otros grupos de "pteridospermas".

Ya que existen controversias acerca de la posición filogenética de las corystospermas, y de la circunscripción de la familia, el presente análisis proporcionaría un ordenamiento detallado de las características de los tallos de corystospermas que puede ser 
útil para la codificación de los rasgos caulinares en estudios cladísticos de otras espermatofitas.

La anatomía caulinar ha mostrado ser, en este estudio, una fuente importante de caracteres de valor filogenético y sistemático.

En los resultados del análisis se observa que:

1. Las corystospermas presentan varias sinapomorfías en sus tallos.

2. Todos los taxones de troncos de corystospermas, excepto $R$. cortaderitanse y $R$. brasilense, manifiestan autapomorfias.

3. Rhexoxylon es un género parafilético, con $R$. cortaderitanse como especie basal.

4. Cuneumxylon y Tranquiloxylon conformarían un clado, apoyando la postura de Artabe y Brea (2003) de un linaje cuneumxyloide (ver Capítulo IX).

Para incrementar el alcance de este análisis, las siguientes etapas implicarán agregar los taxones de los restantes órganos de corystospermas, y así poder evaluar de manera integral la evolución de estas plantas. 


\section{PATRONES EVOLUTIVOS-DEL DESARROLLO EN TALLOS DE CORYSTOSPERMACEAE}

\section{IX.1.Introducción}

Los troncos de las Corystospermaceae, familia de pteridospermas mesozoicas dominantes en la Formación Cortaderita, presentan una anatomía única entre las gimnospermas, como resultado de, al menos, cuatro tipos diferentes de actividad cambial atípica. Se han delineado varias series de transformación en los tallos de esta familia (Petriella, 1981; Artabe y Brea, 2003; Bodnar, 2008), que, aunque no fuera mencionado por los autores, pueden ser asimiladas a procesos evo-devo. La evolución del grupo, al menos en lo que respecta a los troncos, parece guardar una íntima relación con su desarrollo ontogenético (Bodnar, 2007).

La Biología Evolutiva-del Desarrollo (Evo-Devo) se encarga de examinar cómo las alteraciones de los procesos ontogenéticos, reguladas genéticamente, conducen a la diversidad biológica presente en la naturaleza (Bateman y DiMichele, 1994, 2002; Cronk, 2001; Harrison et al., 2002; Shepard y Purugganan, 2002; Smith, 2003; Friedman et al., 2004; Floyd y Bowman, 2007). Bateman (1994) define un cambio evodevo como cualquier cambio genético expresado fenotípicamente, que se produce en un linaje y que altera profundamente la forma y/o el tamaño de cualquier estadio ontogenético del descendiente en relación al ancestro. Estas modificaciones tradicionalmente han abarcado la heterocronía (Haeckel, 1866) (cambio en la tasa relativa y el ritmo del desarrollo), la heterotopía (Haeckel, 1866) (cambio en el patrón espacial de los procesos del desarrollo) y la homeosis (Bateson, 1894) (reemplazo de una estructura por otra) (Cuadro IX.1).

Aunque los tres términos fueron acuñados en el siglo XIX, la heterocronía recién adquirió importancia luego del trabajo de Gould (1977). Por otro lado, la homeosis y la heterotopía tuvieron una resurrección con el descubrimiento de los genes homeóticos a comienzos de la década de 1980. Estos genes reguladores habían sido hallados, en primera instancia, en moscas, pero más tarde fueron aislados en otros insectos, en vertebrados, plantas y hongos. Desde entonces, se descubrió un número significativo de genes que regulan el desarrollo; estableciendo de este modo el punto de partida para la Biología Evo-Devo, en la que convergieron dos enfoques: el genético y el morfológico. 
Los estudios sobre cambios evolutivos-del desarrollo son menos comunes en plantas que en animales. Las investigaciones sobre esta temática estuvieron dirigidas inicialmente a los sistemas animales, y la aplicación de sus principios a las plantas fue extendida con posterioridad (de Renzi, 1995; Li y Johnston, 2000; Friedman et al., 2004)

En Paleontología, los procesos evo-devo pueden explicar la observación de cambios geológicamente instantáneos en los linajes de seres vivos. Inversamente, el registro fósil proporciona el contexto para identificar las secuencias de cambios evolutivos (Sanders et al., 2007). Sin embargo, los estudios ontogenéticos en fósiles son más complejos que en organismos actuales, puesto que no existe la posibilidad de un control detallado sobre la ontogenia (Mosbrugger, 1995).

Aunque no es aún posible identificar un gen específico que regule un patrón morfológico determinado, es plausible relacionar vías regulatorias, controladas por genes, con una consecuencia morfológica particular. Cuando se sabe que un carácter morfológico o anatómico es resultado de una vía regulatoria mediada por genes, ese rasgo puede ser visto como una "huella digital", de la que se puede inferir inequívocamente el patrón regulatorio subyacente de una estructura madura, tanto de plantas vivientes como fósiles (Rothwell y Lev-Yadun, 2005).

A partir de este nueva perspectiva, se ha comenzado a evaluar datos morfológicos y anatómicos para identificar las "huellas digitales" de la regulación del desarrollo, y extrapolarlos para el amplio espectro de estructuras de las plantas fósiles. Una vez que comprendemos cómo los patrones del desarrollo coordinan el origen de rasgos morfológicos particulares, las "huellas digitales" preservadas en el registro fósil proveerán puntos de calibración para el origen y la secuencia evolutiva de los mecanismos regulatorios génicos (Sanders et al., 2007).

Siguiendo este nuevo enfoque, en este capítulo se han aplicado los principios evodevo para explicar el origen y diversificación de la tan peculiar anatomía de los tallos de Corystospermaceae.

\section{IX.2. Conceptos, teorías y clasificaciones de la Biología Evo-Devo}

Desde que Haeckel (1866) erigiera su ley Biogenética la ontogenia recapitula la filogenia, han habido esporádicas discusiones sobre la relación entre el desarrollo del individuo y su historia filogenética (Sewertzoff, 1927; Remane, 1952; de Beer, 1958; Gould, 1977; Alberch et al., 1979; Alberch, 1980; Bonner, 1982; McNamara, 1982, 
1986). Haeckel aplicó el término cenogénesis para describir los casos en que una secuencia ontogenética no recapitula la secuencia filogenética (Russell, 1916), reconociendo dos categorías: 1. adaptación juvenil, y 2. cambios en el ritmo y localización de un órgano con respecto a otros en el mismo cuerpo, incluyendo heterotopía (cambio en el lugar de diferenciación) y heterocronía (cambios en el ritmo) (Gould, 1992).

En los años subsiguientes, los morfólogos transformaron la recapitulación de Haeckel (Müller, 1864; Cope, 1887; Oppel, 1891; Keibel, 1895; Menhert, 1895, 1897). Müller (1864) propuso que los cambios evolutivos de las formas adultas no sólo se originan de la suma de sus variaciones (esto es lo que sostenía Haeckel), sino también ocurrían mediante las alteraciones graduales del desarrollo embrionario y larval (Sewertzoff, 1949). La misma premisa -la filogenia es producto de la ontogenia modificada- fue sustentada por una cantidad de investigadores que examinaron los tópicos de la recapitulación en los primeros años del siglo XX (Franz, 1927; Sewertzoff, 1927; Garstang, 1928; de Beer, 1930).

Siguiendo las ideas de Sewertzoff $(1927,1949)$ y Remane (1952), Takhtajan (1972) organizó los patrones de alteraciones ontogenéticas en la evolución de las plantas superiores, dentro de cuatro categorías (Figura IX.1): prolongación (i.e. adición de nuevos estadios), abreviación (i.e. omisión de estadios), desviación (i.e. alteración de fases del desarrollo de su curso normal) y neotenia (i.e. combinación de la abreviación terminal con la desviación). A pesar de que el esquema de Takhtajan fue escasamente aplicado por los investigadores posteriores, se destaca porque fue el primer intento de sintetizar los cambios evolutivos-del desarrollo en plantas.

La relación entre alteraciones ontogenéticas y la evolución comenzó a adquirir su significado moderno en las contribuciones del embriólogo evolutivo británico de Beer (1930, 1940, 1951, 1958). Este autor en 1930 argumentó que las novedades evolutivas podían aparecer en cualquier estadio de la vida de un organismo, incluyendo cualquier punto de la ontogenia. De esta manera, convirtió el concepto de la heterocronía en un medio que enlazaba el desarrollo con los mecanismos evolutivos (Ridley, 1985). 


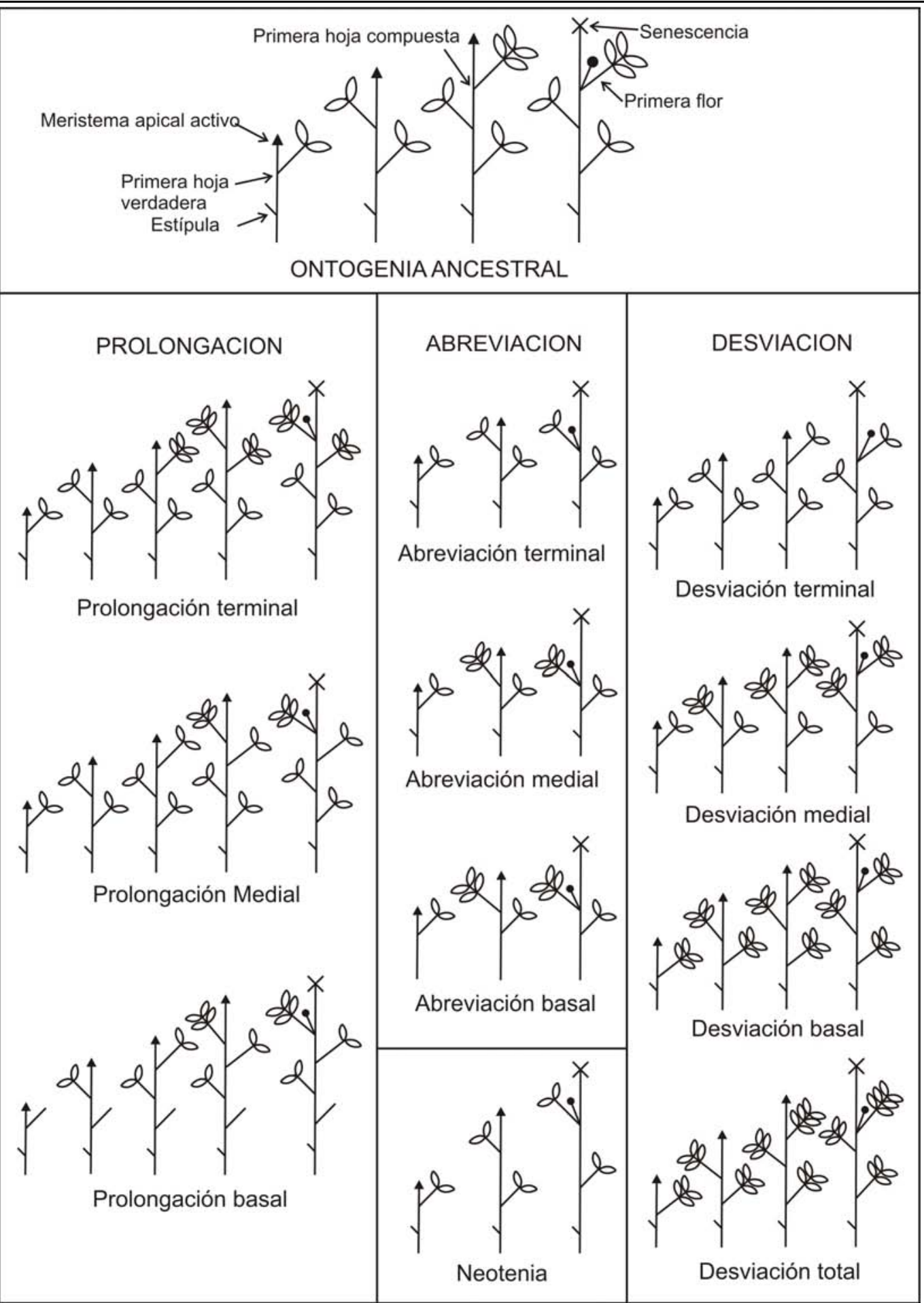

Figura IX.1. Interpretación de los patrones de alteraciones ontogenéticas en la evolución de las plantas superiores de Takhtajan (1972), usando como modelo la trayectoria ontogenética de Pisum sativum tomada de Wiltshire et al. (1994). La prolongación y la abreviación pueden ocurrir en las fases finales, intermedias y tempranas del desarrollo (prolongación o abreviación terminal, prolongación o abreviación medial, y prolongación o abreviación basal, respectivamente); la desviación puede suceder en las etapas del desarrollo finales, intermedias, tempranas o todas (desviación terminal, intermedia, basal, o total, en esa orden). La neotenia es la combinación de abreviación terminal con la desviación. 
Aunque en sus primeros trabajos, de Beer se refirió a la heterocronía con respecto a las diferencias en el ritmo de un órgano con respecto a otro en el mismo individuo, más tarde elaboró una definición del cambio en el ritmo de desarrollo de un órgano en relación al mismo órgano en el ancestro (de Beer, 1958; Gould, 1992).

El trabajo de sistematizar la terminología para estos cambios fue proseguido por Gould (1977), cuya clasificación de la heterocronía -generalizada y ampliada por Alberch et al. (1979)- fue el esquema que generó un renovado interés en la relación entre la ontogenia y la filogenia, y que condujo a un significativo aumento en nuestra comprensión acerca de los patrones evolutivos-del desarrollo (Smith, 2001). En las décadas de 1980, 1990 y 2000, se publicaron numerosas investigaciones siguiendo este enfoque (e.g., McKinney, 1988, 1999; Raff y Wray, 1989; Hall, 1992, 1999; McNamara, 1995, 1997; Raff, 1996; Zelditch y Fink, 1996; Reilly et al., 1997; Klingenberg, 1998; Li y Johnston, 2000; Smith, 2001, 2002, 2003; Zelditch, 2001).

Sobre la base del efecto final de las perturbaciones heterocrónicas, fueron diferenciadas por Alberch et al. (1979) dos expresiones morfológicas o patrones heterocrónicos básicos: pedomorfosis (Garstang, 1928) que es la retención de caracteres juveniles ancestrales en la fase adulta del descendiente, y peramorfosis (Alberch et al., 1979) que es la presencia de la morfología adulta ancestral en un estadio juvenil del descendiente, lo que resulta en un descendiente que tiene una morfología más diferenciada que la del ancestro. Estos dos patrones pueden ser alcanzados mediante tres clases de procesos: cambio en el punto temporal en que cada evento ontogenético es iniciado (i.e. punto de inicio), modificación del momento en que éste es finalizado (i.e. punto de finalización), y la alteración de la tasa en que cada evento se produce (i.e. tasa del desarrollo morfológico) (Alberch et al., 1979; Fink, 1988; Niklas, 1994a; Reilly et al., 1997). El punto de finalización es usualmente determinado por la maduración sexual. En este contexto, Alberch et al. (1979) propusieron seis procesos heterocrónicos (Figura IX.2). Tres dan origen a un patrón pedomórfico: post-desplazamiento (Alberch et al., 1979) o retraso del punto de inicio del desarrollo de ciertas estructuras; progénesis (Giard, 1887) o la aceleración en la maduración sexual con respecto al desarrollo somático (=punto de finalización temprano), y neotenia (Kollman, 1885) o la desaceleración de la tasa de desarrollo (Alberch et al., 1979; McNamara, 1986; Niklas, 1997). Las otras originan un patrón peramórfico; predesplazamiento (Alberch et al., 1979) o el comienzo temprano del desarrollo de una estructura en comparación con el desarrollo del organismo entero; hipermorfosis (de Beer, 1930) o la extensión del 
período juvenil de crecimiento, causada por un retraso en la maduración sexual; y aceleración (Cope, 1887) o el incremento en la tasa de desarrollo morfológico (Alberch et al., 1979; McNamara, 1986).

No existe una taxonomía análoga a la anterior que fuera desarrollada para la heterotopía (Stein y Boyer, 2006). A pesar de que Haeckel (1866) acuñó ambos conceptos como complementarios, la heterocronía fue el más estudiado en las investigaciones paleontológicas (Zelditch y Fink, 1996; Cronk, 2002). No obstante, la heterotopía también es importante (Kellogg, 2000); de hecho existirían pocos ejemplos que impliquen solamente un cambio espacial o temporal, ya que la mayoría de las ontogenias evolucionan por cambios de patrones espacio-temporales (Zelditch y Fink, 1996).

Por otro lado, Bateson (1894) acuñó el término homeosis para definir una clase de variación biológica en la que un elemento, de un cuerpo constituido por segmentos repetitivos, es transformado en otro (McGinnis, 1994). Existe una relación conceptual entre los términos heterotopía y homeosis, que merece ser aclarada. En su concepción moderna, la homeosis es el resultado de un proceso ontogenético en el que los atributos de una estructura son transferidos a la posición normalmente ocupada por una estructura diferente (Ronse de Craene et al., 2003), de aquí que sea un cambio espacial en el desarrollo - esto es heterotopía.

Baum y Donoghue (2002) claramente definieron a la homeosis como un caso especial de heterotopía. Estos autores diferenciaron dos tipos de cambios en el patrón espacial: homeoheterotopía, que es la transferencia de la identidad genética entre los tejidos u órganos preexistentes, y neoheterotopía, que es la aparición de tejidos $\mathrm{u}$ órganos en una posición nueva (Cuadro IX.1). En esta clasificación, homeosis es la categoría de homeoheterotopía en la que todos los aspectos de identidad de una estructura son conferidas a la estructura receptora. Si bien esta concepción clarifica algunas confusiones entre los conceptos, en esta tesis la homeosis y la heterotopía serán tratadas de manera independiente debido a su uso universal.

Los tres mecanismos evo-devo (heterocronía, heterotopía y homeosis) han sido recién sintetizados en un marco conceptual en las últimas tres décadas, con el advenimiento de la Biología Evo-Devo. 


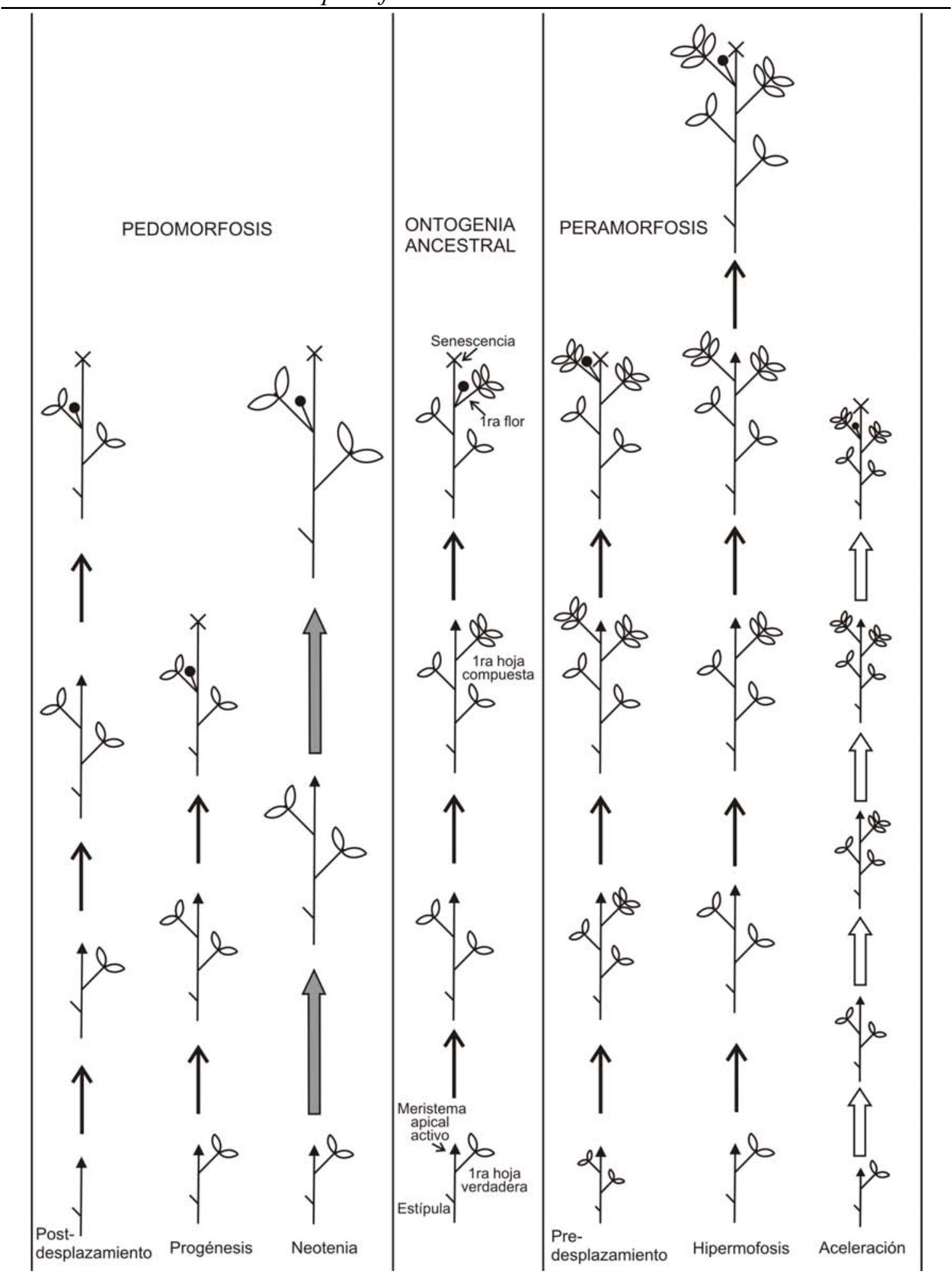

Figura IX.2. Patrones y procesos heterocrónicos propuestos por Alberch et al. (1979), usando como modelo la trayectoria ontogenética de Pisum sativum tomada de Wiltshire et al. (1994).

La homeosis fue la primera en adquirir una totalmente nueva jerarquía con el descubrimiento de los genes Hox (Garber et al., 1983; Scott et al., 1983). En años recientes, la heterocronía y la heterotopía se han revitalizado como resultado de nuevas 
herramientas que han permitido testear modelos en un contexto filogenético explícito y estudiar los cambios temporales y espaciales a nivel genético y molecular (Smith, 2003).

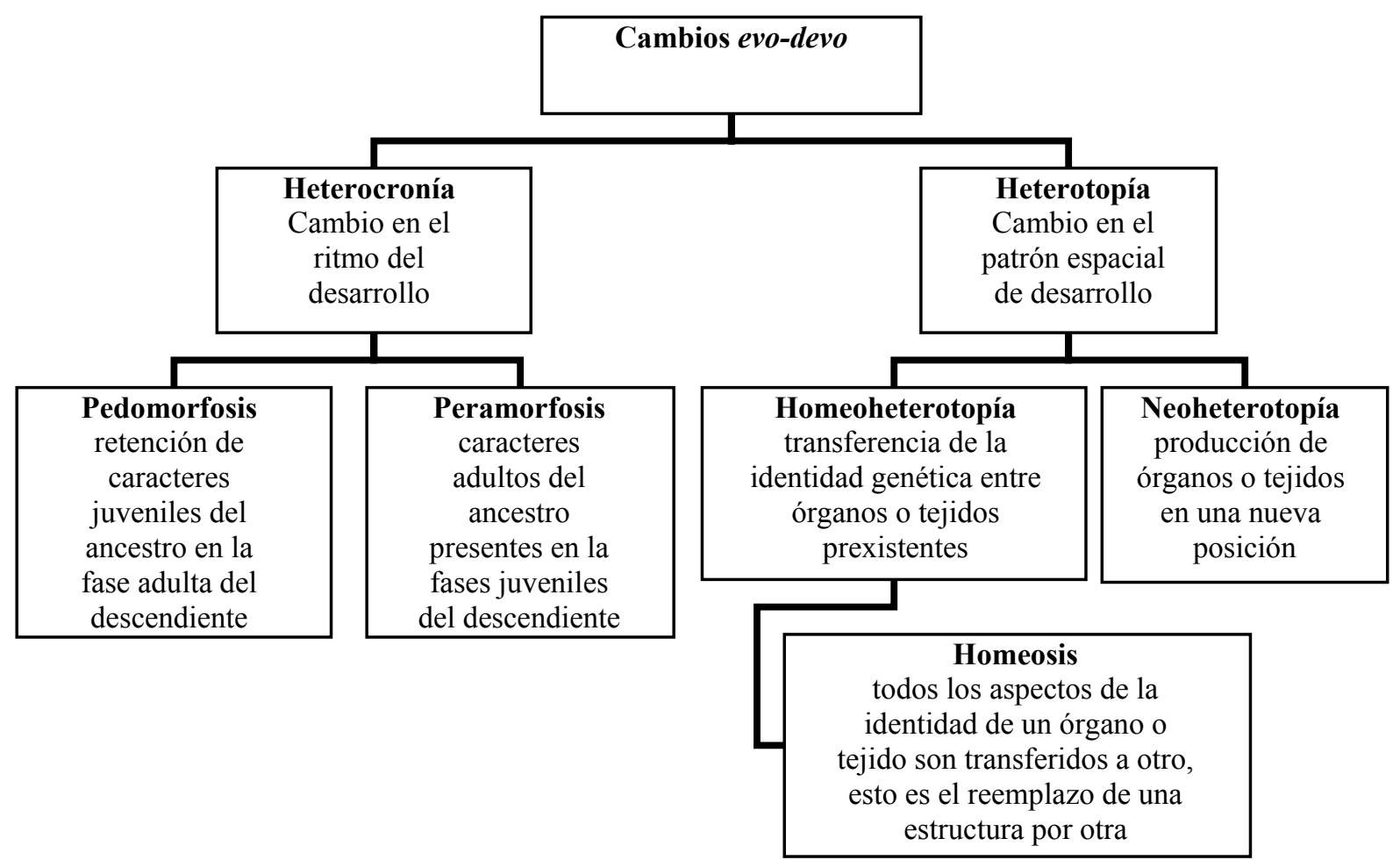

Cuadro IX.1. Tipos de cambios evo-devo (Alberch et al., 1979; Baum y Donoghue, 2002).

\section{IX.3. Estudios evolutivos-del desarrollo en plantas}

Desde Haeckel y Bateson pasando por Gould hasta el descubrimiento de los genes homeóticos, los principios y términos evo-devo han sido siempre aplicados primero en animales. No obstante, los botánicos y paleobotánicos han estado interesados en estos temas desde los comienzos del siglo XX.

La heterocronía es el mecanismo evo-devo más divulgado en la literatura botánica y paleobotánica. Las investigaciones sobre su rol en la evolución de las plantas se extienden desde el origen de grupos taxonómicos superiores a la diversificación específica dentro de un género. Al mismo tiempo, se ha demostrado que la heterocronía puede causar cambios morfológicos de todas las partes y generaciones de la planta: desde el desarrollo del gametofito a la formación de los órganos vegetativos y reproductivos de esporofito (Kampny y Harris, 1998).

Algunas discusiones acerca de la heterocronía han estado relacionadas con la evolución de los ciclos de vida, la teoría del teloma, la evolución estelar y el origen de 
los grupos de plantas terrestres más representativos (Mosbrugger, 1995; Takhtajan, 1991; Zimmermann, 1959).

La heterocronía habría participado en el origen de las estructuras reproductivas más significativas. DiMichele et al. (1989) propusieron que la semilla podría haber evolucionado directamente de un ancestro homospórico, como la progimnosperma Aneurophyton, por progénesis del megagametofito; de tal manera que los arquegonios eran producidos antes que las esporas fueran dispersadas. Para Takhtajan (1969, 1976, 1991) las flores de las angiospermas tendrían un origen pedomórfico.

Varias innovaciones morfológicas vegetativas habrían implicado eventos heterocrónicos. El hábito de crecimiento en roseta, adquirido repetidamente en linajes muy diferentes (e.g., lycofitas, helechos, cycadales, monocotiledóneas $\mathrm{y}$ dicotiledóneas), podría ser consecuencia de una finalización temprana del crecimiento de los entrenudos sucesivos (i.e. progénesis, Niklas, 1994a). Un ejemplo es el árbol no ramificado fósil de Chaloneria (Isoetales), que se cree habría derivado de un árbol con una corona apical muy ramificada, como Sigillaria (Lepidodendrales), mediante progénesis (Bateman, 1994).

Otro caso es el origen de los diferentes patrones foliares. En lycofitas, los microfilos podrían haber evolucionado por peramorfosis de enaciones como resultado del aumento de tamaño de las plantas terrestres (Mosbrugger, 1995). Rothwell (1982) argumentó que un cambio heterocrónico suprimió el desarrollo de frondes a lo largo de los ejes de pteridospermas como Callistophyton y Lyginopteris, dejando sólo a las estípulas como órganos fotosintéticos, las que derivarían en las hojas simples de las coníferas.

La heterocronía también ha jugado un papel importante en la diversificación y evolución de los niveles taxonómicos inferiores. Zhou (1994), y Zhou y Zhang (1989) brindaron evidencias de que los fósiles de Ginkgo y las especies actuales podrían haber evolucionado por medio de procesos peramórficos, que afectaron los órganos ovulíferos y las hojas.

Los análisis modernos de la heterocronía en plantas se han focalizado mayormente en órganos de crecimiento determinado o plantas anuales. Sin embargo, las alteraciones de los patrones ontogenéticos por la heterocronía han tenido un papel principal en la evolución de las plantas leñosas con crecimiento indeterminado (Olson, 2007). Carlquist (1962) elaboró una teoría de la pedomorfosis en leños de dicotiledóneas. Como muchas formas de vida pequeñas de las plantas de dicotiledóneas 
(hierbas leñosas, árboles en roseta, tallos suculentos) muestran caracteres juveniles (es decir, los del xilema primario), estas plantas presentan pedomorfosis tanto en su hábito como en su leño (Carlquist, 1962, 1975). Recientemente, Carlquist (2009) demostró la importancia de la heterocronía en la evolución del xilema de muchas angiospermas.

Los ejemplos de heterotopía en plantas no son tan generalizados como los de heterocronía. Los eventos heterotópicos usualmente caracterizan a las ramas más profundas de la evolución vegetal, y serían responsables del surgimiento de nuevos taxones de alto rango (géneros, familias y órdenes), mientras que los heterocrónicos son más frecuentes en ramas recientes superficiales o taxones de bajo rango (especies) (Meyen, 1987; Kellogg, 2002).

En las plantas, la heterotopía es el resultado de un cambio filogenético de la posición de un primordio o un meristema (Sattler, 1978). Kellogg (2000) argumentó que la macroevolución de las gramíneas implicaba cambios en la posición de los meristemas y meristemoides. Otros casos son la caulifloría y el floema intraxilemático en los leños (Olson, 2007)

Botánicos y paleobotánicos raramente se han referido a la homeosis, hasta el descubrimiento de los genes MADS-box a fines de la década de 1980 y comienzos de la de 1990. Debido a la simplicidad morfológica y la gran plasticidad del desarrollo de las plantas, los intercambios entre partes vegetales, que resultan en homeosis, posiblemente tengan más oportunidades de mantenerse en las líneas evolutivas en comparación con los animales (Svensson, 2000).

La homeosis es indudablemente significativa en la evolución del leño (Olson, 2007). Los ejemplos fueron dados por Carlquist $(1985,1988)$ : la presencia de células muy semejantes a fibras libriformes, que aparecen en lugar de las células parenquimáticas en los radios leñosos (Misodendron, Misodendraceae), y el leño parenquimatizado en leños de Caricaceae.

Actualmente, los mecanismos evo-devo son considerados de vital importancia en la mayoría de los aspectos evolutivos de todos los grupos de plantas. Mientras que la heterocronía ha sido extensamente citada en las plantas fósiles, la heterotopía y la homeosis han sido enormemente bastante ignoradas. Estos dos mecanismos, una vez que la Biología Evo-Devo fue instituida, se han estudiado principalmente desde un enfoque genético, lo que es imposible de analizar directamente en las plantas fósiles. Sanders et al. (2007) han demostrado que la genética y el registro fósil están interrelacionados en el contexto de la Biología Evo-Devo, al explorar la evolución de la 
actividad meristemática en relación a los cambios estructurales por medio de estudios experimentales de la actividad génica en plantas actuales. Al examinar la actividad cambial en lycofitas y esfenofitas paleozoicas, Rothwell et al. (2008) mostraron un ejemplo del potencial de las plantas fósiles para proveer datos del la regulación del desarrollo, e inferir la evolución de tejidos, órganos, y organismos enteros.

\section{IX.4. Dificultades y ventajas de los estudios evo-devo en plantas fósiles}

Las investigaciones de la genética molecular del desarrollo de los órganos reproductivos, hojas y raíces de angiospermas, pinos, helechos y musgos, han revelado que están regulados por genes homeóticos, como ocurre en animales (Weigel y Meyerowitz, 1993; Mouradov et al., 1998; Münster et al., 1997; Henschel et al., 2002). Por ello se puede concluir que mecanismos equivalentes controlan la ontogenia de animales y plantas, y los patrones y procesos evo-devo morfológicos son aplicables para ambos grupos.

La primera familia de genes homeóticos descubierta en plantas fueron los genes $M A D S-b o x$, que codifican un grupo de factores transcripcionales que controlan diversos procesos del desarrollo en angiospermas, desde el desarrollo de la raíz hasta el de la flor y el fruto (Weigel y Meyerowitz, 1993). A través de las reconstrucciones filogenéticas, esta familia de genes puede ser subdividida en clados génicos definidos, cuyos miembros comparten patrones de expresión y funciones similares. El establecimiento de la diversidad de clados génicos fue probablemente un evento importante en la evolución de las plantas terrestres. De acuerdo a Becker et al. (2000), al menos siete genes MADSbox distintos estaban presentes en la base de las espermatofitas hace 300 millones de años, y las familias de genes de las gimnospermas y angiospermas actuales tienen complejidades semejantes.

Los principios derivados de la Zoología (heterocronía, heterotopía y homeosis) no han sido extrapolados directamente a las plantas, debido a que la mayoría de éstas tienen un crecimiento metamérico e indeterminado, condición diferente a la que presentan los animales. La arquitectura metamérica (Hallé et al., 1978) permite un mayor rango de variación estructural intraespecífica controlada ambientalmente y una mayor frecuencia en convergencias y paralelismos evolutivos (Rothwell, 1987). Debido al desarrollo indeterminado en plantas perennes, se generan nuevas hojas y flores en el cuerpo adulto, así como también los tallos, ramas y raíces siguen creciendo durante toda la vida; de este modo, puede no existir un punto final en las proporciones y el tamaño, 
provocando que la distinción entre el juvenil y el adulto sea ambigua (Raff y Wray, 1989; Niklas, 1994a; Li y Johnston, 2000). Algunos órganos de las plantas (flores, frutos, y hojas) son, por separado, determinados en su crecimiento; siendo semiindependientes de la ontogenia de la planta completa. Este hecho puede explicar por qué las mayoría de los estudios evo-devo son efectuados a nivel de órganos, mientras que unos pocos, a nivel del organismo (Kampny y Harris, 1998; Li y Johnston, 2000).

Otra diferencia con respecto a los animales es que la madurez sexual, comúnmente usada como un referente temporal del animal adulto, no está usualmente asociada a la culminación del crecimiento somático en las plantas, y puede incluso alterarse como resultado de un estrés ambiental. Por esto, el uso de la edad cronológica, ampliamente aplicado en animales, es generalmente de valor limitado en los estudios del desarrollo de las plantas (Erickson y Michelini, 1957). Por esto, los botánicos utilizan otras referencias temporales (Guerrant, 1982; Niklas, 1994a), como el índice plastocrónico, un índice numérico que representa el estatus ontogenético de una planta (Erickson y Michelini, 1957; Ade-Ademilua, 2006).

Algunos investigadores perciben que el crecimiento indeterminado y metamérico es la causa de que los cambios evo-devo ocurran más fácilmente en la evolución vegetal (e.g. Mosbrugger, 1995): la morfología adulta indefinida podría promover la aparición de ciertos patrones heterocrónicos (i.e. peramorfosis), mientras que la construcción modular y la persistencia de meristemas podría facilitar cambios tanto heterocrónicos como heterotópicos. De hecho, el estudio de la heterocronía en partes individuales, tan frecuente en plantas fósiles, es posible gracias a la construcción modular (Raff y Raff, 2000).

En los estudios paleobotánicos, uns complicación es que no tenemos un control detallado sobre la ontogenia de las plantas fósiles; no conocemos con certeza cuáles son los estadios del desarrollo, la edad de los tallos recolectados ni la edad máxima de los taxones (Mosbrugger, 1995).

Por otro lado, las controversias de las relaciones filogenéticas entre las plantas fósiles y las actuales (Rothwell y Nixon, 2006) dificultan una mayor frecuencia de investigaciones sobre la filogenia de grupos vegetales extintos, lo que complica delinear patrones evolutivos en un marco cladístico. El conocimiento de las relaciones filogenéticas es necesario para evaluar las hipótesis evo-devo, puesto que la decisión entre escenarios evolutivos opuestos depende de la ontogenia asumida como basal (Olson, 2007). En las últimas dos décadas, los esquemas cladísticos en plantas fósiles se 
han incrementado, y mejorando el entendimiento de las relaciones entre grupos vegetales fósiles (e.g., Bateman et al., 1992; Kenrick y Crane, 1997; Rothwell et al., 2005; Hilton y Bateman, 2006).

La mayoría de los autores apoyan la idea de que las premisas evo-devo son igualmente válidas para plantas vivientes y fósiles (e.g., Iltis, 1983; Rothwell, 1987). Los últimos avances en la genética del desarrollo y el surgimiento de la Biología Molecular del Desarrollo, nos han permitido entender los caracteres estructurales a la luz de los mecanismos regulatorios que determinan la organización ontogenética (Rothwell et al., 2008). Al poder adscribir caracteres estructurales particulares de las plantas a la influencia de genes específicos, es plausible extrapolar estos mecanismos del desarrollo a organismos fósiles (Sanders et al., 2007).

Generalmente se piensa que los fósiles nos ofrecen oportunidades restringidas para inferir la ontogenia de las plantas, pero si se mira en detalle, la paleontología muestra una base teórica y empírica sólida para los estudios evo-devo (Gould, 1977; Rothwell, 1987; Stein, 1993; Sanders et al., 2007). Las plantas fósiles tienen la ventaja de preservar el detalle celular porque el esqueleto vegetal se encuentra a ese nivel (en la forma de la pared celular) en vez de a nivel organísmico como en la mayoría de los animales (Kenrick y Crane, 1997; Boyce y Knoll, 2002; Sanders et al., 2007; Rothwell et al., 2008). Prácticamente todos los tipos de células vegetales quedan preservadas en el registro fósil (Stewart y Rothwell, 1993; Taylor y Taylor, 1993; Taylor et al., 2009); de este modo los especímenes fosilizados de células, tejidos y órganos maduros vegetales, revelan información histológica sobre los patrones celulares y la regulación del desarrollo que sólo en condiciones excepcionales puede ser obtenida de animales fósiles (Sanders et al., 2007). Con todo esto, las secuencias de los procesos del desarrollo y los cambios evo-devo pueden ser trazados en el registro fósil, e incluso pueden ser inferidas las alteraciones genéticas implicadas en esos patrones.

En esta mirada moderna de la Paleontología, las plantas fósiles brindan una oportunidad de reincorporar los patrones evolutivos desde los estudios paleontológicos al flujo principal de procesos evolutivos; combinando análisis ontogenéticos del registro fósil con el conocimiento de los patrones moleculares del desarrollo. En ese sentido, esto nos permite inferir con mayor precisión la evolución de los tejidos, órganos, e individuos a lo largo del tiempo (Rothwell et al., 2008). 
IX.5. Particularidades de los estudios del desarrollo en ejes con crecimiento secundario

Como fue mencionado arriba, las investigaciones evo-devo esporádicamente se han aplicado en órganos vegetales indeterminados, como raíces, tallos y ramas. Los ejes leñosos se prestan satisfactoriamente a estudios del desarrollo porque las células del xilema y floema secundario, y algunas células de la corteza, son producidas en capas sucesivas que retienen su posición de manera permanente (Olson y Rosell, 2006). La ontogenia entera de un árbol puede ser examinada desde las células del centro, producidas cuando el árbol era joven, hasta las capas celulares de la periferia del tronco, producidas recientemente (Chrysler, 1937; Carlquist, 1962; Cumbie, 1963).
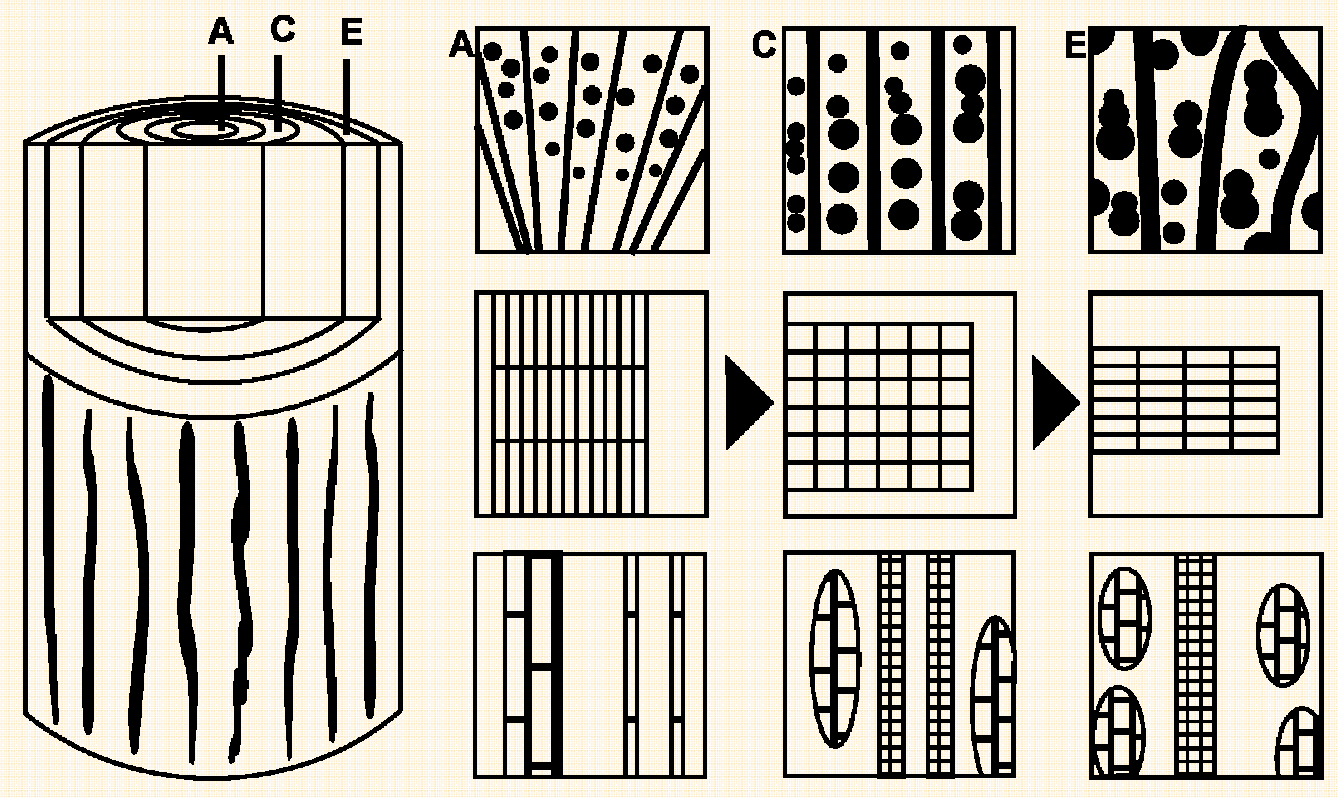

Figura IX.3. Ejemplo del leño de una dicotiledónea como registro del desarrollo. A la izquierda, una sección esquemática de un tronco que abarca el xilema secundario desde la médula a la corteza. Las letras corresponden a las edades expresadas en número de estaciones de crecimiento (A, primera estación de crecimiento; $C$, tercera estación de crecimiento; E, quinta estación de crecimiento). A la derecha, diagramas de los cortes transversales, radiales $y$ tangenciales, correspondientes a cada una de estas edades, mostrando los cambios ontogenéticos. En corte transversal (arriba, a la derecha), el agrupamiento de los vasos aumenta con la edad, puesto que se incrementa el diámetro de los vasos y la amplitud de los radios. En corte radial (medio, a la derecha) las células de los radios cambian de erectas a horizontales. En corte tangencial (abajo, a la derecha), las punteaduras intervasculares cambian de escalariformes a alternas poligonales, mientras que los radios llegan a ser mucho más cortos. Redibujado de Olson (2007). 
Así se puede ordenar inequívocamente los estadios y cambios ontogenéticos para el estudio del desarrollo en organismos plurianuales (Olson y Rosell, 2006), y es posible analizar la ontogenia entera en un solo individuo (Figura IX.3).

En raíces, tallos y ramas perennes, el eje temporal está sujeto a modificaciones porque su desarrollo está afectado directamente por las variaciones de temperatura, y la disponibilidad de luz, agua y nutrientes. Además, la madurez sexual no está asociada con el cese de los cambios ontogenéticos en los tejidos leñosos de los ejes (Olson y Rosell, 2006; Olson, 2007). En las investigaciones sobre órganos indeterminados, que se han desarrollado en los últimos años, los autores utilizan otros parámetros como eje temporal, por ejemplo el tamaño (diámetro, longitud, etc.) que está correlacionado con el tiempo (e.g., Olson y Rosell, 2006; Olson, 2007). Algunos tópicos que se han tratado bajo ese enfoque son la arquitectura caulinar, las formas de crecimiento, y la anatomía del leño y la corteza (Bateman et al., 1998; Civeyrel y Rowe, 2001; Cronk, 2001, 2002; Speck et al., 2003; Olson y Rosell, 2006; Bodnar, 2007; Coturel y Bodnar, 2009).

Una de las limitaciones que encuentran los estudios evo-devo en troncos, es que la regulación de la ontogenia vascular es un tema poco dilucidado de la Biología del Desarrollo vegetal. El desarrollo vascular incluye: (1) la formación del patrón longitudinal de los haces vasculares primarios, (2) la formación del patrón radial del xilema y floema dentro de los haces vasculares, (3) la diferenciación de tipos celulares especializados como precursores del xilema y el floema; y (4) la proliferación y diferenciación celular dentro del cámbium vascular. Para que el xilema y el floema cumplan sus funciones de transporte, son necesarios: (1) la presencia de haces alargados que unan las raíces con los ejes, (2) el alargamiento y la diferenciación de células conductoras especializadas con un patrón alineado en sus extremos, y (3) en plantas leñosas, una ruta de proliferación y diferenciación celular dentro de la zona cambial, que forme canales continuos para el transporte a lo largo del crecimiento.

El xilema y floema secundarios contienen los mismos tipos celulares que los tejidos vasculares primarios, pero en diferentes proporciones y relaciones espaciales. Es probable que los resultados de los estudios de la diferenciación caulinar primaria se apliquen también a la zona cambial, pero indudablemente algunos factores regulatorios son exclusivos de cada sistema (Dengler y Kang, 2001). El crecimiento del xilema y floema secundarios depende de las divisiones de las células del cambium vascular y provoca el incremento en diámetro de los tallos. Es difícil analizar los mecanismos genéticos que controlan la actividad cambial y la diferenciación de los tipos celulares 
del xilema y floema secundarios, en parte por los problemas inherentes a las especies arbóreas - i.e. las generaciones largas, el gran tamaño, y la ausencia de linajes genéticamente puros (Ko et al., 2004; Zhao et al., 2005).

La transición del procambium al cámbium está relacionada a un estímulo físico, que induce la diferenciación del cámbium (Lintilhac yVesecky, 1981), como el peso de la corona de los árboles y estrés físicos - e.g. tacto, heridas y viento (Higuchi, 1997). En las especies con crecimiento secundario, los haces procambiales son "abiertos": la placa de tejido meristemático entre el xilema y floema primarios no se diferencia y se vuelve mitóticamente activa (Esau, 1965; Larson, 1994). La zona mitóticamente activa se extiende lateralmente desde los haces vasculares, y de este modo las células parenquimáticas interfasiculares se transforman en un cámbium (Esau, 1965). La formación del cámbium no está especificada por un programa genético del desarrollo, sino que requiere una retroalimentación fisiológica desde otras partes de la planta: el xilema y floema secundarios se originan en el árbol como resultado del crecimiento masivo en altura (Savidge, 2000).

El cámbium necesita mantener un fino balance entre la proliferación y la diferenciación celular. Como regla general en el desarrollo biológico, la diferenciación no ocurre al mismo tiempo que la división celular, sino que son mutuamente excluyentes. Durante el desarrollo del floema o xilema, las derivadas cambiales pasan a través de estadios sucesivos de diferenciación, abandonando la actividad de división en favor de la expansión de la pared. La producción de derivadas cambiales y la subsecuente diferenciación en células del floema y xilema a veces ocurre paralelamente en lados opuestos de la zona cambial, pero en general cuando un lado se está desarrollando el otro "espera" su turno y permanece indefinido (Larson, 1994). Las células del lado del xilema atraviesan cuatro procesos celulares distintivos: división, expansión, maduración, y muerte programada (Chaffey, 1999; Plomion et al., 2001).

Los patrones mitóticos en la zona cambial no están genéticamente programados (Savidge, 1996, 2001; Chaffey, 1999); al contrario, las células individuales están influenciadas por sus ambientes locales, incluyendo señales hormonales que viajan longitudinal y radialmente (Little y Pharis, 1995; Uggla et al., 1998; Savidge, 2001).

Los mecanismos regulatorios que operan dentro de la zona cambial controlan: qué tejido vascular se va a desarrollar, en qué parte del árbol el cámbium empieza primero su actividad durante cada estación de crecimiento, la tasa a la que las células atraviesan cada zona del desarrollo, y el destino final de cada derivada cambial. Esau 
(1960) notó que el curso de diferenciación de una célula está determinado por su posición dentro del patrón general. Para explicar cómo la planta logra y mantiene la complejidad estructural del cámbium y los tejidos vasculares secundarios, es necesaria una comunicación intercelular, dada por las señales hormonales. Las auxinas constituyen el grupo de fitohormonas clave en varios aspectos de la ontogenia del sistema vascular (Aloni, 1987; Sachs, 2000), siendo importantes reguladores del crecimiento cambial (Aloni, 1987; Ye, 2002) y de la producción de xilema y floema llevada a cabo por el cámbium vascular (Little y Sundberg, 1991; Little et al., 2002; Baima et al., 2000). Una de las peculiaridades principales de las auxinas es que, de todas las hormonas de las plantas, son las única que exhiben un transporte polarizado desde las hojas hacia las ramas y raíces, que es de particular importancia para la regulación del desarrollo vascular (Sachs, 1981, 2000; Little y Pharis, 1995; Lomax et al., 1995; Savidge, 2001; Sundberg et al. 2000).

Los gradientes de concentración de las auxinas proporcionan la información posicional requerida para coordinar la división y diferenciación celular a través de la zona cambial (Savidge et al., 1982; Uggla et al., 1996, 1998; Sundberg et al., 2000). La información posicional parece coordinar el crecimiento y la diferenciación del cámbium al definir el ancho de la zona cambial y regular el número radial de células dividiéndose (Uggla et al., 1996, 1998; Zhong y Ye, 2001). El hallazgo de fibras esclerosadas alrededor de los haces vasculares apoya a la hipótesis de que la difusión lateral de las auxinas desde los haces vasculares es la responsable para la diferenciación de las células (Zhong et al., 1997). En coníferas se ha comprobado que las derivadas cambiales se enriquecen en ácido indolacético (IAA), el representante de las auxinas más abundante en la naturaleza, para sufrir el alargamiento y diferenciación en traqueidas (Savidge et al., 1982, 1998; Savidge 2000). El pico de concentración de IAA coincide con la zona de las células iniciales cambiales, y los niveles bajan dentro de las células xilemáticas y floemáticas derivadas, actuando de este modo como una señal de posición (Uggla et al., 1998; Sundberg et al., 2000). En el cámbium se acumula en abundancia el IAA, que se mueve a través del cámbium hacia la base, y es un factor que induce y mantiene las fusiformes cambiales, y promueve la diferenciación de las derivadas cambiales en elementos del xilema y del floema.

Las auxinas son producidas por las hojas (Savidge y Wareing, 1981; Savidge 1994, 1996, 2000). El crecimiento y el envejecimiento rítmicos de las hojas son los que controlan el ritmo fitohormonal y de este modo la formación de anillos de crecimiento 
(Falcon-Lang, 2000) y otros atributos xilológicos producidos cíclicamente. La superproducción de auxinas en plantas transgénicas incrementa la cantidad de tejidos vasculares. A su vez, la aplicación de IAA puede reemplazar los primordios foliares en la inducción de las conexiones vasculares en los tallos (Jacobs, 1952), y las fuentes locales de auxinas pueden inducir a la formación de nuevos haces vasculares a partir de células parenquimáticas (Sachs, 1981).

El floema secundario (la única parte viva del tejido vascular secundario) está implicado en la síntesis de las auxinas, glucosinolatos, citoquininas, y giberilinas (Zhao et al., 2005) en el interior de los tallos.

Por décadas, se ha sabido que la hormona IAA puede regular la expresión génica (Theologis, 1989). Por otro lado, hay genes que codifican el transporte de las auxinas (Bennett et al., 1996; Palme y Galweiler, 1999); lo que significa que hay una retroalimentación positiva entre la señal de las auxinas y los genes reguladores. Estudios recientes identificaron los genes que codifican las probables proteínas transportadoras de la emanación y afluencia de las auxinas, representadas por las familias génicas AUX y PIN, respectivamente (Bennett et al., 1996; Palme y Galweiler, 1999). Dos familias de proteínas relacionadas, las proteínas Aux/IAA y los factores de respuesta auxínica (ARFs), son reguladores clave de la expresión génica regulada por las auxinas (Guilfoyle et al., 1998a, 1998b; Walker y Estelle, 1998).

El ATHB-8 (At4g32880), un gen homeobox regulado positivamente por las auxinas (Baima et al., 1995), es considerado un marcador temprano de las células procambiales y cambiales, promoviendo su proliferación y diferenciación (Baima et al. 2001; Ko et al., 2004). El cuadro IX.2. sintetiza los genes implicados en el metabolismo $\mathrm{y}$ transporte hormonal en los tejidos vasculares.

\begin{tabular}{|l|l|l|l|}
\hline $\begin{array}{l}\text { Abreviatura } \\
\text { del gen }\end{array}$ & Descripción & $\begin{array}{l}\text { Rol en metabolismo/transporte } \\
\text { hormonal }\end{array}$ & Citas \\
\hline AUX1 & Aminoácido /auxina permeasa & Transporte de las auxinas & Bennett et al. (1996) \\
\hline GA2OX2 & GA 2-oxidasa & Inactivación del ácido giberélico & Bennett et al. (1996) \\
\hline CYP79B3 & Citocromo P450, conversoTrp a IAOx & Biosíntesis de las auxinas & Hull et al. (2000) \\
\hline GA4 & $\begin{array}{l}\text { GA 3-b-dioxigenasa/ } \\
\text { GA 3-b-hidroxilasa }\end{array}$ & Biosíntesis del ácido giberélico & Williams et al. (1998) \\
\hline IPT5 & $\begin{array}{l}\text { Adenilato isopenteniltransferasa } \\
\text { 5/citoquinina sintetasa }\end{array}$ & Biosíntesis de las citoquininas & Takei et al. (2004) \\
\hline IPT3 & $\begin{array}{l}\text { Adenilato isopenteniltransferasa } \\
\text { 3/citoquinina sintetasa }\end{array}$ & Biosíntesis de las citoquininas & Takei et al. (2004) \\
\hline
\end{tabular}

Cuadro IX.2. Genes implicados en el metabolismo y transporte de hormonal en los tejidos vasculares. 
Recientemente, un análisis comparativo de un gran número de secuencias expresadas en el álamo y Arabidopsis, mostró que los genes de transcripción relacionados con la regulación de la actividad cambial son los más divergentes entre las dos especies (S. Park, S. Oh, K.-H. Han, en Ko et al., 2004); por lo que las principales diferencias entre el álamo y Arabidopsis (e.g. crecimiento secundario, hábito de crecimiento perenne) pueden estar en el control transcripcional más que en genes estructurales (Ko et al., 2004).

Un sistema experimental novedoso fue empleado por Ko et al. (2004) para estudiar la regulación molecular de la formación del xilema secundario en Arabidopsis; provocando que en el tallo primario se diferencie un cámbium mediante la inducción por peso. Entre los factores transcripcionales responsables del inicio de la formación del leño, se identificaron siete genes de la familia AP2/ERF (APETALA2 y factores de la respuesta del etileno), cuatro factores de la superfamilia WRKY (que comprende más de 100 genes en Arabidopsis) y cuatro factores de la familia MYB. Por otra parte, se reconocieron factores transcripcionales que actuaban en etapas tardías del crecimiento secundario de Arabidopsis. Los factores tipo R2R3 MYB controlan muchos aspectos del metabolismo secundario de la planta, así como la identidad y el destino de las células (Stracke et al., 2001). Dos de estos genes (AtMYB77, At3g50060 y AtMYB44, At5g67300) fueron reportados como regulados "hacia arriba" en etapas tardías de la embriogénesis (Kirik et al., 1998). Además, 10 genes ATHB fueron expresados en los tallos de Arabidopsis. Entre ellos, los genes ATHB-1 (At3g01470), ATHB-6 (At2g22430), ATHB-7 (At2g46680), ATHB-8 (At4g32880), y ATHB-12 (At3g61890) fueron altamente expresados en el estadio maduro (Ko et al., 2004).

Varios genes ARF fueron regulados diferencialmente durante la xilogénesis. Los elementos AuxREs han sido identificados de las regiones promotoras de los genes que son rápida y específicamente activados por las auxinas (Guilfoyle et al., 1998a). Se examinaron las regiones promotoras de los genes que son altamente regulados en los tallos durante la formación del leño por la presencia de tales AuxREs. Cuatro genes relacionados a la biosíntesis de la pared celular, 8 genes que regulan la expresión génica, 6 genes relacionados con el metabolismo secundario y 4 genes implicados en la transducción de señales, tienen elementos AuxREs biológicamente activos (Ko et al. 2004).

En otros estudios, se analizaron las funciones de los genes ATHB-8, -9, -14, -15, y IFL1/REV (Interfascicular Fiberless 1 o Revoluta), que pertenecen a una pequeña 
familia con homeodominio y cierres de leucina, caracterizados por la expresión en el tejido vascular (Sessa et al., 1998; Baima et al., 2000). Se logró comprobar que la sobreexpresión de ATHB-8 en plantas transgénicas promueve la diferenciación precoz de las células vasculares: se adelanta la transición de crecimiento primario a secundario (Baima et al., 2001). Los genes IFL1/REV (Zhong y Ye, 1999; Ratcliffe et al., 2000), recientemente han sido implicados en los procesos de proliferación y diferenciación celular de las iniciales cambiales. Análisis cuidadosos de varios alelos indicaron que los IFL1/REV son imprescindibles para el inicio del cámbium y el desarrollo normal de los órganos con crecimiento secundario (Talbert et al., 1995; Zhong et al., 1997; Otsuga et al., 2001).

La composición y morfología de la pared celular son rasgos que distinguen una célula cambial de las derivadas xilemáticas, y depende de los procesos de biosíntesis y ensamblaje. Se piensa que estos procesos están dirigidos por genes homeóticos específicos que controlan la síntesis macromolecular y determinan la estructura. Las diferencias entre las células parenquimáticas, esclerenquimáticas y elementos traqueales y traqueidas, se logran a través de un patrón bioquímico. Los genes/proteínas regulatorios gobiernan patrones estructurales independentes, tales como la producción subyacente de celulosa o lignina. La evidencia indica que el desarrollo no se origina espontáneamente, sino que es inducido y está ligado a los genes que regulan el ciclo celular (Savidge, 2000).

Entre las gimnospermas, se han analizado los genes regulatorios de la actividad cambial en la especie Pinus taeda, de los que cerca del 10\% codifican factores implicados en la formación de la pared celular (Allona et al., 1998). La mayoría de los genes conocidos como implicados en el patrón biosintético de la lignina, pertenecen a las familias PAL, C4H, OMT, 4CL, y CAD.

Algunos de los genes que han sido relacionados con la regulación del crecimiento secundario son sintetizados en el Cuadro IX.3., donde se puntualiza la función específica en el tejido vascular de cada uno. 
Josefina Bodnar - La paleoflora triásica de la Formación Cortaderita ...

\begin{tabular}{|c|c|c|c|}
\hline Gen & Descripción & Rol en el tejido vascular & Citas \\
\hline ATHB-8 & Familia con homeobox y cierres de leucina & Diferenciación vascular & Baima et al. (2001) \\
\hline ATHB-9/PHV & Familia con homeobox y cierres de leucina & $\begin{array}{l}\text { Organización de haces } \\
\text { vasculares }\end{array}$ & McConnell et al. (2001) \\
\hline ATHB-14/PHB & Familia con homeobox y cierres de leucina & $\begin{array}{l}\text { Organización de haces } \\
\text { vasculares }\end{array}$ & McConnell et al. (2001) \\
\hline REV/IFL1 & Familia con homeobox y cierres de leucina & Patrón vascular & Zhong y Ye (2004) \\
\hline APL & Factor de transcripción tipo G2 & Diferenciación vascular & Bonke et al. (2003) \\
\hline KAN2 & Factor de transcripción tipo G2 & $\begin{array}{l}\text { Organización de haces } \\
\text { vasculares }\end{array}$ & Emery et al. (2003) \\
\hline KAN3 & Factor de transcripción tipo G2 & $\begin{array}{c}\text { Organización de haces } \\
\text { vasculares }\end{array}$ & Emery et al. (2003) \\
\hline XYP1 & $\begin{array}{l}\text { Familia de proteínas de transferencia lipídica } \\
\qquad \text { (LTP) }\end{array}$ & Patrón vascular & Motose et al. (2004) \\
\hline $\begin{array}{l}\text { AHK4/WOL/ } \\
\text { CRE1 }\end{array}$ & Quinasa His & Diferenciación vascular & $\begin{array}{l}\text { Inoue et al. (2001); } \\
\text { Mahonen et al. (2000) }\end{array}$ \\
\hline CVP1 & S-Adenosil-Met-esterol-C-metiltransferasa & Patrón vascular & Carland et al. (2002) \\
\hline FK & $\mathrm{C}-14$ esterol reductasa & Patrón vascular & Jang et al. (2000) \\
\hline GNOM/EMB30 & No clasificado & Patrón vascular & Steinmann et al. (1999) \\
\hline MP/IAA24 & Proteína IAA 24 & Diferenciación vascular & Hardtke y Berleth (1998) \\
\hline PIN1 & $\begin{array}{l}\text { Proteína transportadora del flujo de las } \\
\text { auxinas }\end{array}$ & Patrón vascular & Galweiler et al. (1998) \\
\hline
\end{tabular}

Cuadro IX. 3. Genes conocidos relacionados con la diferenciación o función de los tejidos vasculares.

\section{IX.6. Aplicabilidad de los principios de la Biología Evo-Devo en los tallos fósiles}

Las plantas fósiles presentan algunas complicaciones con respecto a las plantas vivientes. Al mismo tiempo, otros atributos de los ejes facilitan los estudios ontogenéticos en ejemplares fosilizados. Por esto, al revés de lo que ocurre en las investigaciones de plantas actuales, los análisis del desarrollo son menos complicados en órganos caulinares que en las estructuras reproductivas fósiles.

Los tallos fósiles están frecuentemente preservados como permineralizaciones, un tipo de fosilización que exhibe los detalles celulares e histológicos. Cuando la preservación es delicada, la anatomía caulinar permineralizada puede ser estudiada de la 
misma manera que en especímenes actuales. Por esta razón, aunque es imposible saber con exactitud la edad de los fósiles (Mosbrugger, 1995), las características del crecimiento secundario junto a la posibilidad de examinar la anatomía en las permineralizaciones, permiten estudiar la ontogenia en tallos fósiles leñosos.

Si se recolecta una cantidad suficiente de troncos bien preservados, de diferentes diámetros (que representen distintas edades), y algunos de por lo menos un metro de longitud, es posible realizar análisis ontogenéticos a lo largo del incremento en espesor y altura del árbol. Esto significa estudiar los diferentes estadios del desarrollo (las fases más tempranas en los especímenes más pequeños y en la región apical de los más largos; y las fases tardías en los ejemplares más grandes y en la base de los más largos). De este modo, podemos definir trayectorias ontogenéticas en tallos secundarios fósiles, sin una evidencia directa del tiempo absoluto, haciendo uso de estudios anatómicos de troncos de tamaños diversos y de toda la longitud de un tallo.

Ciertos grupos extintos tienen ejes con características particulares que promueven los análisis del desarrollo (Bodnar, 2007, 2009; Coturel y Bodnar, 2009). Esas plantas (medullosales, cycadales, corystospermales, pentoxylales y algunas angiospermas) tienen un crecimiento secundario atípico que muestra estadios ontogenéticos discretos a lo largo del desarrollo de la organización vascular. La diferenciación morfológica tiene un punto de finalización definido en las ontogenias de estos tallos, independiente de la maduración sexual.

Los patrones del desarrollo de los troncos fósiles de medullosales, cycadales, corystospermales y pentoxylales pudieron ser discernidos extrapolando los mecanismos ontogenéticos que llevan al mismo tipo crecimiento secundario atípico en plantas actuales. Estos procesos han sido dilucidados por diversos autores desde principios del siglo XX (e.g., Worsdell, 1901, 1906; Matte, 1904; Fahn y Schori, 1967; Zamski y Azenkot, 1981; Kirchoff y Fahn, 1984; Fahn, 1990).

Estudios recientes han demostrado que los caracteres diagnósticos para el desarrollo pueden ser identificados en el registro fósil, por ejemplo con el descubrimiento de la evidencia fósil más antigua del flujo polar de las auxinas en el leño de Archaeopteris, progimnosperma del Devónico Tardío. Las auxinas son transportadas basípetamente a través del cámbium vascular, estimulando el patrón de tejidos vasculares secundarios. Cuando el transporte de las auxinas se restringe por la salida de una rama o nudo, su vía de transporte es interrumpida, y las auxinas se concentran arriba de esa restricción, causando la diferenciación de las células conductoras en un 
patrón en espiral (Hejnowicz y Kurczynska, 1987). Este mismo patrón en espiral ha sido identificado en el leño de Archaeopteris, sirviendo como una "huella digital" para la interrupción del transporte de las auxinas y sugiriendo que el crecimiento del cámbium vascular en los ancestros antiguos de las espermatofitas tenía el mismo control hormonal que en las espermatofitas actuales (Rothwell y Lev-Yadun, 2005).

El leño de Archaeopteris es un ejemplo tangible de cómo los rasgos morfológicos de los fósiles pueden proveer información sobre la regulación del desarrollo en taxones extintos. El patrón en espiral fue registrado en otros ejemplares fósiles, como la conífera triásica argentina Protojuniperoxylon ischigualastense Bonetti emend. Bodnar y Artabe 2007 (Bodnar y Coturel, en prep.) (Figura IX.4).

Los patrones observados en el flujo de las auxinas sustentan firmemente la premisa de que los tejidos vasculares secundarios en las lignofitas (=plantas con semilla+sus ancestros progimnospérmicos), han sido regulados por mecanismos homólogos de control genético y fisiológico uniforme (Rothwell y Lev-Yadun, 2005).

Figura IX.4. Patrón en espiral por la interrupción del flujo de las auxinas, en la formación de una traza, en el leño de Protojuniperoxylon ischigualastense.

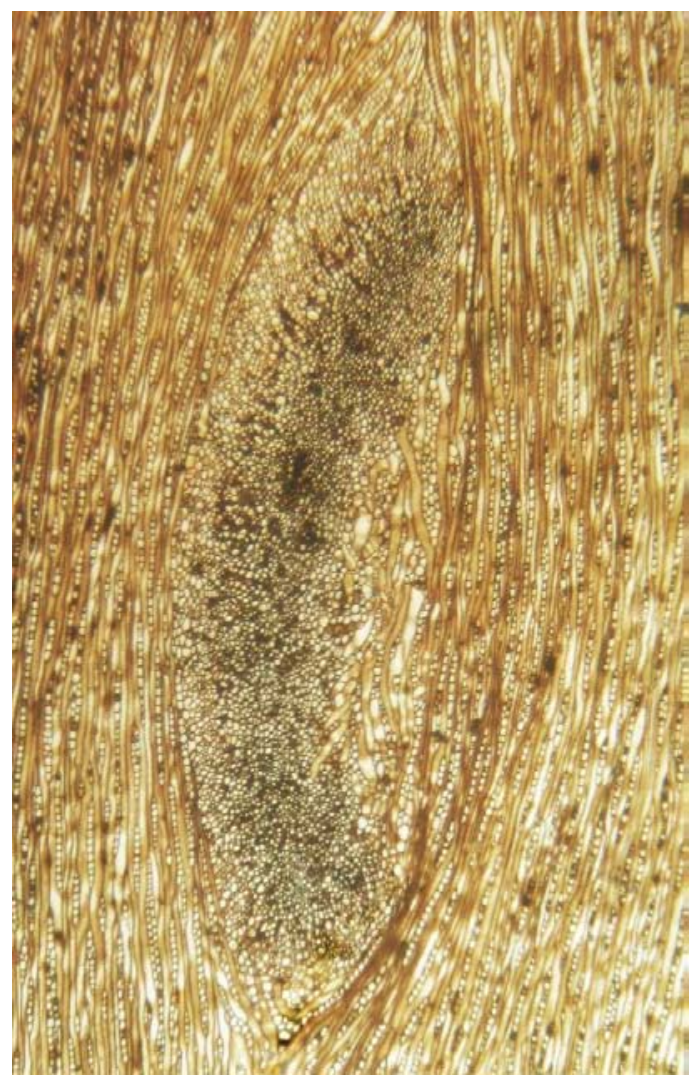

\section{IX.7. Patrones evo-devo en tallos de Corystospermaceae}

Los estudios del desarrollo en pteridospermas tienen la desventaja de que son llevados a cabo sobre grupos totalmente extintos. Como consecuencia, los mecanismos reguladores del desarrollo deben ser discernidos por medio de la comparación con ontogenias de plantas vivientes comparables. Al estudiar las Corystospermaceae, nos encontramos con la misma problemática. 
Se han descripto seis géneros de tallos de corystospermas: Rhexoxylon Bancroft 1913 emend. Archangelsky et Brett 1961 (seis especies), Tranquiloxylon Herbst et Lutz 1995 (una especie), Cuneumxylon Artabe et Brea 2003 (una especie) y Elchaxylon Artabe et Zamuner 2007 (una especie) exhiben un desarrollo anómalo del cilindro vascular secundario (Archangelsky y Brett, 1961; Brett, 1968; Herbst y Lutz, 1995; Chong Díaz et al., 1997; Artabe y Brea, 2003; Artabe y Zamuner, 2007). Por otra parte, Antarcticoxylon Seward 1914 (una especie), Kykloxylon Meyer-Berthaud, Taylor et Taylor 1993 (una especie), y Jeffersonioxylon del Fueyo, Taylor, Taylor et Cúneo 1995 (una especie) tienen un desarrollo típico del cilindro vascular secundario (del Fueyo et al., 1995; Meyer-Berthaud et al., 1992, 1993; Taylor, 1996).

Como se trató en el Capítulo VIII, el crecimiento secundario atípico de Rhexoxylon, Tranquiloxylon, Cuneumxylon y Elchaxylon genera un cilindro vascular secundario disecto y tejidos vasculares de desarrollo y posición inusuales. Esto es causado por cuatro clases de desviación de la actividad cambial normal: 1- actividad diferencial a lo largo de la circunferencia de los ejes; 2- actividad remanente; 3 - cámbium inverso o centrípeto; y 4- cámbium es supernumerarios inversos y/o normales (polixilia). Se pretende mediante el estudio del desarrollo, y en correlación con su evolución, dilucidar las vías por las que se originaron estos tipos tan particulares de actividad cambial.

\section{Base genética}

La Biología Molecular del crecimiento vascular secundario está sorprendentemente poco estudiada, aunque en los últimos años se ha avanzado en esta temática (ver secciones anteriores de este capítulo). Los genes conocidos como reguladores de la actividad cambial podrían haber tenido un papel fundamental en el origen y diversificación de los patrones vasculares observados en los troncos de corystospermas, como se sugiere en el siguiente análisis evo-devo.

\section{$\underline{\text { Series de transformación }}$}

Se ha propuesto que el cilindro vascular secundario de las corystospermas argentinas evolucionó a lo largo de dos series de transformación principales (rhexoxyloide y cuneumxyloide) desde un precursor tipo Medullosa (Artabe y Brea, 2003; Artabe y Zamuner, 2007). Cuneumxylon y Tranquiloxylon componen la serie cuneumxyloide, que se caracteriza por el xilema primario endarco, cuñas centrífugas de xilema secundario separadas por radios parequimatosos y polixilia centrífuga. Dentro de esta serie, parece existir una tendencia evolutiva hacia el incremento de la polixilia centrífuga. 
La serie rhexoxyloide incluye a Rhexoxylon y Elchaxylon y está caracterizada por: xilema primario mesarco, cuñas de xilema secundario centrífugo separadas por radios parenquimatosos, polixilia centrífuga, xilema secundario centrípeto y haces perimedulares dobles. De acuerdo a Artabe y Brea (2003), las especies argentinas de Rhexoxylon se ajustan a una serie evolutiva ( $R$. cortaderitaense, $R$. piatnitzkyi, y $R$. brunoi) que presenta un incremento en la polixilia centrípeta y centrífuga, y la adquisición progresiva de tallos de mayor tamaño. Elchaxylon representaría una rama que se inicia con $R$. cortaderitaense (Artabe y Zamuner, 2007), ya que ambos poseen un xilema secundario centrípeto que no forma verdaderos haces perimedulares.

Un modelo evolutivo alternativo fue hipotetizado por Bodnar (2008), incorporando los caracteres de los taxones no argentinos e interpretando esos caracteres desde un punto de vista diferente. Propone dos series de transformación: una con tendencia al aumento del desarrollo de los tejidos vasculares anómalos, y la otra con tendencia a la reducción de los mismos. R. tetrapteridoides (Sudáfrica) es el punto de partida para ambas secuencias, debido a que su patrón vascular es equivalente al de las medullosas pérmicas. La primer serie de transformación corresponde a: $R$. tetrapteridoides con un anillo completo de haces perimedulares dobles; $\rightarrow$ R. piatnitzkyi (Argentina), con un anillo más conspicuo de haces perimedulares dobles y una cantidad discreta de xilema centrípeto en el sistema cilíndrico; $\rightarrow$ R. brasilense (Brasil) y $R$. brunoi (Argentina), con un anillo completo de haces perimedulares dobles, y xilema centrípeto de mayor espesor en el sistema cilíndrico pero muy ligado al sistema medular; $\mathrm{y} \rightarrow R$. africanum (Sudáfrica), con dos anillos completos de haces perimedulares dobles. La segunda serie de transformación corresponde a: $R$. cortaderitaense (Argentina) con un ciclo conspicuo de xilema secundario centrípeto separado del sistema cilíndrico; $\rightarrow$ Elchaxylon (Argentina), con una cantidad discreta de xilema secundario centrípeto muy relacionado al sistema cilíndrico; $\rightarrow$ Cuneumxylon (Argentina) y Tranquiloxylon (Argentina), que pierden el xilema centrípeto; y $\rightarrow$ Kykloxylon, Jeffersonioxylon y Antarcticoxylon (Antártida), con un cilindro vascular secundario típico.

Si tenemos en cuenta los análisis cladísticos realizados en la presente tesis, sólo algunas de las series de transformación propuestas por Artabe y Brea (2003), Artabe y Zamuner (2007) y Bodnar (2008), quedan delineadas en el cladograma de las corystospermas. La causa de esto es evidente, en los modelos evolutivos se utilizó como ancestro un patrón similar al de una medullosa, mientras que en el análisis filogenético se usó un patrón de crecimiento secundario normal. No obstante, en los árboles se 
reconoce la serie cuneumxyloide y en parte la serie rhexoxyloide de Artabe y Brea (2003). Esto se debe a que en el trabajo de Artabe y Brea (2003), si bien se tomó como ancestral a una anatomía tipo medullosa, no se consideraron todos los caracteres de esa anatomía como primitivos. Por el contrario, Bodnar (2008) tomó como primitivos a todos los caracteres anatómicos de un ancestro tipo medullosa, de ahí tan diferentes resultados.

\section{Análisis evo-devo}

Se tomará como basal un patrón de crecimiento secundario típico, que abarca las siguientes etapas:

1. A partir de las células procambiales de los haces vasculares de una eustela, se desarrollan células cambiales, que conforman el cámbium fascicular.

2. Se diferencia un cámbium interfascicular derivado de las células parenquimáticas ubicadas entre los haces vasculares primarios. En las espermatofitas, se considera que el cámbium recién está completamente formado luego de que el parénquima interfascicular se diferencia en células fusiformes (Larson, 1994).

3. Se forma así un anillo cambial completo, que genera xilema secundario hacia el centro del eje y floema secundario hacia la periferia.

4. La totalidad de los tejidos vasculares secundarios va creciendo hacia la corteza, es decir, en sentido centrífugo.

Las cuatro clases de actividad cambial atípica que presentan las corystospermas, se desvían de este modelo de crecimiento, como se detalla a continuación. Estas variantes en el desarrollo del cámbium pueden relacionarse con patrones heterocrónicos, heterotópicos y homéoticos, y con la regulación de ciertos genes que han sido citados como controladores de la zona cambial:

1. Fragmentación radial del cilindro vascular secundario (actividad diferencial del cámbium): el cámbium interfascicular forma un tejido de relleno y/o sostén, conocido como parenquimatoso (células parenquimáticas, esclerenquimáticas e idioblastos) en una posición donde, en la ontogenia típica, se producen tejidos conductores secundarios (células xilemáticas y floemáticas). Éste es un reemplazo de un tipo tisular por otro, es decir, un cambio homeótico. Como los radios parenquimatosos siguen creciendo en ancho, ampliando la circunferencia del tallo y separando las cuñas xilemáticas, se están generando capas de células en donde no debería producirse más tejido. Por lo tanto, el crecimiento en ancho de los radios parenquimatoso puede responder a un cambio neoheterotópico. 
Un gen que podría estar implicado en estos procesos es el ATHB-8. En su estudio sobre la función de este gen en Arabidopsis, Baima et al. (2001) demostraron que tallos transgénicos con niveles modificados de ATHB-8 tuvieron alteraciones en las regiones interfasciculares. Otros genes que pueden estar implicados con la variación de la actividad del cámbium interfascicular son APL, AHK4/WOL/ CRE1, MP/IAA24, relacionados con la diferenciación de las células vasculares. Se necesitan mutaciones adicionales que eliminen específicamente otros tipos celulares vasculares (i.e. células cambiales, elementos traqueales y células del parénquima vascular o fibras) para identificar y caracterizar los mecanismos genéticos que controlan el destino celular vascular (Zhao et al., 2005).

2. Fragmentación tangencial del cilindro vascular secundario (actividad remanente del cámbium): entre el xilema secundario centrífugo y centrípeto, aparecen tejidos de relleno y/o sostén (=parénquima de dilatación) en forma de arcos, que son producidos por células cambiales que continúan dividiéndose mitóticamente. En la ontogenia típica no hay tejido en la posición que ocupa el parénquima de dilatación en los tallos de corystospermas. Por esto, este evento puede ser explicado vía neoheterotopía. El crecimiento ulterior de este parénquima de dilatación puede considerarse un caso de heterocronía, en dos sentidos: hacia una disminución (pedomorfosis, Figura IX.6.B) y, por otro lado, hacia un aumento (peramorfosis, Figura IX.6.C).

Posiblemente estén involucrados aquellos genes relacionados con el inicio de la actividad cambial. Como se dijo previamente, la composición y morfología de la pared celular diferencian una célula cambial de sus derivadas xilemáticas. En el caso del parénquima de dilatación, algunos grupos de células parenquimáticas mantienen su capacidad mitótica, que está directamente afectada por la construcción de la pared celular. Se han reconocido en Pinus taeda genes codificando proteínas importantes en la formación de la pared celular, la mayoría implicados en el patrón biosintético de la lignina, incluyendo PAL, C4H, OMT, 4CL, y CAD (Allona et al., 1998).

3. Producción de floema y xilema secundarios centrípetos (cámbium inverso): este tipo de floema y xilema secundarios se forma a partir de un cámbium atípico con respecto al cámbium presente en el desarrollo normal de un tallo con crecimiento secundario. Recibe la denominación de cámbium inverso, ya que es un tejido meristemático nuevo que produce tejidos vasculares hacia la médula, dirección opuesta a la observada en la ontogenia basal. Por lo tanto, responde a un cambio 
neoheterotópico. Los genes implicados podrían ser los ATHB-9/PHV, ATHB-14/PHB, KAN2, relacionados con la organización de los haces vasculares.

4. Polixilia o cámbium es supernumerarios: es un caso comparable al anterior, es la aparición de meristemas secundarios nuevos, que puede ser interpretada como un evento neoheterotópico.

En los estadios tempranos del desarrollo del tallo, varios haces vasculares colaterales están unidos por el cámbium interfascicular que resulta en la formación de un cilindro cambial completo. En algunas corystospermas con cilindro vascular disecto los anillos cambiales no son continuos, sino que están constituidos por varios arcos. Luego de funcionar por dos o tres años este anillo cesaría su actividad. Subsecuentemente un segundo anillo de cámbium se forma a partir de las células parenquimáticas corticales más internas. Estas células parenquimáticas pasan por divisiones periclinales para dar origen a células que se lignifican, abaxialmente, y células cambiales, adaxialmente. Las células cambiales se dividen periclinalmente dando origen a haces vasculares individuales con xilema y floema. Más tarde el cámbium en cada haz es unido por la aparición del cámbium interfascicular. Los cámbiumes subsecuentes se desarrollan de manera similar resultando en la formación de anillos sucesivos de xilema y floema (Rajput y Rao, 2003). Carlquist (2007) realizó una interpretación diferente para la polixilia, en la que existiría una zona externa (master cambium) activa mitóticamente de manera ininterrumpida, que genera capas de cámbium en dirección centrípeta

En el origen de la polixilia, están potencialmente involucrados aquellos genes reguladores relacionados con el inicio de la actividad cambial y la composición y morfología de la pared celular.

5. Evolución del sistema vascular medular: El sistema medular tiene su origen en los tejidos vasculares secundarios centrípetos (=cámbium inverso). Está conformado por uno o más ciclos de haces dobles perimedulares con una porción centrípeta y una porción centrífuga. El patrón de desarrollo observado en $R$. cortaderitaense no llega a desarrollar haces perimedulares. En las etapas tempranas de su cilindro vascular secundario consta de un ciclo vascular centrífugo-centrípeto. La actividad del cámbium se torna asimétrica, con un mayor desarrollo de los tejidos centrífugos que los centrípetos. El xilema (y floema) centrípeto se separa del centrífugo por el desarrollo de tejidos parenquimatosos (=actividad remanente) entre ellos. Aquí culmina el desarrollo de los tallos de $R$. cortaderitaense, que, si bien siguen creciendo en espesor, no sufren 
más diferenciaciones morfológicas (Figura IX.6.A). En la base de la filogenia de las corystospermas (Capítulo VIII) se separa Elchaxylon zavattieriae del resto de los taxones de troncos. El patrón de desarrollo de los tallos de Elchaxylon culmina en una etapa más temprana de diferenciación en comparación con $R$. cortaderitaense (basal del clado de las restantes corystospermas). En los ejes adultos de Elchaxylon se observa a los tejidos centrípetos unidos a los centrífugos, representando un caso heterocronía: pedomorfosis (Figura IX.6.B). En todas las especies de Rhexoxylon -excepto $R$. cortaderitaense- durante las etapas tardías, en el borde externo del xilema (y floema) centrípeto comienza a desarrollarse xilema (y floema) centrífugo. Por esto, en la etapa madura, el cilindro vascular secundario consta de un sistema medular, formado por uno a más ciclos de haces perimedulares dobles centrípeto-centrífugos. La aparición de tejidos vasculares centrífugos en el borde externo de los centrípetos (=polixila centrífuga) puede considerarse un evento neoheterotópico. Entre las formas con sistema medular, $R$. tetrapteridoides es la menos compleja. Las ontogenias de los otras especies muestran un incremento progresivo en la complejidad del sistema medular, evidenciado en un aumento del número de ciclos de haces perimedulares. Esto indicaría una adición de estadios ontogenéticos con respecto a $R$. cortaderitaense. $R$. tetrapteridoides se encuentra basal en la hipótesis filogenéticas con respecto a $R$. brasilense, $R$. pianitkzyi, $R$. africanum y R. brunoi. Estas especies presentan etapas del desarrollo adicionales en comparación con la ontogenia de $R$. tetrapteridoides, ya que muestran el crecimiento de un nuevo ciclo de tejido vascular centrípeto en todas las cuñas centrífugas. Dicha serie de transformación $R$. cortaderitaense $\rightarrow R$. tetrapteridoides $\rightarrow R$. brasilense $\rightarrow R$. pianitkzyi, $R$. africanum y $R$. brunoi, se interpreta como un patrón heterocrónico, en particular peramórfico (Figura IX.6.C).

La evolución del sistema medular incluye varios tipos de actividades cambiales: cámbium inverso, actividad remanente y polixilia centrífuga, por lo que aquellos genes implicados en esos procesos tendrían un papel fundamental en la diversificación de este carácter.

\section{IX.8. Conclusiones evolutivas-del desarrollo}

1. La Biología Evolutiva-del Desarrollo ha incrementado su aplicabilidad y relevancia a través de los años. Aunque los zoólogos en estos tópicos superaron a los botánicos y paleobotánicos, éstos siempre han estado comprometidos con cuestiones 
acerca del evo-devo. La heterocronía es el tema evo-devo más estudiado en la literatura paleobotánica y botánica.

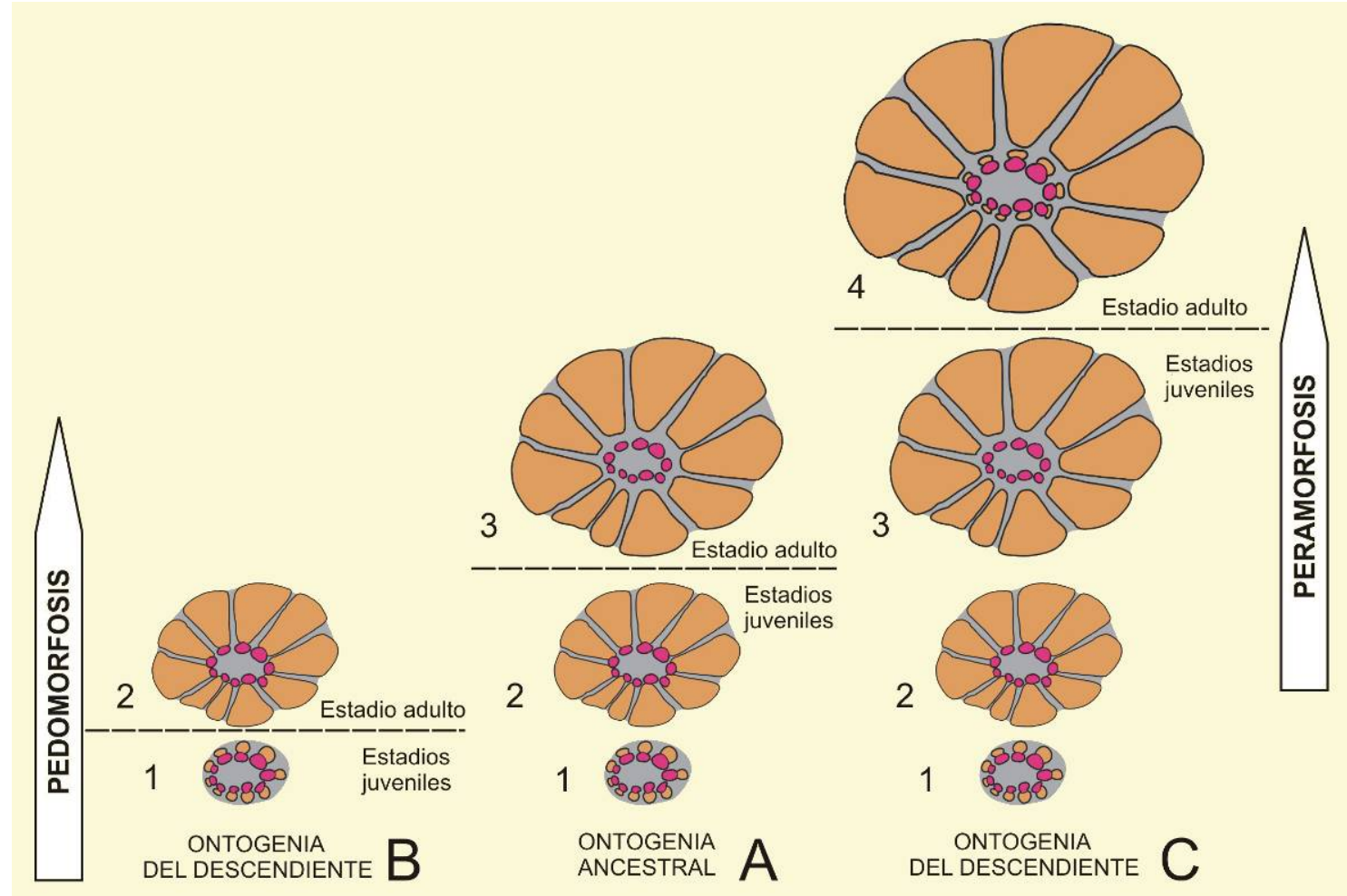

Figura IX.6. Evolución del sistema medular, mediante la comparación de las secuencias de desarrollo de tres taxones de Corystospermales. A- Rhexoxylon cortaderitaense, BElchaxylon zavattierae, C-Rhexoxylon piatnizkyi. Gris $\rightarrow$ parénquima y esclerénquima, Naranja $\rightarrow$ tejidos vasculares centrífugos (producidos por el cámbium normal), Fucsia $\rightarrow$ tejidos vasculares centrípetos (producidos por el cámbium inverso). En el primer estadio (1), dos anillos cambiales, alrededor del haz vascular primario, dan origen a cantidades iguales de tejidos vasculares centrífugos (anillo cambial normal) y centrípetos (anillo cambial inverso). En la fase siguiente (2) los anillos cambiales producen un desarrollo diferencial en la parte centrífuga. En las etapas posteriores (3), el tejido vascular centrípeto se separa del centrífugo debido al desarrollo de parénquima de dilatación entre ellos (resultado de la actividad del cámbium remanente). La fase adulta de $\boldsymbol{R}$. cortaderitaense (A.3) consiste en un ciclo de grandes cuñas de tejidos vasculares secundarios centrífugos separado por una barra tangencial de parénquima de un ciclo de tejidos vasculares centrípetos. La ontogenia de B (Elchaxylon zavattierae) se abrevia (pedomorfosis) y el estado adulto es comparable a la fase 2 de A. La ontogenia de $C(R$. pianitzkyi) se alarga (peramorfosis) y en una etapa ulterior, tejidos vasculares centrífugos crecen en el margen interno de los tejidos vasculares centrípetos generando un ciclo de haces perimedulares dobles (centrípeto-centrífugos). 
2. Aunque ciertas características del desarrollo de las plantas fueron considerados como obstáculos para los estudios evo-devo, la mayoría de las supuestas dificultades son de hecho útiles para los mismos.

3. Es necesario perfeccionar los análisis cladísticos entre plantas extintas y actuales y dentro de grupos fósiles, con el objeto de construir un marco filogenético ampliamente aceptado, en el que los patrones evolutivos pueden ser delineados con certeza.

4. La base genética de los cambios evo-devo puede ser extrapolada a las plantas fósiles, mediante el hallazgo de patrones morfológicos en ejemplares fosilizados homólogos a los regulados por genes homeóticos en plantas vivientes.

5. Los tallos fósiles muestran ventajas prácticas para los estudios evo-devo, que pueden ser aprovechadas por los paleobotánicos. Si bien la biología molecular del cámbium vascular estaba poco estudiada, su conocimiento fue incrementado significativamente en los últimos años.

6. Las cuatro desviaciones del modelo de actividad cambial típica que presentan las corystospermas (diferencial, remanente, inversa y supernumerarira), guardan una relación con eventos evo-devo. Todos los tipos de patrones evo-devo pueden ser invocados en el origen y evolución de estos tallos: heterocronía (pedomorfosis y peramorfosis) y heterotopía (homeosis y neoheterotopía).

7. Como se mencionó anteriormente, los estímulos físicos inducen a la diferenciación del cámbium (Lintilhac y Vesecky, 1981), y la formación del leño está positivamente correlacionada con el estrés físico (Higuchi, 1997). Las plantas pueden estar sujetas a un gran número de estrés (calor, frío, sequía, inundaciones, ataques por patógenos) que inducen la transcripción de genes cuya expresión es específica a tales condiciones (Allona et al., 1998). Se identificaron varios factores en Pinus taeda, como los MADS box, homeodominios de dedos de zinc y dominio LIM, que podrían estar implicadas en el desarrollo del xilema en respuesta del estrés.

8. Las corystospermas dominaron en un intervalo de tiempo caracterizado por condiciones ambientales únicas y estresantes, bajo un clima estacional megamonzónico y actividad volcánica intensa. Por esto, es plausible esperar que las alteraciones del cámbium respondan al estrés ambiental al que estuvieron sujetas estas plantas. 


\section{TAFONOMÍA Y PALEOCLIMATOLOGÍA}

\section{X.1. Introducción}

La Tafonomía es el estudio de los procesos que afectan a los restos de un organismo, durante el intervalo de tiempo que va desde la muerte del individuo hasta que es encontrado por un paleontólogo (e.g. Dodd y Stanton, 1990; Briggs y Crowther, 2001). El término fue creado por Efremov (1940) para referirse a los principios que gobiernan la transición de los restos orgánicos desde la biósfera a la litósfera.

Esta disciplina presenta una particular utilidad cuando los estudios son combinados con la información sedimentológica (Colombi y Parrish, 2008). La tafonomía ha sido recientemente aplicada a la Paleobotánica, con dos enfoques principales: el actualista, que abarca análisis observacionales y estadísticos de los mecanismos predepositacionales (Ferguson, 1985; Spicer y Greer, 1986; Spicer, 1989; Demko, 1995; Gastaldo et al., 1996; Campbell, 1999; Gastaldo y Staub, 1999; Fielding y Alexander, 2001; Gupta y Pancost, 2004; Parrish et al., 2004); y el estudio de la tafonomía en las cuencas sedimentarias, con el objeto de realizar inferencias paleoclimáticas, tectosedimentológicas, paleoecológicas y paleambientales (Ferguson, 1985; Spicer, 1989; Demko,1995; Demko et al., 1998; Campbell, 1999; Parrish et al., 2004, Colombi y Parrish, 2008). En el Triásico, los métodos tafonómicos se han utilizado para completar las interpretaciones paleoambientales y paleoclimáticas de la Formación Chinle en Norteamérica (Demko, 1995) y de la Formación Ischigualasto en Argentina (Colombi y Parrish, 2008).

Este estudio tiene como objeto realizar una caracterización tafonómica de los estratos fosilíferos de la Formación Cortaderita, reconocer las variaciones en la tafonomía de la unidad y correlacionarlas con los cambios en la sedimentología, con el fin de determinar la evolución paleoclimática y paleoambiental. Asimismo, se pudo realizar una comparación con modelos ambientales actuales.

\section{X.2. Tipos de fosilización}

Las clases de fósiles preservados en la Formación Cortaderita, se clasificaron de acuerdo al criterio Archangelsky (1962, 1970), Taylor y Taylor (1993) y Taylor et al. (2009). Se consideraron los siguientes tipos de fosilización: 
1- IMPRESIONES: Se trata de una copia de un resto vegetal, donde se preserva su huella en la sedimentita, sin materia orgánica asociada. En muchos casos quedan de una coloración diferente a la roca, como consecuencia de la presencia de óxidos. En el ejemplo estudiado, este tipo de preservación ocurrió en las hojas del EF5 de la Sección Superior rosada.

2- MOLDES: De este modo se preservan las estructuras tridimensionales, como tallos y semillas. El sedimento forma una copia en negativo tridimensional del fragmento vegetal, esto es, una cavidad, que posteriormente, si el resto se desintegra por completo, puede ser rellenada por sedimento. En este último caso, la copia del resto es en positivo. En los estratos fosilíferos analizados, los moldes de troncos alóctonos son copias negativas, mientras que los moldes de raíces y troncos autóctonos son copias positivas.

3- IMPRESIONES-COMPRESIONES: Los fragmentos vegetales son compactados y aplastados por la columna de sedimento, el agua de la materia orgánica se pierde, la estructura interna es obliterada, y lo que queda del sedimento es una lámina de carbón que recibe el nombre de compresión. Los fósiles de hojas, ramas y estructuras reproductivas encontrados como compresiones en los perfiles relevados siempre están asociadas a una impronta del fragmento, por lo que son denominados impresionescompresiones.

4- CARBONIZACIONES: Técnicamente son compresiones, es decir, que toda la materia orgánica del resto se han convertido en carbón. La diferencia es que no se ha perdido el volumen del fragmento vegetal, porque la transformación a carbón ocurrió rápidamente. En el ejemplo estudiado, los tejidos vegetales se encuentran carbonizados en relación a lluvias de cenizas que los quemaron.

5- PERMINERALIZACIONES: Es un tipo de fósil donde se produjo la imbibición de soluciones minerales en los tejidos vegetales (a nivel de los espacios intra e intercelulares) durante el sepultamiento del resto o poco después de ello (o sea en su diagénesis temprana). En este caso se preserva el detalle celular de los tejidos, por lo que se puede estudiar la anatomía. Troncos y tocones han quedado preservados como permineralizaciones síliceas a lo largo de toda la Formación Cortaderita.

6- MOMIFICACIONES (CUTÍCULAS): Las cutículas están compuestas por elementos ácido-resistentes, por lo que quedan preservadas casi sin modificaciones en sedimentos cuya diagénesis ha permanecido con $\mathrm{pH}$ y eH bajos, sin lixiviado de sustancias. En las sedimentitas estudiadas, las cutículas están asociadas a las compresiones, quedando como una fina película brillante sobre ellas. 


\section{X.3. Marco sedimentológico}

Como se analizó en el Capítulo VI, la Formación Cortaderita comprende dos secciones: Inferior gris y Superior rosada.

La Sección Inferior gris está caracterizada por una preponderancia de limolitas grises masivas con alto contenido piroclástico, intercaladas con areniscas y conglomerados amarillentos, con estratificación entrecruzada, mayormente de geometría lenticular. En el Capítulo VI se interpretó a estas sedimentitas como depósitos de ambientes fluviales meandrosos, gravoso-arenosos de mediana-alta sinuosidad, con planicies de inundación extensas con paleosuelos de tipo vertisoles, en los que se desarrollaron comunidades herbáceo-arbustivas y bosques (ver Capítulos VII y XI). Las planicies de inundación eran cubiertas episódicamente por lluvias de cenizas (bentonitas). Los fósiles quedaron preservados como moldes de troncos en el relleno de los canales de los ríos meandrosos; rizoconcreciones, impresiones-compresiones de briznas, raíces in situ de hojas, ramas y estructuras reproductivas en los paleosuelos; impresiones de hojas y ramas en los canales de crevasse; permineralizaciones de troncos $\mathrm{y}$ tocones en los paleosuelos cubiertos de bentonitas; y carbonizaciones de briznas, ramas, fragmentos troncos y tocones en las bentonitas.

La Sección Superior rosada se distingue por un predominio de areniscas rosadas y violáceas, de alto contenido piroclástico, con laminación y estratificación entrecruzada, en estratos tabulares y lenticulares. En el Capítulo VI se definió a esta sucesión sedimentológica como dos sistemas fluviales entrelazados arenosos, típicos de regiones áridas. En las barras longitudinales abandonadas se formaron paleosuelos de tipo aridisoles, con cementación sílicea y calcárea, en los que crecieron comunidades de bosques de baja diversidad (ver Capítulos VII y XI). Los tipos de fósiles que han quedado preservados son moldes de raíces en los paleosuelos; impresiones e impresiones-compresiones de hojas y ramas en mantos arenosos laminados efímeros los paleosuelos; y permineralizaciones de troncos en los barras longitudinales.

\section{X.4. Estilos preservacionales}

En las tafofloras contenidas en la formación, se identificaron once estilos preservacionales: (A) impresiones-compresiones de raíces, (B) rizoconcreciones, (C) moldes de raíces y rizomas, (D) moldes de troncos orientados horizontalmente, (E) moldes de tallos orientados verticalmente, (F) troncos y tocones silicificados verticales, (G) troncos silicificados horizontales y oblicuos, $(\mathrm{H})$ fragmentos de troncos y raíces 
carbonizados, (I) impresiones-compresiones orientadas horizontalmente, con cutícula preservada, $(\mathrm{J})$ impresiones orientadas horizontalmente, con un lámina de óxidos y $(\mathrm{K})$ briznas vegetales (Figuras X.1 y 2).

(A) IMPRESIONES-COMPRESIONES DE RAÍCES: Son restos autóctonos de raíces que consisten en trazas desde muy delgadas a robustas, mayormente perpendiculares u oblicuas al plano de estratificación, con ramificaciones abundantes. Varían en diámetro desde un milímetro hasta un centímetro, y en longitud desde centímetros hasta un metro o más. Las trazas están presentes en concentraciones medianas a muy altas, y distribuidas al azar. Están preservadas como impresionescompresiones, en muchos casos cubiertas por hematita (Figura X.1.1).

(B) RIZOCONCRECIONES: El material orgánico original se perdió casi enteramente, dejando una marca clara en el lugar donde estaba la raíz. Estos rastros son de coloración gris clara a blanquecina, probablemente porque han precipitado carbonatos. Son muy pequeñas, de 2 milímetros de diámetro y algunos centímetros de longitud. Ocurren en concentraciones bajas, son perpendiculares al plano de estratificación. Se consideran rasgos pedogenéticos (Figura X.1.2).

(C) MOLDES DE RAÍCES Y RIZOMAS: Es el caso de raíces y rizomas de mayor porte, de varios centímetros de diámetro, que dejaron una cavidad al desintegrarse y luego se han rellenado con sedimento. Aparecen aisladas en los estratos. Se preservaron en el mismo paleosuelo donde crecieron las plantas productoras, pero no en posición de vida (Figura X.1.3).

(D) MOLDES DE TRONCOS HORIZONTALES: Son las huellas de los troncos, alóctonos, transportados por las corrientes del canal fluvial. No preservan restos de materia orgánica. Varían en diámetro de 3,5 a $8 \mathrm{~cm}$, con una longitud de aproximadamente $1 \mathrm{a}$ 1,5 $\mathrm{m}$. Muestran en su superficie estrías longitudinales y salientes o abultamientos romboidales. Se presentan en concentraciones bajas. En el estrato se han contado diez moldes. Han quedado en una relación horizontal o paralela al plano de estratificación, tienen en promedio la misma orientación que la estratificación entrecruzada de la roca que los contiene (Figura X.1.4).

(E) MOLDES DE TALLOS VERTICALES: En este caso, los tallos de árboles de mediano porte (probablemente Equisetales u Osmundales) han sido desintegrados en posición de vida. La cavidad resultante se rellenó con sedimento. Varían en diámetro de 1,5 a $34 \mathrm{~cm}$. La altura de los troncos no pudo ser medida porque estaban incluidos en la roca. En casi todos los casos quedó una película carbonosa o de hematita 
(=compresión), como resto de la materia orgánica original. Ocurren en concentraciones medianas, y están orientados perpendicularmente al plano de estratificación (Figura X.1.5).

(F) TRONCOS Y TOCONES SILICIFICADOS VERTICALES: Este tipo preservacional está constituido por troncos y bases (tocones) de árboles autóctonos, pertenecientes a la especie de Corystospermales Rhexoxylon cortaderitaense (Menéndez) Bodnar. Los tocones están en conexión con raíces y/o rizomas. En raros casos, los troncos han quedado en conexión con ramificaciones. El diámetro varía de 13 a $80 \mathrm{~cm}$. La longitud de los troncos no pudo ser medida porque estaban incluidos en la roca, excepto por un ejemplar que mide $1 \mathrm{~m}$ de largo. Los tocones tienen una altura de $30 \mathrm{~cm}$. Su concentración es mediana a alta, y están orientados de manera perpendicular o ligeramente oblicua con respecto al plano de estratificación. En todos los casos la permineralización es por sílice amorfa. La estructura interna de los troncos se encuentra con una preservación regular a buena. La anatomía típica del taxón (cilindro vascular secundario disecto) provoca que los troncos de fragmenten en cuñas, ya que los radios parenquimatosos sufrieron una permineralización con menor resistencia mecánica. En algunos ejemplares, hay una parcial carbonización del tronco o del tocón. Los troncos y tocones están distribuidos en concentraciones medianas, y perpendiculares al plano de estratificación, junto a los troncos de la categoría siguiente (Figura X.1.6).

(G) TRONCOS SILICIFICADOS HORIZONTALES Y OBLICUOS: Son troncos asignables a la especie Rhexoxylon cortaderitaense, autóctonos o parautoctónos. Los primeros son árboles caídos y que no sufrieron transporte, por lo que conservan sus bases. Los segundos ya perdieron sus bases, por lo que ya sufrieron, aunque mínimo, algo de transporte dentro del mismo subambiente sedimentario. Salvo en un ejemplar, todos los troncos están decorticados. Todos los especímenes carecen de ramificaciones en conexión orgánica, si bien algunos se encuentran asociados a ejes de menor porte que probablemente hayan sido sus ramas. Los ejemplares encontrados en la Sección Superior están preservados en paleosuelos asociados a un nivel de silcrete, mientras que los de la Sección Inferior gris están preservados en un paleosuelo cubierto por bentonitas. En la Sección Superior rosada los troncos están parcialmente enterrados, mientras que en la Sección Inferior gris están completamente descubiertos como consecuencia de la explotación de la bentonita por manos del hombre. Miden en diámetro desde 8 hasta $53 \mathrm{~cm}$ y su longitud, en los casos que pudo medirse, varía de 1,5 a 9,5 metros. Como en la categoría anterior, la permineralización es por sílice amorfa y 
la estructura interna tiene una preservación regular a buena. Son comunes los nódulos de hematita en la superficie de los ejemplares. Los troncos y tocones están distribuidos en concentraciones altas junto a los troncos de la categoría anterior, paralelos al plano de estratificación, con rumbos muy diversos (Figura X.1.7).

(H) FRAGMENTOS DE TRONCOS Y RAÍCES CARBONIZADOS: Fragmentos de diversos tamaños de árboles carbonizados. En algunos casos los troncos preservan sus raíces y rizomas. Se hallan aislados o en concentraciones muy bajas. La materia orgánica original está transformada enteramente en carbón, por las temperaturas altas de la lluvia de cenizas que cubrió los restos. Tienen una relación perpendicular o paralela al plano de estratificación (Figura X.2.8).

(I) IMPRESIONES-COMPRESIONES ORIENTADAS HORIZONTALMENTE, CON CUTÍCULA PRESERVADA: Son hojas, ramas y algunas estructuras reproductivas, autóctonas y parautoctónas, en varios niveles superpuestos, de algunos milímetros de espesor. Los fósiles consisten en la huella del resto (=impresión), una película carbonosa de coloración negra a parduzca (=compresión) y la cutícula preservada in situ, que se observa como una lámina brillante entera o craquelada sobre la compresión. La determinación de los ejemplares se detalla en el Capítulo VII. A grandes rasgos, se han identificado musgos, hepáticas, helechos (Asterothecaceae, Dipteridaceae), "pteridospermas" (Corystospermaceae, Peltaspermaceae), cycadales (Incertae sedis, Stangeriaceae), gnetales, ginkgoales y coníferas (Incertae sedis, Voltziaceae, Podocarpaceae). Los ejemplares se encuentran en concentraciones muy altas, mayormente encimados, cubriéndose entre sí parcial o totalmente, y son paralelos al plano de estratificación (Figura X.2.9).

(J) IMPRESIONES ORIENTADAS HORIZONTALMENTE, CON PÁTINA DE ÓXIDOS: Son hojas autóctonas y parautoctónas, en varios niveles superpuestos, de algunos milímetros de espesor. Los fósiles consisten en la huella del resto (=impresión), con una pátina de coloración rosada a roja ladrillo, de óxidos de hierro. La determinación de los ejemplares se detalla en el Capítulo VII. A grandes rasgos, se han identificado "pteridospermas" (Corystospermaceae, Peltaspermaceae), cycadales (Incertae sedis, Stangeriaceae), gnetales y ginkgoales. Los ejemplares se encuentran en concentraciones altas, mayormente encimados, cubriéndose entre sí parcial o totalmente, y son paralelos al plano de estratificación (Figura X.2.10). 
(K) BRIZNAS VEGETALES: fragmentos muy pequeños, no identificables, de hojas y ramas. El tipo de fosilización al que corresponden es tanto compresiones como carbonizaciones, dependiendo del evento que las ha sepultado (Figura X.2.11).
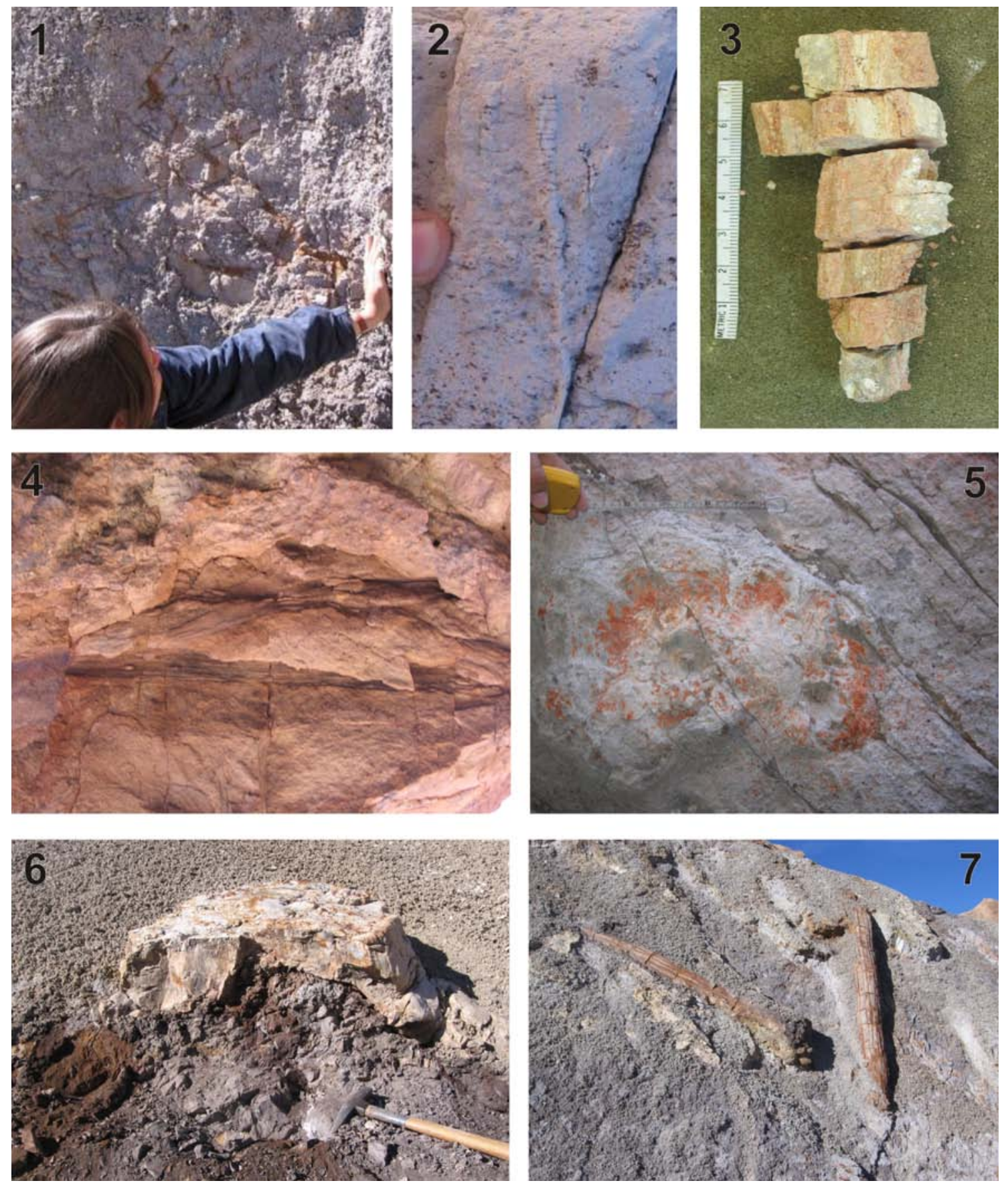

Figura X.1. Estilos preservacionales identificados en la Formación Cortaderita. 1. (A) impresiones-compresiones de raíces. 2. (B) rizoconcreciones. 3. (C) moldes de raíces y rizomas. 4. (D) moldes de troncos horizontales. 5. (E) Moldes de tallos verticales. 6. (F) troncos y tocones silicificados verticales. 7. (G) Troncos silicificados horizontales y oblicuos. 

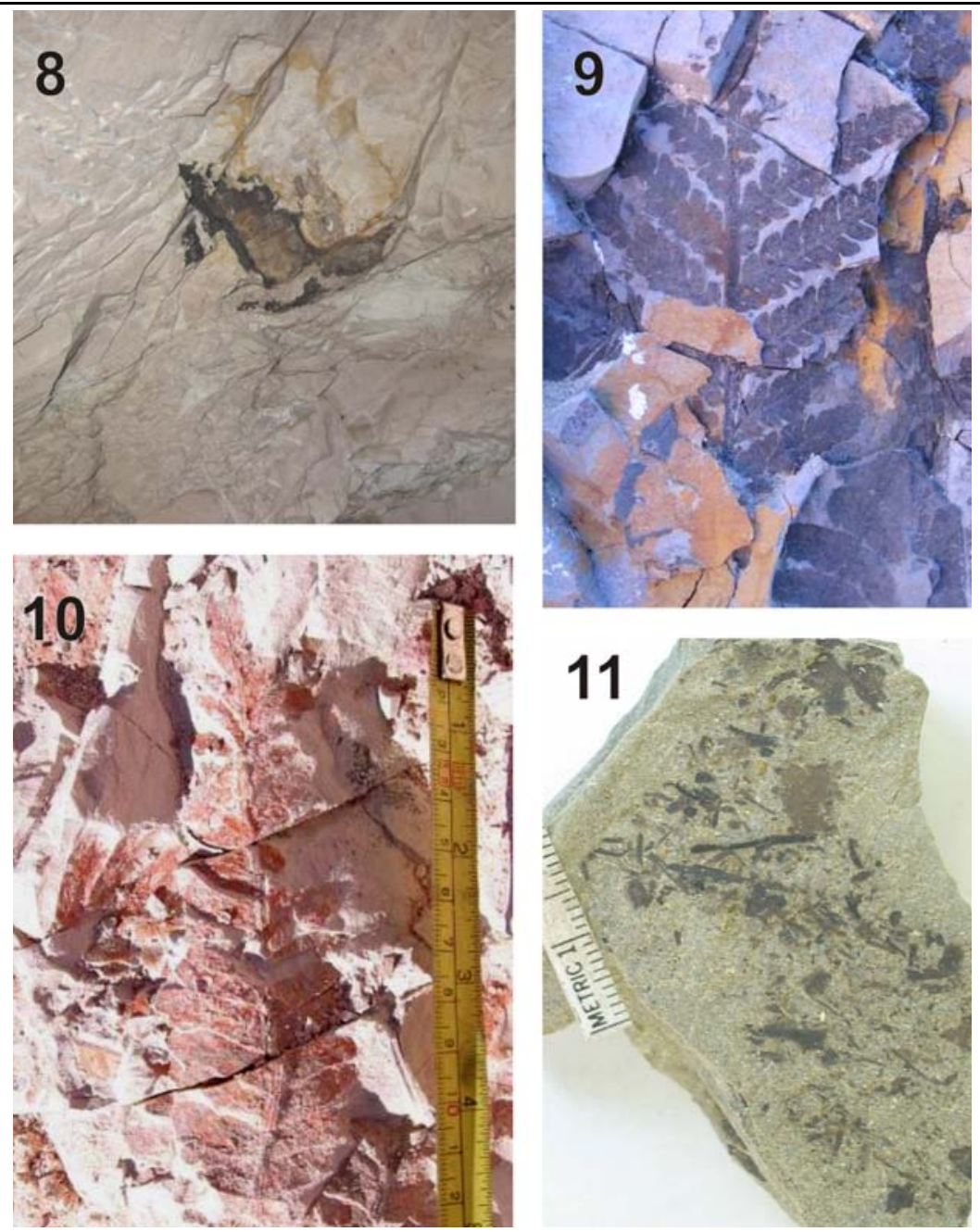

Figura X.2. Estilos preservacionales identificados en la Formación Cortaderita (continuación). 8. (H) fragmentos de troncos y raíces carbonizados. 9. (I) impresionescompresiones orientadas horizontalmente, con cutícula preservada. 10. (J) impresiones orientadas horizontalmente, con pátina de óxidos. 11. (K) briznas vegetales.

\section{X.5. Definición e interpretación de las tafofacies}

El término tafofacies se refiere a conjuntos de rocas sedimentarias caracterizados por una combinación particular de caracteres preservacionales de los fósiles que contienen (Speyer y Brett, 1986; Brett y Speyer, 1990). Para definir y nombrar a las tafofacies, se siguió el criterio de Colombi y Parrish (2008). Estas autoras utilizaron el código para litofacies fluviales propuesto por Miall (1996), agregándole un código alfabético que representa el estilo preservacional. Se aplicará la propuesta de Colombi y Parrish (2008) con la diferencia de que, mientras ellas denominan a las tafofacies con los estilos preservacionales dominantes más el elemento arquitectural al que corresponden las sedimentitas, aquí los nombres de las tafofacies son la combinación de los estilos preservacionales más las litofacies. 
El estudio tafonómico en plantas tiene la particularidad de que los diferentes órganos vegetales (raíces, ramas, tallos, troncos, hojas, cutículas, polen, esporas, semillas) tienen respuestas diferentes a los mismos procesos y condiciones ambientales (Colombi y Parrish, 2008). Por otra parte, los mismos órganos muestran distintos comportamientos cuando las condiciones ambientales cambian. Como consecuencia, el análisis tafonómico de los vegetales sirve como una herramienta adicional para las inferencias paleoambientales y paleoclimáticas.

Las tafofloras estudiadas comprenden ocho tafofacies: (1) $\mathrm{AB}(\mathrm{Fr} / \mathrm{Fm})$ impresiones-compresiones de raíces y rizoconcreciones en areniscas y limolitas grisáceas masivas bioturbadas; (2) $\mathrm{CFG}(\mathrm{P} / \mathrm{Sl})$ moldes de raíces y rizomas, y troncos silicificados parautóctonos, asociados a sabulitas y areniscas sabulíticas con laminación difusa; (3) $\mathrm{D}(\mathrm{Sm} / \mathrm{Stg})$ moldes de troncos horizontales en conglomerados finos, sabulitas y areniscas gruesas masivas y con estratificación entrecruzada; (4) $\mathrm{EFG}(\mathrm{Fr} / \mathrm{Fm} / \mathrm{Bt}$ ) troncos y tocones silicificados autóctonos y paraautóctonos, asociados a areniscas y limolitas grisáceas masivas bioturbadas y bentonitas; (5) $\mathrm{HK}(\mathrm{Bt})$ briznas y fragmentos de troncos y raíces carbonizados, preservados en bentonitas; (6) $\mathrm{IK}(\mathrm{Fr} / \mathrm{Fl}$ ) briznas e impresiones-compresiones con cutículas orientadas horizontalmente, en limolitas y areniscas muy finas masivas y laminadas; (7) $\mathrm{J}(\mathrm{Fl} / \mathrm{Sl})$ impresiones orientadas horizontalmente, con pátina de óxidos, en areniscas, limolitas y arcilitas con laminación horizontal; y (8) $\mathrm{I}(\mathrm{Sl})$ impresiones-compresiones en areniscas tobáceas rosadas laminadas.

(1) TAFOFACIES $\mathrm{AB}(\mathrm{Fr} / \mathrm{Fm})$ : Está conformada por bancos sucesivos de geometría tabular, de limolitas grisáceas bentoníticas masivas. Son frecuentes los niveles oscuros carbonosos y ocres por la presencia de óxidos de hierro. Presentan rasgos de exposición subárea (rizoconcreciones, evaporitas y nódulos de óxidos de hierro). Esta tafofacies es interpretada como depósitos finos de planicie de inundación. La abundancia en contenido piroclástico de las limolitas respondería a que el aporte de sedimentos de granulometría fina también provino de lluvias de cenizas episódicas. Los evidentes rasgos pedogenéticos (bioturbación, raíces in situ, evaporitas, slickensides, nódulos) indicarían se desarrollaron paleosuelos de clima estacional (tipo vertisoles). La presencia de raíces bien desarrolladas y de diversos tamaños sugiere que los paleosuelos sostenían una comunidad arbóreo-arbustiva. A lo largo del espesor de la tafofacies se puede observar las etapas desde colonizadoras hasta bien desarrolladas de los bosques. Las raíces y raicillas fueron sepultadas por las sucesivas capas de sedimentos 
epiclásticos y piroclásticos, y deshidratadas por la presión y temperatura por lo que la materia orgánica se transformó en carbón (=compresión).

(2) TAFOFACIES CFG(P/Gl): Está caracterizada por sabulitas y areniscas sabulíticas con laminación difusa, intercaladas con niveles de sílice, evaporitas y calcita. Estas rocas se disponen en un estrato tabular, y son interpretadas como depósitos generados por precipitación química sobre una barra abandonada, con el consecuente desarrollo de un paleosuelo de clima semiárido (aridisol). La formación de una duricrosta (silcrete) marca una discontinuidad en la sedimentación. La tafocenosis está compuesta por plantas exclusivamente arbóreas, que eran especialistas de un clima semiárido. Hubo una reactivación en la sedimentación, con un nuevo ciclo fluvial entrelazado, que enterró el bosque. Las raíces fueron disueltas y las cavidades resultantes fueron rellenadas por carbonatos. Los troncos se cayeron y quedaron preservados en el mismo paleosuelo que lo sustentó. La abundancia de sílice disuelta en el agua circundante proveyó del mineral necesario para la permineralización de los troncos. La silicificación de los troncos es consecuencia de la percolación de fluidos ricos en sílice a través de los poros de sedimentos gruesos. La saturación de las soluciones por este mineral proviene de la abundancia del mismo en un ambiente que sufrió la influencia de importante actividad volcánica.

(3) TAFOFACIES D(Sm/Stg): Esta tafofacies consiste en areniscas gruesas, areniscas sabulíticas y conglomerados finos de tonalidades rojizas, con intraclastos, masivas y con estratificación entrecruzada. Los bancos tienen una geometría lenticular y fueron interpretados como el relleno de canales arenoso-gravosos. Portan moldes de troncos horizontales, de 1,5 m cuyos rumbos han sido medidos como: $\mathrm{N} 75^{\circ}, \mathrm{N} 102^{\circ}, \mathrm{N}$ $115^{\circ}, \mathrm{N} 120^{\circ}, \mathrm{N} 126^{\circ}, \mathrm{N} 170^{\circ}$ y N $270^{\circ}$. Los troncos pertenecían a árboles de los bosques que se desarrollaban en la planicie de inundación. El transporte y la descomposición del resto original han sido muy importantes ya que sólo ha quedado el molde, sin restos de materia orgánica.

(4) TAFOFACIES EFG(Fr/Fm/Bt): Está representada por limolitas bentoníticas grises oscuras masivas, con venas de yeso y raíces oxidadas en la base, y hacia el techo, láminas de yeso y nódulos de hierro. Estas sedimentitas están cubiertas por bentonitas grisáceas claras con clastos volcánicos y líticos, nódulos de hierro aislados y láminas de yeso. Este conjunto de rocas es interpretado como paleosuelos de tipo vertisol desarrollados sobre los depósitos finos de planicie, que fueron enterrados por una lluvia de cenizas (tobas). Estos depósitos piroclásticos de caída fueron alterados, 
probablemente por bioturbación e inundaciones, y se desvitrificaron, transformándose en bentonitas. Los fósiles abundantes en estas facies son troncos y tocones silicificados de la especie de corystosperma Rhexoxylon cortaderitaense. En menor proporción, ocurren moldes de tallos de probables equisetales y/o osmundales. Ambos tipos fosilíferos se encuentran en el contacto entre las limolitas y las bentonitas. Las tafocenosis representarían comunidades arbóreas bien desarrolladas y diversas, que fueron sepultadas por lluvias de cenizas volcánicas. La presencia de moldes de tallos y bases de troncos silicificados en posición de vida, muestra que el enterramiento por los depósitos piroclásticos fue el motivo de la muerte de esas plantas. En el caso de plantas sin crecimiento secundario, la resistencia a la descomposición fue menor, y sólo quedó de ellas una lámina carbonosa o de hematita. Los árboles de corystospermas tuvieron una resistencia física y química mayor, y fueron permineralizados. Una parte de éstos se encuentran caídos pero unidos a su parte basal. La desvitrificación de las tobas, en su proceso de alteración a bentonitas, ha suministrado la sílice amorfa para la permineralización de los troncos y tocones. Por lo tanto, la lluvia de cenizas representó, para estas paleocomunidades, su causal de muerte, sepultamiento y preservación.

(5) TAFOFACIES HK(Bt): Consiste en cuerpos de importante espesor y bases erosivas, de bentonitas grisáceas claras con clastos volcánicos y líticos, nódulos de hierro aislados y láminas de yeso. Inferidos como depósitos piroclásticos de caída (tobas) posteriormente alterados por bioturbación, meteorización y diagénesis, albergan impresiones-compresiones de hojas, y fragmentos de troncos, raíces y briznas carbonizados. Estos restos provienen de las paleocomunidades árboreas subyacentes. Probablemente éstas fueron muriendo con las sucesivas lluvias piroclásticas, quedando algunas plantas sobrevivientes cuyos troncos son los que se encuentran carbonizados en las bentonitas. La materia orgánica de estos restos fue convertida en carbón por la pirólisis causada por las altas temperaturas de las cenizas volcánicas. Están últimas carbonizaron muy rápidamente los restos, por lo que el material quedó como carbón sólido.

(6) TAFOFACIES IK(Fr/Fl): Limolitas grises bentoníticas masivas con intercalaciones de areniscas finas y limolitas grises y amarillentas laminadas. Se infieren que estos depósitos de capa plana de alto régimen (flujo crítico), representarían un flujo en manto sobre la planicie de inundación (cuenca de inundación propiamente dicha). Los eventos de inundación por desborde del canal sepultaron los niveles de hojarasca de los bosques que se desarrollaban en la planicie de inundación, preservando briznas 
vegetales, hojas, ramas y estructuras reproductivas como impresiones-compresiones en varios niveles de pocos milímetros de espesor. La presencia de numerosas compresiones y cutículas, indicaría condiciones reductoras en el ambiente. Estas condiciones pudieron ser generadas por la abundancia de materia orgánica provista por un sotobosque profuso, y que el agua proveniente del desborde del canal quedó estancada, permitiendo la decantación de materiales finos.

(7) TAFOFACIES J(F1/S1): Está definida por la abundancia de impresiones orientadas horizontalmente, con pátina de óxidos, en areniscas, limolitas y arcilitas grises y rosadas con laminación horizontal. Estos depósitos también son interpretados como un flujo en manto de la planicie de inundación. En este subambiente los fósiles se han preservado en diferentes niveles superpuestos al ser sepultados sucesivamente por varios eventos de inundación por desborde del canal, pero las condiciones oxidantes provocaron que se desintegre por completo la materia orgánica original de los fósiles o sólo quede una pátina de hematita sobre los mismos.

(8) TAFOFACIES $\mathrm{I}(\mathrm{Sl})$ : Esta tafofacies se caracteriza porque alberga impresiones-compresiones aisladas de frondes muy grandes de la especie Zuberia feistmanteli (corystosperma). Las sedimentitas consisten en areniscas muy finas rosadas a blanquecinas tobáceaes, con laminación de bajo ángulo, y son interpretadas como depósitos de capa plana de alto régimen (flujo crítico), constituyendo mantos arenosos laminados efímeros. Los fósiles representan los restos de las copas de los árboles que conformaban un bosque monotípico de corystospermas (ver Capítulos VII y XI).

\section{X.6. Distribución de las tafofacies}

En la figura X.3 se esquematizó la distribución estratigráfica y espacial de las tafofacies en cuatro de las perfiles sedimentológicos relevados (ver Capítulo VI). Hay una distinción notoria entre las dos secciones de la Formación Cortaderita en cuanto a los tipos de tafofacies presentes. Por otra parte, en cada una de las secciones hay una uniformidad lateral, ya que las tafofacies se distribuyen en toda la extensión de las quebradas de la Cortaderita y la Tinta. Sólo las tafofacies J(Fl/Sl) e I(Sl) están restringidas a un área determinada y un sector reducido de la columna estratigráfica.

En la Sección Inferior gris, las tafofacies $\mathrm{AB}(\mathrm{Fr} / \mathrm{Fm}), \mathrm{EFG}(\mathrm{Fr} / \mathrm{Fm} / \mathrm{Bt}) \mathrm{y}$ $\mathrm{IK}(\mathrm{Fr} / \mathrm{Fl})$ son las más abundantes tanto vertical como lateralmente. En la Sección Superior rosada, las tafofacies $\mathrm{CFG}(\mathrm{P} / \mathrm{Gl})$ y $\mathrm{J}(\mathrm{Fl} / \mathrm{Sl})$ son las más frecuentes. 
Las diferencias tafonómicas entre ambas secciones muestran que los contextos sedimentológicos y geoquímicos cambiaron sustancialmente a lo largo del tiempo. En la Sección Inferior gris, las tafofacies indicarían un mayor aporte de sedimentos finos, en gran parte provenientes de lluvias de cenizas volcánicas que pudieron depositarse en las amplias planicies de inundación de sistemas fluviales meandrosos; y por otro lado las condiciones habrían sido bastante reductoras, gracias a la abundante materia orgánica en descomposición, lo que permitió la preservación de compresiones y cutículas. En la Sección Superior rosada, el aporte de sedimentos finos estuvo muy acotado, dominando las arenas. Si bien en las sedimentitas se reconoce un contenido piroclástico importante, no se lograron acumularse grandes espesores de tobas o bentonitas. A su vez, las condiciones en esta sección fueron más oxidantes, lo que queda evidenciado por la ausencia de cutículas preservadas.

\section{X.7. Inferencias paleoclimáticas}

Robinson (1973) fue el primero en referirse al clima durante el desarrollo de Pangea, como un sistema monzónico. En las décadas de 1980 y 1990, el clima de la Pangea fue estudiado por varios grupos (e.g. Parrish y Curtis, 1982; Rowley et al., 1985; Parrish et al., 1986; Parrish y Peterson, 1988; Crowley et al., 1989; Chandler et al., 1992; Valdes y Sellwood, 1992; Parrish, 1993), que apoyaron la hipótesis de un clima monzónico, no zonal. Kutzbach y Gallimore (1989) fueron los primeros en referirse al clima triásico como un megamonzón. El desarrollo máximo del monzón estuvo caracterizado por la extensión de climas áridos en regiones de latitudes relativamente altas, marcada estacionalidad de las precipitaciones en gran parte del supercontinente, y una circulación atmosférica contraria en la Pangea ecuatorial occidental. Además, el clima aparentemente continuó calentándose y haciéndose más estacional a través del Triásico (Parrish y Peterson, 1988; Parrish, 1993; Parrish et al., 1996).

En Australia, la presencia de capas rojas con depósitos fluviales marca un importante cambio abrupto en la sedimentación durante el límite Permo-Triásico, posiblemente causado por la máxima fuerza del monzón (Parrish et al., 1996). En Sudamérica, hay capas rojas dispersas por todo el continente, con ocurrencia locales de arenas eólicas, que son consistentes con el clima monzónico (Volkheimer, 1969; RochaCampos, 1973; Parrish y Peterson, 1988; Colombi y Parrish, 2008). 


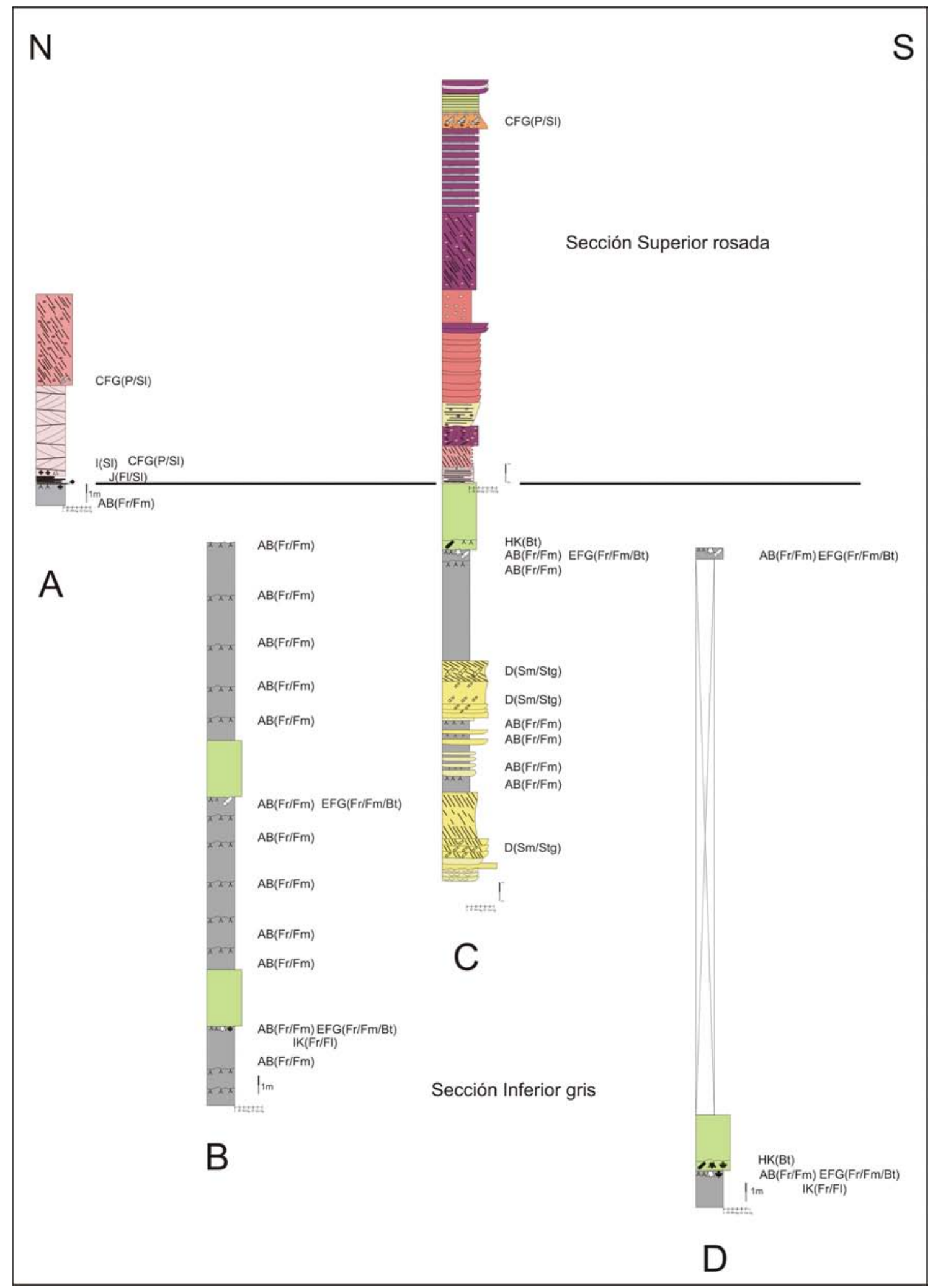

Figura X.3. Distribución espacial y temporal de las tafofacies en los perfiles relevado en la Formación Cortaderita. A. Perfil 4 (Localidad 6: S 31 38' 19,8" W 69 25' 19,8"). B. Perfil 2 (Localidad 3: S 31 39' 00,1" W 69 23' 52,1"). C. Perfil 1 (entre Localidad 4: S 31 39' 05,9" W 69॰ 23' 52,3" y Localidad 10: S 31 39' 09,1" W 69 23' 53,1"). D. Perfil 3 (Localidad 5: S $\left.31^{\circ} 39^{\prime} 16,4^{\prime \prime} \mathrm{W} 69^{\circ} 23^{\prime} 16,4^{\prime \prime}\right)$. No fue necesaria la inclusión del perfil 5 porque en cuanto a su tafonomía es muy semejante al perfil 2. 
La tectónica determina el ritmo e intensidad de las oscilaciones del nivel de base así como también la tasa de subsidencia en las cuencas sedimentarias (Spalletti et al., 2003), ejerciendo un control fundamental sobre el desarrollo de diferentes tipos climáticos. Las principales cuencas triásicas de la Argentina se presentan como un conjunto de depresiones angostas y alongadas en sentido NW-SE, localizadas en el Centro-Oeste del país (Spalletti, 2001b), y que son consideradas por diversos autores como depresiones tipo rift, limitadas por importantes sistemas fallas que han manifestado distinto grado de actividad durante el desarrollo de los rellenos sedimentario (e.g. Strelkov y Alvárez, 1984; Legarreta y Gulisano, 1989; Ramos y Kay, 1991; Kokogián et al., 1999; López Gamundí, 1994). El rift de la cuenca Cuyana (incluida la cuenca de Barreal-Calingasta) es el mejor conocido, dada su importancia petrolera y los excelentes afloramientos triásicos. Dicha cubeta sedimentaria tuvo tres estados de desarrollo: sinrift, postrift (o sag) y transtensional. El estado de sinrift está caracterizado por fuerte subsidencia tectónica, y las facies sedimentarias experimentan rápidas variaciones. El postrift se desarrolla cuando los procesos de subsidencia son muchos más generalizados y atenuados; mientras que la etapa transtensional se presenta como un episodio de extensión, se generan relieves topográficos abruptos y discontinuidades (Spalletti, 2001b). Cada una de estas etapas se distingue por variaciones en el nivel de base, relieves topográficos, ambientes depositacionales, y vulcanismo. Durante el sinrift, la oscilación del nivel de base fue intensa, afectando el desarrollo de los suelos regionales y produciendo variaciones sistemáticas en la posición de la tabla de agua. Los importantes relieves topográficos generados favorecieron la presencia de barreras climáticas (Spalletti et al., 2003).

El intenso vulcanismo ha sido sugerido como el responsable del calentamiento y efecto de greenhouse ocurrido en el Triásico (Kemp, 1999). Simms y Ruffel (1990) señalaron, además, que el vulcanismo puede causar un incremento de la humedad ambiental. Para el Sudoeste de Gondwana, el Triásico fue un período en el que la intensificación de los procesos volcánicos, especialmente del tipo explosivo, causó importantes efectos: presencia de facies muy peculiares (volcaniclásticas y piroclásticas), destrucción instantánea de perfiles de suelos regionales y la generación de relieves; que podrían haber alterado los patrones de precipitaciones (Spalletti et al, 2003).

Los aparentes cambios en la humedad registrados geológicamente pueden resultar no sólo del desecamiento o las influencias tectónicas sino también de cambios 
en la temperatura (Colombi y Parrish, 2008). Las determinaciones de paleotemperaturas para el Triásico son escasas y, hasta los estudios de Tabor et al. (2004, 2006), completamente ausentes para sedimentos continentales. Tabor et al. (2006), analizando los carbonatos del suelo, propusieron que las temperaturas durante la depositación de la Formación Ischigualasto fueron de $11^{\circ} \mathrm{C}$ y tan bajas para helar $\left(63^{\circ} \mathrm{C}\right.$ en Tabor et al., 2004).

Las cuencas triásicas del Centro-Oeste de Argentina se localizaban en el centro del supercontinente de Pangea, para el que se infieren climas subtropicales secos (Scotese et al., 1999).

Durante el intervalo de tiempo en que se depositó la Formación Cortaderita, se produjo el descenso de la actividad volcánica y la cuenca Cuyana estaba en una fase de postrift dominada por subsidencia termal y expansión del área ocupada por sedimentación continental. En esta fase, los indicadores sedimentológicos y paleopedológicos sugieren condiciones semiáridas. Estas condiciones son similares a aquellas descriptas para otras cuencas triásicas desarrolladas bajo un estadio principal de régimen subtropical megamonzónico, caracterizado por una marcada estacionalidad (Dubiel et al., 1991; Tanner, 2000). Prevalecían sistemas fluviales distales y sistemas lacustres parcialmente cerrados meromícticos y amplios interfluvios dominados por depósitos loessiticos (Spalletti, 2001b). Las planicies de inundación y los depósitos loessíticos muestran evidencias de paleosuelos regionales ústicos y xéricos, como los vertisoles y los mollisoles (Mack et al., 1993; Retallack, 1988, 1999). Las paleocomunidades vegetales se desarrollaron preferentemente cerca de cuerpos de agua lénticos y lóticos, donde la influencia de las tablas de agua, en un marco árido subtropical, era mucho más efectivo (Spalletti et al., 2003).

Sobre la base de las tafofacies plantíferas e información adicional de los paleosuelos y la arquitectura fluvial, se pudo inferir las condiciones climáticas imperantes durante la sedimentación de la Formación Cortaderita. La Sección Inferior gris, representada por sistemas fluviales meandrosos, con amplio desarrollo de paleosuelos de tipo vertisoles, abundantes lluvias de cenizas piroclásticas y vegetaciones arbóreo-arbustivas altamente diversas (con presencia de briofitas), fue depositada bajo condiciones tectónicas estables y un clima subtropical subúmedo a semiárido, estacional. La Sección Superior rosada, caracterizada por sistemas fluviales entrelazados, desarrollo local de paleosuelos de tipos aridisoles con duricostras, aporte depósitos piroclásticos de caída y vegetaciones arbóreo-arbustivas poco diversas 
(dominado por plantas xeromórficas), fue sedimentada bajo condiciones tectónicas menos estables (con la presencia de pendientes pronunciadas) y un clima subtropical estacional semiárido, con un aumento en la duración de la estación seca.

\section{X.8. Conclusiones tafonómicas y paleoclimáticas}

En las tafofloras contenidas en la Formación Cortaderita, se identificaron 11 estilos preservacionales: (A) impresiones-compresiones de raíces, (B) rizoconcreciones, (C) moldes de raíces y rizomas, (D) moldes de troncos orientados horizontalmente, (E) moldes de tallos orientados verticalmente, (F) troncos y tocones silicificados verticales, (G) troncos silicificados horizontales y oblicuos, $(\mathrm{H})$ fragmentos de troncos y raíces carbonizados, (I) impresiones-compresiones orientadas horizontalmente, con cutícula preservada, ( $\mathrm{J}$ ) impresiones orientadas horizontalmente, con lámina de óxidos y $(\mathrm{K})$ briznas vegetales. A partir de éstas, se definieron 8 tafofacies, muy diversas en cuanto a los estilos preservacionales.

Con respecto a la distribución estratigráfica de las tafofacies, se observó en primer lugar, una mayor abundancia y diversidad de de restos fosilíferos en la Sección Inferior gris. Además, la Sección Superior rosada se diferencia claramente de la Inferior gris en relación a las condiciones tafonómicas. La distribución lateral de las tafofacies ha resultado uniforme.

El estudio de las tafofacies ha brindado información valiosa para la interpretación paleoambiental, paleoecológica, paleoclimática y estratigráfica de la Formación Cortaderita:

1- Se certifica con los atributos tafonómicos, el cambio paleambiental de una Sección a la otra. En la Sección Inferior son frecuentes los tipos fosíliferos de las comprensiones, cutículas y troncos in situ, cuya presencia disminuye abruptamente en la Sección Superior, lo que se relaciona con un incremento en la energía del ambiente.

2- La condiciones geoquímicas variaron en la columna estratigráfica. Las compresiones y cutículas son abundantes en la parte basal y media de la Sección Inferior, indicando condiciones reductoras. En la base de la Sección Superior la alta frecuencia de impresiones con pátinas de óxidos de hierro indican un cambio hacia condiciones más oxidantes.

3- De acuerdo a las tafofacies presentes, de la Sección Inferior gris a la Sección Superior Rosada el clima sufrió una desecación, pasando de subtropcial subhúmedosemiárido a un clima subtropical semiárido. 
4- Las dos secciones de la Formación Cortaderita muestran claras discrepancias tafonómicas, que pueden ser un fundamente adicional para sostener la propuesta de considerarlos dos subdivisiones litoestratigráficas. 


\section{RECONSTRUCCIÓN ECOLÓGICA DE LAS PALEOCOMUNIDADES}

\section{XI.1. Introducción}

Los bosques permineralizados in situ son muy escasos en el registro geológico, pero cuando se encuentran preservados contribuyen significativamente a nuestra comprensión de los ecosistemas pasados (Artabe et al., 2007b). Se conocen varios bosques permineralizados del Triásico en el Centro-Oeste de la Argentina, algunos de los que han sido estudiados por Brea et al. (2008, 2009) y Artabe et al. (2007b), y otros, como el bosque de la Formación Cortaderita, han sido analizados de manera preliminar (Artabe et al. 1995a, b, 2001a).

Artabe et al. (1995a, b, 2001a) han interpretado las tafocenosis de la Formación Cortaderita y definieron tres paleocomunidades preservadas en la Sección Inferior, presentes en la localidad de Mina Don Francisco de la quebrada de la Tinta, y una en la Sección Superior, en la quebrada de la Cortaderita. La más basal de las primeras fue descripta como un bosque subtropical siempreverde estacional o mesoxeromórfico, mixto, con dos estratos arbóreo de mesofanerofitas (corystospermas: Rhexoxylon sp. y coníferas "protopináceas": "Protocircoporoxylon cortaderitaense"). La siguiente paleocomunidad fue definida como matorrales monotípicos y monoestratificados de esfenofitas (Neocalamites carrerei). La tercera paleocomunidad fue determinada como un bosque subtropical esclerófilo, con un estrato arbóreo constituido exclusivamente por árboles mesoxerofíticos (corystospermas: Zuberia) y un sotobosque herbáceo arbustivo, compuesto por helechos (Cladophlebis sp.), peltaspermas (Scytophyllum bonettiae) y cycadales (Pseudoctenis sp. nov.). En la Sección Superior Artabe et al. (1995a, b, 2001a), en la entrada de la quebrada Cortaderita, identificaron una paleocomunidad herbáceo-arbustiva compuesta por corystospermas: Dicroidium odontopteroides y D. lancifolium y ginkgoales.

Este análisis pretende profundizar y actualizar el conocimiento de los atributos ecológicos de las paleocomunidades registradas en la Formación Cortaderita. Los bosques son reconstruidos sobre la base de información cuantitativa (separación promedio de los árboles, densidad, clases de diámetro y altura, dominancia, estimación de altura y estimación de biomasa). Los datos espaciales son a su vez integrados con la información fenológica y taxonómica para caracterizar de manera cualitativa las 
paleocomunidades. Los datos estructurales fueron utilizados para comparar la vegetación con otros bosques fosilizados triásicos y bosque actuales comparables.

\section{XI.2. Las paleocomunidades del Triásico}

A finales del Pérmico y comienzos del Triásico, ocurrieron grandes cambios florísticos; simultáneamente aparecieron en diferentes linajes de plantas nuevos tipos adaptativos, diferentes a aquellos presentes en sus ancestros paleozoicos. El proceso evolutivo de reemplazo de los diferentes morfotipos ocurrió en todos los grupos paleozoicos. Tanto en el Reino Laurásico como en el Gondwánico, la sustitución de los elementos paleofíticos por mesofíticos parece ser gradual en áreas pantropicales (Meyen, 1987; McLoughlin et al., 1997) pero abrupto en las regiones extratropicales (Retallack, 1997).

Las características de las asociaciones florísticas y las modificaciones en los tipos de vegetación están íntimamente relacionadas con los atributos físicos del ambiente (Spalletti et al., 2003). El cambio de las floras paleofíticas a las mesofíticas está relacionado con la coalescencia de Pangea y el cambio climático global hacia condiciones megamonzónicas (Parrish, 1993; Scotese et al., 1999). Scotese et al. (1999) han mostrado que se produce el pasaje de climas globales fríos (coldhouse) a cálidos (greenhouse o hothouse) entre el Pérmico y el Triásico. Generalmente se asocia el fenómeno de calentamiento global (Kemp, 1999) con episodios de actividad volcánica intensa. De este modo, el Triásico está caracterizado por la ausencia de hielo en las regiones polares y un promedio global de temperaturas entre los $18^{\circ}$ y $\operatorname{los} 22^{\circ} \mathrm{C}$ (Scotese et al., 1999).

La tectónica, el vulcanismo y las condiciones climáticas locales, junto con las dimensiones de las cuencas, las barreras topográficas y las características de las facies sedimentarias son controles esenciales en la generación de varios tipos de suelos y en el posicionamiento del nivel del agua, y de este modo, del desarrollo de las paleocomunidades. El desarrollo de taxones endémicos, la competencia con linajes exóticos que migraron desde regiones de latitudes bajas, la diversificación de las floras triásicas, así como también, su declinación y reemplazo por elementos de afinidad jurásica, está asociado con la interacción de los factores y eventos abióticos. La tendencia hacia la uniformidad de la vegetación, que implica la síntesis de cuatro reinos florísticos pérmicos a dos reinos triásicos, puede encontrar una correlación con los factores climáticos mencionados (Spalletti et al., 2003). 
Durante el Triásico, Pangea estuvo caracterizada por un clima fuertemente estacional o megamonzónico, lo que provocó que las regiones subtropicales se extendieran en latitudes altas, con la resultante desaparición de las regiones templadofrías y polares (Dubiel et al., 1991; Wing y Sues, 1992; Parrish, 1993; Retallack y Alonso Zarza, 1998; Scotese et al., 1999). Esto podrá explicar el reemplazo temporal de diferentes grupos de pteridospermas, Glossopteridaceae en el Pérmico y Corystospermaceae en el Triásico. Las Glossopteridaceae vivían en áreas periglaciales como elementos dominantes y en regiones subtropicales como subordinados, lo que sugeriría una plasticidad ecológica (Archangelsky, 1990). Sin embargo el registro de las floras de Glossopteris en capas rojas del Pérmico Superior sugiere que el cambio florístico no puede ser atribuido solamente al clima, y las extinciones podrían estar relacionadas con una combinación de factores ambientales como las fluctuaciones en el nivel del mar y los cambios en la proporción de los gases atmosféricos (McLoughlin et al., 1997). Para el final del Pérmico y el comienzo del Triásico, algunas especies del cinturón ecuatorial "preadaptadas" a las nuevas condiciones ambientales (elementos mesofíticos) han extendido su rango de distribución con la expansión de las áreas subtropicales hacia altas latitudes; varias Apocalamitaceae, Peltaspermaceae, Cycadales y Voltziales migraron desde áreas pantropicales al Gondwana (Archangelsky, 1990, 1996). Por otro lado, las Pleuromeiaceae alcanzaron una distribución cosmopolita, migrando de áreas extratropicales (Godwana o Angará) a áreas de bajas latitudes (Wang, 1991; Retallack, 1997). Retallack (1997) señaló que la distribución cosmopolita de las Pleuromeiaceae durante el Triásico Temprano fue causada por su capacidad pionera para colonizar ambientes oligotróficos.

La flora triásica del Reino Gondwánico, conocida como la flora de Dicroidium, está caracterizada por una asociación de grupos endémicos con una historia evolutiva particular. La megaflora triásica de la Argentina, asignada al área extratropical y a la provincia del Sudoeste del Godwana (Artabe et al., 2003), está integrada por pteridófitas de las clases Lycopsida, Sphenopsida y Filicopsida. Las Gymnospermopsida están presentes a través de las Corystospermales, Peltaspermales, Matatiellales, Petriellales, Pteridospermas Incertae Sedis, Cycadales, Bennettitales, Cycadofitas Incertae Sedis, Ginkgoales, Czekanowskiales, Dordrechtitiales, Voltziales, Coniferales y gimnospermas con vinculación sistemática incierta (Artabe et al., 2007a).

Las Corystospermaceae eran los elementos endémicos de las floras gondwánicas, y algunos de los invasores pantropicales (e.g. Peltaspermaceae) tuvieron 
relativamente poco impacto en las formas indígenas. Probablemente, las corystospermas habrían tenido una ventaja adaptativa que las peltaspermas carecían (Petriella, 1985; Artabe y Brea, 2003).

Los bosques del Triásico estaban dominados por corystospermas y coniferofitas, y en el sotobosque se desarrollaban otras corystospermas, peltaspermas, cycadofitas y helechos. En el Sudoeste de Gondwana, las floras triásicas se caracterizan por la diversificación de ciertos grupos de gimnospermas (Anderson et al., 1999), que desarrollaron atributos adaptativos de tipo mesofítico y mesoxerofítico (Wing y Sues, 1992). Sobre la base de los rasgos morfoanatómicos observados en raíces, tallos y hojas, Petriella (1985) sugirió que las Corystospermaceae eran plantas mesoxeromórficas con adaptaciones a climas estacionales. Al igual que en las plantas actuales que viven en regiones áridas, la polixilia desarrollada en las Corystospermaceae puede haber sido un carácter adaptativo importante para evitar el estrés hídrico (Artabe y Brea, 2003). Las corystospermas pueden ser usadas como indicadores paleoclimáticos debido a su hábito cycadofítico (Norstog y Nichols, 1997) sugiriendo áreas cálidas y secas sin heladas o con heladas ocasionales (Artabe et al., 2001a).

En el Triásico Temprano tardío y Medio, las corystospermas constituyeron bosques principalmente siempreverdes mixtos subtropicales estacionales (con Ginkgoales, Voltziales, y coníferas incertae sedis). También desarrollaron bosques subtropicales esclerófilos donde el estrato arbóreo estaba exclusivamente compuesto por corystopermas. Las Equisetales constituían matorrales de cañas monoespecíficos tanto en ambientes fluviales como lacustres (Spalletti et al., 1999; Artabe et al., 2001a).

En el Triásico Tardío, en los depocentros localizados en el margen protopacífico, se identificaron bosques caducifolios con un estrato arbóreo intregado por coniferofitas, ginkgofitas y Linguifolium (Spalletti et al., 1999; Artabe et al., 2001a). Estas comunidades podrían haberse desarrollado bajo climas oceánicos estacionales y subtropicales, los últimos influenciados por corrientes húmedas del Protopacífico, con lluvias durante todo el año.

La distribución paleogeográfica de las Dipteridaceae y las Marattiales tiene una relación íntima con el clima del Triásico. En el Hemisferio Sur, las Marattiales son dominantes en paleolatitudes altas (Herbst, 1988; Webb, 1982; Morel et al., 2000), mientras que las Dipteridaceae son típicas de las paleolatitudes más bajas (Herbst, 1993, 2000; Webb, 1982; Spalletti et al., 1999). Esta distribución es congruente con la de las formas actuales, siendo las Marattiales indicativas de climas templado-cálidos húmedos 
(Webb, 2001) y las Dipteridaceae de condiciones subtropicales fuertemente estacionales (Cantrill, 1995). Las floras triásicas de Dipteridaceae están restringidas a las cuencas del interior continental del Centro-Oeste de Argentina y el Norte de Patagonia, y apoyaría el desarrollo de climas megamonzónicos. Inversamente, las floras con Marattiales registradas a una paleolatitud de aproximadamente $60^{\circ} \mathrm{S}$ en la Patagonia (cuenca El Tranquilo), estuvieron probablemente controlados por un clima templado-cálido con lluvias durante todo el año (Spalletti et al., 2003).

\section{XI.3. Tafocenosis estudiadas en la Formación Cortaderita}

Se pudieron estudiar ocho tafocenosis en esta unidad formacional, cada una interpretada como una paleocomunidad. Su posición estratigráfica y localización geográfica se resumen en el siguiente cuadro (Cuadro XI.1).

\begin{tabular}{|c|c|c|c|c|}
\hline Tafocenosis & $\begin{array}{c}\begin{array}{c}\text { Sección de la } \\
\text { formación }\end{array} \\
\end{array}$ & $\begin{array}{c}\text { Estrato } \\
\text { fosilífero }\end{array}$ & Localidad & $\begin{array}{l}\text { Coordenadas } \\
\text { GPS }\end{array}$ \\
\hline Paleocomunidad 1 & $\begin{array}{c}\text { Sección Inferior } \\
\text { gris }\end{array}$ & EF1 & $\begin{array}{l}1 \text { (Arroyo Cortaderita, de Spalletti, } \\
\text { 2001) }\end{array}$ & $\begin{array}{l}\text { S 313 } 39^{\prime} 17,2^{\prime \prime} \\
\text { W } 69^{\circ} 24^{\prime} 33,2^{\prime \prime}\end{array}$ \\
\hline Paleocomunidad 2 & $\begin{array}{l}\text { Sección Inferior } \\
\text { gris }\end{array}$ & EF2 & 5 (Mina Don Francisco) & $\begin{array}{c}\text { S 31 } 31^{\circ} 39^{\prime} 27,3^{\prime \prime} \\
\text { W } 69^{\circ} 24^{\prime} 16,1^{\prime \prime} \mathrm{y} \\
\text { S } 31^{\circ} 39^{\prime} 23,5^{\prime \prime} \\
\text { W 69 } 29^{\circ} 24^{\prime} 18^{\prime \prime}\end{array}$ \\
\hline Paleocomunidad 3 & $\begin{array}{c}\text { Sección Inferior } \\
\text { gris }\end{array}$ & EF2 & 2 (Tapera) & $\begin{array}{l}\mathrm{S} 31^{\circ} 39^{\prime} 31,2^{\prime \prime} \\
\mathrm{W} 69^{\circ} 24^{\prime} 34,9^{\prime \prime}\end{array}$ \\
\hline Paleocomunidad 4 & $\begin{array}{c}\text { Sección Inferior } \\
\text { gris }\end{array}$ & EF3 & $\begin{array}{l}3 \text { (300 m NE del Punto } 12 \text { de Bonetti, } \\
1963)\end{array}$ & $\begin{array}{l}\mathrm{S} 31^{\circ} 39^{\prime} 00,1^{\prime \prime} \\
\mathrm{W} 69^{\circ} 23^{\prime} 52,1^{\prime \prime}\end{array}$ \\
\hline Paleocomunidad 5 & $\begin{array}{l}\text { Sección Inferior } \\
\text { gris }\end{array}$ & EF4 & 4 (Punto 12 de Bonetti, 1963) & $\begin{array}{l}\mathrm{S} 31^{\circ} 39^{\prime} 08,4^{\prime \prime} \\
\mathrm{W} 69^{\circ} 24^{\prime} 28^{\prime \prime}\end{array}$ \\
\hline Paleocomunidad 6 & $\begin{array}{c}\text { Sección } \\
\text { Superior rosada }\end{array}$ & EF5 & $\begin{array}{c}6 \text { (Punto } 32 \text { de Bonetti, } 1963 \text { o } \\
\text { Anticlinal al E de Barreal de Spalletti, } \\
\text { 2001) }\end{array}$ & $\begin{array}{l}\mathrm{S} 31^{\circ} 38^{\prime} 19,8^{\prime \prime} \\
\mathrm{W} 69^{\circ} 25^{\prime} 19,8^{\prime \prime}\end{array}$ \\
\hline Paleocomunidad 7 & $\begin{array}{c}\text { Sección } \\
\text { Superior rosada }\end{array}$ & EF5 & $\begin{array}{l}7 \text { (Margen derecha del Anticlinal al E } \\
\text { de Barreal) }\end{array}$ & $\begin{array}{l}\mathrm{S} 31^{\circ} 38^{\prime} 21,2^{\prime \prime} \\
\mathrm{W} 69^{\circ} 25^{\prime} 03,3^{\prime \prime}\end{array}$ \\
\hline Paleocomunidad 8 & $\begin{array}{c}\text { Sección } \\
\text { Superior rosada }\end{array}$ & EF8 & $\begin{array}{c}\text { 9, } 10 \text { y } 11 \text { Entrada de la quebrada de } \\
\text { la Tinta }\end{array}$ & $\begin{array}{l}\mathrm{S} 31^{\circ} 39^{\prime} 12,6^{\prime \prime} \\
\mathrm{W} 69^{\circ} 23^{\prime} 50,5^{\prime \prime}\end{array}$ \\
\hline
\end{tabular}

Cuadro XI.1. Localización de las paleocomunidades identificadas.

\section{X.4. Análisis estructural de las paleocomunidades}

El análisis de la vegetación incluye tres aspectos principales: 1. composición taxonómica, 2. estructura horizontal (densidad y biomasa), y 3. distribución vertical (posición del dosel).

\section{Composición taxonómica}

En el Cuadro XI.2 se detalla el tipo de vegetación, la composición taxonómica y los elementos dominantes y subordinados de cada una de las paleocomunidades definidas. 


\begin{tabular}{|c|c|c|c|}
\hline Tafocenosis & $\begin{array}{c}\text { Tipo de } \\
\text { vegetación }\end{array}$ & Elementos dominantes & Elementos subordinados \\
\hline Paleocomunidad 1 & $\begin{array}{l}\text { Herbáceo- } \\
\text { arbustiva }\end{array}$ & $\begin{array}{l}\text { Peltaspermas (Scytophyllum } \\
\text { bonettiae) y cycadales (Pseudoctenis } \\
\text { sp. nov.). }\end{array}$ & ---- \\
\hline Paleocomunidad 2 & Arbórea & $\begin{array}{l}\text { Árboles de gran porte } \\
\text { (corystospermas: Rhexoxylon } \\
\text { cortaderitaense) }\end{array}$ & $\begin{array}{l}\text { Sotobosque con helechos (probables } \\
\text { osmundales), equisetales arbustivas y } \\
\text { cycadales (Pseudoctenis sp. nov.). }\end{array}$ \\
\hline Paleocomunidad 3 & Arbórea & $\begin{array}{l}\text { Estrato arbóreo dominado por } \\
\text { corystospermas arbóreas ( } R \text {. } \\
\text { cortaderitaense) } \\
\text { Sotobosque dominado por } \\
\text { corystospermas arbustivas } \\
\text { (Dicroidium dubium, D. } \\
\text { odontopteroides, D. lancifolium) }\end{array}$ & $\begin{array}{l}\text { Estrato arbóreo con ginkgoales } \\
\text { (Ginkgoites waldeckensis, } \\
\text { Sphenobaiera sectina, S. schenkii, S. } \\
\text { argentinae) y coníferas (Heidiphyllum } \\
\text { elongatum, H. clarifolium, } \\
\text { Elatocladus plana) muy subordinadas } \\
\text { Sotobosque herbáceo-arbustivo muy } \\
\text { diverso, con: briofitas (Thallites, } \\
\text { Muscites), marattiales (Rienitsia), } \\
\text { corystospermas (Zuberia zuberi), } \\
\text { peltaspermas (Pachydermophyllum } \\
\text { papillosum) }\end{array}$ \\
\hline Paleocomunidad 4 & Arbórea & $\begin{array}{l}\text { Estrato arbóreo dominado por } \\
\text { corystospermas ( } R . \text { cortaderitaense) }\end{array}$ & $\begin{array}{l}\text { Estrato arbóreo con ginkgoales } \\
\text { (Baiera cuyana) y coníferas } \\
\text { (Heidiphyllum minutifolium, Rissikia } \\
\text { media, Elatocladus plana) muy } \\
\text { subordinadas } \\
\text { Sotobosque herbáceo-arbustivo con: } \\
\text { dipteridáceas (Dictyophyllum } \\
\text { tenuifolium), corystospermas } \\
\text { (Dicroidium odontopteroides D. } \\
\text { lancifolium, D. dubium), peltaspermas } \\
\text { (Pachydermophyllum papillosum, } P . \\
\text { praecordillerae, Lepidopteris } \\
\text { stormbergensis, Delnortea abbottiae) }\end{array}$ \\
\hline Paleocomunidad 5 & Arbórea & $\begin{array}{l}\text { Bosque monotípico de } \\
\text { corystospermas ( } R \text {. cortaderitaense) }\end{array}$ & ----- \\
\hline Paleocomunidad 6 & $\begin{array}{c}\text { Herbáceo- } \\
\text { arbustiva }\end{array}$ & $\begin{array}{l}\text { Corystospermas (Dicroidium } \\
\text { odontopteroides y D. lancifolium) }\end{array}$ & $\begin{array}{l}\text { Ginkgoales (Sphenobaiera argentinae) } \\
\text { y gnetales (Yabeiella } \\
\text { brackesbuschiana), muy subordinadas }\end{array}$ \\
\hline Paleocomunidad 7 & $\begin{array}{l}\text { Herbáceo- } \\
\text { arbustiva }\end{array}$ & $\begin{array}{l}\text { Peltaspermas (Lepidopteris } \\
\text { stormbergensis, L. africana, } \\
\text { Scytophyllum bonettiae) }\end{array}$ & $\begin{array}{l}\text { Ginkgoales (Ginkgodium nathorsti, } \\
\text { Sphenobaiera argentinae) y cycadales } \\
\text { (Kurtziana cacheutensis, Pseudoctenis } \\
\text { longipinnata) subordinadas }\end{array}$ \\
\hline Paleocomunidad 8 & Arbórea & $\begin{array}{l}\text { Bosque monotípico de } \\
\text { corystospermas ( } R \text {. cortaderitaense } \\
\text { y Zuberia feistmanteli) }\end{array}$ & ---- \\
\hline
\end{tabular}

Cuadro XI.2. Tipo de vegetación, taxones dominantes y taxones subordinados de las paleocomunidades.

Los bosques de la Formación Cortaderita están claramente dominados por corystospermas. Como formas subordinadas, se encuentran las cycadales y peltaspermas. Los tres grupos tienen características anatómicas y fisiológicas típicas de climas estacionales (polixila, cavidades secretoras, cutículas gruesas, papilas, estomas hundidos, reproducción vegetativa muy frecuente) (Petriella 1985, Spalletti et al. 2003).

El estrato arbóreo de todos los bosques registrados, está dominado por la corystosperma Rhexoxylon cortaderitaense. Los troncos de esta especie están en íntima asociación con hojas de hasta más de $50 \mathrm{~cm}$ de largo de Zuberia feistmanteli en el EF8, 
por lo que podría representa el follaje de los árboles correspondiente a $R$. cortaderitaense. Utilizando el hábito de las corystospermas propuesto por Petriella (1978) se realizó una reconstrucción esquemática de la planta hipotética Rhexoxylon cortaderitaense + Zuberia feistmanteli (Figura XI.1) caracterizada por ser un árbol no ramificado, de mediano porte, de tronco lobulado y flexionado, con grandes hojas pinnadas dispuestas en una corona apical y de vernación circinada.

Figura IX.1. Reconstrucción hipotética y esquemática de Rhexoxylon cortaderitaense+Zuberia feistmanteli

\section{Estructura horizontal}

Se eligieron tres bosques para el estudio estructural

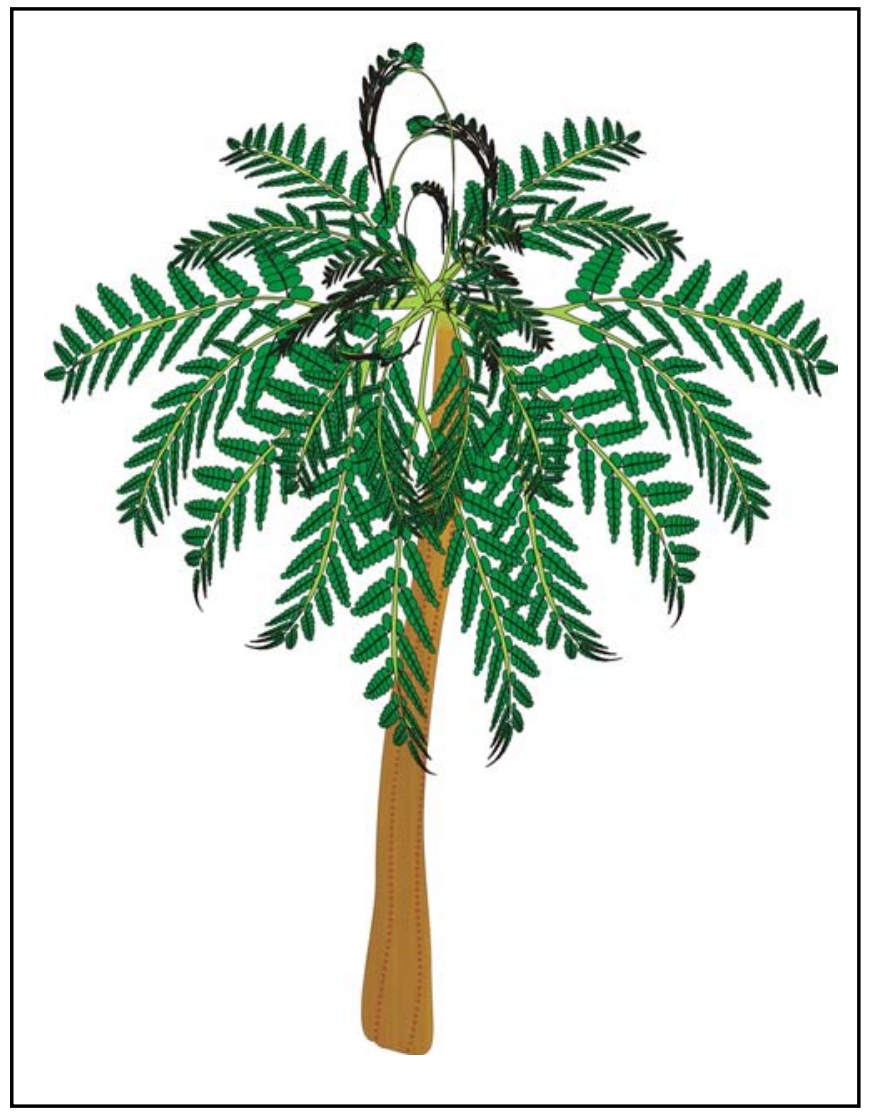
horizontal y vertical: el de la Mina Don Francisco (paleocomunidad 2), el del Punto 12 de Bonetti (1963) (paleocomunidad 5) y el bosque de la Entrada a la quebrada de la Tinta (paleocomunidad 8). Además de su facilidad de muestreo, estos bosques son representativos de toda la columna estratrigráfica, por lo que permiten estudiar la evolución temporal de las comunidades arbóreas de Cortaderita. De estos bosques, el único preservado íntegramente in situ es el de la Mina Don Francisco, mientras que el bosque del Punto 12 está constituido por árboles en posición de vida y caídos con sus tocones en conexión y el bosque de la entrada de la quebrada de la Tinta presenta sólo árboles autóctonos pero caídos. Se consideraron todos los árboles y tocones muestreados (25 en la paleocomunidad 2, de los 79 troncos en la paleocomunidad 5 se consideró que representaban 45 árboles, 20 en la paleocomunidad 8) (Tablas XI.1, 2 y 3).

En primer lugar, se calculó una densidad mínima (1), considerando el área total muestreada y la cantidad de árboles presentes. Luego, se obtuvo otro valor de densidad 
(2) con el promedio de las distancias al vecino más próximo, medida en el campo. Por último, se obtuvo un valor máximo de densidad (3) mediante el análisis del vecino más próximo, utilizando el programa de software Crimestat III (Levine, 2009). A su vez, se calculó una densidad promedio con los dos valores. Todos estos datos son sintetizados en el cuadro XI.3.

La biomasa de los bosques fue estimada siguiendo el método de Brown (1997) (Figura XI.2 y 3) para bosques subtropicales secos: $\mathrm{Y}=\exp [-1,996+2,32 \mathrm{x} \operatorname{lnD}]$, donde $\mathrm{Y}$ es la biomasa por árbol en kg y D es el diámetro del árbol. Se utilizó la densidad mínima para calcular la biomasa en cada paleocomunidad. Para el bosque de la localidad 5, se obtuvo un valor de 186,44 tn/ha; para el bosque de la localidad 4, 272,67 tn/ha, y para el bosque de las localidades 9 a 11, 34,84 tn/ha.

En la figura XI.4 se ilustra la distribución espacial de los ejemplares en cada bosque estudiado.

Figura XI.2. Valores totales de biomasa observados $\quad \mathbf{y}$ estimados para cada árbol de bosques subtropicales secos. Modificado de Brandeis et al. (2006).

Figura XI.3. Valores de biomasa calculados para cada árbol de las paleocomunidades de la Formación Cortaderita.
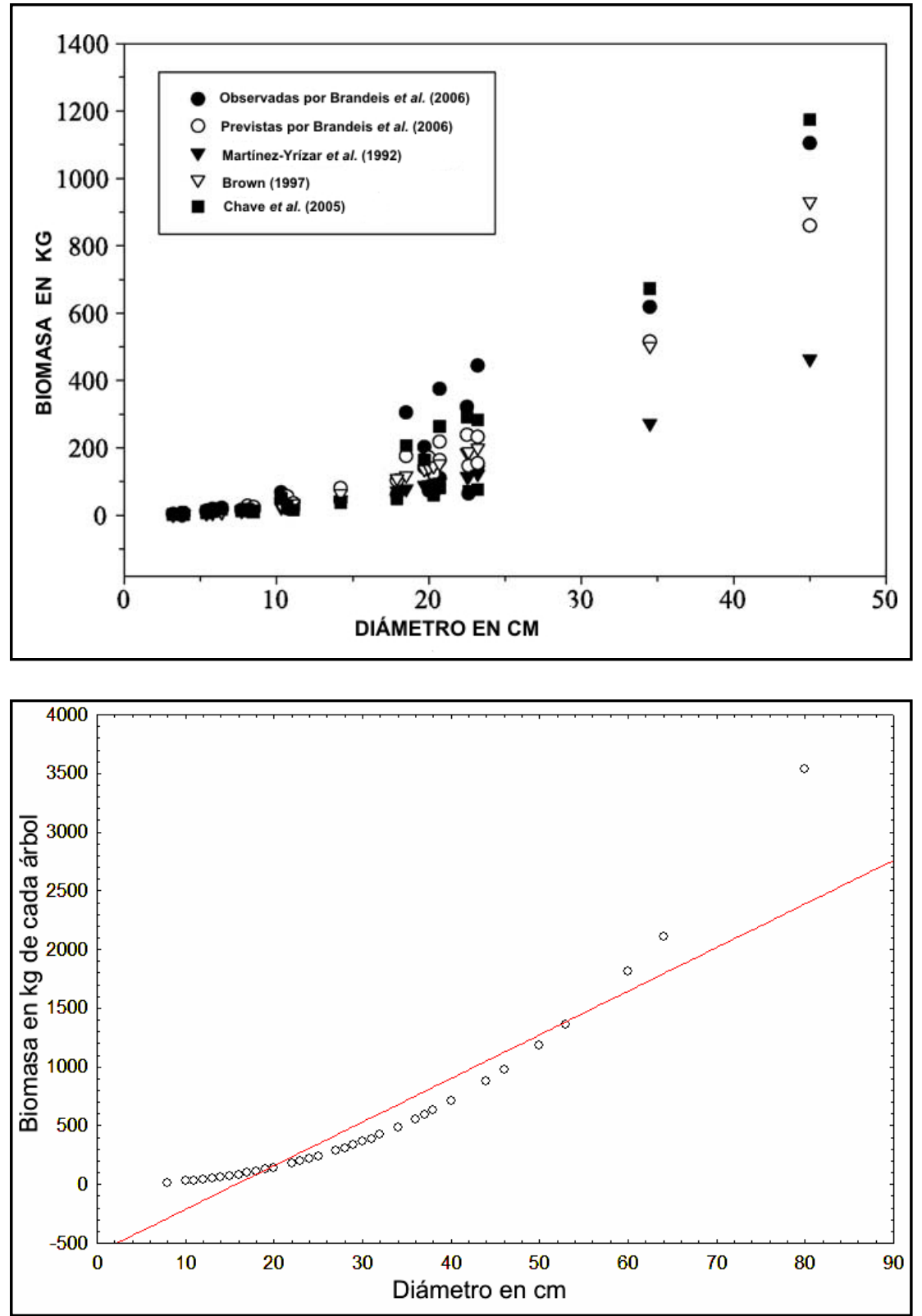


\begin{tabular}{|c|c|c|c|c|c|c|}
\hline $\begin{array}{c}\text { Número de } \\
\text { árbol }\end{array}$ & $\begin{array}{c}\text { Coordenadas } X \\
\text { en metros } \\
\end{array}$ & $\begin{array}{c}\text { Coordenadas } Y \\
\text { en metros* }\end{array}$ & $\begin{array}{c}\begin{array}{c}\text { Diámetro en } \\
\text { metros }\end{array} \\
\end{array}$ & $\begin{array}{l}\text { Diámetro en } \\
\text { centímetros }\end{array}$ & $\begin{array}{c}\text { Altura crítica } \\
\text { en metros }\end{array}$ & $\begin{array}{c}\text { Altura estimada } \\
\text { en metros }\end{array}$ \\
\hline 1 & 1,00 & 1,00 & 0,34 & 34 & 46,64 & 17,48 \\
\hline 2 & 14,2 & 1,00 & 0,015 & 1,5 & 5,82 & 4,57 \\
\hline 3 & 14,5 & 1,00 & 0,045 & 4,5 & 12,11 & 7,33 \\
\hline 4 & 1,00 & 1,00 & 0,11 & 11 & 21,98 & 10,76 \\
\hline 5 & 16,2 & 1,00 & 0,53 & 53 & 62,71 & 21,16 \\
\hline 6 & 45,8 & 1,00 & 0,2 & 20 & 32,75 & 13,92 \\
\hline 7 & 46,8 & 1,00 & 0,5 & 50 & 60,32 & 20,63 \\
\hline 8 & 47,6 & 1,00 & 0,1 & 10 & 20,63 & 10,33 \\
\hline 9 & 57,6 & 1,00 & 0,6 & 60 & 68,11 & 22,32 \\
\hline 10 & 57,75 & 1,00 & 0,6 & 60 & 68,11 & 22,32 \\
\hline 11 & 43,00 & 1,00 & 0,3 & 30 & 42,91 & 16,57 \\
\hline 12 & 122,35 & 1,00 & 0,38 & 38 & 50,23 & 18,34 \\
\hline 13 & 123,35 & 1,00 & 0,5 & 50 & 60,32 & 20,63 \\
\hline 14 & 125,02 & 1,00 & 0,14 & 14 & 25,82 & 11,94 \\
\hline 15 & 126,05 & 1,00 & 0,3 & 30 & 42,91 & 16,57 \\
\hline 16 & 126,35 & 1,00 & 0,38 & 38 & 50,23 & 18,34 \\
\hline 17 & 127,35 & 1,00 & 0,055 & 5,5 & 13,85 & 7,99 \\
\hline 18 & 128,05 & 1,00 & 0,12 & 12 & 23,29 & 11,17 \\
\hline 19 & 128,69 & 1,00 & 0,13 & 13 & 24,57 & 11,56 \\
\hline 20 & 128,73 & 1,00 & 0,14 & 14 & 25,82 & 11,94 \\
\hline 21 & 129,73 & 1,00 & 0,11 & 11 & 21,98 & 10,76 \\
\hline 22 & 130,34 & 1,00 & 0,08 & 8 & 17,78 & 9,38 \\
\hline 23 & 131,34 & 1,00 & 0,1 & 10 & 20,63 & 10,33 \\
\hline 24 & 131,52 & 1,00 & 0,08 & 8 & 17,78 & 9,38 \\
\hline 25 & 135,15 & 1,00 & 0,8 & 80 & 82,51 & 25,26 \\
\hline
\end{tabular}

Tabla XI. 1. Coordenadas y diámetros de los árboles del bosque de la localidad 5 (Mina

Don Francisco, paleocomunidad 2). *Tomadas en una transecta.

\begin{tabular}{ccccccc}
\hline $\begin{array}{c}\text { Número de } \\
\text { árbol }\end{array}$ & $\begin{array}{c}\text { Coordenadas X } \\
\text { en metros }\end{array}$ & $\begin{array}{c}\text { Coordenadas Y } \\
\text { en metros }\end{array}$ & $\begin{array}{c}\text { Diámetro en } \\
\text { metros }\end{array}$ & $\begin{array}{c}\text { Diámetro en } \\
\text { centímetros }\end{array}$ & $\begin{array}{c}\text { Altura crítica } \\
\text { en metros }\end{array}$ & $\begin{array}{c}\text { Altura estimada } \\
\text { en metros }\end{array}$ \\
\hline 1 & 45,90 & 9,42 & 0,53 & 53 & 62,71 & 21,16 \\
2 & 45,36 & 9,24 & 0,18 & 18 & 30,52 & 13,30 \\
3 & 45,74 & 8,07 & 0,25 & 25 & 38,00 & 15,32 \\
4 & 44,60 & 6,81 & 0,24 & 24 & 36,98 & 15,05 \\
5 & 45,63 & 5,65 & 0,28 & 28 & 40,98 & 16,08 \\
6 & 44,55 & 6,05 & 0,36 & 36 & 48,46 & 17,92 \\
7 & 43,90 & 6,19 & 0,16 & 16 & 28,22 & 12,64 \\
8 & 42,66 & 6,01 & 0,25 & 25 & 38,00 & 15,32 \\
9 & 42,12 & 4,21 & 0,15 & 15 & 27,03 & 12,30 \\
10 & 42,39 & 3,36 & 0,13 & 13 & 24,57 & 11,56 \\
11 & 38,18 & 2,47 & 0,16 & 16 & 28,22 & 12,64 \\
12 & 36,77 & 5,11 & 0,27 & 27 & 40,00 & 15,83 \\
13 & 36,50 & 5,38 & 0,13 & 13 & 24,57 & 11,56 \\
14 & 35,64 & 6,19 & 0,32 & 32 & 44,80 & 17,03 \\
15 & 35,86 & 7,40 & 0,23 & 23 & 35,94 & 14,78 \\
16 & 35,80 & 7,85 & 0,22 & 22 & 34,89 & 14,50 \\
17 & 36,56 & 7,62 & 0,44 & 44 & 55,39 & 19,53 \\
18 & 36,34 & 7,26 & 0,2 & 20 & 32,75 & 13,92 \\
19 & 33,26 & 6,86 & 0,28 & 28 & 40,98 & 16,08 \\
20 & 34,18 & 9,15 & 0,25 & 25 & 38,00 & 15,32 \\
21 & 32,56 & 9,51 & 0,15 & 15 & 27,03 & 12,30 \\
\hline
\end{tabular}


Josefina Bodnar - La paleoflora triásica de la Formación Cortaderita...

\begin{tabular}{|c|c|c|c|c|c|c|}
\hline 22 & 32,83 & 8,07 & 0,23 & 23 & 35,94 & 14,78 \\
\hline 23 & 32,08 & 8,70 & 0,46 & 46 & 57,06 & 19,91 \\
\hline 24 & 29,59 & 7,44 & 0,38 & 38 & 50,23 & 18,34 \\
\hline 25 & 32,02 & 6,73 & 0,27 & 27 & 40,00 & 15,83 \\
\hline 26 & 32,02 & 9,42 & 0,18 & 18 & 30,52 & 13,30 \\
\hline 27 & 30,13 & 9,24 & 0,22 & 22 & 34,89 & 14,50 \\
\hline 28 & 30,13 & 8,07 & 0,22 & 22 & 34,89 & 14,50 \\
\hline 29 & 28,89 & 6,81 & 0,2 & 20 & 32,75 & 13,92 \\
\hline 30 & 28,67 & 5,65 & 0,18 & 18 & 30,52 & 13,30 \\
\hline 31 & 27,54 & 6,05 & 0,16 & 16 & 28,22 & 12,64 \\
\hline 32 & 25,92 & 6,19 & 0,25 & 25 & 38,00 & 15,32 \\
\hline 33 & 28,08 & 8,52 & 0,35 & 35 & 47,55 & 17,70 \\
\hline 34 & 28,62 & 7,89 & 0,16 & 16 & 28,22 & 12,64 \\
\hline 35 & 27,27 & 6,95 & 0,14 & 14 & 25,82 & 11,94 \\
\hline 36 & 27,00 & 6,73 & 0,12 & 12 & 23,29 & 11,17 \\
\hline 37 & 27,43 & 5,74 & 0,16 & 16 & 28,22 & 12,64 \\
\hline 38 & 27,11 & 5,38 & 0,15 & 15 & 27,03 & 12,30 \\
\hline 39 & 26,89 & 5,11 & 0,18 & 18 & 30,52 & 13,30 \\
\hline 40 & 27,70 & 6,46 & 0,16 & 16 & 28,22 & 12,64 \\
\hline 41 & 25,11 & 5,20 & 0,19 & 19 & 31,65 & 13,61 \\
\hline 42 & 21,33 & 10,04 & 0,25 & 25 & 38,00 & 15,32 \\
\hline 43 & 24,3 & 10,13 & 0,12 & 12 & 23,29 & 11,17 \\
\hline 44 & 19,17 & 4,93 & 0,13 & 13 & 24,57 & 11,56 \\
\hline 45 & 23,76 & 12,73 & 0,21 & 21 & 33,83 & 14,21 \\
\hline 46 & 23,76 & 12,82 & 0,34 & 34 & 46,64 & 17,48 \\
\hline 47 & 20,79 & 13,63 & 0,3 & 30 & 42,91 & 16,57 \\
\hline 48 & 20,25 & 13,45 & 0,15 & 15 & 27,03 & 12,30 \\
\hline 49 & 15,12 & 14,62 & 0,15 & 15 & 27,03 & 12,30 \\
\hline 50 & 21,33 & 14,08 & 0,185 & 18,5 & 31,09 & 13,46 \\
\hline 51 & 12,42 & 11,66 & 0,31 & 31 & 43,86 & 16,80 \\
\hline 52 & 11,61 & 11,93 & 0,29 & 29 & 41,95 & 16,33 \\
\hline 53 & 0,00 & 7,62 & 0,3 & 30 & 42,91 & 16,57 \\
\hline 54 & 1,73 & 5,83 & 0,23 & 23 & 35,94 & 14,78 \\
\hline 55 & 11,88 & 13,90 & 0,4 & 40 & 51,98 & 18,75 \\
\hline 56 & 0,83 & 4,49 & 0,19 & 19 & 31,65 & 13,61 \\
\hline 57 & 0,00 & 4,69 & 0,3 & 30 & 42,91 & 16,57 \\
\hline 58 & 1,17 & 4,10 & 0,12 & 12 & 23,29 & 11,17 \\
\hline 59 & 1,52 & 4,94 & 0,3 & 30 & 42,91 & 16,57 \\
\hline 60 & 1,86 & 4,21 & 0,24 & 24 & 36,98 & 15,05 \\
\hline 61 & 2,07 & 4,94 & 0,31 & 31 & 43,86 & 16,80 \\
\hline 62 & 2,42 & 4,72 & 0,28 & 28 & 40,98 & 16,08 \\
\hline 63 & 2,62 & 4,21 & 0,24 & 24 & 36,98 & 15,05 \\
\hline 64 & 2,97 & 4,66 & 0,35 & 20 & 32,75 & 13,92 \\
\hline 65 & 3,04 & 4,94 & 0,16 & 16 & 28,22 & 12,64 \\
\hline 66 & 3,80 & 5,05 & 0,29 & 29 & 41,95 & 16,33 \\
\hline 67 & 3,73 & 5,56 & 0,37 & 37 & 49,35 & 18,13 \\
\hline 68 & 4,63 & 4,55 & 0,125 & 12,5 & 23,94 & 11,37 \\
\hline 69 & 4,01 & 4,21 & 0,16 & 16 & 28,22 & 12,64 \\
\hline 70 & 3,66 & 4,21 & 0,08 & 8 & 17,78 & 9,38 \\
\hline 71 & 4,01 & 4,21 & 0,2 & 20 & 32,75 & 13,92 \\
\hline 72 & 6,49 & 5,01 & 0,2 & 20 & 32,75 & 13,92 \\
\hline 73 & 6,91 & 5,62 & 0,19 & 19 & 31,65 & 13,61 \\
\hline 74 & 1,73 & 5,90 & 0,6 & 60 & 68,11 & 22,32 \\
\hline 75 & 2,31 & 5,45 & 0,64 & 64 & 71,11 & 22,95 \\
\hline
\end{tabular}




\begin{tabular}{lllllll}
\hline 76 & 2,90 & 6,35 & 0,34 & 34 & 46,64 & 17,48 \\
77 & 5,53 & 7,08 & 0,38 & 38 & 50,23 & 18,34 \\
78 & 4,28 & 7,24 & 0,12 & 12 & 23,29 & 11,17 \\
79 & 3,18 & 7,02 & 0,16 & 16 & 28,22 & 12,64 \\
\hline
\end{tabular}

Tabla XI. 2. Coordenadas y diámetros de los árboles del bosque de la localidad 4 (Punto 12 de Bonetti, 1963; paleocomunidad 5).

\begin{tabular}{ccccccc}
\hline $\begin{array}{c}\text { Número de } \\
\text { árbol }\end{array}$ & $\begin{array}{c}\text { Coordenadas X } \\
\text { en metros }\end{array}$ & $\begin{array}{c}\text { Coordenadas Y } \\
\text { en metros }\end{array}$ & $\begin{array}{c}\text { Diámetro en } \\
\text { metros }\end{array}$ & $\begin{array}{c}\text { Diámetro en } \\
\text { centímetros }\end{array}$ & $\begin{array}{c}\text { Altura crítica } \\
\text { en metros }\end{array}$ & $\begin{array}{c}\text { Altura estimada } \\
\text { en metros }\end{array}$ \\
\hline 1 & 1,00 & 4,00 & 0,18 & 18 & 30,52 & 13,30 \\
2 & 13,30 & 4,00 & 0,15 & 15 & 27,03 & 12,30 \\
3 & 13,40 & 4,00 & 0,17 & 17 & 29,38 & 12,98 \\
4 & 14,40 & 4,00 & 0,2 & 20 & 32,75 & 13,92 \\
5 & 21,00 & 4,00 & 0,2 & 20 & 32,75 & 13,92 \\
6 & 26,34 & 0,51 & 0,2 & 20 & 32,75 & 13,92 \\
7 & 26,34 & 8,34 & 0,3 & 30 & 42,91 & 16,57 \\
8 & 27,79 & 6,19 & 0,24 & 24 & 36,98 & 15,05 \\
9 & 30,15 & 2,70 & 0,2 & 20 & 32,75 & 13,92 \\
10 & 32,79 & 6,19 & 0,2 & 20 & 32,75 & 13,92 \\
11 & 39,89 & 2,70 & 0,23 & 23 & 35,94 & 14,78 \\
12 & 42,00 & 6,19 & 0,2 & 20 & 32,75 & 13,92 \\
13 & 46,64 & 4,00 & 0,2 & 20 & 32,75 & 13,92 \\
14 & 107,12 & 4,00 & 0,25 & 25 & 38,00 & 15,32 \\
15 & 107,12 & 4,16 & 0,15 & 15 & 27,03 & 12,30 \\
16 & 107,79 & 3,80 & 0,27 & 27 & 40,00 & 15,83 \\
17 & 108,00 & 3,70 & 0,15 & 15 & 27,03 & 12,30 \\
18 & 108,00 & 3,80 & 0,1 & 10 & 20,63 & 10,33 \\
19 & 108,10 & 3,60 & 0,1 & 10 & 20,63 & 10,33 \\
20 & 108,20 & 3,40 & 0,2 & 20 & 32,75 & 13,92 \\
\hline
\end{tabular}

Tabla XI. 3. Coordenadas y diámetros de los árboles de las localidades 9 a 10 (Entrada de la quebrada de la Tinta, paleocomunidad 8).

\begin{tabular}{cccc}
\hline Parámetros & Paleocomunidad 2 & Paleocomunidad 5 & Paleocomunidad 8 \\
\hline Tamaño de la muestra & 20 & 45 & 25 \\
Área total muestreada & $134,25 \mathrm{~m}^{2}$ & $645,81 \mathrm{~m}^{2}$ & $836,38 \mathrm{~m}^{2}$ \\
Densidad mínima (1) & No calculada* & 696,8 árboles/ha & 239,02 árboles/ha \\
$\begin{array}{c}\text { Distancia media al vecino más próximo } \\
\text { (tomada en el campo) }\end{array}$ & $5,46 \mathrm{~m}$ & $1,51 \mathrm{~m}$ & $5,01 \mathrm{~m}$ \\
$\begin{array}{c}\text { Densidad (2) } \\
\begin{array}{c}\text { Distancia media al vecino más próximo } \\
\text { (obtenida por Crime stat III) }\end{array}\end{array}$ & 335,62 árboles/ha & 4401,66 árboles/ha & 789,26 árboles/ha \\
$\begin{array}{c}\text { Distancia media al vecino más próximo } \\
\text { promedio }\end{array}$ & $1,21 \mathrm{~m}$ & $2,14 \mathrm{~m}$ & $2,11 \mathrm{~m}$ \\
Densidad máxima (3) & $3,33 \mathrm{~m}$ & $1,48 \mathrm{~m}$ & $3,56 \mathrm{~m}$ \\
Densidad promedio & 4345,04 árboles/ha & 4672,09 árboles/ha & 2241,45 árboles/ha \\
\hline
\end{tabular}

Cuadro XI.3. Análisis del vecino más próximo y densidad de los bosques estudiados de la

Formación Cortaderita. *Tafocenosis medida en una transecta. 


\section{Distribución vertical}

Se calculó la altura crítica (Hcrit) y la altura estimada (Hest) de los ejemplares, mediante las fórmulas propuestas por Niklas (1993, 1994b, c): Hcrit=95,75 x D $2 / 3 / /$ Hest $=27,8 \times \mathrm{D}^{0.430}$, donde $\mathrm{D}$ es el diámetro en metros, medido en cada ejemplar. Las alturas resultantes son resumidas en las últimas columnas de la tabla X.1 y en el Cuadro X.4. Los histogramas de las figuras XI.4 y 5 muestran las frecuencias absolutas de las clases de diámetro y altura. Por último, la figura XI.6 pretende mostrar un perfil estimado de cada bosque.

\begin{tabular}{cccc}
\hline Parámetros & Paleocomunidad 2 & Paleocomunidad 5 & Paleocomunidad 8 \\
\hline Diámetro mínimo & $1,5 \mathrm{~cm}$ & $8 \mathrm{~cm}$ & $10 \mathrm{~cm}$ \\
Diámetro máximo & $80 \mathrm{~cm}$ & $64 \mathrm{~cm}$ & $30 \mathrm{~cm}$ \\
Diámetro promedio & $26,62 \mathrm{~cm}$ & $24,18 \mathrm{~cm}$ & $19,45 \mathrm{~cm}$ \\
\hline Altura crítica mínima & $5,82 \mathrm{~m}$ & $17,78 \mathrm{~m}$ & $20,63 \mathrm{~m}$ \\
Altura crítica máxima & $82,51 \mathrm{~m}$ & $71,11 \mathrm{~m}$ & $42,91 \mathrm{~m}$ \\
Altura crítica máxima & $36,79 \mathrm{~m}$ & $36,44 \mathrm{~m}$ & $31,90 \mathrm{~m}$ \\
\hline Altura estimada mínima & $4,57 \mathrm{~m}$ & $9,38 \mathrm{~m}$ & $10,33 \mathrm{~m}$ \\
Altura estimada máxima & $25,26 \mathrm{~m}$ & $22,95 \mathrm{~m}$ & $16,57 \mathrm{~m}$ \\
Altura estimada promedio & $14,44 \mathrm{~m}$ & $14,78 \mathrm{~m}$ & $13,63 \mathrm{~m}$ \\
\hline
\end{tabular}

Cuadro XI.4. Valores de altura y diámetro de los bosques estudiados de la Formación

Cortaderita.

Los histogramas de clases de diámetros muestran curvas normales con picos en diámetros menores a $30 \mathrm{~cm}$, y colas en los valores mayores. En la paleocomunidad 2, el $56 \%$ de los ejemplares tienen un diámetro basal de 0-20 cm; el 28\%, entre 20-40 cm; y $24 \%$, más de $40 \mathrm{~cm}$. En la paleocomunidad 5, el 33,33\% tienen diámetros basales de 0 $20 \mathrm{~cm}$; el 47,63\%, entre 20-40 cm; y el 20\%, más de $40 \mathrm{~cm}$. En la paleocomunidad 8 , el $75 \%$ presenta diámetros de $0-20 \mathrm{~cm}$; y el $25 \%$, más de $20 \mathrm{~cm}$. Sobre la base de la configuración de los histogramas, se puede apreciar que hay pocos especímenes viejos (más de $40 \mathrm{~cm}$ de diámetro), y gran cantidad de árboles jóvenes (menos de $40 \mathrm{~cm}$ de diámetro).

La altura de los ejemplares indica posiciones del dosel semejantes para las palecomunidades de la Sección Inferior gris: 9-20 m en la palecomunidad 2 (64\% de los árboles alcanzan esas alturas) y 10-20 m en la paleocomunidad 5 (91,11\% de los ejemplares miden entre esas alturas). Por otra parte, para la paleocomunidad 8 , de la Sección Superior rosada, se estima que el dosel se ubicaba entre los 12 y 14 m (65\% de los árboles tienen estas alturas estimadas), algo más bajo que en los otros bosques estudiados. 

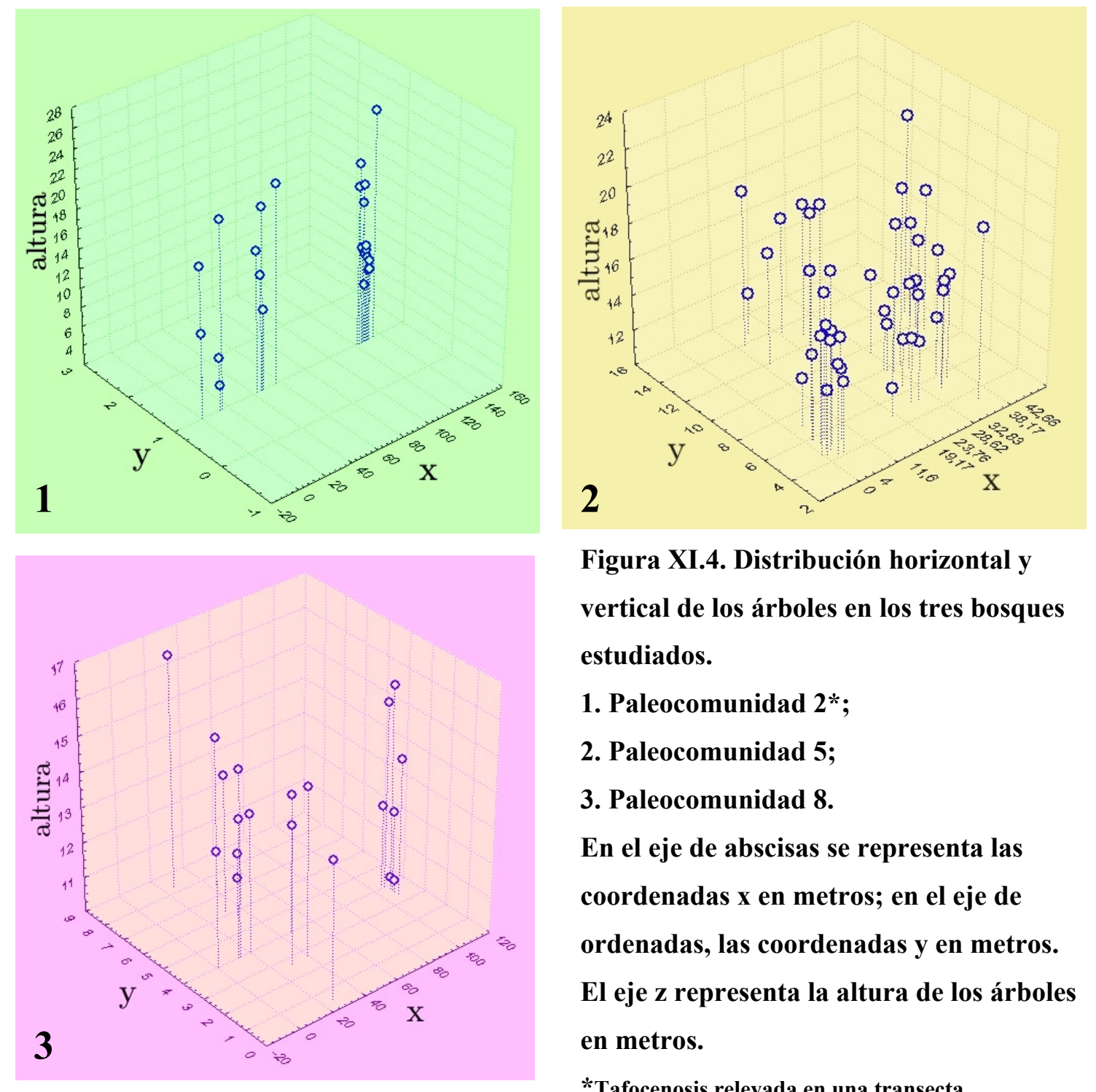

Figura XI.4. Distribución horizontal y vertical de los árboles en los tres bosques estudiados.

1. Paleocomunidad 2*;

2. Paleocomunidad 5;

3. Paleocomunidad 8.

En el eje de abscisas se representa las coordenadas $x$ en metros; en el eje de ordenadas, las coordenadas y en metros. El eje $\mathrm{z}$ representa la altura de los árboles en metros.

*Tafocenosis relevada en una transecta

\section{XI.5. Interpretación, comparaciones y discusión}

Este tipo de estudios se han realizado en dos bosques del Triásico de la Argentina: el bosque de Darwin (Brea, 1995; Brea et al., 2008) y el bosque de la Mina La Elcha (Artabe et al., 2007b). El primero fue descubierto en la Formación Paramillo, en el área Agua de la Zorra, Noroeste de la provincia de Mendoza (6912'W 32³0’S) (Brea, 1995; Brea et al., 2008). De edad mesotriásica, éste es un bosque mixto compuesto por corystospermas (Cuneumxylon spallettii) y coníferas (Agathoxylon protoaraucana). El segundo se encuentra en la Formación Río Blanco, de edad triásica tardía, en Mina la Elcha, cerca del Cerro Cacheuta, también en el Noroeste de la provincia de Mendoza ( $69^{\circ} 09^{\prime}$ 24,3"W $\left.33^{\circ} 03^{\prime} 36,8^{\prime \prime} \mathrm{S}\right)$. Ha sido interpretado como un bosque monotípico de corystospermas (Elchaxylon zavattieriae) (Artabe et al., 2007b). 

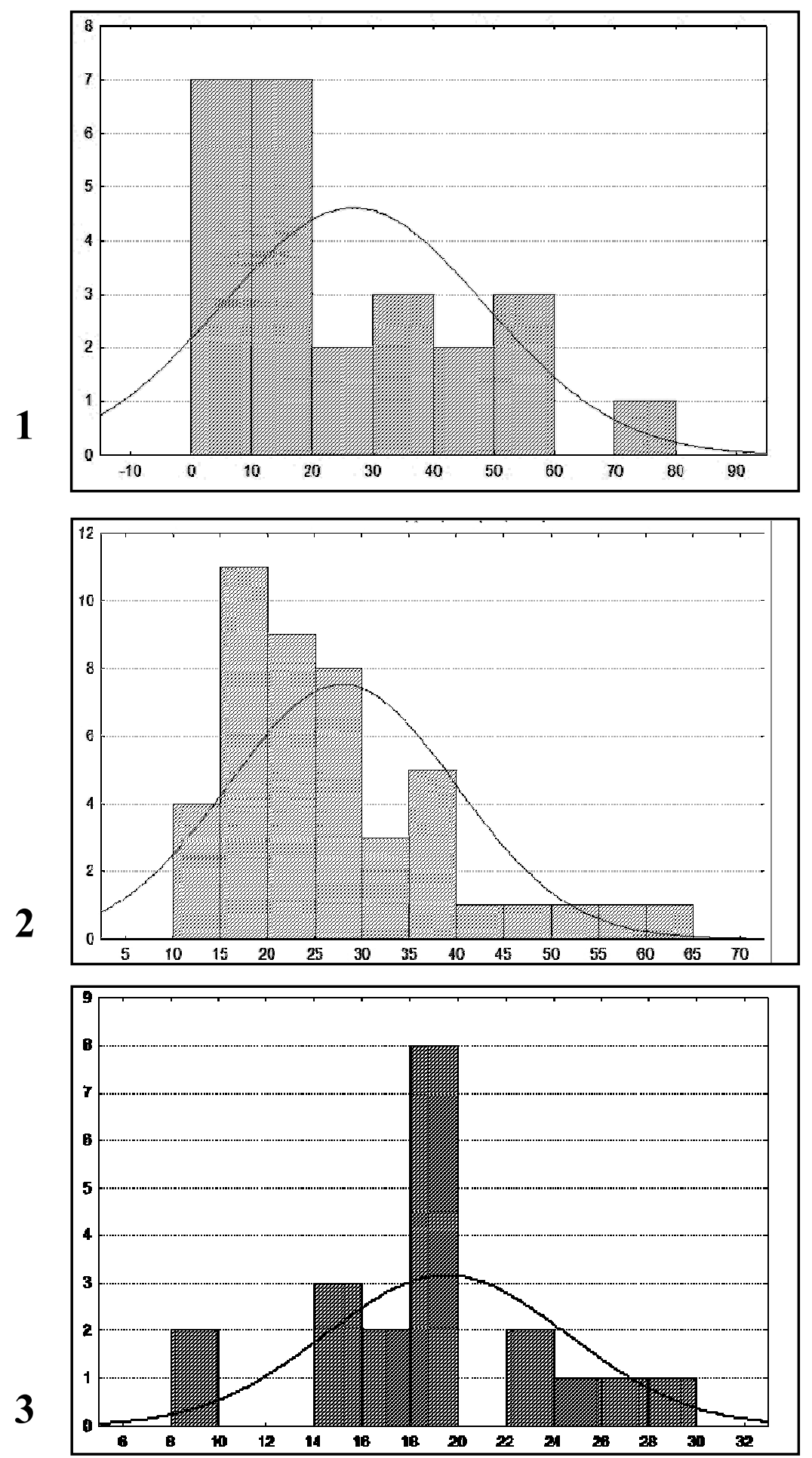

Figura XI.4. Histogramas y curva de frecuencias acumuladas, de clases de diámetro. 1. Paleocomunidad 2; 2. Paleocomunidad 5; 3. Paleocomunidad 8. En el eje de abscisas se representa las clases de diámetro en $\mathrm{cm}$; en el eje de ordenadas, las frecuencias absolutas, en número de observaciones. 

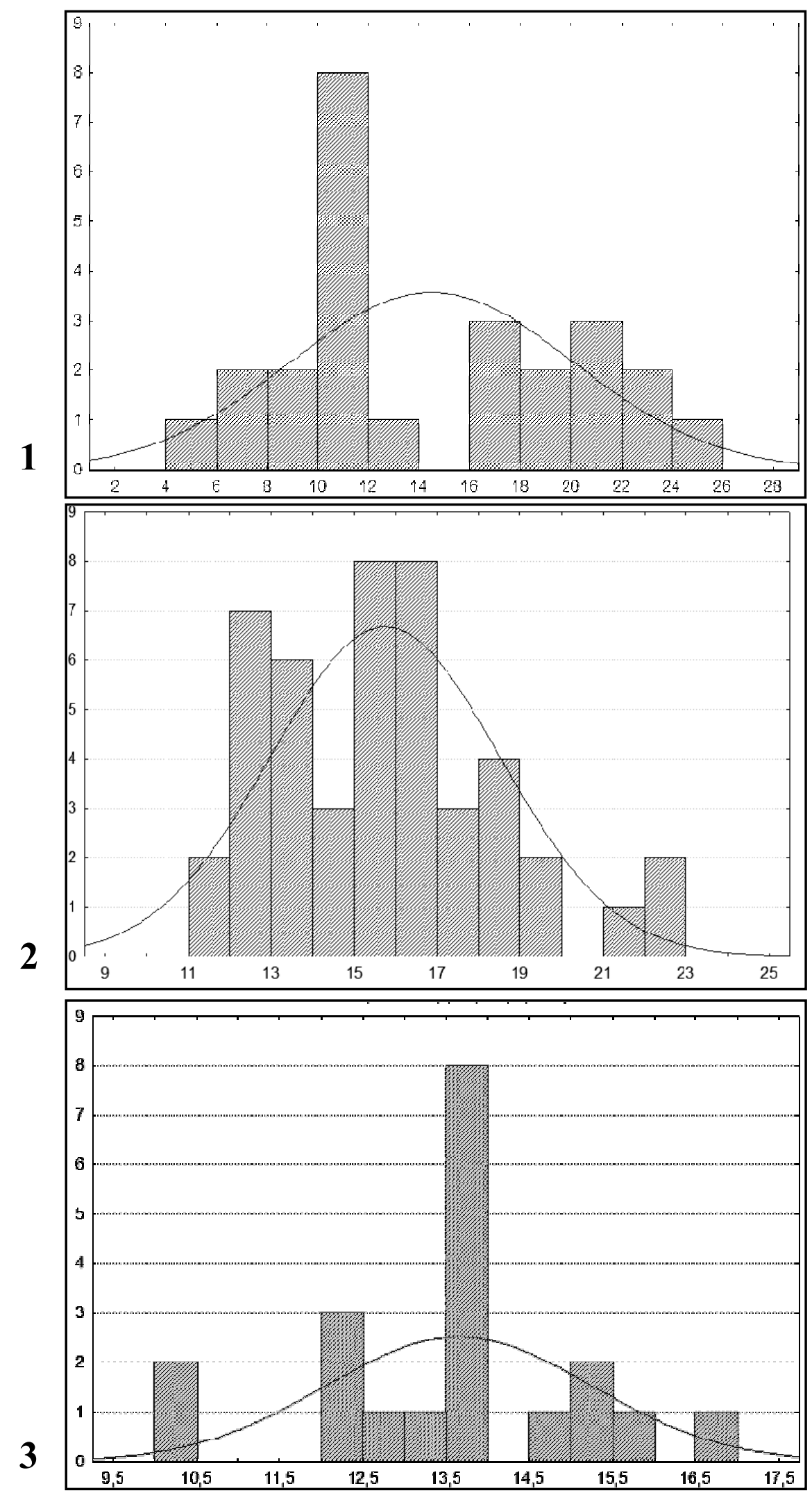

Figura XI.5. Histogramas y curva de frecuencias acumuladas, de clases de altura. 1. Paleocomunidad 2; 2. Paleocomunidad 5; 3. Paleocomunidad 8.

En el eje de abscisas se representa las clases de altura en m; en el eje de ordenadas, las frecuencias absolutas, en número de observaciones. 

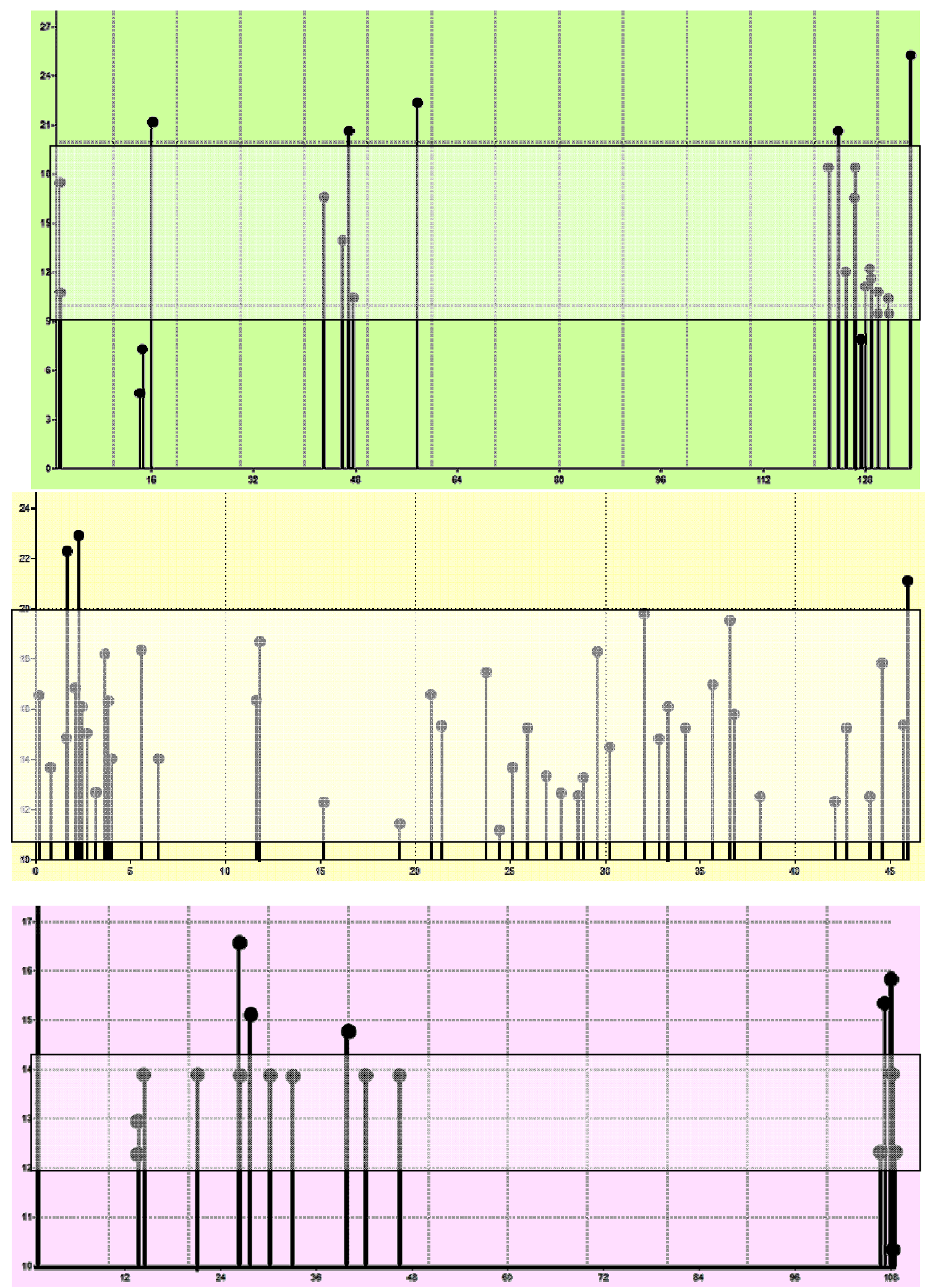

Figura XI.6. Vista lateral de los bosques estudiados, mostrando la altura estimada, deducida a partir de los diámetros de los especímenes. En Verde: paleocomunidad 2; en amarillo: paleocomunidad 5; en rosado: paleocomunidad 8. En el eje de abscisas se representa las coordenadas $x$ en metros; en el eje de ordenadas, altura estimada (Hest) en metros. El rectángulo más claro indica la posición inferida del dosel de cada bosque. 
Al comparar los valores de densidad y biomasa de estos bosques con los de la Formación Cortaderita (Cuadros XI.5 y 6), se observa que las comunidades arbóreas presentan densidades mínimas comparables a las densidades de los bosques de la Formación Paramillo. Las distancias medias al vecino más próximo son muy pequeñas en bosques de la Formación Cortaderita, con respecto a otros bosques del Triásico argentino. En cuanto a los valores de biomasa estimada para las paleocomunidades de la Sección Inferior gris son muy altos, en comparación con los de Paramillo. Por otro lado, la paleocomunidad 8 de la Sección Superior rosada se acerca a los valores de biomasa de los bosques de Agua de la Zorra (Paramillo) (Cuadro XI.5). En cuanto a la estructura vertical, los bosques de la Formación Cortaderita tienen una posición del dosel semejante al bosque de La Elcha (Formación Río Blanco), y más bajo que los bosques de Agua de la Zorra.

Al contrastar las densidades y biomasas calculadas para las paleocomunidades arbóreas de la Formación Cortaderita con los valores conocidos para algunos biomas actuales, se observó que: la palecomunidad 2 presenta una densidad comparable a la del Parque Chaqueño, la paleocomunidad 5 se equipara a los bosques andino-patagónicos en cuanto a su densidad, y la paleocomunidad 8 también se acerca a la densidad del Parque Chaqueño (Cuadro XI.6). La biomasa de la paleocomunidad 2 se aproxima a la conocida para la Selva Tucumano Boliviana, mientras que la inferida para la paleocomunidad 5 es más cercana a la calculada para la Selva Misionera. Por otra parte, la biomasa interpretada para la paleocomunidad 8 es semejante a la de los bosques subtropicales secos (Cuadro XI.7).

Las semejanzas con biomas de bosques húmedos tienen que ser tomadas con cautela, ya que es evidente que estas paleocomunidades no son comparables con este tipo de bosques, por su menor diversidad y la ausencia de estratificación biológica. Probablemente, los valores altos resultantes sean por un problema de aplicación de las fórmulas de biomasa - no son totalmente aplicables a bosques mesozoicos- o un sesgo tafonómico. Otra cuestión a tener en cuenta es que muy probablemente las tafocenosis estudiadas representen comunidades en etapas pioneras, y no en su etapa climáx.

Además, teniendo en cuenta las características paleopedológicas, paleoclimáticas y rasgos morfoanatómicos de las plantas presentes en la Formación Cortaderita, los bosques estudiados se asemejan más a bosques subtropicales secos. En Argentina, este tipo de bosques se desarrollan en la región Chaqueña. El clima en esa zona es subtropical cálido con estación seca, predominando el tipo continental con amplitud 
térmica del orden de $\operatorname{los} 50^{\circ} \mathrm{C}$. La alternancia de períodos de sequía y humedad han generado un mosaico de suelos, arenosos y arcillosos, con abundancia de carbonatos. El rasgo típico del Chaco son sus bosques, altos densos y más diversificados cuando hay mayor disponibilidad de agua y mas bajos, abiertos y con menor variedad de especies arbóreas mientras más seco sea el ambiente. Otra característica de ésta zona, son las comunidades arbóreas colonizadoras, que en algunos casos constituyen comunidades monoespecíficas. Las alturas de los árboles se encuentran entre 8 y 16 metros, con 12 metros de promedio. Los diámetros más frecuentes de los árboles se hallan entre 10 y 20 cm) (PIARFON, 2005).

\begin{tabular}{|c|c|c|c|c|c|c|c|c|}
\hline $\begin{array}{c}\text { Unidad } \\
\text { formacional }\end{array}$ & & $\begin{array}{c}\text { Composición } \\
\text { del estrato } \\
\text { arbóreo }\end{array}$ & $\begin{array}{c}N^{\circ} \text { de } \\
\text { ejemplares }\end{array}$ & $\begin{array}{c}\text { Distancia } \\
\text { media al } \\
\text { vecino más } \\
\text { próximo } \\
\text { (m) }\end{array}$ & $\begin{array}{c}\text { Densidad } \\
\text { (árboles/ha) }\end{array}$ & $\begin{array}{c}\text { Biomasa } \\
\text { (tn/ha) }\end{array}$ & $\begin{array}{c}\text { Hest } \\
\text { promedio } \\
\text { (m) }\end{array}$ & $\begin{array}{c}\text { Diámetro } \\
\text { promedio } \\
\text { (cm) }\end{array}$ \\
\hline \multirow{3}{*}{$\begin{array}{l}\text { Formación } \\
\text { Cortaderita }\end{array}$} & Pc 2 & Monotípica & 20 & 1,21 & 335,61 & 186,44 & 14,44 & 26,62 \\
\hline & Pc 5 & Monotípica & $79(45)$ & 0,80 & 696,8 & 272,67 & 14,78 & 24,18 \\
\hline & Pc 8 & Monotípica & 25 & 2,11 & 239,02 & 34,84 & 13,63 & 19,45 \\
\hline \multirow{4}{*}{$\begin{array}{l}\text { Formación } \\
\text { Paramillo }\end{array}$} & $\begin{array}{c}\text { Loc } \\
\text { A }\end{array}$ & Mixta & 30 & 4,84 & 427 & 39,64 & 19,52 & 44,64 \\
\hline & $\begin{array}{c}\text { Loc } \\
\text { B }\end{array}$ & Mixta & 23 & 3,63 & 759 & 41,62 & 20,34 & 44,50 \\
\hline & $\begin{array}{c}\text { Loc } \\
\text { C }\end{array}$ & Mixta & 42 & 3,67 & 742 & 73,20 & 20,56 & 49,13 \\
\hline & $\begin{array}{c}\text { Loc } \\
\text { D }\end{array}$ & Mixta & 25 & 4,81 & 432 & 33,75 & 15,74 & 26,76 \\
\hline Formación & Ar 1 & Monotípica & 59 & 2,58 & 1503 & ---- & 15,83 & 27 \\
\hline Río Blanco & Ar 2 & Monotípica & 61 & 3,71 & 726 & ---- & 14,21 & 21 \\
\hline
\end{tabular}

Cuadro XI.5.Comparación de los rasgos estructurales de los bosques triásicos de

Argentina (Formación Paramillo, Brea et al., 2008; Formación Río Blanco, Artabe et al., 2007b; Formación Cortaderita, este trabajo).

\begin{tabular}{c|ccc}
\hline \multirow{2}{*}{ Distribución } & Comunidad & Densidad (árboles/ha) & Fuente \\
\hline Formación & Paleocomunidad 2 & 335,61 & Este trabajo \\
$\begin{array}{c}\text { Cortaderita } \\
\text { (Triásico) }\end{array}$ & Paleocomunidad 5 & 696,8 & Este trabajo \\
& Paleocomunidad 8 & 239,02 & Este trabajo \\
\hline \multirow{2}{*}{$\begin{array}{c}\text { Patagonia } \\
\text { (Actual) }\end{array}$} & Bosque mixto de Fitzroya cupressoides y & $660-4400$ & Donoso (1993) \\
\cline { 2 - 3 } & Nothofagus betuloides & & Donoso (1993), \\
\cline { 2 - 3 } & Bosque mixto de Austrocedrus chilensis & $150-460$ & Quiroga (2007) \\
\hline $\begin{array}{c}\text { Chaco } \\
\text { (Actual) }\end{array}$ & Parque Chaqueño (2007) \\
\hline
\end{tabular}

Cuadro XI.6. Comparación con la densidad de bosques actuales y los bosques de la Formación Cortaderita. 


\begin{tabular}{|c|c|c|c|}
\hline Distribución & Comunidad & Biomasa (tn/ha) & Fuente \\
\hline $\begin{array}{c}\text { Formación } \\
\text { Cortaderita } \\
\text { (Triásico) }\end{array}$ & $\begin{array}{l}\text { Paleocomunidad } 2 \\
\text { Paleocomunidad } 5 \\
\text { Paleocomunidad } 8 \\
\end{array}$ & $\begin{array}{l}186,44 \\
272,67 \\
34,84 \\
\end{array}$ & $\begin{array}{l}\text { Este trabajo } \\
\text { Este trabajo } \\
\text { Este trabajo }\end{array}$ \\
\hline $\begin{array}{c}\text { Puerto Rico } \\
\text { (Actual) }\end{array}$ & Bosque subtropical seco & $33,9-76,5$ & $\begin{array}{c}\text { Brandeis y Suárez- } \\
\text { Rozo (2005) }\end{array}$ \\
\hline \multirow{3}{*}{$\begin{array}{l}\text { Argentina } \\
\text { (Actual) }\end{array}$} & Parque Chaqueño & 98,80 & $\begin{array}{c}\text { Gasparri y Manghi } \\
\text { (2004) }\end{array}$ \\
\hline & $\begin{array}{l}\text { Selva Misionera } \\
\text { Selva Tucumano Boliviana }\end{array}$ & $\begin{array}{l}266,24 \\
172,87\end{array}$ & $\begin{array}{c}\text { Gasparri y Manghi } \\
\text { (2004) } \\
\text { Gasparri y Manghi } \\
(2004)\end{array}$ \\
\hline & Bosque Andino Patagónico & 540,20 & $\begin{array}{c}\text { Gasparri y Manghi } \\
\text { (2004) }\end{array}$ \\
\hline
\end{tabular}

Cuadro XI.7. Comparación con la biomasa de bosques actuales y los bosques de la Formación Cortaderita. Todos los valores de biomasa fueron calculados con las ecuaciones de Brown (1997).

\section{XI.6. Conclusiones paleoecológicas}

1. Teniendo en cuenta las condiciones climáticas y paleoambientales analizadas en capítulos anteriores, y el análisis ecológico del presente capítulo, se puede interpretar cuatro tipos diferentes de paleocomunidades: vegetación herbáceo-arbustiva constituida por corystospermas, peltaspermas y cycadales, (paleocomunidades 1, 6 y 7), bosque subtropical siempreverde estacional, con un estrato arbóreo integrado mayormente por corystospermas y un sotobosque de alta diversidad taxonómica (paleocomunidades 2, 3 y 4), y bosque subtropical esclerófilo ribereño, dominado exclusivamente por corystospermas (paleocomunidades 5 y 8 ).

2. La configuración de los histogramas de clases de diámetro sugiere que la colonización de los suelos fue llevada a cabo por unos pocos individuos pioneros (de diámetros mayores), seguidos por el establecimiento de gran número de árboles coetáneos. Esta situación se hace extrema en el bosque de la Sección Superior. El alto porcentaje de árboles jóvenes sugeriría un ambiente con frecuentes disrupciones, lo que queda evidenciado en las características sedimentológicas de la unidad formacional. Lo que parece haber ocurrido es que las paleocomunidades no lograban llegar a su clímax y eran interrumpidas por disrupciones ambientales, conduciendo a la puesta en marcha de una nueva sucesión ecológica. Las causas físicas que habrían generado esta situación serían las sucesivas erupciones volcánicas explosivas que sepultaban las comunidades con mantos muy espesos de cenizas.

4. Las características de composición y fenología, y los valores de altura estimada, diámetro promedio, densidad y biomasa de los bosques de la Formación 
Cortaderita, junto con las interpretaciones paleambientales, paleopedológicas y paleoclimáticas explicadas previamente, permiten comparar estas paleocomunidades con el Parque Chaqueño. Los dos bosques analizados en la Sección Inferior gris, con valores de densidad y biomasa más altos, árboles de mayor porte y estrato árboreo más de una especie, se asemejarían al Parque Chaqueño Subhúmedo. El bosque estudiado en la Sección Superior rosada, con valores más bajos de densidad y biomasa, árboles de menor porte y estrato arbóreo monoespecífico, sería equiparable al Parque chaqueño.Semiárido.

5. Es evidente un cambio en las paleocomunidades a lo largo del intervalo de tiempo que abarca la Formación Cortaderita: la Sección Inferior representada por vegetaciones arbóreo-arbustivas altamente diversas mientras que en la Sección Superior se caracteriza por vegetaciones arbóreo-arbustivas poco diversas. Este hecho se correlaciona claramente con el cambio paleoambiental y paleoclimático, interpretado a partir de las evidencias sedimentológicas y tafonómicas. 


\section{BIOESTRATIGRAFÍA Y EDAD DE LA FORMACIÓN CORTADERITA}

\section{XII.1. Introducción}

El Triásico es un período de grandes cambios en la configuración de los continentes, en el clima global y, en consecuencia, en las comunidades florísticas. De aquí que el estudio del Triásico sea esencial para comprender la evolución de los ecosistemas terrestres del Mesozoico (Artabe et al., 2001b).

En este período se terminó de conformar el supercontinente Pangea, cuyos fragmentos se fueron uniendo por partes. Las colisiones continentales que condujeron a la formación de Pangea comenzaron en el Devónico y continuaron hasta el Triásico Superior, y modificaron de manera sustancial el clima global, alterando la circulación general de la atmósfera (Scotesse et al., 1999).

En cuanto al clima, se produce un cambio de casa fría a casa cálida a finales del Pérmico. El clima global era cálido durante el Triásico. Hacia los polos, era templado durante todo el año, impidiendo la conformación de casquetes glaciales. La circulación general de la atmósfera era megaestacional o megamonzónica, esto es, con una estación muy seca bastante extendida y con una estación de lluvias breve (Parrish, 1993).

Aunque aún no estaban separadas en el Triásico, se pueden reconocer dos regiones: Laurasia (Eurasia y Norteamérica) y Gondwana (Sudamérica, África, Australia, Antártida e India). Nuestro territorio se ubicaba en el Sudoeste de Gondwana.

Para está región, se infieren climas estacionales o monzónicos, subtropicales o templado-cálidos, con veranos lluviosos e inviernos secos. Las cuencas de la Patagonia y del Centro-Oeste de la Argentina estaban controladas por un clima subtropical estacional, mientras que las cuencas abiertas al mar recibían la influencia de las corrientes oceánicas del Pacífico y el clima era subtropical oceánico con lluvias todo el año (Spalletti et al., 2003).

Los cambios físicos en los ambientes continentales determinaron durante el Triásico un recambio florístico a nivel mundial, y en la mayoría de los grupos vegetales terrestres se observa la extinción de algunas líneas y el desarrollo de otras más modernas y competitivas (Zamuner et al., 2001). Se produce una fase de rápida reorganización y cambio, especialmente a nivel genérico y familiar (Wing y Suess, 1992) estableciéndose un nuevo tipo de vegetación. 
En Gondwana, se produjo una sustitución de floras: la flora de Glossopteris del Pérmico (y las microfloras de granos monosacados y bisacados estríados) es reemplazada por la flora de Dicroidium del Triásico (y las microfloras de granos bisacados no estríados) (Balme y Helby, 1973). El clima megaestacional instalado en el Triásico favoreció la dominancia de grupos adaptados a las estacionalidad climática y a la aridez, como son las corystospermas, familia que caracteriza las comunidades del Gondwana para el período.

Las floras argentinas triásicas se caracterizan por presentar taxones endémicos gondwánicos, y con una distribución temporal relativamente restringida. Los principales grupos constituyentes de las floras son las Pleuromeiaceae, Phyllothecaceae, Equisetaceae, Apocalamitaceae, Asterothecaceae, Osmundaceae, Gleicheniaceae, Dipteridaceae, Peltaspermaceae, Corystospermaceae, Zamiaceae, Stangeriaceae, Ginkgoales, Voltziaceae, Podocarpaceae, Araucariaceae, y algunos géneros de vinculación incierta (e.g. Linguifolium) (Zamuner et al., 2001; Morel et al., 2003).

A fines del Triásico Tardío, los componentes de la Flora de Dicroidium pierden importancia en las comunidades. En el Jurásico, la vegetación es más cosmopolita y está dominada por filicales, coníferas, cycadales y bennettitales (Zamuner et al., 2001).

Estos recambios florísticos, más la existencia de taxones diagnósticos, con amplia distribución geográfica en las cuencas de nuestro país, han permitido establecer una biozonación paleoflorística y un esquema cronoestratigráfico para el Triásico de la Argentina (Spalletti et al, 1999).

Como las secuencias triásicas de la Argentina son fundamentalmente continentales, las escalas del Triásico Alpino o del Pacífico -que definen los pisos y edades en secuencias marinas caracterizadas por amonites- no podían ser aplicadas. Por lo tanto, debería dividirse al Sistema Triásico argentino en Inferior, Medio y Superior (sensu Stipanicic y Bonaparte, 1972; Comité Argentino de Estratigrafía, 1992). Las equivalencias en las unidades geocronóligas son: Eotriásico (Triásico Inferior), Mesotriásico (Triásico Medio) y Neotriásico (Triásico Superior). Aproximadamente, las equivalencias con el Triásico marino son: los pisos Induaniano y Olenekiano comprenden el Triásico Inferior; los pisos Anisiano y Ladiniano, el Triásico Medio; y los pisos Carniano, Noriano y Retiano, el Triásico Superior (Morel et al, 2001).

En este sentido, las propuestas que se basen en fósiles terrestres, como tetrápodos (Bonaparte, 1973, 1978, 1997; Stipanicic y Bonaparte, 1979), invertebrados contintentales (Gallego y Martins-Neto, 2005), palinomorfos (Yrigoyen y Stover, 1970; Zavattieri, 1995) 
y plantas (Retallack, 1977; Spalletti et al., 1999), han sido de considerable valor (Morel et al., 2001).

Puesto que en las sedimentitas mesozoicas de la cuenca de Barreal-Calingasta, no se ha citado hasta el momento el hallazgo de fósiles de animales y palinomorfos, los modelos analizados para la Formación Cortaderita serán los basados en megafloras.

\section{XII.2. Biozonación paleoflorística para Gondwana}

Retallack (1977) definió cuatro zonas de Oppel para las floras triásicas del Gondwana, dominadas por pteridospermas. Este autor analizó las paleofloras del Este de Autralia, y correlacionó los resultados con otras cuencas gondwánicas: la del Karoo, en Sudáfrica, y las de Barreal-Calingasta y Cuyana, en Argentina.

Los límites de las zonas biostratigráficas de Retallack (1977) están marcados por cinco eventos: la inmigración de Lepidopteris (= "Thinnfeldia") callipteroides a las floras gondwánicas; la diferenciación de Zuberia (=Dicroidium) zuberi y luego de Dicroidium odontopteroides, la aparición de Yabeiella y la extinción de Dicroidium. Para la identificación de las zonas se utilizaron taxones asociados a los nombrados, ya que éstos persisten en unidades más jóvenes, siendo por sí solos insuficientes para caracterizar las zonas. La edad cronestratigráfica de las biozonas fue determinada por Retallack (1977) mediante fósiles marinos asociados, principalmente ammonoideos (Furnish, 1973; Tozer, 1971), y de la extrapolación de datos isotópicos de rocas extrusivas.

Las biozonas definidas por Retallack (1977) son, de base a techo, las siguientes:

1. Zona de Oppel de Lepidopteris (= "Thinnfeldia") callipteroides: de edad eotriásica (=Chhidruano a Smithiano), está dominada por Lepidopteris (= "Thinnfeldia") callipteroides, siendo también comunes algunas especies de Voltziopsis, Diplasiophyllum (=Dicroidium) hughesi y Zuberia barrealensis (=Dicroidium brownii). Esta zona suprayace sedimentitas portadoras de la flora de Glossopteris.

2. Zona de Oppel de Zuberia (=Dicroidium) zuberi de edad mesotriásica temprana (=Smithiano a Anisiano temprano), está caracterizada por la abundancia de hojas de Zuberia (=Dicroidium) zuberi, sus estructuras reproductivas Pteruchus (="Pterorrachis") barrealensis y órganos cupulados grandes comparables Umkomasia. Dicroidium dubium subsp. australe, Pleuromiea spp. y sus conos Cylostrobus están aparentemente restringidos a esta zona. 
3. Zona de Oppel de Dicroidium odontopteroides: de edad mesotriásica tardía (=Anisiano tardío a Ladiniano), se distingue por la presencia de Dicroidium odontopteroides, Pteruchus johnstonii y Pilophorosperma spp. También son distintivas Dicroidium eskense, Johnstonia, y Linguifolium.

4. Zona de Oppel de Yabeiella: de edad neotriásica (=Carniano a Retiano), está definida por la presencia de Yabeiella y Fraxinopsis.

De estas zonas se ha reconocido en la Argentina a la Zona de Zuberia (=Dicroidium) zuberi en la Formación Barreal (cuenca de Barreal-Calingasta) y la Zona de Yabeiella en la Formación Potrerillos (cuenca Cuyana).

\section{XII.3. Biozonación paleoflorística de la Argentina}

Spalletti et al. (1999) elaboran un esquema bioestratigráfico sobre la base de megafloras, para la Argentina. Definen cinco biozonas de asociación, delimitadas a partir de la abundancia de grupos de taxones a través del tiempo. Dichos grupos fueron establecidos por la presencia de elementos abundantes y/o exclusivos, para los que se tomaron en cuenta tres aspectos: su estirpe pérmica o afinidad jurásica, el nivel evolutivo y el acmé. Para otorgarle una edad a las biozonas, se consideró las relaciones geológicas y dataciones absolutas preexistentes (Spalletti et al., 1999; Morel et al., 2003). De esta manera, identifican las siguientes zonas bioestratigráficas

1. Biozona de Dictyophyllum castellanosii, Johnstonia stelzneriana, Saportaea dichotoma (CSD): de edad mesotriásica temprana, sus elementos diagnósticos son Dictyophyllum castellanosii y $D$. barrealensis (Dipteridaceae); Zuberia feistmanteli, Z. barrealensis, Z. zuberi, Dicroidium dubium y Johnstonia stelzneriana (Corystospermaceae); Saportaea flabellata, S. dichotoma y S. intermedia (Ginkgoales); y Heidiphyllum elongatum (Voltziaceae).

2. Biozona de Yabeiella mareyesiaca, Scytophyllum bonettiae, Rhexoxylon (=Protophyllocladoxylon) cortaderitaense (MBC): de edad mesotriásica tardía, sus taxones diagnósticos son Zuberia feistmanteli, Z. papillata, Z. zuberi, Rhexoxylon (=Protophyllocladoxylon) cortaderitaense, Cuneumxylon spallettii y Tranquiloxylon (Corystospermaceae); Scytophyllum bonettiae y Pachydermophyllum praecordillerae (Peltaspermaceae); Kurtziana cacheutensis (Cycadales); Yabeiella mareyesiaca (Gnetales); y Araucarioxylon protoaraucana (Araucariaceae). 
3. Biozona de Yabeiella brackebuschiana, Scytophyllum neuburgianum, Rhexoxylon piatnitzkyi (BNP): de edad neotriásica temprana, sus elementos diagnósticos son Zuberia papillata, Z. zuberi, Z. sahnii, Johnstonia coriacea, Rhexoxylon piatnitzkyi (Corystospermaceae); Scytophyllum neuburgianum y Pachydermophyllum praecordillerae (Peltaspermaceae); Yabeiella brackebuschiana (Gnetales); Araucarioxylon sp. y Protojuniperoxylon ischigualastense (Coniferales); y Heidiphyllum elongatum (Voltziaceae).

4. Biozona de Dicroidium odontopteroides y Dicroidium lancifolium (OL) de edad neotriásica, sus taxones diagnósticos son Dicroidium (Corystospermaceae); y Yabeiella (Gnetales).

5. Biozona de Dictyophyllum tenuiserratum. Linguifolium arctum, Protocircoporoxylon marianaensis (DLM): de edad neotriásica tardía, sus elementos diagnósticos son Cladophlebis grahami y $C$. denticulata (Osmundaceae), Dictyophyllum chihuihuensis, D. tenuiserratum y D. rothi (Dipteridaceae); Rhexoxylon brunoi, Dicroidium crassum, D. odontopteroides, D. lancifolium, Xylopteris argentina y X. elongata, (Corystospermaceae). También son abundantes Scleropters grandis, Linguifolium arctum, L. lillealum, L. steinmanii y L. tenison-woodsi; y coniferofitas como Fraxinopsis, Telemachus, Heidiphyllum y Protocircoporoxylon marianaensis.

En la cuenca de Barreal-Calingasta se reconocieron las biozonas CSD (Formación Barreal), MBC (Sección Inferior de la Formación Cortaderita) y OL (Sección Superior de la Formación Cortaderita).

Para el Eotriásico, Spalletti et al. (2003) y Morel et al. (2003), adicionan la "Flora de Pleuromeia", caracterizada por comunidades dominadas por lycofitas del grupo de las Pleuromeiales, con escasos representantes de otros grupos.

\section{XII.4. Cronoestratigrafía del Triásico de la Argentina}

Spalletti et al. (1999) a su vez proponen un esquema cronoestratigráfico sobre la base de las biozonas establecidas más datos geocronológicos, criterios evolutivos de las plantas fósiles, la evolución de los rellenos sedimentarios de los depocentros de nuestro país y las principales discontinuidades observadas. De esta manera establecen los pisos ilustrados en el cuadro XII.1. Cada piso está delimitado por eventos florísticos de gran escala. 


\begin{tabular}{|l|l|l|}
\hline Piso & Edad & Evento \\
\hline Floriano & Neotriásico Tardío & $\begin{array}{l}\text { Tercer evento } \\
\text { DECLINACIÓN DE LAS CORYSTOSPERMAS Y APARICIÓN DE } \\
\text { TAXONES JURÁSICOS }\end{array}$ \\
\hline Cortaderitiano & $\begin{array}{l}\text { Mesotriásico Tardío - } \\
\text { Neotriásico Medio }\end{array}$ & $\begin{array}{l}\text { Segundo evento } \\
\text { MÁXIMA DIVERSIFICACIÓN DE LA FLORA DE DICROIDIUM } \\
\text { RADIACIÓN DE LAS CORYSTOSPERMAS Y PELTASPERMAS }\end{array}$ \\
\hline Barrealiano & $\begin{array}{l}\text { Eotriásico - Mesotriásico } \\
\text { Temprano }\end{array}$ & $\begin{array}{l}\text { Primer evento } \\
\text { FLORAS CON DIPTERIDACEAE PRIMITIVAS, } \\
\text { CORYSTOSPERMAS Y GINKGOALES }\end{array}$ \\
& & FLORA DE PLEUROMEIA \\
\hline
\end{tabular}

Cuadro XII.1 Pisos propuestos por Spalletti et al. (1999) para el Triásico de la Argentina.

\section{XII.5. Bioestratigrafía y edad de la Formación Cortaderita}

Stipanicic $(1972,1979)$ consideró que las tafofloras de las Formaciones Barreal y Cortaderita, tomadas en conjunto, presentaban sus mayores afinidades con las del Neotriásico (78\% de las especies en común con las de otros yacimientos bien fechados), pero también con las del Mesotriásico Tardío (60\%), aunque en varios casos, yacimientos portantes de estas últimas pasaron a ser considerados como del Neotriásico, sea por el reajuste de los fechados radimétricos del Período o por la revaluación cronológica de las tafofloras en juego. En consecuencia, Stipanicic (1972, 1979, 2002) estima que la Formación Cortaderita debería ubicarse, con mucha posibilidad, en el Neotriásico Temprano de acuerdo con análisis florísticos a nivel mundial (Retallack, 1977; Anderson y Anderson, 1993a, b). La idea de que todo el paquete sedimentario de la formación es Neotriásico, ya era mantenida por Frenguelli (1948), quien lo correlacionaba con el Retiano

Spalletti et al. (1999) y Morel et al. (2001) ubicaron a la Sección Inferior de Cortaderita en el Mesotriásico Tardío y a la Sección Superior, en el Neotriásico Medio, sobre la base de correlaciones con las Formaciones Potrerillos y Cacheuta, respectivamente. Además, sostienen que entre ambas secciones que hay un hiatus temporal importante.

A la luz de los aportes sistemáticos de la presente tesis, se realizó una comparación entre el contenido paleoflorístico de la Sección Inferior gris y el de la Sección Superior rosada de la Formación Cortaderita (Cuadro XII.2). De los 64 taxones 
registrados en dicha unidad, 58 constituyen la paleoflora de la Sección Inferior y 19 la de la Superior.

\begin{tabular}{|c|c|c|}
\hline Taxones & Sección Inferior gris & Sección Superior rosada \\
\hline Thallites sp. 1 & $\mathrm{x}$ & \\
\hline Thallites sp. 2 & $\mathrm{x}$ & \\
\hline Muscites sp. & $\mathrm{x}$ & \\
\hline Lepidanthium sporiferum (Feistmantel) Frenguelli 1944b & $\mathrm{x}$ & \\
\hline Neocalamites sp. & $\mathrm{x}$ & \\
\hline Equisetites fertilis Frenguelli 1944c & $\mathrm{x}$ & \\
\hline Phylloteca australis Brongniart $1828 \mathrm{a}$ & $\mathrm{x}$ & \\
\hline Cf. Rienitsia arrondiana Herbst $1977 \mathrm{~b}$ & $\mathrm{x}$ & \\
\hline Cladophlebis mendozaensis (Geinitz) Frenguelli 1947 & $\mathrm{x}$ & $\mathrm{x}$ \\
\hline Cladophlebis sp. & $\mathrm{x}$ & \\
\hline $\begin{array}{l}\text { Dictyophyllum tenuifolium Stipanicic et Menéndez emend. } \\
\text { Bonetti et Herbst } 1964\end{array}$ & $\mathrm{x}$ & \\
\hline Coniopteris? sp. & $\mathrm{x}$ & \\
\hline Dicroidium dubium (Feistmantel) Gothan 1912 & $\mathrm{x}$ & \\
\hline D. odontopteroides (Morris) Gothan 1912 & $\mathrm{x}$ & $\mathrm{x}$ \\
\hline D. lancifolium (Morris) Gothan 1912 & $\mathrm{x}$ & $\mathrm{x}$ \\
\hline D. crassum (Menéndez) Petriella 1979 & $\mathrm{x}$ & \\
\hline $\begin{array}{l}\text { Cf. Dicroidium argenteum (Retallack) Gnaedinger in } \\
\text { Gnaedinger } \text { et Herbst } 2001\end{array}$ & $\mathrm{x}$ & \\
\hline Zuberia. feistmanteli (Johnston) Frenguelli emend. Artabe 1990 & & $\mathrm{x}$ \\
\hline Z. papillata (Townrow.) Artabe 1990 & $\mathrm{x}$ & \\
\hline Z. zuberi (Szajnocha) Frenguelli 1943 & $\mathrm{x}$ & \\
\hline Z. barrealensis Frenguelli 1943 & $\mathrm{x}$ & \\
\hline Johnstonia stelzneriana (Geinitz) Frenguelli 1943 & $\mathrm{x}$ & \\
\hline Xylopteris argentina (Kurtz) Frenguelli1943 & $\mathrm{x}$ & \\
\hline X. elongata (Carruthers) Frenguelli 1943 & $\mathrm{x}$ & \\
\hline Pteruchus barrealensis (Frenguelli) Holmes et Ash 1979 & & $\mathrm{x}$ \\
\hline Umkomasia macleani Thomas 1933 & $\mathrm{x}$ & \\
\hline Rhexoxylon cortaderitaense (Menéndez) Bodnar 2008 & $\mathrm{x}$ & $\mathrm{x}$ \\
\hline Scytophyllum bonettiae Zamuner, Artabe et Ganuza 1999 & $\mathrm{x}$ & $\mathrm{x}$ \\
\hline Peltaspermun sp. & $\mathrm{x}$ & \\
\hline $\begin{array}{l}\text { Pachydermophyllum praecordillerae (Frenguelli) Retallack } \\
1981\end{array}$ & $x$ & \\
\hline P. papillosum Thomas et Bose 1955 & $\mathrm{x}$ & $\mathrm{x}$ \\
\hline Lepidopteris stormbergensis (Seward) Townrow 1956 & $\mathrm{x}$ & $\mathrm{x}$ \\
\hline L. africana (Du Toit) Holmes 1982 & & $\mathrm{x}$ \\
\hline Cf. Delnortea abbottiae Mamay, Miller, Rohr et Stein 1986 & $\mathrm{x}$ & \\
\hline Cordaicarpus mackayi (Arber) comb. nov. & $\mathrm{x}$ & $\mathrm{x}$ \\
\hline Pseudoctenis ctenophylloides Bonetti 1968 & & $\mathrm{x}$ \\
\hline P.longipinnata Anderson et Anderson 1989 & & $\mathrm{x}$ \\
\hline P. falconeriana Bonetti 1968 & $\mathrm{x}$ & \\
\hline P. anomozamoides Bonetti 1968 & $\mathrm{x}$ & \\
\hline Pseudoctenis sp. nov. & $\mathrm{x}$ & \\
\hline $\begin{array}{l}\text { Ginkgoites waldeckensis (Anderson et Anderson) Troncoso et } \\
\text { Herbst } 1999\end{array}$ & $\mathrm{x}$ & \\
\hline Sphenobaiera sectina Anderson et Anderson 1989 & $\mathrm{x}$ & \\
\hline S. schenkii (Feistmantel) Florin 1936 & $\mathrm{x}$ & \\
\hline S. argentinae (Kurtz) Florin 1940 & $\mathrm{x}$ & $\mathrm{x}$ \\
\hline S. stormbergensis (Seward) Frenguelli 1948 & $\mathrm{x}$ & $\mathrm{x}$ \\
\hline Baiera cuyana Frenguelli 1942 a & $\mathrm{x}$ & \\
\hline Ginkgodium nathorsti Yokoyama 1889 & & $\mathrm{x}$ \\
\hline
\end{tabular}


Josefina Bodnar - La paleoflora triásica de la Formación Cortaderita...

\begin{tabular}{|c|c|c|}
\hline Yabeiella brackebuschiana (Kurtz) Ôishi 1931 & $\mathrm{x}$ & $\mathrm{x}$ \\
\hline Y. spathulata Ôishi 1931 & $\mathrm{x}$ & \\
\hline Y. wielandi Ôishi 1931 & $\mathrm{x}$ & \\
\hline Y. mareyesiaca (Geinitz) Ôishi 1931 & $\mathrm{x}$ & $\mathrm{x}$ \\
\hline Taeniopteris carruthersi Tenison-Woods 1883 & $\mathrm{x}$ & \\
\hline T. macclellandi Oldham et Morris 1862 & $\mathrm{x}$ & \\
\hline T. plicatella (Solms) Menéndez 1950 & $\mathrm{x}$ & \\
\hline Rochipteris cyclopteroides (Frenguelli) comb. nov. & $\mathrm{x}$ & \\
\hline $\begin{array}{l}\text { Kurtziana cacheutensis (Kurtz) Frenguelli emend. Petriella et } \\
\text { Arrondo } 1982\end{array}$ & $\mathrm{x}$ & $\mathrm{x}$ \\
\hline Heidiphyllum elongatum (Morris) Retallack 1981 & $\mathrm{x}$ & \\
\hline H. clarifolium Anderson et Anderson 1989 & $\mathrm{x}$ & \\
\hline H. minutifolium Anderson et Anderson 1989 & $\mathrm{x}$ & \\
\hline Fraxinopsis andium (Frenguelli) Anderson et Anderson 2003 & $\mathrm{x}$ & \\
\hline Rissikia media (Tenison-Woods) Townrow 1967 & $\mathrm{x}$ & \\
\hline Elatocladus planus (Feistmantel) Seward 1919 & $\mathrm{x}$ & \\
\hline Pagiophyllum sp. & $\mathrm{x}$ & \\
\hline Linguifolium sp. & $\mathrm{x}$ & \\
\hline
\end{tabular}

Cuadro XII.2. Contenido paleoflorístico de las dos secciones de la Formación Cortaderita.

El $20,31 \%$ del total de la flora de Cortaderita es compartido por ambas secciones. Por lo tanto, 13 taxones registrados en la Sección Inferior (Dicroidium odontopteroides, D. lancifolium, Rhexoxylon cortaderitaense, Scytophyllum bonettiae, Pachydermophyllum papillosum, Lepidopteris stormbergensis, Cordaicarpus mackayi, Sphenobaiera argentinae, S. stormbergensis, Yabeiella brackebuschiana, $Y$. mareyesiaca y Kurtziana cacheutensis) pasan a la Superior (Figura XII.1). Esto significa que de los 19 taxones presentes en la Sección Superior, el 68,72\% ya estaban presentes en la Inferior, por lo que las diferencias en la flora de ambas secciones se da especialmente por la desparición de elementos y una disminución de la diversidad.

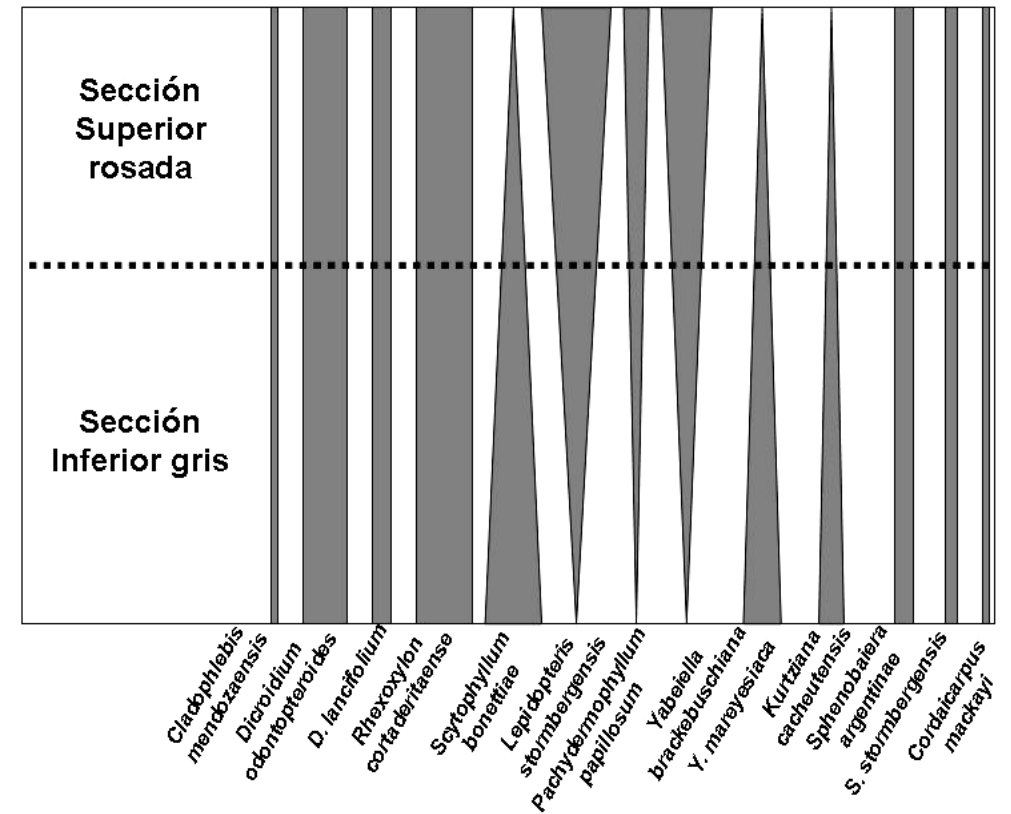

Figura XII.1. Abundancia a lo largo de la Formación Cortaderita de los taxones que pasan el límite entre Sección Inferior gris $\mathbf{y}$ Sección Superior rosada. 
De estas especies que atraviesan el límite Rhexoxylon cortaderitaense, Scytophyllum bonettiae, Yabeiella mareyesiaca y Kurtziana cacheutensis son elementos diagnósticos de la biozona MBC (Mesotriásico Tardío) definida en la Sección Inferior gris de Cortaderita (Spalletti et al., 1999). Siendo que dichas especies son considerados fósiles guía (de corto biocrón, restringido al Mesotriásico tardío) se podría considerar que en el límite entre las secciones de Cortaderita, no habría un hiatus temporal importante.

En segundo lugar, se comparó el contenido paleoflorístico de la Sección Inferior gris con el de otras formaciones triásicas de la Argentina (Cuadro XII.3).

\begin{tabular}{|c|c|c|c|c|c|c|c|c|c|c|c|c|c|c|c|c|c|c|c|}
\hline Taxones & 1 & 2 & 3 & 4 & 5 & 6 & 7 & 8 & 9 & 10 & 11 & 12 & 13 & 14 & 15 & 16 & 17 & 18 & 19 \\
\hline \multicolumn{20}{|l|}{ Thallites sp. 1} \\
\hline \multicolumn{20}{|l|}{ Thallites sp. 2} \\
\hline \multicolumn{20}{|l|}{ Muscites $s p$} \\
\hline \multicolumn{20}{|l|}{ Lepidanthium sporiferum } \\
\hline Neocalamites sp. & $\mathrm{X}$ & & & & & & & & & & & & & & $\mathrm{X}$ & $\mathrm{X}$ & $\mathrm{X}$ & & $\mathrm{X}$ \\
\hline Equisetites fertilis & & & $\mathrm{X}$ & & & & & & & $\mathrm{X}$ & & & $\mathrm{X}$ & & $\mathrm{X}$ & & & & \\
\hline Phylloteca australis & & & $\mathrm{X}$ & & & & & & & $\mathrm{X}$ & & & $\mathrm{X}$ & & & & & & \\
\hline Rienitsia arrondiana & & & & & & & & $\mathrm{X}$ & & & & & & & & & & & \\
\hline Cladophlebis mendozaensis & & & $\mathrm{X}$ & $\mathrm{X}$ & & $\mathrm{X}$ & & $\mathrm{X}$ & $\mathrm{X}$ & $\mathrm{X}$ & $\mathrm{X}$ & & $\mathrm{X}$ & $\mathrm{X}$ & & $\mathrm{X}$ & & & $\mathrm{X}$ \\
\hline Cladophlebis sp. & $\mathrm{X}$ & & $\mathrm{X}$ & $\mathrm{X}$ & & & $\mathrm{X}$ & & & & & & & & & $\mathrm{X}$ & & & $\mathrm{X}$ \\
\hline Dictyophyllum tenuifolium & $\mathrm{X}$ & & & & & & & & & & $\mathrm{X}$ & & & & & & & & \\
\hline Coniopteris sp. & $\mathrm{X}$ & & & & & & & & & & & & & & & & & & \\
\hline Dicroidium dubium & & & $\mathrm{X}$ & & & & & $\mathrm{X}$ & & $\mathrm{X}$ & & $\mathrm{X}$ & $\mathrm{X}$ & & & $\mathrm{X}$ & & & \\
\hline D. odontopteroides & $\mathrm{X}$ & & $\mathrm{X}$ & $\mathrm{X}$ & & $\mathrm{X}$ & $\mathrm{X}$ & $\mathrm{X}$ & $\mathrm{X}$ & $\mathrm{X}$ & $\mathrm{X}$ & $\mathrm{X}$ & $\mathrm{X}$ & $\mathrm{X}$ & & $\mathrm{X}$ & & & $\mathrm{X}$ \\
\hline D. lancifolium & $\mathrm{X}$ & & $\mathrm{X}$ & $\mathrm{X}$ & & $\mathrm{X}$ & $\mathrm{X}$ & $\mathrm{X}$ & $\mathrm{X}$ & $\mathrm{X}$ & $\mathrm{X}$ & $\mathrm{X}$ & $\mathrm{X}$ & $\mathrm{X}$ & & $\mathrm{X}$ & & $\mathrm{X}$ & $\mathrm{X}$ \\
\hline D. crassum & & & $\mathrm{X}$ & & $\mathrm{X}$ & $\mathrm{X}$ & $\mathrm{X}$ & $\mathrm{X}$ & & $\mathrm{X}$ & $\mathrm{X}$ & & $\mathrm{X}$ & & & & & & \\
\hline D. argenteum & & & $\mathrm{X}$ & & & & & $\mathrm{X}$ & & & & & $\mathrm{X}$ & & & & & & \\
\hline Z. papillata & $X$ & & & & & & & & & $\mathrm{X}$ & & & & $\mathrm{X}$ & & & & & \\
\hline Z. zuberi & $\mathrm{X}$ & $\mathrm{X}$ & $\mathrm{X}$ & $\mathrm{X}$ & $\mathrm{X}$ & & $\mathrm{X}$ & $\mathrm{X}$ & & $\mathrm{X}$ & $\mathrm{X}$ & $\mathrm{X}$ & $\mathrm{X}$ & $\mathrm{X}$ & $\mathrm{X}$ & $\mathrm{X}$ & & & \\
\hline Z. barrealensis & $\mathrm{X}$ & & & & & & & & & $\mathrm{X}$ & & $\mathrm{X}$ & & & & & & & \\
\hline Johnstonia stelzneriana & $\mathrm{X}$ & & $\mathrm{X}$ & $\mathrm{X}$ & & $\mathrm{X}$ & & & & & $\mathrm{X}$ & $\mathrm{X}$ & $\mathrm{X}$ & $\mathrm{X}$ & $\mathrm{X}$ & & & & $\mathrm{X}$ \\
\hline Xylopteris argentina & $\mathrm{X}$ & & $\mathrm{X}$ & $\mathrm{X}$ & & $\mathrm{X}$ & $\mathrm{X}$ & & $\mathrm{X}$ & & & $\mathrm{X}$ & $\mathrm{X}$ & $\mathrm{X}$ & & & & & \\
\hline X. elongata & $\mathrm{X}$ & & $\mathrm{X}$ & & $\mathrm{X}$ & $\mathrm{X}$ & $\mathrm{X}$ & & $\mathrm{X}$ & & $\mathrm{X}$ & $\mathrm{X}$ & $\mathrm{X}$ & $\mathrm{X}$ & & $\mathrm{X}$ & & & \\
\hline \multicolumn{20}{|l|}{ Umkomasia macleani } \\
\hline \multicolumn{20}{|l|}{ Rhexoxylon cortaderitaense } \\
\hline \multicolumn{20}{|l|}{ Scytophyllum bonettiae } \\
\hline \multicolumn{20}{|l|}{ Peltaspermun sp. } \\
\hline $\begin{array}{c}\text { Pachydermophyllum } \\
\text { praecordillerae }\end{array}$ & $\mathrm{X}$ & & $\mathrm{X}$ & & & $\mathrm{X}$ & & & & $\mathrm{X}$ & $\mathrm{X}$ & & $\mathrm{X}$ & & & $\mathrm{X}$ & & & \\
\hline P.papillosum & & & & & & & & & & & & & $\mathrm{X}$ & & & & & & \\
\hline Lepidopteris stormbergensis & & & & & & & & $\mathrm{X}$ & & & & & & $\mathrm{X}$ & & & & & \\
\hline \multicolumn{20}{|l|}{ Delnortea abbottiae } \\
\hline \multicolumn{20}{|l|}{ Cordaicarpus mackayi } \\
\hline \multicolumn{20}{|l|}{ Pseudoctenis sp. nov. } \\
\hline \multicolumn{20}{|l|}{ P. anomozamoides } \\
\hline \multicolumn{20}{|l|}{ P. falconeriana } \\
\hline Kurtziana cacheutensis & & & $\mathrm{X}$ & $\mathrm{X}$ & & & & & & & $\mathrm{X}$ & & & & & $\mathrm{X}$ & & & \\
\hline Ginkgoites waldeckensis & & & & & & & & & $\mathrm{X}$ & & & & & & & & & & \\
\hline Sphenobaiera sectina & & & & & & & & $\mathrm{X}$ & & & & & & & & & & & \\
\hline S. schenkii & & & & & & & & & & & & & & & & & & & \\
\hline
\end{tabular}




\begin{tabular}{|c|c|c|c|c|c|c|c|c|c|c|c|c|c|c|c|c|c|c|c|}
\hline S. argentinae & $\mathrm{X}$ & & $\mathrm{X}$ & $\mathrm{X}$ & & & $\mathrm{X}$ & $\mathrm{X}$ & $\mathrm{X}$ & & & & & & $\mathrm{X}$ & & $\mathrm{X}$ \\
\hline S. stormbergensis. & $\mathrm{X}$ & & & & & & & $\mathrm{X}$ & & $\mathrm{X}$ & & & & & & $\mathrm{X}$ & & \\
\hline Baiera cuyana & $\mathrm{X}$ & & $\mathrm{X}$ & & & & & & & & & & & & & $\mathrm{X}$ & & \\
\hline Yabeiella brackebuschiana & $\mathrm{X}$ & & $\mathrm{X}$ & $\mathrm{X}$ & & $\mathrm{X}$ & & & & & & $\mathrm{X}$ & $\mathrm{X}$ & & & $\mathrm{X}$ & & \\
\hline Y. spathulata & & & $\mathrm{X}$ & & & & & & & $\mathrm{X}$ & & & $\mathrm{X}$ & & & & & & \\
\hline Y. wielandi & & & $\mathrm{X}$ & & & & & & $\mathrm{X}$ & & & & & & & & & & \\
\hline Y. mareyesiaca & & & $\mathrm{X}$ & $\mathrm{X}$ & & $\mathrm{X}$ & & & $\mathrm{X}$ & & & $\mathrm{X}$ & $\mathrm{X}$ & & & $\mathrm{X}$ & & $\mathrm{X}$ & $\mathrm{X}$ \\
\hline Taeniopteris carruthersi & & & & & & & & & & & & & & & & & & & \\
\hline T. macclellandi & & & & & & & & & & & & & & & & & & & \\
\hline T. plicatella & & & & & & & $\mathrm{X}$ & & & & & & & & & & & & \\
\hline Rochipteris cyclopteroides & & & & & & & & & & & & & $\mathrm{X}$ & & & & & & \\
\hline Heidiphyllum elongatum & & & $\mathrm{X}$ & $\mathrm{X}$ & $\mathrm{X}$ & & $\mathrm{X}$ & $\mathrm{X}$ & $\mathrm{X}$ & $\mathrm{X}$ & $\mathrm{X}$ & $\mathrm{X}$ & $\mathrm{X}$ & $\mathrm{X}$ & & $\mathrm{X}$ & & & \\
\hline H. clarifolium & & & & & & & & & & & & & & & & & & & \\
\hline H. minutifolium & & & $\mathrm{X}$ & $\mathrm{X}$ & & & $\mathrm{X}$ & & & & & & & & & & & & \\
\hline Fraxinopsis andium & & & $\mathrm{X}$ & $\mathrm{X}$ & & & & & & & $\mathrm{X}$ & & $\mathrm{X}$ & & & & & & \\
\hline Rissikia media & & & & & & & & $\mathrm{X}$ & & & & & & & & & & & \\
\hline Elatocladus plana & & & & $\mathrm{X}$ & & & & & & & & & & & & & & & \\
\hline Pagiophyllum sp. & & & & & & & & & & & & & & & & & & \\
\hline Linguifolium sp. & $\mathrm{X}$ & & & & & & & & & & & & & & & $\mathrm{X}$ & & \\
\hline
\end{tabular}

Cuadro XII.3. Lista paleoflorística de la Sección Inferior gris de la Formación Cortaderita. Comparación con otras unidades estratigráficas de la Argentina. 1. Formación Barreal. 2. Formación Cerro de las Cabras. 3. Formación Potrerillos. 4. Formación Cacheuta. 5. Formación Río Blanco. 6. Formación Chihuido. 7. Formación Llantenes. 8. Formación Cañadón Largo. 9. Formación Laguna Colorada. 10. Formación Vera. 11. Formación Paso Flores. 12. Formación Ischichuca. 13. Formación Los Rastros. 14. Formación Ischigualasto. 15. Formación Agua de Los Pajaritos. 16. Formación El Alcázar. 17. Formación Hilario. 18. Formación Quebrada de La Mina. 20. Formación Carrizal. En gris se resaltan los taxones que no han sido citados para otra formación triásica de la Argentina.

Las semejanzas entre la paleoflora de la Sección Inferior gris y las registradas en otras formaciones triásicas argentinas se detallan a continuación, en número de taxones en común y porcentaje de similitud:

1- Formación Barreal: 18 taxones en común, 31,03\%

2- Formación Cerro de las Cabras: 1 taxón en común, 1,72 \%

3- Formación Potrerillos: 24 taxones en común, 41,38\%

4- Formación Cacheuta: 15 taxones en común, 25,86\%

5- Formación Río Blanco: 4 taxones en común, 6,88 \%

6- Formación Chihuido: 10 taxones en común, 17,24\%

7- Formación Llantenes: 10 taxones en común, 17,24\%

8- Formación Cañadón Largo: 14 taxones en común, 24,14\%

9- Formación Laguna Colorada: 9 taxones en común, 15,51\%

10- Formación Vera: 15 taxones en común, 25,86\%

11- Formación Paso Flores: 12 taxones en común, 20,69\%

12- Formación Ischichuca: 11 taxones en común, 18,96\%

13- Formación Los Rastros: 20 taxones en común, 34,48\% 
14- Formación Ischigualasto: 10 taxones en común, 17,24 \%

15- Formación Agua de Los Pajaritos: 4 taxones en común, 6,88\%

16- Formación El Alcázar: 17 taxones en común, 29,31\%

17- Formación Hilario: 1 taxón en común, 1,72\%

18-Formación Quebrada de La Mina: 2 taxones en común, 3,44\%

19- Formación Carrizal: 9 taxones en común, 15,51\%.

En tercer lugar, el contenido paleoflorístico de la Sección Superior rosada fue contrastado también con el de otras formaciones triásicas de la Argentina (Cuadro XII.4).

\begin{tabular}{|c|c|c|c|c|c|c|c|c|c|c|c|c|c|c|c|c|c|c|c|}
\hline Taxones & 1 & 2 & 3 & 4 & 5 & 6 & 7 & 8 & 9 & 10 & 11 & 12 & 13 & 14 & 15 & 16 & 17 & 18 & 19 \\
\hline Cladophlebis mendozaensis & & & $\mathrm{X}$ & $\mathrm{X}$ & & $\mathrm{X}$ & & $\mathrm{X}$ & $\mathrm{X}$ & $\mathrm{X}$ & $\mathrm{X}$ & & $\mathrm{X}$ & $\mathrm{X}$ & & $\mathrm{X}$ & & & $\mathrm{X}$ \\
\hline $\begin{array}{c}\text { Dicroidium } \\
\text { odontopteroides }\end{array}$ & $\mathrm{X}$ & & $\mathrm{X}$ & $X$ & & $\mathrm{X}$ & $\mathrm{X}$ & $\mathrm{X}$ & $X$ & $\mathrm{X}$ & $\mathrm{X}$ & $\mathrm{X}$ & $\mathrm{X}$ & $X$ & & $\mathrm{X}$ & & & $\mathrm{X}$ \\
\hline D. lancifolium & $\mathrm{X}$ & & $\mathrm{X}$ & $\mathrm{X}$ & & $\mathrm{X}$ & $\mathrm{X}$ & $\mathrm{X}$ & $\mathrm{X}$ & $\mathrm{X}$ & $\mathrm{X}$ & $\mathrm{X}$ & $\mathrm{X}$ & $\mathrm{X}$ & & $\mathrm{X}$ & & $\mathrm{X}$ & $\mathrm{X}$ \\
\hline Zuberia. feistmanteli & $\mathrm{X}$ & $\mathrm{X}$ & $\mathrm{X}$ & $\mathrm{X}$ & & $\mathrm{X}$ & $\mathrm{X}$ & & & & & & & & & & & & \\
\hline Pteruchus barrealensis & $\mathrm{X}$ & & & & & & & & & $\mathrm{X}$ & & & & & & & & & \\
\hline \multicolumn{20}{|l|}{ Rhexoxylon cortaderitaense } \\
\hline $\begin{array}{c}\text { Pachydermophyllum } \\
\text { papillosum }\end{array}$ & & & & & & & & & & & & & $\mathrm{X}$ & & & & & & \\
\hline $\begin{array}{c}\text { Lepidopteris } \\
\text { stormbergensis }\end{array}$ & & & & & & & & $\mathrm{X}$ & & & & & & $\mathrm{X}$ & & & & & \\
\hline \multicolumn{20}{|l|}{ L. africana } \\
\hline \multicolumn{20}{|l|}{ Scytophyllum bonettiae } \\
\hline \multicolumn{20}{|l|}{ Cordaicarpus mackayi - } \\
\hline \multicolumn{20}{|l|}{$\begin{array}{c}\text { Pseudoctenis } \\
\text { ctenophylloides }\end{array}$} \\
\hline \multicolumn{20}{|l|}{ P.longipinnata } \\
\hline Kurtziana cacheutensis & & & $\mathrm{X}$ & $\mathrm{X}$ & & & & & & & $\mathrm{X}$ & & & & & $\mathrm{X}$ & & & \\
\hline Sphenobaiera argentinae & $\mathrm{X}$ & & $\mathrm{X}$ & $\mathrm{X}$ & & & & $\mathrm{X}$ & & $\mathrm{X}$ & & & & & & $\mathrm{X}$ & & & $\mathrm{X}$ \\
\hline S. stormbergensis. & $\mathrm{X}$ & & & & & & & $\mathrm{X}$ & & $\mathrm{X}$ & & & & & & $\mathrm{X}$ & & & \\
\hline Ginkgodium nathorsti & & & & & & & $\mathrm{X}$ & $\mathrm{X}$ & & & & & & & & & & & \\
\hline Yabeiella brackebuschiana & $\mathrm{X}$ & & $\mathrm{X}$ & $\mathrm{X}$ & & $\mathrm{X}$ & & & & & & $\mathrm{X}$ & $\mathrm{X}$ & & & $\mathrm{X}$ & & & \\
\hline Y. mareyesiaca & & & $\mathrm{X}$ & $\mathrm{X}$ & & $\mathrm{X}$ & & & $\mathrm{X}$ & & & $\mathrm{X}$ & $\mathrm{X}$ & & & $\mathrm{X}$ & & $\mathrm{X}$ & $\mathrm{X}$ \\
\hline
\end{tabular}

Cuadro XII.4. Lista paleoflorística de la Sección Superior rosada de la Formación Cortaderita.

Comparación con otras unidades estratigráficas de la Argentina. 1. Formación Barreal. 2. Formación Cerro de las Cabras. 3. Formación Potrerillos. 4. Formación Cacheuta. 5. Formación Río Blanco. 6. Formación Chihuido. 7. Formación Llantenes. 8. Formación Cañadón Largo. 9. Formación Laguna Colorada. 10. Formación Vera. 11. Formación Paso Flores. 12. Formación Ischichuca. 13. Formación Los Rastros. 14. Formación Ischigualasto. 15. Formación Agua de Los Pajaritos. 16. Formación EI Alcázar. 17. Formación Hilario. 18. Formación Quebrada de La Mina. 20. Formación Carrizal. En rosa se resaltan los taxones que no han sido citados para otra formación triásica de la Argentina.

Las similitudes entre la paleoflora de la Sección Superior rosada con las de otras formaciones triásicas argentinas se enumeran en la siguiente lista, en número de taxones en común y porcentaje de similitud: 
1- Formación Barreal: 7 taxones en común, 36,84\%

2- Formación Cerro de las Cabras: 1 taxón en común, 5,26 \%

3- Formación Potrerillos: 8 taxones en común, 42,1\%

4- Formación Cacheuta: 8 taxones en común, $42,1 \%$

5- Formación Río Blanco: 0 taxones en común, $0 \%$

6- Formación Chihuido: 6 taxones en común, 31,58\%

7- Formación Llantenes: 4 taxones en común, 21,05\%

8- Formación Cañadón Largo: 7 taxones en común, 36,84\%

9- $\quad$ Formación Laguna Colorada: 4 taxones en común, 21,05 \%

10- Formación Vera: 6 taxones en común, 31,58\%

11- Formación Paso Flores: 4 taxones en común, 21,05\%

12- Formación Ischichuca: 4 taxones en común, 21,05\%

13- Formación Los Rastros: 6 taxones en común, 31,58\%

14- Formación Ischigualasto: 4 taxones en común, 21,05\%

15- Formación Agua de Los Pajaritos: 0 taxones en común, $0 \%$

16- Formación El Alcázar: 8 taxones en común, 42,1\%

17- Formación Hilario: 0 taxones en común, $0 \%$

18- Formación Quebrada de La Mina: 2 taxones en común, 10,53\%

19- Formación Carrizal: 5 taxones en común, 26,32\%.

Por último, se comparó el contenido paleoflorístico de toda la Formación Cortaderita, con el de otras formaciones triásicas de la Argentina (Cuadro XII.5).

\begin{tabular}{|l|l|l|l|l|l|l|l|l|l|l|l|l|l|l|l|l|l|l|l|}
\hline Taxones & $\mathbf{1}$ & $\mathbf{2}$ & $\mathbf{3}$ & $\mathbf{4}$ & $\mathbf{5}$ & $\mathbf{6}$ & $\mathbf{7}$ & $\mathbf{8}$ & $\mathbf{9}$ & $\mathbf{1 0}$ & $\mathbf{1 1}$ & $\mathbf{1 2}$ & $\mathbf{1 3}$ & $\mathbf{1 4}$ & $\mathbf{1 5}$ & $\mathbf{1 6}$ & $\mathbf{1 7}$ & $\mathbf{1 8}$ & $\mathbf{1 9}$ \\
\hline Thallites sp. 1 & & & & & & & & & & & & & & & & & & & \\
\hline Thallites sp. 2 & & & & & & & & & & & & & & & & & & & \\
\hline Muscites sp & & & & & & & & & & & & & & & & & & & \\
\hline $\begin{array}{l}\text { Lepidanthium sporiferum } \\
\text { (Feistmantel) Frenguelli 1944b }\end{array}$ & & & & & & & & & & & & & & & & & & & \\
\hline Neocalamites sp. & $\mathrm{X}$ & & & & & & & & & & & & & & $\mathrm{X}$ & $\mathrm{X}$ & $\mathrm{X}$ & & $\mathrm{X}$ \\
\hline $\begin{array}{l}\text { Equisetites fertilis Frenguelli } \\
\text { 1944c }\end{array}$ & & & $\mathrm{X}$ & & & & & & & $\mathrm{X}$ & & & $\mathrm{X}$ & & $\mathrm{X}$ & & & & \\
\hline $\begin{array}{l}\text { Phylloteca australis Brongniart } \\
\text { 1828a }\end{array}$ & & & $\mathrm{X}$ & & & & & & & $\mathrm{X}$ & & & $\mathrm{X}$ & & & & & & \\
\hline $\begin{array}{l}\text { Rienitsia arrondiana Herbst } \\
\text { 1977b }\end{array}$ & & & & & & & & $\mathrm{X}$ & & & & & & & & & & & \\
\hline $\begin{array}{l}\text { Cladophlebis mendozaensis } \\
\text { (Geinitz) Frenguelli 1947 }\end{array}$ & & & $\mathrm{X}$ & $\mathrm{X}$ & & $\mathrm{X}$ & & $\mathrm{X}$ & $\mathrm{X}$ & $\mathrm{X}$ & $\mathrm{X}$ & & $\mathrm{X}$ & $\mathrm{X}$ & & $\mathrm{X}$ & & & $\mathrm{X}$ \\
\hline Cladophlebis sp. & $\mathrm{X}$ & & $\mathrm{X}$ & $\mathrm{X}$ & & & $\mathrm{X}$ & & & & & & & & & $\mathrm{X}$ & & & $\mathrm{X}$ \\
\hline $\begin{array}{l}\text { Dictyophyllum tenuifolium } \\
\text { Stipanicic } \text { et Menéndez emend. } \\
\text { Bonetti } \text { et Herbst 1964 }\end{array}$ & $\mathrm{X}$ & & & & & & & & & & $\mathrm{X}$ & & & & & & & & \\
\hline Coniopteris sp. & $\mathrm{X}$ & & & & & & & & & & & & & & & & & \\
\hline $\begin{array}{l}\text { Dicroidium dubium } \\
\text { (Feistmantel) Gothan 1912 }\end{array}$ & & & $\mathrm{X}$ & & & & & $\mathrm{X}$ & & $\mathrm{X}$ & & $\mathrm{X}$ & $\mathrm{X}$ & & & $\mathrm{X}$ & & & \\
\hline $\begin{array}{l}\text { D. odontopteroides (Feistmantel) } \\
\text { Gothan 1912 }\end{array}$ & $\mathrm{X}$ & & $\mathrm{X}$ & $\mathrm{X}$ & & $\mathrm{X}$ & $\mathrm{X}$ & $\mathrm{X}$ & $\mathrm{X}$ & $\mathrm{X}$ & $\mathrm{X}$ & $\mathrm{X}$ & $\mathrm{X}$ & $\mathrm{X}$ & & $\mathrm{X}$ & & $\mathrm{X}$ \\
\hline D. lancifolium (Feistmantel) & $\mathrm{X}$ & & $\mathrm{X}$ & $\mathrm{X}$ & & $\mathrm{X}$ & $\mathrm{X}$ & $\mathrm{X}$ & $\mathrm{X}$ & $\mathrm{X}$ & $\mathrm{X}$ & $\mathrm{X}$ & $\mathrm{X}$ & $\mathrm{X}$ & & $\mathrm{X}$ & & $\mathrm{X}$ & $\mathrm{X}$ \\
\hline
\end{tabular}


Josefina Bodnar - La paleoflora triásica de la Formación Cortaderita...

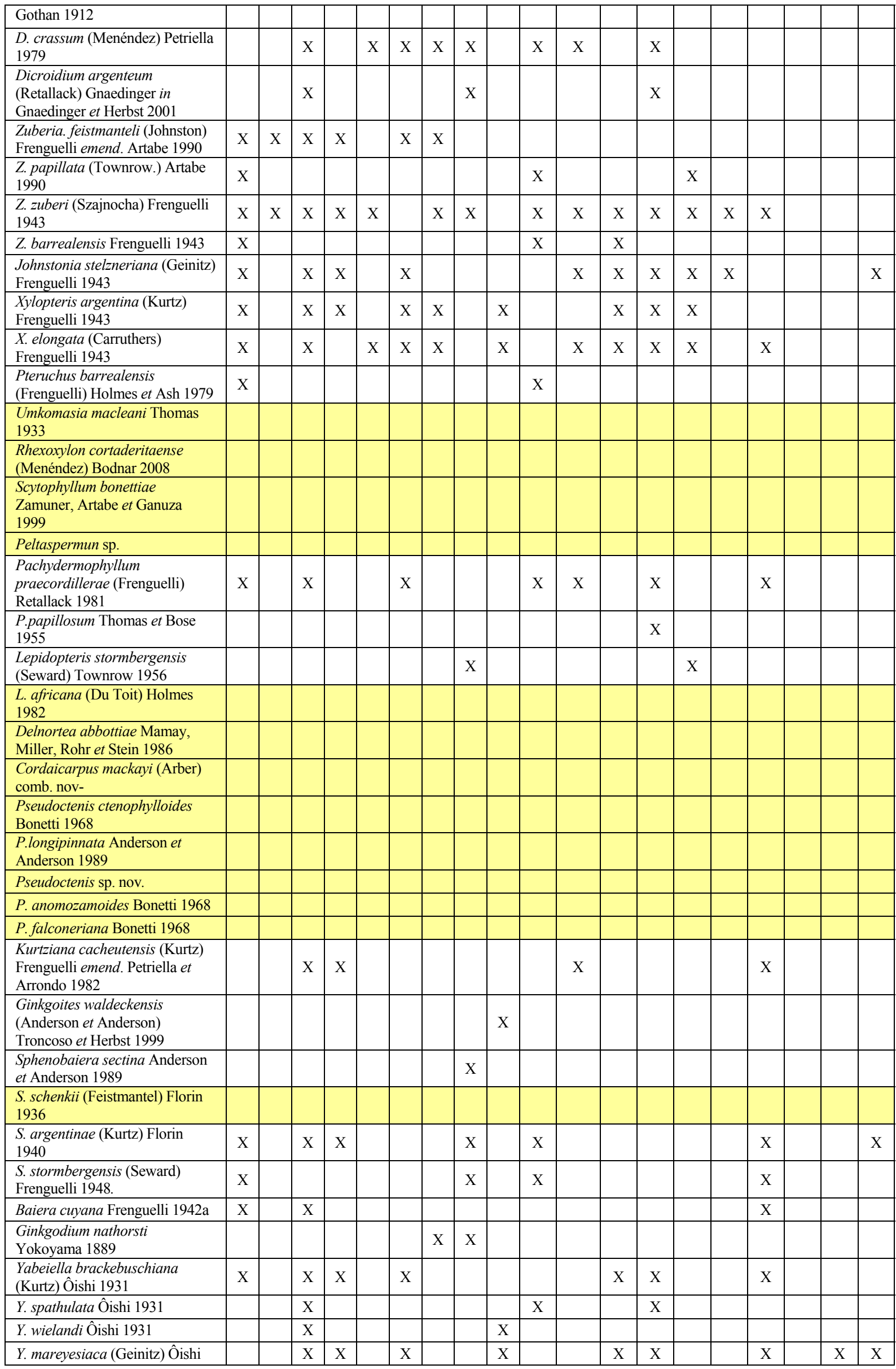




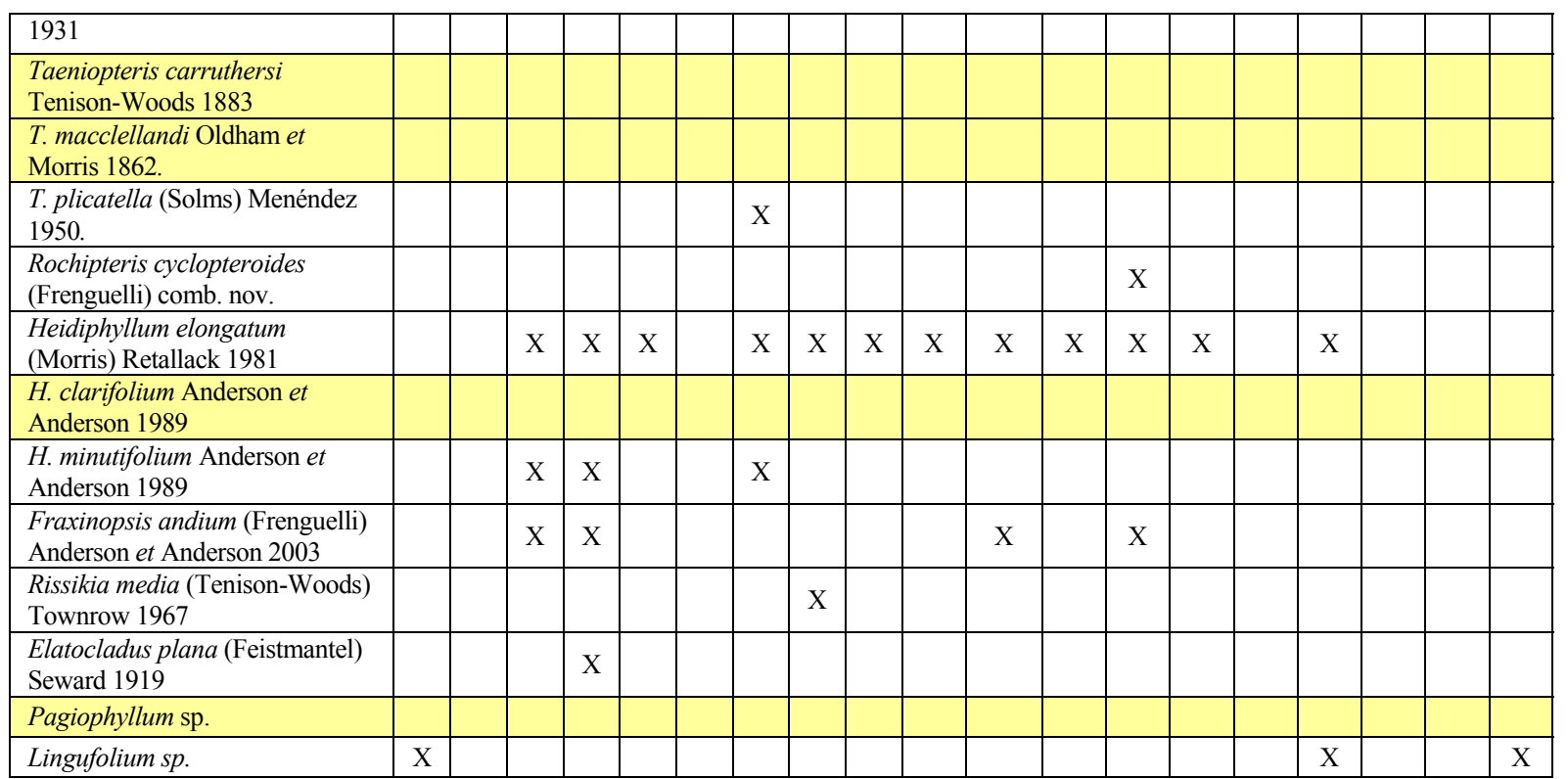

Cuadro XII.5. Lista paleoflorística de la Formación Cortaderita. Comparación con otras unidades estratigráficas de la Argentina. 1. Formación Barreal. 2. Formación Cerro de las Cabras. 3. Formación Potrerillos. 4. Formación Cacheuta. 5. Formación Río Blanco. 6. Formación Chihuido. 7. Formación Llantenes. 8. Formación Cañadón Largo. 9. Formación Laguna Colorada. 10. Formación Vera. 11. Formación Paso Flores. 12. Formación Ischichuca. 13. Formación Los Rastros. 14. Formación Ischigualasto. 15. Formación Agua de Los Pajaritos. 16. Formación El Alcázar. 17. Formación Hilario, 18. Formación Quebrada de La Mina. 20. Formación Carrizal. En amarillo se resaltan los taxones que no han sido citados para otra formación triásica de la Argentina.

De los 64 taxones en total registrados en la Formación Cortaderita, 21 no son compartidos con otras unidades triásicas de la Argentina. De esos 21 taxones, 4 taxones son endémicos de la formación, con respecto al resto del Gondwana (Rhexoxylon cortaderitaense, Scytophyllum bonettiae, Pseudoctenis sp. nov. y Pseudoctenis ctenophylloides). Por lo tanto, la Formación Cortaderita presenta los siguientes grados de similitud con las unidades comparadas:

1- Formación Barreal: 20 taxones en común, 29,85\%

2- Formación Cerro de las Cabras: 2 taxones en común, 2,98 \%

3- Formación Potrerillos: 26 taxones en común, 38,80\%

4- Formación Cacheuta: 16 taxones en común, 23,88\%

5- Formación Río Blanco: 4 taxones en común, 5,97\%

6- Formación Chihuido: 11 taxones en común, 16,47\%

7- Formación Llantenes: 12 taxones en común, 17,91\%

8- Formación Cañadón Largo: 16 taxones en común, 23,88\% 
9- Formación Laguna Colorada: 9 taxones en común, 13,43\%

10- Formación Vera: 16 taxones en común, 23,88\%

11- Formación Paso Flores: 12 taxones en común, 17,91\%

12- Formación Ischichuca: 11 taxones en común, 16,47\%

13- Formación Los Rastros: 20 taxones en común, 29,85 \%

14- Formación Ischigualasto: 11 taxones en común, 16,47\%

15- Formación Agua de Los Pajaritos: 4 taxones en común, 5,97\%

16- Formación El Alcázar: 17 taxones en común, 25,37\%

17- Formación Hilario: 1 taxón en común, 1,49\%

18- Formación Quebrada de La Mina: 2 taxones en común, 2,98\%

19- Formación Carrizal: 9 taxones en común, 5,97\%.

De acuerdo a este análisis, en cuanto a su contenido florístico, la Formación Cortaderita presenta mayores semejanzas con la Formación Potrerillos, tanto si es tomada de manera integral $(38,80 \%)$, como si cada sección es considerada por separado (Inferior gris: 41,38\%; Superior rosada: 42,1\%). En segundo lugar, la Formación Cortaderita en su totalidad, presenta similitudes con las Formaciones Los Rastros y Barreal $(29,85 \%)$. Lo mismo ocurre con la Sección Inferior gris, que comparte el $34,48 \%$ de la paleflora con la Formación Los Rastros y el 31,03\% con la Formación Barreal. Por otro lado, la Sección Superior rosada muestra también semejanzas con la paleoflora de las Formaciones Cacheuta (42,1\%) y El Alcázar (42,1\%). Esto encuentra relación con la posición de dichas formaciones en la columna estratigráfica de cada cuenca (Formación Potrerillos subyace a Cacheuta así como la Sección Inferior de Cortaderita subyace a la Sección Superior). Además muestra que si bien no hay un hiatus temporal muy importante, y el registro paleoflorístico es bastante continuo, la flora sufre un cambio a lo largo de la Formación Cortaderita.

Si se considera las dataciones radimétricas disponibles, la Formación Cerro de Las Cabras (subyacente a Potrerillos), en Paramillo de Uspallata, manifiesta valores de $235 \pm 5$ y $240 \pm 10$ millones de años (Ma) (Ramos y Kay, 1991). Esto es, Triásico Medio Temprano a Tardío, de acuerdo a la Carta Estratigráfica Internacional (International Commission on Stratigraphy, 2008). Más recientemente, Spalletti et al. (2008) acotan la edad absoluta de la Formación Potrerillos, en el cerro Bayo, a 239.2 $\pm 4.5 \mathrm{Ma}, 239.7 \pm$ 2.2 Ma y $230.3 \pm 2.3$ Ma (Mesotriásico Tardío). 
Por otra parte, se debe tomar el cuenta los "niveles evolutivos" y las filiaciones temporales de los taxones registrados, que se encuentran sintetizados en el cuadro X. 6 . La Formación Cortaderita contiene mayormente linajes primitivos.

\begin{tabular}{lll}
\hline Taxones & Filiación temporal & "Nivel evolutivo" \\
\hline Phyllotheca australis & pérmica & \\
Dictyophyllum tenuifolium & & primitivo \\
Dicroidium dubium & & primitivo \\
Zuberia barrealensis & primitivo \\
Johnstonia stelzneriana & & primitivo \\
Rhexoxylon cortaderitaense & & primitivo \\
Scytophyllum bonettiae & & primitivo \\
Lepidopteris stormbergensis & & derivado \\
L. africana & & derivado \\
Delnortea abbottiae & pérmica & \\
Pagiophyllum sp. & jurásica & \\
\hline
\end{tabular}

Cuadro XII.3. Filiación temporal y nivel evolutivo de los taxones con importancia biostratigráfica citados para la Formación Cortaderita (Zamuner et al., 2001).

\section{XII.6. Conclusiones bioestratigráficas}

El análisis bioestratigráfico pudo establecer que:

1. La Sección Inferior gris y la Sección Superior rosada de la Formación Cortaderita no muestras diferencias significativas en cuanto a sus asociaciones paleoflorísticas. Ambas muestran continuidad en la flora, no evidenciando un hiatus temporal, por lo que ambas podrían ser asignadas a la biozona MBC.

2. La Formación Cortaderita es correlacionable con la Formación Potrerillos, por lo que la primera tendría una edad mesotriásica.

3. Tomando en cuenta que también muestra muchas similitudes con unidades más antiguas que Potrerillos, y la presencia de taxones de "nivel evolutivo" primitivo en toda su secuencia (tanto en la Sección Inferior como en la Superior), podría ubicarse a la Formación Cortaderita en el Mesotriásico Medio.

4. Puesto que la biozona MBC fue definida en esta formación, los presentes aportes en cuanto a su contenido paleoflorístico servirán para incrementar el conocimiento acerca de la edad de la biozona. 


\section{CONCLUSIONES GENERALES}

1. La Formación Cortaderita está conformada por dos secciones: una Inferior grir y otra Superior rosada, con litologías bien distintivas, que ameritan que sean consideradas como Miembro gris y Miembro rosado de la formación, respectivamente.

2. Entre las dos secciones de la formación, el contacto es discordante, pero no se resgistra una discordancia estratigráfica regional ni un hiatus temporal significativo, como fuera mencionado en trabajo anteriores ( $c f$. Spalletti et al., 1999, Spalletti, 2001a). Esta interpretación encuentra sustento en la permanencia temporal de los mismos taxones a lo largo de la columna estratigráfica de Cortaderita (e.g. Rhexoxylon cortaderitaense, elemento dominante en los bosques de toda la unidad formacional).

3. La Sección Inferior gris está dominada por facies Fr y Fm (limolitas y areniscas limosas grises bentoníticas), y es inferida como dos ciclos de sistemas fluviales meandrosos, con un importante desarrollo de paleosuelos de tipo vertisoles y eventos episódicos de lluvias de cenizas.

4. La Sección Superior rosada está caracterizada por la predominancia de facies Sm y Sh (areniscas finas a gruesas y sabulíticas rosadas y rojizas), e interpretada como dos ciclos de sistemas fluviales entrelazadas, con desarrollo de paleosuelos de tipo aridisoles y abundante actividad hidrotermal.

5. En comparación con trabajos previos, se redefinió el esquema estratigráfico de los estratos plantíferos. Los dos niveles fosilíferos de Bonetti (1963) y los dos estratos definidos por Artabe et al. (1995a), se han reajustado en 8 estratos fosilíferos (EF): cuatro la Sección Inferior, y cuatro en la Sección Superior.

6. Todos los ejemplares de troncos permineralizados encontrados hasta ahora pertenecen a la especie Rhexoxylon cortaderitaense, la cual persiste a lo largo de toda la columna estratigráfica de la formación.

7. Es la primera vez que se cita para la formación las divisiones Marchantiophyta y Bryophyta y las familias Asterothecaceae y Podocarpaceae, los géneros Thallites, Muscites, Rienitsia, Lepidopteris, Delnortea, Ginkgoites, Ginkgodium, Baiera, Rissikia; y las especies Rienitsia arrondiana, Dicroidium dubium, Pachydermophyllum papillosum, Lepidopteris stormbergensis, L.africana, Delnortea abbottiae, Ginkgoites walckedensis, Sphenobaiera schenckii, S.sectina, Baiera cuyana, Ginkgoidium nathorsti, Elatocladus plana, Rissikia media y Pseudoctenis longipinnata para la unidad. 
8. Las Peltaspermales, y las Ginkgoales, con siete especies cada orden, mostraron una mayor diversidad específica que la previamente conocida para dicha unidad.

9. El estrato arbóreo de los bosques de la Formación Cortaderita está dominado por corystospermas, con otros elementos que aparecen de manera subordinados u ocasional (ginkgoales y coníferas).

10. La primera aproximación de las relaciones filogenéticas de las corystospermas, realizada en el presente trabajo, ha demostrado que los tallos son una fuente valiosa de caracteres para los estudios sistemáticos-filogenéticos.

11. La Biología Evolutiva-del Desarrollo ha incrementado su aplicabilidad y relevancia a través de los años, y desde esta perspectiva se prosiguió elaborar modelos evolutivos-del desarrollo que explicar el origen y diversificación de la anatomía caulinar de las corystospermas.

12. Las cuatro desviaciones de la actividad cambial típica que presentan las corystospermas (diferencial, remanente, inversa y supernumerarira), guardan una relación íntima con eventos evo-devo.

13. En las tafofloras contenidas en la Formación Cortaderita, se identificaron 11 estilos preservacionales, a partir de las que se definieron 8 tafofacies. Es de destacar que la definición de tafofacies para ambientes continentales se ha aplicado escasamente en la literatura, por lo que esta contribución aporta datos novedosos sobre la dinámica de estos paleoambientes.

14. De acuerdo a las tafofacies presentes, de la Sección Inferior gris a la Sección Superior Rosada el clima sufrió una desecación, pasando de subtropical subhúmedosemiárido a subtropical semiárido.

15. Cuatro tipos diferentes de paleocomunidades son inferidas para la Formación Cortaderita: vegetación herbáceo-arbustiva constituida por corystospermas, peltaspermas y cycadales, bosque subtropical siempreverde estacional, con un estrato arbóreo integrado mayormente por corystospermas y un sotobosque de alta diversidad taxonómica y bosque subtropical esclerófilo ribereño, dominado exclusivamente por corystospermas.

16. Considerando los rasgos cuantitativos, los bosques pueden ser comparados con bosques subtropicales estacionales secos o monzónicos secos. Hay una variación de los bosques a lo largo de la columna de Cortaderita, en la Sección Superior las 
paleocomunidades se hacen monotípicas y de menor densidad y biomasa que en la Sección Inferior.

17. El análisis bioestratigráfico pudo establecer que la Formación Cortaderita es correlacionable con la Formación Potrerillos, por lo que la primera tendría una edad mesotriásica. El hallazgo reciente de taxones de estirpe pérmica, bajarían la edad de la formación a mesotriásica media.

18. La información obtenida de los análisis sedimentológicos, taxonómicos, evolutivos, tafonómicos y paleoecológicos, permiten elaborar un modelo de evolución de los ecosistemas de la formación. La Sección Inferior, caracterizada por sistemas fluviales meandrosos, condiciones climáticas estacionales subhúmedas a semiáridas, con desarrollo de paleosuelos de tipo vertisoles, albergaba comunidades herbáceoarbustivas y arbóreas, donde el elemento dominante correspondía a las corystospermas. Las sucesiones ecológicas eran interrumpidas por frecuentes disrupciones físicas (erupciones volcánicas) que cubrían los bosques y conducían a una nueva sucesión. En este marco ambiental, las corystospermas -con características anatómicas xeromórficasparecían haber estado bien adaptadas. Las densidades altas de los bosques pueden estar correlacionadas con estrategias reproductivas colonizadoras, con frecuente reproducción vegetativa, lo que podría haberles facilitado la supervivencia en estos ambientes desfavorables. Esta situación se hace extrema en el bosque de la Sección Superior, las paleocomunidades arbóreas se hacen monotípicas, menos densas y los troncos presentan diámetros y alturas menores. El cambio que se habría producido es un aumento de la energía del sistema fluvial que pasa a ser entrelazado, las condiciones climáticas muestran una estación seca más pronunciada, y la influencia volcánica más importante es la actividad hidrotermal, evidenciada por los niveles de silcrete.

En particular, las características xilológicas de las corystospermas habrían sido claves para la colonización de estos ambientes estresantes. Los estímulos físicos inducen a la diferenciación del cámbium, y la formación del leño está positivamente correlacionada con el estrés físico. Las características anatómicas caulinares únicas de las corystospermas parecen tener relación con su dominancia en los ambientes triásicos, también únicos en la historia geológica. La especialización extrema que presentan estas plantas al clima monzónico, no habría permitido la supervivencia del grupo cuando el clima se hizo más húmedo y menos estacional hacia finales del Triásico y principios del Jurásico. 


\section{BIBLIOGRAFÍA}

Abu Hamad, A., Kerp, H., Vörding, B. y Bandel, K. 2008. A Late Permian flora with Dicroidium from the Dead Sea region, Jordan. Review of Palaeobotany and Palynology 149: 85-130.

Ade-Ademilua, O.E. 2006. Plastochron index- an indicator of plant strucure and function: a case study using Pisum sativum $L$. Tesis Doctoral, Faculty of Science, Rhodes University, 183 pp. Inédito.

Agardh, C.A. 1825. Equisetopsida. En: Aphorismi Botanici. Literis Berlingianis, Lund, p. 7.

Alberch, P. 1980. Ontogenesis and morphological diversification. American Zoologist 20: 653-667.

Alberch, P., Gould, S.J., Oster, G.F. y Wake, D.B. 1979. Size and shape in ontogeny and phylogeny. Paleobiology 5: 296-317.

Aloni, R. 1987. Differentiation of vascular tissues. Annual Review of Plant Physiology 38: 179-204.

Allona, I., Quinn, M., Shoop, E., Swope, K., St Cyr, S.S., Carlis, J., Riedl, J., Retzel, E., Campbell, M.M. y Sederoff, R. 1998. Analysis of xylem formation in pine by cDNA sequencing. Proceedings of the National Academy of the United States of America 95: 9693-9698.

Anderberg, A.A. 1992. The circumscription of the Ericales, and their cladistic relationships to other families of "higher" dicotyledons. Systematic Botany 17: 660-675.

Anderson, H.M. y Anderson, J.M. 1970. A preliminary review of the biostratigraphy of the upper most Permian, Triassic and lowermost Jurassic of Gondwanaland. Palaeontologia Africana 13: 1-22.

Anderson, J.M. y Anderson, H.M. 1983. Palaeoflora of Southern Africa Molteno Formation (Triassic). Vol. 1, Part 1-2. Introduction: Dicroidium. A.A. Balkema, Rotterdam, 227pp.

Anderson, J.M. y Anderson H.M. 1985. Palaeoflora of Southern Africa: Prodromus of South African Megafloras Devonian to Lower Cretaceous. A.A. Balkema, Rotterdam, 423 pp.

Anderson, J.M. y Anderson H.M. 1989. Palaeoflora of Southern Africa Molteno Formation (Triassic). Vol. 2: Gymnosperms (excluding Dicroidium). A. A. Balkema, Rotterdam, 567 pp.

Anderson, J.M. y Anderson, H.M. 1993a. Terrestrial flora and fauna of the Gondwana Triassic: Part 1. Occurrences. En: Lucas, S.G. y Morales, M. (eds), The Nonmarine Triassic, Bulletin, New Mexico Museum of Natural History and Sciences 3: 3-12.

Anderson, J.M. y Anderson, H.M. 1993b Terrestrial flora and fauna of the Gondwana Triassic: Part. 2. Coevolution. En: Lucas, S.G. y Morales, M. (eds), The Nonmarine Triassic, Bulletin, New Mexico Museum of Natural History and Sciences 3: 13-25.

Anderson, J.M. y Anderson, H.M. 2003. Heyday of gymnosperms: systematics and biodiversity of the Late Triassic Molteno fructifications. Strelitzia 15, 398 pp.

Anderson, J.M., Anderson, H.M. y Cruickshank, A.R.I. 1999. Late Triassic ecosystems of the Molteno/Lower Elliot Biome of Southern Africa. Palaeontology 41: 387-421.

Andreis, R. 1981. Identificación e importancia geológica de los Paleosuelos. Universidade Federal do Rio Grande do Sul, Porto Alegre PT., Livro-Texto 2, 67 pp.

Antevs, E. 1913. Die Gattungen Thinnfeldia Ett. und Dicroidium Goth. Kungliga Svenska Vetenskapsakademiens Handlingar 51: 1-71.

Arce, F.E. y Lutz, A.I. 2010. Fructificaciones de la Formación Los Rastros, Triásico Superior, provincia de San Juan, Argentina. Revista Mexicana de Ciencias Geológicas 27: 32-42. 
Arber, E.A.N. 1913. A preliminary note on the fossil plants of the Mount Potts beds, New Zealand, collected by Mr. D.G. Lillie, biologist to Captain Scott's Antarctic Expedition in the "Terra Nova". Proceedings of the Royal Society of London 86: 344-347.

Arber, E.A.N. 1917. Earlier Mesozoic flora of New Zealand. New Zealand Geological Survey, Paleontological Bulletin 6: 1-80.

Archangelsky, S. 1958. Estudio geológico y paleontológico del Bajo de la Leona (Santa Cruz). Acta Geológica Lilloana 2: 5-133.

Archangelsky, S. 1962. Conceptos y métodos en Paleobotánica. Facultad de Ciencias Naturales y Museo, Universidad Nacional de la Plata. Serie técnica y Didáctica 9, 34 pp.

Archangelsky, S. 1965. Tafofloras paleozoicas y eomesozoicas de Argentina. Boletín Sociedad Argentina de Botánica 10: 247-291.

Archangelsky, S. 1968. Studies on Triassic fossil plants from Argentina. IV. The leaf genus Dicroidium and its possible relation to Rhexoxylon stems. Palaeontology 11: 500-512.

Archangelsky, S. 1970. Fundamentos de Paleobotánica. Facultad de Ciencias Naturales y Museo, Universidad Nacional de la Plata, Serie técnica y Didáctica 10, 347 pp.

Archangelsky, S. 1990. Plant distribution in Gondwana during the late Paleozoic. En: Taylor, T.N y Taylor, E.L. (eds), Antarctic Paleobiology, Springer Verlag, Berlín, pp. 102-117.

Archangelsky, S. 1996. Aspects of Gondwana paleobotany: gymnosperms of the Paleozoic - Mesozoic transition. Review of Palaeobotany and Palynology 90: 287-302.

Archangelsky, S. y Arrondo, O.G. 1971. Palaeophytología Kurtziana III. 2. Estudio sobre el género Botrychiopsis Kurtz (= Gondwanidium Gothan) del Carbónico y Pérmico Gondwánico. Ameghiniana 8: 189-227

Archangelsky, S. y Brett, D.W.1961. Studies on Triassic fossil plants from Argentina. 1. Rhexoxylon from the Ischigualasto Formation. Philosophical Transactions of the Royal Society London B 706: 1-19.

Archangelsky, S. y Brett, D.W. 1963. Studies on Triassic plants from Argentina. II. Michelilloa waltonii nov. gen. et sp. from the Ischigualasto Formation. Annals of Botany 27: 146-154.

Arnold, C.A. 1947 . An Introduction to Paleobotany, 1st ed. McGraw-Hill Book Co., Inc., New York, $433 \mathrm{pp}$.

Arrondo, O.G. y Petriella, B. 1982. Revisión del género Goeppertella Oishi y Yamasita emend. (Goeppertelloideae-Dipteridaceae). Ameghiniana 19: 67-78.

Artabe, A.E. 1984. Estudio de la flora triásica de Los Menucos (provincia de Río Negro) y sus vinculaciones con otras floras fósiles coetáneas. Tesis Doctoral 426, Facultad de Ciencias Naturales y Museo, Universidad Nacional de La Plata, 144 pp. (Inédito).

Artabe, A.E. 1985. Estudio sistemático de la Tafoflora Triásica de Los Menucos, provincia de Río Negro, Argentina. Parte I. Sphenophyta, Filicophyta, Pteridospermophyta. Ameghiniana 22: 3-22.

Artabe, A.E. 1986. Estudio sistemático de la tafoflora triásica de Los Menucos, provincia de Río Negro, Argentina. Parte II. Cyacdophyta, Ginkgophyta y Coniferophyta. Ameghiniana 22: 159-180.

Artabe, A.E. 1990. Revalidación del género triásico Zuberia Frenguelli 1943, Familia Corystospermaceae. Revista del Museo de La Plata (n.s.) Paleontología 9: 145-157. 
Artabe, A.E. y Brea, M. 2003. A New Approach to Corystospermales based on petrified stems from the Triassic of Argentina. Alcheringa 27: 209-229.

Artabe, A.E. y Brea, M. 2007. Réplica al trabajo de Axsmith et al. Publicado en: Ameghiniana, 44: 223230: "The 'New Approach to Corystospermales' and the Antarctic Fossil Record: A Critique". Ameghiniana 44: 739-746.

Artabe, A.E. y Stevenson, D.W. 1999. Fossil Cycadales of Argentina. The Botanical Review 65: 219-238.

Artabe, A.E. y Zamuner, A.B. 1991. Una nueva Equisetal del Triásico de Cacheuta, Argentina, con estructura interna preservada. Ameghiniana 28: 287-294.

Artabe, A.E. y Zamuner, A.B. 2007. Elchaxylon, a new corystosperm based on permineralized stems of the Late Triassic of Argentina. Alcheringa 31: 85-96.

Artabe, A.E., Zamuner, A.B. y Archangelsky, S. 1991. Estudios cuticulares en cycadópsidas fósiles. El género Kurtziana Frenguelli. Ameghiniana 28: 365-374

Artabe, A.E., Morel, E. y Zamuner, A.B. 1994a. Estudio paleobotánico y tafonómico de la Formación Paso Flores (Triásico Superior), en el Cañadón de Pancho, provincia del Neuquén, Argentina. Ameghiniana 31: 153-160.

Artabe, A.E., Zamuner, A.B. y Archangelsky, S. 1994b. Estructura y ultraestructura de las cutículas de Zuberia papillata (Townrow) Artabe 1990, de la Hoyada de Ischigualasto (Neotriásico), Provincia de San Juan, Argentina. VI Congreso de Paleontología y Bioestratigrafia (Trelew), Resúmenes: 1.

Artabe, A.E., Zamuner, A.B., Ganuza, D.G. y Spalletti, L.A. 1995a. Novedades en la tafoflora triásica de la quebrada de la Cortaderita, Barreal, Provincia de San Juan, Argentina. II Reunión del triásico del Cono Sur (Bahía Blanca), Actas I: 7.

Artabe, A E., Brea, M., Zamuner, A.B., Ganuza, D.G. y Spalletti, L.A. 1995b. Paleoecología de la vegetación triásica asociada a un lago de la Formación Cortaderita, provincia de San Juan, Argentina. II Reunión del Triásico del Cono Sur (Bahía Blanca), Actas I: 4.

Artabe, A.E., Morel, E.M., Spalletti, L.A. y Brea, M. 1999a. Paleoambientes sedimentarios y paleoflora asociada en el Triásico Tardío de Malargüe (Mendoza). Revista de la Asociación Geológica Argentina 53: 526-548.

Artabe, A.E., Brea, M. y Zamuner, A.B. 1999b. Rhexoxylon brunoi n. sp., a new Triassic Corystosperm from the Paramillo Uspallata, Mendoza, Argentina. Review of Paleobotany and Palynology 105: $63-74$.

Artabe, A.E., Morel, E.M. y Spalletti, L.A. 2001a. Paleoecología de las floras triásicas argentinas. En: Artabe, A.E., Morel, E.M. y Zamuner, A.B. (eds). El Sistema Triásico de Argentina. Fundación Museo de La Plata “Francisco Pascasio Moreno”, La Plata, pp. 199-225.

Artabe A.E., Morel E.M. y Zamuner A.B. 2001b. El Sistema Triásico en la Argentina. Fundación Museo de La Plata "Francisco P. Moreno", La Plata, 358 pp.

Artabe, A.E., Morel, E.M. y Spalletti, L.A. 2003. Caracterización de las provincias fitogeográficas triásicas del Gondwana Extratropical. Ameghiniana 40: 387-405.

Artabe, A.E., Zamuner, A.B. y Stevenson, D.W. 2005. A new genus of Late Cretaceous cycad stem from Argentina, with reappraisal of known forms. Alcheringa 29: 87-100. 
Artabe, A.E., Morel, E.M. y Ganuza, D.G. 2007a. Las floras triásicas de la Argentina. Asociación Paleontológica Argentina. Publicación Especial 11, Ameghiniana 50ªniversario: 75-86.

Artabe, A.E., Spalletti, L.A., Brea, M., Iglesias, A., Morel, E.M. y Ganuza, D.G. 2007b. Structure of a corystosperm fossil forest from the Late Triassic of Argentina. Palaeogeography, Palaeoclimatology, Palaeoecology 243: 451-470.

Artabe, A.E., Morel, E.M., Ganuza, D.G., Spalletti, L.A. y Zavattieri, A.M. 2007c. La paleoflora triásica de Potrerillos, provincia de Mendoza, Argentina. Ameghiniana 44: 279-301.

Artabe, A.E., Spalletti, L.A., Bodnar, J. y Morel, E.M. 2009. Estudio paleoxilológico y sedimentológico de la Formación Montaña (Triásico), provincia de Mendoza, Argentina. Ameghiniana 46: 141152.

Avé Lallemant, G. 1890. El Paramillo de Uspallata. Memorias de la Sociedad Cientifica Argentina, Buenos Aires, pp. 3-136.

Axsmith, B.J., Taylor, E.L., Taylor, T.N. y Cúneo, N.R. 2000. New perspectives on the Mesozoic seed fern Order Corystospermales based on attached organs from the Triassic of Antarctica. American Journal of Botany 87: 757-768.

Baas, P. y Zweypfenning, R.C.V.J. 1978. Wood anatomy of the Lythraceae. Acta Botanica Neerlandica 28: $117-155$.

Baas, P., Esser, P.M., van der Westen, M.E.T. y Zandee, M. 1988. Wood anatomy of the Oleaceae. IAWA Bulletin n. s. 9: 103-182.

Baima, S., Nobili, F., Sessa, G., Lucchetti, S., Ruberti, I. y Morelli, G. 1995. The expression of the Athb8 homeobox gene is restricted to provascular cells in Arabidopsis thaliana. Development 12: 4171-4182.

Baima, S., Tomassi, M., Matteucci, A., Altamura, M.M., Ruberti, I. y Morelli, G. 2000. Role of the ATHB-8 gene in xylem formation. En: Savidge, R., Barnett, J. y Napier, R. (eds), Cambium: The Biology of Wood Formation, BIOS Scientific Publishers LTD, Oxford, pp. 445-455.

Baima, S., Possenti, M., Matteucci, A., Wisman, E., Altamura, M.M., Ruberti, I. y Morelli, G. 2001. The Arabidopsis ATHB-8 HD-ZIP protein acts as a differentiation-promoting transcription factor of the vascular meristems. Plant Physiology 126: 643-655.

Baldoni, A.M. 1972. El género Lepidopteris (Pteridosperma) en el Triásico de Argentina. Ameghiniana 9: 1-16.

Baldoni, A.M. 1980a. Revisión de las especies del género Xylopteris (Corystospermaceae) en el Triásico de Argentina, Australia y Sudáfrica. Ameghiniana 17: 135-155.

Baldoni, A.M. 1980b. Baiera africana, una nueva especie de Ginkgoal del Triásico de Sudáfrica. Ameghiniana 17: 156-162.

Balme, B.E. y Helby, R.J. 1973. Floral modifications at the Permian-Triassic boundary in Australia. En: Logan, A. y Hills, L.V. (eds), The Permian and Triassic Systems and their Mutual Boundary. Canadian Society of Petroleum Geologists, Memoir 2: 433-444.

Bancroft, N. 1913. Rhexoxylon africanum, a new Medullosean stem. Transactions of the Linnean Society of London, Series 2 (Botany) 8: 87-103. 
Baraldo, J.A. y Guerstein, P.G. 1984. Nuevo ordenamiento estratigráfico para el Triásico de Hilario (Calingasta, San Juan). IX Congreso Geológico Argentino (San Carlos de Bariloche), Actas 1: 79-94.

Barredo, S.P. y Ramos, V.A. 1997. Los depósitos de Rincón Blanco (Precordillera de San Juan): un rift triásico. II Jornadas sobre Geología de Precordillera (San Juan), Actas 1: 130-135.

Bateman, R.M. 1994. Evolutionary-developmental change in the growth architecture of fossil rhizomorphic lycopsids: scenarios constructed on cladistic foundations. Biological Reviews 69: $527-597$.

Bateman, R.M. y DiMichele, W.A. 1994. Saltational evolution of form in vascular plants: a neoGoldschmidtian synthesis. En: Ingram, D.S. y Hudson, A. (eds), Shape and form in plants and fungi, The Linnean Society of London Academic Press, Londres, pp. 63-100.

Bateman, R.M. y DiMichele, W.A. 2002. Generating and filtering major phenotypic novelties: neoGoldschmidtian saltation revisited. En: Cronk, Q.C.B., Bateman, R.M. y Hawkins, J.A. (eds), Developmental genetics and plant evolution, Taylor \& Francis, Londres, pp. 109-159.

Bateman, R.M., DiMichele, W.A. y Willard, D.A. 1992. Experimental cladistic analysis of anatomicallypreserved arborescent lycopsids from the Carboniferous of Euramerica: an essay on paleobotanical phylogenetics. Annals of the Missouri Botanical Garden 79: 500-559.

Bateman, R.M., Crane, P.R., DiMichele, W.A., Kenrick, P., Rowe, N.P. y Speck, T. 1998. Early evolution of land plants: phylogeny, physiology, and ecology of the primary terrestrial radiation. Annual Review of Ecology and Systematics 29: 263-292.

Bateson, W. 1894. Materials for the study of variation: treated with especial regard to discontinuity in the origin of species. Macmillan, Londres, $598 \mathrm{pp}$.

Baum, D.A. y Donoghue, M.J. 2002 Transference of function, heterotopy an the evolution of plant development. En: Cronk, Q.C.B., Bateman, R.M. y Hawkins, J.A. (eds) Developmental genetics and plant evolution, Taylor \& Francis, Londres, pp. 52-69.

Becker, A., Winter, K-U., Meyer, B., Saedler, H. y Theißen, G. 2000. MADS-Box Gene Diversity in Seed Plants 300 Million Years Ago. Molecular Biology and Evolution 17:1425-1434.

Bennett, M.J., Marchant, A., Green, H.G., May, S.T., Ward, S.P., Millner, P.A., Walker, A.R., Schulz, B. y Feldmann, K.A. 1996. Arabidopsis AUX1 gene: a permease-like regulator of root gravitropism. Science 273: 948-950.

Birkeland, P.W. 1984. Soils and Geomorphology. Oxford University Press, Oxford, 372 pp.

Bodenbender, G. 1902. Contribuciones al conocimiento de la Precordillera de San Juan, de Mendoza y de las Sierras Centrales de la República Argentina. Boletín de la Academia Nacional de Ciencias 17: 203-261.

Bodnar, J. 2006. Nueva interpretación del material tipo de Protocircoporoxylon cortaderitaense (Menéndez) Vogellehner, leño fósil del Triásico Superior de Barreal, San Juan, Argentina. $9^{\circ}$ Congreso Argentino de Paleontología y Bioestratigrafía (Córdoba), Resúmenes: 123.

Bodnar, J. 2007. Patrones evo-devo en tallos de Corystospermaceae (Corystospermales, Gymnospermopsida). Reunión Anual de Comunicaciones de la Asociación Paleontológica Argentina (Corrientes), Resúmenes: 22. 
Bodnar, J. 2008. Rhexoxylon cortaderitaense (Menéndez) comb. nov., a species of permineralized stems newly assigned to the Corystospermaceae, from the Triassic of Argentina. Alcheringa 32: 171190

Bodnar, J. 2009. Application of evolutionary developmental studies in Triassic seed fern stems from Gondwana. XIV Simposio Argentino de Paleobotánica y Palinología (Mar del Plata), Resúmenes: 25.

Bodnar, J. y Artabe, A.E. 2005. Análisis paleodendrológicos en una Cupressaceae de la Formación Ischigualasto (Triásico), provincia de San Juan, Argentina. Reunión Anual de Comunicaciones de la Asociación Paleontológica Argentina (Puerto Madryn), Resúmenes: 34.

Bodnar, J. y Artabe, A.E. 2007. Estudio sistemático y paleodendrológico del leño de una Cupressaceae triásica de la Formación Ischigualasto, provincia de San Juan, Argentina. Ameghiniana 44: 303319.

Bodnar, J. y Coturel, E.P. en preparación. Patrones de regulación del cambium en el registro fósil: un ejemplo del Triásico Tardío de Argentina.

Bonaparte, J.F. 1973. Edades/Reptil para el Triásico de Argentina y Brasil. V Congreso Geológico Argentino (Villa Carlos Paz), Actas III: 93-129.

Bonaparte, J.F. 1978. El Mesozoico de América del Sur y sus tetrápodos. Opera Lilloana 26: 1-596.

Bonaparte, J.F. 1997. El Triásico de San Juan - La Rioja, Argentina y sus dinosaurios. Museo Argentino de Ciencias Naturales "Bernardino Rivadavia”, Buenos Aires, 190 pp.

Bonetti, M.I.R. 1963. Contribución al conocimiento de la flora fósil de Barreal, departamento de Calingasta (provincia de San Juan). Tesis Doctoral, Facultad de Ciencias Exactas y Naturales, Universidad de Buenos Aires, 260 pp. Inédito.

Bonetti, M.I.R. 1966a. Consideraciones sobre algunos representantes de la Familia Corystospermaceae. Ameghiniana 4: 389-395.

Bonetti, M.I.R. 1966b. Protojuniperoxylon ischigualastensis sp. nov. del Triásico de Ischigualasto (San Juan). Ameghiniana 4: 211-218.

Bonetti, M.I.R. 1968. Las especies del género Pseudoctenis en la flora triásica de Barreal (San Juan). Ameghiniana 5: 433-446.

Bonetti, M.I.R. 1972. Las "Benettitales" de la flora Triásica de Barreal (San Juan). Revista del Museo Argentino de Ciencias Naturales Bernardino Rivadavia 1: 307- 322.

Bonetti, M.I.R. y Herbst, R. 1964. Dos especies de Dictyophyllum del Triásico de Paso Flores. Provincia del Neuquén, Argentina. Ameghiniana 3: 273-279.

Bonke, M., Thitamadee, S., Mähönen, A.P., Hauser, M.-T., Helariutta, Y. 2003. APL regulates vascular tissue identity in Arabidopsis. Nature 426: 181-186.

Bonner, J.T. (ed.) 1982. Evolution and Development. Springer-Verlag, Berlín, 356 pp.

Bornemann, J. 1856. Uber organische Reste aus der Lettenkohlengruppe Thüringens, Ein Beitrag zur Fauna und Flora dieser Formation besonders über fossile Cycadeen, nebst vergleichenden Untersuchungen über die Blattstruktur der jetztweltlichen Cycadeengattungen, Leipzig, 85 pp.

Boureau, E. 1956. Anatomie Végétale. Tome 2. Presses Universitaires de France, París, pp. 333-503. 
Boureau, E. 1964. Traité de Paléobotanique 3, Sphenophyta, Noeggerathiophyta. Masson et Cie, París, pp. 1-544.

Boureau, E. y Doubinger, J. 1975. Traité de Paléobotanique 4, Pteridophylla. Masson et Cie, París, pp. 1768

Bowe, L.M., Coat, G. y de Pamphilis, C.W. 2000. Phylogeny of seed plants based on all three genomic compartments: Extant gymnosperms are monophyletic and Gnetales' closest relatives are conifers. Proceedings of the National Academy of the United States of America 97: 4092-4097.

Boyce, K.C. y Knoll, A.H. 2002. Evolution of developmental potential and the multiple independent origins of leaves in Paleozoic vascular plants. Paleobiology 28: 70-100.

Brandeis, T.J. y Suárez Rozo, M.R. 2005. Effects of model choice and forest structure on inventorybased estimations of Puerto Rican Forest biomass. Caribbean Journal of Science 41: 250-268.

Brandeis, T.J., Delaney, M., Parresol, B.R. y Royer, L. 2006. Development of equations for predicting Puerto Rican subtropical dry forest biomass and volume. Forest Ecology and Management 233: $133-142$

Braun, C.F.W. 1843. En: Münster, G (ed.) Beiträge der Petrefaktenkunde, part 6, Leipzig, pp. 1-100.

Brea, M. 1995. Estudio de la paleoflora de la secuencia triásica de Agua de la Zorra, provincia de Mendoza. Tesis Doctoral No 642, Facultad de Ciencias Naturales y Museo, Universidad Nacional de La Plata, 202 pp. Inédito.

Brea, M. 1997. Una nueva especie fósil del género Araucarioxylon Kraus 1870, emend. Maheshwari 1972 del Triásico de Agua de la Zorra, Uspalllata, Mendoza, Argentina. Ameghiniana 34: 485-496.

Brea, M. 2000. Paleoflora triásica de Agua de la Zorra, Uspallata, provincia de Mendoza, Argentina: Lycophyta y Filicophyta. Ameghiniana 37: 199-204.

Brea, M. y Artabe, A.E. 1999. Apocalamitaceae (Sphenophyta) triásicas de la Formación Paramillo, Agua de la Zorra, provincia de Mendoza, Argentina. Ameghiniana 36: 389-400.

Brea, M., Artabe, A.E. y Spalletti, L.A. 2006. Estructura de un bosque mixto del Triásico Medio de Mendoza Argentina. $9^{\circ}$ Congreso Argentino de Paleontología y Bioestratigrafía (Córdoba), Resúmenes: 241.

Brea, M., Artabe, A.E. y Spalletti, L.A. 2008. Ecological reconstruction of a mixed Middle Triassic forest from Argentina. Alcheringa 32: 365-393.

Brea, M., Artabe, A.E. y Spalletti, L.A. 2009. Darwin forest at Agua de la Zorra: the first in situ forest discovered in South America by Darwin in 1835. Revista de la Asociación Geológica Argentina 64: $21-31$.

Brett, D.W. 1968. Studies on Triassic fossil plants from Argentina. III. The trunk of Rhexoxylon. Palaeontology 11: 236-245.

Brett, C.E. y Speyer, S.E. 1990.Taphofacies. En: Briggs, D.E.G. y Crowther, P.R. (eds), Paleobiology: A Synthesis, Blackwell Science, Oxford, pp. 258-263.

Briggs, D.E.G. y Crowther, P.R. (eds) 2001. Paleobiology II: A Synthesis, Blackwell Science, Oxford, 583 pp. 
Brongniart, A. 1828a-1832. Histoire des végétaux fossiles ou recherches botaniques et géologiques sur les végétaux renfermés dans les diverses couches du globe. Tome Premiere. G. Dufour et E. d'Ocagne, Paris, 488 pp.

Brongniart, A. 1828b. Prodome d'une Historie des Végétaux Fossiles. Dictionnaire Science Naturale 57: 16- 212.

Brongniart, A. 1849. Tableau des genres de végétaux fossiles considerés sous le point de vue de leur classification botanique et de leur distribution géologique. Dictionnaire Universel de Histoire Naturelle 13, París: 1-127.

Brown, S. 1997. Estimating biomass and biomass change in tropical forests. FAO Forestry Paper 134, Food and Agriculture Organization of the United Nations, Rome, 49 pp.

Buol, S.W. (ed.) 1973. Soil genesis and classification. Iowa State University Press, Ames, 360 pp.

Buol, S.W. (ed.) 1989. Soil genesis and classification, 3rd ed. Iowa State University Press, Ames, 446 pp.

Campbell, I.D. 1999. Quaternary pollen taphonomy: Examples of differential redeposition and differential preservation. Palaeogeography, Palaeoclimatology, Palaeoecology 149: 245-256.

Cantino, P.D. y de Queiroz, K. 2006 . International Code of Phylogenetic Nomenclature, Version $3 a$. Part 1: Clade Names. International Society for Phylogenetic Nomenclature, 83 pp. http://www.ohiou.edu/phylocode/PhyloCode3a.pdf.

Cantino, P.D., Doyle, J.A., Graham, S.W., Judd, W.S., Olmstead, R.G., Soltis, D.E., Soltis, P.S. y Donoghue, M.J. 2007. Towards a phylogenetic nomenclature of Tracheophyta. Taxon 56: 822846.

Cantrill, D.J. 1995. The occurrence of the fern Hausmannia Dunker (Dipteridaceae) in the Cretaceous of Alexander Island, Antarctica. Alcheringa 19: 243-254.

Carland, F.M., Fujioka, S., Takatsuto, S., Yoshida, S. y Nelson, T. 2002. The identification of CVP1 reveals a role for sterols in vascular patterning. Plant Cell 14: 2045-2058

Carlquist, S. 1962. A theory of paedomorphosis in dicotyledonous woods. Phytomorphology 12: 30-45.

Carlquist, S. 1975. Ecological strategies of xylem evolution. University of California Press, Berkeley, 259 pp.

Carlquist, S. 1985. Wood and stem anatomy of Misodendraceae: systematic and ecological conclusions. Brittonia 37: 58-75.

Carlquist, S. 1988. Comparative Wood Anatomy. Systematic, Ecological, and Evolutionary Aspects of Dicotyledon Wood. Springer-Verlag, Berlin, 460 pp.

Carlquist, S. 2007. Successive cambia revisited: ontogeny, histology, diversity, and functional significance. Journal of the Torrey Botanical Society 134: 301-332.

Carlquist, S. 2009. Xylem heterochrony: an unappreciated key to angiosperm origin and diversifications. Botanical Journal of the Linnean Society 161: 26-65.

Cavallier-Smith, T. 1998. A revised six kingdom system of life. Biological Reviews 73: 203-266.

Césari, S.N., Archangelsky, S. y Vega, J.C. 2005. Anatomy of a new probable pteridosperm stem from the Late Carboniferous of Argentina. Revista del Museo Argentino de Ciencias Naturales, n.s. 7: $7-15$. 
Chandler, M.A., Rind, D. y Ruedy, R. 1992. Pangaean climate during the Early Jurassic: GCM simulations and the sedimentary record of paleoclimate. Geological Society of America Bulletin 104: 543-559.

Chaffey, N. 1999. Cambium : old challenges-new opportunities. Trees (Berl) 13: 138-151.

Chave, J., Andalo, C., Brown, S.L., Cairns, M.A., Chambers, J.Q., Eamus, D., Fölster, H., Fromard, F., Higuchi, N., Kira, T., Lescure, J.P., Nelson, B.W., Ogawa, H., Puig, H., Riéra, B. y Yamakura, T. 2005. Tree allometry and improved estimation of carbon stocks and balance in tropical forests. Oecologia 145: 87-99.

Chaw S.-M., Parkinson, C.L., Cheng, Y., Vincent, T.M. y Palmer, J.D. 2000. Seed plant phylogeny inferred from all three plant genomes: Monophyly of extant gymnosperms and origin of Gnetales from Conifers. Proceedings of the National Academy of the United States of America 97: 40864086.

Chong Díaz, G., Zamuner, A.B. y Lamelli Herrera, C. 1997. Primer hallazgo de flora triásica en Quebrada Guanaqueros, Sierra de Almeida, Alta Cordillera de la Segunda Región de Antofagasta, Chile. $X$ Simposio Argentino de Paleobotánica y Palinología (Mendoza), Resúmenes: 17.

Chrysler, M.A. 1937. Persistent juveniles among the cycads. Botanical Gazette 98: 696-710.

Civeyrel, L. y Rowe, N.P. 2001 Phylogenetic relationships of Secamonoideae based on the plastid gene matK, morphology and biomechanics. Annals of the Missouri Botanical Garden 88: 583-602.

Colombi, C.E. y Parrish, J.T. 2008. Late Triassic environmental evolution in Southwestern Pangea: plant taphonomy of the Ischigualasto Formation. PALAOIS 23: 778-795.

Comité Argentino de Estratigrafía, 1992. Código Argentino de Estratigrafía. Asociación Geológica Argentina, Serie B (Didáctica y Complementaria) 20: 1-64.

Cope, E.D. 1887. The Origin of the Fittest. Macmillan, New York, 467 pp.

Coturel, E.P.y Bodnar, J. 2009. Procesos evo-devo en la evolución del crecimiento secundario atípico en plantas fósiles. Reunión Anual de Comunicaciones de la Asociación Paleontológica Argentina (Buenos Aires), Resúmenes: 31-32

Crane, P.R. 1985. Phylogenetic analysis of seed plants and the origin of angiosperms. Annals of Missouri Botanical Garden 72: 716-793.

Crane, P.R. 1996. The fossil history of the Gnetales. International Journal of Plant Sciences 157(Supplement): S50-S57.

Crane, P.R., Herendeen, P. y Friis, E.M. 2004. Fossils and plant phylogeny. American Journal of Botany 91: 1683-1699.

Criado Roqué, P. 1979. Subcuenca de Alvear (Provincia de Mendoza). En: Turner, J.C.M. (ed.), Segundo Simposio de Geología Regional Argentina. Academia Nacional de Ciencias Córdoba, Actas I: 811-836.

Crisafulli, A. y Lutz, A. 2008.Una Equisetal de la Formación Los Rastros (Triásico Medio-Superior), Provincia de San Juan, Argentina. Revista del Museo Argentino de Ciencias Naturales, n.s.: 7179.

Cronk, Q.C.B. 2001. Plant evolution and development in a post-genomic context. Nature Reviews Genetics 2: 607-619. 
Cronk, Q.C.B. 2002. Perspectives and paradigms in plant evo-devo. En: Cronk, Q.C.B., Bateman, R.M. y Hawkins, J.A. (eds), Developmental genetics and plant evolution, Taylor \& Francis, Londres, pp. $1-14$.

Cronquist, A., Takhtajan, A. y Zimmerman, W. 1966. On the higher taxa of Embryobionta. Taxon 15: 129-134.

Crowley, T.J., Hyde, W.T. y Short, D.A. 1989. Seasonal cycle variations on the supercontinent of Pangaea: Implications for Early Permian vertebrate extinctions. Geology. 17: 457-460.

Cuerda, A. J. 1945. Estratigrafía y tectónica al este de Barreal, provincia de San Juan. Tesis Doctoral N78, Facultad de Ciencias Naturales y Museo, Universidad Nacional de La Plata, 44 pp. Inédito.

Cumbie, B.G. 1963. The vascular cambium and xylem development in Hibiscus lasiocarpus. American Journal of Botany 50: 944-951.

Darwin, C. 1846. Geological observations on South America. Being the third part of the geology of the voyage of the Beagle under the command of Cspt. Fitz Roy, 1832 to 1836. Appleton \& Co., Londres, $648 \mathrm{pp}$.

de Beer, G.R. 1930. Embryology and evolution. Clarendon Press, Oxford, 116 pp.

de Beer, G.R. 1940. Embryos and ancestors. Clarendon Press, Oxford, 128 pp.

de Beer, G.R. 1951. Embryos and ancestors, revised edition. Clarendon Press, Oxford, 157 pp.

de Beer, G.R. 1958. Embryos and ancestors, third edition. Clarendon Press, Oxford, 116 pp.

de Renzi, M. 1995. Plantas: Un caso especial de evolución y morfogénesis. Coloquios de Paleontología, Editorial Complutense, Madrid 47: 201-218.

de Candolle, A.P. 1804. Essai sur les propriétés médicales des plantes, comparées aves leurs formes extérieures et leur classification naturelle. Didot Jeune, París, 424 pp.

del Fueyo, G., Taylor, E., Taylor, T. y Cúneo, N.R. 1995. Triassic wood from the Gordon Valley, Central Transantarctic Mountains, Antarctica. IAWA Journal 16: 111-126.

Delevoryas, T. 1955. The Medullosae-structure and relationships. Palaeontographica B 97: 114-67.

Delevoryas, T. y Morgan, J. 1954. A new pteridosperm from the Upper Pennsylvanian deposits of North America. Palaeontographica B 96:12-23.

Demko, T.M. 1995. Taphonomy of fossil plants in the Upper Triassic Chinle Formation. Tesis Doctoral, University of Arizona, Tucson, $274 \mathrm{pp}$. Inédito.

Demko, T.M., Dubiel, R.F. y Parrish, J.T. 1998. Plant taphonomy in incised valleys: Implications for interpreting paleoclimate from fossil plants. Geology 26: 1119-1122.

Dengler, N. y Kang, J. 2001 Vascular patterning and leaf shape. Current Opinion in Plant Biology 4: 5056.

DiMichele, W.A., Davis, J.I. y Olmstead, R.G. 1989. Origins of heterospory and the seed habit: the role of heterochrony. Taxon 3: 1-11.

DiMichele, W.A., Chaney, D.S., Dixon, W.H., Nelson, W.J. y Hook, R.W. 2000. An Early Permian coastal flora from the central basin platform of Gaines County, West Texas. PALAIOS 15: 524534. 
DiMichele, W.A., Kerp, H., Krings, M. y Chaney, D.S. 2005. The Permian Peltasperm Radiation: evidence from the Southwestern United States. En: Lucas, S.G. y Zeigler, K.E. (eds), The Nonmarine Permian, New Mexico Museum of Natural Histoiy and Science Bulletin No. 30: 6779.

Dodd, J.R. y Stanton, R. 1990. Paleoecology: concepts and applications. Wiley \& Sons, 2nd. Ed., New Jersey, $502 \mathrm{pp}$.

Donoso, C. 1993. Bosques templados de Chile y Argentina. Variación, Estructura y Dinámica. Ecología Forestal. Editorial Universitaria, Santiago de Chile, 484 pp.

Doweld. A.B. 2001. Prosyllabus tracheophytorum, tentamen systematis plantarum vascularium (Tracheophyta). Geos, Moscú, 110 + LXXX pp. (En Inglés, pp. 7-29, En Latín pp. I-LXXX, En Ruso, pp. 33-55 seguido de un índice en Latín)

Doyle, J.A. 1996. Seed plant phylogeny and the relationships of Gnetales. International Journal of Plant Sciences 157 (Supplement): S3-S39.

Doyle, J.A. y Donoghue, M.J. 1986. Seed plant phylogeny and the origin of angiosperms: An experimental cladistic approach. The Botanical Review 52: 321-341.

Doyle, J.A. y Donoghue, M.J. 1987. The importance of fossils in elucidating seed plant phylogeny and macroevolution. Review of Palaeobotany and Palynology 50: 63-96.

Doyle, J.A. y Donoghue, M.J. 1992. Fossils and seed plant phylogeny reanalyzed. Brittonia 44: 89-106.

Du Toit, A.L. 1927a. A geological comparison of South America with South Africa. Carnegie Institution, Publication 381: 1-150.

Du Toit, A.L. 1927b. The fossil flora of the Upper Karroo Beds. Annals of the South African Museum 22: 289-418.

Dubiel, R.F., Parrish, J.T., Parrish, J.M. y Good, S.C. 1991. The Pagaean megamonsoon - evidence from the Upper Triassic Chinle Formation, Colorado Plateau. PALAIOS 6: 347-370.

Dumortier, B.C.J. 1829. Analyse des familles des plantes, avec l'indication des principaux genres qui s'y rattachent. J. Casterman aîné, Tournay, 104 pp.

Efremov, I. 1940. Taphonomy: a new branch of Paleontology. Pan-American Geologist 74: 81-93.

Emery, J.F., Floyd, S.K., Alvarez, J., Eshed, Y., Hawker, N.P., Bizhaki, A., Baum, S.F., y Bowman, J.L. 2003. Radial patterning of Arabidopsis shoots by class IIIHD-ZIP and KANADI genes. Current Biology 13: 1768-1774.

Endlicher, S.L. 1847. Synopsis Coniferarum. S. Publisher, Sangalli: apud Scheitlin \& Zollikofer, 368pp.

Engler, A. 1897. Coniferales. En: Engler, A. y Prantl, K. (eds), Die Natürlichen Pflanzenfamilien. II.-IV: 144-149.

Erickson, R.O. y Michelini, F.J. 1957. The plastochron index. American Journal of Botany 44: 297-305.

Esau, K. 1960. Anatomy of Seed Plants, 2nd Ed. John Wiley \& Sons, New York, 550 pp.

Esau. K. 1965. Vascular differentiation in plants. Holt, Rinehart \& Winston, New York, 160 pp.

Escapa, I., Taylor, T.N. y Taylor, E.L. 2009. Misconceptions, potential problems and methodological advances in cladistics analyses: relevance for the study of fossil plants. XIV Simposio Argentino de Paleobotánica y Palinología (Mar del Plata), Resúmenes: 24. 
Ettingshausen, C. 1852. Begrtindung einiger neuen oder nicht genau bekannten Arten der Lias- und Oolithflora. Abhandlungen der kaiserlichköniglichen Geologischen Reichsanstalt 1: 110.

Fahn, A. y Schori, Y. 1967. The organization of the secondary conducting tissue in some species of the Chenopodiaceae. Phytomorphology 17: 147-154.

Fahn, A. 1990. Plant anatomy. Pergamon Press, Oxford, 588 pp.

Falcon-Lang, H.J. 2000. The relationship between leaf longevity and growth ring markedness in modern conifer woods and its implications for palaeoclimatic studies. Palaeogeography, Palaeoclimatolology, Palaeoecology 160: 317-328.

Feistmantel, O. 1890. Geological and Palaeontological relations of the coal and plant bearing beds of Paleozoic and Mesozoic age in easterns Australia and Tasmania. Memoirs of Geological Survey of New South Wales, Palaeontology 3: 1-85.

Ferguson, D.K. 1985. The origin of leaf assemblages-New light on an old problem. Review of Palaeobotany and Palynology 46: 117-188.

Fielding, C.R. y Alexander, J. 2001. Fossil trees in ancient fluvial channel deposits: Evidence of seasonal and longer-term climatic variability. Palaeogeography, Palaeoclimatology, Palaeoecology 170: 59-80.

Fink, W.L. 1988. Phylogenetic analysis and the detection of ontogenetic patterns. En: McKinney, M.L., (ed.), Heterochrony in evolution, Plenum Publishing Corporation, New York, pp. 71-91.

Florin, R. 1936. Die fossilen Ginkgophyten von Franz -Joseph-Land. Nebst erörterungen über vermeintliche Cordaitales Mesozoischen Alters. 1. Spezieller Teil. Palaeontographica Abteilung B 81: 71-173.

Florin, R. 1940. On the occurrence of the genus Sphenobaiera (Ginkgoales) in the Tertiary of South Chile. Pontificia Universidad Católica de Chile, Revista Universitaria 25: 147-154.

Floyd, S.K. y Bowman, J.L. 2007. The ancestral developmental tool kit of land plants. International Journal of Plant Sciences 168: 1-35.

Font Quer, P. 1963. Diccionario de Botánica. $2^{\mathrm{a}}$ reimpresión. Ed. Labor, S.A, Barcelona, 1244 pp.

Font Quer, P. 1982. Diccionario de Botánica. $8^{\mathrm{a}}$ reimpresión. Ed. Labor, S.A, Barcelona, 1244 pp.

Franz, V. 1927. Ontogenie und Phylogenie. Abhandlungen zur Theorie der organischen Entwicklung 3: $1-51$.

Frenguelli, J. 1937. La Flórula Jurásica de Paso Flores en el Neuquén, con referencia a la de Piedra Pintada y otras floras jurásicas argentinas. Revista del Museo de La Plata (n.s.), Paleontología 1: 67-108.

Frenguelli, J. 1941. Sobre Cycadocarpidium andium n. sp., del Rético de Cacheuta, Mendoza. Notas del Museo de La Plata, Paleontología 6: 485-498.

Frenguelli, J. 1942a. Contribuciones al conocimiento de la flora del Gondwana Superior en la Argentina. V. Baiera cuyana n. sp. Notas del Museo de La Plata, Paleontología 7: 297-302.

Frenguelli, J. 1942b. Contribuciones al conocimiento de la flora del Gondwana Superior en la Argentina. IX. Kurtziana cacheutensis Kurtz sp. n., gen. et n. comb. Notas del Museo de La Plata, Paleontología 7: 331-339. 
Frenguelli, J. 1943. Reseña crítica de los géneros atribuídos a la "Serie de Thinnfeldia". Revista del Museo de La Plata (n.s.), Paleontología 2: 225-342.

Frenguelli, J. 1944a. Las especies del género Zuberia en la Argentina. Anales del Museo de La Plata. Paleontología, sección B; Paleobotánica 1: 1-30.

Frenguelli, J. 1944b. Contribución al conocimiento de la flora del Gondwana Superior en la Argentina, XXVII, Lepidanthium sporiferum Feist. sp.?. Notas del Museo de La Plata, Paleontología 9: 531-537.

Frenguelli, J. 1944c. Contribuciones al conocimiento de la flora del Gondwana Superior en la Argentina. XXIV, Equisetites fertilis n. comb. Notas del Museo de La Plata, Paleontología 9: 501-509.

Frenguelli, J. 1944d. Contribuciones al conocimiento de la flora del Gondwana superior en la Argentina: XXIII. Phyllotheca australis Brongt. Notas del Museo de La Plata, Paleontología. 9: 493-500.

Frenguelli, J. 1944e. Contribuciones al conocimiento de la flora del Gondwana superior en la Argentina: XXVIII. Cardiopteridium cyclopteroides n. sp. Notas del Museo de La Plata, Paleontología 9: 539-542.

Frenguelli, J. 1944f. Contribuciones al conocimiento de la flora del Gondwana superior en la Argentina. 31. Cycadocarpidium majus y C. minus (Wiel). Notas Museo La Plata, Paleontología 9: 557568.

Frenguelli, J. 1944g. Contribuciones al conocimiento de la flora del Gondwana Superior en la Argentina. XV. La flórula de la base de la "Serie de Cacheuta" en el cerro de Los Baños, Mendoza. Notas del Museo de La Plata, Paleontología 9: 271-310.

Frenguelli, J. 1946. Contribuciones al conocimiento de la flora del Gonwana Superior en la Argentina, XXXIII, Ginkgoales de los estratos de Potrerillos en la Precordillera de Mendoza. Notas del Museo de La Plata, Paleontología 11: 101-127.

Frenguelli, J. 1947. El género Cladophlebis y sus representantes en la Argentina. Anales del Museo de La Plata (nueva serie), Paleontología 2: 1-74.

Frenguelli, J. 1948. Estratigrafía y edad del llamado Rético en la Argentina. Anales de la Sociedad Argentina de Estudios Geográficos, GAEA 8: 159-309.

Frenguelli, J. 1950. Addenda a la Flora del Gondwana Superior en la Argentina. Revista de la Asociación Geológica Argentina 5: 15-30.

Friedman, W.E., Moore, R.C. y Purugganan, M.D. 2004. The evolution of plant development. American Journal of Botany 91: 1726-1741.

Furnish, W.M. 1973. Permian stage names. En: Logan, A y Hills, L.V. (eds.), The Permian and Triassic Systems and their Mutual Boundary. Canadian Society of Petroleum Geologists, Calgary, pp. $522-548$.

Galweiler, L., Guan, C., Müller, A., Wisman, E., Mendgen, K., Yephremov, A. y Palme, K. 1998. Regulation of polar auxin transport by AtPIN1 in Arabidopsis vascular tissue. Science 282: 2226-2230.

Gallego, O.F. y Martins-Neto, R.G. 2005. Propuesta preliminar sobre la distribución geográfica de las triásicas de insectos y conchostracos de Argentina, Chile y sur de Brasil. Gondwana 12, Geological and Biological Heritage of Gondwana (Mendoza), Abstracts: 164. 
Ganuza, D.G., Spalletti, L.A., Morel, E.M. y Arrondo, O.G. 1995. Paleofloras y sedimentología de una asociación lacustre-fluvial del Triásico tardío; la Formación Paso Flores en Cañadón de Pancho, Neuquén. Argentina. Ameghiniana 32: 3-18.

Ganuza, D.G., Zamuner, A.B., Artabe, A.E. y Spalletti, L.A. 1998. Sistemática y Paleoecología de la Flora Triásica de Hilario-Agua de Los Pajaritos (Formación El Alcázar), Provincia de San Juan, Argentina. Ameghiniana 35: 271-283.

Garber, R.L, Kuroiwa, A. y Gehring, W.J. 1983. Genomic and cDNA clones of the homeotic locus Antennapedia in Drosophila. EMBO Journal 2: 2027-2036.

Garstang, W. 1928. The morphology of the Tunicata and its bearing on the phylogeny of the Chordata. Quarterly Journal of Microscopical Science 72: 51-54.

Gasparri, I. y Manghi, E. 2004. Estimación de volumen, biomasa y contenido de carbono de las regiones forestales argentinas. Dirección de Bosques, Secretaría de Ambiente y Desarrollo Sustentable, http://www.ambiente.gov.ar/archivos/web/UMSEF/File/volumen_biomasa_carbono.pdf, 25 pp.

Gasson, P. 1994. Wood anatomy of the Sophoreae and related Caesalpinioideae and Papilionoideae. En: K. Ferguson y S. Tucker (eds), Advances in Legume Systematics, part 6, Structural Botany, Royal Botanic Gardens, Kew, pp. 165-203.

Gasson, P. 1996. Wood anatomy of the tribe Swartzieae with comments on related papilionoid and caesalpinioid Leguminosae. IAWA Journal 17: 45-75.

Gastaldo, R.A., Ferguson, D.K., Walter, H. y Rabold, J.M. 1996. Criteria to distinguish parautochthonous leaves in Tertiary alluvial channel-fills. Review of Palaeobotany and Palynology 91: 1-21.

Gastaldo, R.A. y Staub, J.R. 1999. A mechanism to explain the preservation of leaf litter lenses in coals derived from raised mires. Palaeogeography, Palaeoclimatology, Palaeoecology 149: 1-14.

Geinitz, H.B. 1862. Dyas oder die Zechsteinformation und das Rothliegende, II, Die Pflanzen der Dyas und Geologisches. W. Engelmann, Leipzig, 342 pp.

Geinitz, H.B. 1876. Über rhaetische Pflanzen und Tierreste in den argentinischen Provinzen La Rioja, San Juan und Mendoza. Beiträge zur Geologie und Paläontologie der argentinischen Republik. II. Paläontologischer Theil. II. Abteilung. Palaeontographica Supplement 3: 1-14.

Giard, A. 1887. La castration parasitaire et son influence sur les caractères extérieurs du sexe male chez les crustacés décapodes. Bulletin des Sciences Departemente du Nord 18: 1-28.

Gnaedinger, S. 1999. La flora triásica del Grupo El Tranquilo, provincia de Santa Cruz, Patagonia. Parte VII. Cycadophyta. Asociación Paleontológica Argentina, Publicación Especial 6, X Simposio Argentino de Paleobotánica y Palinología: 27-32.

Gnaedinger, S. y Herbst, R. 1998a. La flora triásica del Grupo El Tranquilo, provincia de Santa Cruz (Patagonia). Parte IV. Pteridospermae. Ameghiniana 35: 33-52.

Gnaedinger, S. y Herbst, R. 1998b. La flora triásica del Grupo El Tranquilo, provincia de Santa Cruz (Patagonia). Parte V. Pteridophylla. Ameghiniana 35: 53-65.

Gnaedinger, S. y Herbst, R. 1999. La flora triásica del Grupo El Tranquilo, provincia de Santa Cruz (Patagonia). Parte VI. Ginkgoales. Ameghiniana 36: 275-296.

Gnaedinger, S. y Herbst, R. 2001. Pteridospermas triásicas del Norte Chico de Chile. Ameghiniana 38: 281-298. 
Gnaedinger, S. y Herbst, R. 2009. Primer registro de maderas gimnospérmicas de la Formación Roca Blanca (Jurásico Inferior), provincia de Santa Cruz, Argentina. Ameghiniana 46: 59-72.

Goloboff, P.A., Farris, J.S. y Nixon, K. 2008. TNT, a free program for phylogenetic analysis. Cladistics 24: 774-786.

Google Earth, 2009. http://earth.google.es/

Gorožankin, I.N. 1904. Ordo Ginkgoales. Lekts Morf Sist Archegon: 73, 93.

Gothan, W. 1912. Über die Gattung Thinnfeldia Ettingshausen. Abhandlung der Naturhistorische Gesellschaft zu Nümberg 19: 67-80.

Gould, S.J. 1977. Ontogeny and phylogeny. MA: Belknap Press of Harvard University Press, Cambridge, $520 \mathrm{pp}$.

Gould, S.J. 1992. Heterochrony. En: Fox, E. y Lloyd, E. (eds), Keywords in evolutionary biology, MA: Harvard University Press. Cambridge, pp. 158-167.

Graham, S.A., Crisci, J.V. y Hoch, P.C. 1993. Cladistic analysis of the Lythraceae sensu lato based on morphological characters. Botanical Journal of Linnean Society 113: 1-33.

Greguss, P. 1955. Identification of Gymnosperms on the basis of xylotomy. Akadémiai Kiadó, Budapest, $263 \mathrm{pp}$.

Greguss, P. 1968. Xylotomy of the living cycads with a description of their leaves and epidermis. Akademiai Kiadó, Budapest, 260 pp.

Groeber, P. y Stipanicic, P.N. 1953. Triásico. En: Geografía de la República Argentina, II. Sociedad Argentina de Estudios Geográficos GAEA, pp. 13-131.

Guerrant, E.O. 1982. Neotenic evolution of Delphinium nudicaule (Ranunculaceae): a hummingbirdpollinated larkspur. Evolution 36: 699-712.

Guilfoyle, T., Hagen, G., Ulmasov, T. y Murfett, J. 1998a. How does auxin turn on genes? Plant Physiology 118: 341-347.

Guilfoyle, T.J., Ulmasov, T. y Hagen, G. 1998b. The ARF family of transcription factors and their role in plant hormone-responsive transcription. Cell Mol Life Science 54: 619-627.

Gupta, N.S. y Pancost, R.D. 2004. Biomolecular and physical taphonomy of angiosperm leaves during early decay: Implications for fossilization. PALAIOS 19: 428-440.

Haeckel, E. 1866. Generelle Morphologie der Organismen, Vols. 1-2. Georg Reimer Verlag, Berlin, 1036 pp., $186 \mathrm{pl}$.

Hall, B.K. 1992. Evolutionary developmental biology. Chapman and Hall, London, 275 pp.

Hall, B.K 1999. Evolutionary developmental biology, 2nd edition Kluwer Academia Publishers, Dordrecht, $512 \mathrm{pp}$.

Halle, T.G. 1908. Zur Kenntnis der Mesozoischen equisetales Schwedens. Kungliska Svenska Vetenskapsademiens Handlingar 43: 3-42.

Halle, T.G. 1913. The mesozoic flora of Graham Land. Wissenschaftliche Ergebnisse Schwedische Südpol Expedition 1901-1903, 3: 1-123.

Halle, T.G. 1927. Palaeozoic plants from central Shansi. Palaeontologia Sinica, Series A, 2: 1-316.

Hallé, F., Oldeman, R.A.A. y Tomlinson, P.B. 1978. Tropical Trees and Forests. An Architectural Analysis. Springer-Verlag, Berlin, 441 pp. 
Hammer, O., Harper, D.A.T. y Ryan, P.D. 2007. Past-Palaeontological Statistics, ver. 1.75, 86 pp. [versión original 2001, Palaeontologia Electronica 4(1)8, 1-9].

Hardtke, C.S. y Berleth, T. 1998. The Arabidopsis gene MONOPTEROS encodes a transcription factor mediating embryo axis formation and vascular development. EMBO Journal 2: 1405-1411

Harris, T.M. 1932a. The fossil flora of Scoresby Sound, east Greenland 3. Meddelelser om Grønland, Bd. 85: 1-112, pls. 1-9.

Harris, T.M. 1932b. The fossil flors of Scoresby Sound, east Greenland 5. Meddelelser om Grønland, Bd. 85: 1- 133.

Harris, T.M. 1937. The fossil flora of Scoresby Sound East Greenland. Part 5: Stratigraphic relations of the plant beds. Meddelelser om Grønland 112: 1-114.

Harris, T.M. 1961. The Yorkshire Jurassic Flora. 1 Tallophyta-Pteridophyta. Trustees of the British Museum (Natural History), Londres, $212 \mathrm{pp}$.

Harris, T.M. 1964. The Yorkshire Jurassic Flora II Caytoniales, Cycadales, Pteridosperms. Trustees of British Museum (Natural History) Londres, $191 \mathrm{pp}$.

Harris, T.M. 1969. The Yorkshire Jurassic Flora. III. Bennettitales. British Museum (Natural History), Londres, $186 \mathrm{pp}$.

Harris, T.M. 1979. The Yorkshire Jurassic Flora. V. Coniferales. British Museum (Natural History), Londres, $167 \mathrm{pp}$.

Harrison, C.J., Cronk, Q.C.B. y Hudson, A. 2002. An overview of seed plant leaf evolution. En: Cronk, Q.C.B., Bateman, R.M. y Hawkins, J.A. (eds), Developmental genetics and plant evolution, Taylor \& Francis, Londres, pp. 395-403.

Heer, O. 1877. Beiträge zur Jura-Flora Ostsibiriens und des Amurlandes. Mémoires de L'Acadamie Imperiale des Sciences de St. Petesburg, VII Serie 25: 1-58.

Heer, O. 1881. Contribuitions a la flore fossile du Portugal. Section des Travaux Gelogiques du Portugal, Lisbonne, $51 \mathrm{pp}$.

Heim, A. 1945. Observaciones tectónicas en Barreal, Precordillera de San Juan. Revista del Museo de La Plata (n.s.), Geología 2: 267-286.

Hejnowicz, Z. y Kurczynska, E.U. 1987. Occurrence of circular vessels above axillary buds in stems of woody plants. Acta Societatis Botanicorum Poloniae 56: 415-419.

Henschel, K., Kofuji, R., Hasebe, M., Saedler, H., Münster, T. y Theißen, G. 2002. Two ancient classes of MIKC-type MADS-box genes are present in the moss Physcomitrella patens. Molecular Biology and Evolution 19: 801-814.

Herbst, R. 1963. Chansiteca argentina n. sp. del Triásico Superior de Santa Cruz, Patagonia. Ameghiniana 3: 108-112.

Herbst, R. 1971. Palaeophytología Kurtziana III. 7. Revisión de las especies argentinas del género Cladophlebis. Ameghiniana 8: 265-281.

Herbst, R. 1979a. Sobre Marattiales (Filicopsidae) triásicas de Argentina y Australia. Parte 1. El género Asterotheca. Ameghiniana 14: 1-18.

Herbst, R. 1979b. Sobre Marattiales (Filicopsidae) triásicas de Argentina y Australia. Parte II. Los géneros Danaeopsis y Rienitsia. Ameghiniana 14: 19-32. 
Herbst, R. 1988. La flora triásica del Grupo El Tranquilo, Provincia de Santa Cruz (Patagonia). Parte II. Filicopsida. Ameghiniana 25: 365-379.

Herbst, R. 1993. Propuesta de clasificación de las Dipteridaceae, con un Atlas de las especies argentinas. D’Orbignyana 6: 1-71.

Herbst, R. 1995. Millerocaulis stipabonettiii nov. sp. (Osmundaceae, Filices) from the Late Traissic Cepeda Formation of San Juan Province, Argentina. Mededelingen Rijks Geologische Dienst 53: 13-19.

Herbst, R. 2000. Dipteridaceae (Filicales) del Triásico Superior de Chile. Revista Geológica de Chile 27: 65-81.

Herbst, R. y Gnaedinger, S. 2002. Kurtziana Frenguelli (Pteridospermae? incertae sedis) y Alicurana nov. gen. (Cycadopsida) del Triásico y Jurásico Temprano de Argentina y Chile. Ameghiniana 39: 331-341.

Herbst, R. y Lutz, A.I. 1988. Rhexoxylon brasiliensis n. sp. (Corystospermaceae, Pteridospermales) from the Upper Triassic Caturrita Formation, Brazil, with comments on biology and environment. Mededelingen Rijks Geologische Dienst 42: 21-28.

Herbst, R. y Lutz, A.I. 1995. Tranquiloxylon petriellai nov. gen. et sp. (Pteridospermales) from the Upper Triassic Laguna Colorada Formation, Santa Cruz province, Argentina. Ameghiniana 32: 231236.

Herbst, R. y Troncoso, A. 2000. Las Cycadophyta del Triásico de las Formaciones La Ternera y El Puquén (Chile). Ameghiniana 37: 283-292.

Herbst, R., Troncoso, A. y Gnaedinger, S. 2001. Rochipteris nov. gen., hojas incertae sedis (= Chiropteris pro parte) del Triásico Superior de Argentina y Chile. Ameghiniana 38: 257-269.

Herendeen, P.S. y Miller, R.B. 2000 Utility of wood anatomical characters in cladistic analyses. IAWA Journal 21: 247-276

Higuchi, T. 1997. Biochemistry and molecular biology of wood. En: Timell, T.E. (ed.), Formation and Development of Wood Tissues, Springer-Verlag, New York, pp 263-290.

Hilton, J. y Bateman, R.M. 2006. Pteridosperms are the backbone of seed-plant phylogeny. Journal of the Torrey Botanical Society 133: 119-168.

Holmes, W.B.K. 1982. The Middle Trassic flora from Benolong, near Dubbo, central - western New South Wales. Alcheringa 6:1-33.

Holmes, W.B.K. y Anderson, H.M. 2005. The Middle Triassic megafossil flora of the Basin Creek Formation, Nymboida Coal Measures, New South Wales, Australia. Part 5. The Genera Lepidopteris, Kurtziana, Rochipteris and Walkomiopteris. Proceedings of the Linnean Society of New South Wales 126: 39-79.

Holmes, W.B.K. y Ash, B.R. 1979. An Early Triassic megaflora from the Lorne Basin, New South Wales. Proceedings of the Linnean Society of New South Wales 103: 44-70.

Hufford, L. 1992. Rosidae and their relationships to other nonmagnoliid dicotyledons: a phylogenetic analysis using morphological and chemical data. Annals of Missouri Botanical Garden 79: 218248. 
Hufford, L. y Dickinson, W.C. 1992. A phylogenetic analysis of Cunoniaceae. Systematic Botany 17: $181-200$.

Hull, A.K, Vij, R. y Celenza, J.L. 2000. Arabidopsis cytochrome P450s that catalyze the first step of tryptophan-dependent indole-3-acetic acid biosynthesis. Proceedings of the National Academy of the United States of America 97: 2379-2384.

IAWA Comittee. 2004. International Association of Wood Anatomists list of microscopic features for softwood identification. IAWA Journal 25: 1-70.

Iltis, H.H., 1983. From Teosinte to Maize: The Catastrophic Sexual Transmutation. Science, New Series 222: 886-894.

Inoue, T., Higuchi, M., Hashimoto, Y., Seki, M., Kobayashi, M, Kato, T., Tabata, S., Shinozaki, K. y Kakimoto, T. 2001. Identification of CRE1 as a cytokinin receptor from Arabidopsis. Nature 409: 1060-1063

International Comission on Stratigraphy, 2008. International Stratigraphic Chart. http://www.stratigraphy.org/upload/ISChart2008.pdf

Jacob, K. y Jacob, C. 1950 A preliminary account of the structure of the cuticles of Dicroidium (Thinnfeldia) from the Mesozoic of Australia. Proceedings of the National Institute of Sciences India 16:101-126.

Jacobs, W.P. 1952. The role of auxin in differentiation of xylem around a wound. American Journal of Botany 39: 301-309.

Jain, R. y Delevoryas, T. 1967. A Middle Triassic Flora from the Cacheuta Formation, Minas de Petróleo, Argentina. Palaeontology 10: 564-589.

Jalfin, G.A. y Herbst, R. 1995. La flora triásica del Grupo El Tranquilo, provincia de Santa Cruz (Patagonia). Estratigrafía. Ameghiniana, 32: 211-229.

Jang, J.C., Fujioka, S., Tasaka, M., Seto, H., Takatsuto, S., Ishii, A., Aida, M., Yoshida, S. y Sheen, J. 2000. A critical role of sterols in embryonic patterning and meristem programming revealed by the fackel mutants of Arabidopsis thaliana. Genes \& Development 14: 1485-1497

Jenny, H. 1941. Factors of Soil Formation. McGraw-Hill Book Company, Inc., 281 pp.

Joffe, J.S. 1949. Pedology. Pedology Publ., New Brunswick, New Jersey, 662 pp.

Johnson, L.A.S. 1959. The families of cycads and the Zamiaceae of Australia. Proceedings of the Linnean Society of New South Wales 84: 64-117.

Kampny, C. y Harris, E. 1998. Heterochrony in plants. Annual Meeting of the Botanical Society of America (Baltimore), Abstract Index, http://www.ou.edu/cas/botany-micro/bsa-abst/title.shtml.

Keibel, F. 1895. Normentafeln zur Entwickelungsgeschichte der Wirbeltiere. Anatomischer Anzeiger 11: 225-234.

Keller, J.A., Herendeen, P.S. y Crane, P.R. 1996. Fossil flowers and fruits of the Actinidiaceae from the Campanian (Late Cretaceous) of Georgia. American Journal of Botany 83: 528-541.

Kellogg, E.A. 2000. The grasses: a case study in macroevolution. Annual Review of Ecology and Systematics 31: 217-238. 
Kellogg, E.A. 2002. Are macroevolution and microevolution qualitatively different? Evidence from Poaceae and other families. En: Cronk, Q.C.B., Bateman, R.M. y Hawkins, J.A. (eds), Developmental genetics and plant evolution, Taylor \& Francis, Londres, pp. 70-84.

Kemp, T.S. 1999. Fossils and evolution. Oxford University Press: Oxford. pp284

Kenrick, P. y Crane, P.R. 1997. The origin and early diversification of land plants. Smithsonian Institution Press, Washington D.C., 441 pp.

Kirchoff, B.K. y Fahn, A. 1984. Initiation and structure of the secondary vascular system in Phytolacca dioica L. (Phytolaccaceae). Canadian Journal of Botany 62: 2580-2586.

Kirik, V., Kolle, K., Misera, S., Baumlein, H. 1998. Two novel MYB homologues with changed expression in late embryogenesis-defective Arabidopsis mutants. Plant Molecular Biology 37: 819-827.

Klaassen, R. 1999. Wood anatomy of the Sapindaceae. IAWA Journal Supplement 2: 1-214.

Klavins, S.D., Taylor, T.N. y Taylor, E.L. 2002. Anatomy of Umkomasia (Corystospermales) from the Triassic of Antarctica. American Journal of Botany 89: 664-676.

Klingenberg, C.P. 1998. Heterochrony and allometry: the analysis of evolutionary change in ontogeny. Biological Reviews 73: 79-23.

Ko, J.-H., Yang, J., Oh, S., Park, S. y Han, K.-H. 2004. Genomics of wood formation. En: Kumar, S. y Fladung, M. (eds), Molecular genetics and breeding of forest trees, Haworth's Food Products Press, New York, pp. 113-140.

Kokogián, D.A. y Mancilla, O. 1989. Análisis estratigráfico secuencial de la Cuenca Cuyana. En: Chebli, G.A. y Spalletti, L.A. (eds), Cuencas Sedimentarias Argentinas. Universidad Nacional de Tucumán, Serie Correlación Geológica 6, San Miguel de Tucumán: 169-201.

Kokogián, D.A., Spalletti, L.A., Morel, E., Artabe, A.E., Martinez, R.N., Alcóber, O.A., Milana, J.P., Zavattieri, A.M. y Papú, O.H. 1999. Los depósitos continentales triásicos. En: Caminos, R. (ed.) Geología Regional Argentina, Secretaría de Estado de Minería de la Nación, Buenos Aires, pp. 377-398.

Kokogián, D.A., Spalletti, L.A., Morel, E.M., Artabe, A.E., Martinez, R.N., Alcóber, O.A., Milana, J.P. y Zavattieri, A.M. 2001. Estratigrafía del Triásico argentino. En: Artabe, A.E., Morel, E.M. y Zamuner, A.B. (eds), El Sistema Triásico de Argentina. Fundación Museo de La Plata "Francisco Pascasio Moreno", La Plata, pp. 25-54.

Kollman, J. 1885. Das Ueberwintern von europäischen Frosch- und Tritonlarven und die Umwandlung des mexikanischen Axolotl. Verhandlungen der Naturforschendeden Gesellschaft in Basel 7: 387-398.

Kräusel, R. 1949. Die fossilen Koniferen-Hölzer (Unter Ausschluß von Araucarioxylon Kraus) II. Teil. Kritische Untersuchungen zur Diagnostik lebender und fossiler Koniferen-Hölzer. Palaeontographica B 89: 83-203.

Kurtz, F. 1893. Dos viajes botánicos al Río Salado Superior (Cordillera de Mendoza). Boletín de la Academia Nacional de Ciencias 13: 1-42. 
Kurtz, F. 1902. Contribuciones a la Palaeophytologia Argentina. III. Sobre la existencia de una DakotaFlora en la Patagonia austro-occidental (Cerro Guido, Gobernación de Santa Cruz) Informe Preliminar. Revista del Museo de La Plata 10: 45-60.

Kurtz, F. 1921. Atlas de las plantas fósiles de la República Argentina. Actas Academia Nacional de Ciencias 7: 129-153.

Kutzbach, J.E. y Gallimore, R.G. 1989. Pangean climates: Megamonsoons of the megacontinent. Journal of Geophysical Research 94: 3341-3357.

Labudía, C.H., Llambías, E.J., Rapela, C.W. y Artabe, A.E. 1995. El Triásico de Los Menucos: procesos volcánicos y sedimentarios. II Reunión del Triásico del Cono Sur (Bahía Blanca), Actas I: 17-21.

Larson, P. 1994. The Vascular Cambium. Development and Structure. Springer Series in Wood Science, Berlín, 720 pp.

Legarreta, L. y Gulisano, C.A. 1989. Análisis estratigráfico secuencial de la Cuenca Neuquina (Triásico superior-Terciario). En Chebli, G. y Spalletti, L. (eds.), Cuencas Sedimentarias Argentinas, Facultad de Ciencias Naturales, Universidad Nacional de Tucumán, Serie Correlación Geológica 6, Tucumán: 221-243.

Lepekhina, V.G. 1972. Woods of Palaeozoic pycnoxylic Gymnosperms with special reference to North Eurasia representatives. Palaeontographica B 138: 44-106, $15 \mathrm{pl}$.

Leppe, M. y Moisan, P. 2003. Nuevos registros de Cycadales y Cycadeoidales del Triásico Superior del río Bíobío, Chile. Revista Chilena de Historia Natural 76: 475-484.

Leunis, J. 1877. Ordo Cyatheales. Syn Pflanzenk, ed. 2, 3: 1453.

Levine, N. 2009. CrimeStat: A Spatial Statistics Program for the Analysis of Crime Incident Locations (v 3.2a). Ned Levine \& Associates, Houston, TX, and the National Institute of Justice, Washington, DC.http://www.icpsr.umich.edu/icpsrweb/CRIMESTAT/

Li, P. y Johnston, M.O. 2000. Heterochrony in plant evolutionary studies through the twentieth century. The Botanical Review 66: 57-88.

Lindley, J. y Hutton, W. 1834. The fossil flora of Great Britain. Vol. 2, Londres, 223 pp., 79 pls.

Link, 1833. Marattiales. Hort Berol 2: 148

Lintilhac, P.M. y Vesecky, T.B. 1981. Mechanical-stress and cell-wall orientation in plants. 2. The application of controlled directional stress to growing plants with a discussion on the nature of the wound reaction. American Journal of Botany 68: 1222-1230.

Little, C.H.A. y Pharis, R.P. 1995. Hormonal control of radial and longitudinal growth in the tree stem. En: Gartner, B.L. (ed.), Plant stems: physiology and functional morphology, Academic Press, San Diego, pp 281-319.

Little, C.H.A. y Sundberg, B. 1991. Tracheid production in response to indole-3-acetic acid varies with internode age in Pinus sylvestris stems. Trees (Berl) 5: 101-106

Little, C.H.A., MacDonald, J.E. y Olsson, O. 2002. Involvement of indole-3-acetic acid in fascicular and interfascicular cambial growth and interfascicular extraxylary fiber differentiation in Arabidopsis thaliana inflorescence stems. International Journal of Plant Sciennces 163: 519-529. 
Lizcano, A., Herrera, M.C. y Santamarina, J.C. 2006. Suelos derivados de cenizas volcánicas en Colombia. Revista Internacional de Desastres Naturales, Accidentes e Infraestructura Civil 6: 167-197.

Lomax, T.L, Muday, G.K. y Rubery, P.H. 1995. Auxin transport. En: Davies, P.J. (ed.), Plant Hormones: Physiology, Biochemistry and Molecular Biology, Ed 2, Kluwer Academic Publishers, Dordrecht, pp. 509-530.

López Gamundí, O. 1994. Facies distribution in an asymmetric half-graben: the northern Cuyo Basin (Triassic), western Argentina. XIV International Sedimentological Congress (Recife). Abstracts: 6-7.

Luerssen, C. 1879. Gnetales. Handbook of Systematic Botany 2: 79.

Lutz, A.I. y Herbst, R. 1992. Una nueva especie de Rhexoxylon del Triásico de Barreal, San Juan Argentina. Asociación Paleontológica Argentina. Publicación Especial No 2: 73-76.

Mack, G.H., James, W.C. y Monger, H.C. 1993. Classification of paleosoils. Geological Society of America, Bulletin 105: 129-136.

Maheshwari, H.K. y Bajpai, U. 1992. Ginkgophyte leaves from the permian Gondwana of the Rajmahal basin, India. Palaeontographica B 224:131-149.

Mahonen, A.P., Bonke, M., Kauppinen, L., Riikonen, M., Benfey, P.N. y Helariutta, Y. 2000. A novel two-component hybrid molecule regulates vascular morphogenesis of the Arabidopsis root. Genes \& Development 14: 2938-2943.

Mamay, S.H., Miller, J.M., Rohr, D.M. y Stein, W.E.Jr. 1986. Delnortea, a genus of Permian plants from west Texas. Phytologia 60: 345-346.

Mamay, S.H., Miller, J.M., Rohr, D.M. y Stein,W.E.Jr. 1988. Foliar morphology and anatomy of the gigantopterid plant Delnortea abbottiae, from the Lower Permian of West Texas. American Journal of Botany 75: 1409-1433.

Martínez-Yrízar, A., Sarukhán, J., Pérez-Jiménez, A., Rincón, E., Maass, M., Solís-Magallanes, A. y Cervantes, L. 1992. Above-ground phytomass of a tropical deciduous forest on the coast of Jalisco, México. Journal of Tropical Ecology 8: 87-96.

Martinov, I. 1820. Osmundaceae. Tekhno-Bot. Slovar: 445

Matte, H. 1904. Recherches sur l'appareil libero-ligneux des Cycadacées. Mémoires de la Société Linnéenne de Normandie 22: 1-233.

McCarthy, P.J. y Plint, A.G. 1999. Floodplain palaeosols of the Cenomanian Dunvegan Formation, Alberta and British Columbia, Canada: Micromorphology, pedogenic processes and palaeoenvironmental implications. En: Marriott, S., Alexander, J. y Hey, R. (eds), Floodplains: Interdisciplinary Approaches, Geological Society Special Publication 163: 289-310.

McConnell, J.R., Emery, J., Eshed, Y., Bao, N., Bowman, J. y Barton, M.K. 2001. Role of PHABULOSA and PHAVOLUTA in determining radial patterning in shoots. Nature 411: 709-713.

McGinnis, W. 1994. A Century of Homeosis, a Decade of Homeoboxes. Genetics 137: 607-611.

McKinney, M.L. 1988. Heterochrony in evolution. Plenum, New York, 348 pp.

McKinney, M.L. 1999. Heterochrony: beyond words. Paleobiology 25: 149-153. 
McLoughlin, S., Lindström, S. y Drinnan, A.N. 1997. Gondwanan floristic and sedimentological trends during the Permian-Triassic transition: new evidence from the Amery Group, northern Prince Charles Mountains, East Antarctica. Antarctic Science 9: 281-298.

McNamara, K.J. 1982. Heterochrony and Phylogenetic Trends. Paleobiology 8: 130-142.

McNamara, K.J. 1986. A guide to the nomenclature of heterochrony. Journal of Paleontology 60: 4-13.

McNamara, K.J. 1995. Evolutionary change and heterochrony. John Wiley \& Sons Press, New York, 298 pp.

McNamara, K.J. (ed.) 1997. Shapes of time: the evolution of growth and development. Johns Hopkins University Press, Baltimore, 306 pp.

McNeill, J., Barrie, F.R., Burdet, H.M., Demoulin, V., Hawksworth, D.L., Marhold, K., Nicolson, D.H., Prado, J., Silva, P.C., Skog, J.E., Wiersema, J.H. y Turland, N.J.(eds). 2006. International Code of Botanical Nomenclature (Vienna Code). Adopted by the Seventeenth International Botanical Congress, Vienna, July 2005. Regnum Vegetabile 146: 1-568.

Mehnert, E. 1895. Die individuelle Variation des Wirbelthierembryo. Eine Zusammenstellung. Morphologische Arbeiten 5: 386-444.

Mehnert, E. 1897. Kainogenese. Eine gesetzmässige Abänderung der embryonalen Entfaltung in Folge von erblicher Uebertragung in der Phylogenese erworbener Eigenthümlichkeiten. Morphologische Arbeiten 7: 1-156.

Menéndez, C.A. 1951. La flora mesozoica de la Formación Llantenes (provincia de Mendoza). Revista del Instituto Nacional de Investigaciones en Ciencias Naturales (Botánica) 2: 147-261.

Menéndez, C.A. 1956. Protophyllocladoxylon cortaderitaensis sp. nov. Tronco fósil del Triásico de Barreal (provincia de San Juan). Revista de la Asociación Geológica Argentina 11: 273-280.

Mésigos, M.G. 1953. El Paleozoico Superior de Barreal y su continuación austral, Sierra de Barreal, Provincia de San Juan. Revista de la Asociación Geológica Argentina 8: 65-109.

Meyen, B. 1984. Basic features of Gymnosperms: systematics and phylogeny as evidenced by the fossil record. Botanical Review 50: 1-111.

Meyen, S.V. 1987. Fundamentals of Palaeobotany. Chapman and Hall, Londres, 432 pp.

Meyer-Berthaud, B., Taylor, E.L. y Taylor, T.N. 1992. Reconstructing the Gondwana seed fern Dicroidium: evidence from the Triassic of Antarctica. Geobios 25: 341-344.

Meyer-Berthaud, B., Taylor, T.N. y Taylor, E.L. 1993. Petrified stems bearing Dicroidium leaves from the Triassic of Antarctica. Palaeontology 36: 337-356.

Miall, A.D. 1978: Lithofacies types and vertical profile models in braided rivers: a summary. En: Miall, A.D. (ed.) Fluvial Sedimentology. Canadian Society of Petroleum Geology, Memoir 5: 597-604.

Miall, A.D. 1996. The Geology of Fluvial Deposits. Sedimentary Facies, Basin Analysis, and Petroleum Geology. Springer eds., New York, 582 pp.

Millan, J.H. 1974. As sementes platispérmicas do Gondwana face ao Esquema Maithy. Anais da Academia Brasileira de Ciências 46: 538-547

Morel, E.M. 1991. Estudio paleoflorístico y paleoambiental de la secuencia triásica en el área de Cacheuta, provincia de Mendoza. Tesis Doctoral. Facultad de Ciencias Naturales y Museo. Universidad Nacional de La Plata, 368 pp. Inédito. 
Morel, E.M. 1994. El Triásico del Cerro Cacheuta, Mendoza (Argentina). Parte I: Geología, contenido paleoflorístico y Cronoestratigrafía. Ameghiniana. 31: 161-176.

Morel, E.M. y Povilauskas, L. 2002. Addenda a la flora triásica de la Formación Potrerillos en el Cerro Cacheuta, provincia de Mendoza, Argentina. Ameghiniana 39: 501-503.

Morel, E.M., Spalletti, L.A., Arrondo, O.G. y Ganuza, D. 1992. Los estratos plantíferos de la Formación Paso Flores. Triásico Superior de las Lomas y Cañadón de Ranquel-huao. Provincia del Neuquén. Argentina. Revista del Museo de La Plata (n.s) Paleontología 58: 199-221.

Morel, E.M, Ganuza, D. y Zúñiga, A. 2000. Revisión paleoflorística de la Formación Paso Flores, Triásico Superior de Río Negro y del Neuquén, Argentina. Revista de la Asociación Geológica Argentina 54: 469-479.

Morel, E.M. Artabe, A.E., Zavattieri, A.M. y Bonaparte, J. 2001. Cronología del Triásico de Argentina. En: Artabe, A.E., Morel, E.M. y Zamuner, A.B. (eds). El Sistema Triásico de Argentina. Fundación Museo de La Plata "Francisco Pascasio Moreno", La Plata, pp. 227-253.

Morel, E.M., Artabe, A.E. y Spalletti, L.A. 2003. The Triassic floras of Argentina: Biostratigraphy, Floristic events and comparison with other areas of Gondwana and Laurasia. Alcheringa 27: 231-243.

Morel, E.M., Artabe, A.E., Ganuza, D. y Zúñiga. A. 2010. La paleoflora triásica del cerro Cacheuta, provincia de Mendoza, Argentina. Bryopsida, Lycopsida, Sphenopsida, Filicopsida y Gymnospermopsida (Corystospermales y Peltaspermales). Ameghiniana 47: 3-23.

Mosbrugger, V. 1995. Heterochrony and the evolution of land plants. En: McNamara, K.J. (ed.), Evolutionary change and heterochrony, John Wiley \& Sons, Chichester, pp. 93-105.

Motose, H., Sugiyama, M., y Fukuda, H. 2004. A proteoglycan mediates inductive interaction during plant vascular development. Nature 429: 873-878.

Mouradov, A., Glassick, T., Hamdorf, B., Murphy, L., Fowler, B., Marla, S. y Teasdale, R.D. 1998. NEEDLY, a Pinus radiata ortholog of FLORICAULA/LEAFY genes, expressed in both reproductive and vegetative meristems. Proceedings of the National Academy of the United States of America 95: 6537-6542.

Müller, F. 1864. Für Darwin. Wilhelm Engelmann, Leipzig, 91 pp.

Münster, T., Pahnke, J., Di Rosa, A., Kim, J.T., Martin, W., Saedler, H. y Theißen, G. 1997. Floral homeotic genes were recruited from homologous MADS-box genes preexisting in the common ancestor of ferns and seed plants. Proceedings of the National Academy of the United States of America 94: 2415-2420.

Mussa, D. 1980. Ocurrência do genero Antarcticoxylon Seward, Na Formação Irati (Permiano) do Estado de São Paulo, Brasil. Actas del $2^{\circ}$ Congreso Argentino de Paleontología y Bioestratigrafía y $1^{\circ}$ Congreso Latinoamericano de Paleontología (Buenos Aires, 1978), Resúmenes: 139-155.

Niemeyer, H., Zavattieri, A.M., Ballent, S., Zamuner, A. y Gallego, O. 2008. Triassic age of the continental Pular Formation, Sierra de Almeida, Antofagasta, northern Chile. Revista geológica de Chile 35: 147-161.

Niklas, K.J. 1993. The scaling of plant height: a comparison among major plant clades and anatomical grades. Annals of Botany 72: 165-172. 
Niklas, K.J. 1994a. Plant allometry: the scaling of form and process. University of Chicago Press, Chicago, 412 pp.

Niklas, K.J. 1994b. The allometry of safety-factors for plant height. American Journal of Botany 81: 345351.

Niklas, K.J. 1994c. Predicting the height of fossil plant remains: an allometric approach to an old problem. American Journal of Botany 81: 1235-1242.

Niklas, K.J. 1997. The Evolutionary Biology of Plants. University of Chicago Press, Chicago, 449 pp.

Nixon, K.C. 1996. Paleobotany in cladistics and cladistics in paleobotany: enlightenment and uncertainty. Review of Palaeobotany and Palynology 90: 361-373.

Nixon K.C., Crepet, W.L., Stevenson, D. y Friis, E.M. 1994 A reevaluation of seed plant phylogeny. Annals of the Missouri Botanical Garden 81: 484-533.

Norstog, K.J. y Nicholls, T.J. 1997. The Biology of the Cycads, Cornell University Press, Ithaca, 363 pp.

Noshiro, S. y Baas, P. 1998. Systematic wood anatomy of Cornaceae and allies. IAWA Journal 19: 43-97.

Ôishi, S. 1931. On Fraxinopsis and Yabeiella Oishi gen. nov. Japan Japanese Journal of Geology and Geography 8: 259-267.

Oldham, T. y Morris, J. 1862. The fossil flora of the Rajmahal Series, Rajmahal Hills, Bengal. Memoir of the Geological Society of India, Palaeontologica Indica, Series 2, 1: 1-52.

Olson, M. E. 2005. Commentary: typology, homology, and homoplasy in comparative wood anatomy. IAWA Journal 26: 507-522

Olson, M.E. 2007. Wood ontogeny as a model for studying heterochrony, with an example of paedomorphosis in Moringa (Moringaceae). Systematics and Biodiversity 5: 145-158.

Olson, M.E. y Rosell, J.A. 2006. Using heterochrony to detect modularity in the evolution of stem diversity in the plant family Moringaceae. Evolution 60: 724-734.

Oostendorp, C. 1987 . The Bryophytes of the Palaeozoic and the Mesozoic. Bryophytorum Bibliotheca 34. J. Cramer, Berlín, 112 pp.

Oppel, A. 1891. Vergleichung des Entwicklungsgrades der Organe zu verschiedenen Entwicklungszeiten bei Wirbeltieren. Fischer, Jena, 181 pp.

Otsuga, D., Deguzman, B., Prigge, M., Drews, G. y Clark, S. 2001. REVOLUTA regulates meristem initiation at lateral positions. The Plant Journal 25: 223-236.

Ottone, E.G. 2006. Plantas triásicas del Grupo Rincón Blanco, provincia de San Juan, Argentina. Ameghiniana 43: 477-486.

Ottone, E.G. y Archangelsky, S. 2001. A new bryophythe from the Upper Carboniferous of Argentina. Ameghiniana 38: 219-223

Pal, P.K. 1984. Triassic plant megafossil from the Tiki Formation, South Rewa, Gondwana Basin, India. The Palaeobotanist 32: 253-309.

Palme, K. y Gälweiler, L. 1999 PIN-pointing the molecular basis of auxin transport. Current Opinion in Plant Biology 2: 375-381.

Parrish, J.T. 1993. Climate of the Supercontinent Pangea. Journal of Geology 101: 215-233.

Parrish, J.M., Parrish, J.T. y Ziegler, A.M. 1986. Permian-Triassic paleogeography and paleoclimatology and implications for therapsid distributions. En: Hotton, N.H., MacLean, P.D., Roth, J.J. y Roth, 
E.C. (eds), The Ecology and Biology of Mammal-like Reptile, Smithsonian Institution Press, Washington, DC, pp. 109-132.

Parrish, J.T. y Curtis, R.L. 1982. Atmospheric circulation, upwelling, and organic-rich rocks in the Mesozoic and Cenozoic Eras. Palaeogeography, Palaeoclimatology, Palaeoecology 40: 31-66.

Parrish, J.T. y Peterson, F. 1988. Wind directions predicted from global circulation models and wind directions determined from eolian sandstones of the western United States-A comparison. Sedimentary Geology 56: 261-282.

Parrish, J.T., Bradshaw, M.T., Brakel, A.T., Mulholland, S.M., Totterdell, J.M. y Yeates, A.N. 1996. Paleoclimatology of Australia during the Pangean interval: Palaeoclimates. Data and Modelling $1: 23-57$.

Parrish, J.T., Peterson, F. y Turner, C.E. 2004. Jurassic “savannah"_-Plant taphonomy and climate of the Morrison Formation (Jurassic, Western U.S.A.). Sedimentary Geology 167: 137-162.

Petriella, B.T. 1978. La recostrucción de Dicroidium (Pteridospermopsida, Corystospermaceae). Obra del Centenario del Museo La Plata 5: 107-110.

Petriella, B.T. 1985. Caracteres adaptativos y autoecología de las Corystospermaceae. $3^{\circ}$ Congreso Latinoamericano de Paleontología (México, 1984). Simposio Floras del Triásico, Memorias: 53-57.

Petriella, B.T. 1979. Sinopsis de las Corystospermaceae (Corystospermales, Pteridospermophyta) de Argentina. 1. Hojas. Ameghiniana 16: 81-102.

Petriella, B.T. 1980. Sinopsis de las Corystospermaceae (Corystospermales, Pteridospermophyta) de Argentina. 2. Estructuras fértiles. Ameghiniana 17: 168-180.

Petriella, B.T. 1981. Sistemática y vinculaciones de las Corystospermaceae H. Thomas. Ameghiniana 18: 221-234.

Petriella, B.T. 1983. Sinopsis de las Corystospermaceae (Corystospermales, Pteridospermophyta) de Argentina. 3. Troncos y Cronoestratigrafía. Ameghiniana 20: 41-46.

Petriella, B.T. y Arrondo, O.G. 1982. El género Kurtziana Frenguelli: su morfología y vinculaciones. Ameghiniana 19: 209-215.

PIARFON, 2005. Parque Chaqueño Subregión subhúmeda y semiárida. Universidad Nacional del Nordeste y Universidad Nacional de Formosa. Secretaría de Medio Ambiente y Desarrollo Sustentable. http://www.ambiente.gov.ar/?idarticulo $=945$

Pigg, K.B. 1990. Anatomically preserved Dicroidium foliage from the central Transantarctic Mountains. Review of Palaeobotany and Palinology 66: 129-145.

Plomion, C., Leprovost, G. y Stokes, A. 2001. Wood formation in trees. Plant Physiology 127: 15131523.

Pozzo, A. 1948. Estudio geológico, estratigráfico y tectónico de la Precordillera, al este del río de los Patos y al sud de Calingasta (Provincia de San Juan). Tesis doctoral, Facultad de Ciencias Exactas, Físicas y Naturales, Universidad de Buenos Aires, 101 pp., 12 láms, 3 perf., 1 mapa. Inédito.

Quiroga, A. 2007. Impacto de la explotación forestal. ÁREA ECOLOGÍA, Editorial Científica Universitaria, Universidad Nacional de Catamarca, Catamarca, 12 pp. 
Radczenko, G.P. 1957. Particularités mosphologiques et anatomiques de certains types de végetaux du Carbonifére ancien de la province du Kuznets. Sbornik Pamjati AN Kysofovich Institut Bot. Kamorov Akademii Nauk S.S.S.R.: 33-54.

Raff, R.A. 1996. The shape of life. University of Chicago Press, Chicago, 544 pp.

Raff, E.C. y Raff, R.A. 2000. Dissociability, modularity, evolvability. Evolution and Development 2: 235237.

Raff, R.A. y Wray, G.A. 1989. Heterochrony: developmental mechanisms and evolutionary results. Journal of Evolutionary Biology 2: 409-434.

Rajput, K.S. y Rao, K.S. 2003. Cambial variant and xylem structure in the stem of Cocculus hirsutus (Menispermaceae). IAWA Journal 24:411-420.

Ramos, V. y Kay, S. 1991. Triassic rifting and associated basalts in the Cuyo basin, central Argentina. En: Harmon, R.S. y Rapela, C.W. (eds.), Andean Magmatism and its Tectonic Setting. Geological Society of America, Special Paper 265: 79-91.

Ratcliffe, O.J., Riechmann, J.L. y Zhang J.Z. 2000. INTERFASCICULAR FIBERLESS1 is the same gene as REVOLUTA. Plant Cell 12: 315-317.

Reading, H. (ed.) 1986. Sedimentary Environments and Facies, 2nd. edition. Blackwell, Oxford, 615 pp.

Reilly, S.M., Wiley, E.O. y Meinhardt, D.J. 1997. An integrative approach to heterochrony: the distinction between interspecific and intraspecific phenomena. Biological Journal of the Linnean Society 60: 119-143.

Remane, A. 1952. Die Grundlagen des natürlichen Systems, der vergleichenden Anatomie und der Phylogenetik. Akademische Verlagsgesellschaft, Leipzig, 400 pp.

Retallack, G.J. 1977. Reconstructing Triassic vegetation of eastern Australasia: a new approach for the biostratigraphy of Gondwanaland. Alcheringa 1: 253-283. (Microfiche supplement).

Retallack, G.J. 1980. Late Carboniferous to Middle Triassic megafossil floras from the Sydney Basin. En: A Guide to the Sydney Basin. Bulletin of the Geological Survey New South Wales 26: 385-430.

Retallack, G.J. 1981. Middle Triassic megafossil plants from Long Gully, near Otematata, north Otago, New Zealand. Journal of the Royal Society of New Zealand 1: 167-200.

Retallack, G.J. 1988. Field recognition of paleosols. En: Reinhardt, J. y Sigles, W.R. (eds) Paleosols and Weathering Through Geologic Time: PrincipIes and Applications, Special Paper, Geological Society of America 216: 1-20.

Retallack, G.J. 1997. Earliest Triassic origin of Isoetes and quillwort evolutionary radiation. Journal of Paleontology 71: 500-521.

Retallack, G. 1999. Palaeosols. En: Jones, T.P. y Rowe, N.P. (eds), Fossil Plants and Spores: modern techniques, Geological Society of London, pp. 214-219.

Retallack, G.J. 2002. Lepidopteris callipteroides, an earliest Triassic seed fern of the Sydney Basin, southeastern Australia. Alcheringa 26: 475-500.

Retallack, G.J. y Dilcher, D.L. 1988. Reconstructions of selected seed ferms. Annals of the Missouri Botanical Garden 75: 1010-1057.

Retallack, G.J. y Alonso-Zarza, A.M. 1998. Middle Triassic Paleosols and paleoclimate of Antarctica. Journal of Sedimentary Research 68: 169-184. 
Reveal, J.L. 1996. Subdivision Lycopodiophytina. Phytologia 79: 70.

Reveal, J.L. 2007. Indices Nominum Supragenericorum Plantarum Vascularium. http://www.plantsystematics.org/reveal/pbio/fam/allspgfile.html

Ridley, M. 1985. Embryology and classical zoology in Great Britain. En: Horder, T.J., Witkowski, J.A. y Wylie, C.C. (eds), A history of embryology, Cambridge University Press, Cambridge, pp. 35-67.

Ricardi, F., Rosler, O. y Odreman, O. 1999. Tafoflora de Delnortea (gigantopterideae) de Loma de San Juan (Formacion Palmarito, NO de Venezuela) y sus relaciones paleofitogeograficas en el artinskiano (Neopaleozoico). Plantula 2: 73-86.

Robinson, P.L. 1973. Palaeoclimatology and continental drift. En: Tarling, D.H. y Runcorn, S.K. (eds), Implications of Continental Drift to the Earth Sciences, Academic Press, Londres, pp. 449-476.

Rocha-Campos, A.C. 1973. Upper Paleozoic and Lower Mesozoic paleogeography, and paleoclimatological and tectonic events in South America En: Logan, A. y Hills, L.V. (eds), The Permian and Triassic Systems and Their Mutual Boundary, Canadian Society of Petroleum Geologists, Memoirs 2: 398-424.

Rolle, T. 1885. Isoetopsida. Naturwiss. 2: 264.

Rolleri, C.H. 2004. Revisión del género Danaea (Marattiaceae - Pteridophyta). Darwiniana 42: 217-301.

Rolleri, E.O. y Criado Roqué, P. 1968. La cuenca triásica del norte de Mendoza. III Jornadas Geológicas Argentinas (Comodoro Rivadavia), Actas 1: 1-76.

Rolleri, E.O. y Fernández Garrasino, C. 1979. Comarca septentrional de Mendoza. En: Turner, J.C.M. (ed.), Segundo Simposio de Geología Regional Argentina (Córdoba) Academia Nacional de Ciencias, I: 771-809.

Ronse de Craene, L.P.R., Soltis, P.S. y Soltis, D.E. 2003. Evolution of floral structures in basal angiosperms. International Journal of Plant Sciences 164: S329-S363.

Rothwell, G.W. 1982. New interpretations of the earliest conifers. Review of Palaeobotany and Palynology 37: 7-28.

Rothwell, G.W. 1987. The role of development in plant phylogeny: a paleobotanical perspective. Review of Palaeobotany and Palynology 50: 97-114.

Rothwell, G.W. y Lev-Yadun, S. 2005. Evidence of polar auxin flow in 375 million-year-old fossil wood. American Journal of Botany 92: 903-906.

Rothwell, G.W. y Nixon, K.C. 2006. How does the inclusion of fossil data change our conclusions about the phylogenetic history of euphyllophytes? International Journal of Plant Sciences 167: 737749.

Rothwell, G.W. y Serbet, R. 1994. Lignophyte phylogeny andthe evolution of spermatophytes: A numerical cladistic analysis. Systematic Botany 19: 443-482.

Rothwell, G.W., Mapes, G. y Hernández-Castillo, G.R. 2005. Cladistic Relationships among the Most Ancient Conifers (Voltziales). Taxon 54: 733-750.

Rothwell, G.W., Sanders, H., Wyatt, S.E. y Lev-Yadun, S. 2008. A fossil record for growth regulation: the role of auxin in wood evolution. Annals of Missouri Botanical Garden 95: 121-134. 
Rothwell, G.W., Crepet, W.L. y Stockey, R.A. 2009. Is the anthophyte hypothesis alive and well? New evidence from the reproductive structures of Bennettitales. American Journal of Botany 96: 296322.

Rowley, D.B., Raymond, A., Parrish, J.T., Lottes, A.L., Scotese, C.R. y Ziegler, A.M. 1985. Carboniferous paleogeographic, phytogeographic, and paleoclimatic reconstructions. International Journal of Coal Geology 5: 7-42.

Russell, E.S. 1916. Form and function. John Murray Ltd, Londres, 383 pp.

Sachs, T. 1981. The control of the patterned differentiation of vascular tissues. Advances in Botanical Research 9: 152-262.

Sachs, T. 2000. Integrating cellular and organismic aspects of vascular differentiation. Plant Cell Physiology 41: 649-656

Sanders, H., Rothwell, G.W. y Wyatt, S. 2007. Paleontological context for the developmental mechanisms of evolution. International Journal of Plant Sciences 168: 719-728.

Saporta, G. 1872-1875. Paléontologie français ou description des fossiles, plantes jurassique. (En tres partes), Végétaux, Plantes, Jurassiques, París, 858 pp.

Sattler, R. 1978. Introduction. En: Sattler, R. (ed.), Theoretical plant morphology, Acta Biotheoretica, Vol. 27, Supplement: Folia Biotheoretica No.7, Leiden University Press, The Hague, 5-20.

Savidge, R.A. 1994. The tracheid-differentiation factor of conifer needles. International Journal of Plant Sciences 155: 272-290.

Savidge, R.A. 1996. Xylogenesis, genetic and environmental regulation-a review. IAWA Journal 17: 269-310.

Savidge, R.A. 2000. Intrinsic Regulation of Cambial Growth. Journal of Plant Growth Regulation 20: 52-77

Savidge, R.A. y Wareing, P.F. 1981. Plant growth regulators and the differentiation of vascular elements. En: Barnett, J.R. (ed.), Xylem cell development. Tunbridge Wells, Castle House, Londres, pp. 192-235.

Savidge, R.A., Heald, J.K. yWareing, P.F. 1982. Non-uniform distribution and seasonal variation of endogenous indol 3-ylacetic acid in the cambial region of Pinus contorta Dougl. Planta 155:8992.

Savidge, R.A., Udagama-Randeniya, P.V., Xu, Y., Leinhos, V. y Förster, H. 1998. Coniferyl alcohol oxidase: a new enzyme spatiotemporally associated with lignifying tissues. En: Lewis, N.G. y Sarkanen, S. (eds). Lignin and lignan biosynthesis, ACS Symp. Ser. 697, American Chemistry Society, Washington, DC, pp. 109-130.

Schultze-Motel, J. 1961. Gymnospermenhölzer aus dem Jura des nördlichen Harzvorlandes: Protophyllocladoxylon quedlinburgense sp. n. Monatsberichte der Deutschen Akademie der Wissenschaften zu Berlin 3: 418-426.

Schimper, W.P. 1869. Traité de paléontologie végétale ou la flore du monde primitif dans ses raports avec les formations géologiques et la flore du monde actuel, Vols. 1- 3, atlas. Baillère et fils, París, 740 pp. 
Schimper, W.P. 1872. Traité de paléontologie végétale: ou, La flore du monde primitif dans ses rapports avec les formations géologiques et la flore du monde actuel, Volumen 2. J. B. Baillière et fils, Librairie del'Académie de médecine, París, 966 pp.

Scott, M.P., Weiner, A.J., Hazelrigg, T.I., Polisky, B.A., Pirrotta, V., Scalenghe, F. y Kaufman, T.C. 1983. The molecular organization of the Antennapedia locus of Drosophila. Cell 35: 763-776.

Scotese, C.R., Boucot, A.J. y McKerrow, W.S. 1999. Gondwanan palaeogeography and palaeoclimatology. Journal of African Earth Sciences 28: 99-114.

Serbet, R. y Rothwell, G.W. 1995 . Functional morphology and homologies of gymnospermous ovules: Evidence from a new species of Stephanospermum (Medullosales). Canadian Journal of Botany 73: 650-661.

Serra, C. 1966. Etude anatomique et paléogéographique de quelques espèces homoxylées du Sud Viêtnam et du Cambodge. Archives géologiquesViêtnam, Saîgon 8: 59-131.

Sessa, G., Steindler, C., Morelli, G. y Ruberti, I. 1998. The Arabidopsis Athb-8, -9 and -14 genes are members of a small gene family coding for highly related HD-ZIP proteins. Plant Molecular Biology 38: 609-622.

Seward, A.C. 1911. The Jurassic flora of Sutherland. Transactions of the Royal Society ef Edinburgh 47: 643-709

Seward, A.C. 1914. Antarctic fossil plants. British Museum (Natural History), British Antarctic (Terra Nova) Expedition (Geology) 1: 1-49.

Seward, A.C. 1917. Fossil Plants, Volumen III. Cambridge University Press. 656 pp.

Seward, A.C. 1919. Fossil Plants, Volume IV. Ginkgoales, Coniferales, Gnetales. Cambridge University Press, Cambridge, 543 pp.

Seward, A.C. y Dale, E. 1901. On the structure and affinities of Dipteris, with notes on th geological history of the Dipteridinae. Philosophical Transactions of Royal Society of London 194: 1-187.

Sewertzoff, A.N. 1927. Über die Beziehung zwischen der Ontogenese und der Phylogenese der Tiere. Jena Zeitrschr Naturwiss 63: 51-180.

Sewertzoff, A.N. 1949. Sobranje socinenij, Vol. V. Izd Akad Naut, Moskva-Leningrad, 500 pp.

Shepard, K.A. y Purugganan, M.D. 2002. The genetics of plant morphological evolution. Current Opinion in Plant Biology 5: 49-55.

Shirley, J. 1898. Additions to the Fossil Flora of Queensland, mainly from the Ipswich Formation, Triassic Jurassic System. Geological Survey of Queensland 7: 1-25.

Simms, M.J. y Ruffell, A.H. 1990. Synchronity of climatic change and extinctions in the Late Triassic. Geology 17: 265-268.

Smith, K.K. 2001. Heterochrony revisited: the evolution of developmental sequences. Biological Journal of the Linnean Society 73: 169-186.

Smith, K.K. 2002. Sequence heterochrony and the evolution of development. Journal of Morphology 252: 82-97.

Smith, K.K. 2003. Time's arrow: heterochrony and the evolution of development. International Journal of Development Biology 47: 613-621. 
Smith, A.R., Pryer, K.M., Schuettpelz, E., Korall, P., Schneider, H. y Wolf, P.G. 2006. A classification for extant ferns. Taxon 55: 705-731.

Soil Survey Staff. 1999. Soil Taxonomy: A Basic System of Soil Classification for Making and Interpreting Soil Surveys. Agriculture Handbook, USDA Natural Resources Conservation Service: Washington, DC, 869 pp.

Spalletti, L.A. 1980. Paleoambientes Sedimentarios en Secuencias Silicoclásticas. Asociación Geológica Argentina, Serie B, Buenos Aires, 175 pp.

Spalletti, L. . 1995. Los sistemas de acumulación fluviales y lacustres del Triásico en la región occidental en la Precordillera sanjuanina, República Argentina. II Reunión sobre el Triásico del Cono Sur (Bahía Blanca), Actas: 27-28.

Spalletti, L.A. 2001a. Modelo de sedimentación fluvial y lacustre en el margen pasivo de un hemigraben: el Triásico de la Precordillera occidental de San Juan, República Argentina. Revista de la Asociación Geológica Argentina 56: 189-210.

Spalletti, L.A. 2001b. Evolución de las cuencas sedimentarias. En: Artabe, A.E., Morel, E.M. y Zamuner, A.B. (eds.). El Sistema Triásico de Argentina. Fundación Museo de La Plata "Francisco Pascasio Moreno", La Plata, pp. 81-101.

Spalletti, L.A., Artabe, A.E., Morel, E.M. y Brea, M. 1999. Biozonación paleoflorística y cronoestratigrafía del Triásico Argentino. Ameghiniana 36: 419 -451.

Spalletti, L.A., Artabe, A.E. y Morel, E.M. 2003. Geological factors and evolution of southwestern Gondwana Triassic plants. Gondwana Research 6: 119-134.

Spalletti, L.A., Fanning, C.M. y Rapela, C.W. 2008. Dating the Triassic continental rift in the southern Andes: the Potrerillos Formation, Cuyo Basin, Argentina. Geologica Acta 6: 267-283.

Speck, T., Rowe, N.P., Civeyrel, L., Claßen-Bockhoff, R., Neinhuis, C. y Spatz, H.-C. 2003. The potential of plant biomechanics in functional biology and systematics. En: Stuessy, T.F., Mayer, V. y Hörandl, E. (eds), Deep morphology: toward a renaissance of morphology in plant systematics, Koeltz Scientific Books, Königstein, pp. 241-271.

Spicer, R.A. 1989. The formation and interpretation of plant fossil assemblages. Advances in Botanical Research 16: 96-191.

Spicer, R.A. y Greer, A.G. 1986, Plant taphonomy in fluvial and lacustrine systems. En: Gastaldo, R.A. y Broadhead, T.W. (eds), Land Plants: Notes for a Short Course, University of Tennessee, Department of Geological Sciences, Studies in Geology 15, Knoxville, pp. 10-26.

Stappenbeck, R. 1910. La Precordillera de San Juan y Mendoza. Anales del Ministerio de Agricultura de la Nación, Sección Geología, Mineralogía y Minería 4: 3-187.

Stat Soft, 1984-2004. STATISTICA 7.0. http://www.statsoft.com.

Steidtman, W.E. 1937. A Preliminary Report on the Anatomy and Affinities of Medullosa noei sp. nov. from the Pennsylvanian of Illinois. American Journal of Botany 24: 124-125.

Stein, W.E. 1993. Modeling the evolution of stelar architecture in vascular plants. International Journal of Plant Sciences 154: 229-263.

Stein, W.E. y Boyer, J.S. 2006. Evolution of land plant architecture: beyond the telome theory. Paleobiology 32: 450-482. 
Steinmann, T., Geldner, N., Grebe, M., Mangold, S., Jackson, C.L., Paris, S., Galweiler, L., Palme, K. y Jurgens, G. 1999. Coordinated polar localization of auxin efflux carrier PIN1 by GNOM ARF GEF. Science 286: 316-318.

Sternberg, W.P. 1833. Versuch einer geognostichen botanischen. Darstellung der flora der Vorwelt 2: 180.

Stelzner, A. 1885. Beiträge zur Geologie und Paläontologie der Argentinischen Republik und des angrenzenden, zwischen dem $32^{\circ}$ u $33^{\circ} \mathrm{S}$. Br. gelegenden Teiles der Chilenischen Cordillere. I. Geologischer Theil, Cassel \& Berlin, 329 pp.

Stewart, W.R. Y Rothwell, G.W. 1993. Paleobotany and the evolution of plants. Cambridge University Press, Cambridge, 521 pp.

Stipanicic, P.N. 1947. Estudio geológico, estratigráfico y tectónico de la Precordillera, al este del río de Los Patos en Sorocayense (San Juan). Tesis Doctoral. Universidad de Buenos Aires. Buenos Aires. (Inédito).

Stipanicic, P.N. 1955. Aclaración sobre las Dipteridaceae de Barreal (prov. de San Juan) y la repartición geológica de los géneros de esta familia. Revista de la Asociación Geológica Argentina 10: 5459.

Stipanicic, P.N. 1957. El Sistema Triásico en la Argentina. 20 Congreso Geológico Internacional (México), Sección II: El Mesozoico en el Hemisferio Occidental y sus correlaciones mundiales: 77-112.

Stipanicic, P.N. 1969. Las sucesiones triásicas argentinas. Gondwana Stratigraphy, Proceedings of the 1st International Union of Geological Sciences (UNESCO, París), Gondwana Symposium: 11211149.

Stipanicic, P.N. 1972. Cuenca triásica de Barreal. En: Leanza, A.F. (ed.) Geología Regional Argentina, Academia Nacional de Ciencias, Córdoba, pp. 537- 566.

Stipanicic, P.N. 1979. El Triásico del valle del Río de Los Patos (provincia de San Juan). En: Turner, J.C.M. (ed.), Geología Regional Argentina, Academia Nacional de Ciencias, Córdoba, pp. 695744.

Stipanicic, P.N. 1983. The Triassic of Argentina and Chile. En: Moullade, M. y Nairim, A.E.M. (eds), The Phanerozoic geology of the World. II, The Mesozoic, Elsevier, Amsterdam, pp. 181-199

Stipanicic, P.N. 2001. Antecedentes geológicos y paleontológicos. En: Artabe, A.E., Morel, E.M. y Zamuner, A.B. (eds.), El Sistema Triásico de Argentina. Fundación Museo de La Plata "Francisco Pascasio Moreno", La Plata, pp. 1-21.

Stipanicic, P.N. 2002. CORTADERITA (Formación...), Nota 1 y 2. En: Stipanicic, P. N y Marsicano, C. A (eds) Lexico Estratigráfico de La Argentina. Vol. VIII Triásico. Asociación Geológica Argentina Serie "B” (Didáctica y Complementaria), Buenos Aires: 106.

Stipanicic, P.N. 2007. Sobre la presencia de Dicroidium odontopteroides (Morris) Gothan var. moltenense Retallack en la Formación Cacheuta, subsuelo del depocentro triásico de Beazley (San Luis, Argentina). Ameghiniana 44: 251-253. 
Stipanicic, P.N. y Archangelsky, S. 2002. Megafloras, Anexos 1, 2 y 3. En: Stipanicic, P.N y Marsicano, C.A. (eds), Léxico Estratigráfico de La Argentina, Vol. VIII Triásico, Asociación Geológica Argentina Serie “B” (Didáctica y Complementaria), Buenos Aires: 309-317.

Stipanicic, P.N. y Bonaparte, J.F. 1972. Cuenca triásica de Ischigualasto-Villa Unión. En: Leanza, A.F. (ed.), Geología Regional Argentina, Academia Nacional de Ciencias, Córdoba, pp. 507-536.

Stipanicic, P.N. y Bonaparte, J.F. 1979. Cuenca triásica de Ischigualasto-Villa Unión (Provincias de La Rioja y San Juan). En: Turner, J.C.M. (ed.), Segundo Simposio de Geología Regional Argentina (Córdoba), Academia Nacional de Ciencias 1: 523-575.

Stipanicic, P.N. y Bonetti, M.I.R. 1965. Las especies del género Saportaea del Triásico de Barreal (San Juan). Revista del Museo Argentino de Ciencias Naturales "Bernardino Rivadavia", Paleontología 1: 81-114.

Stipanicic, P.N. y Bonetti, M.I.R. 1969. Consideraciones sobre la cronología de los terrenos triásicos argentinos. Gondwana Stratigraphy, Proceedings of the 1st International Union of Geological Sciences (UNESCO, Paris) Gondwana Symposium I: 1081-1119.

Stipanicic, P.N y Marsicano, C.A. 2002. Lexico Estratigráfico de La Argentina. Vol. VIII Triásico. Asociación Geológica Argentina Serie “B” (Didáctica y Complementaria). Buenos Aires, 370 pp.

Stipanicic, P.N. y Menéndez, C.A. 1949. Contribución al conocimiento de la flora fósil de Barreal (provincia de San Juan). I. Dipteridaceae. Boletín de Informaciones Petroleras, Buenos Aires 24: 44-73.

Stipanicic, P.N., Herbst, R. y Bonetti, M.I.R. 1996. Floras Triásicas. En: Stipanicic, P.N. y Hünicken, M.A. (eds), Revisión y actualización de la obra paleobotánica de Kurtz en la República Argentina, Actas de la Academia Nacional de Ciencias 11, Córdoba: 127-184.

Strelkov, E. y Alvarez, L. 1984. Análisis estratigráfico y evolutivo de la cuenca triásica mendocinasanjuanina. $9^{\circ}$ Congreso Geológico Argentino (San Carlos de Bariloche), Actas 3: 115-130.

Sundberg, S., Uggla, C. y Tuominen, H. 2000. Cambial growth and auxin gradients. En: Savidge, R.A., Barnett, J.R. y Napier, R. (eds), Cell and Molecular Biology of Wood Formation. BIOS Sci, Oxford, pp. 169-188.

Svensson, M. 2000. Evolution of a Family of Plant Genes with Regulatory Functions in Development; Studies on Picea abies and Lycopodium annotinum. Comprehensive Summaries of Uppsala Dissertations from the Faculty of Science and Technology 573, Acta Universitatis Upsaliensis, Uppsala, 46 pp. Inédito.

Szajnocha, L. 1889. Uber fossile Pflanzenreste aus Cacheuta in der Argentinischen Republik. Sitzungsberischte der kaiserlichen. Akademie der Wissenschaft, MathematischNaturwissenschaftliche, Classe 9: 219-246.

Tabor, N.J., Montañez, I.P., Zierenberg, R. y Currie, B.S. 2004, Mineralogical and geochemical evolution of a basalt-hosted fossil soil (Late Triassic, Ischigualasto Formation, northwest Argentina): Potential for paleoenvironmental reconstruction. Geological Society of America Bulletin 116: $1280-1293$. 
Tabor, N.J., Montañez, I.P., Kelso, K.A., Currie, B.S., Shipman, T.A. y Colombi, C.E. 2006. Late Triassic soil catena: Landscape and climate controls on paleosol morphology and chemistry across the Carnian-age Ischigualasto-Villa Union basin, northwestern Argentina. En: AlonsoZarza, A.M. y Tanner, L.H. (eds), Paleoenvironmental Record and Applications of Calcretes and Palustrine Carbonates, Geological Society of America Special Paper 416: 17-42.

Takei, K., Ueda, N., Aoki, K., Kuromori, T., Hirayama, T., Shinozaki, K., Yamaya, T. y Sakakibara, H. 2004. AtIPT3 is a key determinant of nitratedependent cytokinin biosynthesis in Arabidopsis. Plant and Cell Physiology 45: 1053-1062.

Takhtajan, A.L. 1969. Flowering Plants. Origin and Dispersal. Trans, by C. Jeffrey, Oliver \& Boyd, Edinburgh, 310 pp.

Takhtajan, A.L. 1972. Patterns of ontogenetic alteration in the evolution of higher plants. Phytomorphology 22: 164-171.

Takhtajan, A.L. 1976. Neoteny and the origin of flowering plants. En: Beck, C.B. (ed.), Origin and Early Evolution of Angiosperms, Columbia University Press, New York, pp. 207-219.

Takhtajan, A.L. 1991. Evolutionary trends in flowering plants. Columbia University Press, New York, $241 \mathrm{pp}$.

Talbert, P.B., Adler, H.T., Parks, D.W. y Comai, L. 1995. The REVOLUTA gene is necessary for apical meristem development and for limiting cell divisions in the leaves and stems of Arabidopsis thaliana. Development 121: 2723-2735.

Tanner, L.H. 2000. Palustrine/lacustrine and alluvial facies of the Norian Owl Rock Formation (Chinle Group), Four Corners region, southwestern USA: Implications for Late Triassic paleoclimate. Journal of Sedimentary Research 70: 1280-1289.

Taylor, E.L. 1992. The occurrence of a Rhexoxylon-like stem in Antarctica. Courrier Forschungsinstitut Senckenberg 147: 183-189.

Taylor, E.L. 1996. Enigmatic gymnosperms? Structurally preserved Permian and Triassic seed ferns from Antarctica. Review of Palaeobotany and Palynology 90: 303-318.

Taylor, T.N. y Taylor, E.L. 1993. The Biology and Evolution of Fossil Plants. Prentice Hall, Englewood Cliffs, New Jersey, $981 \mathrm{pp}$.

Taylor, T.N., del Fueyo, G.M. y Taylor, E.L. 1994. Permineralized seed fern cupules from the Triassic of Antarctica: implications for cupule and carpel evolution. American Journal of Botany 81: 666677.

Taylor, E.L, Taylor, T.N., Kerp, H. y Hermsen, E.J. 2006. Mesozoic seed ferns: Old paradigms, new discoveries. Journal of the Torrey Botanical Society 133: 62-82.

Taylor, T.N., Taylor, E.L. y Krings, M. 2009. Paleobotany, The Biology and Evolution of Fossil Plants, Second Edition, Academic Press, Amsterdam, 1230 pp.

Tenison-Woods, J.E. 1883. On the fossil flora of coal deposits of Australia. Proceedings of the Linnean Society of New South Wales 8: 37-167.

Terrazas, T.S. 1994. Wood anatomy of the Anacardiaceae: ecological and phylogenetic interpretation. Disertación inédita, University of North Carolina-Chapel Hill, 321 pp. 
Terruggi, M.E. 1971. Criterios para el reconocimiento y estudio de los paleosuelos. Revista de la Asociación Geológica Argentina 26: 485-490

Theologis, A. 1989. Auxin-regulated gene expression in plants. Biotechnology 12: 229-243.

Thomas, H.H. 1933. On some Pteridospermous plants from the Mesozoic rocks of South Africa. Philosophical Transactions of the Royal Society London B 222: 193-254.

Thomas, H.H. y Bose, M.N. 1955. Pachydermophyllum papillosum, (gen. et sp. nov.) from the Yorkshire Jurassic. Annals and Magazine of Natural History 12: 335-543.

Townrow, J.A. 1955. On some species of Phyllotheca. Journal and Proceedings of the Royal Society of New South Wales 89: 39-63.

Townrow, J.A. 1956. The genus Lepidopteris and its Southern Hemisphere species. Abhandlungen ut. Arbok d. Norske Videnskaps-Akademi, Oslo, I. Matematisk-NaturvitenskapeligKlasse: 3-28.

Townrow, J.A. 1957. On Dicroidium probably a Pteridospermous leaf, and other leaves now removed from this genus. Transactions Geological Society South Africa 60: 21-56.

Townrow, J.A. 1960. The Peltaspermaceae, a pteridosperm family of Permian and Triassic age. Paleontology 3: 333-361.

Townrow, J.A. 1962. On Pteruchus, a microsporophylll of the Corystospermaceae. Bulletin of the British Museum of Natural History (Geology) 6: 287-320.

Townrow, J.A. 1966a. On Dicroidium odontopteroides and D. obtusifolium in Tasmania. The Palaeobotanist 14: 128136.

Townrow, J.A. 1966b. On Lepidopteris madagascariensis Carpenter (Peltaspermaceae). Journal and Proceedings of the Royal Society of New South Wales 98: 203-214.

Townrow, J.A. 1967. On Rissikia and Mataia podocarpaceous conifers from the lower Mesozoic of southern lands. Papers and Proceedings of the Royal Society of Tasmania 101: 103-136.

Tozer, E.T. 1971. One, two or three connecting links between Triassic and Jurassic ammonoids? Nature 232: $565-566$

Troncoso, A. y Herbst, R. 1999. Ginkgoales del Triásico del norte de Chile. Revista Geológica de Chile 26: $255-273$.

Uggla, C., Moritz, T., Sandberg, G. y Sundberg, B. 1996. Auxin as a positional signal in pattern formation in plants. Proceedings of the National Academy of the United States of America 93: 9282-9286.

Uggla, C., Mellerowicz, E.J. y Sundberg, B. 1998. Indole-3-acetic acid controls cambial growth in Scots pine by positional signaling. Plant Physiology 117:113-122.

Valdes, P.J. y Sellwood, B.W. 1992. A palaeoclimate model for the Kimmeridgian. Palaeogeography, Palaeoclimatology, Palaeoecology 95: 45-72.

Vega, J.C. y Archangelsky, S. 2001. Austrocalyxaceae, a new pteridosperm family from Gondwana. Palaeontographica B 257: 1-16.

Vogellehner, D. 1965. Untersuchungen zur Anatomie und Systematik der verkieselten Hölzer aus dem fränkischen und südthüringische Keuper. Erlanger geologische Abhandlungen 59: 1-76. 
Vogellehner, D. 1967. Zur anatomie und phylogenie mesozoischer Gymnospermenhölzer, 5: Prodomus zu einer Monographie der Protopinaceae. 1. Die protopinoiden Hölzer der Trias. Palaeontographica B 124: 125-162.

Volkheimer, W. 1969. Palaeoclimatic evolution in Argentina and relations with other regions of Gondwana. En: Amos, A.J. (ed.), Gondwana Stratigraphy (1st International Union of Geological Sciences Gondwana Symposium, 1967), Earth Sciences Series, v. 2, UNESCO, Paris, pp. 551-587.

Walker, L. y Estelle, M. 1998. Molecular mechanisms of auxin action. Current Opinion in Plant Biology 1: 434-439.

Walkom, A.B. 1915-1917, Mesozoic floras of Queensland. Queensland Geological Survey Bulletin. pt. 1, no. 252 ; pt. 11 , no. 257 ; pt. 3 , no. 259.

Walkom, A.B. 1925. Notes on some Tasmanian Mesozoic plants. Papers and proceedings of the Royal Society of Tasmania 1: 73-89.

Walkom, A.B. 1932. Fossil plants from Mount Piddington and Clarence Siding. Proceedings of the Linnean Society of New South Wales 57: 123-126.

Walton, J. 1923. On Rhexoxylon Bancroft, a Triassic genus of plants exhibiting a liana-type of vascular organization. Philosophical Transactions of the Royal Society of London, Series B 212: 79-109.

Walton, J. 1925. Carboniferous Bryophytas. Annals of Botany 39: 363-372.

Wang, Z. Advances on the Permo-Triassic lycopods in North China. I. An Isoetes from the Mid-Triassic in northern Shaanxi Province.

Webb, J.A. 1982 . Triassic species of Dictyophyllum from eastern Australia. Alcheringa 6: 79-91.

Webb, J.A. 2001. A new marattialean fern from the Middle Triassic of Eastern Autralia. Proceedings of the Linnean Society of New South Wales 123: 215-224.

Weigel, D. y Meyerowitz, E.M. 1993. Activation of floral homeotic genes in Arabidopsis. Science 261: 1723-1726.

Wiltshire, R.J.E., Murfet, I.C. y Reid, J.B. 1994. The genetic control of heterochrony: Evidence from developmental mutants of Pisum sativum L. Journal of Evolutionary Biology 7: 447-65.

Wieland, G.R. 1929. Antiquity of the Angiosperms. International Congress of Plant Sciences (Ithaca, New York), Proceedings: 429-456.

Williams, G.E. 1971. Flood deposits of the sand-bed ephemeral streams of Central Australia. Sedimentology 17: 1-40.

Williams, J., Phillips, A.L., Gaskin, P. y Hedden, P. 1998. Function and substrate specificity of the gibberellin 3 beta-hydroxylase encoded by the Arabidopsis GA4 gene. Plant Physiology 117: $559-563$

Wing, S. y Sues, H.D. 1992. Mesozoic and Early Cenozoic Terrestrial Ecosystems. En: Behrensmeyer, A., Damuth, J., DiMichele, W., Potts, R., Sues, H.D. y Wing, S. (eds) Terrestrial ecosystems through time: evolutionary palecoecology of terrestrial plants and animals. The University of Chicago Press, pp. 327-416.

Worsdell, W.C. 1901. Contributions to the Comparative Anatomy of the Cycadaceae. Transactions of the Linnean Society, Series II 6: 109-121. 
Worsdell, W.C. 1906. The structure and origin of the Cycadaceae. Annals of Botany 20: 129-155.

Yao, X., Taylor, T.N. y Taylor, E.L. 1995. The corystosperm pollen organ Pteruchus from the Triassic of Antarctica. American Journal of Botany 82: 535-546.

Ye, Z.-H. 2002. Vascular tissue differentiation and pattern formation in plants. Annual Review of Plant Biology 53: 183-202.

Yokoyama, Z. 1889. Jurassic plants from Kaga, Hida, and Echizen. Journal of College of Science, Imperial University of Japan 3: 1-66.

Yrigoyen, M.R. y Stover, L.E. 1970. La palinología como elemento de correlación del Triásico en la Cuenca Cuyana. Cuartas Jornadas Geológicas Argentinas (Mendoza), Actas 2: 427-447.

Zamski, E. y Azenkot, A. 1981. Sugar beet Vasculature. I. Cambial Development and the ThreeDimensional Structure of the Vascular System. Botanical Gazette 142: 334-343.

Zamuner, A.B. 1991. Estudio de una tafoflora de la localidad tipo de la Formación Ischigualasto (Neotrías), Provincia de San Juan. Tesis Doctoral No 583, Facultad de Ciencias Naturales y Museo, Universidad Nacional de La Plata, 97 pp., 25 láms. Inédito.

Zamuner, A.B. y Artabe, A.E. 1994. Estudio de un leño fósil, Protocircoporoylon marianaensis n.sp., proveniente de las sedimentitas triásicas de la Formación Paso Flores, Provincia del Río Negro, Argentina. Ameghiniana 31: 203-207.

Zamuner, A.B., Artabe, A.E. y Ganuza, D.G. 1999. A new Peltasperm (Gymnospermopsida) from the Middle Triassic of Argentina. Alcheringa, 23: 185-191.

Zamuner, A.B., Zavattieri, A.M., Artabe, A.E. y Morel, E.M. 2001. Paleobotánica. En: Artabe, A.E., Morel, E.M. y Zamuner, A.B. (eds), El Sistema Triásico de Argentina. Fundación Museo de La Plata "Francisco Pascasio Moreno", La Plata, pp. 143-184.

Zavattieri, A.M. 1995. Revisión de microfloras triásicas de Argentina. Correlación. II Reunión del Triásico del Cono Sur (Bahía Blanca, 1995), Actas: 30-35.

Zelditch, M. 2001. Beyond heterochrony: the evolution of development. Wiley-Liss, New York, $392 \mathrm{pp}$.

Zelditch, M.L. y Fink, W.M. 1996. Heterochrony and heterotopy: stability and innovation in the evolution of form. Paleobiology 22: 241-254.

Zhao, C., Craig, J.C, Earl Petzold, H., Dickerman, A.W. y Beers, E.P. 2005. The Xylem and Phloem Transcriptomes from Secondary Tissues of the Arabidopsis Root-Hypocotyl. Plant Physiology 138: $803-818$.

Zhang, S.-Y. 1992. Systematic wood anatomy of the Rosaceae. Blumea 37: 81-158.

Zhong, R. y Ye, Z.-H. 1999. IFL1, a gene regulating interfascicular fiber differentiation in Arabidopsis, encodes a homeodomain-leucine zipper protein. Plant Cell 11: 2139-2152.

Zhong, R, y Ye, Z.-H. 2001. Alteration of auxin polar transport in the Arabidopsis ifl1 mutants. Plant Physiology 126: 549-563.

Zhong, R., Taylor, J.J. y Ye, Z.-H. 1997. Disruption of interfascicular fiber differentiation in an Arabidopsis mutant. Plant Cell 9: 2159-2170.

Zhou, Z.-Y. 1994. Heterochronic origin of Ginkgo biloba-type ovule organs (in Chinese with English summary). Acta Palaeontologica Sinica 33: 131-139. 
Zhou, Z.-Y. y Zhang, B.-L. 1989. A Middle Jurassic Ginkgo with ovule-bearing organs from Henan, China. Palaeontographica B 211: 113-133.

Zimmermann, W. 1959. Die Phylogenie der Pflanzen 2nd edition. Fischer, Stuttgart, 777 pp.

Zöllner, W. 1950. Observaciones tectónicas en la Precordillera Sanjuanina, zona de Barreal. Revista de la Asociación Geológica Argentina 5: 111-126.

Zuber, R. 1889. Estudio geológico del cerro Cacheuta y sus contornos. Academia Nacional de Ciencias 10: 448-472. Córdoba. 